MÁRCIA CRISTINA ITO MEDEIROS

\title{
GESTÃO DO CONHECIMENTO APLICADA AO PROCESSO DE PROJETO NA CONSTRUÇÃO CIVIL: ESTUDOS DE CASO EM CONSTRUTORAS
}

Dissertação apresentada à Escola Politécnica de Universidade de São Paulo para obtenção do título de Mestre em Engenharia 

MÁRCIA CRISTINA ITO MEDEIROS

\title{
GESTÃO DO CONHECIMENTO APLICADA AO PROCESSO DE PROJETO NA CONSTRUÇÃO CIVIL: ESTUDOS DE CASO EM CONSTRUTORAS
}

\author{
Dissertação apresentada à Escola \\ Politécnica de Universidade de São \\ Paulo para obtenção do título de \\ Mestre em Engenharia
}

Área de Concentração:

Engenharia de Construção Civil e Urbana

Orientador:

Prof. Dr. Silvio Burrattino Melhado

São Paulo 
FICHA CATALOGRÁFICA

Medeiros, Márcia Cristina Ito

Gestão do conhecimento aplicada ao processo de projeto na construção civil: estudos de caso em construtoras / M.C.I. Medeiros. -- São Paulo, 2012.

$395 \mathrm{p}$.

Dissertação (Mestrado) - Escola Politécnica da Universidade de São Paulo. Departamento de Engenharia de Construção Civil.

1. Gestão do conhecimento 2. Construção civil 3. Coordenação (Projeto) I. Universidade de São Paulo. Escola Politécnica. Departamento de Engenharia de Construção Civil II. t. 
Dedico este trabalho ao Carlos meu marido e à Carolina, nossa filha,

que passou vários domingos ensolarados ao lado "desse computador chato". 



\section{AGRADECIMENTOS}

Gostaria de expressar meus agradecimentos a todos que colaboraram, direta ou indiretamente, na execução deste trabalho.

Ao professor Silvio B. Melhado pela orientação e incentivo, principalmente, nos momentos mais críticos.

Aos profissionais das empresas pesquisadas pela valorosa contribuição ao trabalho.

Ao colega Fernando Ferreira pelo apoio, sem o qual não teria iniciado o mestrado.

A meu pai Pedro Ito, que não pôde ver este trabalho finalizado, mas que, com certeza, estaria prestigiando-me na primeira fileira no dia da apresentação.

À minha mãe Gisela que, com meu pai, sempre dedicou a vida para que seus filhos tivessem acesso ao melhor do conhecimento.

A meu marido Carlos pelo apoio e paciência.

E à minha filha Carolina, que passou quase metade de sua vida ao meu lado, aprendendo a importância da persistência, dedicação e paciência para atingir nossos objetivos. 



\section{RESUMO}

Os empreendimentos desenvolvidos no setor da construção têm se tornado cada vez mais complexos exigindo uma articulação eficiente entre os processos de toda a equipe multidisciplinar envolvida para o sucesso de sua implementação.

Visto que decisões na fase de projeto podem influenciar todo o ciclo de vida do empreendimento, a colaboração e compartilhamento de conhecimento entre as equipes, aliada ao atendimento às expectativas do cliente, representa um potencial para melhorar o desempenho dos projetos e minimizar estruturas e processos ineficientes no setor da construção, aumentando o valor agregado ao projeto, obra e operação.

A função de gestor do processo de projeto (design), antes exercida pelos arquitetos, tem sido conduzida em muitos casos, por incorporadoras ou construtoras, que têm desenvolvido competências para a gestão do empreendimento como um todo, como estratégia de criação de valor para seus clientes e para controlar os riscos associados ao projeto.

O estudo propõe analisar a forma de atuação das construtoras na gestão do processo de projeto através de estudos de caso e verificar quais práticas associadas à gestão de conhecimento têm sido empregadas e qual a aplicação no processo de projeto (estruturas de comunicação e informação; mecanismos de alimentação de novos projetos; transmissão de informações do projeto para a obra; ferramentas e técnicas para captação e armazenamento de conhecimento gerado ao longo do projeto e adquirido nas obras).

Com base nas revisões bibliográficas e estudos de caso serão propostas diretrizes para implantação de iniciativas voltadas à gestão de conhecimento, que aliada à gestão de projetos atuem como ativos estratégicos da empresa construtora.

Palavras-chave: Gestão de projetos. Gestão do conhecimento. Construção civil. 



\begin{abstract}
Projects developed in construction sector have become more complex demanding an efficient articulation of the multidisciplinary team processes to achieve the success of its implementation.

Due to the fact that decisions made in the design phase may influence all the project life cycle, the multidisciplinary team knowledge sharing and collaboration across organizational boundaries, represents a potential for client and user expectations attendance and project performance improvement. Besides, minimizing inefficient structures and processes in construction sector may improve the earned value of the design, construction, operation and maintenance.

Design manager function, usually performed by architects, has been lead by management companies, and in many cases, by contractors, who have developed project and design management competences as a strategy to create value for their clients and control risks associated with the project.

The aim of the research is to analyze contractors performance in the design process management through case studies and to verify knowledge management practices applied in this process (communication and information structures; feedback mechanisms for new design; design information transmission to the construction site; techniques to capture and storage knowledge generated throughout the project and acquired in the construction site).
\end{abstract}

Based on the bibliographical review and case studies, guidelines for knowledge management allied to design management will be proposed to increase construction company strategical advantages.

Key words: Design Management. Knowledge Management. Construction. 



\section{SUMÁRIO}

\section{LISTA DE FIGURAS, $i$}

LISTA DE QUADROS, v

LISTA DE TABELAS, vi

LISTA DE ABREVIATURAS E SIGLAS, vii

INTRODUÇÃO.

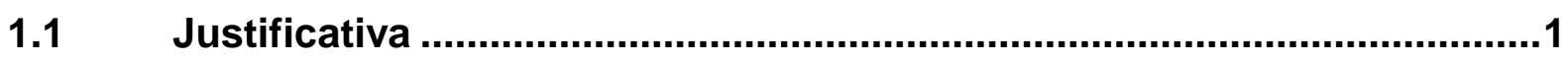

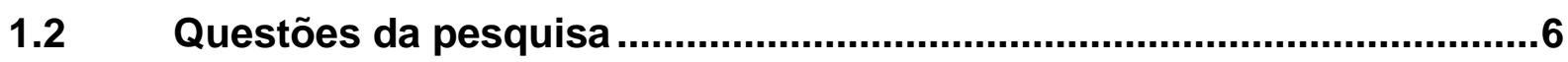

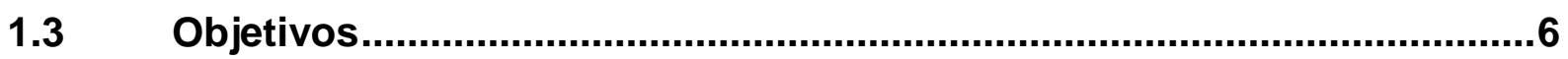

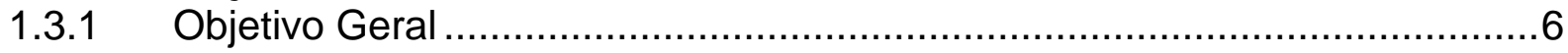

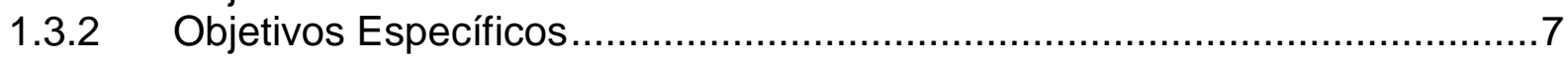

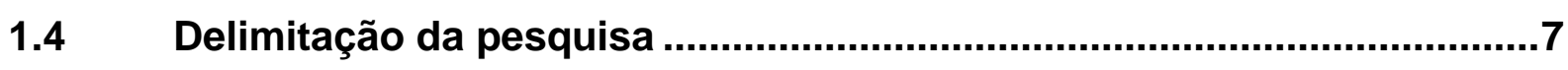

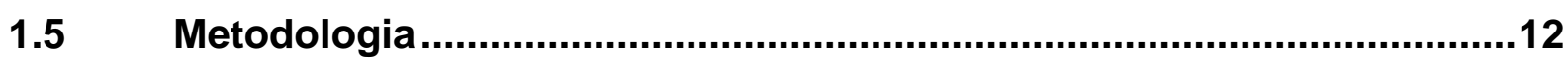

1.6 Estrutura de apresentação do trabalho ...........................................17

2 Caracterização do setor da construção civil no Brasil.........................19

2.1 A construção na economia do Brasil ................................................19

2.2 Sustentabilidade .........................................................................21

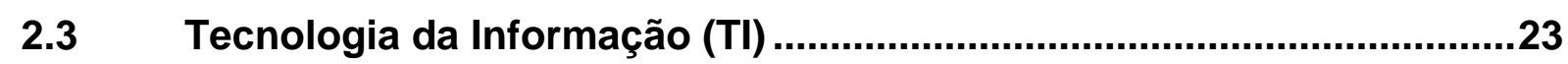

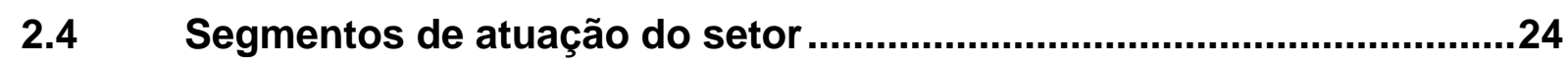

2.5 Método de seleção de equipe e sistemas contratuais...........................26

2.6 Ciclo de vida de um empreendimento e do processo de projeto ..........35

2.7 Gestão do empreendimento, do processo de projeto e da produção..43

$2.8 \quad$ Estratégia das construtoras....................................................................46

2.9 Integração e colaboração entre projeto-construção..............................55

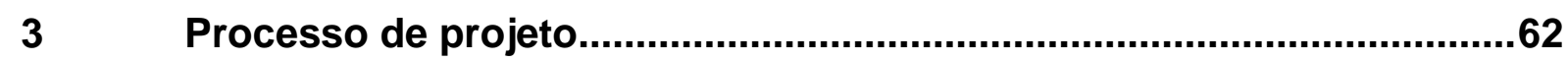

3.1 O papel do projeto no ciclo de vida do empreendimento .....................63

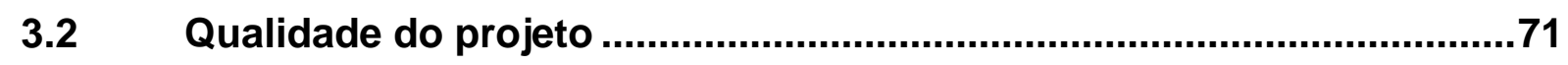

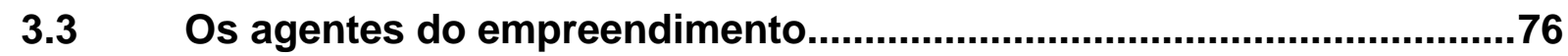

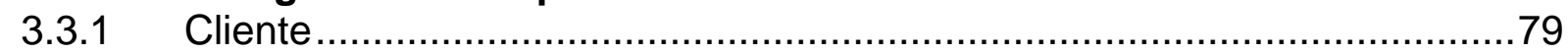

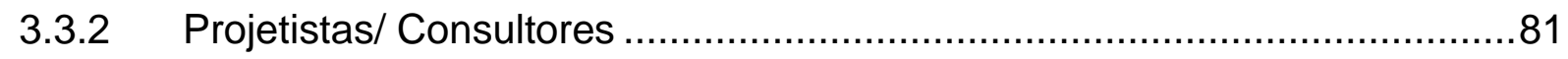

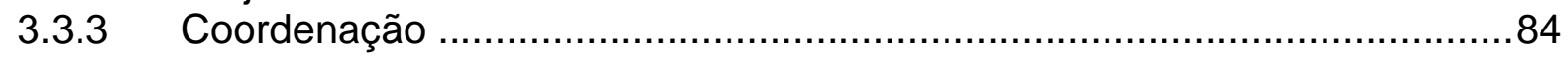

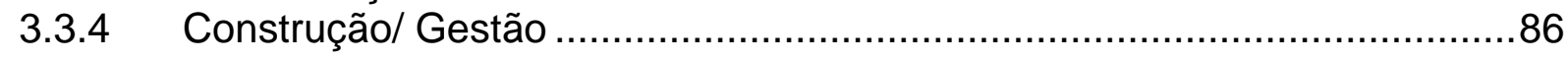

3.4 Comunicação no processo de projeto ................................................. 


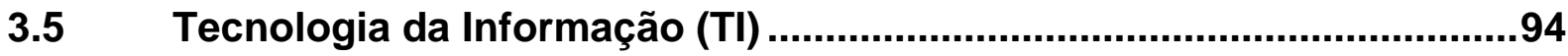

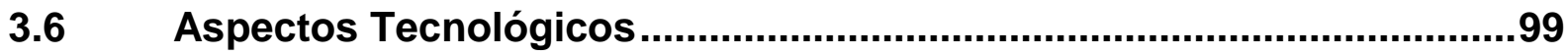

3.7 Problemas/ Deficiências no processo de projeto .................................101

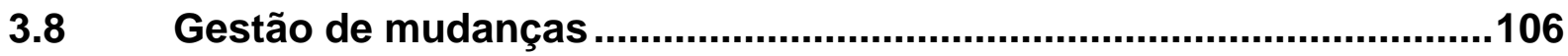

4 Gestão do conhecimento

4.1 O conhecimento nas organizações ....................................................112

4.2.1 Fatores interdisciplinares que impactam a gestão do conhecimento ........124

4.2.2 Atividades dos processos de gestão do conhecimento...........................129

4.2.3 Ferramentas e aplicações de gestão do conhecimento ..........................132

4.2.4 Retroalimentação ....................................................................136

4.2.6 Exemplos de aplicação da gestão do conhecimento ............................145

4.3.1 Razões para implementar uma estratégia de gestão do conhecimento....153

4.3.2 Esforços e barreiras para implementação...........................................155

4.3.3 Evolução da gestão do conhecimento na construção .............................159

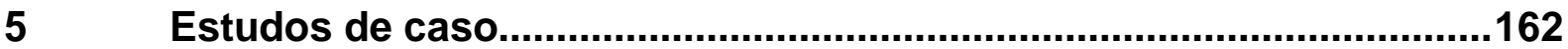

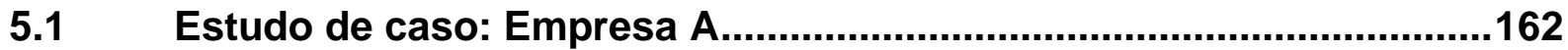

5.1.1 Caracterização da Empresa A ……….......................................162

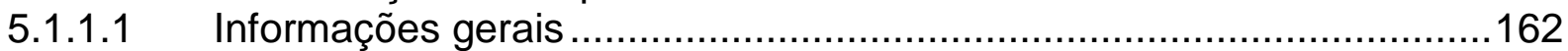

5.1.1.2 Evolução da empresa.............................................................163

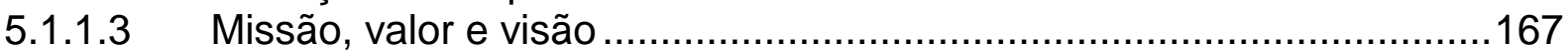

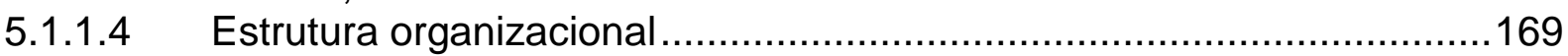

5.1.1.5 Ciclo de vida dos empreendimentos............................................171

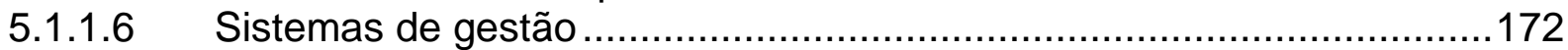

5.1.1.7 Assistência Técnica..............................................................175

5.1.1.8 Funcionários entrevistados (unidades de análise).............................182

5.1.1.9 Caracterização do empreendimento analisado .................................183

5.1.1.10 Os agentes do empreendimento ................................................186

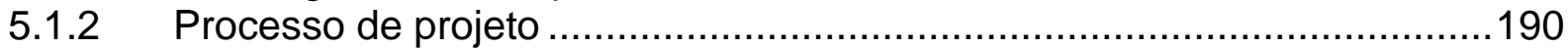

5.1.2.1 Formação da equipe de projeto....................................................190

5.1.2.2 Gestão do processo de projeto......................................................192

5.1.2.3 Atuação da construtora no processo de projeto .................................197

5.1.2.4 Comunicação no processo de projeto e obra .....................................201

5.1.2.5 Tecnologia da Informação (TI) ………........................................204

5.1.2.6 Aspectos Tecnológicos.............................................................206

5.1.2.7 Problemas/ Deficiências no processo de projeto..................................209

5.1.2.8 Gestão de mudanças ...............................................................211

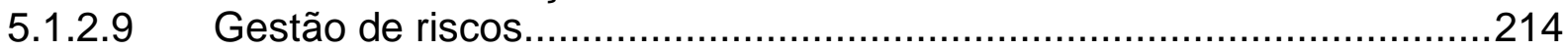

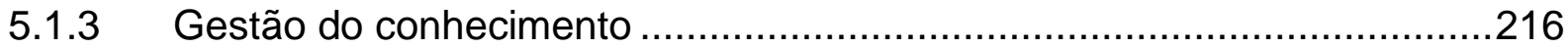

5.1.3.1 Iniciativas de gestão do conhecimento ..........................................216

5.1.3.2 Esforços e barreiras para implementação ............................................223

5.1.3.3 Síntese do Estudo de Caso Empresa A ..........................................225

5.2 Estudo de caso: Empresa B.......................................................230

5.2.1 Caracterização da Empresa B .........................................................230

5.2.1.1 Informações gerais .................................................................230

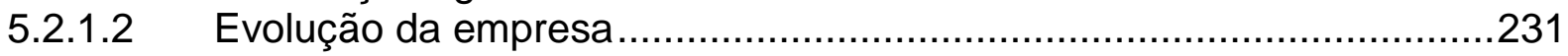

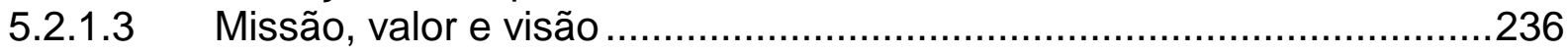




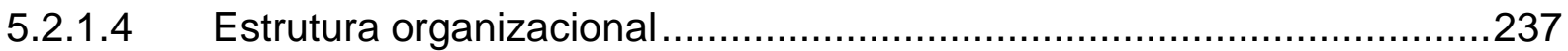

5.2.1.5 Ciclo de vida dos empreendimentos............................................239

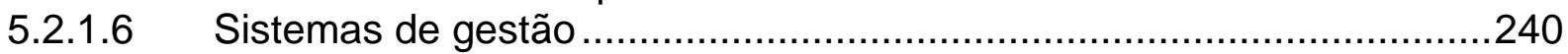

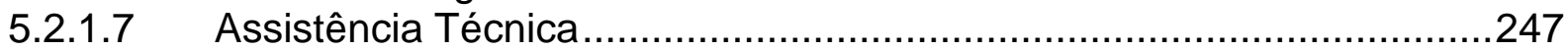

5.2.1.8 Funcionários entrevistados (unidades de análise) ............................247

5.2.1.9 Caracterização do empreendimento analisado ................................248

5.2.1.10 Os agentes do empreendimento ………......................................250

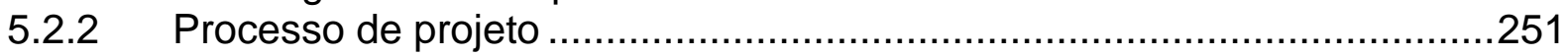

5.2.2.1 Formação da equipe de projeto..................................................251

5.2.2.2 Gestão do processo de projeto...................................................253

5.2.2.3 Atuação da construtora no processo de projeto ..................................256

5.2.2.4 Comunicação no processo de projeto e obra .....................................259

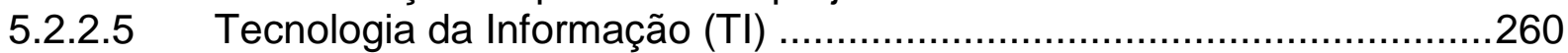

5.2.2.6 Aspectos Tecnológicos...............................................................261

5.2.2.7 Problemas/ Deficiências no processo de projeto..................................263

5.2.2.8 Gestão de mudanças ...................................................................263

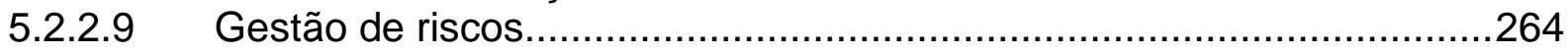

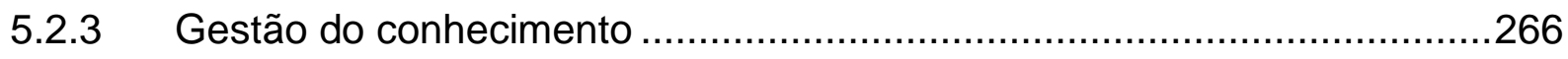

5.2.3.1 Iniciativas de gestão do conhecimento ...........................................266

5.2.3.2 Esforços e barreiras para implementação ..........................................269

5.2.3.3 Síntese do Estudo de Caso B ....................................................272

5.3 Estudo de caso: Empresa C.......................................................275

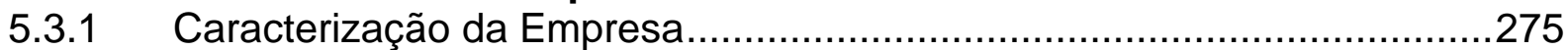

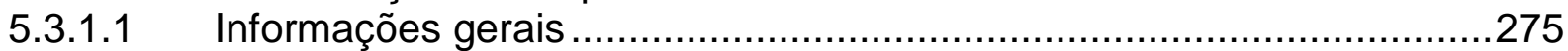

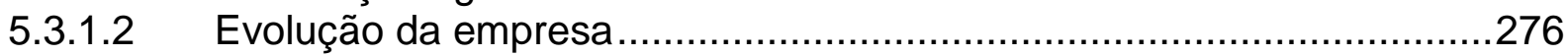

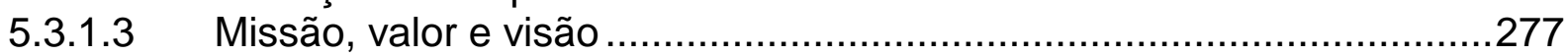

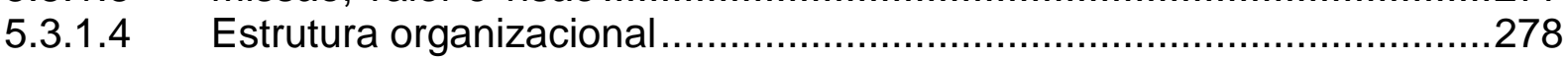

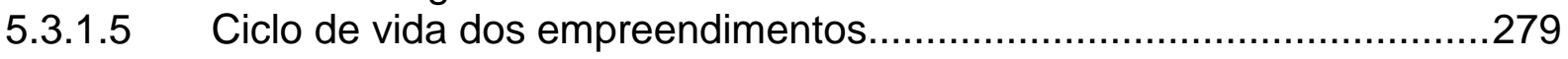

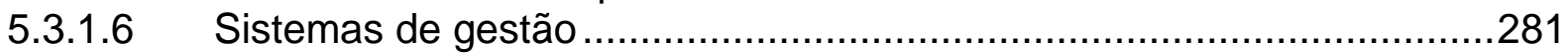

5.3.1.7 Assistência Técnica................................................................28

5.3.1.8 Memória Técnica - MT .........................................................28

5.3.1.9 Funcionários entrevistados (unidades de análise).............................290

5.3.1.10 Caracterização do empreendimento analisado .................................290

5.3.1.11 Os agentes do empreendimento .................................................296

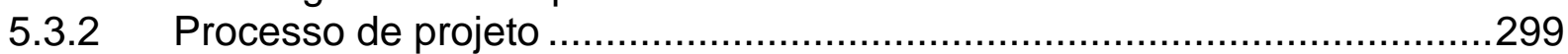

5.3.2.1 Formação da equipe de projeto....................................................299

5.3.2.2 Gestão do processo de projeto.........................................................300

5.3.2.3 Atuação da construtora no processo de projeto ………........................303

5.3.2.4 Comunicação no processo de projeto e obra ......................................304

5.3.2.5 Tecnologia da Informação (TI) …………....................................306

5.3.2.6 Aspectos Tecnológicos..............................................................306

5.3.2.7 Problemas/ Deficiências no processo de projeto.................................310

5.3.2.8 Gestão de mudanças ....................................................................

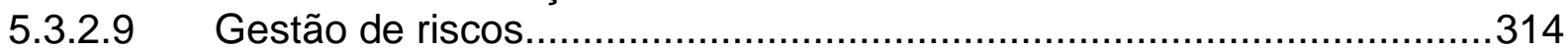

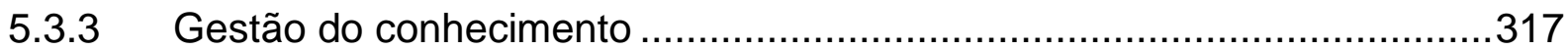

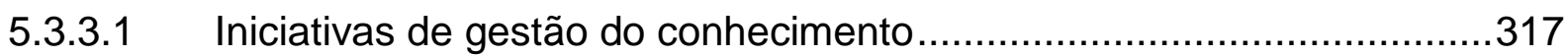

5.3.3.2 Esforços e barreiras para implementação ..........................................322

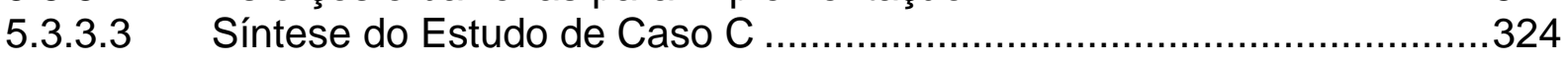

5.4 Análise comparativa dos estudos de caso........................................327 


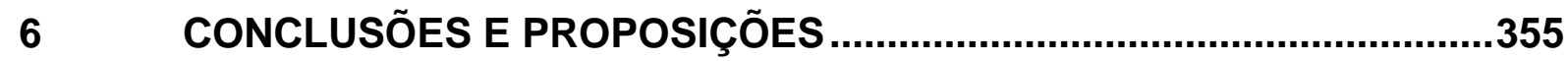

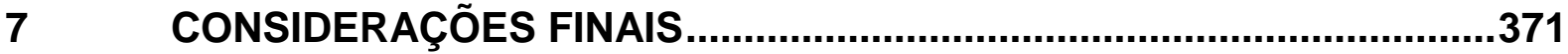

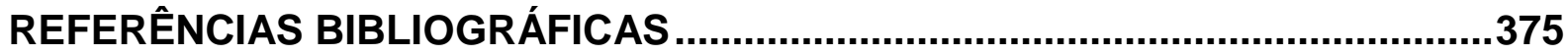

ANEXO A - ROTEIRO DE ENTREVISTA ESTUDO DE CASO ..............................389 


\section{LISTA DE FIGURAS}

Figura 1- Pesquisa - um processo iterativo (adaptado de EMMITT, 2002) ..............12

Figura 2 - Condução do estudo de caso (MIGUEL, 2007) …...............................13

Figura 3 - Tipos de empreendimento de construção considerados segundo o agente

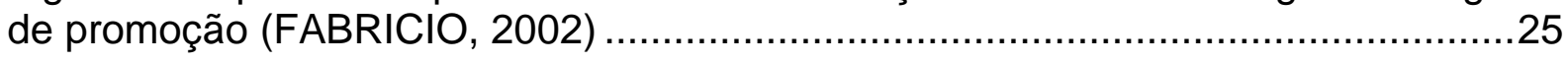

Figura 4 - Modelo genérico proposto para sistemas contratuais (GRILO, 2002)......28

Figura 5 - Estrutura de contrato convencional (adaptado de GRISHAM;

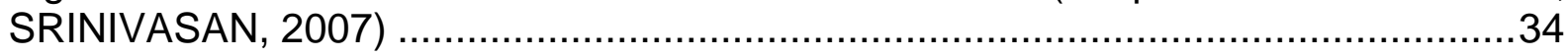

Figura 6 - Fluxo do conhecimento (adaptado de GRISHAM; SRINIVASAN, 2007)...35

Figura 7 - Processo de desenvolvimento tradicional de empreendimentos de

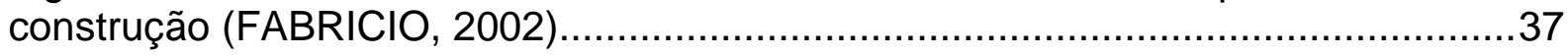

Figura 8 - Etapas de concepção do empreendimento de construção (FABRICIO, 2002).

Figura 9 - Modelo simplificado do processo de construção (adaptado de KAMARA et al., 2002)

Figura 10 - O processo de projeto de edificações (ROMANO, 2003).

Figura 11 - O ciclo de vida total de um ativo do edifício (adaptado de VAKILIARDEBILI; BOUSSABAINE, 2007)

Figura 12 - Fluxo de valor do Projeto no ciclo de vida do edifício (adaptado de VAKILI-ARDEBILI; BOUSSABAINE, 2007).

Figura 13 - Envolvimento dos agentes ao longo do processo de produção (GRILO, 2002).....

Figura 14 - Lacunas nos serviços ao longo do ciclo de vida do empreendimento (GRILO, 2002).

Figura 15 - Gestão do projeto arquitetônico no ciclo de vida do projeto (adaptado de EMMITT, 2002) 46

Figura 16 - Modelo de estágios de transformação de uma organização (adaptado de CHAKRAVARTHY; MCEVILE, 2007) . 47

Figura 17 - Definindo a cadeia de valor: Incorporação Imobiliária (PORTER, 2008) 50 Figura 18 - Renovação contínua (adaptado de CHAKRAVARTHY, 1996 apud CHAKRAVARTHY; MCEVILE, 2007) . .52

Figura 19 - A evolução para a situação ideal (PRADO; ARCHIBALD, 2010). .54

Figura 20 - Evolução da maturidade da área de negócios da construção comparada com geral (PRADO; ARCHIBALD, 2010).

Figura 21 - Engenharia Sequencial x Engenharia Simultânea (FABRICIO, 2002) ....56

Figura 22 - Comparação do desenvolvimento de produto em engenharia sequencial e em engenharia simultânea (FABRICIO, 2002) .

Figura 23 - Visão FIATECH-CPTR (adaptado de SHEN et al., 2010)..... 
Figura 24 - Itens da Prioridade H da Agenda de Pesquisa Estratégica do ECTP http://www.ectp.org/ (adaptado de SHEN et al., 2010)...

Figura 25 - Capacidade de influenciar o custo final de um empreendimento de edifício ao longo de suas fases (CII, 1987 apud MELHADO, 1994).

Figura 26 - $O$ avanço do empreendimento em relação à chance de reduzir o custo de falhas do edifício (HAMMARLUND; JOSEPHSON, 1992)

Figura 27 - Relação situação de maior "investimento" na fase de projetos X práticas convencionais (BARROS; MELHADO, 1993 apud MELHADO, 1994) …..................66

Figura 28 - Incorporando opinião (adaptado de EMMITT, 2002). 76

Figura 29 - Proposta de estruturação para a equipe multidisciplinar envolvida no desenvolvimento do projeto (MELHADO, 1994) .................................................78

Figura 30 - Problemas que ocorrem com mais frequência nos Projetos da Organização (PMI, 2010)

Figura 31 - Comunicação entre os diferentes agentes da construção (adaptado de EMMITT, 2002) 91

Figura 32 - Construção integrada (FARIA, 2011)

Figura 33 - O BTC inserido no Sistema de Qualidade de uma empresa incorporadora e construtora (FONTENELLE, 2002). 100

Figura 34 - Perda da estratégia genérica em função da carência de programação estratégica. (BROWN, 2001). 108

Figura 35 - Espiral do conhecimento (NAKAMORI, 2003 apud LÊ, BRøNN, 2007)114 Figura 36 - Duas rotas de transferência de conhecimento entre Projetos (adaptado de JEON, 2009).

Figura 37 - Processos de aprendizagem e gestão do conhecimento das proposições de perspectiva cognitiva (NAKANO; FLEURY, 2005)

Figura 38 - Dimensões da gestão do conhecimento (adaptado de JASHAPARA, 2004 apud CARRILO; CHINOWSKY, 2006) ...

Figura 39 - Ponte da gestão do conhecimento (adaptado de AMIN et al., 2001 apud LÊ, BRøNN, 2007). 126

Figura 40 - Processos essenciais da gestão do conhecimento (PROBST; RAUB; ROMHARDT, 2002 apud MATOS et al., 2008) 130

Figura 41 - Áreas definidas para a gestão do conhecimento (MERTINS; HEISIG; VORBECK, 2003 apud SANTOS; NETO, 2008) 131

Figura 42 - Principais processos de retroalimentação (adaptado de LÊ, BRØNN, 2007)

Figura 43 - Um modelo integrado de aprendizado organizacional (adaptado de KIM, 1993 apud LÊ, BRØNN, 2007)

Figura 44 - Estrutura de Gestão de Projetos e Competências do Sistema de Engenharia da NASA (adaptado de NASA, 2011)

Figura 45 - Aprendizagem ao longo dos empreendimentos (adaptado de BROWN, 2001) 
Figura 46 - Barreiras para implantação da gestão do conhecimento por nível de importância (adaptado de CARRILLO, 2004)... 158

Figura 47 - Propostas de gerações da gestão do conhecimento no setor da engenharia e construção (adaptado de REZGUI; HOFPE; VORAKULPIPAT, 2010)

Figura 48 - Estrutura organizacional da Empresa A........................................169

Figura 49 - Ciclo de vida do produto (PARDINI, 2010)..................................172

Figura 50 - Foto da obra no dia da visita.........................................................183

Figura 51 - Perspectiva do edifício..........................................................183

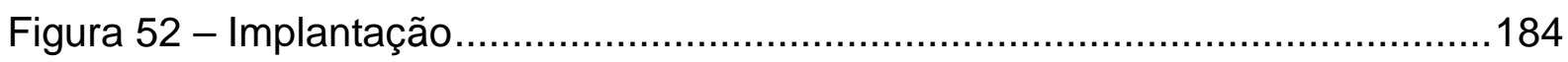

Figura 53 - Planta do pavimento tipo.................................................... 184

Figura 54 - Organograma da obra ......................................................... 188

Figura 55 - Dimensões estratégicas da Empresa B ........................................235

Figura 56 - Estrutura organizacional da Empresa B: Estrutura Nuclear .................237

Figura 57 - Dimensões Estratégicas x Células de Processos (VILLA; SARTORELLI,

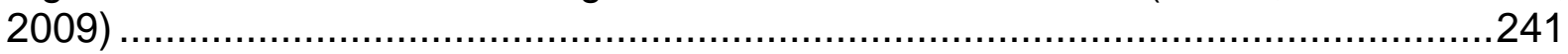

Figura 58 - Organização matricial do PRqd (VILLA; SARTORELLI, 2009) .............242

Figura 59 - Células de Processos (VILLA; SARTORELLI, 2009) ..........................245

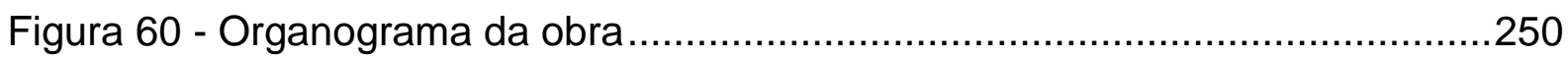

Figura 61 - Modelo de trabalho do PRqd (VILLA; SARTORELLI, 2009) .................266

Figura 62 - Estrutura organizada por Projetos (KOWALEWSKI, 2008) ..................278

Figura 63 - Ciclo de vida do empreendimento (KOWALEWSKI, 2008) .................279

Figura 64 - Processo principal do negócio ao longo do ciclo de vida do empreendimento (adaptado de KOWALEWSKI, 2004) .....................................280

Figura 65 - Estrutura de documentação do Management System (KOWALEWSKI,

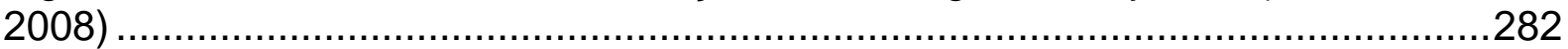

Figura 66 - Processo principal do negócio ao longo do ciclo de vida do

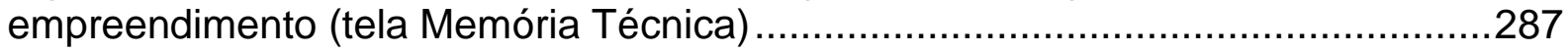

Figura 67 - Fotomontagem do empreendimento (MAGALHÃES, 2008) .................291

Figura 68 - Planta pavimento tipo com área de 1.600 m2 (MAGALHÃES, 2008)...291

Figura 69 - Foto da implosão do edifício existente no terreno (SILVA, 2008) .........293

Figura 70 - Corte longitudinal ao terreno (MAGALHÃES, 2008) ...........................294

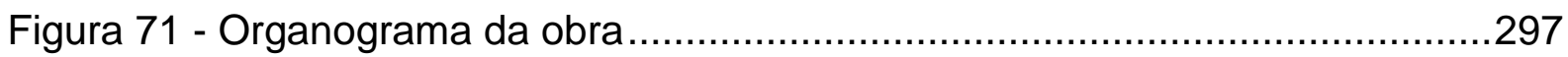

Figura 72 - Datas de contrato das entregas parciais da obra e datas de conclusão

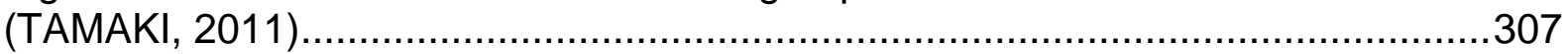

Figura 73 - Banheiro pronto chegando à obra (GARCIA, 2010) ...........................309

Figura 74 - Dinâmica Operacional (KOWALEWSKI, 2008) ..................................318 
Figura 75 - Comparativo de fluxo de valor do projeto com atuação da construtora a partir da fase de Desenvolvimento dos projetos ou apenas na fase de Execução da Obra .

Figura 76 - Requisitos do projeto. 357

Figura 77 - Projetos (empreendimentos) de segmentos diversos realizados pela construtora e interação entre agentes. 359

Figura 78 - Fluxos de transferência do conhecimento: entre Projetos 1, 2, 3 e 4 (empreendimentos), entre fases do ciclo de vida do Projeto, entre empresas e agentes

Figura 79 - Processos de aprendizagem e gestão do conhecimento em empresa construtora no desenvolvimento de empreendimentos imobiliários

Figura 80 - Aspectos fundamentais para eficácia do processo de projeto e sucesso na transferência de conhecimento 


\section{LISTA DE QUADROS}

Quadro 1 - Base bibliográfica para estruturação e análise dos estudos de caso .......6 Quadro 2 - Funcionários entrevistados (unidades de coleta de dados)......................9

Quadro 3 - Empreendimentos analisados em cada estudo de caso ......................10 Quadro 4 - Questões da pesquisa em relação às fases do ciclo de vida do

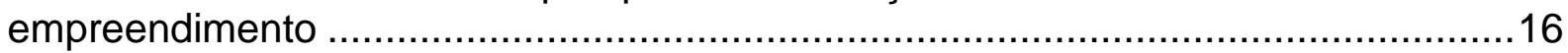

Quadro 5 - Arranjos funcionais das equipes de projeto e construção (GRILO, 2002) 32

Quadro 6 - Possibilidade de interação entre coordenação de projetos e execução de obras (adaptado de MELHADO et al., 2005). .57

Quadro 7 - Problemas e Oportunidades - Temas prioritários do CIB - IDS Integrated Design Solutions - Solução Integrada de Projeto (adaptado de KOKKALA, 2009) ...61

Quadro 8 - Vantagens e desvantagens de diferentes agentes como representantes do cliente (GRILO, 2002)

Quadro 9 - Vantagens e desvantagens conforme o perfil do coordenador de projetos (FABRICIO, 2002) .86

Quadro 10 - Deficiências no processo de projeto e impacto na gestão da obra (GRILO, 2002). 106

Quadro 11 - Proposições de perspectiva construtivista (NAKANO; FLEURY, 2005) 119

Quadro 12 - Resultados da pesquisa sobre principais atividades da gestão do conhecimento (adaptado de MERTINS; HEISIG; VORBECK, 2003) ..

Quadro 13 - Rompimento de aprendizado da OADI (observe-assess-designimplement) - SMM (shared mental model) relacionada à indústria da construção (adaptado de LẾ; BRØNN, 2007)...............................................................141

Quadro 14 - Funcionários entrevistados da Empresa A.....................................183

Quadro 15 - Descrição do empreendimento estudo de caso Empresa A................184

Quadro 16 - Funcionários entrevistados da Empresa B (unidade de coleta de dados) 248

Quadro 17 - Descrição do empreendimento do estudo de caso Empresa B...........248

Quadro 18 - Funcionários entrevistados da Empresa C........................................290

Quadro 19 - Descrição do empreendimento do estudo de caso da Empresa C......292

Quadro 20 - Lideranças à frente das iniciativas de gestão do conhecimento das

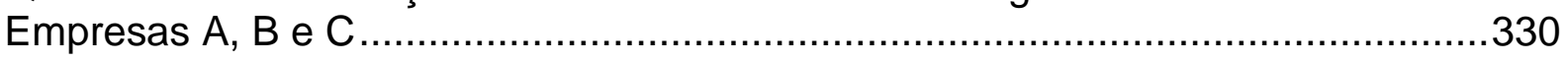

Quadro 21 - Missão e visão das Empresas A, B e C ……..................................330

Quadro 22 - Ferramentas e práticas associadas à gestão do conhecimento identificadas nas Empresas A, B e C .............................................................33 
Quadro 23 - Fatores que impactam a gestão do conhecimento, levantados nas

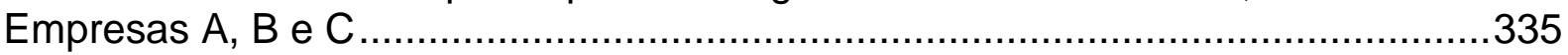

Quadro 24 - Ciclo de vida dos negócios das Empresas A, B e C comparado ao ciclo

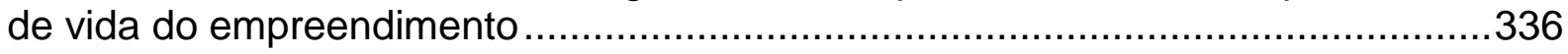

Quadro 25 - Práticas associadas à gestão do conhecimento identificadas na fase de Planejamento do Empreendimento nas Empresas A, B e C 338

Quadro 26 - Práticas associadas à gestão do conhecimento identificadas na fase de Desenvolvimento do projeto nas Empresas A, B e C 340

Quadro 27 - Práticas associadas à gestão do conhecimento identificadas na fase de Execução da obra nas Empresas A, B e C 344

Quadro 28 - Práticas associadas à gestão do conhecimento identificadas na fase de Operação e Manutenção nas Empresas A, B e C. 346

Quadro 29 - Agentes envolvidos e iniciativas de gestão do conhecimento aplicadas ao ciclo de vida do empreendimento nas Empresas A, B e C 348

Quadro 30 - Barreiras encontradas pelas empresas no decorrer da implantação de suas iniciativas de gestão do conhecimento e detectadas no estudo de caso. 353

\section{LISTA DE TABELAS}

Tabela 1 - Resumo das características das empresas analisadas. Dados extraídos do Ranking 500 da Engenharia Brasileira da revista O Empreiteiro (2010)

Tabela 2 - Grau de envolvimento da empresa nas obras em andamento (1 $1^{\underline{a}}$ quinzena de abril/2011) (Pessotto; Simões; Villa, 2011). 


\section{LISTA DE ABREVIATURAS E SIGLAS}

AAR

ABNT

APO

APPEL

APQC

AQUA

AsBEA

BIM

BNDES

BOT

BTC

CAD

CBIC

CD

CIB

CII

CPTR

EAV

EBITIDA

ECTP

EPC

EPCM

ERP
After Action Review

Associação Brasileira de Normas Técnicas

Avaliações de Pós-Ocupação

Academy of Programe-Project and Engineering Leadership

American Productivity \& Quality Center

Alta Qualidade Ambiental

Associação Brasileira dos Escritórios de Arquitetura

Building Information Modeling

Banco Nacional de Desenvolvimento Econômico e Social

Build-Operate-Transfer

Banco de Tecnologia Construtiva

Computer Aided Design

Câmara Brasileira da Indústria da Construção

Compact Disk

Conseil International du Bâtiment

Construction Industry Institute

Capital Projects Technology Roadmap

Engenharia e Análise de Valor

Earnings Before Interest Taxes Depreciation Amortization

European Construction Technology Plataform

Engineering, Procurement and Construction

Engineering, Procurement, Construction and Management

Enterprise Resource Planning 
FIATECH

FINEP

FM

GE

IDS

IPI

ISO

LEED

NASA

NBR

NSC

PAC

PEO

PIB

PIO

PMBoK

PMG

PMI

PMO

PPMI

PSPP

SADP

SIG

SSMA

TI
Fully Integrated and Automated TECHnology

Financiadora de Estudos e Projetos

Facilities Managagement

General Eletric

Integrated Design Solution

Imposto Sobre Produtos Industrializados

International Standardization Organization

Leadership in Energy and Environmental Design

National Aeronautics and Space Administration

Norma Brasileira

Núcleo de Sistemas Construtivos

Programa de Aceleração do Crescimento

Preparação de Execução de Obras

Produto Interno Bruto

Process Improvement Opportunities

Project Management Book of Knowledge

Preço Máximo Garantido

Project Management Institute

Project Management Office

Program and Project Management Initiative

Projeto Simultâneo do Produto e de sua Produção

Sistema de Armazenamento de Dados de Projeto

Sistema Integrado de Gestão

Saúde, Segurança e Meio Ambiente

Tecnologia da Informação 


\section{INTRODUÇÃO}

\subsection{Justificativa}

A implantação de um empreendimento imobiliário demanda dois tipos complementares e inter-relacionados de competências: a gestão da produção e a gestão do empreendimento. A gestão da produção, de acordo com Fabrício (2002), trata de processos e práticas de trabalho que admitem a repetição ou reprodução, como na indústria seriada, enquanto o empreendimento pode ser caracterizado como um Projeto ${ }^{1}$ único, temporário e multidisciplinar com características próprias que exige uma gestão específica.

Frente ao mercado cada vez mais competitivo e em constante mutação, com empreendimentos cada vez mais complexos e diversos agentes envolvidos para sua viabilização, Vargas (2009) identifica uma mudança de postura das construtoras em busca de um diferencial de mercado. Com seu campo de atuação, antigamente restrito às atividades relacionadas à produção do edifício, as construtoras vêm atuando como integradoras de negócios e de conhecimento ao agregar novas atividades em seu escopo de serviço, como por exemplo, a gestão do processo de projeto e a engenharia de valor.

A crescente concorrência no setor impulsionou as construtoras a buscar estratégias para estabelecer práticas de gestão que possibilitem acompanhar as mudanças do ambiente, agregando valor aos negócios atuais e inovando com novos negócios. Além de desenvolver metodologias e aplicar práticas de gestão de projetos, um aspecto fundamental a ser explorado pelas construtoras para melhorar seu

\footnotetext{
1 termo projeto será utilizado para indicar os produtos técnicos gerados pelos projetistas (desenhos, especificações, detalhes, modelos), assim como a atividade criativa em busca de soluções ótimas de produtos técnicos, diferenciando-o do Projeto (esforço temporário empreendido para criar um produto, serviço ou resultado exclusivo). Assim, a gestão do Projeto (relacionado ao empreendimento), consiste no desenvolvimento de um grupo de atividades coordenadas e controladas com limitações de tempo, custo e recursos (PMI, 2008), que engloba a gestão do processo de projeto, da produção, de suprimentos, entre outros.
} 
desempenho e aumentar sua competitividade é a gestão do conhecimento (ICHIJO; NONAKA, 2007).

No setor da construção, a gestão do conhecimento está relacionada à construtibilidade, gestão de suprimentos/ fornecedores e gestão do processo de projeto (CARRILLO; CHINOWSKY, 2006). A importância do processo de projeto na gestão do conhecimento deve-se ao fato deste processo permear todo processo desde a estruturação do empreendimento até a construção da edificação, iniciando no planejamento, passando pela elaboração dos projetos do produto (edificação) e dos projetos para produção (projetos detalhados para execução), pela execução da obra, estendendo-se até a fase de uso e manutenção (MELHADO, 1994; KAMARA et al., 2002; EMMITT, 2002; ROMANO, 2003; VAKILI-ARDEBILI; BOUSSABAINE, 2007).

Conforme citado em Jo et al. (1993) apud Romano (2003), decisões na fase de projeto podem influenciar todo o ciclo de vida do empreendimento, onde 80 ou $90 \%$ do custo do ciclo de vida do produto é determinado durante a fase do projeto. Ao mesmo tempo, cerca de $40 \%$ de todos os problemas de qualidade podem ser associados a projetos deficientes e de $35 \%$ a $50 \%$ de falhas em edifícios tem origem no processo de projeto.

As deficiências nesta fase, decorrentes de decisões erradas ou falta de decisões (CORNICK, 1991 apud FONTENELLE, 2002) são apontadas como maiores responsáveis por patologias nas construções (PICCHI, 1993). Na fase de elaboração dos projetos são tomadas várias decisões por parte do empreendedor, principalmente relacionadas aos aspectos mercadológicos envolvidos, como por exemplo: definições de produto, equipamentos e ambientes, especificação de materiais, de sistemas prediais e relativos à tecnologia construtiva, que podem afetar diretamente a fase de produção e posteriormente de manutenção, assim como no custo total do empreendimento (CARRILLO; CHINOWSKY, 2006).

$\mathrm{Na}$ atual economia, as pessoas não são mais vistas como fornecedoras de mão-deobra, mas de conhecimento (CHIAVENATO, 2004). Este conhecimento deve ser gerenciado possibilitando agregar valor ao negócio, à empresa e ao cliente. Neste cenário, as empresas bem sucedidas são as que sabem conquistar e motivar as pessoas a aprender e aplicar seus conhecimentos na solução de problemas e na busca de inovações, além de disseminar o conhecimento corporativo entre todos 
membros da organização. A fase de projeto é a principal porta de entrada para a implementação sistêmica de inovações tecnológicas no setor da construção, introduzindo ganhos de produtividade (BARROS, 1996).

Para uma empresa existem três formas principais de criação de valor: a dominação pelos custos, a diferenciação e a focalização (PORTER, 1989). Com empreendimentos de caráter exclusivo, com projetos e requisitos cada vez mais específicos, o domínio e disseminação do conhecimento em engenharia deveriam ser explorados pelas construtoras como um diferencial competitivo garantindo sua permanência no mercado, além de constituir uma ferramenta para melhoria de desempenho da empresa.

A função de gestor do processo de projeto, antes exercida pelo arquiteto-autor do projeto, tem sido conduzida por gerenciadoras e, em muitos casos, por construtoras, que têm desenvolvido competências para a gestão do empreendimento como um todo, como estratégia de criação de valor para seus clientes e diferencial competitivo, não se limitando apenas à gestão do processo de produção da edificação. No caso de empresas construtoras e construtoras-incorporadoras, esta gestão pode envolver desde o planejamento da operação imobiliária, administração dos contratos, controle físico e financeiro, aprovações legais, até a gestão do processo de projeto da edificação, entre outros.

Romano (2003) destaca que, apesar do número de construtoras engajadas em programas de qualidade, muitas empresas não estão preparadas para a gestão do processo de projeto da edificação, e continuam a conduzir esta atividade sem uma estrutura organizacional adequada, conservando práticas que são a causa de muitos problemas no processo construtivo como um todo. A gestão do processo de projeto da edificação muitas vezes é conduzida apenas para controle das entregas dos projetos. No entanto, sua abrangência é mais ampla, envolvendo o planejamento do processo de projeto, gestão das informações (armazenamento e transmissão), documentação final do produto (projeto) e, principalmente, garantia da integração de todos os agentes envolvidos no processo.

Neste cenário, é importante avaliar quais são as competências necessárias para o profissional responsável pela gestão do processo de projeto (TZORTZOPOULOS; COOPER, 2007). De acordo com Press; Cooper (2002) apud Tzortzopoulus; Cooper (2007) há pouca ênfase nas pesquisas sobre o papel da construtora na gestão do 
processo de projeto e quais as barreiras encontradas. Os estudos de caso terão como objetivo observar como é conduzido este processo em construtoras, que conquistaram um posicionamento no mercado, caracterizadas por conduzir empreendimentos de caráter exclusivo.

Fabricio (2002) ressalta que grande parte das empresas que desenvolvem os projetos são de organizações distintas, com diferente formação e experiência, que muitas vezes nunca trabalharam juntas, o que pode ocasionar incompatibilidade entre projetos por problemas de compreensão e requisitos de projeto.

Apesar da natureza específica de cada Projeto, as empresas têm a necessidade de transferir e disponibilizar o conhecimento de Projeto para Projeto. No entanto, ao término dos Projetos o conhecimento acumulado ao longo do processo é registrado nos próprios documentos do Projeto, mas o conhecimento não documentado, na maioria das vezes, não é incorporado pelas empresas que participaram de todo processo por falta de processos de gestão deste conhecimento (KAMARA et al., 2002; KAMARA; ANUMBA; CARRILLO, 2009).

A falta de um sistema de captura e transferência do conhecimento gerado em um Projeto para outro, pode gerar retrabalho ou repetição de erros que prejudicam o desempenho da empresa como um todo. Frequentemente, ao término dos Projetos, todas as informações e conhecimento gerado são perdidos ou arquivados de forma indevida por causa da mudança das pessoas envolvidas para outros Projetos ou falta de um processo de gestão do conhecimento ou um responsável designado para este fim (CARRILLO; ANUMBA; KAMARA, 2000).

No entanto, apenas processos bem definidos, com um inter-relacionamento adequado, bem gerenciados e alinhados à estratégia organizacional não garantem que as organizações alcancem seus objetivos. É necessária uma análise de como os processos de gestão do conhecimento estão estruturados: a forma de organização, transmissão e utilização do conhecimento ao nível dos processos e entre os processos (TERRA, 2009).

Outro desafio da gestão do conhecimento na construção é a transferência do conhecimento entre as diferentes fases de um Projeto, como por exemplo, transferir conhecimento das necessidades de negócio dos clientes em especificações técnicas ou transferir a intenção e lógica do projeto para a equipe de construção. 
Kamara et al. (2002) destacam a importância da gestão do conhecimento entre Projetos e entre as empresas envolvidas no desenvolvimento do empreendimento, abrangendo além da fase de produção do edifício, todas as fases do ciclo de vida. $\mathrm{O}$ envolvimento de múltiplas empresas em um Projeto significa que a transferência de conhecimento de um estágio para o próximo depende muito do tipo de estratégia de suprimentos ou tipo de contrato adotado para o Projeto (MC CARTHY et al., 2000 apud KAMARA, 2002).

A transferência de conhecimento que ocorrer dentro de cada fase do Projeto, entre as fases de um Projeto ou entre diferentes Projetos representa um potencial para melhoria do desempenho dos Projetos através de uma transferência de aprendizado eficiente e eficaz (CARRILLO, 2005; LÊ, BRØNN, 2007). O grupo de pesquisa de gestão do conhecimento na indústria da construção da Universidade de Loughborough (prof. Chimay J. Anumba, prof. Patricia M. Carrillo) no Reino Unido desenvolve trabalhos com equipes das Universidades de Glasgow Caledonian (prof. Charles O. Egbu), Universidade Newcastle (prof. John M. Kamara), Universidade London South Bank (prof. Herbert S. Robinson), além de Universidade Calgary no Canadá, Universidade do Colorado, EUA, Universidade Stanford, EUA entre outros.

A colaboração entre as equipes e o compartilhamento de conhecimento no setor da construção são apontados como prioridade em diversos grupos de pesquisa para minimizar estruturas e processos ineficientes e aumentar $O$ valor agregado ao projeto, obra e operação, e entre Projetos (KOKKALA, 2009; RATH, 2010; SHEN et al., 2010).

Destacam-se algumas referências da literatura, no Quadro 1, que abordam temas relacionados à gestão de projeto, integração projeto-produção e gestão do conhecimento na construção utilizados como base para estruturação e análise dos estudos de caso.

\begin{tabular}{|c|c|}
\hline Temas & Literatura \\
\hline $\begin{array}{l}\text { Integração } \\
\text { produção }\end{array}$ & $\begin{array}{l}\text { MELHADO, 1999; MELHADO, 2001; FABRICIO, 2002; } \\
\text { FONTENELLE, 2002; GRILO, 2002; ROMANO, 2003; } \\
\text { MELHADO et al., 2005; TZORTZOPOULOS; COOPER, } \\
\text { 2007; KOKKALA, 2009; SHEN et al., 2010 }\end{array}$ \\
\hline 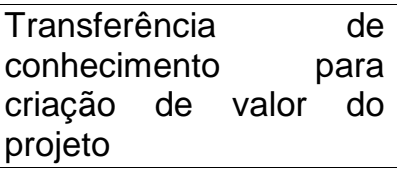 & $\begin{array}{l}\text { TIWANA, } 2000 \text { apud CARRILLO; CARRILLO; ANUMBA; } \\
\text { KAMARA, 2000; GRILO, 2002; CARRILLO, CHINOWSKY, } \\
\text { 2006; CHAKRAVARTHY; MCEVILE, 2007; OTTER; LÊ, } \\
\text { BRØNN, 2007; VAKILI-ARDEBILI; BOUSSABAINE, 2007; }\end{array}$ \\
\hline
\end{tabular}




\begin{tabular}{|c|c|}
\hline & EMMITT, 2008; JEON, 2009; BAKKER et al., 2011 \\
\hline $\begin{array}{lrr}\text { Comunicação } & \text { e } \\
\text { colaboração entre } & \text { as } \\
\text { equipes } & \text { e } & \text { o } \\
\text { compartilhamento } & \text { de } \\
\text { conhecimento } & \end{array}$ & $\begin{array}{l}\text { EMMITT, 2002; GRISHAM; WALKER, 2005; GRISHAM; } \\
\text { SRINIVASAN, 2007; KOKKALA, 2009; SENARATNE; } \\
\text { SEXTON, 2009; SUN; MENG, 2009; RATH, 2010; SHEN et } \\
\text { al., 2010; REZGUI; HOFPE; VORAKULPIPAT, } 2010\end{array}$ \\
\hline $\begin{array}{l}\text { Estratégia de gestão do } \\
\text { conhecimento } \\
\text { barreiras encontradas }\end{array}$ & $\begin{array}{l}\text { KAMARA; ANUMBA; CARRILLO, 2004; BROWN, 2001; } \\
\text { ROBINSON et al., 2001; KAMARA et al., 2002; CARRILLO } \\
\text { et al., 2004; EGBU, 2004; CARRILLO; CHINOWSKY, 2006; } \\
\text { CHAKRAVARTHY; MCEVILE, 2007; KAMARA; ANUMBA; } \\
\text { CARRILLO, } 2009\end{array}$ \\
\hline
\end{tabular}

Quadro 1 - Base bibliográfica para estruturação e análise dos estudos de caso

\subsection{Questão da pesquisa}

Partindo-se do pressuposto de que o projeto, por estar associado a uma linha de tomada de decisões, é um elemento estratégico que pode influenciar diretamente o processo de produção, assim como todos processos a ele relacionados (orçamento, suprimentos, planejamento, etc) e a gestão do conhecimento pode ser explorada para melhorar o desempenho e aumentar a competitividade das construtoras, a gestão do conhecimento no processo de projeto tem cada vez mais relevância. Foi levantada como questão principal para estabelecer a estratégia da pesquisa:

Como é gerenciado o conhecimento em empresas construtoras durante o ciclo de vida do empreendimento e sua aplicação no processo de projeto de novos empreendimento?

\subsection{Objetivos}

\subsubsection{Objetivo Geral}

A pesquisa tem como objetivo identificar práticas associadas à gestão do conhecimento utilizadas por empresas construtoras e analisar sua influência no processo de projeto, destacando as práticas aplicadas à transferência de conhecimento entre os processos de projeto e de produção, e no desenvolvimento de novos projetos. 


\subsubsection{Objetivos Específicos}

Como desdobramento do Objetivo Geral e para nortear os estudos de caso, foram estabelecidos os seguintes objetivos específicos:

- Identificar qual a atuação da empresa no processo de projeto em cada fase do ciclo de vida do empreendimento e a integração entre as fases;

- Verificar a existência de estratégias, processos, ferramentas ou técnicas específicas para gestão do conhecimento. Identificar os conceitos relativos à criação, registro e disseminação do conhecimento aplicados ao processo de projeto. Como a experiência das pessoas (conhecimento tácito) é compartilhada e transformada em conhecimento organizacional;

- Verificar a influência das mudanças no processo de projeto no decorrer do ciclo de vida do empreendimento. Como são conduzidas e incorporadas das mudanças não planejadas no processo de projeto e durante a fase de construção. Como o conhecimento gerado e compartilhado entre a equipe, decorrente das mudanças, é transmitido e armazenado para Projetos futuros;

- Identificar como se relacionam os agentes do empreendimento (fornecedores, clientes, empreendedor, projetistas, consultores, gerenciadora, construtora) e qual sua influência e atuação no processo de projeto. Meios e ferramentas de comunicação e tecnologia da informação utilizados.

\subsection{Delimitação da pesquisa}

A pesquisa delimita-se a estudos de caso em empresas construtoras, líderes do mercado da construção com sede na cidade de São Paulo, em que foram identificadas iniciativas de gestão do conhecimento, através de consulta a sites de empresas de construção e periódicos do setor.

A definição das três empresas utilizadas como unidades de análise para os estudos de caso levou em consideração a similaridade em relação a alguns aspectos quanto: ao porte da empresa, à área de atuação (com abrangência nacional); ao tempo de atuação no mercado da construção e à consolidação da marca; à construção como atividade principal; ao foco no subsetor de empreendimentos imobiliários para o setor privado; conforme alguns dados da Tabela 1, e à existência de equipes 
dedicadas à coordenação de projetos; à terceirização do desenvolvimento dos projetos; à especialização em obras por encomenda sem projetos repetitivos/ padronizados.

\begin{tabular}{|c|c|c|c|c|c|c|c|c|}
\hline 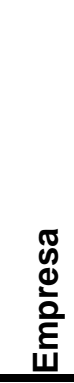 & 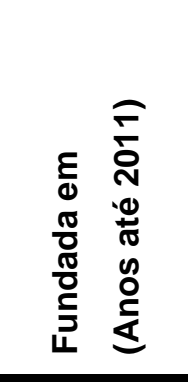 & 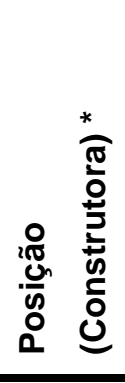 & 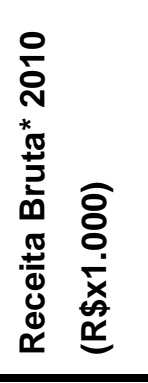 & 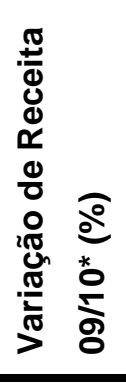 & 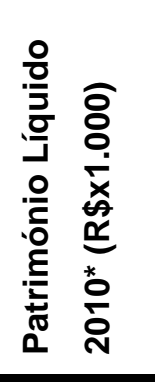 & 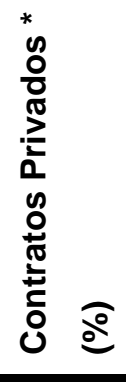 & 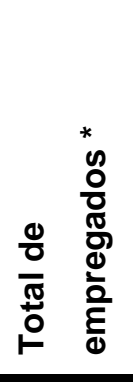 & 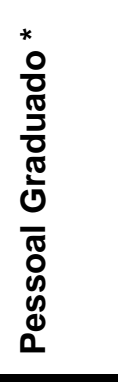 \\
\hline A & $\begin{array}{c}\text { São Paulo } \\
1973 \\
\text { (37 anos) }\end{array}$ & 24 & 755.700 & $14 \%$ & 55.442 & 100 & 292 & 185 \\
\hline B & $\begin{array}{c}\text { São Paulo } \\
1971 \\
\text { (39 anos) }\end{array}$ & 22 & 803.799 & $45 \%$ & 143.044 & 93 & 671 & 216 \\
\hline C & $\begin{array}{c}\text { São Paulo } \\
1966 \\
\text { (44 anos) }\end{array}$ & 34 & 518.092 & $69 \%$ & 12.632 & 91 & 1.382 & 254 \\
\hline
\end{tabular}

Tabela 1 - Resumo das características das empresas analisadas. Dados extraídos do Ranking 500 da Engenharia Brasileira da revista O Empreiteiro (2010)

Foram definidos como unidades básicas de coleta de dados para cada estudo de caso profissionais que, em geral ficam alocados no escritório central da empresa:

- Gerente responsável pela área em que foram identificadas iniciativas de gestão do conhecimento;

- Gerente responsável pela área de projetos da empresa.

Durante as entrevistas com os Gerentes de projeto, foi solicitada a indicação de uma obra de edifício comercial sob encomenda em fase de construção, para coleta de dados em campo, em que foram entrevistados os profissionais com dedicação exclusiva à obra:

- Arquiteto responsável pela coordenação de projetos;

- Engenheiro de Produção (civil ou instalações).

De acordo com o Quadro 2, além das unidades básicas de coleta de dados, no estudo de caso da Empresa A foram acrescidas unidades de coleta de dados relacionadas a iniciativas de gestão do conhecimento, indicadas pela Gerente de 
projetos, Processos e Desenvolvimento. Na obra, a Coordenadora de projetos apontou a influência da certificação LEED no processo de projeto indicando a Engenheira Qualidade e Sustentabilidade responsável pelo acompanhamento deste processo junto à consultoria externa especializada e a Engenheira de Qualidade e Planejamento, responsável pelo registro de lições aprendidas da obra.

\section{Empresa A \\ Empresa B \\ Empresa C}

\begin{tabular}{|c|c|c|}
\hline \multicolumn{3}{|c|}{ Escritório central: áreas com iniciativas de gestão do conhecimento } \\
\hline $\begin{array}{l}\text { Gerente do PMO (Escritório de } \\
\text { Projetos) e Gerente de projetos, } \\
\text { Processos e Desenvolvimento } \\
\text { Iniciativa: implantação do } \\
\text { SMGl/ SharePoint }\end{array}$ & $\begin{array}{l}\text { Gerente de Planejamento do } \\
\text { Núcleo de Gestão Técnica } \\
\text { Iniciativa: implantação do PRqd } \\
\text { (Programa Racional de } \\
\text { qualidade e desempenho) }\end{array}$ & $\begin{array}{l}\text { Gerente de Controlling/ CTE } \\
\text { (Controlling Técnico) } \\
\text { Iniciativa: Controle e otimização } \\
\text { da Memória Técnica }\end{array}$ \\
\hline $\begin{array}{l}\text { Coordenador do NSC (Núcleo } \\
\text { de Sistemas Construtivos) } \\
\text { Iniciativa: gestão de tecnologias } \\
\text { construtivas }\end{array}$ & & \\
\hline $\begin{array}{l}\text { Gerente Assistência Técnica } \\
\text { Iniciativa: Curso de patologias }\end{array}$ & & \\
\hline $\begin{array}{l}\text { Engenheiro de Instalações } \\
\text { Orçamentos } \\
\text { Iniciativa: Engenharia de Valor }\end{array}$ & & \\
\hline
\end{tabular}

Escritório central: área de projetos

\begin{tabular}{l|l|l}
\hline $\begin{array}{l}\text { Gerente Projetos, Processos e } \\
\text { Desenvolvimento }\end{array}$ & $\begin{array}{l}\text { Gerente de projetos do Núcleo } \\
\text { de Engenharia }\end{array}$ & $\begin{array}{l}\text { Gerente de projetos da US } \\
\text { ENG }\end{array}$ \\
\hline Obra & Coordenadora de projetos & Coordenadora de projetos \\
\hline Coordenadora de projetos & & \\
\hline Estagiária de projetos & Engenheiro de Produção & Engenheiro de Produção \\
\hline Gerente de Instalações & & \\
\hline $\begin{array}{l}\text { Engenheira de Qualidade e } \\
\text { Sustentabilidade }\end{array}$ & & \\
\hline $\begin{array}{l}\text { Engenheira Coordenadora de } \\
\text { Planejamento e controle }\end{array}$ & & \\
\hline
\end{tabular}

Quadro 2 - Funcionários entrevistados (unidades de coleta de dados)

Os edifícios analisados, assim como o portfólio geral das empresas, são de obras sob encomenda com projetos exclusivos, não sendo replicados em outros 
empreendimentos, no qual o cliente é uma incorporadora ou o usuário final do setor privado. Os empreendimentos dos três estudos de caso são edifícios comerciais localizados no estado de São Paulo em fase de construção, com meta de obtenção de certificação LEED2, conforme indicado na Quadro 3.

\begin{tabular}{c|l|l}
\hline Empresa & \multicolumn{1}{|c|}{ Empreendimento } & \multicolumn{1}{c}{ Cliente (contratante)/ Gerenciadora } \\
\hline \multirow{4}{*}{ A } & $\begin{array}{l}\text { Edifício comercial de } \\
\text { escritórios de alto } \\
\text { padrão com certificação } \\
\text { LEED }\end{array}$ & $\begin{array}{l}\text { Promotor imobiliário privado (incorporadora brasileira com } \\
\text { investidor americano) responsável pela definição do produto, } \\
\text { incorporação, vendas, contratação dos projetistas e } \\
\text { construtora. A própria incorporadora atua como gerenciadora. }\end{array}$ \\
\hline \multirow{4}{*}{ B } & $\begin{array}{l}\text { Data center para } \\
\text { empresa de } \\
\text { telecomunicações com } \\
\text { atuação internacional } \\
\text { com certificação LEED }\end{array}$ & $\begin{array}{l}\text { Usuário final. Contrato por encomenda, em que os projetistas, } \\
\text { com exceção do arquiteto-autor do projeto, são contratados } \\
\text { pela construtora. A gerenciadora atua como mediadora entre } \\
\text { o cliente e a construtora. }\end{array}$ \\
\hline \multirow{4}{*}{ C } & $\begin{array}{l}\text { Edifício comercial de } \\
\text { escritórios de alto } \\
\text { padrão com certificação } \\
\text { LEED }\end{array}$ & $\begin{array}{l}\text { Promotor imobiliário privado (gestor de fundos imobiliário } \\
\text { brasileiro com investidores estrangeiros) responsável pela } \\
\text { definição do produto, incorporação, vendas, contratação dos } \\
\text { projetistas e construtora. A gerenciadora atua como } \\
\text { mediadora entre o cliente e a construtora. }\end{array}$ \\
\hline
\end{tabular}

Quadro 3 - Empreendimentos analisados em cada estudo de caso

Optou-se por realizar as entrevistas com a equipe de obra dos três estudos de caso no mesmo período de tempo ( $2^{\circ}$ semestre de 2010) para que não houvessem eventuais interferências de fatores do ambiente externos, tais como situação econômica do país, que pudessem interferir nas obras em andamento ou estratégia das empresas.

\footnotetext{
${ }^{2}$ O LEED (Leadership in Energy and Environmental Design) é um sistema de certificação e orientação ambiental de edificações com diferentes categorias (sustentabilidade da localização; eficiência no uso da água; eficiência energética e cuidados com as emissões na atmosfera; otimização do uso de materiais e recursos; qualidade ambiental no interior da edificação) criado pelo USGBC (United States Green Building Council). Para cada categoria, é dada uma determinada pontuação, Silver (Prata), Gold (Ouro) e Platinum (Platina), que varia de acordo com o tipo de edificação e o desempenho do empreendimento.
} 
Além da equipe responsável pela execução das obras, as empresas contam com profissionais da área de projeto (arquitetos e engenheiros), cuja atuação na gestão do processo de projetos varia de acordo com o contrato estabelecido com o cliente.

A concepção e elaboração dos projetos, contratadas pela própria construtora ou pelo cliente, são desenvolvidas por empresas terceirizadas de projeto de organizações distintas.

$\mathrm{Na}$ análise das obras de cada empresa será feito um paralelo levando em consideração as três situações identificadas por Melhado et al. (2005) quanto à possibilidade de interação entre coordenação de projetos e coordenação da execução de obras:

1) Grande interação entre coordenação de projetos e produção: Uma mesma empresa realiza o empreendimento e a obra.

2) Interação entre coordenação de projetos e produção depende do tipo de contratação da empresa: O empreendedor contrata uma construtora após o projeto desenvolvido e o produto definido.

3) Nenhuma interação entre coordenação de projetos e produção: Desenvolvese o projeto executivo ou básico e contrata-se a construtora como empreiteira.

Com base na literatura, serão analisados em cada empresa os principais fatores interdisciplinares que podem impactar na gestão do conhecimento:

- Estrutura Organizacional

- Cultura e Aprendizagem Organizacional

- $\quad$ Sistemas e tecnologias de informação (TI)

- Meios de comunicação entre os agentes

As práticas de gestão do conhecimento identificadas em cada fase do ciclo de vida

\footnotetext{
${ }^{3}$ Data center, também chamados de Centro de Processamento de Dados - CPD, são construções que abrigam as centrais de processamento e armazenamento de dados de empresas, tais como bancos, que exigem sólida segurança do ponto de vista físico e patrimonial com serviço em operação 24 horas por dia (D’AMBROSIO, 2011).
} 
do empreendimento serão classificadas de acordo com os principais processos de aprendizagem e gestão do conhecimento, compilados a partir da revisão bibliográfica:

- Recuperação e Uso do conhecimento

- Criação de novo conhecimento

- $\quad$ Aquisição de conhecimento

- Retenção do conhecimento

- Compartilhamento de conhecimento

\subsection{Metodologia}

Segundo Emmitt (2002), uma pesquisa deve seguir um planejamento, que vai da identificação do escopo da pesquisa, revisão da literatura, definição da metodologia, coleta de dados, análise dos dados, preparação das descobertas, conclusões e recomendações. No entanto, trata-se de um processo iterativo e progressivo, onde as incertezas reduzem ao longo do tempo, que pode ser representado pela pirâmide invertida da Figura 1.

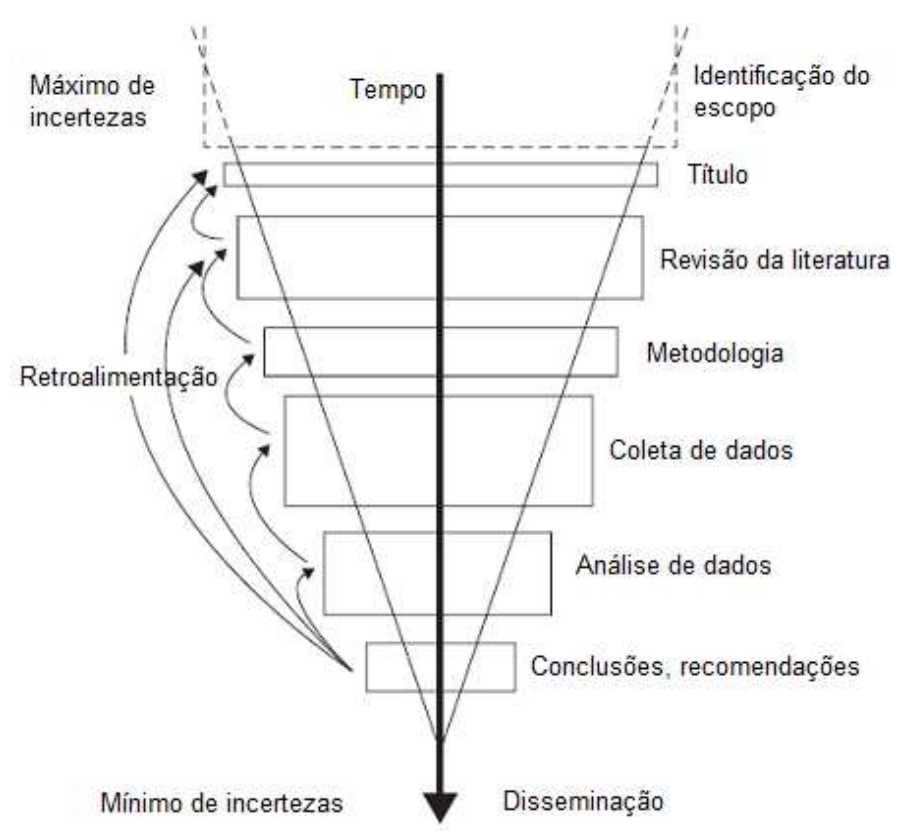

Figura 1- Pesquisa - um processo iterativo (adaptado de EMMITT, 2002)

A metodologia deve descrever como serão coletados e analisados os dados da pesquisa (EMMITT, 2002). 
Para atingir os objetivos do trabalho foi utilizada na pesquisa a metodologia de Estudo de Caso, considerando um estudo de casos múltiplos, baseado na realização de três estudos de casos em empresas construtoras atuantes no setor da construção civil na cidade de São Paulo.

O planejamento e estruturação dos estudos de caso foram baseados em Yin (2001) e Miguel (2007) que sugere a condução do estudo de caso, conforme Figura 2.

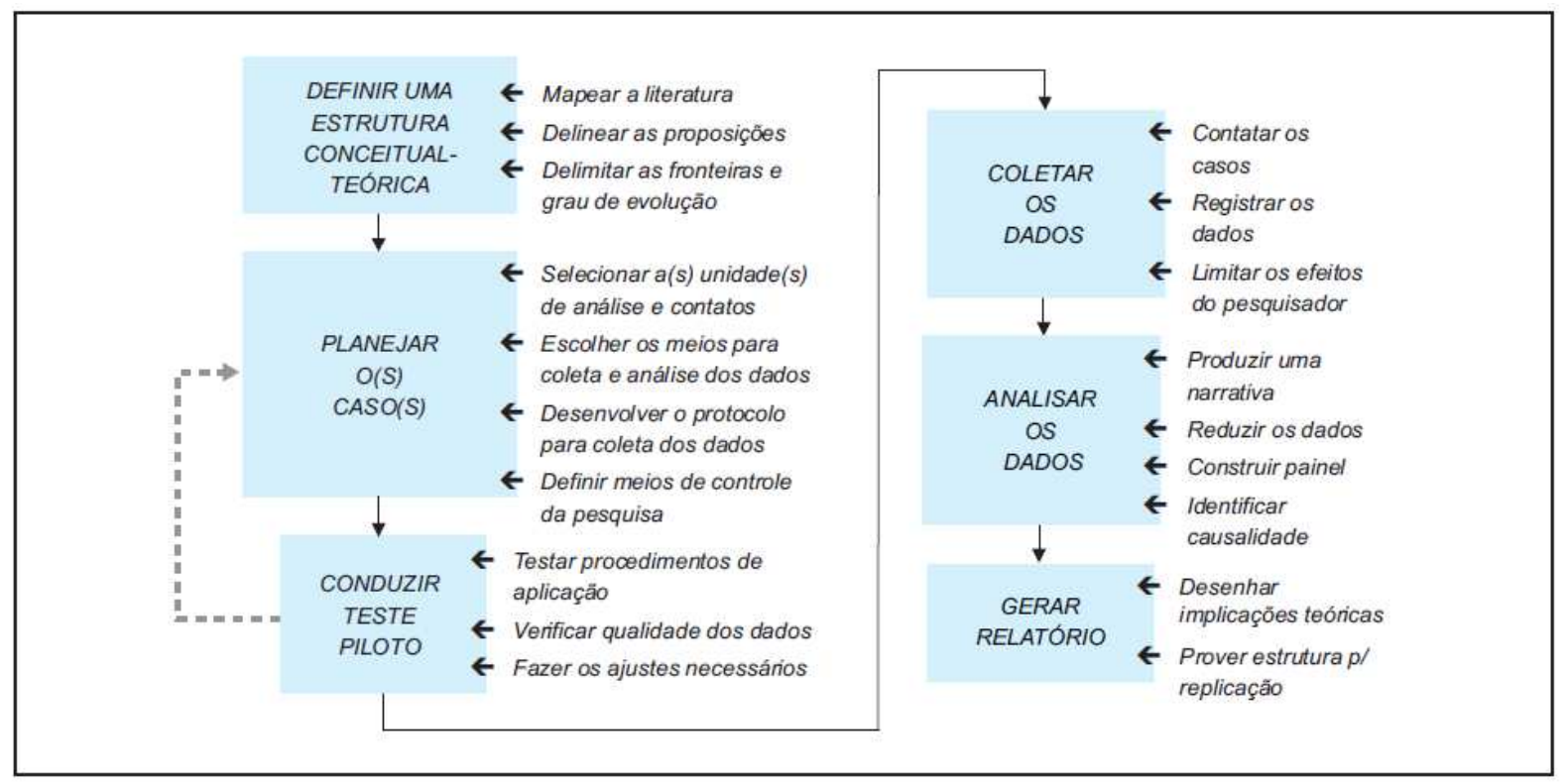

Figura 2 - Condução do estudo de caso (MIGUEL, 2007)

Após a definição da estrutura conceitual-teórica, foi elaborado o Protocolo de Estudo de Caso para orientar e padronizar a linha de investigação, estabelecendo os procedimentos da coleta de dados indicandos abaixo:

- Locais a serem visitados: lista das empresas e os respectivos contatos (fontes de informações)

- Plano de coleta de dados: Agenda das atividades: calendário de visitas, tempo da visita, dados dos entrevistados (informações para contato, cargo, departamento)

- Contato com as fontes de informação: O primeiro contato com a empresa foi realizado para solicitar autorização para o desenvolvimento do estudo de caso. Para esclarecimento foi encaminhada uma carta de apresentação com a visão geral da pesquisa e seus principais objetivos. 
- Unidades de análise: Empresas construtoras atuantes no setor da construção civil da cidade de São Paulo, sendo as unidades de coleta de dados os funcionários envolvidos em iniciativas de gestão do conhecimento e no processo de projeto dos empreendimentos, abrangendo cargos e funções mapeados no organograma da empresa.

- As entrevistas semi-estruturadas foram aplicadas com mais de um colaborador da empresa em um prazo médio de 1,5 hora, sendo a primeira entrevista com o responsável pela gestão dos projetos.

- Fontes de evidência utilizadas neste estudo de caso:

1) Entrevistas semi-estruturadas: com funcionários das empresas de construção envolvidos no processo de projeto e gestão do conhecimento, e outros agentes identificados no decorrer dos estudos de caso que tenham influência sobre este processo. Para coleta de dados e informações para caracterização do processo de projeto praticado pelas empresas (envolvendo o planejamento do projeto, formação da equipe, integração entre os agentes, gestão da documentação técnica), sistemas de gestão e iniciativas de gestão do conhecimento, foi elaborado um Roteiro de Entrevistas Estudo de Caso, que consta no Anexo A, baseado nas referências bibliográficas.

2) Documentação: documentos da empresa que demonstrem seus procedimentos relativos à gestão de projeto e de conhecimento, tais como:

- Normas internas ou manuais de procedimento relacionados à coordenação de projetos e gestão de empreendimentos;

- Modelo de referência de planejamento e controle de progresso dos projetos (atas de reunião, fluxograma do processo de projeto, cronogramas de projeto, relatórios de controle, avaliação de projeto);

- Documentos que demonstrem o fluxo de informações na empresa (controle de documentos e arquivos - padrão, controle, acesso, distribuição);

- Evidências de gestão de conhecimento em sites ou jornais internos da empresa.

O material coletado será utilizado como fonte de evidência buscando linhas convergentes de investigação. A obtenção de informações de diversas fontes de 
dados possibilitará uma triangulação de dados favorecendo a validade do constructo.

3) Observação direta: foram realizadas visitas às obras dos estudos de caso para verificar o organograma da equipe de obra e a interação entre equipe de obra e projeto.

Limites de tempo: foram estabelecidas como limites de tempo da coleta e da análise dos dados as fases do processo de projeto alinhadas ao ciclo de vida do empreendimento, conforme Quadro 4.

\begin{tabular}{|c|c|c|}
\hline Fase & Descrição & Questões \\
\hline $\begin{array}{l}\text { Planejamento do } \\
\text { empreendimento }\end{array}$ & $\begin{array}{l}\text { Fase de início de desenvolvimento de } \\
\text { projetos e estudos de viabilidade, } \\
\text { contratação do arquiteto-autor do } \\
\text { projeto. Nesta fase a construtora } \\
\text { pode ser contratada pelo cliente para } \\
\text { fornecer alternativas de sistemas } \\
\text { construtivos e estimativas de custo da } \\
\text { obra para composição da viabilidade } \\
\text { do negócio ou participar de licitação } \\
\text { para execução da obra baseada em } \\
\text { projetos básicos. }\end{array}$ & $\begin{array}{l}\text { Como são aplicados os } \\
\text { conhecimentos da construtora nos } \\
\text { projetos ou concorrência? Como é a } \\
\text { interação entre projetistas, cliente e } \\
\text { construtora para viabilização do } \\
\text { empreendimento? }\end{array}$ \\
\hline $\begin{array}{c}\text { Desenvolvimento } \\
\text { do projeto }\end{array}$ & $\begin{array}{l}\text { Fase de desenvolvimento de projeto } \\
\text { executivo e detalhamento, revisão de } \\
\text { estimativa de custo da obra. } \\
\text { Contratação da construtora para } \\
\text { execução da obra baseada nos } \\
\text { projetos executivos completos ou } \\
\text { continuidade dos serviços já } \\
\text { contratados na fase de planejamento. }\end{array}$ & $\begin{array}{l}\text { Como é aplicado o conhecimento da } \\
\text { construtora? Quais conhecimentos } \\
\text { podem agregar valor ao projeto? } \\
\text { Como são aplicadas as lições } \\
\text { aprendidas de obras anteriores? } \\
\text { Como é a interação entre a } \\
\text { construtora e os demais agentes? }\end{array}$ \\
\hline $\begin{array}{c}\text { Preparação e } \\
\text { Execução da } \\
\text { Obra }\end{array}$ & $\begin{array}{l}\text { Fase de planejamento e execução da } \\
\text { obra. Arquiteto coordenador de } \\
\text { projetos da obra dá suporte à equipe } \\
\text { de produção e faz a interface com } \\
\text { projetistas, consultores e/ou } \\
\text { gerenciadora para esclarecimento de } \\
\text { dúvidas ou acompanhamento de }\end{array}$ & $\begin{array}{l}\text { Como é a interação entre } \\
\text { coordenação de projetos, projetistas } \\
\text { e equipes de produção da } \\
\text { construtora? Como a experiência } \\
\text { adquirida no dia a dia da obra } \\
\text { (conhecimento tácito) é } \\
\text { compartilhada e transformada em }\end{array}$ \\
\hline
\end{tabular}




\begin{tabular}{|c|c|c|}
\hline & entrega de revisões de projeto. & $\begin{array}{l}\text { conhecimento organizacional? Como } \\
\text { são gerenciadas as mudanças de } \\
\text { projeto durante a execução da obra? } \\
\text { Existe retroalimentação a partir da } \\
\text { obra? }\end{array}$ \\
\hline $\begin{array}{l}\text { Operação e } \\
\text { Manutenção }\end{array}$ & $\begin{array}{l}\text { Fase de entrega da obra: As built e } \\
\text { Pós-obra. Passagem de } \\
\text { responsabilidade da equipe de } \\
\text { produção para a equipe de } \\
\text { assistência técnica da construtora } \\
\text { (atua em caso de patologias) e para } \\
\text { responsáveis pela operação/ } \\
\text { manutenção do cliente. }\end{array}$ & $\begin{array}{l}\text { Existe alguma integração entre } \\
\text { equipe de obra e pós-obra? O } \\
\text { conhecimento adquirido pela equipe } \\
\text { da assistência técnica é aplicado } \\
\text { para novos Projetos (evitar repetição } \\
\text { de erros, retrabalho, desperdício)? } \\
\text { Existe retroalimentação a partir do } \\
\text { uso? }\end{array}$ \\
\hline $\begin{array}{c}\text { Obsolescência e } \\
\text { Reciclagem }\end{array}$ & $\begin{array}{l}\text { Fase onde cessa a criação de valor } \\
\text { ao usuário e pode ser iniciado o } \\
\text { processo de desenvolvimento de um } \\
\text { novo empreendimento através da } \\
\text { renovação, re-uso ou demolição para } \\
\text { construção de novo edifício. }\end{array}$ & $\begin{array}{l}\text { Como são aplicados os } \\
\text { conhecimentos da construtora nesta } \\
\text { fase? }\end{array}$ \\
\hline
\end{tabular}

Quadro 4 - Questões da pesquisa em relação às fases do ciclo de vida do empreendimento

O primeiro estudo de caso denominado "estudo de caso piloto" teve como finalidade aprimorar os planos de coleta de dados, incorporando as lições assimiladas tanto para o projeto de pesquisa quanto para os procedimentos de campo, sendo o critério de seleção inicial a facilidade de acesso à empresa.

Após a realização da coleta de evidências e dados descritivos sobre o caso estudado foram avaliados os seguintes pontos:

- Clareza de formulação e terminologia utilizada nas questões das entrevistas, para verificar a necessidade de reformulação de perguntas que pudessem gerar dúvidas de interpretação ou acréscimo de novas perguntas;

- Quantidade de questões em relação ao tempo disponível dos entrevistados (tempo estimado para cada entrevista: 1,5 hora);

- Procedimento adotado para solicitação de fontes de evidência; 
- Qualidade das informações coletadas (atendem aos principais questionamentos da pesquisa?).

Com base nos pontos levantados, o questionário foi revisado direcionando algumas perguntas de acordo com o a relação do cargo do entrevistado com o processo de projeto e acrescentando algumas questões baseadas nas entrevistas anteriores.

No segundo estudo de caso foi validado o questionário revisado após estudo piloto para aplicação no terceiro estudo de caso.

O terceiro estudo de caso teve como finalidade validar as questões que sofreram alteração além de agregar informações aos estudos de caso anteriores.

A análise comparativa dos estudos de caso múltiplos terá como objetivo estabelecer uma ligação com a teoria vigente possibilitando extrair sólidas conclusões sustentadas com base nas evidências coletadas.

\subsection{Estrutura de apresentação do trabalho}

O trabalho está estruturado em sete capítulos:

O Capítulo 1 apresenta as justificativas para o desenvolvimento do trabalho, as questões que nortearam a pesquisa, os objetivos geral e especifíco, a delimitação da pesquisa e a metodologia utilizada para a coleta e processamento de dados dos estudos de caso.

No Capítulo 2 é feita a caracterização do setor da construção civil no Brasil e os segmentos de atuação com as modalidades de contratação; descrição do ciclo de vida de um empreendimento com abordagem de diversos autores; identificação de estratégias das empresas construtoras para acompanhar as mudanças do ambiente e manter sua vantagem competitiva.

O Capítulo 3 apresenta a revisão da literatura referente ao papel do processo de projeto no ciclo de vida do empreendimento; problemas e deficiências encontradas; agentes e sua influência no processo; a importância da comunicação e a gestão de mudanças no decorrer do processo. 
O Capítulo 4 apresenta a base de conhecimento para conceituar a gestão do conhecimento e indicar a tendência desta gestão nas organizações; estratégias para implementação; a gestão do conhecimento na construção, identificando os esforços e barreiras para sua implementação.

O Capítulo 5 apresenta os estudos de caso nas três empresas pesquisadas com uma análise comparativa dos estudos.

No Capítulo 6 serão apresentadas as conclusões e constatações sobre como as iniciativas voltadas à gestão de conhecimento, aliada à gestão de projetos, podem criar valor e atuar como ativos estratégicos da empresa construtora.

No Capítulo 7 serão apresentadas as considerações finais do trabalho, indicando as contribuições da pesquisa realizada e sugestões para estudos futuros.

E ao final são apresentadas as referências bibliográficas utilizadas na pesquisa. 


\section{Caracterização do setor da construção civil no Brasil}

\subsection{A construção na economia do Brasil}

Com a implantação do Plano Real em 1994, o Brasil inicia um processo de estabilização econômica e, em 2010, passa a ocupar o posto de oitava economia mundial, com um crescimento de $8,4 \%$ nos primeiros nove meses do ano, acompanhado pelo setor da construção civil com $13,6 \%$ de crescimento.

O setor da construção civil tem grande relevância na economia e, de acordo com CBIC (2010), é um importante motor para impulsionar o desenvolvimento do país pelo número de empregos gerados, volume de capital envolvido, renda gerada (responsável por cerca de $43 \%$ dos investimentos nacionais) e pela extensa cadeia produtiva ( $8,3 \%$ do PIB total do país). Dentro da cadeia produtiva da Construção Civil e Indústria de Materiais, a construção tem uma representação de 61,2\%, conforme dados de 2009 da CBIC - Câmara Brasileira da Indústria da Construção.

Com a retomada da crise econômica mundial de 2008, houve um crescimento do mercado consumidor interno e aumento do crédito imobiliário em decorrência da estabilidade econômica, recuperação de renda da população, crescimento do emprego formal e flexibilização das condições de financiamento. A indústria da construção civil no Brasil retomou o forte crescimento no setor público e privado, impulsionada por programas de incentivo à construção residencial (Programa Minha Casa, Minha Vida lançado em 2009), à redução do IPI (Imposto Sobre Produtos Industrializados) sobre materiais de construção, além da realização da Copa do Mundo em 2014 e Olímpiadas em 2016. Apesar do déficit habitacional de mais de 5,5 milhões de moradias, o financiamento imobiliário no Brasil ainda é muito baixo (passou de 1,3\% do PIB em 2004 para 3,7\% do PIB em 2010) se comparado às nações onde corresponde a 50\% do PIB. De 2007 a 2010, o programa do Governo Federal que propiciou a liberação de $\mathrm{R} \$ 559,6$ bilhões (85\% do previsto) em recursos do BNDES - Banco Nacional de Desenvolvimento Econômico e Social e incentivou o investimento privado e público em obras de infraestrutura (transporte, energia, saneamento, habitação e recursos hídricos) foi o Programa de Aceleração 
do Crescimento - PAC 1 e a partir de 2010, o PAC 2 com investimentos em geração e transmissão de energia elétrica, petroléo e gás natural, marinha mercante, combustíveis renováveis, eficiência energética e pequisa mineral (CBIC, 2010; BRASIL, 2011).

Com o crescimento surgem iniciativas para investimentos em inovação, o que foi desestimulado nas décadas de protecionismo, inflação elevada e estagnação econômica da indústria nacional. Para acelerar o processo, analisar e definir diretrizes para o desenvolvimento de inovações tecnológicas na construção civil nacional, a Câmara Brasileira da Indústria da Construção - CBIC cria o Programa Inovação (CBIC, 2010), e o Governo Federal através da FINEP (Financiadora de Estudos e Projetos) apoia as iniciativas de inovação, como Lei da Inovação e Lei do Bem. Esta nova situação permite ao setor da construção obter benefícios com investimento de médio prazo destinados à inovação (AGOPYAN, 2011).

Com a globalização, o mercado aquecido torna-se atrativo para empresas do exterior, atingindo toda cadeia produtiva da construção (AGOPYAN, 2011). No entanto, alguns fatores ainda exercem uma influência negativa no país: carga tributária elevada, escassez de terrenos em grandes centros que elevam seu custo, burocracia excessiva no licenciamento de empreendimentos, rigidez nas regras do mercado de trabalho, maiores taxas de juros reais no mundo, infraestrutura básica (redes de água e esgoto) precária, falta de mão de obra qualificada (CBIC, 2010).

Apesar de ser classificado como indústria da construção, o setor da construção civil apresenta características bem peculiares. Ao contrário das indústrias de manufatura, sua estrutura de produção é deslocada até o local onde o produto, de caráter único e não seriado (edificação), será produzido, e desmontada ao final da obra para entrega do produto ao cliente (VIVANCOS; CARDOSO, 2001; FABRICIO, 2002). Essa produção pode ser executada por uma construtora ou por empresas especializadas na execução de algumas parcelas da obra ou de serviços especializados, como é o caso dos projetos. Outros pontos característicos da construção são: a grande diversidade de agentes intervenientes ao longo do processo de estruturação do empreendimento e construtivo (usuários, responsáveis pelo planejamento do empreeendimento, projetistas, fabricantes de materiais de construção, responsáveis pela excecução da obra, operação e manutenção); requistos de clientes incompletos ou conflitantes; o grande número de decisões e 
interdependências que envolvem o projeto; ineficiência do processo de retroalimentação da produção/ operação para o projeto; utilização de mão de obra intensiva e pouco qualificada; emprego de especificações complexas, muitas vezes conflitantes e confusas; baixo grau de precisão com que se trabalha, entre outros: medidas, orçamentos, prazo (HELENE; SOUZA, 1999; ROMANO, 2003; TZORTZOPOULOS; COOPER, 2007).

O aumento da demanda tem gerado uma preocupação no setor quanto à escassez de materiais, disponibilidade de mão-de-obra para construção, assim como recursos humanos qualificados para as obras e projetos. Para alcançar maior produtividade, as empresas do setor têm buscado inovar em seus canteiros de obra com nova técnicas construtivas, novos materiais, equipamentos, gestão de processos e industrialização, o que impacta na mão de obra que tem que ser mais qualificada. Escritórios de projeto e construtoras tem delegado a profissionais inexperientes a responsabilidade pelo desenvolvimento de projetos e gestão de obras complexas. As consequências são projetos de baixa qualidade com erros de soluções técnicas e falta de compatibilização que exigem uma coordenação mais efetiva e produtiva, onerando o custo das obras e aumentando seus prazos. Etapas importantes da obra são iniciadas sem que o projeto esteja corretamente detalhado ou mesmo disponibilizado com a antecedência necessária para análise de quem vai executá-lo, aumentando a possibilidade de erros, principalmente nas mãos de engenheiros inexperientes (LOTURCO, 2008; OLIVEIRA, 2008; CBCI, 2010; CEOTTO, 2011).

\subsection{Sustentabilidade}

A construção civil é considerada uma das atividades de maior impacto negativo no meio ambiente através dos edifícios, que consomem muita energia e água durante sua vida útil e na fase de construção, quando são utilizados materiais de alto consumo de energia e com alta emissão de $\mathrm{CO}_{2}$ decorrente de seu transporte e produção, aliado à falta de uma cultura de regulamentação dos processos de produção, que acarreta em problemas de baixa produtividade, baixa qualidade e grande desperdício de material por perdas (FIGUEIREDO, 2007). 
Pesquisas realizadas no Reino Unido mostram que o pobre desempenho da indústria da construção em 1994 foi praticamente o mesmo de 1934, e o custo da ineficiência e desperdício representavam $30 \%$ da custo total da indústria da construção (CAIN, 2003 apud LÊ, BRØNN, 2007). A ineficiência do setor da construção é decorrente de vários fatores; entre eles, foi levantado por Lê (2002) a falta de foco na transferência de conhecimento e experiência entre os responsáveis pelas operações e os projetistas (LÊ, BRØNN, 2007).

A introdução do conceito de sustentabilidade na construção civil tem contribuido para conscientizar, principalmente as construtoras, sobre a importância de garantir a sustentabilidade ambiental de seus empreendimentos. Ao incorporar a seus procedimentos práticas sustentáveis de construção, treinamento das equipes de obra e controle de qualidade, propiciam maior produtividade e redução de custos em função do controle dos processos e redução de desperdícios, que vem de encontro à estratégia competitiva de várias empresas (FIGUEIREDO, 2007; JOHN, 2008).

No entanto, John (2007) alerta que muitos profissionais confundem construção sustentável com "green building" (edifício verde), utilizando o conceito como estratégia de marketing, deixando de lado a dimensão social. O desenvolvimento sustentável exige a transformação radical das tecnologias de produção, dos hábitos, consumo e da ética, e os desafios a vencer são:

- Mudar o paradigma das atividades produtivas, incorporando análises ambientais e sociais nos processos de produção. No desenvolvimento dos projetos aspectos como durabilidade, manutenção, custos de operação e os impactos sociais devem ser analisados ao longo do ciclo de vida das edificações.

- Substituir a abordagem tradicional segmentada dos projetos por uma abordagem sistêmica com a participação de equipes multidisciplinares incluindo pessoas de áreas social e ambiental.

- Desenvolver a capacidade de inovação em toda a cadeia buscando soluções para cada situação específica, e estimulando o relacionamento entre empresas e universidades para troca de conhecimento.

Ao projetar um edifício sustentável, segundo os arquitetos da Foster and Partners, deve-se ter em mente criar edifícios que tem eficiência energética, são salubres, 
confortáveis e flexíveis ao uso e projetados para uma longa vida útil (VAKILIARDEBILI; BOUSSABAINE, 2007).

A sustentabilidade está relacionada à criação de valor do projeto ao longo do ciclo de vida do edificio. Conceitos de projeto devem ser definidos prevendo prolongar ao máximo o valor criado nas fases que antecedem a fase de uso. Aliado ao objetivo de prolongar a durabilidade, devem fazer parte da estratégia avaliar a longevidade da funcionalidade, desempenho, eficácia e manutenibilidade na fase de uso e os impactos ambientais (VAKILI-ARDEBILI; BOUSSABAINE, 2007).

\subsection{Tecnologia da Informação (TI)}

Em todos os setores da economia a TI (Tecnologia da Informação) adquiriu um significado estratégico, pois permeia todos os pontos da cadeia de valor, transformando a forma como as atividades são desempenhadas e a natureza das ligações entre elas. Devido ao novo fluxo de informações e às novas tecnologias, a $\mathrm{TI}$ intensifica a habilidade da empresa de explorar as ligações entre atividades, tanto interna quanto externamente, o que aumenta o seu alcance competitivo permitindo que a empresa coordene atividades de valor em localizações geográficas dispersas (PORTER; MILLAR, 1985).

A TI encontra vasto território para difundir-se no setor da construção civil, mas a permanência dos controles manuais é explicada devido ao alto investimento necessário para implantação dos sistemas e treinamento, aos prazos relativamente curtos em que as ferramentas se tornam obsoletas e às consequências inerentes à implantação de sistemas informatizados, tais como necessidade de capacitação da mão-de-obra interna, adaptação dos processos das empresas e, por vezes, a mudança da própria estrutura organizacional.

Com o avanço da TI e tecnologias de comunicação, vários sistemas de integração e de colaboração tem sido desenvolvidos e aplicados em diferentes ramos de atividade, incluindo a indústria da construção. Estas tecnologias propiciam a criação colaborativa, gestão, disseminação e uso da informação por todo ciclo de vida do produto e do Projeto, além de integrar pessoas, processos, sistemas de negócio e 
informação de forma mais eficiente (SHEN et al., 2010). Desenhos e documentos são transmitidos e disponibilizados via internet a todos os agentes envolvidos no processo de forma virtual, aumentando a eficiência da transmissão de informações e eliminando barreiras geográficas.

Devido ao envolvimento de equipe multidisciplinar (cliente, arquitetos, consultores, engenheiros, construtores, fornecedores) e utilização de programas, sistemas e ferramentas de equipamentos heterogêneos, a integração dos sistemas, também chamada de interoperabilidade, é um requisito de extrema importância para que a colaboração seja eficiente e efetiva (MELHADO, 2001; SHEN et al., 2010).

\subsection{Segmentos de atuação do setor}

No subsetor de empreendimentos imobiliários, Assumpção (1996) destaca as atividades, que podem ou não ser desempenhadas pela mesma empresa, mas que devem ser integradas para a geração e desenvolvimento de um empreendimento:

- Empreender, onde a empresa é responsável pela definição do produto, incorporação e vendas, com o foco no negócio e na rentabilidade

- Construir, onde a empresa é responsável pela sua produção, onde o foco é a construção e sua racionalização

Fabricio (2002) distingue a empresa de incorporação-construção, responsável pelas atividades de promoção e construção do edifício, da empresa de promoção independente, que se caracteriza quando o empreendedor do edifício não tem nenhum vínculo direto com o construtor e o usuário. Destacam-se duas modalidades de promoção independente: promotor imobiliário privado que incorpora um terreno, monta o empreendimento para ser vendido no mercado imobiliário e contrata uma construtora para execução da obra e o promotor público (órgão público municipal, estadual ou federal) que contrata os serviços de engenharia, projeto e construção com o intuito de repassar ou vender o produto para determinada população beneficiária (exemplo: habitações populares), conforme ilustrado na Figura 3. 


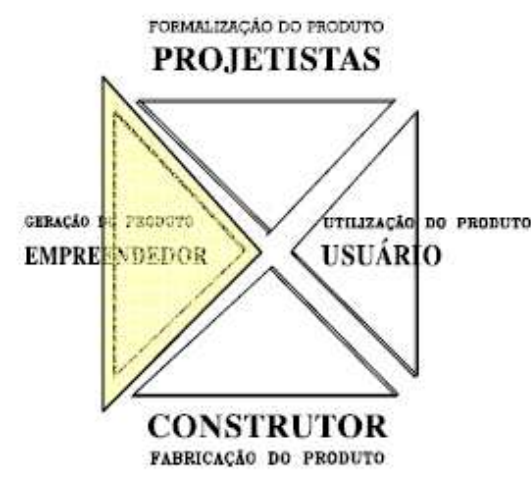

(a) promoção independente

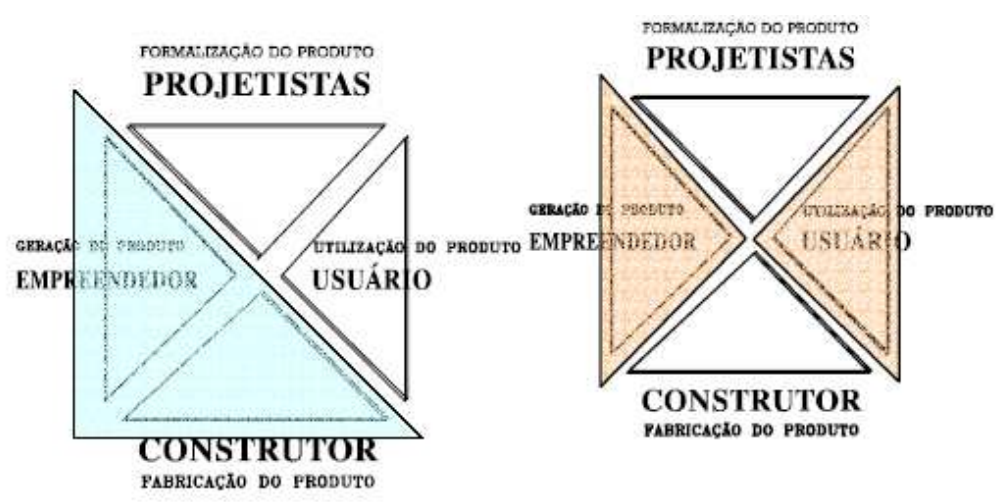

(b) incorporação-construção

(c) obras sob encomenda

Adaptado de MELHADO (1994)

Figura 3 - Tipos de empreendimento de construção considerados segundo o agente de promoção (FABRICIO, 2002)

As Obras sob encomenda (ou obras empreitadas) caracterizam os empreendimentos nos quais o usuário final é o cliente direto da construtora e dos projetistas, ficando responsável pela montagem do empreendimento e, em alguns casos, pela gestão global da obra e aquisição dos materiais. Enquadram-se os pequenos empreendedores (auto-promoção) e empresas que promovem grandes edifícios para abrigar empreendimento industrial ou comercial (FABRICIO, 2002).

A avaliação da qualidade do projeto encontra diferenças segundo Melhado (1994), de acordo com as diferentes expectativas:

- Empreendedor: penetração do produto no mercado, formação de imagem da empresa e retorno dos investimentos;

- Construtor: clareza da apresentação (facilitando o planejamento e execução), potencial de economia de materiais e mão-de-obra.

Melhado (1994) visualiza duas dimensões do projeto neste contexto:

- "projeto como processo estratégico, visando atender às necessidades e exigências do empreendedor, portanto voltado à definição de características de produto final";

- "projeto como processo operacional, visando a eficiência e a confiabilidade dos processos que geram os mesmos produtos".

Fontenelle (2002) delineia duas interfaces no processo de projeto: 
- Interface "produto-projeto": relacionada com a conceituação do empreeendimento baseada no atendimento dos aspectos mercadológicos do projeto (interface estratégica): definição de tipologia da edificação, especificação de materiais, exigências de desempenho, etc.

- Interface "projeto-produção": relacionada com a solução dos aspectos técnicos-construtivos do projeto: normas técnicas, seleção tecnológica dos subsistemas construtivos, resolução das interfaces entre subsistemas construtivos, dispciplinas e agentes envolvidos, etc.

Silva (1996) constatou uma tendência no mercado do estado de São Paulo de especialização das empresas em uma das duas atividades (incorporação ou construção) como forma de "reestruturação competitiva". A concentração das atividades da empresa conforme sua competência essencial visa reduzir os entraves à modernização, dadas as diferentes contribuições das duas atividades para a rentabilidade da empresa. A aquisição de terrenos, cada vez mais escassos, exige investimentos elevados que pode representar uma restrição para uma empresa com bom desempenho técnico-operacional, mas sem capacidade financeira de investimento inicial.

Do ponto de vista do desempenho comercial e da sobrevivência da empresa de incorporação no setor, a interface produto-projeto assume caráter primordial, pois é condição de base para que o processo de produção tenha continuidade, o que não ocorre no caso do subsetor de obras empreitadas onde a harmonização com as necessidades da produção (obra) figura como mais importante (FONTENELLE, 2002).

\subsection{Método de seleção de equipe e sistemas contratuais}

Um conjunto de fatores inerentes à gestão do empreendimento influencia a gestão do processo de projeto ao longo do processo de produção, tais como o método de seleção das equipes e o sistema contratual adotado que define as relações contratuais e funcionais entre os agentes. 
O aumento da complexidade tecnológica e gerencial dos empreendimentos induziu a introdução de sistemas contratuais alternativos, tais como projeto-construção e a gestão, que flexibilizam os métodos de contratação e organização dos empreendimentos, mas acabam repercutindo na sequência das fases do processo de produção e nas relações funcionais entre clientes, projetistas e construtores. Neste cenário, verifica-se a perda da autoridade dos projetistas na gestão do processo de projeto e do empreendimento, que são assumidos pelas incorporadoras, construtoras e gerenciadoras (GRILO, 2002).

Os contratos são particularizados em função de múltiplos fatores, tais como: características do empreendimento (tipo de edifício, complexidade do programa); características do cliente (experiência, competências internas e complexidade da organização); prioridades do cliente (prazos, custos, qualidade, flexibilidade, envolvimento do cliente e do construtor durante o projeto); alocação de risco; prazo disponível para projeto e construção; possibilidade de realização de uma concorrência; detalhamento das informações na seleção das equipes e necessidade de flexibilidade ou mudança do escopo do trabalho no decorrer da obra (GRILO, 2002).

Para o setor da construção de edifícios sob encomenda no Brasil, Grilo (2002) sugere um modelo para sistemas contratuais, conforme ilustrado na Figura 4 , que compreende a definição de:

1. Método de seleção onde são definidos os procedimento de seleção dos membros do empreendimento: Concorrência (aberta ou fechada): melhor preço ou melhor técnica; Negociação e Qualificação.

2. Estrutura organizacional das equipes de projeto e construção adotada que define as relações contratuais e funcionais entre clientes, projetistas e construtores; o envolvimento do cliente e do construtor no desenvolvimento do produto; a estrutura de comunicação; o fluxo de informação e o processo de tomada de decisão.

Os sistemas contratuais podem ser classificados como:

- Integrados: Projeto-Construção (Design-build), que pode promover redução de custo e prazo de construção; Chave na mão (turn-key); Construir-OperarTransferir (BOT - Build-Operate-Transfer); 
- Separados (de projeto e construção): Sequencial tradicional e Acelerado tradicional;

- Gerenciados.

3. Modalidade de pagamento onde os contratos podem ser definidos em diferentes categorias relacionados à:

- Fixação do preço: Preço Fixo (Preço alvo; Preço global: fixa-se o preço global antecipadamente, mediante estudos e orçamentos apresentados ao contratante, instruindo ou compondo o contrato); Custo Fixo (Preço unitário onde as partes convencionam preços por unidades, medidos conforme a produção com remuneração prestada mediante medições periódicas dos serviços; Taxa de administração onde a execução da obra ocorre mediante o reembolso das despesas incorridas e o pagamento de uma remuneração ao construtor, geralmente fixada como um percentual do valor das despesas) ou Misto (englobando preço alvo com taxa de administração)

- Liberação

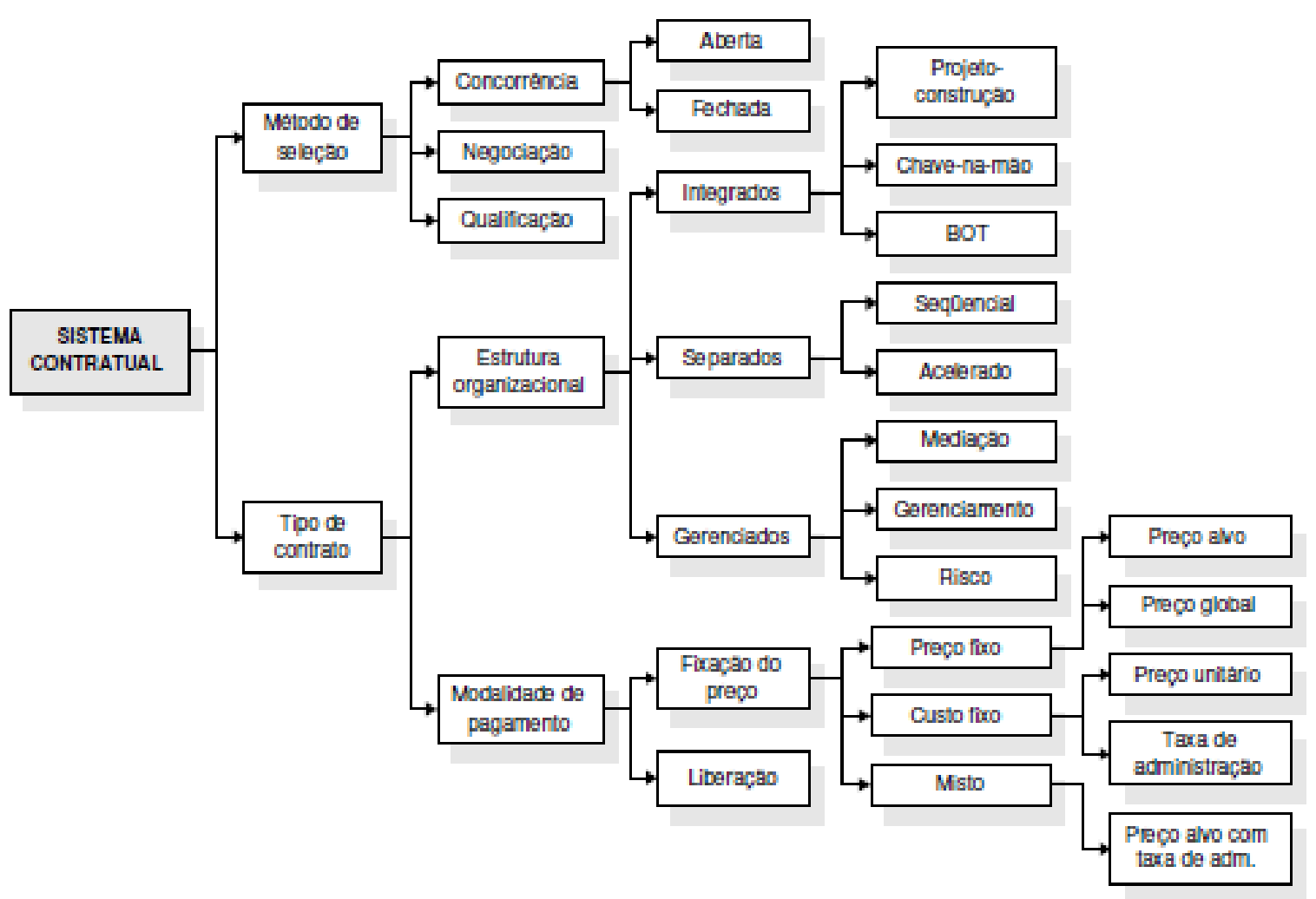

Figura 4 - Modelo genérico proposto para sistemas contratuais (GRILO, 2002) 
A escolha do contrato envolve a alocação dos riscos que devem ser cuidadosamente avaliados durante a seleção do sistema contratual (GRILO, 2002). Uma alocação de riscos inadequada pode resultar em aumento dos custos ou na dificuldade de cumprimento do contrato por uma das partes (MOLENAAR et al., 1998 apud GRILO, 2002).

A gestão dos riscos constitui um aspecto fundamental na seleção, contratação e organização da equipe do empreendimento. Em sistemas integrados, o construtor assimila a maior parcela dos riscos. Por sua vez, o empreendedor absorve os riscos na gestão da construção. No sistema separado ou tradicional, a alocação dos riscos depende da fixação do preço. Em contratos com preço global, os riscos normalmente são transferidos para o construtor. Geralmente, projetistas não assumem riscos relacionados com a construção, exceto no prime contracting (contratante principal), onde fornecem ponto único de responsabilidade para o cliente, modalidade de contratação restrita, devido à pequena capacidade financeira dos escritórios.

No setor privado prevalecem os contratos de preço fixo, onde o construtor assume a maior parte dos riscos técnicos e pecuniários da construção. No entanto, com a demanda por redução dos prazos pressiona o início de concorrências antes do término dos projetos, oferencendo ao construtor a oportunidade de intervir no desenvolvimento do produto, fixando um preço global ou preço máximo. Neste caso, o construtor pode apresentar soluções específicas, baseadas em experiência ou negociação com fornecedores, levantar pendências ou considerações sobre itens pouco detalhados no edital.

Nos contratos de preço máximo ou preço máximo garantido (PMG) o construtor propõe ao cliente alternativas técnicas e econômicas para redução de prazo ou custo, que serão confirmados ao término dos projetos. Ou o construtor propõe um PMG no inicio da construção, com o compromisso de reduzir a proposta conforme as incertezas são eliminadas, assumindo riscos maiores, visto que os projetos ainda não estão detalhados. Taxas de administração podem ser estabelecidas com prêmios por desempenho, em geral repartidos entre o construtor, cliente e gerenciador (GRILO, 2002).

Bueno (2009) aponta alguns motivos de insatisfação na adoção de contratos do modelo de "Empreitada de preço global e de chave-na-mão" (EPC Turnkey Lump 
Sum), em que a construtora responsabiliza-se pelo projeto (Engineering), aquisição de materiais e equipamentos (Procurement), construção (Construction), montagem e comissionamento dos equipamentos do empreendimento: falta de confiança do empreendedor em relação à construtora e sua dificuldade de delegar-lhe atribuições; conflito de interesses com as gerenciadoras; concorrência cada vez mais predatória entre as construtoras na etapa de apresentação de propostas; e carência de competências internas às construtoras para a gestão do projeto.

Grilo (2002) apresenta diversos arranjos funcionais das equipes de projeto e construção, conforme descrito no Quadro 5.

\begin{tabular}{|c|c|c|c|}
\hline $\begin{array}{l}\text { 1) Sistema Separado de projeto e } \\
\text { construção }\end{array}$ & Característica & $\begin{array}{l}\text { Benefícios } \\
\text { potenciais para } \\
\text { os clientes }\end{array}$ & Riscos \\
\hline \begin{tabular}{c|c|} 
Fornecedores & Subempreiteiros \\
& Relaçào contratual \\
& Relaçăo funcional
\end{tabular} & \begin{tabular}{lr}
\multicolumn{2}{l}{ Responsabilidade } \\
s: - Projetistas: \\
transmissão & dos \\
objetivos & e \\
requisitos & do \\
cliente, & \\
incentivando & a \\
qualidade & dos \\
serviços & de \\
construção. & \\
Construtor: & \\
entregar o edifício \\
em conformidade \\
com & os \\
documentos & de \\
projeto & as \\
condições & do \\
contrato. & Em \\
geral, & \\
concorrências & são \\
realizadas ram & com \\
base & em \\
documentos & de \\
projeto completos.
\end{tabular} & $\begin{array}{lr}\begin{array}{lr}\text { Análises } \\
\text { sistemáticas }\end{array} \\
\text { desempenho do da } \\
\text { construção, } \\
\text { devido } \\
\text { separação entre o } \\
\text { arquiteto-autor } \\
\text { projeto e } \\
\text { construtor; } \\
\text { período longo } \\
\text { para efetuar } \\
\text { alterações de } \\
\text { projeto, a um } \\
\text { custo moderado; } \\
\text { fixação do preço } \\
\text { antes } \\
\text { construção; da } \\
\text { transferência de } \\
\text { riscos para } \\
\text { construtor. }\end{array}$ & $\begin{array}{l}\text { Para o cliente: } \\
\text { Tempo de entrega } \\
\text { longo; falta de } \\
\text { incorporação da } \\
\text { construtibilidade } \\
\text { no projeto; } \\
\text { possibilidade de } \\
\text { conflitos entre os } \\
\text { participantes; e } \\
\text { alterações } \\
\text { projeto de } \\
\text { (MOLENAAR et } \\
\text { al., 1998). }\end{array}$ \\
\hline $\begin{array}{l}\text { 1.2) Acelerado (sobreposto ou } \\
\text { construção por fases) } \\
\text { (FISK, 1997) }\end{array}$ & 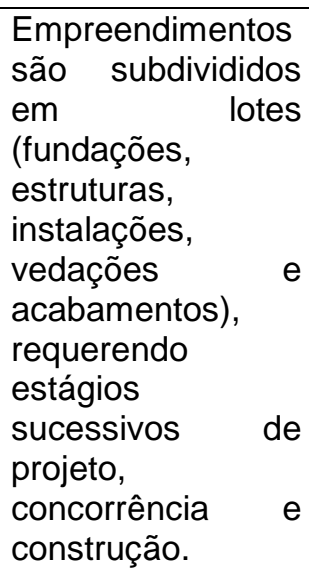 & $\begin{array}{lr}\text { A rincipal } & \text { pring } \\
\text { vantagem consiste } \\
\text { na redução do } \\
\text { prazo de entrega, } \\
\text { visto que a } \\
\text { construção se } \\
\text { inicia } \\
\text { imediatamente } \\
\text { após a elaboracaão } \\
\text { do projeto, ainda } \\
\text { que outros } \\
\text { componentes do } \\
\text { edifício não } \\
\text { tenham sido }\end{array}$ & 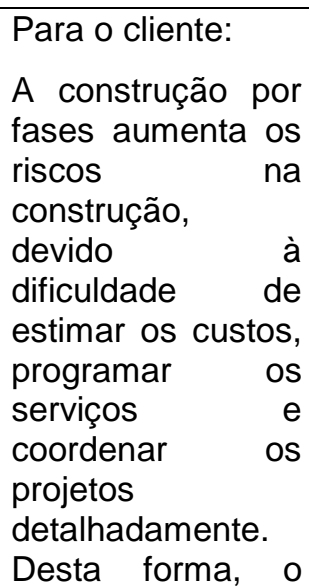 \\
\hline
\end{tabular}




\begin{tabular}{|c|c|c|c|}
\hline & $\begin{array}{lr}\text { A construção por } \\
\text { fases demanda } \\
\text { habilidade para } \\
\text { selecionar } r \text { os } \\
\text { pacotes } \\
\text { trabalho, de } \\
\text { programar } \\
\text { controlar o esforço } \\
\text { de projeto. }\end{array}$ & projetados. & $\begin{array}{lr}\text { cliente } & \text { deve } \\
\text { assegurar } & \\
\text { recursos } & \\
\text { adicionais } & \text { para } \\
\text { despesas } & \text { com } \\
\text { alterações } & \text { de } \\
\text { projeto. } & \end{array}$ \\
\hline \multirow[t]{2}{*}{ 2) Gerenciados } & \multicolumn{3}{|c|}{$\begin{array}{l}\text { O gerenciador deve prover os seguintes serviços: mediação } \\
\text { entre o cliente e os projetistas; liderança da equipe de } \\
\text { construção; proposição de alternativas técnicas com } \\
\text { avaliação do impacto nos custos e prazos; controle físico e } \\
\text { financeiro; coordenação da aquisição de recursos; } \\
\text { monitoramento da atividade do construtor e dos } \\
\text { subempreiteiros; inspeção da conformidade com os } \\
\text { requisitos do projeto; provisão de relatórios sobre o } \\
\text { progresso da construção; e manutenção de uma relação } \\
\text { harmoniosa com as equipes. }\end{array}$} \\
\hline & Característica & $\begin{array}{l}\text { Benefícios } \\
\text { potenciais para } \\
\text { os clientes }\end{array}$ & Riscos \\
\hline 2.1) Gerenciador como mediador & \multirow[t]{2}{*}{\begin{tabular}{lr}
\multicolumn{2}{l}{ Gerenciador } \\
fornece instruções \\
sobre \\
construtibilidade e \\
monitora uma \\
parcela das \\
atividades de \\
construção.
\end{tabular}} & \multirow[t]{2}{*}{$\begin{array}{lr}\begin{array}{l}\text { Apresenta } \\
\text { mesmas }\end{array} & \text { as } \\
\text { vantagens } & \text { e } \\
\text { desvantagens } & \text { do } \\
\text { sistema } & \\
\text { tradicional, na } \\
\text { medida em que as } \\
\text { relações } & \\
\text { contratuais e } & \text { as } \\
\text { estruturas } & \text { de } \\
\text { comunicação } & \text { se } \\
\text { assemelham. } & \end{array}$} & \multirow[t]{2}{*}{$\begin{array}{l}\text { Gerenciadores } \\
\text { não contratam } \\
\text { diretamente } \\
\text { projetistas ou } \\
\text { assumem riscos } \\
\text { referentes a } \\
\text { prazos e custos. }\end{array}$} \\
\hline $\begin{array}{c}- \text { Relaçăo contratual } \\
\text { (G.................. Relaçăo funcional } \\
\text { (GRILO, 2002) p.38 }\end{array}$ & & & \\
\hline 2.2) Gerenciador como construtor & $\begin{array}{l}\text { Gerenciador } \\
\text { subdivide o } \\
\text { empreendimento } \\
\text { em lotes, } \\
\text { submetidos a } \\
\text { concorrências } \\
\text { individuais. A } \\
\text { principal diferença } \\
\text { com relação aos } \\
\text { sistemas } \\
\text { acelerados } \\
\text { consiste na } \\
\text { subcontratação } \\
\text { dos serviços } \\
\text { (infra-estrutura, } \\
\text { superestrutura, }\end{array}$ & & $\begin{array}{l}\text { Demanda uma } \\
\text { intensa } \\
\text { comunicação } \\
\text { entre } \\
\text { gerenciador e os } \\
\text { subempreiteiros. }\end{array}$ \\
\hline
\end{tabular}




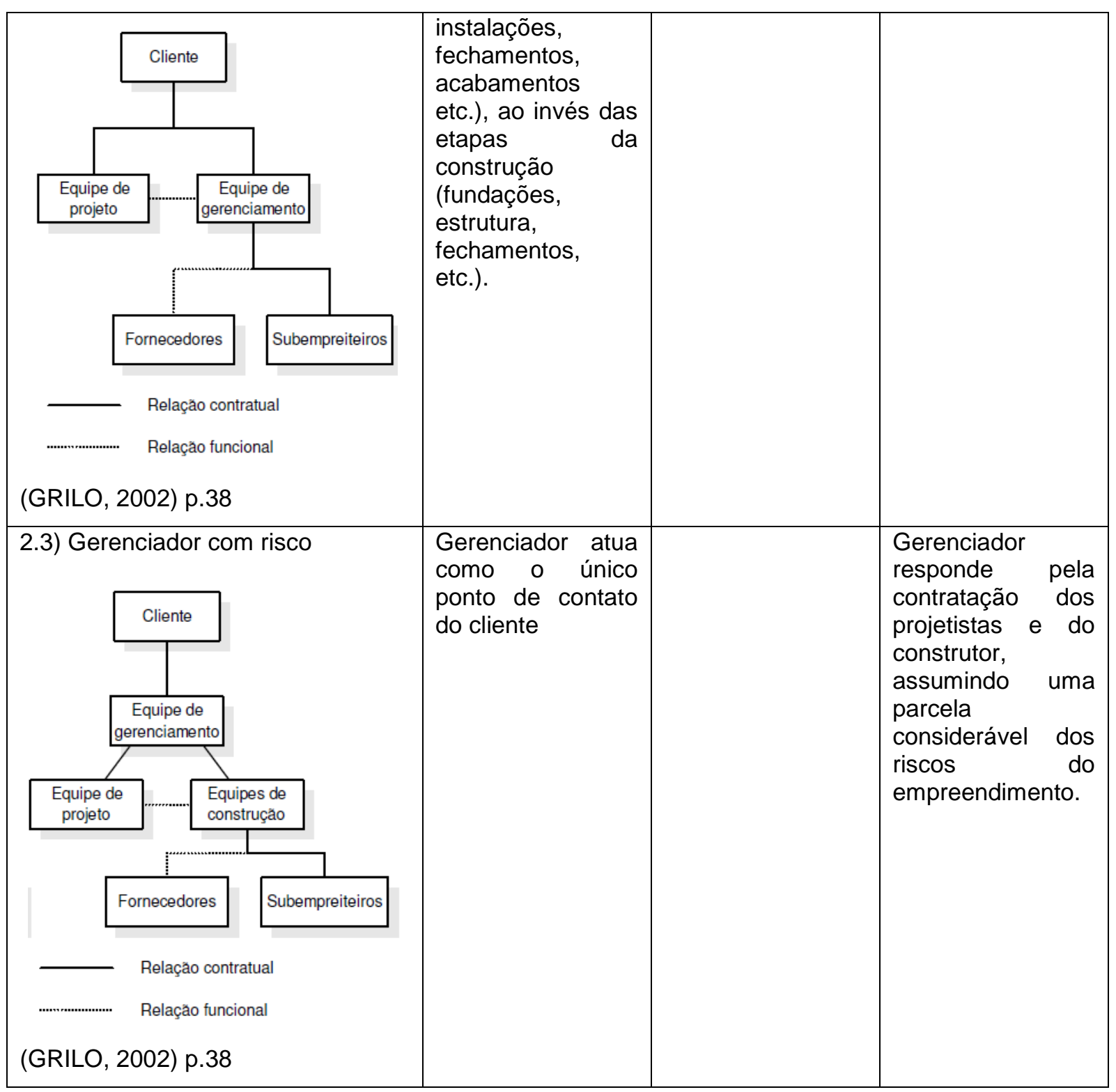

Quadro 5 - Arranjos funcionais das equipes de projeto e construção (GRILO, 2002)

Segundo AsBEA (2000), os métodos de seleção de projetos usuais em empreendimentos públicos e privados consistem em:

- convite direto (escritórios contratados diretamente pelos clientes privados ou por indicação de terceiros ou como notória especialização em empresas públicas);

- seleção restrita (qualificação de um número restrito de escritórios para seleção após avaliação da experiência e recursos humanos); 
- propostas técnicas em seleção restrita (solicitação de proposta a um número restrito de escritórios onde o cliente seleciona a proposta mais compatível com o trabalho);

- licitações (concorrências, tomada de preço, convites e concursos, adotando um critério de seleção o menor preço, melhor técnica e melhor técnica e preço)

- concursos (público ou privado realizado nos níveis de concurso de idéias e estudos preliminares ou anteprojetos).

Em relação ao processo de projeto, Assumpção (1996) observa que quando são criados ambientes e estruturas administrativas independentes para as funções de "Empreender" e "Construir" surgem posições conflitantes entre o empreendedor e o construtor que possuem enfoques e necessidades particulares ao longo do processo de projeto. No entanto, muitas das situações de conflito são caracterizadas como restrições que devem ser respeitadas para viabilização comercial do empreendimento na fase de projeto e obra, como por exemplo, as diretrizes impostas pelo empreendedor que são necessárias para viabilizar a comercialização, mas pode não representar a melhor alternativa para a produção.

As relações entre os participantes do Projeto são afetadas pela estrutura dos contratos, pelas preferências do cliente, a reputação dos projetistas e o planejamento das comunicações do Projeto (GRISHAM; SRINIVASAN, 2007).

A estrutura do contrato pode restringir a comunicação e interação entre as partes, reduzindo ou eliminando um ambiente propício ao crescimento do trabalho em equipe. Na estrutura dos contratos tradicionais, ilustrada na Figura 5, o cliente contrata o projetista e o construtor e define o papel de cada um e alguns protocolos ou barreiras de comunicação. Por exemplo, os subcontratados podem ser proibidos de comunicar-se diretamente com os projetistas e o projetista ser proibido de contatar o usuário final sem a presença do cliente. Uma das razões de limitar a comunicação é a antiga idéia do conhecimento como forma de poder. O cliente pode eliminar uma comunicação direta entre o projetista e a construtora acreditando que pode evitar que erros de projeto fiquem visíveis ao construtor (GRISHAM; WALKER, 2005; GRISHAM; SRINIVASAN, 2007) . 
Esta visão impede que todos se beneficiem quando problemas detectados antecipadamente possam ser reparados ou ao invés de mascarados ou postergados.

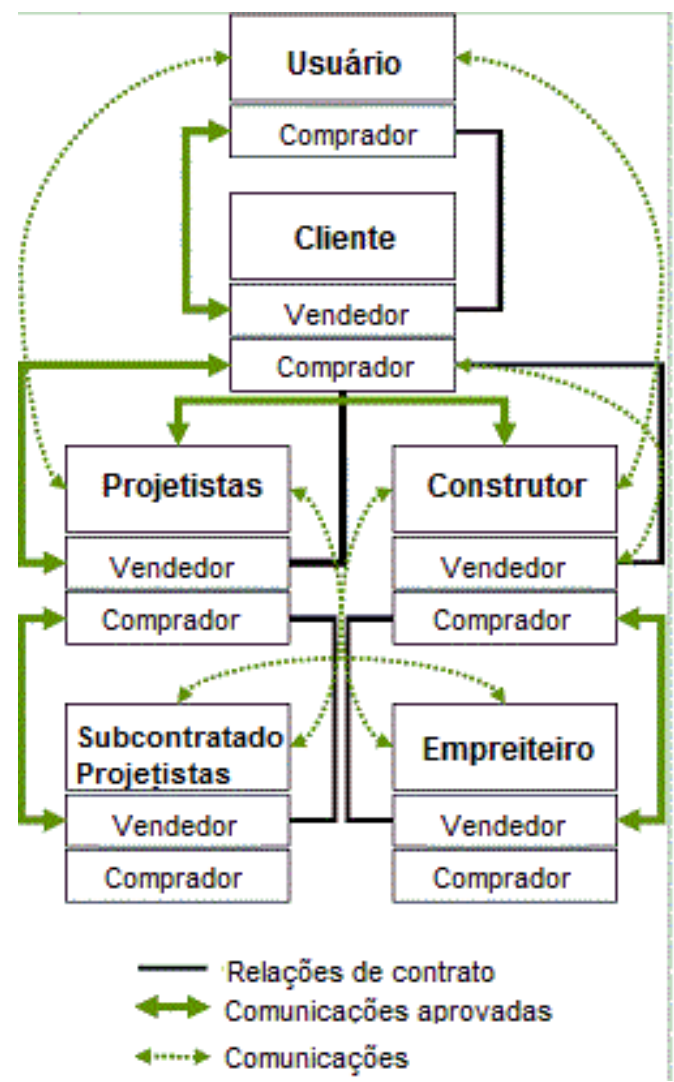

Figura 5 - Estrutura de contrato convencional (adaptado de GRISHAM; SRINIVASAN, 2007)

O sucesso de um contrato depende da escolha de um modelo de comunicação entre os participantes que permita acrescentar o conhecimento de cada parte às metas $\mathrm{e}$ objetivo comuns do Projeto, e não metas individuais.

O modelo tradicional pode ser alterado pelo contratante permitindo um fluxo livre de informações entre todos envolvidos e criando um ambiente que motive a transferência de informação e conhecimento. Grisham; Walker (2005) acreditam que o sistema de aquisição/ contratação pode apoiar efetivamente o fluxo de transferência de conhecimento e propõe um modelo baseado na metáfora de um sistema hidráulico, onde o fluxo do conhecimento é regulado por válvulas estabelecidas pelas partes envolvidas, não especificados em contrato, mas incorporados às regras estabelecidas no Projeto. Os filtros de contrato são definidos nos acordos contratuais que estabelecem condições gerais (como será conduzido o 
negócio) ou específicas (estabelece circunstâncias especiais de um projeto específico) e os filtros da empresa são relacionados aos valores e normas da organização. Organizações do tipo matricial, acostumadas a compartilhar informações são mais flexíveis e abertas à comunicação enquanto organizações altamente hierarquizadas são mais fechadas à outras organizações.

A Figura 6 mostra que a estrutura que propicia a inovação e o sucesso do Projeto consiste em criar uma atmosfera positiva que conduza as partes a compartilhar as inovações sem inibições ou reservas. A inovação pode ser a descoberta de uma nova técnica para determinada tarefa, uma melhoria na gestão da comunicação ou a redução de custo (engenharia de valor).

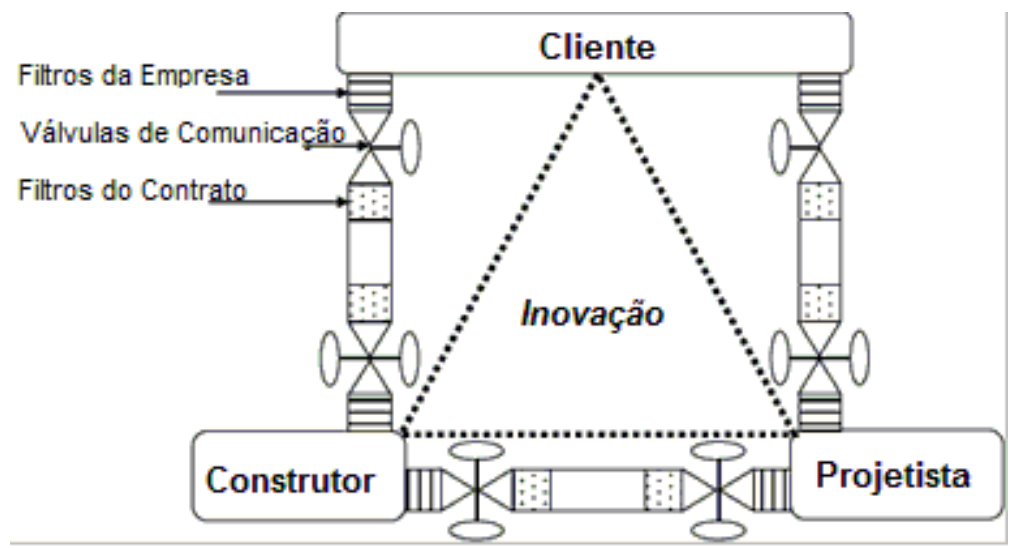

Figura 6 - Fluxo do conhecimento (adaptado de GRISHAM; SRINIVASAN, 2007)

\subsection{Ciclo de vida de um empreendimento e do processo de projeto}

Encontra-se na literatura diversas formas de divisão em fases do processo de desenvolvimento de um empreendimento imobiliário ao longo do seu ciclo de vida.

A divisão em várias fases facilita a gestão e o estabelecimento de vínculos adequados com as operações contínuas da empresa (PMI, 2008).

Grilo (2002) identifica que o número de etapas do ciclo de vida do empreendimento varia conforme o país, segmento de mercado, o cliente e de acordo com o tipo de contratação: sistema por encomenda ou sistemas integrados (onde o construtor responde pelo projeto e pela construção).

O conjunto das diversas fases do projeto, marcadas pela conclusão de um ou mais resultados principais (um estudo de viabilidade, um desenho ou um protótipo), 
estabelece o ciclo de vida do processo de projeto. Não há um consenso sobre o número de subdivisões deste processo e conteúdo de cada uma, mas em geral essas subdivisões seguem as etapas do projeto arquitetônico, que define comercialmente o produto e suas características, ou entregas parciais do projeto (FONTENELE, 2002; ROMANO, 2003). Além da norma NBR 13531 "Elaboração de projetos de edificações - Atividades técnicas" (ABNT, 2000) e "Manual de Contratação de Serviços de Arquitetura e Urbanismo" desenvolvido pela Associação Brasileira dos Escritórios de Arquitetura (ASBEA, 2000), foram desenvolvidos vários trabalhos acadêmicos sobre o processo de projeto, identificando as etapas, entregas, agentes envolvidos, muitos deles visando a implantação de sistemas de gestão da qualidade em empresas de projeto (GUS, 1996; MELHADO et al., 1996b apud ROMANO, 2003; NOVAES, 1996 apud FONTENELLE, 2002; CTE, 1997 apud FONTENELE, 2002 e TZORTZOPOULOS, 1999; JOBIN at al., 1999 apud FABRICIO, 2002). Fontenelle (2002) destaca como ponto em comum entre os autores a necessidade de integração dos vários intervenientes, desde as etapas iniciais do processo de projeto e a necessidade de consolidação das várias interfaces entre interveniente na fase de anteprojeto, de modo que o projeto legal já incorpore as definições gerais de processos e subsistemas construtivos, evitando modificações/ adaptações futuras que possam gerar insatisfação do cliente final.

Gobin (1993) apud Fabricio (2002), sugere um encadeamento do processo de desenvolvimento dos empreendimentos composto por três etapas, como mostra a Figura 7, onde a possibilidade de intervenção é ampla no início de cada etapa e, conforme vai amadurecendo, afunila até a solução final adotada que é o ponto de partida para a etapa seguinte. Neste encadeamento qualquer revisão de tomada de decisão de etapas anteriores implica em retrabalho. As três fases do processo são identificadas como:

- Programação: onde o empreeendedor propõe um novo produto baseado em sua experiência e na demanda de mercado.

- Projeto: onde o programa é apresentado a um arquiteto-autor do projeto que em geral identifica falhas e propõe reabertura do funil para incluir suas próprias ambições. 
- Construção: onde a construtora identifica falhas nos projetos, principalmente quanto à construtubilidade levando à nova abertura do funil que representa o processo de amadurecimento do projeto.

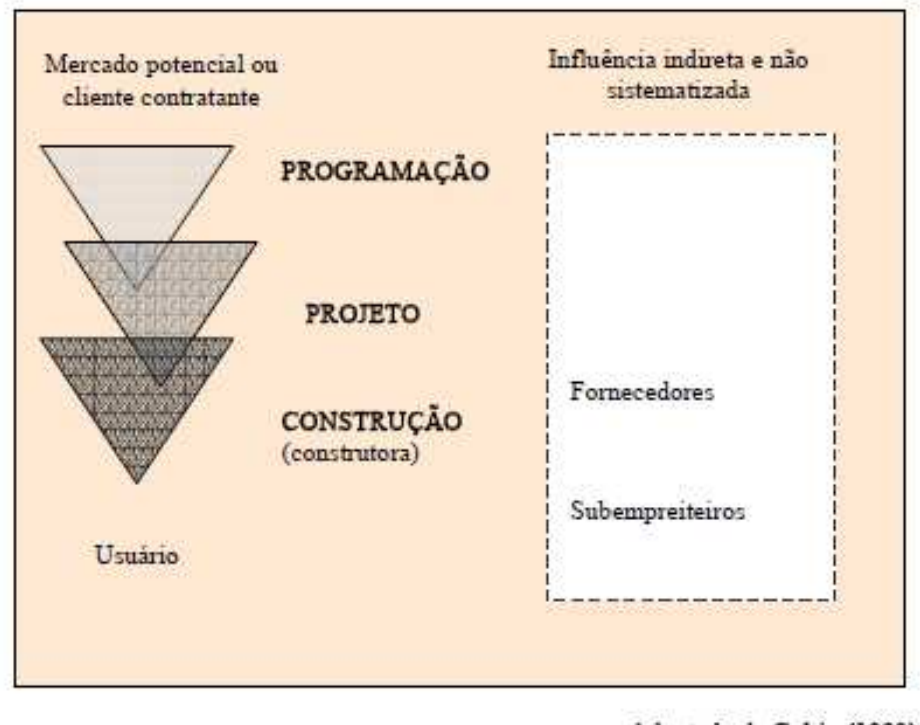

Adaptado de Gobin (1993)

Figura 7 - Processo de desenvolvimento tradicional de empreendimentos de construção (FABRICIO, 2002)

Para Jouini; Midler (2000) apud Fabricio (2002), há três etapas para desenvolvimento de novos empreendimentos: Concepção do negócio (formulação do programa de necessidades), Projeto do produto edifício e Execução da obra, como ilustrado na Figura 8.

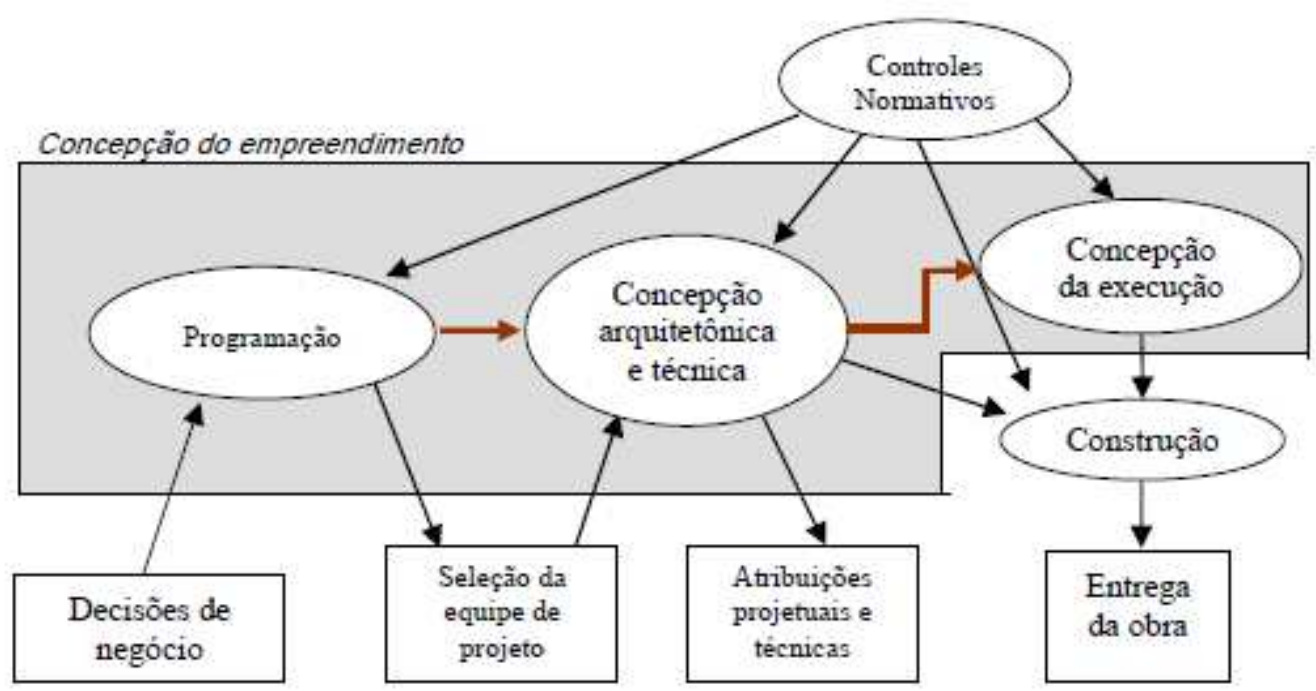


Melhado (2001) identifica quatro principais fases na construção de empreendimentos na França:

- Montagem do empreendimento, onde são desenvolvidos os estudos e programa e o principal agente é o empreendedor;

- Desenvolvimento do projeto e contratação das empresas construtoras, que inclui a fase de preparação da execução da obra - PEO. Os projetistas garantem a proposta arquitetônica, técnica e econômica com relação ao programa estabelecido pelo empreendedor;

- Coordenação da execução das obras, onde a construtota é o agente principal;

- Recepção e gestão do empreendimento - uso, operação e manutenção, onde o empreendedor é o agente responsável pela aceitação da obra com o apoio do arquiteto-autor do projeto.

A definição clara de papéis e responsabilidade de cada um dos agentes que participam do empreendimento contribui para uma melhor coordenação das atividades e tem estreita ligação com os resultados finais atingidos, quanto à qualidade.

Souza (2001) aponta a importância da fase de preparação para execução das obras (PEO) onde os agentes envolvidos com o projeto e a execução do empreendimento (empreendedor, coordenador, projetistas, consultor de gestão de qualidade, construtora e fornecedores) teriam a oportunidade de estudar o projeto, planejar e otimizar a execução dos serviços, antecipando decisões e prevenindo os riscos de uma não-qualidade, além de evitar o conflito projeto-obra que compromete os resultados finais do empreendimento.

Kamara et al. (2002) apresentam um modelo simplificado do processo de construção, como mostra a Figura 9. Durante a fase de concepção do projeto, o cliente estabelece suas necessidades para o projeto e desenvolve uma lista de requisitos que são convertidos pela equipe de projetistas em desenhos, especificações, etc. Na fase de construção, o desenho é transformado em facilidade (edificação) para posterior utilização do cliente. 


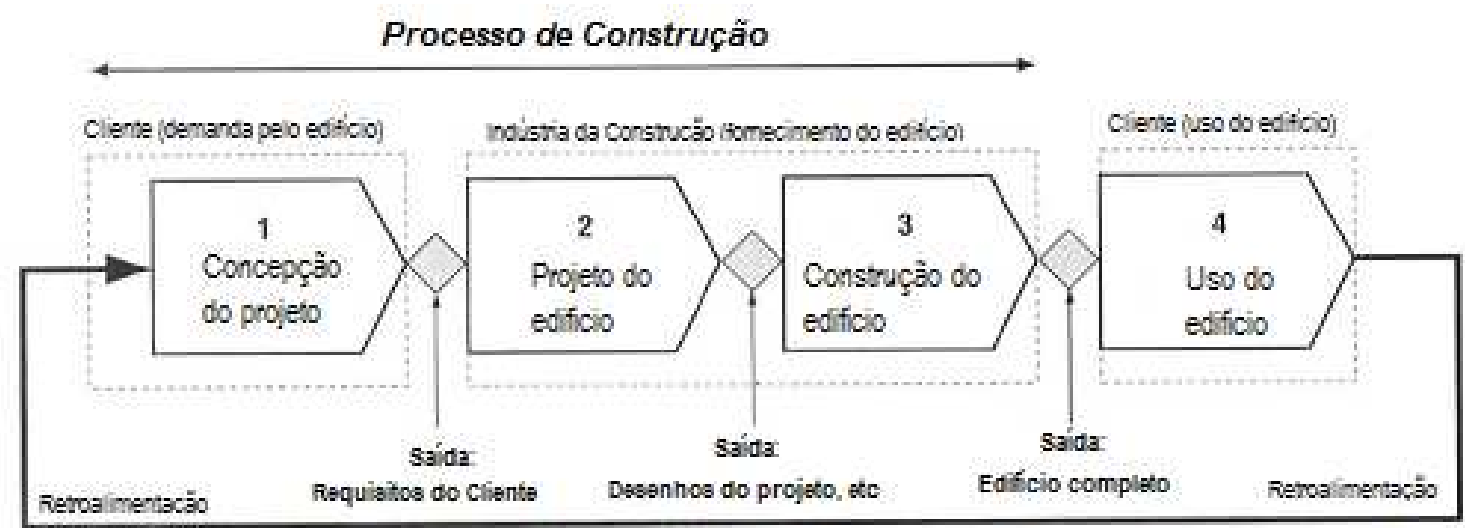

Figura 9 - Modelo simplificado do processo de construção (adaptado de KAMARA et al., 2002)

Segundo Emmitt (2002), o processo de projeto inicia na concepção, baseada nos requisitos do cliente, depois da fase de projeto e construção tem início a fase de manutenção e um novo ciclo do produto pode ser iniciado após a demolição ou reuso do edifício.

Segundo Silva (2007), a gestão estratégica dos empreendimentos pode ser dividida em duas fases: estruturação e implantação. A primeira fase comumente desempenhada pelos empreendedores e projetistas, destinada ao planejamento do empreendimento, elaboração dos projetos, e a segunda por construtoras e gerenciadoras que compreende a gestão e execução da obra.

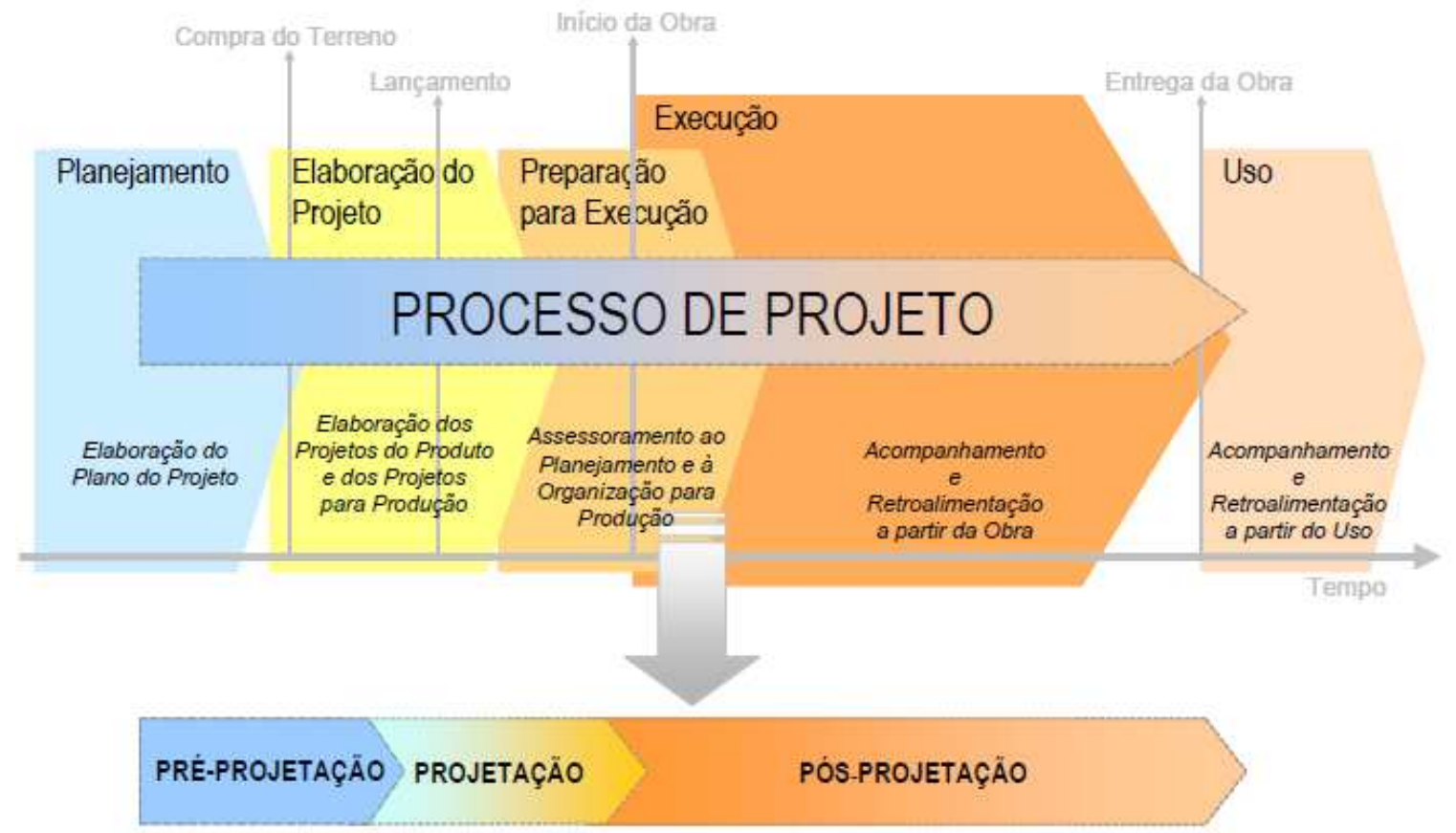

Figura 10 - O processo de projeto de edificações (ROMANO, 2003) 
Romano (2003) destaca as cinco etapas descritas por Tzortzopoulos (1999), conforme Figura 10, separando-as em quatro etapas de curta duração: planejamento, elaboração de projetos, preparação para execução e execução, e uma etapa final de uso com longa duração, em que estão envolvidas as atividades de operação e manutenção, destacando a impotância do processo de projeto que permeia todas as fases.

Do ponto de vista da sustentabilidade e geração de valor, Vakili-Ardebili; Boussabane (2007) dividem o ciclo de vida do edifício em quatro estágios, conforme a Figura 11. Em cada fase há a criação e compartilhamento de valor do Projeto baseado na natureza da atividade desenvolvida em cada fase em particular.

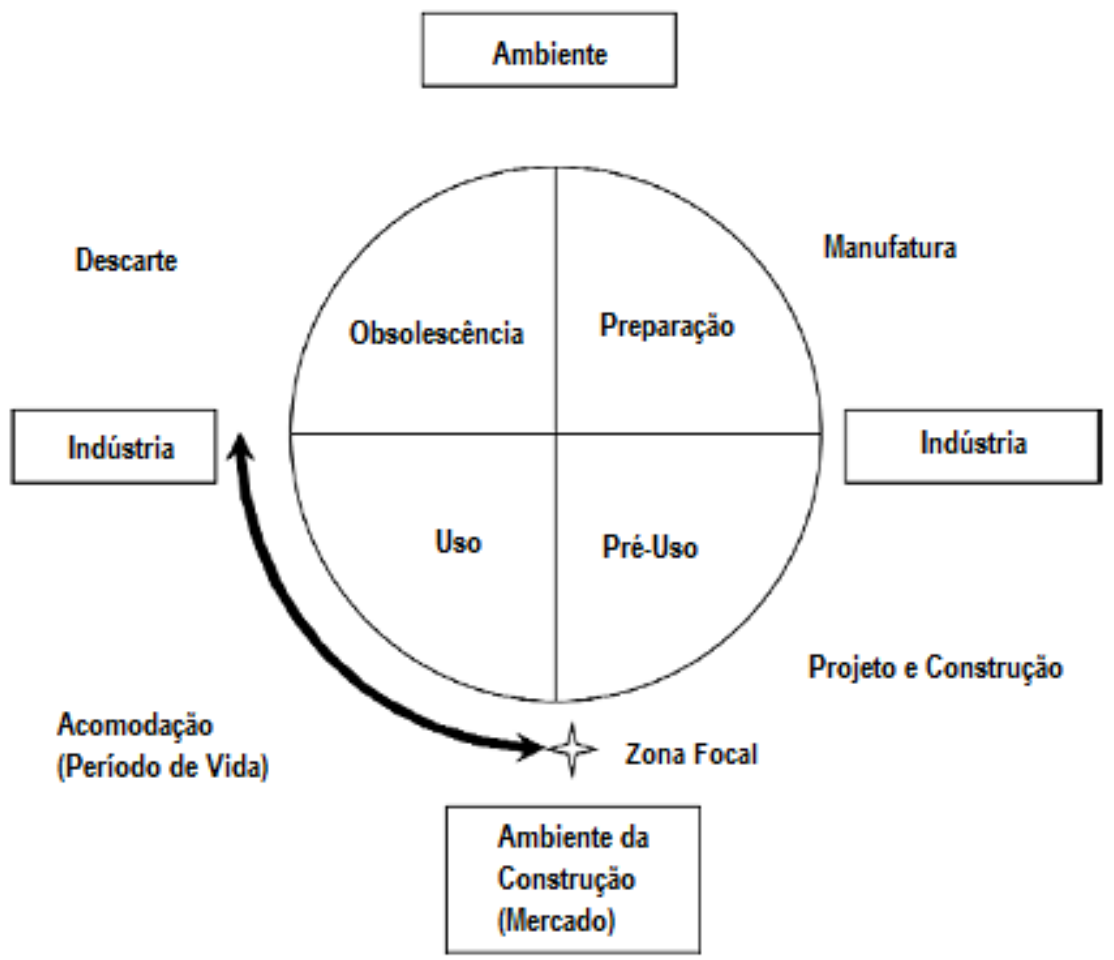

Figura 11 - 0 ciclo de vida total de um ativo do edifício (adaptado de VAKILI-ARDEBILI; BOUSSABAINE, 2007)

Na fase de Preparação são adquiridas as matérias primas para a construção, base para o processo de manufatura. Neste estágio a criação de valor está atrelada a definições das partes interessadas em relação à tecnologia, gestão de produtos, impacto ambiental, economia e eficiência. A fase de Pré-uso inclui atividades tais como: projeto, suprimentos e construção. $O$ valor é criado através da aplicação da tecnologia, estratégias de projeto e conceitos relacionados a necessidades 
específicas. Neste estágio o valor é criado através de aspectos técnicos, de gestão e econômicos do Projeto. Na fase de Uso, o produto tem mais valor para o usuário quando prolonga a vida util da operação com um edifício de maior durabilidade, aliado à flexibilidade, manutenibilidade, adaptabilidade a mudanças sociais, ecoeficiência, desempenho e facilidade de uso pelo usuário. O estágio de Obsolescência é a fase onde cessa a criação de valor ao usuário. Os esforços devem ser direcionados para a renovação e re-uso ou redução dos impactos de uma demolição.

A Figura 12 mostra o fluxo do valor do Projeto ao longo do ciclo de vida do edifício. A criação de valor não cresce linearmente e o Projeto atinge o seu máximo valor quando o edifício está pronto para $\circ$ uso/ comercialização. A partir deste ponto começa a redução de valor e o objetivo da sustentabilidade é criar condições para conservar o máximo valor do Projeto pelo maior período possível desenvolvendo em projeto conceitos, tais como durabilidade, para maximizar a eficiência na fase de uso, minimizando a obsolescência.

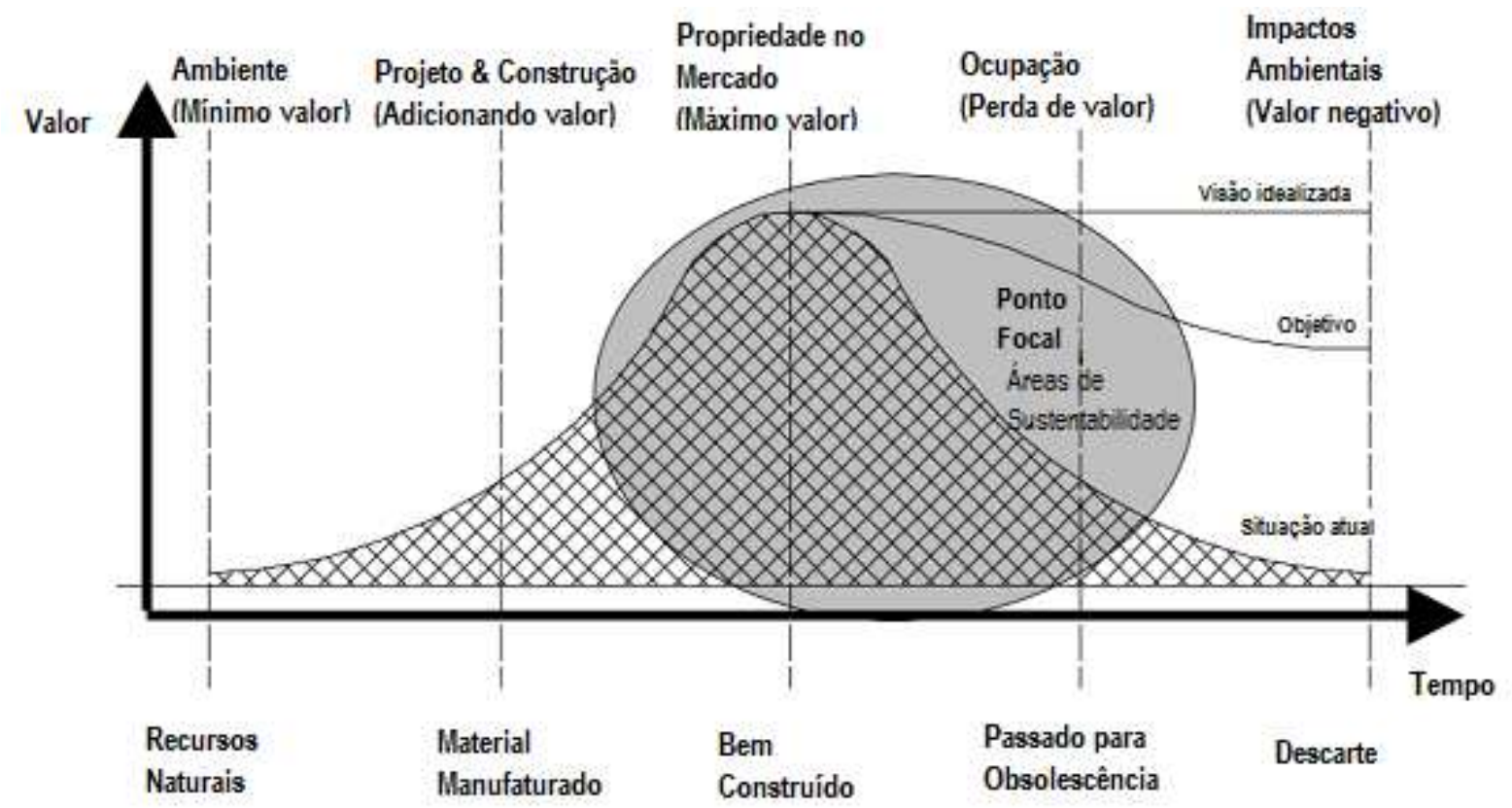

Figura 12 - Fluxo de valor do Projeto no ciclo de vida do edifício (adaptado de VAKILIARDEBILI; BOUSSABAINE, 2007)

Grilo (2002) constata que a falta de uniformização das terminologias referentes a etapas, atividades e funções desempenhadas no processo pode comprometer a gestão do empreendimento, por não deixar claros o escopo dos serviços e as 
atribuições dos diversos agentes participantes em cada etapa do processo de implantação do empreendimento, como mostra a Figura 13.

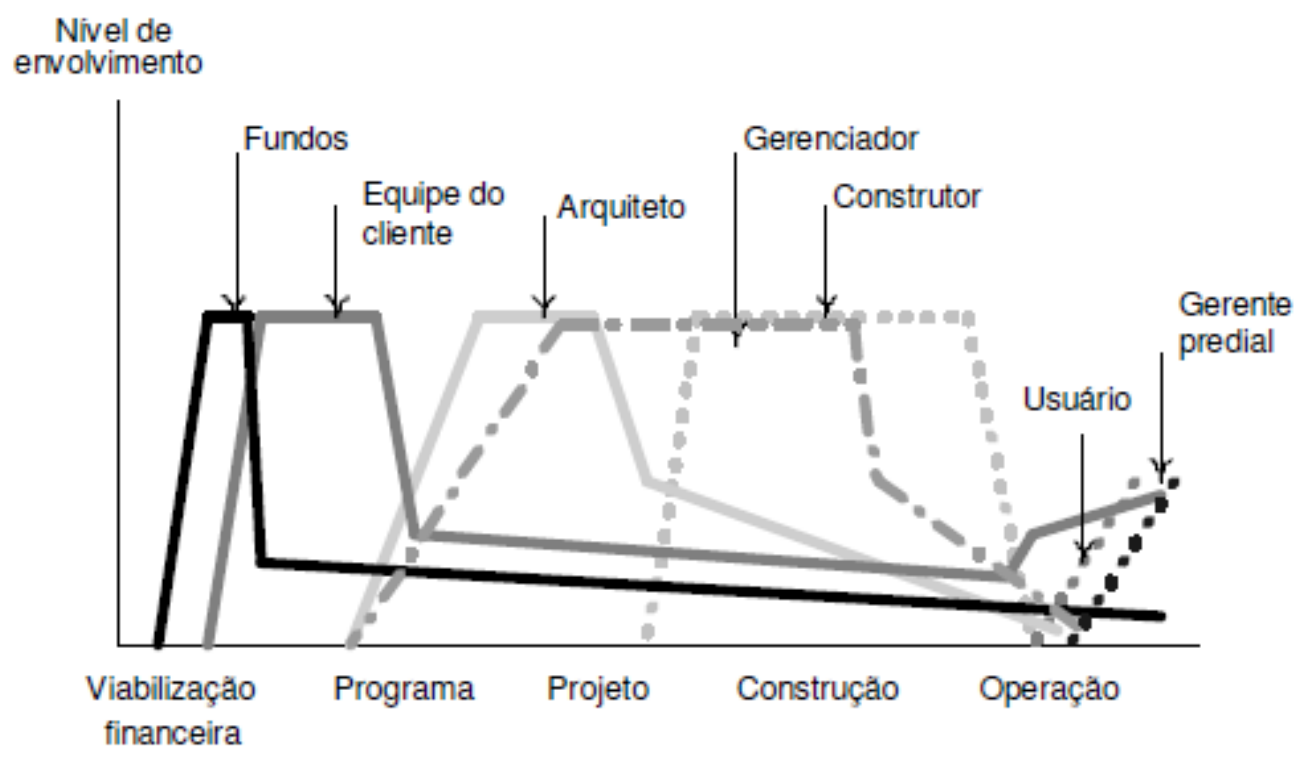

Figura 13 - Envolvimento dos agentes ao longo do processo de produção (GRILO, 2002)

O relacionamento dos membros da equipe é apontado por Grilo (2002), como essencial para a melhoria do desempenho do empreendimento, sendo a atuação dos agentes maior ou menor de acordo com as fases do ciclo de vida do empreendimento, conforme Figura 13. No entanto, outros fatores podem influir negativamente no desempenho, gerando lacunas apontadas na Figura 14: contratação de construtores e subempreiteiros com margem reduzida, assumindo maiores riscos; diferenças de cultura organizacional das empresas envolvidas; requisitos técnicos e econômicos conflituosos entre cliente, projetistas e construtora; seleção das empresas, pelo cliente, influenciada por fatores subjetivos (critérios comerciais e políticos, valores subjetivos, interesses pessoais e indicações) e não técnicos e econômicos; fragmentação do processo que impõe profunda interdependência entre os membros da equipe (projetistas devem desenvolver um projeto de acordo com um preço fixo estabelecido na fase de viabilidade da qual não participaram; assim como construtores que não participaram da viabilidade do produto devem atender ao custo, prazo e qualidade estabelecidos pelo cliente nesta fase). 


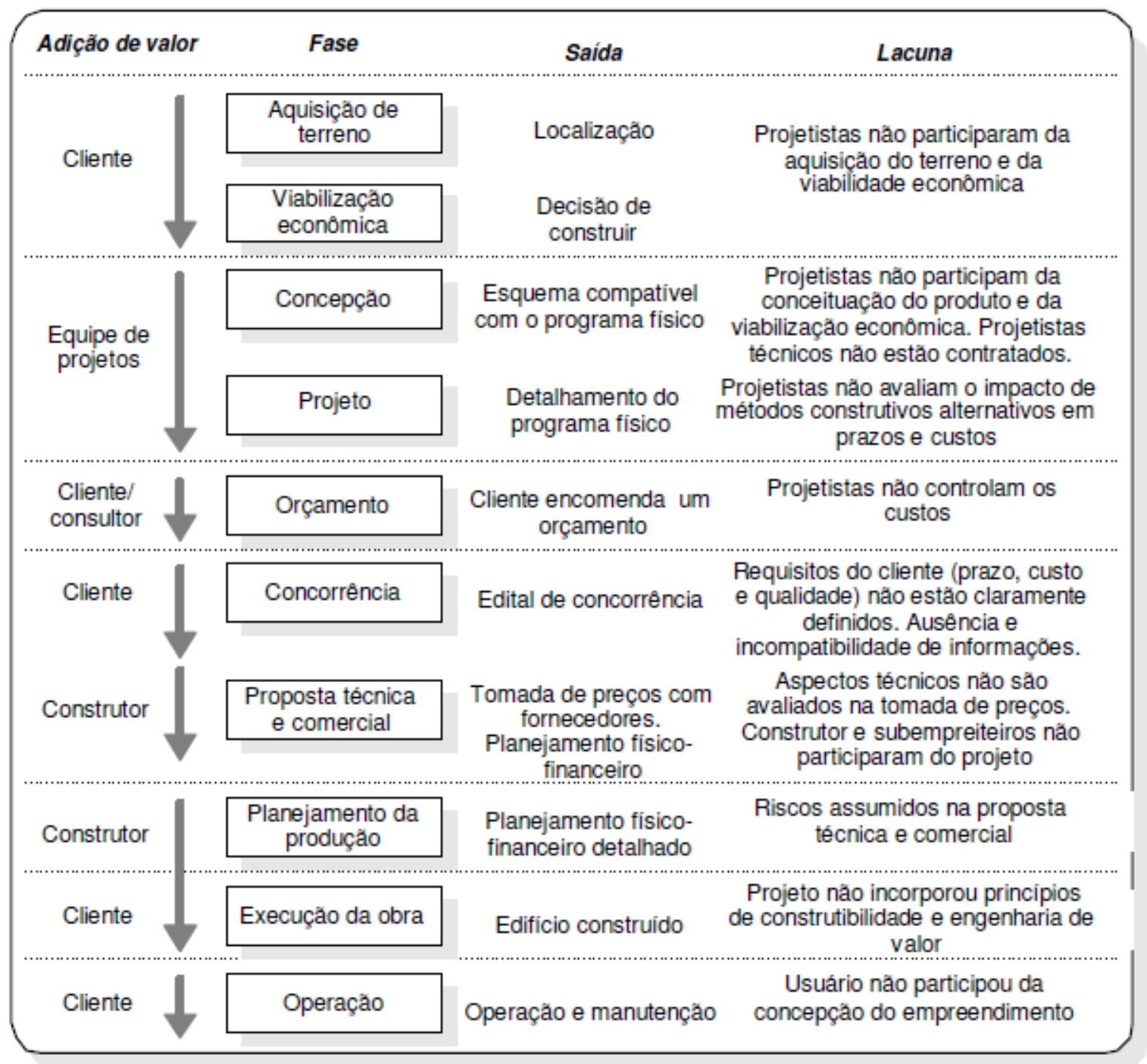

Figura 14 - Lacunas nos serviços ao longo do ciclo de vida do empreendimento (GRILO, 2002)

\subsection{Gestão do empreendimento, do processo de projeto e da produção}

A implantação do empreendimento demanda dois tipos complementares e interrelacionados de competências: a gestão da produção (fase de implantação sob responsabilidade da construtora) e a gestão do empreendimento (pode abranger o ciclo de vida do empreendimento como um todo). A gestão da produção, de acordo com Fabrício (2002), trata de processos e práticas de trabalho que admitem a repetição ou reprodução, como na indústria seriada, enquanto o empreendimento pode ser caracterizado como um Projeto único, temporário e multidisciplinar com características próprias que exigem uma gestão específica. 
Diversas empresas de engenharia e construtoras vem adotando metodologias de gestão de Projetos como base de sistema de trabalho, organizando seus processos, a fim de assegurar confiabilidade no atendimento de prazos, nos orçamentos, na qualidade e nos demais requisitos esperados pelos investidores, clientes e usuários da edificação. No entanto, as empresas devem distinguir bem a eficiência operacional de estratégia, para evitar que técnicas e ferramentas gerenciais implantadas com bons resultados operacionais tomem lugar da estratégia. Enquanto posicionamento estratégico significa executar diferentes atividades dos concorrentes e executar atividades similares de forma diferente, eficiência operacional significa executar atividades semelhantes melhor que a concorrência (PORTER, 1996; CARVALHO; LAURINDO, 2007; TZORTZOPOULOS; COOPER, 2007).

Enquanto o Projeto é "um esforço temporário empreendido para criar um produto, serviço ou resultado exclusivo", a gestão de Projetos trata da "aplicação de conhecimento, habilidades, ferramentas e técnicas às atividades do Projeto a fim de atender aos seus requisitos" e atingir as expectativas das partes envolvidas (clientes, empreendedor, parceiros, fornecedores, órgãos jurídicos ou legais, etc) com relação ao Projeto, o que envolve o equilíbrio entre demandas concorrentes: escopo, prazo, custo e qualidade (PMI, 2008).

Os Projetos são um meio de organizar as atividades que não podem ser abordadas dentro dos limites operacionais normais da organização e são utilizados para atingir o plano estratégico da empresa. As operações são esforços permanentes para execução de atividades contínuas que produzem o mesmo produto ou serviços repetitivos que exige uma gestão de processos ou operações. Durante o ciclo de vida do produto os Projetos cruzam com as operações em vários pontos. Nestes pontos ocorre a transferência de entregas, conhecimentos ou recursos entre o Projeto e as operações para viabilizar a entrega do trabalho.

Os Projetos, por sua natureza temporária, têm um início e um fim e o conjunto de fases que o compõe pode ser definido como ciclo de vida do Projeto.

O conjunto de atividades inter-relacionadas para alcançar o produto, resultado ou serviço definidos pode ser definido como processo. Uma gestão de Projetos bem sucedida requer uma gestão eficaz dos processos. Os processos do Projeto podem ser divididos em processos de gestão de Projetos e processos orientados aos produtos (como criar o produto especificado). Cada Projeto pode ser influenciado por 
restrições, tais como: escopo, qualidade, cronograma, orçamento, recursos e risco, que devem ser balanceadas para o sucesso do Projeto.

A gestão de Projetos pode ser influenciada pela cultura, estilo e estrutura organizacional, grau de maturidade da empresa em gestão de Projeto e ativos de processos organizacionais. Os ativos organizacionais podem ser agrupados em duas categorias: processos e procedimentos para a condução do trabalho (normas, diretrizes, políticas, modelos) e a base de conhecimento corporativo para armazenamento e recuperação de informações, tais como: banco de dados, arquivos do Projeto, informações históricas e lições aprendidas.

Para Emmitt (1999), a gestão das pessoas e características sociais dos funcionários envolvidos cria uma cultura única de cada empresa de projeto que afetará diretamente na forma como cada Projeto será gerenciado.

No caso da construção civil, Romano (2003) esclarece a distinção entre o processo de projeto orientado à criação do produto do Projeto (atividade criativa em busca de soluções ótimas de produtos técnicos -estudos, desenhos, especificações, cálculos) e o processo de gestão de Projeto relacionado à descrição e organização do trabalho do Projeto, processo único que consiste no desenvolvimento de um grupo de atividades coordenadas e controladas com limitações de tempo, custo e recursos (PMI, 2008).

Assim, o processo de gestão do empreendimento engloba a gestão do processo de projeto que permeia todo ciclo de vida do empreendimento e gestão da produção, que refere-se à fase de execução da obra.

Conforme a Figura 15, o processo de projeto acompanha todo ciclo de vida do edifício. Após a fase de uso e manutenção pode ter início um novo ciclo do produto após sua demolição ou reuso. Em todas as fases é ressaltada a importância da comunicação e colaboração entre todos os agentes no processo de gestão dos Projetos (EMMITT, 2002).

Para que a gestão dos projetos seja eficaz, o gestor do processo de projeto deve apresentar habilidades e competências apropriadas e devem ser claros os papéis e responsabilidades de todos envolvidos, assim como as expectativas dos contratantes (cliente, construtora, projetistas). 


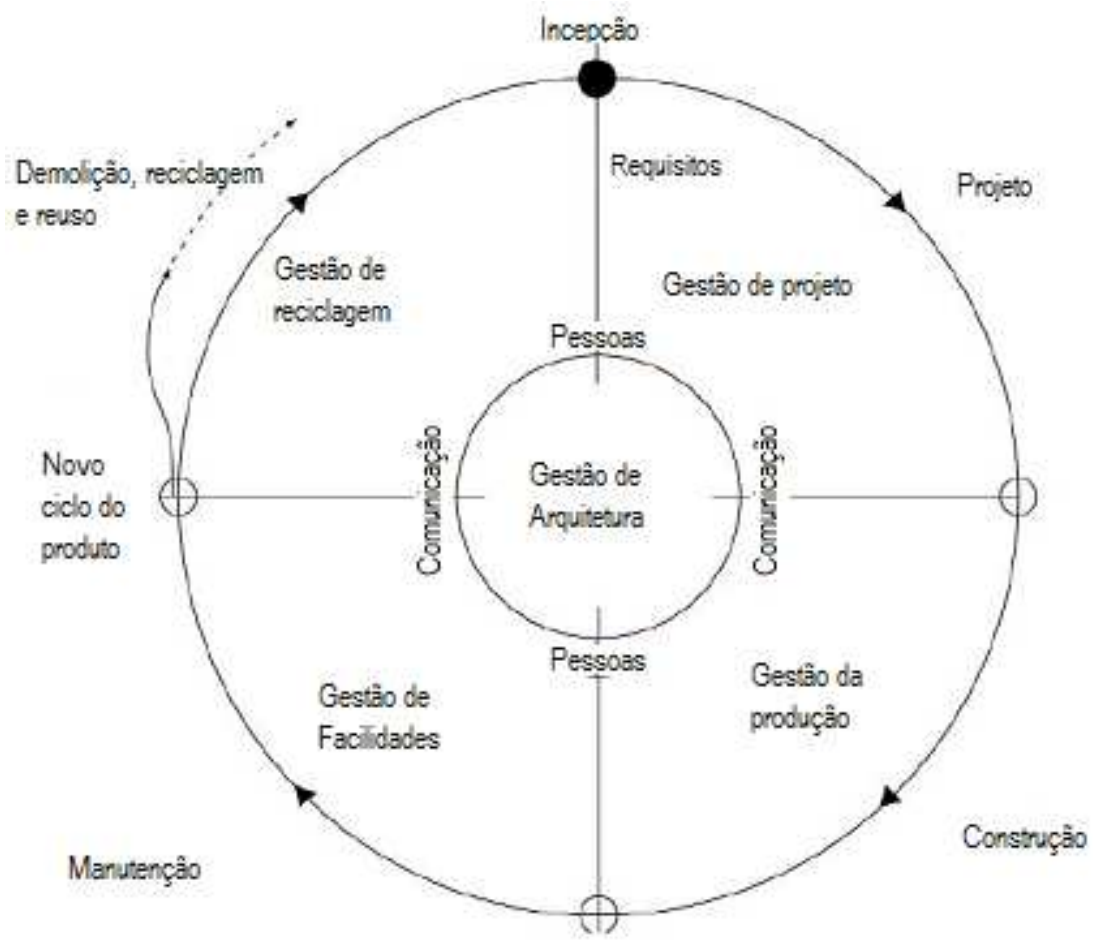

Figura 15 - Gestão do projeto arquitetônico no ciclo de vida do projeto (adaptado de EMMITT, 2002)

\subsection{Estratégia das construtoras}

Conforme definição de Porter (1996), estratégia é a criação de uma posição única e de valor, envolvendo um conjunto diferente de atividades. Visto que a vantagem competitiva pode ser temporária, face às mudanças de mercado e da tecnologia, e à possibilidade de empresas concorrentes ocuparem rapidamente sua posição, posicionamento não é mais a alma da estratégia no mercado atual.

Muitas construtoras estão à busca de estratégias para estabelecer práticas de gestão que possibilitem acompanhar as mudanças do ambiente, agregando valor aos negócios atuais e inovando com novos negócios alinhados com planos de ação de $\mathrm{TI}$, como por exemplo sistemas ERP ${ }^{4}$ (Enterprise Resource Planning) que unificam as atividades operacionais de diferentes departamentos da empresa (MÉTODO, 2008; VARGAS, 2009).

\footnotetext{
${ }^{4}$ Sistemas de ERP (Enterprise Resourse Planning) ou Sistemas Integrados de Gestão Empresarial.
} 
Além de ser flexíveis para responder rapidamente às mudanças tecnológicas e do mercado, e manter sua vantagem competitiva, as empresas devem: fazer benchmark (analisar os concorrentes) continuamente em busca de boas práticas; terceirizar agressivamente para ganhar eficiência; estimular algumas competências essenciais para manter-se à frente dos concorrentes; desenvolver novas competências; prospectar oportunidades de negócios (PORTER, 1996; GRILO, 2002; CARVALHO, LAURINDO, 2007).

O processo de transformação de uma empresa passa tipicamente por um processo de vários estágios, conforme Figura 16, no qual podem ser identificados novos mercados (PRAHALAD; HAMEL, 1994 apud CHAKRAVARTHY; MCEVILE, 2007). Este processo segue uma sequência: Reconstrução (também chamada de "simplificação", onde há uma re-engenharia de processos de negócio, redução da estrutura organizacional. Em geral, não é suficiente para restaurar a competitividade da empresa); Revitalização (foco no crescimento) e Renovação (a empresa busca melhoria contínua de excelência operacional, explorar novos mercados e renovar competências) (CHAKRAVARTHY; MCEVILE, 2007).

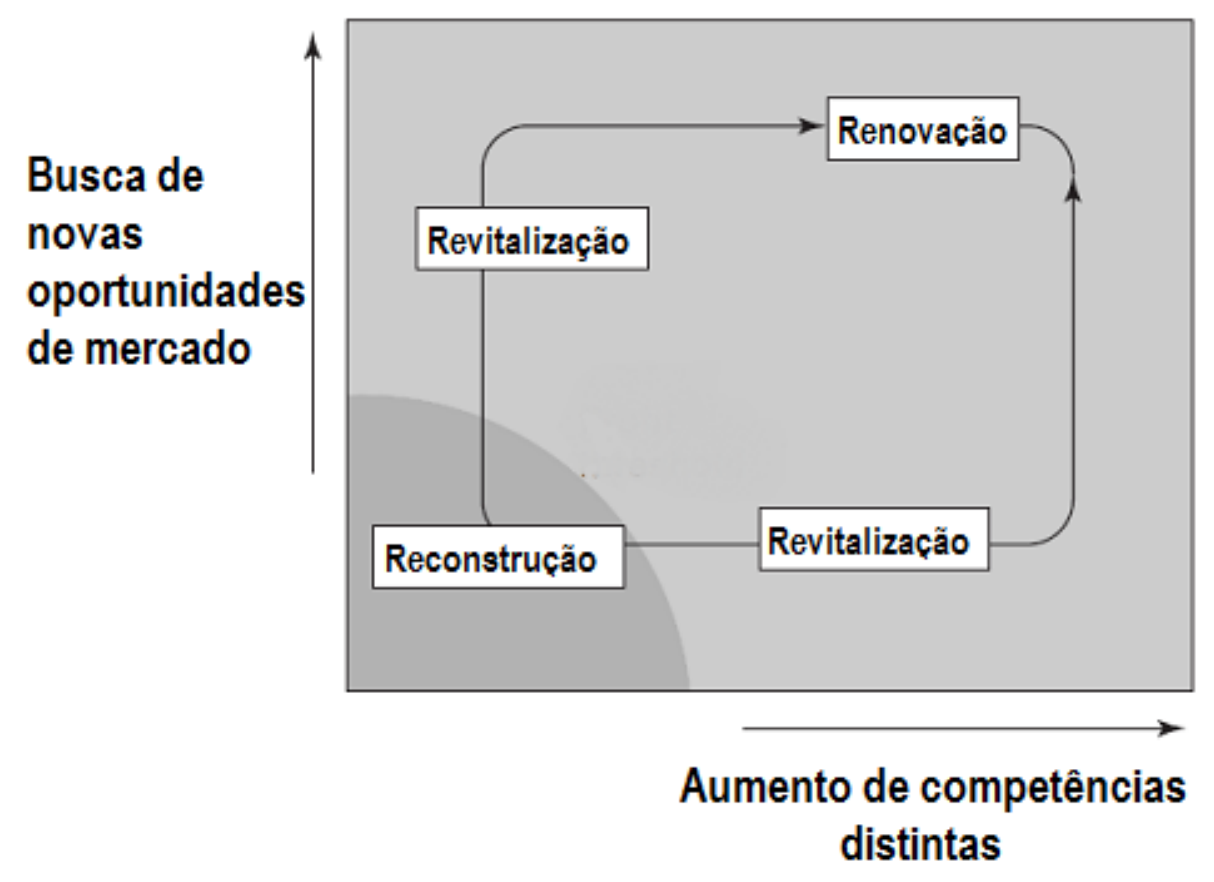

Figura 16 - Modelo de estágios de transformação de uma organização (adaptado de CHAKRAVARTHY; MCEVILE, 2007)

Chakravarthy; Gargiulo (1998) apud Chakravarthy; McEvile (2007) verificaram que não há exemplos de empresas que passaram por todos estes estágios 
progressivamente com sucesso e, uma das principais dificuldades é o comportamento da organização. Por exemplo, a capacitação dos funcionários, essencial para a revitalização, é suprimida durante a re-estruturação e uma reestruturação seguida de revitalização é inevitável em uma empresa que esteja oscilando a beira de uma falência.

O foco da estratégia deve basear-se nas principais formas de criação de valor apontadas por Porter (1989): a dominação pelos custos (custo competitivo é viabilizado ao executar certas atividades com maior eficiência que os concorrentes), a diferenciação (decorrente da escolha das atividades e como elas são realizadas) e a focalização (obter vantagens competitivas ou pela oferta de produtos e serviços com menores custos, ou pela diferenciação dos mesmos, mas em um segmento de mercado mais localizado ou restrito). Markides (1999) alerta que a busca de uma posição estratégica através da diferenciação deve responder a questões que envolvem três dimensões: quais clientes focar, quais produtos oferecer e como realizar estas atividades de maneira eficiente.

Com a entrada de novos concorrentes de menor porte no mercado da construção, com custos competitivos, uma estrutura mais enxuta e, consequentemente, despesas indiretas menores (GRILO, 2002), as construtoras de maior porte, como as pequisadas nos estudos de caso, têm oferecido novos serviços a seus clientes como forma de diferenciação, agregando novas atividades, não restritas apenas à execução da edificação, como é o caso da coordenação de projetos e sustentabilidade, para justificar seus preços mais elevados. Este fato também foi verificado na Inglaterra, onde as construtoras agregaram a gestão de Projetos para manter a competitividade e reduzir desperdícios, tanto na obra quanto no projeto (TZORTZOPOULOS; COOPER, 2007).

A adoção de contratos do modelo de "Empreitada de preço global e de chave-namão" (EPC Turnkey Lump Sum), onde a construtora responsabiliza-se pelo Projeto (engineering), aquisição de materiais e equipamentos (procurement), construção (construction), montagem e comissionamento dos equipamentos do empreendimento, tem impulsionado a competência das construtoras na gestão dos Projetos, de modo a controlar os riscos associados ao projeto (BUENO, 2009).

Para garantir uma vantagem sustentável, além do posicionamento, é necessário fazer escolhas e definir o que não fazer, para potencializar as competências da 
empresa e proteger-se de imitações dos concorrentes. A necessidade destas escolhas surge por três razões: manter consistência da imagem ou reputação; compatibilidade com as características das próprias atividades (diferente posicionamento requer diferentes equipamentos, comportamento dos funcionários, habilidades, sistemas de gestão); limites de coordenação interna e controle das atividades (não é possível atender todos os clientes de variadas formas) (PORTER, 1996). Estas decisões são influenciadas diretamente pelo ambiente externo competitivo no qual a empresa atua (onde se encontram ameaças e oportunidades) e suas características internas (CARVALHO; LAURINDO, 2007).

Ao imitar as melhorias em qualidade, tempo, parcerias com fornecedores, as estratégias das empresas se convergem e a competição torna-se uma corrida pelo mesmo caminho. O resultado é uma competição sem vencedores, preços estáticos ou em declínio e pressão em custos que comprometem a habilidade da empresa em investir em negócios em longo prazo (PORTER, 1996).

A base para uma estratégia corporativa de sucesso através da diversificação, segundo Porter (1987), seria estruturar a organização de acordo com a lógica de unidades de negócio, criando mais valor para o acionista.

Prahalad e Hamel (1991) contestam alegando que a fragmentação das competências essenciais é inevitável quando um sistema de informações de uma empresa diversificada, padrões de comunicação, planos de carreira, recompensas gerencias, e processos de desenvolvimento estratégico estão confinados em unidades de negócio. Quando o foco está apenas na atratividade de mercado ou no retorno rápido aos acionistas por meio das unidades de negócios, as competências essenciais podem ser perdidas. Os fatores negativos apontados desta estrutura são: baixo investimento no desenvolvimento das competências e produtos essenciais, recursos presos nas unidades de negócio e inovações limitadas.

O sucesso da estratégia depende da integração do conjunto de atividades da empresa, o que pode reduzir substancialmente os custos e aumentar a diferenciação, tornando a estratégia sustentável e dificultando a imitação dos concorrentes. De acordo com Porter (1996), existem três níveis de compatibilização: consistência entre a estratégia da empresa e cada atividade funcional (visão única da estratégia facilita sua implementação e transmissão para clientes, funcionários e acionistas), reforço mútuo das atividades e otimização dos esforços. Collin e 
Rukstad (2008) ressaltam que a estratégia deve ser resumida na forma de uma declaração simples, clara e sucinta de forma que toda empresa possa internalizá-la, o que permite que as decisões individuais estejam alinhadas aos negócios da empresa e reforcem umas às outras aumentando sua efetividade, evitando a falha recorrente de muitas empresas ao criar planos estratégicos complexos que nunca são implantados.

A vantagem competitiva, tanto de custo quanto diferenciação, é função da cadeia de valor da empresa que é um sistema de atividades interdependentes que estão conectadas por ligações. A habilidade de diferenciação de uma empresa reflete a contribuição de cada atividade de valor para atender às necessidades do cliente.

Porter $(1985,2008)$ enquadra as atividades de valor em nove diferentes categorias, que podem ser aplicadas à cadeia de valor da construção de um empreendimento imobiliário, conforme Figura 17, na qual: as atividades principais são as atividades envolvidas na criação física do produto - a aquisição do terreno e a construção, o marketing, entrega ao cliente e serviço pós-venda (assistência técnica).

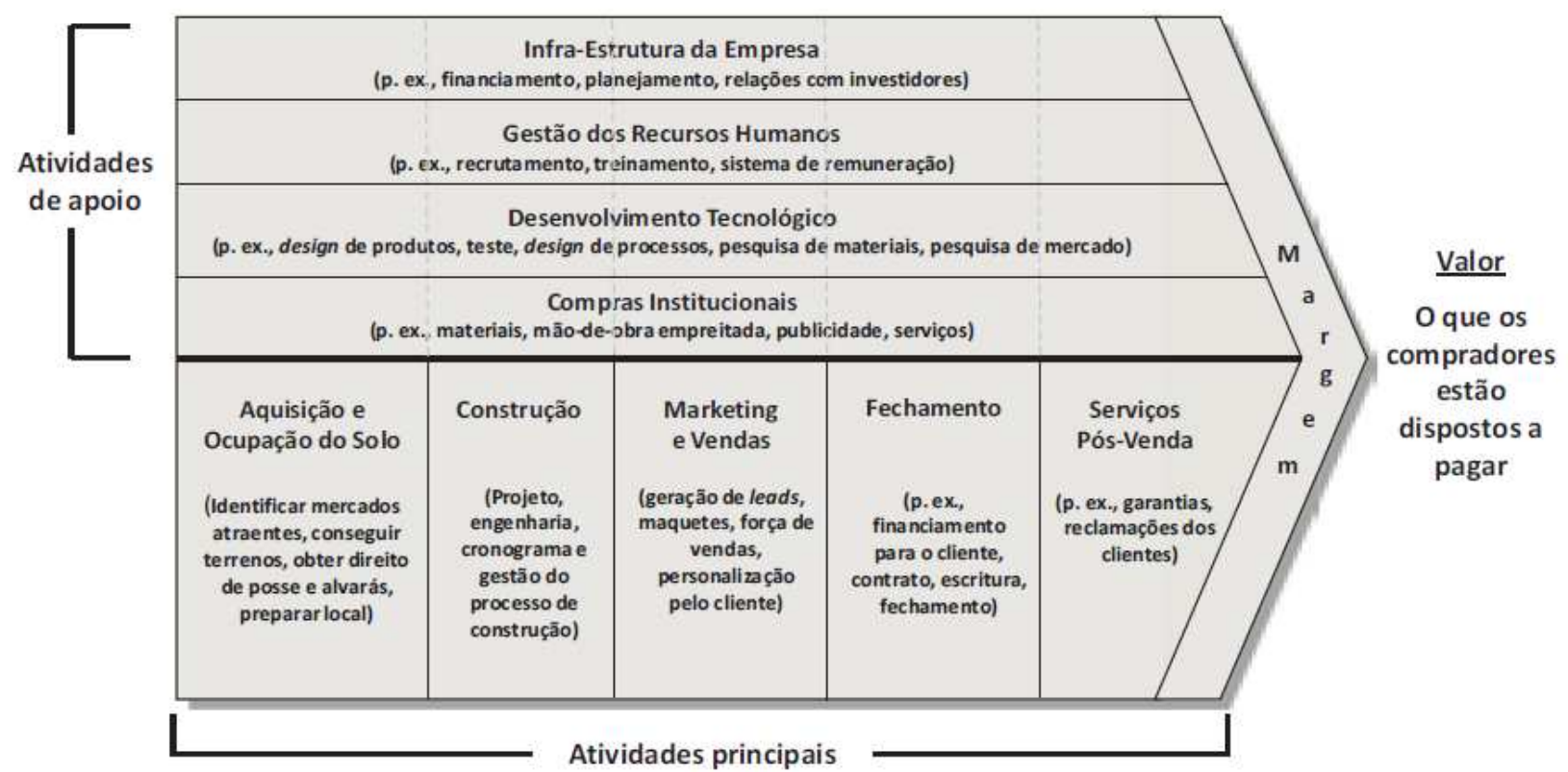

- Podem haver maneiras diferentes de configurar a cadeia de valor no mesmo setor.

Figura 17 - Definindo a cadeia de valor: Incorporação Imobiliária (PORTER, 2008) 
A infra-estrutura da empresa, incluindo funções tais como planejamento, gestão de recursos humanos, procedimentos jurídicos, contabilidade, suprimentos, representam as atividades de apoio de toda a cadeia.

Porter (1996) propõe que a popularidade da terceirização e da organização virtual reflete o reconhecimento que é difícil desempenhar todas as atividades de forma tão produtiva como os especialistas.

Para Prahalad, Hamel (1991), a terceirização pode ser um atalho para um produto mais competitivo, mas tipicamente contribui pouco para construir as habilidades pessoais necessárias para sustentar a liderança do produto. A terceirização pode ser uma forma de perder competência e deixar passar oportunidades de estabelecer competências para o desenvolvimento de novos negócios.

Competência é a forma através da qual o conhecimento é extraído, utilizado e aplicado em um contexto específico, agindo no processo de transformação que finaliza na geração de um novo produto ou conhecimento (MALERBA; ORSENIGO, 2000).

Do ponto de vista da organização, competência é o resultado do processo de aprendizado, onde o histórico se transforma em rotinas que guiam as condutas. Em empresas baseadas em Projetos há uma dificuldade maior em acumular conhecimento e desenvolver estas rotinas. As competências nestas empresas são armazenadas em objetos que incorporam representações do conhecimento (desenhos, modelos virtuais, guias de procedimento, etc) que podem ser reutilizados em outros Projetos semelhantes (CACCIATORI, 2008).

Como as competências essenciais são construídas através de um processo de melhoria e crescimento contínuos que podem estender-se por décadas ou mais, a empresa que falhou em investir em construir competências essenciais terá dificuldade em entrar em um mercado emergente, ao menos que se contente em simplesmente servir como canal de distribuição (PRAHALAD; HAMEL, 1991).

No mercado globalizado, a administração das competências torna-se mais complexa e exige das empresas: conquistar acesso ao conhecimento e absorver novos conhecimentos de acordo com a orientação estratégica da empresa; associar os fluxos de conhecimento novos aos existentes para criar novas oportunidades de negócio; compartilhar culturas e encurtar distâncias; aprender a esquecer para 
adaptar-se às mudanças de mercado; levar as competências além das fronteiras das unidades de negócios propiciando compartilhamento (PRAHALAD, 1999).

Partindo do príncipio que o conhecimento é uma competência essencial da empresa, a renovação contínua da empresa deve ser alinhada à gestão do conhecimento que tem três atividades chave: construir, proteger e alavancar conversão de recursos e conhecimento de posicionamento no mercado. Se a empresa já construiu um conhecimento diferenciado, deve empenhar-se em proteger e extender este conhecimento buscando a renovação. Ao alavancar sua base de conhecimento e aplicá-la a novas oportunidades de mercado, o crescimento estará assegurado. No entanto, nenhuma base de conhecimento será diferenciada para sempre, e caso a empresa entre em um novo mercado precisará, eventualmente, de novos conhecimentos. Como mostra a Figura 18, a gestão do conhecimento é um processo de contínua iteratividade entre as três atividades chave (CHAKRAVARTHY; MCEVILE, 2007).

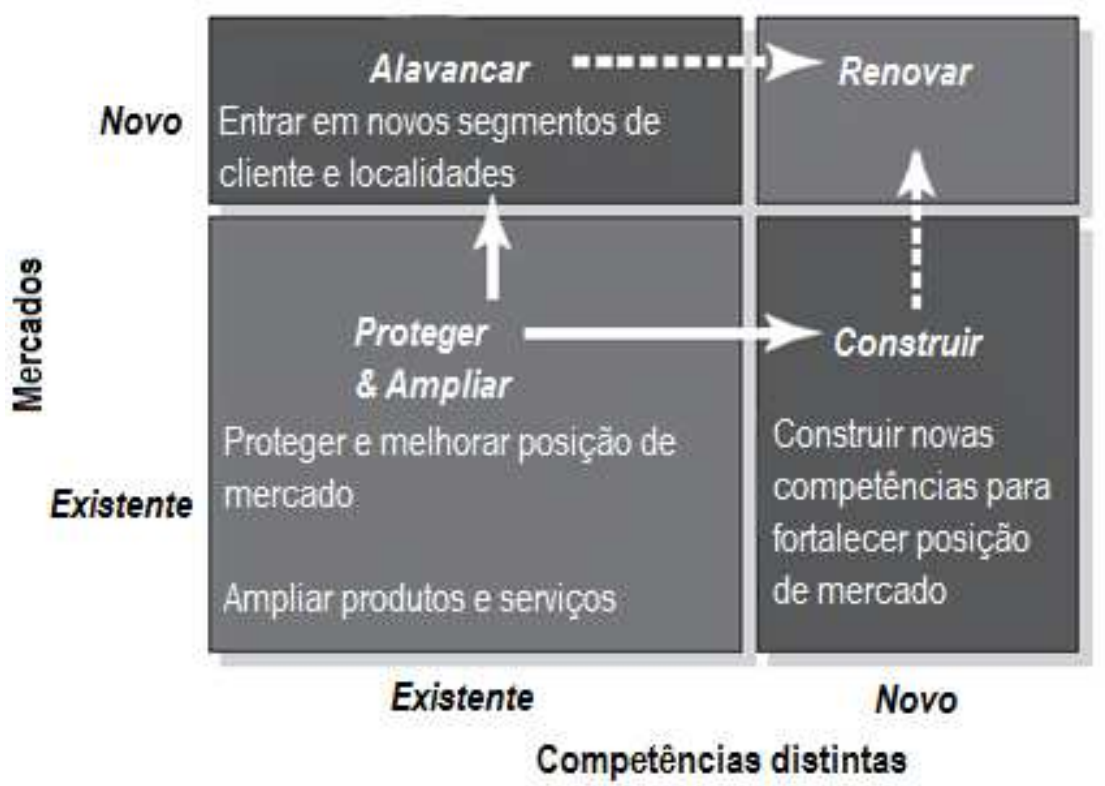

Figura 18 - Renovação contínua (adaptado de CHAKRAVARTHY, 1996 apud CHAKRAVARTHY; MCEVILE, 2007)

Leonard-Barton (1992) apud Chakravarthy; McEvile (2007) observou que as competências essenciais de uma empresa tendem a tornar-se rígidas devido à falhas gerenciais de construir novos conhecimentos e descartar conhecimentos antigos que se tornaram obsoletos. 
A revisão periódica é um pré-requisito para a renovação. A construção de competências essenciais demanda um longo período de tempo, e ao invés de esperar que se tornem rígidas, é importante buscar oportunidades para que estas competências sejam utilizadas como base de outras áreas da empresa (CHAKRAVARTHY; MCEVILE, 2007).

Muitas construtoras atuam basicamente como intermediárias de terceiros: a equipe de projetos é externa; a mão-de-obra é terceirizada, do setor, e não própria; os subempreiteiros e os serviços técnicos especializados trabalham para qualquer construtora; as metodologias construtivas e os índices de custos são de domínio público; e a pesquisa, desenvolvimento e produção dos materiais são de propriedade do fornecedor. Sob esta ótica, Vargas (2003) questiona se as construtoras, ao fabricar um produto físico com características peculiares (edificação), devem ser classificadas como indústria ou prestadoras de serviço.

Algumas construtoras adotam iniciativas de oferecer serviços globais de construção para controlar os riscos dos empreendimentos, diversificar seu escopo de atuação e aumentar as margens de lucro, conforme citado por Grilo (2002): "desenvolvimento de fornecedores de mateiriais e parcerias com projetistas de arquitetura $e$ engenharia; estabelecimento de competências internas para análise de investimentos e coordenação de projetos; introdução de uma fase de préconstrução, na qual alternativas técnicas e econômicas são propostas com o objetivo de ajustar o projeto ao programa, orçamento e cronograma do cliente; e uma participação mais intensa na viabilização do negócio e na conceituação, concepção e detalhamento do produto". No entanto, muitas vezes recebem pouca valorização por parte do cliente, e aumentam sua vulnerabilidade no mercado cada vez mais competitivo.

O termo construtora-gerenciadora, muitas vezes é empregado nos empreendimentos onde assume o papel de integrador, por meio da gestão global das interfaces necessárias para sua implantação, denominado EPCM - Engineering, Procurement, Construction and Management (Engenharia, Suprimentos, Construção e Gestão).

Segundo Paul Dinsmore (PETRELLA, 2004), as empresas do setor da construção, cuja atividade principal são os Projetos, para manter a competitividade devem: diversificar os tipos de Projetos; organizá-los em Programas; ${ }^{5}$ otimizar a estrutura da 
empresa e manter alinhado o Portifólio ${ }^{6}$ com a estratégia empresarial. Para atingir estes objetivos de forma eficiente as empresas devem desenvolver a maturidade da organização na gestão de Projetos.

Existem vários modelos para medir a maturidade em gestão de Projetos organizacionais das empresas onde é avaliada a capacidade de uma organização de coordenar os esforços para entregar Projetos alinhados à sua estratégia geral e propor uma estrutura de melhoria contínua para amadurecimento progressivo da organização.

Diversos estudos têm demonstrado que a maturidade está relacionada com a capacidade da organização de gerenciar seus Projetos com sucesso. Assim, para concretizar a estratégia da empresa e buscar níveis superiores de sucesso, é necessária uma evolução da maturidade em gestão de Projeto, como ilustrado na Figura 19 (PRADO; ARCHIBALD, 2010).

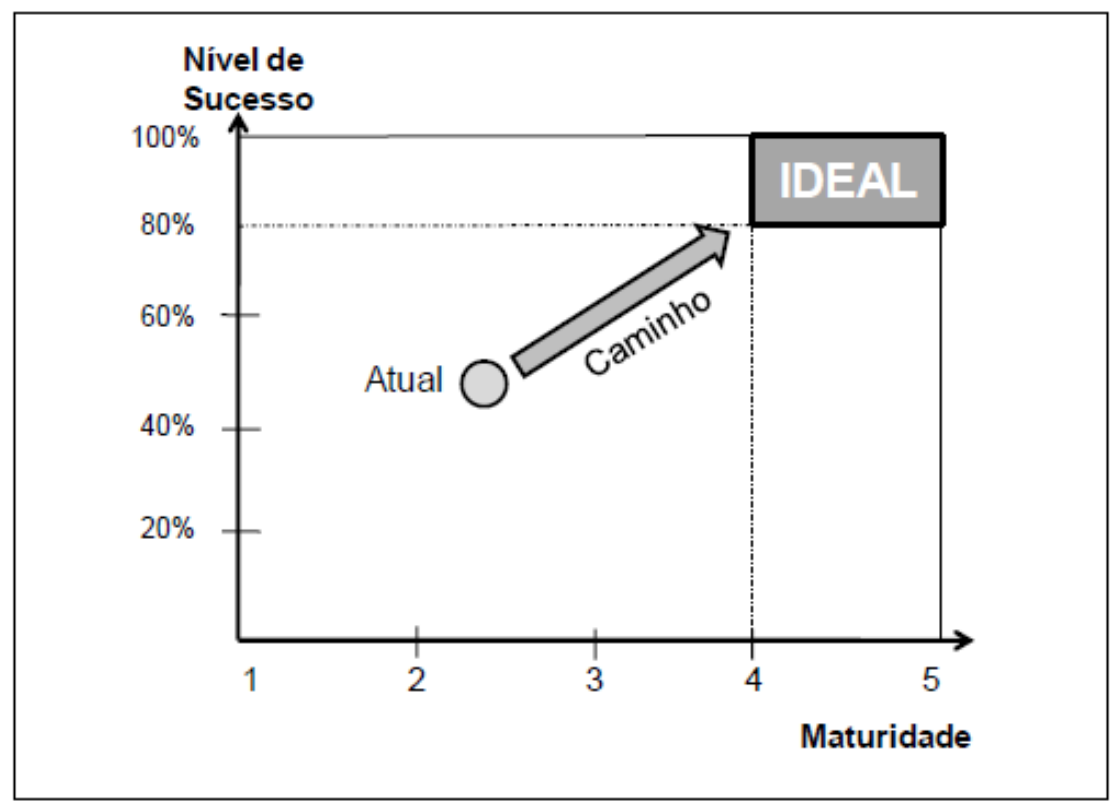

Figura 19 - A evolução para a situação ideal (PRADO; ARCHIBALD, 2010).

\footnotetext{
${ }^{5}$ Um programa é definido como um grupo de Projetos relacionados gerenciados de modo coordenado para a obtenção de benefícios e controle que não estariam disponíveis se eles fossem gerenciados individualmente (PMI, 2008).

${ }^{6}$ Um portifólio refere-se a um conjunto de Projetos ou programas agrupados para facilitar 0 gerenciamento eficaz desse trabalho. Os portifólios e os programas podem incluir elementos de trabalhos relacionados fora do escopo de Projetos distintos no programa (PMI, 2008).
} 
Segundo Kerzner (2006) apud Prado; Archibald (2010), gasta-se até 7 anos para atingir o nível 5 de excelência de maturidade, partindo-se do nível inicial. Segundo pesquisa de maturidade de gestão de Projetos no Brasil realizada em 2010 com 354 organizações, sendo 9\% empresas de engenharia e 9\% construção, apenas 11\% das organizações encontravam-se nos níveis 4 e 5 . No entanto, a maturidade do setor da construção $(3,04)$ foi superior à média global $(2,61)$, o que mostra uma evolução comparado aos últimos anos, como ilustrado na Figura 20 (PRADO; ARCHIBALD, 2010).

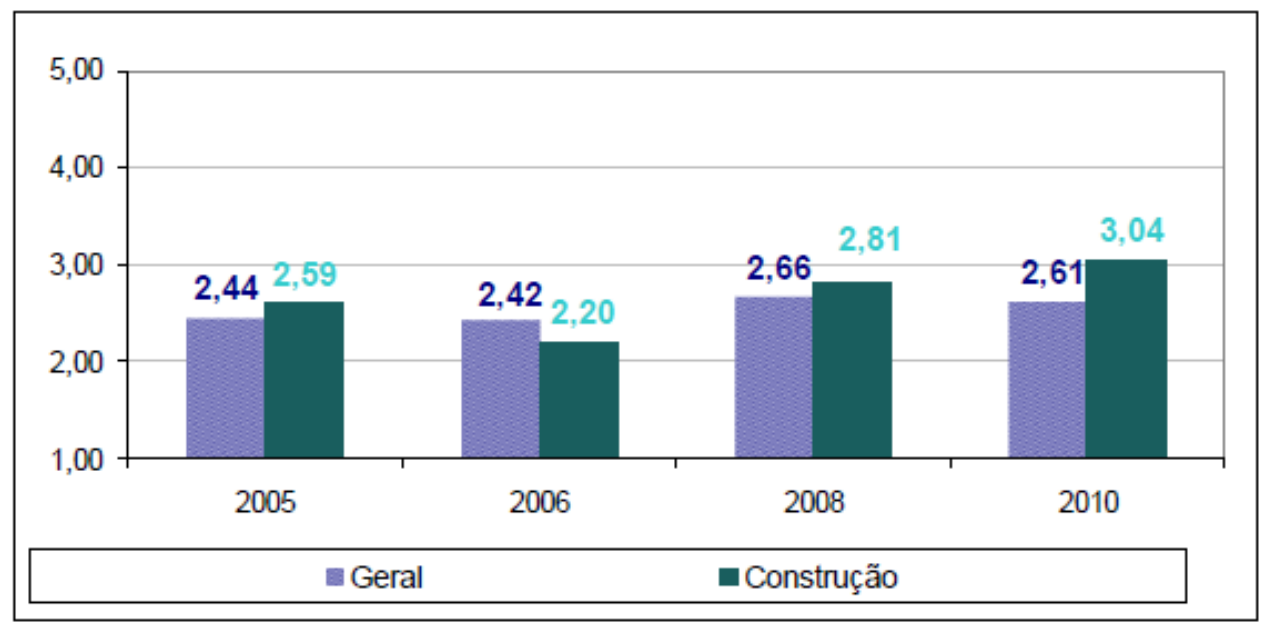

Figura 20 - Evolução da maturidade da área de negócios da construção comparada com geral (PRADO; ARCHIBALD, 2010)

\subsection{Integração e colaboração entre projeto-construção}

Diante de um ambiente competitivo e o aquecimento do mercado imobiliário, onde os contratantes público e privados estão cada vez mais exigentes e seletivos quanto aos produtos, as empresas da construção civil seguem a tendência de outros setores, sendo pressionadas a buscar a melhoria da qualidade de seus produtos e processos, para reduzir custos e prazo de entrega do produto, aumentar a satisfação dos clientes, aumentar as vendas e agilizar o retorno do investimento (GRILO, 2002; ROMANO, 2003). Neste cenário, as construtoras são impulsionadas a buscar estratégias para garantir seu sucesso, atendendo às expectativas dos clientes, e manter sua competitividade.

Vários estudos convergem para o conceito de que a integração entre o projeto e a construção constitui uma premissa para o desempenho do empreendimento, que pode ser medido em função do aumento do custo, do prazo de construção e do 
número de modificações (MELHADO, 1999; FABRICIO, 2002; GRILO, 2002; ROMANO, 2003; SHEN et al., 2010).

Em sua pesquisa, Romano (2003) verificou o crescente número de estudos acadêmicos sobre a melhoria da qualidade no processo de projeto e iniciativas de empresas construtoras-incorporadoras de desenvolver e implementar alguns procedimentos para modificar o modelo tradicional sequencial de desenvolvimento de produto. Uma das mudanças mais significativas foi a implementação da Engenharia Simultânea que busca encurtar o prazo para desenvolvimento do produto através do paralelismo de atividades de projeto e maior interação entre projetistas e demais agentes envolvidos no processo, como mostra a Figura 21 (FABRICIO, 2002; SHEN et al., 2010).

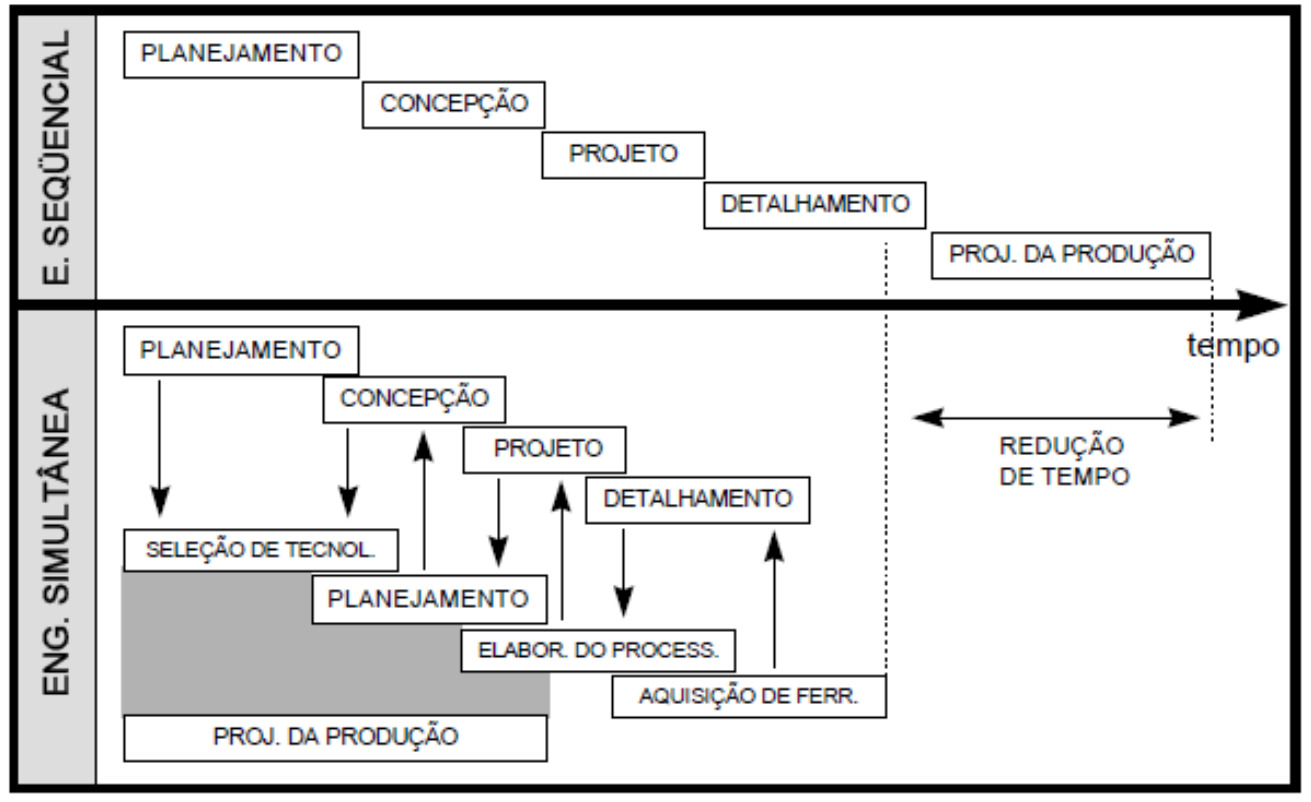

adaptado de Weck et al. (1991) apud Takahashi (1996)

Figura 21 - Engenharia Sequencial x Engenharia Simultânea (FABRICIO, 2002)

A integração projeto-produção (projetista, construtor, fornecedor) possibilita antecipar os conflitos, disseminar as informações de projeto aos responsáveis pela obra, favorecendo a retroalimentação dos projetos e ampliando as competências dos projetistas (MELHADO, 2001) visando não só "a qualidade do produto, mas também a qualidade do processo" (PICCHI, 1993).

Além de melhorar a manufaturabilidade dos produtos por meio do desenvolvimento conjunto do projeto do produto e do projeto para produção, a Engenharia Simultânea 
possibilita diminuir as incertezas no processo de projeto (KOSKELA; HUOVILA, 1997 apud FABRICIO, 2002) e reduzir o custo decorrente de revisões e modificações de projeto tardias, como ilustrado na Figura 22.

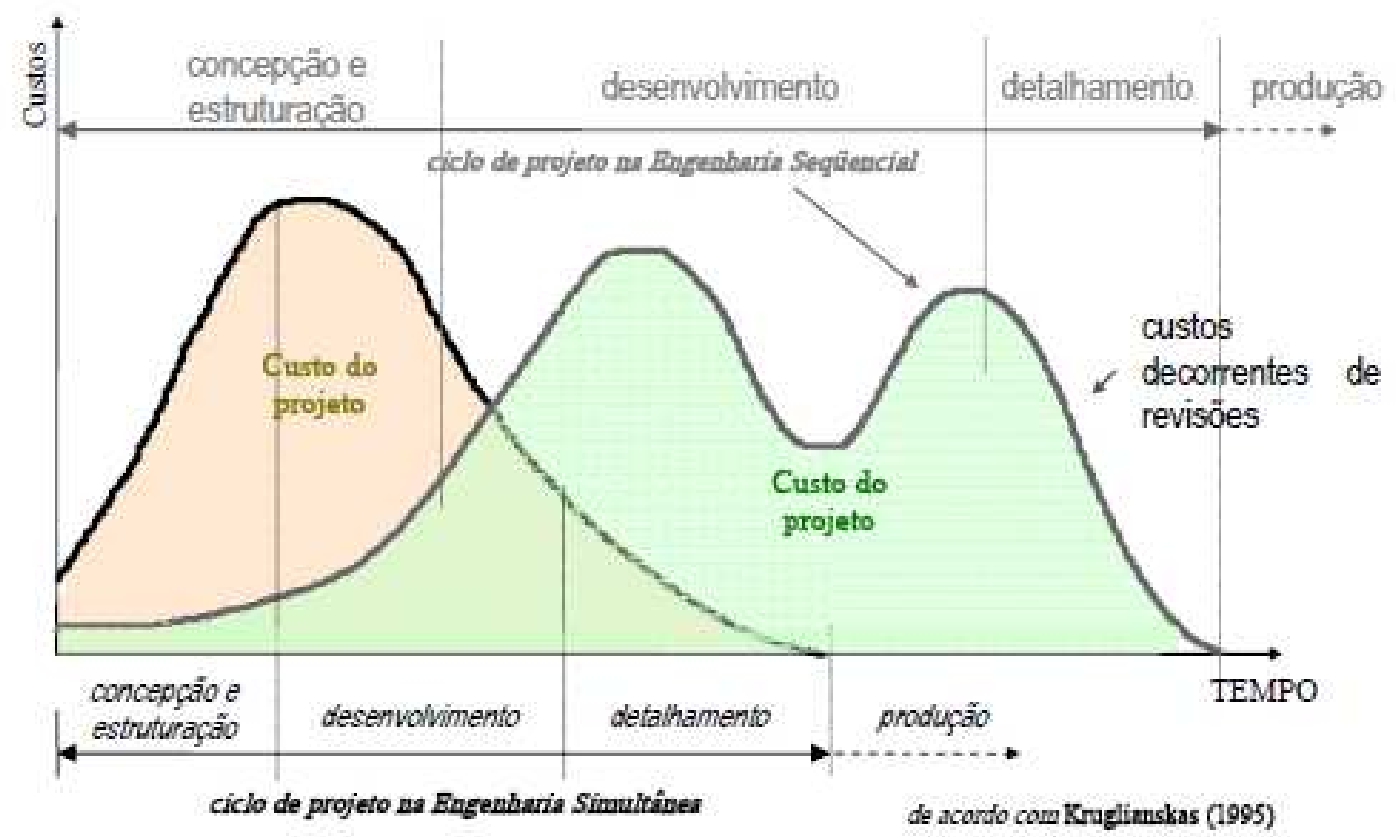

Figura 22 - Comparação do desenvolvimento de produto em engenharia sequencial e em engenharia simultânea (FABRICIO, 2002)

Melhado et al. (2005) identificam três situações, conforme Quadro 6, quanto à possibilidade de interação entre coordenação de projetos e coordenação da execução de obras.

\begin{tabular}{|c|c|c|}
\hline Situação & $\begin{array}{l}\text { Possibilidade de interação } \\
\text { entre coordenação de } \\
\text { projetos e execução de obras }\end{array}$ & Tipo de interação \\
\hline $\begin{array}{l}\text { Uma mesma empresa realiza } \\
\text { o empreendimento e a obra }\end{array}$ & Grande & $\begin{array}{l}\text { Incorporação de profissionais } \\
\text { de execução da construtora ao } \\
\text { desenvolvimento dos projetos }\end{array}$ \\
\hline $\begin{array}{l}\text { O empreendedor contrata uma } \\
\text { construtora após o projeto } \\
\text { desenvolvido e o produto } \\
\text { definido }\end{array}$ & $\begin{array}{l}\text { Depende dos termos de } \\
\text { contratação da construtora e } \\
\text { interesse do empreendedor que } \\
\text { a construtora participe do } \\
\text { detalhamento do projeto }\end{array}$ & $\begin{array}{l}\text { Construtora } \\
\text { modificações do projeto para } \\
\text { beneficiar custo, prazo ou } \\
\text { construtibilidade }\end{array}$ \\
\hline $\begin{array}{l}\text { Desenvolve-se o projeto } \\
\text { executivo ou básico e contrata- } \\
\text { se a construtora como } \\
\text { empreiteira }\end{array}$ & Nenhuma & $\begin{array}{l}\text { Interferências da construtora } \\
\text { apenas no caso de mudanças } \\
\text { no projeto executivo }\end{array}$ \\
\hline
\end{tabular}

Quadro 6 - Possibilidade de interação entre coordenação de projetos e execução de obras (adaptado de MELHADO et al., 2005) 
Diversas pesquisas conduzidas no Canadá, assim como outros países, indicaram a colaboração baseada na internet e sistemas de gestão de Projetos como tendências de TI mais importantes na indústria da construção (67\%) seguidas por integração de ferramentas de programa ao longo do ciclo de vida do Projeto (43\%) (SHEN et al., 2010). Segundo Tapscott; Willians (2007) apud Shen et al. (2010), a nova regra para competitividade é "colaborar ou morrer".

A colaboração envolve o compartilhamento de idéias, planejamento de atividades, entregas de Projetos ou revisão de resultados. Equipes tornam-se mais produtivas em ambientes compartilhados através do compartilhamento de fóruns, agendas, blogs (site que permite rápida atualização e pode ser escrito por várias pessoas) e wikis (programa colaborativo que permite a edição colectiva dos documentos). No entanto, todas as informações compartilhadas devem ser gerenciadas e rastreáveis para justificar determinadas tomadas de decisão durante o Projeto, registrar novas criações ou mesmo resgatar registros históricos ou operacionais, no caso de processos legais (RATH, 2010).

Além da Engenharia Simultânea, Shen et al. (2010) destacam as três maiores iniciativas de integração entre projeto-construção-FM (Gestão de Facilidades) identificadas em sua pesquisa: FIATECH nos EUA, ECPT na Europa e CIB IDS (Soluções Integradas de projeto), como mostra a Figura 23.

A FIATECH - Fully Integrated and Automated TECHnology (Tecnologia Totalmente Automatizada e Integrada) é uma sub-unidade do Instituto da Indústria da Construção, consórcio de mais de 100 proprietários, construtores e fornecedores do setor público e privado dos EUA, baseado na Universidade do Texas com o objetivo de aumentar a efetividade e sustentabilidade dos negócios através de pesquisas e alianças. O Projeto mais importante da FIATECH foi o CPTR - Capital Projects Technology Roadmap (Mapa das Tecnologias dos Principais Projetos) que apresenta a visão da indústria da construção para desenvolver um ambiente integrado entre projeto e FM - Facility Management (Gestão de Facilidades) por todas as fases do ciclo de vida de facilidades. 


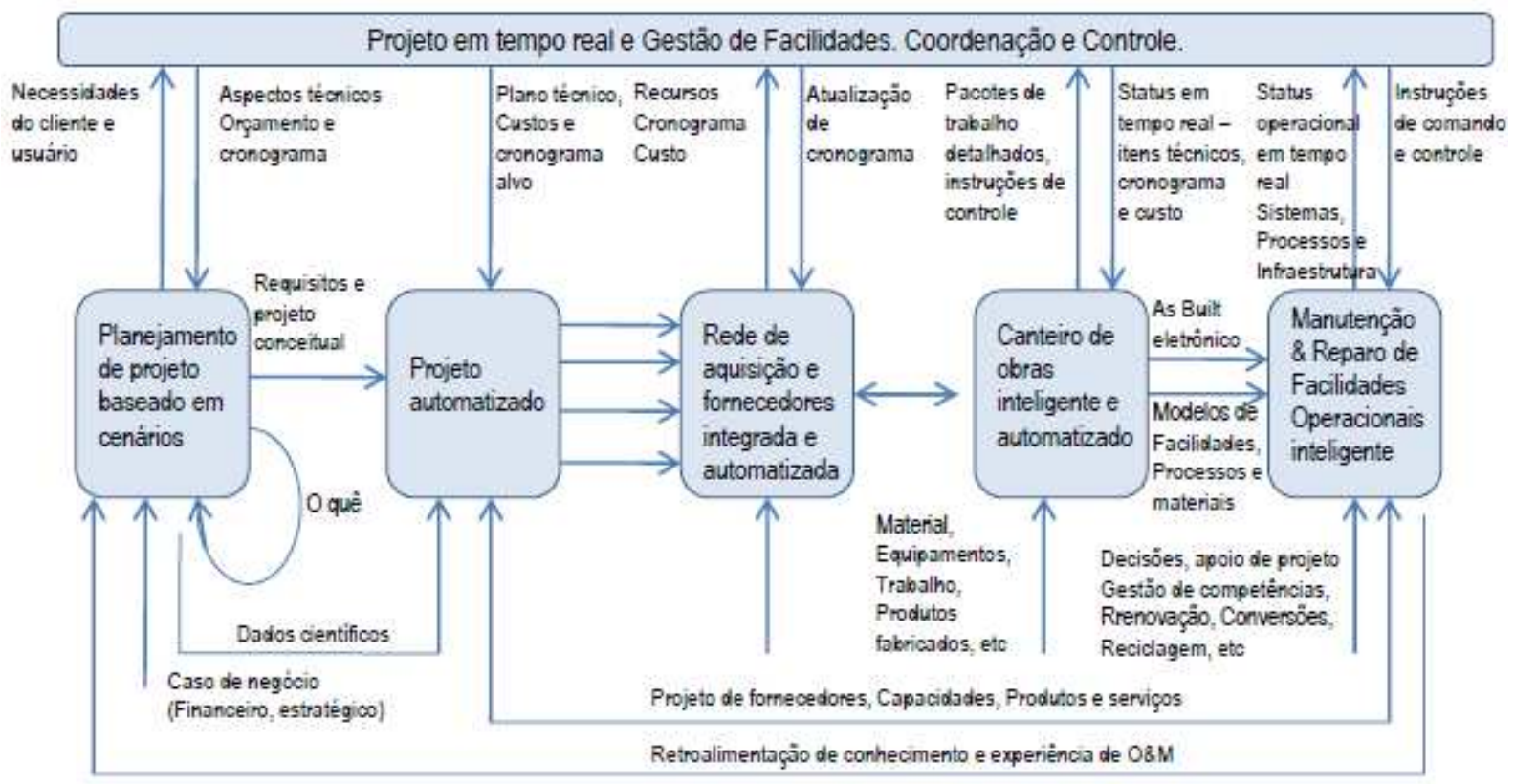

Novos materiais, Métodos, Produtos e Equipamentos

Tecnologia e esforço para habilitar Conhecimento

Gestão de dados do ciclo de vida e Integração de Informação

Figura 23 - Visão FIATECH-CPTR (adaptado de SHEN et al., 2010)

O mais recente Projeto guia de tecnologia da construção conduzido na Europa é o ECTP - European Construction Technology Plataform (Plataforma Tecnológica da Construção Européia), que tem como objetivo mobilizar o setor da construção para definir as principais prioridades em comum. A Prioridade $\mathrm{H}$ da Agenda de Pesquisa Estratégica, conforme Figura 24, Novos processos integrados para o setor da construção destaca o compartilhamento de conhecimento, suporte para colaboração, interoperabilidade e modelos digitais como temas estratégicos. 


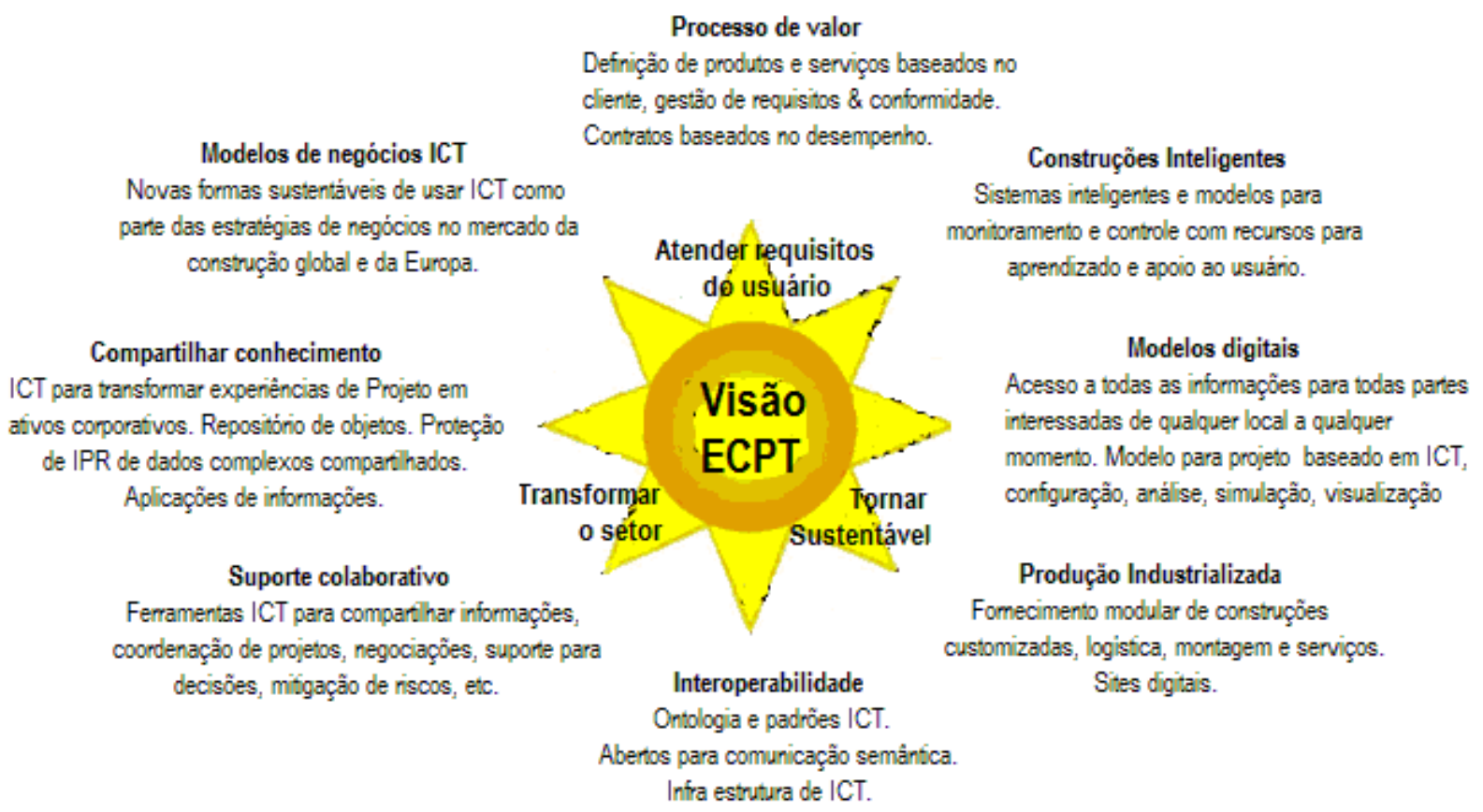

Figura 24 - Itens da Prioridade H da Agenda de Pesquisa Estratégica do ECTP http://www.ectp.org/ (adaptado de SHEN et al., 2010)

O CIB - Conseil International du Bâtiment (Conselho Internacional da Construção), cujo nome foi alterado para Conselho Internacional para Pesquisa e Inovação na Edificação e Construção em 1998, tem como objetivo estimular a colaboração internacional e troca de informação entre institutos de pesquisas governamentais no setor de edificação e construção.

Desde 2006, o CIB tem desenvolvido o tema prioritário de IDS - Integrated Design Solution (Solução Integrada de Projeto) utilizando um processo de trabalho colaborativo, habilidades, informações e dados integrados e gestão do conhecimento para minimizar estruturas e processos ineficientes e aumentar o valor agregado ao projeto, obra e operação, e entre Projetos. No encontro de 2008, foi definido iniciar um trabalho de identificação da ineficiência na construção a partir do ponto de vista dos diversos agentes do processo que servirá de base para as PIO's - Process Improvement Opportunities (Oportunidades de Melhoria de Processo) (SHEN et al., 2010).

No encontro do CIB de 2009, foram levantados, conforme Quadro 7, os problemas e oportunidades que resultaram na definição da visão de futuro da construção: 
- A construção será como a manufatura: simultânea, com poucos defeitos, eficiente, com integração dos materiais até o produto final entregue ao cliente. Digitalmente mantida, controlada e modelada.

- A indústria será 30-50\% industrializada.

- Verdadeira colaboração entre as equipes possibilitando integração entre sistemas e serviços em todos os níveis do ciclo de vida do Projeto.

- Exigir que o cliente defina suas necessidades junto com os profissionais de projeto. Projetistas entregam guias e parâmetros de processos para a construção. Uma eficiente cadeia de suprimentos preenche os requisitos técnicos utilizando informações compartilhadas (KOKKALA, 2009).

\begin{tabular}{|c|c|c|}
\hline \multicolumn{3}{|l|}{ Os problemas } \\
\hline Pessoas & Processos & Tecnologia \\
\hline $\begin{array}{l}\text { - Falta de motivação para } \\
\text { mudanças } \\
\text { - Falta de comunicação e } \\
\text { confiança } \\
\text { - Dissonância entre educação e } \\
\text { requisitos da indústria } \\
\text { - Egos pessoais } \\
\text { - Falta de visão holística } \\
\text { - Ilhas de profissões }\end{array}$ & $\begin{array}{l}\text { - Falta de "Porque" na } \\
\text { descrição dos processos } \\
\text { - Modelos, não base para } \\
\text { contratos } \\
\text { - Falta de lógica dos serviços } \\
\text { - Multiplicidade de resultados e } \\
\text { interdependência entre atores } \\
\text { - Posse do modelo }\end{array}$ & $\begin{array}{l}\text { - Troca de informação entre } \\
\text { disciplinas } \\
\text { - Tecnologias e padrões } \\
\text { existentes impedem } \\
\text { interoperabilidade } \\
\text { - Expectativas excessivas e } \\
\text { não realistas } \\
\text { - llhas de automação }\end{array}$ \\
\hline \multicolumn{3}{|l|}{ As oportunidades } \\
\hline Pessoas & Processos & Tecnologia \\
\hline $\begin{array}{l}\text { Educação através das } \\
\text { pessoas e para as pessoas } \\
\text { - Força de trabalho bem } \\
\text { treinada, motivada e habilitada } \\
\text { - Recessão atual de mercado } \\
\text { possibilita oportunidade de } \\
\text { sincronizar as habilidades } \\
\text { - Equipes multidisciplinares } \\
\text { distribuídas, colaborando além } \\
\text { das fronteiras organizacionais }\end{array}$ & $\begin{array}{l}\text { - Modularização de processos } \\
\text { - Automatização para permitir } \\
\text { concentração no que importa } \\
\text { ao invés de rotinas } \\
\text { - Foco nos resultados e não } \\
\text { rotinas } \\
\text { - Uso de conhecimento } \\
\text { manufaturado. Incentivos inter- } \\
\text { organizacionais comuns a } \\
\text { todos paros pos } \\
\text { - Mudança de processos } \\
\text { guiados pelos custos por } \\
\text { provisão de valor }\end{array}$ & $\begin{array}{l}\text { - Integração de padrões } \\
\text { - Penetração da tecnologia } \\
\text { através da demonstração de } \\
\text { benefícios } \\
\text { - Soluções para aprendizado } \\
\text { através de "modelos" } \\
\text { - Múltiplo tipo de usuários e } \\
\text { interface específica do contexto } \\
\text { e soluções } \\
\text { - Adaptação e não adoção } \\
\text { - Uso criativo da tecnologia }\end{array}$ \\
\hline
\end{tabular}

Quadro 7 - Problemas e Oportunidades - Temas prioritários do CIB - IDS Integrated Design Solutions - Solução Integrada de Projeto (adaptado de KOKKALA, 2009) 


\section{Processo de projeto}

Assim como a viabilização de um empreendimento, a entrega de um projeto da edificação envolve diferentes estágios e requer a formação de uma organização virtual, temporária e multidisciplinar que consiste no cliente e representantes da cadeia de fornecedores, composta por uma gama de profissionais empregados em diferentes organizações, tais como arquitetos, engenheiros, construtores, especialistas, fornecedores de materiais, etc (CARRILLO et al., 2004).

O processo de projeto, segundo Melhado et al. (1996), deve atender às seguintes diretrizes metodológicas: envolver desde análises de marketing, custo até decisões tecnológicas e do processo de produção; antecipar a produção envolvendo informações sobre tecnologia, métodos construtivos, controle de qualidade; introduzir inovações e ser encarado como serviço necessário até a entrega da obra e assistência ao usuário.

Naveiro (2001) apud Romano (2003) aponta os principais aspectos a ser considerados no processo de projeto: a organização das atividades do projeto e a relação entre os participantes; o contexto dos projetistas e os condicionantes do projeto: especificações e restrições (tecnológicas, de custo, tempo, desempenho, etc). Também identifica alguns dos principais problemas envolvidos no processo de projeto: criar um ambiente para o trabalho intelectual cooperativo; gerenciar e controlar o estado da informação; compartilhar a informação de conteúdo adequado e no tempo correto.

A função de gestor do processo de projeto, antes exercida pelo arquiteto-autor do projeto, tem sido conduzida por gerenciadoras, escritórios de coordenação independentes e, em muitos casos, por construtoras, que têm desenvolvido competências para a gestão do empreendimento como um todo, como estratégia de criação de valor para seus clientes, como é o caso das incorporadorasconstrutoras (GRILO, 2002). No entanto, os estudos de caso detectaram a tendência das empresas construtoras em desenvolver competências internas para coordenação dos projetos como forma de controlar os riscos associados ao desenvolvimento do produto, principalmente nos contratos de preço fixo, suprindo as 
deficiências dos projetos e agregando conhecimento da experiência da produção à fase de projeto.

A participação da construtora na fase de projeto possibilita maior foco na construtibilidade, mas para não comprometer a intenção inicial do projeto, o cliente pode designar gerenciadores ou coordenadores para condução deste processo (FABRICIO, 2002).

Decisões não acertadas na fase de projeto podem comprometer o desempenho do produto nas demais fases de seu ciclo de vida (BACK; OGLIARI, 2000 apud ROMANO, 2003). A integração entre projeto/ produção tem potencial de aperfeiçoar

o processo de projeto tendo como consequência redução de prazos, custo e aumento da qualidade e satisfação do cliente, devido a redução de problemas da produção decorrentes do projeto e racionalização do processo de execução (ROMANO, 2003).

\subsection{O papel do projeto no ciclo de vida do empreendimento}

Com o aumento da complexidade das edificações, o projeto com funções de registro e comunicação, passa a assumir a função de documento: permite a interpretação da proposta concebida; a pressuposição dos encargos exigidos para a materialização da obra; aprovação junto aos órgãos legais e a representação de uma imagem mental para entendimento, por parte dos executores (SILVA, 1998 apud ROMANO, 2003).

Ceotto (2002) apud Romano (2003) define a função do projeto como "a transformação da idéia do empreendedor (público ou privado) em planos, especificações e desenhos que viabilizem tecnologicamente a construção, dentro das premissas adotadas, obedecendo todas as regulamentações pertinentes. É também a principal atividade de comunicação do processo de empreender."

O desenvolvimento do projeto envolve habilidades intelectuais relacionadas à capacidade de análise e síntese de informações e problemas, à criatividade e ao raciocínio (propor soluções originais e coerentes com o problema), ao conhecimento (ligado ao campo de memória, experiência e das técnicas de armazenamento de 
informações) e à capacidade de comunicação (forma de apresentar as soluções desenvolvidas - desenhos técnicos, maquetes, etc) e interação entre diferentes indivíduos envolvidos no processo (FABRICIO, 2002).

O projeto é visto como instrumento estratégico com um papel essencial na definição do produto imobiliário nas empresas incorporadoras-construtoras, onde o enfoque é dado ao desempenho comercial do empreendimento que está diretamente relacionado à sobrevivência e permanência da empresa no mercado competitivo (CTE; NGI, 1999 apud FONTENELLE, 2002; FONTENELLE, 2002).

Partindo do conceito de estratégias competitivas genéricas de Porter (1996), na estratégia da liderança em custo, o projeto é peça fundamental para a definição do custo global do empreendimento, e na estratégia de diferenciação o projetista é essencial na caracterização do produto.

A fase de projeto envolve o processo decisório em relação à seleção tecnológica que definirá o processo de produção da edificação. As diretrizes para a seleção tecnológica devem estar alinhadas à estratégia competitiva do empreendedor: diferenciação do produto em relação aos concorrentes ou custo do produto final (SILVA, 1996).

O projeto tem um papel importante em relação aos custos totais da construção e ao longo do ciclo de vida do empreendimento, como mostra a Figura 25. Diversos autores apontam que a fase de estudo de viabilidade e de projeto, onde são tomadas decisões sobre sistemas construtivos, acabamentos, etc, tem maior capacidade de influência no custo final do empreendimento (GOBIN, 1993 apud FABRICIO, 2002; CII, 1987 apud FABRICIO, 2002; HAMMARLUND; JOSEPHSON, 1992. 


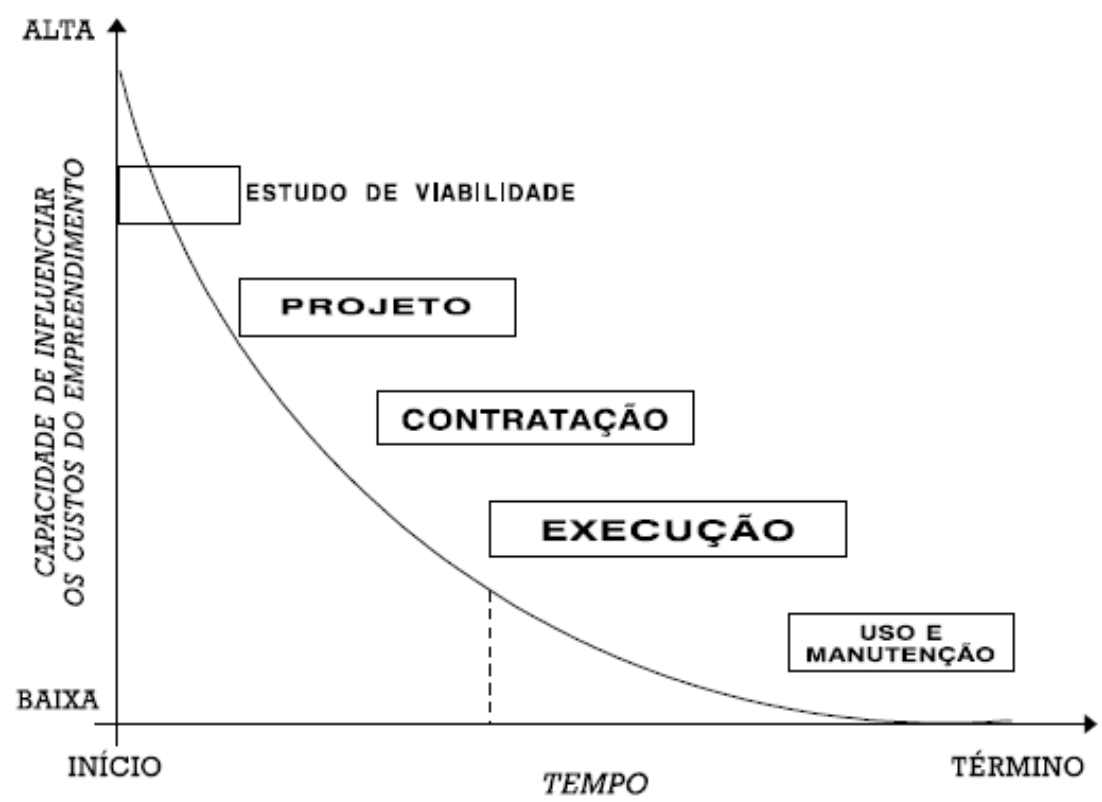

Figura 25 - Capacidade de influenciar o custo final de um empreendimento de edifício ao longo de suas fases (CII, 1987 apud MELHADO, 1994)

Nas fases iniciais do projeto concentram-se boa parte das chances de redução da incidência de falhas do edifício e os custos a elas relacionados, como mostra a Figura 26 (HAMMARLUND; JOSEPHSON, 1992).

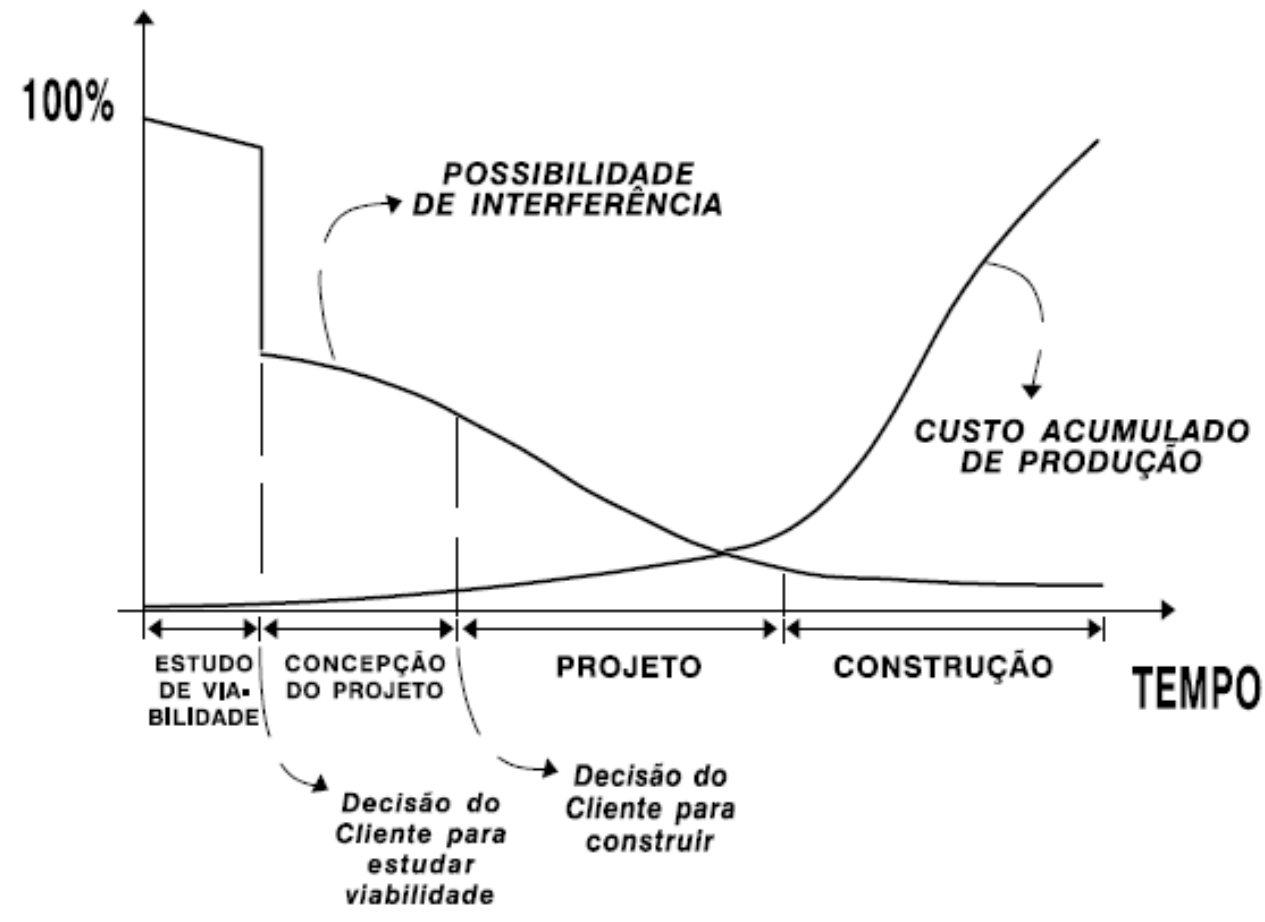

Figura 26 - 0 avanço do empreendimento em relação à chance de reduzir o custo de falhas do edifício (HAMMARLUND; JOSEPHSON, 1992) 
A medida que o projeto avança, diminui o grau de incerteza em relação ao objeto projetado, através do processo contínuo de tomada de decisão ao longo do qual o estado do projeto vai sendo alterado (NAVIERO, 2001 apud ROMANO, 2003).

Diversos autores destacam a importância do projeto na construção civil como forma de aumentar a satisfação dos diversos agentes (cliente, usuário, projetistas, empreendedor, construtora) envolvidos no produto - edificação, pois é nesta fase em que são definidas todas as diretrizes para 0 desenvolvimento do empreeendimento e são tomadas as decisões que criam valor ao Projeto. Decisões nesta fase tem o grande potencial de racionalização da execução, que reflete na produtividade, qualidade final do produto e custo total de produção (MELHADO, 1994; FABRICIO, 2002; FONTENELLE, 2002; ROMANO, 2003; LÊ, BRØNN, 2007).

Apesar desta importância, os projetos são desenvolvidos na maioria das vezes por escritórios sub contratados pela construtora, segundo critérios de preço do serviço, sem levar em conta questões como a qualidade e a integração entre os diversos projetos, e entre Projetos e o sistema de produção da empresa (FABRICIO, 2002). O projeto ainda é visto, por muitas empresas, como um custo, quando deveria ser entendido como um investimento cujo retorno será refletido na maior eficiência da produção e melhor qualidade do produto gerado, como mostra a Figura 27 (BARROS; MELHADO, 1993 apud MELHADO, 1994).

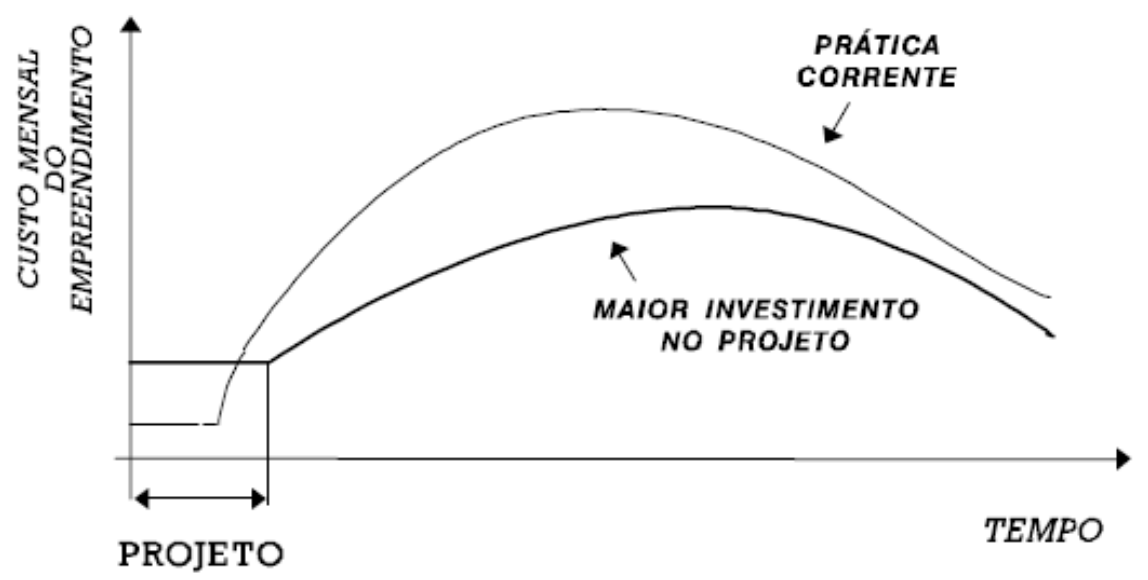

de acordo com Barros; Melhado (1993) apud Melhado (1994)

Figura 27 - Relação situação de maior "investimento" na fase de projetos X práticas convencionais (BARROS; MELHADO, 1993 apud MELHADO, 1994) 
Segundo Jo et al. apud Romano (2003), o projeto do produto pode influenciar diversas áreas da organização produzindo o chamado "efeito onda":

- Embora contabilize apenas 5\% do custo total do produto, o projeto influencia $70 \%$ dos custos.

- Cerca de $40 \%$ de todos os problemas de qualidade podem ser associados a projetos deficientes.

- De 70 a $80 \%$ da produtividade da manufatura pode ser determinada no estágio de projeto.

- Um percentual igual ou superior a 80 ou $90 \%$ do custo de vida total do produto é determinado durante a fase de projeto.

Como grande parte das empresas do setor da construção não deram conta da importância da fase de projetos, são poucas que têm alguma documentação referente a procedimentos e controle de projetos, dificultando sua gestão (FONTENELLE, 2002; ROMANO, 2003).

Apesar do projeto repercutir nos custos e qualidade do empreendimento, a garantia da qualidade global do projeto e do empreendimento envolve, não apenas a gestão dos processos de cada agente, mas a articulação entre os processos de todas empresas. Melhado (2001) propõe Planos da Qualidade do Empreendimento como forma de gestão das relações temporárias entre os principais agentes aliado a novos métodos de gestão: Preparação de Execução de Obras (PEO) e Projeto Simultâneo do Produto e de sua Produção (PSPP). A implementação deste modelo dependerá do contexto e dos objetivos dos envolvidos.

Ao iniciar a fase de execução da obra, diminui a possibilidade de interferência no projeto sem que haja um impacto no custo da produção.

Enquanto produto, "o projeto assume enorme responsabilidade sobre a qualidade do produto final e satisfação dos clientes externos e internos, pois é o elemento que vai orientar a maioria das ações futuras, ou seja, o projeto será o gerador e o responsável pelo bom andamento de todas as atividades posteriores ao seu desenvolvimento, formando a 'espinha dorsal' do empreendimento" (MELHADO, 1998 apud ROMANO, 2003). Além da entrega do produto (desenhos, memoriais), os 
projetistas devem estar comprometidos com a prestação de serviço de apoio às demais atividades do empreendimento e agentes envolvidos (MELHADO, 2001).

Para atenuar a dificuldade encontrada no canteiro de obras pela falta de detalhamento ou informações dos projetos, surgiram profissionais oferecendo serviços de detalhamento especializado para alguns aspectos críticos da execução, tais como projetos de fôrmas e de impermeabilização (MELHADO, 2001).

Estes detalhamentos evoluiram para os chamados projetos para produção que, devido ao caráter singular da produção de edifícios, tem um importante papel no setor da construção, que difere da indústria seriada onde os projetos do produto e da produção permanecem os mesmos por vários ciclos de produção (Fabricio, 2002).

Segundo Melhado; Fabricio (1998), o desenvolvimento do processo de produção de edifícios deve considerar duas etapas distintas:

- Procedimentos de Produção que consistem "no estabelecimento, para cada tipo de processo construtivo utilizado pela empresa, das estratégias gerais de produção, das normas e roteiros de execução, metas de produtividade em cada atividade padrão, e controles a serem observados. Estas normas de procedimentos se caracterizam pela prescrição detalhada das técnicas construtivas, das ferramentas e dos materiais empregados em cada serviço, configurando padrões de referência a serem seguidos em cada obra específica, além de tratarem os requisitos para compra e recebimento dos materiais e componentes de construção."

- Projetos para Produção voltados à orientação da produção sobre determinados elementos ou subsistemas próprios da obra (projeto de canteiro, projeto de formas, de alvenaria, etc), definidos como "conjunto de elementos de projeto elaborados de forma simultânea ao detalhamento do projeto executivo, para utilização no âmbito das atividades de produção em obra, contendo as definições de: disposição e seqüência de atividades de obra e frentes de serviço; uso de equipamentos; arranjo e evolução do canteiro; dentre outros itens vinculados às características e recursos próprios da empresa construtora" (MELHADO, 1994).

A definição clara dos procedimentos de produção representa o domínio da tecnologia utilizada pela empresa construtora, que deve ser incorporado na 
realização dos projetos para produção de determinada obra. Esse domínio, precário até recentemente, foi estimulado pela introdução de sistemas de qualidade nas empresas, que tem adotado procedimentos construtivos padronizados e controlados (FABRICIO, 2002).

O desenvolvimento dos projetos para produção devem ocorrer de forma integrada aos projetos do produto, estabelecendo intercâmbio entre profissionais de áreas de conhecimentos diferentes de forma a facilitar a ampliação da construtibilidade dos projetos, eliminar incompatibilidade entre os projetos e minimizar a possibilidade de execução inadequada ao traduzir especificações do produto em procedimentos e sequencias de produção. A realização simultânea de projetos do produto e para produção exige maior coordenação, mas facilita a introdução de inovações tecnológicas de produto e de processo, à medida que as inovações podem ser analisadas segundo seus impactos nas várias etapas do ciclo do empreendimento (FABRICIO, 2002).

Aquino, Melhado (2001); Romero (2002) apud Fabricio (2002) apresentam diretrizes para incorporação dos projetos para produção ao processo de projeto de edifícios destacando a importância de indicadores de qualidade do empreendimento e da construtora que permitam avaliar a eficácia dos projetos para produção e retroalimentar o processo de projeto.

Segundo Boggentater (2000) apud Grilo (2002), definições de projeto podem impactar na vida útil do edifício e influenciar nos custos da manutenção (projetos inadequados podem aumentar o custo de limpeza em até 74\%) e operação (consumo de água, ar condicionado, energia). O desenvolvimento de edifícios sustentáveis visa reduzir os impactos negativos na vida útil do edifício e promover incremento da produtividade dos recursos, redução do consumo de energia e das emissões para o meio ambiente. São apresentadas alternativas como: a otimização dos espaços, flexibilidade das áreas através de estruturas livres como redução de custo de necessidade de reformas, utilização de luz natural para reduzir consumo de ar condicionado, construção de valor onde a qualidade elevada não significa custos de construção ou operação elevados.

Poucos clientes enfocam o planejamento da manutenção como um aspecto essencial na fase de projeto, que depende diretamente do interesse do cliente no uso do edifício. Cabe ao projetista avaliar a durabilidade ao selecionar materiais e 
equipamentos, além de definir soluções técnicas de forma a assegurar que o edifício atenda à vida útil especificada pelo cliente e pelas normas locais, sem que apresente manifestações de patologia em estágio prematuro (GRILO, 2002). No entanto, a vida útil projetada pode não ser obtida se a construção e manutenção não forem adequadas (NIREKI, 1996 apud GRILO, 2002).

Grilo (2002) aponta como principais barreiras para incorporar a durabilidade ${ }^{7}$ no processo de projeto: a carência de informações sobre o desempenho dos materiais; a falta de retroalimentação sobre o desempenho dos edifícios e seus componentes para projetistas e construtores; reduzida difusão do conceito de desempenho nos cursos de graduação e entre os agentes da cadeia produtiva; carência de normas técnicas estabelecendo tempos de serviço e desempenhos mínimos aceitáveis para o edifício e seus componentes.

Em 2008, teve início a redação da Norma de Desempenho para Edifícios Habitacionais de até cinco pavimentos - NBR 15575 da ABNT (Associação Brasileira de Normas Técnicas), que estabelece critérios e métodos de avaliação do desempenho de alguns sistemas construtivos (estruturas, pisos internos, paredes e vedações, coberturas e sistemas hidrossanitários), com exigibilidade prevista para início em 2013. Alguns dos requisitos de desempenho que devem ser atendidos são: segurança estrutural, segurança contra incêndio, desempenho térmico, acústico, lumínico, manutenibilidade, conforto tátil e antropodinâmico, etc. Apesar da norma estar limitada a uma parcela do setor da construção, é um primeiro passo para ressaltar a importância da integração de todos os agentes envolvidos no desenvolvimento de um empreendimento (incorporadores, construtoras, projetistas, fornecedores de material e responsáveis da manutenção do edifício) para atingir o desempenho satisfatório ao longo da vida útil, condizente com as necessidades do cliente. Amparado pelo Código de Defesa do Consumidor que considera abusiva a venda de produtos não-conformes, e o código de ética dos engenheiros e arquitetos

\footnotetext{
7 "Durabilidade: habilidade de um edifício, suas partes, componentes e materiais resistirem à ação de agentes de degradação durante um período de tempo; Vida útil: período durante o qual as características de desempenho essenciais de um item, com manutenção adequada, excede os valores mínimos aceitáveis. Vida útil projetada: vida útil a ser alcançada por um item sujeito à condições de serviço esperadas e mantido de acordo com um plano de manutenção." (NIREKI, 1996 apud GRILO, 2002)
} 
que afirma que o cumprimento de norma é uma obrigação, o cliente terá um instrumento contundente para exigir o desempenho dos imóveis (BLANCO, 2011; PINI, 2011).

\subsection{Qualidade do projeto}

"A falta de aprofundamento das questões construtivas conduz, inevitavelmente, a desperdícios e ao surgimento de patologias" (FRANCO, 1993; SOIBELMAN, 1993 apud GRILO, 2002).

"Estima-se que 6\% dos custos da construção decorrem de falta de racionalização do projeto" (PICCHI, 1993).

"Estudos apontam uma média de 35\% a 50\% de falhas em edifícios com origem no processo de projeto“ (PICCHI, 1993; SINAENCO, 1997; SOLANO, 2000)

As causas para estas falhas podem ser avaliadas sob várias perspectivas: qualidade dos projetos, forma de controle e coordenação do processo de desenvolvimento de projeto, articulação entre os agentes, forma de contratação dos projetistas, fluxo de informações entre agentes, estrutura organizacional das empresas envolvidas, gestão de mudanças.

O projeto é uma atividade de processamento de informações que envolve diversas tomadas de decisões. Segundo Emmitt (2002), não há respostas certas ou erradas aos problemas encontrados, mas respostas melhores ou piores. Decisões erradas são facilmente identificáveis e podem acarretar em altos custos.

Como o conceito de qualidade pode estar associado à dimensão objetiva (relativa às propriedades físicas do objeto em questão) e à dimensão subjetiva (referente à capacidade da pessoa perceber e mensurar as características objetivas ou subjetivas agregadas ao objeto) é passível de diferentes interpretações conforme o tempo, seu uso e interesse de quem utiliza o conceito (GRAVIN, 1984 apud FABRICIO, 2002; PICCHI, 1993; TOLEDO, 1993). Ao longo do ciclo de vida do empreendimento a qualidade pode assumir diferentes significados de acordo com ao fase do processo e os agentes envolvidos.

$\mathrm{Na}$ fase de lançamento e venda, os critérios de avaliação de qualidade do empreendimento consideram aceitação do produto pelos clientes, velocidade de 
venda, facilidade na tramitação de contratos; em outra etapa do empreendimento, como a de execução de um edifício, a qualidade é avaliada com base em critérios de produtividade dos processos, atendimento às especificações dos projetos, número de acidentes de trabalho, etc. Para os clientes e usuários finais, a qualidade do empreendimento tende a ser avaliada, por um lado, por critérios mais subjetivos e, por outro, por critérios mais complexos e multiparamétricos que vão sendo mudados e incrementados ao longo do uso e da vida do edifício. Assim, por exemplo, a manutenibilidade e a habitabilidade do edifício podem não ser consideradas adequadamente no momento da compra do imóvel por negligência ou falta de parâmetros e capacidade de julgamento dos clientes, mas, ao longo do tempo de uso, assumem um papel relevante na avaliação que os usuários farão do edifício (FABRICIO, 2002).

Diversos autores (PICCHI, 1993, 2002; CTE apud BAIA, MELHADO, 1998; CEOTTO, 2011; ROMANO, 2003) definem que a qualidade do projeto está vinculada à:

- Qualidade da solução de projeto, relacionada com à satisfação do usuário; à racionalidade, construtibilidade, funcionalidade, flexibilidade da edificação, manutenibilidade, sustentabilidade, atendimento a exigências de desempenho, obediência ao ambiente regulatório e ao custo da obra.

- Qualidade da apresentação, relacionada à adequação da documentação (clareza e quantidade de informações), eliminando as decisões improvisadas no canteiro da obra.

- Qualidade da elaboração do projeto, relacionada à garantia de: desenvolvimento de planejamento prévio das atividades; manutenção de um fluxo contínuo de atividades sem a incidência de tempos de espera evitáveis; comunicação eficaz entre os agentes envolvidos, de forma a não permitir a ocorrência de erros e retrabalhos; atendimento às necessidades dos clientes internos e externos; confiabilidade e rastreabilidade das decisões por meio de registros e documentação adequada; controle da qualidade durante todo o desenvolvimento do processo de projeto, inclusive fazendo uma análise crítica do mesmo ao final de cada etapa; controle da qualidade no recebimento do projeto pelo contratante; validação do projeto pelo cliente; 
coordenação de projeto, que tem como objetivo assegurar que as interfaces entre os diversos Projetos e entre estes e o processo de execução da obra, tenham sido adequadamente trabalhadas para gerar a solução global do planejamento previsto.

Romano (2003) cita autores (MELHADO, 1998; SOLANO, 2000; SiQ-Construtoras, Brasil, 2002) que propõem, dentro do contexto de melhoria de qualidade, que as empresas incorporadoras-construtoras devem desenvolver seus próprios modelos de projeto, padronizando o fluxo das atividades e documentar os procedimentos especificando a forma de controle e coordenação do processo de desenvolvimento de projeto. Os procedimentos devem prever a forma como a empresa:

- Qualifica, contrata e avalia os projetistas envolvidos;

- Subsidia todos os projetistas com diretrizes bem definidas;

- Analisa os custos e a viabilidade das alternativas propostas;

- Procede ao controle de recebimento e distribuição de documentos de projeto;

- Retroalimenta o processo.

Para garantir a efetiva gestão da qualidade é necessário avaliar as formas de controle e gestão do processo de projeto. Ao intensificar o controle, segundo Grilo (2002), as causas dos problemas podem ser eliminadas antes da entrega dos projetos, reduzindo falhas e retrabalho. Empreendimentos complexos requerem múltiplas verificações antes das entregas.

Na década de 90, ocorreram as primeiras certificações de qualidade de acordo com a norma da série NBR ISO 9000, encabeçada por construtoras de São Paulo como forma de melhorar sua competitividade no mercado da construção. As incorporadoras e empresas de projeto demoraram mais para envolver-se neste processo de certificação, mas foram impulsionadas pelos clientes e entrada de projetistas estrangeiros no mercado (MELHADO, 2001).

Com a atualização da versão de 1994 das normas ISO 9000, segundo a NBR ISO 9001:2000, o processo de projeto passou a ser contemplado no sistema de gestão da qualidade da empresa construtora, independente de ser desenvolvido por equipe própria ou totalmente terceirzada; e só pode ser desconsiderado quando o escopo da empresa envolver apenas a execução de empreendimento, sendo o projeto 
totalmente definido pelo cliente e recebido em "pacote fechado", sem a mínima possibilidade de revisão ou análise crítica (ROMANO, 2003).

As empresas construtoras que recebem os projetos de seus clientes devem realizar a análise crítica dos projetos do produto como um todo e caso a análise aponte a necessidade de qualquer ação, a empresa deve apresentar ao cliente propostas de modificações e adaptações necessárias de qualquer natureza (ROMANO, 2003).

Segundo Romano (2003), para alcançar a qualidade dos projetos é necessário estabelecer uma sistemática de gestão e integração do processo de projeto de edificações que inclua procedimentos que auxiliem a empresa no planejamento e controle do processo de elaboração do projeto incluindo "orientações quanto:

- À definição das etapas do processo de elaboração do projeto e das diferentes especialidades técnicas envolvidas;

- A como qualificar, contratar e avaliar os envolvidos;

- A como gerenciar as interfaces entre as diferentes especialidades técnicas (internas ou externas) envolvidas para assegurar a comunicação eficaz e a designação clara de responsabilidades;

- À definição e registro de requisitos funcionais e de desempenho, requisitos regulamentares e legais aplicáveis, e quaisquer outros requisitos essenciais para o projeto;

- À documentação e verificação das saídas do processo, tais como: memoriais de cálculo, descritivos ou justificativos; especificações técnicas, desenhos e demais elementos grágicos;

- A análises críticas sistemáticas para garantir a compatibilização do projeto, identificar todo tipo de problema e propor ações necessárias;

- À verificação de projeto para assegura que as saídas atendam aos requisitos de entrada;

- A validação do projeto de forma assegurar que o produto resultante é capaz de atender aos requisitos para o uso ou aplicação especificados ou pretendidos; 
- Ao controle de alteração de projeto, que devem ser identificadas, analisadas criticamente e registradas de modo apropriado;

- À análise crítica de projetos fornecidos pelo cliente, quando for o caso."

A retroalimentação, baseada em informações coletadas junto a clientes, construtores, usuários e gerentes prediais, constitui um mecanismo de aprendizagem organizacional, cujo objetivo consiste em identificar, documentar e comunicar os erros cometidos, proporcionando oportunidades para melhoria contínua dos produtos e serviços do projetista (GRILO, 2002).

O período de tempo para o projetista obter a retroalimentação da produção e operação costuma ser muito longo ou ineficiente (FORMOSO et al, 2002).

As empresas podem alcançar a melhoria e aprendizagem contínua, mas a justaposição dos sistemas de gestão não garantem a melhoria e aprendizagem contínua no nível do empreendimento devido: à falta de integração entre os sistemas de qualidade dos agentes; à fragmentação da cadeia produtiva; à natureza temporária das relações e de um suporte ineficiente de gestão do conhecimento (MELHADO, 2001; GRILO, 2002).

Existem várias ferramentas e técnicas para avaliação de uso que são conhecidas como Avaliações de Pós-Ocupação (APO). No entanto, segundo Emmitt (2002) ao término de um projeto, a maioria dos projetistas inicia novos projetos e a tendência é esquecer os projetos já entregues, sem que haja uma preocupação com a retroalimentação. Os projetistas só revisitam seus projetos caso esteja previsto em contrato ou para verificar problemas pós-obra, pois não há verba para isto. A retroalimentação demanda tempo e tem um custo associado que deveria ser incorporado ao custo de projeto. Esta atividade deveria fazer parte de um processo de melhoria contínua, conforme ilustrado na Figura 28, onde os projetistas teriam a oportunidade de refletir sobre as soluções de projeto (avaliando aspectos de custo, estética, funcionalidade e construtibilidade), além de alimentar a base de conhecimento da organização tornando-a mais competitiva. A retroalimentação deveria ser conduzida, principalmente, em projetos que ultrapassaram o limite de verba disponível ou não atenderam às expectativas do cliente, para verificar-se o que não ocorreu de acordo com o planejado e auxiliar a eliminar erros futuros. 


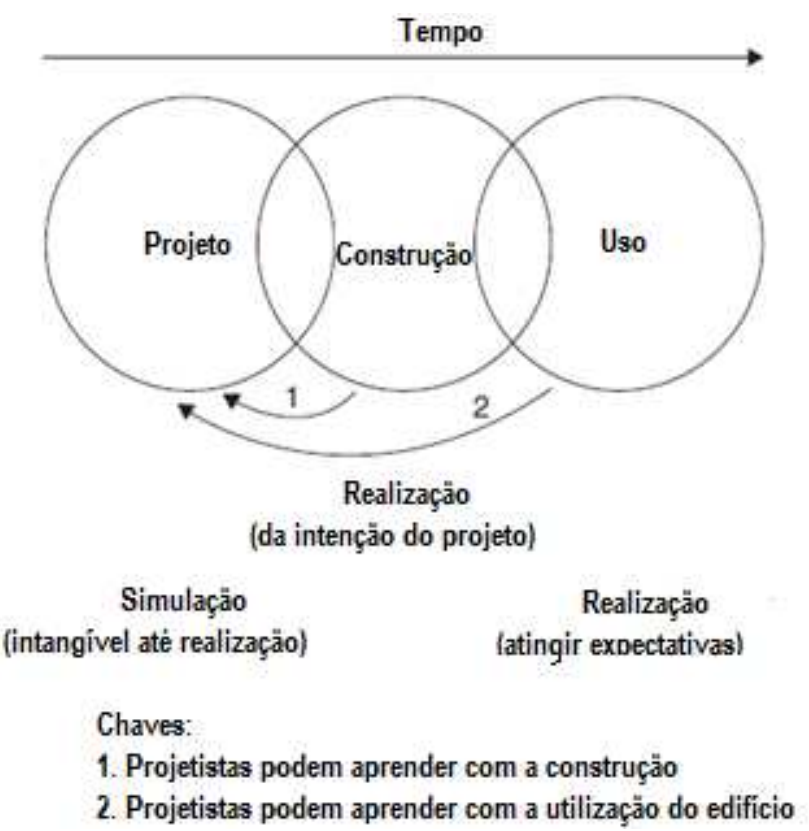

Figura 28 - Incorporando opinião (adaptado de EMMITT, 2002)

\subsection{Os agentes do empreendimento}

O desenvolvimento de um empreendimento depende da interação entre os diversos agentes que atuam em cada etapa de seu ciclo de vida e que interferem direta ou indiretamente no processo de projeto.

Em oposição à indústria seriada, na construção civil o vínculo contratual entre os diversos agentes envolvidos é restrito à duração do empreendimento e ao contrato. Embora as equipes sejam mobilizadas temporariamente para o desenvolvimento do produto, é importante criar um ambiente de cooperação baseado na confiança e respeito mútuo entre os agentes, caracterizados pela heterogeneidade em relação ao porte econômico, desenvolvimento cultural e técnico (FABRICIO, 2002).

Segundo ASCE (2000) apud Grilo (2002), em geral são constituídas equipes multidisciplinares formadas por três agentes primários, para prover recursos necessários para a construção do edifício:

- Cliente: indivíduo ou entidade que inicia um empreendimento de construção e se torna responsável pelo financiamento;

- Projetista: pessoa ou entidade qualificada e licenciada para desempenhar os serviços de arquitetura e engenharia; 
- Construtor: indivíduo ou entidade responsável por desempenhar e completar a construção de um edifício conforme especificado pelos documentos do contrato

Com o aumento da complexidade dos empreendimentos as equipes podem incluir: gerenciadores, consultores, fornecedores, investidores, agências reguladoras e órgãos de aprovação. A equipe do empreendimento pode apresentar diferentes configurações em função do grau de experiência e da constituição da organização do cliente, o tipo e complexidade do edifício, a estrutura funcional das equipes de projetos e construção e o tipo de contrato. Outros fatores que influenciam a constituição das equipes são: dispersão espacial, caráter nômade e temporário do empreendimento, tendência de subcontratação dos serviços, métodos de seleção, as especificidades dos sistemas contratuais. $O$ aumento do número de agentes que, com frequência, nunca trabalharam juntos apresentando interesses e expectativas particulares, exige um esforço de coordenação para ajuste das práticas, procedimentos e balanceamento das personalidades e para a convergência dos esforços individuais em torno de objetivos comuns (GRILO, 2002).

Evbuomwan; Anumba (1998) apud Fabricio (2002) destacam que a fragmentação das disciplinas somada à abordagem de "jogar os problemas para cima do muro" resultam em diversos problemas: eliminação da possibilidade de discussão de propostas alternativas de projeto; alto custo de tempo e recursos para a introdução de modificações no projeto; uma lacuna entre os profissionais das várias disciplinas envolvidas; construtibilidade não considerada durante o projeto; fragmentação dos dados dificultando a manutenção das consistência deste dados; perda de informações ao longo do processo de projeto; estimativas incorretas do custo do produto.

Melhado (1994; 1999) propõe um modelo, conforme indicado na Figura 29, com a formação de uma equipe multidisciplinar para o processo de projeto constituída por: um representante do empreendedor, arquiteto-autor do projeto ou grupo de projeto de arquitetura, engenheiro ou grupo de projeto de estruturas, engenheiro ou grupo de projeto de sistemas prediais, grupo de projeto para produção, ligado ao construtor, participando com a visão de processo, consultores especializados (especialistas e, tecnologia da construção, analistas de custos, de acordo com a necessidade de cada empreendimento). Neste modelo as soluções de projeto tem 
como restrições as necessidades do cliente, restrições legais e normativas e as diretrizes de projeto estabelecidas pela empresa contratante.

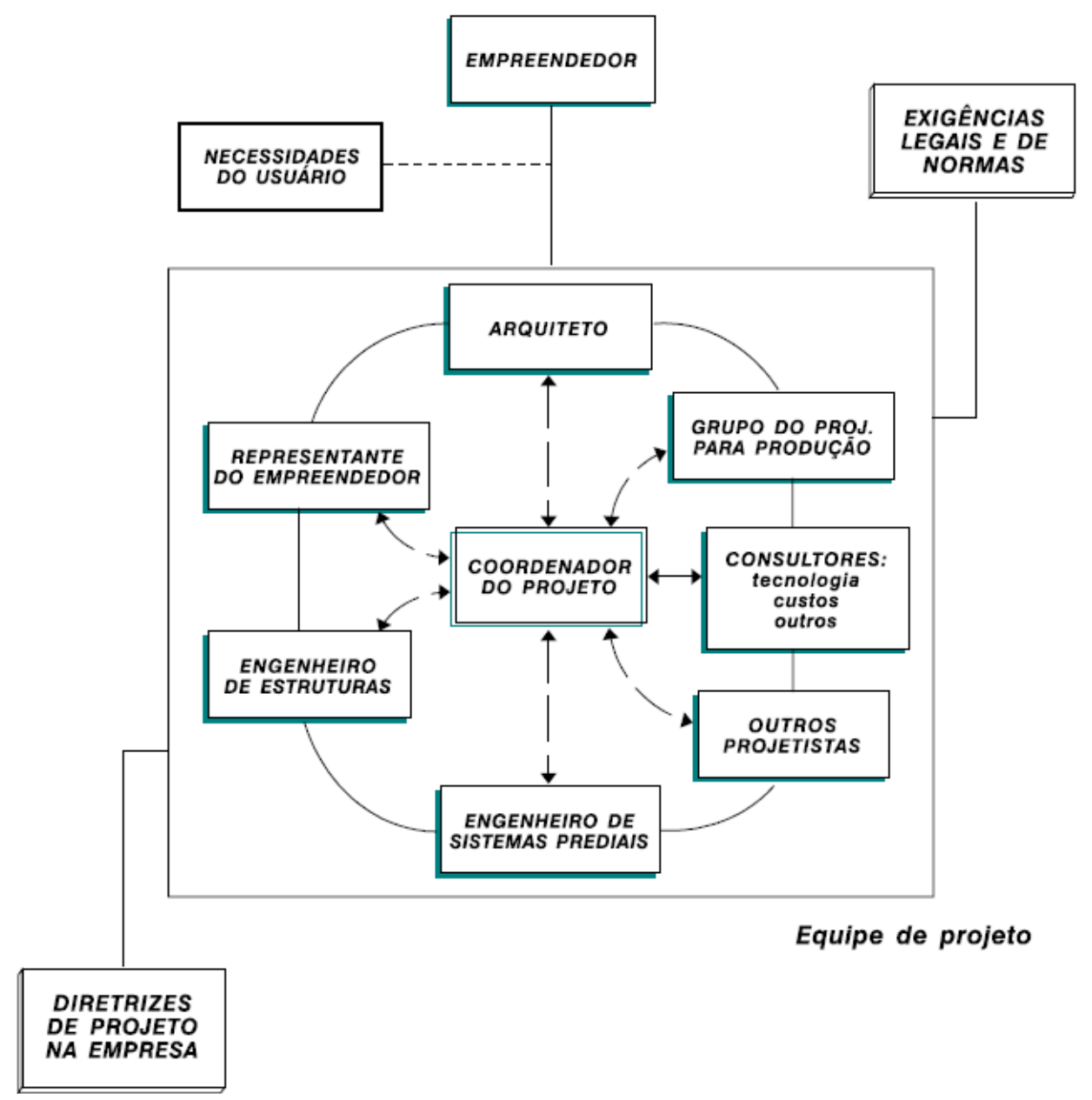

Figura 29 - Proposta de estruturação para a equipe multidisciplinar envolvida no desenvolvimento do projeto (MELHADO, 1994)

Para Fontenelle (2002), a equipe multidisciplinar deve ser formada desde as etapas iniciais do processo de projeto para integrar com sinergia as necessidades e os conhecimentos de todos os especialistas e agentes envolvidos, dando um novo enfoque ao modelo de gestão sequencial tradicional.

A integração e comunicação efetiva na fase inicial do projeto faz com que inúmeros problemas sejam levantados e resolvidos de forma simultânea, além de promover o intercâmbio de conhecimentos, de técnicas novas, de sucessos e frustrações (CHUDEK et al., 2000 apud ROMANO, 2003).

Segundo Scardoelli et al. (1994) apud Romano (2003), a cooperação técnica entre os intervenientes no processo de projeto de edificações propicia: "redução dos 
problemas de incompatibilidade entre os projetos; integração positiva entre os diversos projetistas; cronograma e coordenação adequados das etapas de projeto e suas interfaces; maior preocupação com a qualidade dos projetos devida à reciprocidade de expectativas e espírito de equipe; colaboração constante entre os membros da equipe; melhoria das soluções adotadas em função da ampla discussão anterior".

No entanto, Smith (1999) apud Grilo (2002) alerta que a definição insuficiente da hierarquia em equipes multidisciplinares complexas pode prejudicar o processo decisório e, como consequência, o desempenho do empreendimento.

Neste contexto, o papel da coordenação de projetos ganha força e é ampliado para o de gestão de projetos, responsável pela definição clara dos papéis e poderes de cada agente do processo, e para tomada de decisões para mediação e solução de conflitos entre projetos (FABRICIO, 2002; ROMANO, 2003), que segundo Ceotto (2011), deve basear-se em alguns instrumentos básicos de coordenação.

Romano (2003) aponta que na construção civil a expressão "gestão do processo de projeto" não é comumente utilizada e ainda é confundida com "coordenação do processo de projeto" e apresenta a definição das duas funções segundo alguns autores (CTE, 1997; ASBEA, 2000; FONTENELLE, 2002, CEOTTO, 2002).

\subsubsection{Cliente}

O cliente é responsável pelo desenvolvimento do empreendimento que, segundo Grilo (2002), depende de profissionais internos experientes ou demanda a contratação de um gerenciador ou construtor para garantir a eficácia das atividades a ele atribuídas: estabelecer objetivos básicos (técnico, econômico, comercial e simbólico); definir a estrutura funcional, modalidade de pagamento e método de seleção; selecionar as equipes de projeto e construção; transmitir os requisitos a todos participantes; assegurar a qualidade do investimento e aportar recursos financeiros requeridos.

A atuação do cliente depende de diversos fatores: experiência anterior com o programa; existência de especialistas internos ou a contratação de um profissional 
externo para participar como seu representante; o escopo e a complexidade do empreendimento e a modalidade contratual adotada.

Em Projetos internacionais, que envolvem agentes de diversas localizações geográficas e culturas, o cliente assume o principal papel de liderança da organização temporária estabelecida para atingir os objetivos do Projeto. Para o sucesso do Projeto, o cliente deve estabelecer por meio das estruturas contratuais, relações de responsabilidade, confiança entre os agentes, propiciando a troca de conhecimento (GRISHAM; SRINIVASAN, 2007).

Diversos agentes podem ser designados como representante do cliente: arquitetos, engenheiros, construtores ou gerenciadoras, dependendo da natureza do empreendimento e os interesses do cliente. Grilo (2002) aponta as vantagens e desvantagens dos diferentes agentes na Quadro 8.

\begin{tabular}{|c|c|c|}
\hline Agente & Vantagens & Desvantagens \\
\hline Arquiteto & $\begin{array}{l}\text { Desenvolvimento do programa e do } \\
\text { produto; flexibilidade para alteraçōes } \\
\text { durante a construçáo; } \\
\text { representatividade do cliente. }\end{array}$ & $\begin{array}{l}\text { Integraçāo entre o projeto e o processo } \\
\text { de produção; empreendimentos } \\
\text { complexos; controle de custos; } \\
\text { parcialidade. }\end{array}$ \\
\hline Gerenciador & $\begin{array}{l}\text { Mediaçăo entre os agentes; } \\
\text { integraçâo entre projeto e } \\
\text { construção; controle dos custos; } \\
\text { representatividade; imparcialidade. }\end{array}$ & $\begin{array}{l}\text { Ausência de regulamentaçáo } \\
\text { profissional; aumento dos custos } \\
\text { administrativos; risco de perda de } \\
\text { agilidade na tomada de decisão. }\end{array}$ \\
\hline Construtor & $\begin{array}{l}\text { Integraçăo entre o projeto e o } \\
\text { processo de produçăo; elevada } \\
\text { construtibilidade; controle dos } \\
\text { custos; ponto de contato único. }\end{array}$ & $\begin{array}{l}\text { Desenvolvimento do programa e do } \\
\text { produto; representatividade do cliente; } \\
\text { flexibilidade para alteraçōes durante o } \\
\text { processo de produção. }\end{array}$ \\
\hline
\end{tabular}

Quadro 8 - Vantagens e desvantagens de diferentes agentes como representantes do cliente (GRILO, 2002)

As principais categorias de clientes no segmento de obras por encomenda são:

- Usuários do edifício utilizado como meio de produção ou habitação;

- Investidores, tais como seguradoras, fundos de pensão e empresas privadas, que vislumbram a construção como um investimento a longo prazo; 
- Empreendedores, que podem construir ou modificar propriedades existentes.

Os clientes do setor privado são influenciados por fatores econômicos, aspectos como demanda de mercado, estética, geração de valor para o usuário, enquanto clientes do setor público (municípios, concessionárias, órgãos públicos) são influenciados por aspectos políticos e regulamentações.

Mudanças geradas pelos clientes no fluxo financeiro, escopo ou projeto influenciam diretamente o processo de produção. Estas mudanças podem ser atribuídas à: "falta de experiência com o programa; necessidade de prazo para compreensão do projeto; lacuna entre expectativa e realização; pressuposta facilidade de alteração do projeto; introdução contínua de inovações e melhorias; mudança nas expectativas, devido ao longo período de maturação; e ausência ou excesso de interlocutores, principalmente no setor público" (GRILO, 2002).

\subsubsection{Projetistas/ Consultores}

A equipe de projetos é composta por projetistas e consultores de diferentes especialidades (arquitetura, fundações, estrutura, sistemas prediais, ar condicionado, segurança, automação, sonorização, acústica, transporte vertical, impermeabilização, urbanismo, paisagismo, alvenaria entre outros) que, em geral, são contratados pelo cliente/ empreendedor, mas podem ser contratados pelo construtor. Os projetistas podem pertencer à organização do cliente ou do construtor, atuar em uma empresa de projeto ou de forma independente. $O$ relacionamento entre $o$ cliente $e$ os projetistas limita-se a duração do empreendimento e a contratação é pautada no preço de mercado do serviço (CARDOSO et al., 1998).

No caso em que os clientes delegam a contratação dos projetos para a construtora, em geral, são realizadas tomadas de preço apenas com empresas de projeto previamente qualificadas. Verifica-se a crescente relação de parceria e alianças estratégicas entre projetistas e construtoras, com o intuito de oferecer serviços globais de construção, com alta velocidade de resposta e geração de valor para o cliente (GRILO, 2002). 
Os escritórios de projeto prestam serviço a diferentes contratantes e estão envolvidos com diferentes projetos simultaneamente. Nesta condição o tempo de dedicação dos projetistas para cada projeto varia conforme a demanda, assim como a qualidade e produtividade do serviço (FABRICIO, 2002).

Os escritórios de projeto são constituídos por três níveis hierárquicos: estratégico ocupado por titulares e sócios, responsáveis pela concepção do projeto, atendimento aos clientes e prospecção de negócios; gerencial: ocupado por associados e coordenadores, que supervisionam o desenvolvimento do projeto, podendo assumir algumas atividades administrativas; operacional: formado por projetistas juniores, desenhistas, técnicos e estagiários, responsáveis pelo desenvolvimento do projeto executivo. Uma característica do setor é a terceirização dos projetos, onde são subcontratados profissionais autônomos ou pequenos escritórios durante picos de trabalho ou como forma de redução de custo fixo nos escritórios, estimulados pelo fluxo descontínuo de trabalho, oscilações econômicas e natureza temporária dos empreendimentos. No caso de escritórios maiores, há um quarto nível, formado por diretores, responsáveis pelos processos gerenciais, comerciais e administrativos, com pouco envolvimento com os projetos (GRILO, 2002).

No sistema sequencial tradicional, a atuação do arquiteto-autor do projeto inicia com a concepção de um estudo preliminar ou anteprojeto baseado nas expectativas e necessidades definidas pelo cliente com reduzida interação com os demais projetistas ou equipe de obra. Segundo Castells; Heineck (2001) apud Fabricio (2002), esta primeira etapa de concepção e definição do produto, exercida pelo escritório de arquitetura, concentra-se na elaboração qualitativa e a segunda etapa, exercida pela construtora ou escritórios, de desenvovlvimento tecnológico das opções selecionadas voltada ao desenvolvimento quantitativo. No caso de empreendimentos imobiliários, muitas vezes os demais projetistas são contratados apenas após o lançamento do empreendimento no mercado (FABRICIO, 2002). A aprovação dos projetos junto aos órgão públicos, em geral, é de responsabilidade do projetista ou cliente, mas a atividade pode ser atribuída à construtora, quando esta é responsável pela coordenação e contratação dos projetos complementares. Os projetos executivos e detalhamentos são desenvolvidos pelos projetistas para seleção do construtor e execução da obra (GRILO, 2002). 
Além dos projetistas, empreendimentos complexos tem exigido a colaboração de consultores para dar subsídeo aos projetistas de aspectos específicos de algumas soluções ou sistemas adotados no projeto, como por exemplo, consultores de acústica, caixilhos, pedras ou para obter certificados de sustentabilidade, como é o caso da certificação norte americana LEED - Leadership in Energy and Environmental Design ou brasileira, de origem francesa, AQUA - Alta Qualidade Ambiental.

Os projetos desenvolvidos pelos projetistas restringem-se a fornecer informações técnicas sobre o produto sem a preocupação com sua produção e, muitas vezes, sem um nível de detalhamento adequado à execução ou com especificações incompletas (FRANCO, 1992). O arquiteto-autor do projeto se afastou da execução da obra não sendo de sua responsabilidade o arranjo físico do canteiro, projetos de fôrmas ou planos de segurança (GRILO, 2002). Os projetos para produção surgiram para suprir estas deficiências e fomentar a racionalização da construção. Segundo Melhado (1998), estes projetos podem ser desenvolvidos por:

- Projetistas, que podem ser funcionários da empresa construtora ou tercerizados, permitindo a integração do projeto do produto e para produção, mas esbarra na deficiência de conhecimento de muitos projetistas de produto em relação à produção;

- Consultores externos, que podem auxiliar os projetistas com relação ao conteúdo tecnológico do projeto ou desenvolver os projetos; por ter mais conhecimento tecnológico podem contribuir com a introdução de soluções inovadoras e projetos de maior construtibilidade, mas podem desconhecer os procedimentos de produção da empresa;

- Funcionários da construtora, desde um diretor técnico, ou um integrante do departamento de qualidade (quando existir), ao engenheiro da obra, permitindo que esteja refletida a realidade da empresa, além de obter maior agilidade;

- Fornecedores, agregando serviços de projeto aos itens comercializados, apesar do risco de comercial predominar o enfoque sobre o técnico. 
O ideal seria que o projeto para produção fosse realizado por uma equipe multidisciplinar, simultaneamente aos projetos do produto, levando em consideração a cultura construtiva da construtora.

\subsubsection{Coordenação}

A coordenação entre as disciplinas desde o início do processo de projeto é apontada por Fabricio (2002) como fundamental para garantir que as soluções de projeto sejam eficientes, principalmente nos projetos simultâneos.

Segundo Melhado et al. (2008), a coordenação é uma atividade de suporte ao desenvolvimento de projeto, com o objetivo de fomentar a interatividade entre os membros da equipe de projeto e melhorar a qualidade dos projetos. Não existe um modelo único, ideal para todos os tipos de empreendimento, portanto a escolha da coordenação deve considerar a estratégia competitiva e a capacidade técnica gerencial dos agentes envolvidos e características especifícas de cada empreendimento. No caso de uma empresa incorporadora-construtora com estratégia competitiva bem definida e com uma tecnologia construtiva padronizada, a coordenação será mais efetiva se exercida por um coordenador interno. E no caso de uma empresa construtora sem grande domínio tecnológico e construtivo, a coordenação externa pode aprimorar tecnologicamente o projeto e incrementar inovações construtivas.

A coordenação de projetos pode ser exercida por uma equipe interna da construtora, pela empresa responsável pelo desenvolvimento do projeto arquitetônico do empreendimento (modelo tradicional) e por profissionais de empresas contratadas especificamente para exercer esta função. Grandes construtoras têm desenvolvido competência para coordenação dos projetos como forma de agregar valor ao cliente. Fabricio (2002) apresenta uma síntese das vantagens, desvantagens e resultados esperados em cada alternativa de coordenação no Quadro 9. 


\section{Coordenação exercida por consultor especializado:}

\section{Aspectos positivos:}

- há profissionais de excelente nivel técnico no mercado da construção de edificios no Brasil, oniundos de empresas construtoras que investem em tecnologia, mas que optam pela terceirização, pela inexistência de demanda constante para os mesmos;

- o coordenador possui agilidade no desenvolvimento de soluçōes de projeto, jả que conhece casos de diversas empresas construtoras e sabe que para manter-se no mercado precisa de reciclagem continua de conhecimento, adquirido através de periódicos, feiras intemacionais de construção, soluções aplicadas em obras, etc;

- o coordenador considera como qualidade o desenvolvimento do melhor produto no tempo entendido como o mais adequado para as necessidades da empresa construtora.

\section{Aspectos negativos:}

- o coordenador possui pouco poder no estabelecimento de cobranças e consequiências para projetistas que não cumpram as metas determinadas no processo, já que são contratados pela empresa construtora e não pelo coordenador;

- ausência de responsabilidade efetiva sobre o produto final, a não ser sobre a sua própria imagem enquanto consultor;

- o coordenador costuma ser remunerado em horas trabalhadas, o que pode ocasionar morosidade no desenvolvimento do processo de projeto.

\section{Resultados:}

- quanto ao tempo dedicado ao processo de coordenação: de 5 a 8 meses, considerando um periodo de 6 meses entre o lançamento do empreendimento e o inicio das obras;

- quanto à qualidade técnica das soluçōes: alta, em razão dos aspectos positivos mencionados;

- quanto às soluções operacionais contempladas em projetos para produção: soluções condizentes com as necessidades operacionais, já que o coordenador, em geral, possui contato contimuo com a obra;

- quanto ao uso de cronogramas de projeto: entende o uso e, em geral, gostaria de utilizá-los, mas encontra dificuldades, devido ao ponco poder no estabelecimento de cobranças e consequiências sobre os projetistas. Portanto, usa apenas quando considera favorável

\section{Coordenação exercida pelo arquiteto da obra:}

\section{Aspectos positivos:}

- agilidade no desenvolvimento da arquitetura;

- conhecimento amplo do projeto das premissas do projeto de arquitetura;

- a elaboração simultânea do projeto de arquitetura e da sua coordenação com os demais projetos.

Aspectos negativos:

- postura de, geralmente, organização das idéias dos demais parceiros, sem intervir nas soluções especializadas;

- geralmente o coordenador se posiciona de forma passiva quanto às soluções apresentada pelos demais projetistas, devido à falta de traquejo no tratamento dos conhecimentos técnicos envolvidos nos outros projetos, especialmente nos de instalações;

- em geral, as reumiões resultam pouco objetivas no que conceme a definições especificas para os projetos.

\section{Resultados esperados:}

- baixa qualidade técnica das soluções, pois não há interlocutor que julgue as decisões técnicas tomadas, o que, em geral, é feito durante a execução da obra;

- com relaçâo às soluções operacionais contempladas em projetos para produçâo: quando existem, restringe-se a elevações de vedações, contemplando as instalações em paredes e, possivelmente, furações de pisos, não havendo discussões sobre métodos construtivos para os sistemas de vedações, estruturas e instalações;

- ausência de cronogramas de projeto, devido à falta de compreensão quanto ao seu uso e, em geral, por falta de confiabilidade na sistematização de prazos para entrega de informações. 
Coordenação exercida por arquiteto ou engenheiro da empresa construtora:

Aspectos positivos:

- em geral, o coordenador tende a direcionar as soluções técnicas para as necessidades da empresa e tem assimilado a cultura de construção da empresa, facilitando o fluxo de informações para os projetistas;

- o coordenador apresenta amplos conhecimentos do projeto e de soluções operacionais, já que está em contato simultâneo com diversos projetos e projetistas e com base de informaçôes referentes a casos ocorridos nas obras da própria construtora;

- apoiar a realização de projetos para produção, além dos projetos do produto, enfatizando a necessidade de compatibilização de soluções. A esse respeito, no entanto, há que se destacar 0 grave problema da ausência de profissionais que realizem projetos de vedações no mercado da construção de edificios no Brasil, que possam contribuir para as atividades de compatibilização.

Aspectos negativos:

- o coordenador possui pouco tempo para consideração dos problemas correntes de obra. Com isso, perde importante fonte de conhecimento e de realimentação de seu trabalho;

- morosidade na tomada de decisões devido, essencialmente, aos seguintes fatores: [1] insegurança quanto a soluçōes em projetos, por suas repercussōes no desempenho técnico e econômico em obras da própria empresa construtora; [2] devido ao trâmite burocrático do coordenador ao agir como mediador de discussões entre projetistas;

- em geral, as reuniões resultam objetivas no que conceme à necessidade de resultados do processo de projeto, mas o coordenador dedica-se em demasia ao gerenciamento dos conflitos de interesses que ocorrem entre projetistas para a seleção de solução mais adequada para um projeto isolado, em detrimento do empreendimento como um todo.

Resultados esperados:

- quanto à qualidade técnica das soluções: média (poderia ser melhor caso o profissional coordenasse menos projetos simultaneamente e, consequentemente, dispusesse de mais tempo para reflexão e análise das soluções, bem como para visitas regulares às obras da empresa);

- quanto às soluções operacionais contempladas em projetos para produção: em geral, são contratados projetos para produção e estes possuem por caracteristica contemplar informações sobre as interferências construtivas dos sistemas envolvidos, facilitando a visualização dos problemas;

- quanto ao uso de cronogramas de projeto: o coordenador compreende a importância do uso, porém nem sempre os emprega, pela preocupação de que possa ser responsabilizado por atrasos que eventualmente venham a ocorrer no processo de projeto.

\section{Quadro 9 - Vantagens e desvantagens conforme o perfil do coordenador de projetos} (FABRICIO, 2002)

\subsubsection{Construção/ Gestão}

No sistema tradicional, o construtor é responsável pela execução da atividade de construção do empreendimento, baseado nos projetos e documentos desenvolvidos pelos projetistas, que envolve o planejamento e gestão da obra. Suas responsabilidades envolvem: "definição dos meios e métodos de construção; atendimento das condições do contrato; construção do edifício em conformidade com os documentos fornecidos; contratação de fornecedores; realização de tomadas de preço; clareza e postura pró-ativa na comunicação; segurança no canteiro de obra, incluindo a preparação de um plano de segurança; pontualidade na tomada de decisão; monitoramento do desempenho dos subempreiteiros; provisão de mão-deobra habilitada e em situação regular; coordenação das atividades com demais 
agentes de forma cooperativa; e observação de códigos, regulamentos e leis aplicáveis." (GRILO, 2002).

A equipe de construção é dimensionada de acordo com a complexidade do empreendimento, porte da construtora e tipo de contrato. Em geral as equipes são compostas por gerente de obras, mestre de obras, encarregados e equipes de apoio, supervisionados por coordenadores de obras, gerentes de operações ou diretores técnicos. Arquitetos compõem a equipe de empreendimentos mais complexos para controle do projeto e engenheiros para o planejamento físicofinanceiro, a aquisição de serviços e materiais e a produção. A negociação com fornecedores pode ser realizada, de acordo com a política de empresa e porte da obra, no canteiro ou no escritório.

Para redução de custos fixos, adequação às constantes oscilações da economia, as construtoras tem contratado subempreiteiros de diversos serviços, equipamentos e materiais.

As grandes construtoras têm integrado atividades de projeto, planejamento operacional e equacionamento econômico pela demanda dos clientes e devido ao aumento da complexidade dos edifícios que exige novas competências; investidores e incorporadores, para os quais os parâmetros de custo e prazo são cruciais e preferem contratar gerenciadoras e construtoras, ao invés de escritórios de arquitetura, mesmo que estejam habilitados para satisfazer as demandas (SYBEN, 2000a apud GRILO, 2002).

As construtoras têm participado na viabilização econômica e no desenvolvimento do projeto, em consórcios com clientes, investidores, com o objetivo de incrementar a margem de lucro e minimizar os riscos na construção. Nos contratos ProjetoConstrução, o cliente pode designar o arquiteto-autor do projeto para definição do programa e desenvolvimento parcial ou integral do projeto arquitetônico, atribuindo ao construtor a contratação dos projetistas das demais disciplinas, a coordenação e a adaptação do projeto às necessidades técnicas e econômicas do empreendimento, por meio de entrada de construtibilidade e engenharia de valor. $O$ cliente pode contratar um gerenciador, com a finalidade de adquirir um controle equivalente ao construtor, que incorporou as funções de projeto e construção (GRILO, 2002). 


\subsection{Comunicação no processo de projeto}

Neste contexto de empreendimentos complexos com grande quantidade de informações distribuídas entre inúmeros agentes envolvidos em todas etapas do processo de projeto, a comunicação é um aspecto de fundamental importância.

A construção de um edifício envolve a transferência, troca e utilização de informações na forma de desenhos, especificações, gráficos, cálculos e instruções escritas, gerados para diferentes propósitos e por indivíduos com experiências e conhecimento distintos, tais como arquitetos, engenheiros, sub-contratados, consultores. Mesmo utilizando o mesmo programa e formato para os desenhos eletrônicos, cada especialidade tem sua prórpia linguagem e utiliza diferentes símbolos e terminologias que podem ser compreendidos de diferentes formas pelo receptor, e que pode requerer esclarecimentos ou gerar interpretações erradas com consequências diretas nos custos (EMMITT, 2002).

Uma pesquisa realizada pelo Instituto da Indústria da Construção em 1965 nos EUA, com 582 questionários relativos a indivíduos participando de 72 Projetos, constatou que o maior obstáculo para o sucesso dos Projetos era a falta de comunicação eficaz (THOMAS et al., 1998 apud EMMITT, 2002).

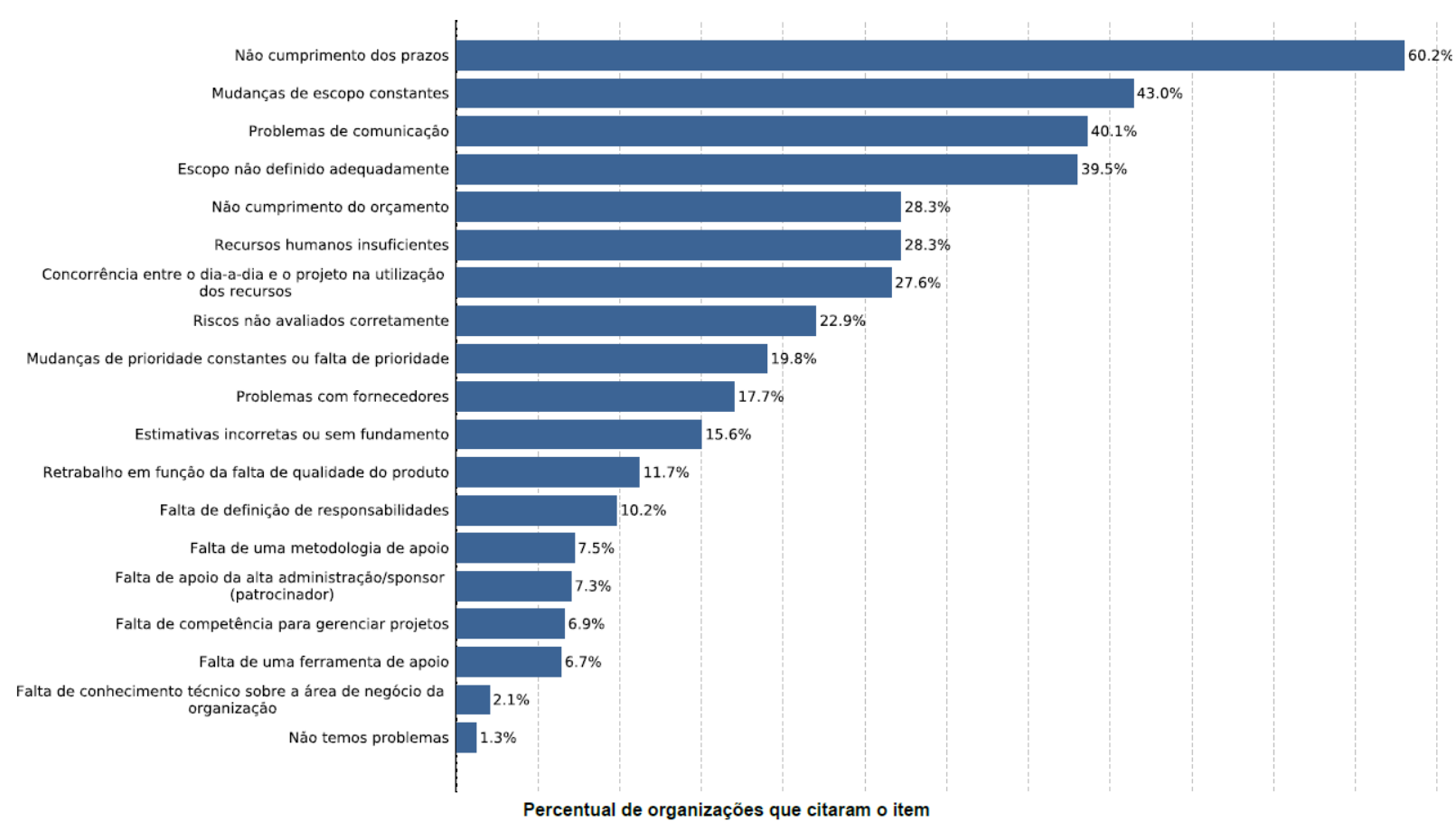

Figura 30 - Problemas que ocorrem com mais frequência nos Projetos da Organização (PMI, 2010) 
O PMI (2010) publicou o resultado do estudo de benchmarking em gestão de Projetos Brasil, realizado em 2010, com 460 organizações agrupadas de acordo com setores definidos na pesquisa sendo: $7 \%$ do setor de Engenharia \& EPC, 18\% de Tecnologia da Informação, 12\% Automobilístico, 11\% Indústria, 9\% Consultoria, entre outros. A pesquisa indicou que entre os problemas que ocorrem com maior frequência nas organizações estão os "problemas relacionados a comunicação" (40,1\%), além de "não cumprimento de prazo" (60,2\%), e "mudanças de escopo constantes" (43,0\%), como mostrado na Figura 30.

Este item é ressaltado em outros resultados da pesquisa onde a "comunicação" está em segundo lugar $(44,2 \%)$ como característica mais valorizada pelas organizações na gestão de Projetos, depois de "liderança" (47,9\%). Quanto às habilidades que as organizações consideram deficientes em seus gerentes de Projeto, a "comunicação" figura em primeiro lugar (53,8\%), seguida por "gestão de conflitos" $(42,6 \%)$ e “capacidade de integrar as partes" (35,0\%).

Segundo 54,0\% das empresas participantes, a gestão de Projetos trouxe como benefício "disponibilidade de informações para tomada de decisão", e para 42,4\% "aumento de integração entre as áreas".

Analisando os dados da pesquisa, constata-se que além dos processos, ferramentas e procedimentos estabelecidos pela organização, o resultado positivo da gestão de Projetos depende da integração e comunicação eficaz entre membros da equipe. Mudanças de escopo também interferem diretamente nos resultados do Projeto.

A efetiva aplicação das ferramentas de gestão de Projeto é necessária, mas o foco está mudando para as pessoas envolvidas no Projeto onde o gerente de Projetos tem o papel de "nó" a partir do qual toda a comunicação deve fluir, minimizando equívocos, divergências e conflitos (EMMITT, 2002).

A indústria da construção não é uma indústria homogênia, sendo composta por diversas empresas parceiras ou competindo entre si que são unidas como uma equipe para realização de um Projeto específico e desfeitas após o seu término. Emmitt (2002) questiona se há um real esforço de equipe neste processo onde as relações são de curta duração e instáveis, quando comparada à indústria de manufatura. O processo de aquisições de uma construção é um processo complexo, 
que consome muito tempo e recursos. O processo de projeto envolve projetistas, consultores e fornecedores. Neste cenário, o gerente de Projetos deve lidar com uma intrincada rede de comunicação formada por diferentes empresas e indivíduos, potencializada com a globalização onde podem surgir barreiras de linguagem e culturais que podem afetar a transferência de conhecimento.

Durante a elaboração do projeto a falta de intercâmbio de informações entre os agentes acarreta um projeto "mal definido, mal especificado e mal resolvido" que pode levar a um acréscimo de custo e de tempo de execução (MELHADO, 2001).

Segundo Grilo (2002), a principal função do coordenador consiste em comunicar as necessidades e atualizar as equipes de projeto. A comunicação eficaz deve criar uma "ponte entre as diversas partes interessadas envolvidas no Projeto, conectando vários ambientes culturais e organizacionais, diferentes níveis de conhecimento, e diversas perspectivas e interesses na execução ou nos resultados do Projeto" (PMI, 2008).

Estudos de seguradoras britânicas apontam a coordenação e a comunicação como causas primárias de litígio por parte dos clientes frustados por requisitos não atendidos e informações incompletas (BROWN, 2001). Em geral, o arquiteto-autor do projeto reponsável pela captura das necessidades do cliente para definição do programa não utiliza métodos formais para transmitir os requisitos dos clientes à equipe de projeto ou mesmo para equipe interna ao escritório, onde os titulares tem envolvimento com os projetistas em diferentes fases do projeto. No sistema tradicional, os projetistas usualmente não participam do planejamento do empreendimento quando decisões estratégicas são tomadas, restringindo a compreensão da organização do cliente e requisitos do projeto (GRILO, 2002).

A transmissão informal de informações, sem registros, que torna difícil a gestão das atividades desenvolvidas é apontada como ponto de melhoria nas organizações (NOVAES; FRANCO, 1997; ROMANO, 2003). A comunicação escrita é mais concisa, precisa e livre da ambiguidade da comunicação oral (EMMITT, 2002).

Emmitt (2002) identifica três principais divisas no processo de construção que devem ser consideradas para melhoria da comunicação: a divisa entre o cliente e o projetista; a divisa entre o projetista e o construtor e a divisa entre o construtor e os 
fornecedores de sistemas, materiais, componentes; além de divisas menores, como mostra a Figura 31.

1.

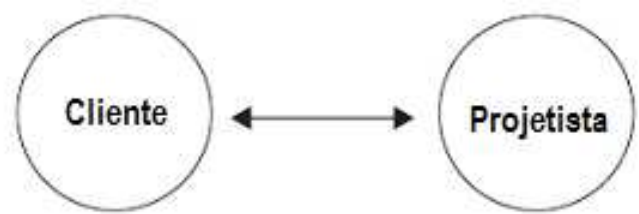

2.

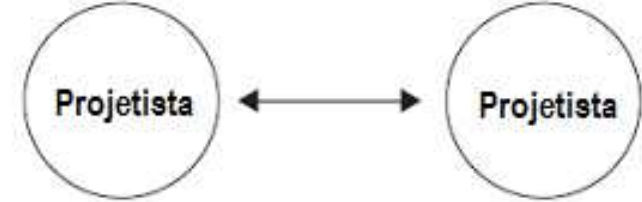

3.

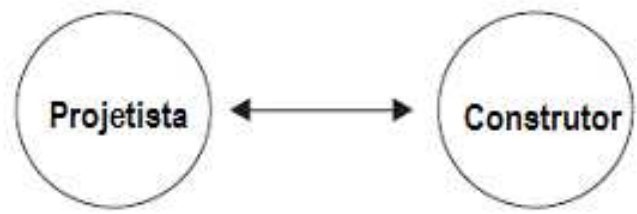

4.
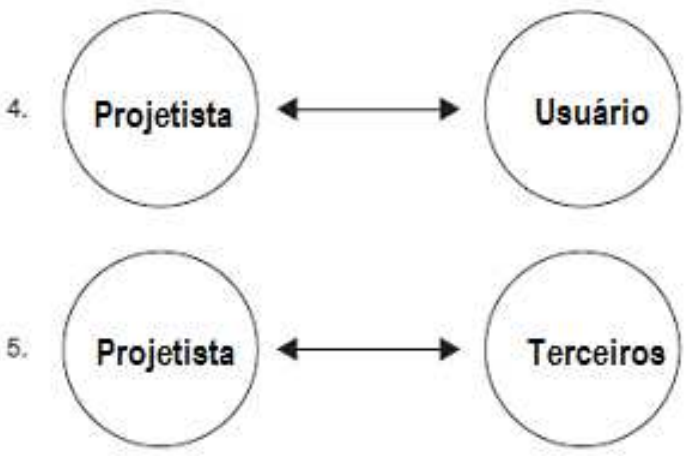

Prioridades e passados diferentes.

Cliente não habituado à linguagem gráfica.

Passado e objetivos compartilhados. Podem comunicar-se de forma codificada elevada. Preferência por linguagem gráfica.

Algum passado e conhecimento compartilhado. Prioridades diferentes; utilização de várias mideas. Podem tornar-se antagonistas.

Assim como 1. os usuários apenas são envolvidos "após o evento", e podem solicitar mudanças.

Planejadores, grupo de usuários, etc. Prioridades diferentes - em geral tentam interromper ou influenciar o desenvolvimento. Em geral são conservativos e antagonistas. Tem influência no processo de projeto.

Figura 31 - Comunicação entre os diferentes agentes da construção (adaptado de EMMITT, 2002)

Grisham; Srinivasan (2007) argumentam que a confiança entre as partes envolvidas, o relacionamento, experiência, habilidades e estrutura do contrato têm papel crítico para determinar a eficácia das comunicações em Projetos internacionais que envolvem membros da equipe de diferentes países e culturas. Como os Projetos são temporários e, em geral de duração média de dois a cinco anos, os planos de comunicação devem ser implantados com rapidez. A reputação e experiência dos lideres das equipes é essencial para formar uma relação fundamentada na confiança, que facilitará a comunicação aberta e efetiva, assim como o fluxo do conhecimento.

O método de narrativa (storytelling) pode ser utilizado para construir relações de confiança de forma rápida. Pesquisas indicam que quando pessoas contam estórias sobre outras pessoas há um estímulo à confiança e ao conhecimento. As estórias 
podem incluir assuntos sobre pessoas, a organização, o trabalho, vínculos sociais, o passado, o futuro, a vida e sinais (COHEN; PRUSAK, 2001 apud GRISHAM; SRINIVASAN, 2007).

ASCE (2000) apud GRILO (2002) destaca como formas de comunicação empregadas na coordenação de projetos: comunicação direta (reuniões, consultas); telecomunicações (telefonemas, teleconferência e transmissão de rádio); comunicação escrita (registro de decisões, acordos e ações).

A comunicação via internet, extranet devem ser destacadas como novos meios de comunicação, assim como as redes sociais que podem operar em diferentes níveis, como por exemplo, redes de relacionamento (facebook, orkut, myspace, twitter), redes profissionais (linkedin), comunidades de prática para compartilhamento de conhecimento, narrativa, etc. Com exceção das ferramentas de colaboração de projetos acessadas via internet, as empresas ainda não assimilaram todas as novas formas de comunicação e, portanto, não estabeleceram padrões ou regras de utilização corporativos.

A comunicação face-a-face é reconhecida como o mais efetivo meio de transmitir as intenções da mente de uma indivíduo para outro, especialmente com participantes do processo de projeto tão diferentes um dos outros e com diferentes requisitos. Esta comunicação é importante nas fases de início dos projetos quando o projeto ainda é implícito e fragmentado na mente de cada participante (EMMITT, 2002; OTTER; EMMITT, 2008).

A comunicação entre os membros da equipe de projetos pode ser definida como a compilação de todos os processos de envio e recebimento de mensagens entre os membros, individual ou coletivamente, utilizando todos os meios de comunicação disponíveis (OTTER; EMMITT, 2008). Croquis e imagens são importantes meios para comunicar as idéias e conceitos do projeto (BATES, 2008 apud OTTER; EMMITT, 2008).

Gray; Hughes (2001) apud Romano (2003) classificam dois tipos de reunião: coordenação (empregadas para coordenar as tomadas e decisão da equipe de projeto) e controle (avaliar o progresso do projeto com relação ao planejado e definir ações no caso de ser identificadas falhas ou detectados pontos que necessitem uma tomada de decisão). 
As reuniões podem ser usadas para: melhorar a compreensão dos projetos e para obter o consenso sobre o progresso do projeto; organizar as disciplinas envolvidas e trocar experiências; avaliar o progresso do projeto e alertar o cliente sobre eventuais problemas de projeto. A frequência das reuniões varia de acordo com as fases do projeto, distância entre as organizações e disponibilidade de ferramentas de comunicação, podendo ocorrer a cada duas ou três semanas, e com mais frequência na fase de concepção inicial do projeto. A eficácia das reuniões depende da forma como foi organizada e conduzida (OTTER; EMMITT, 2008).

Os dados de pesquisa realizada na Irlanda indicou que os membros da equipe de projeto preferem comunicar-se através de dialógos do que em reuniões formais. Os diálogos são importantes para estabelecer os acordos entre o líder da equipe e demais indivíduos que compõe cada disciplina e que, posteriormente, podem ser discutidos com todos envolvidos no processo nas reuniões formais, onde ocorre o compartilhamento de conhecimento e comprensão mútua do projeto (OTTER; EMMITT, 2008).

Baseado na constatação de que metade do tempo dedicado à fase de projetos é despendido na coleta de informações, no desenvolvimento preliminar dos projetos e na verificação da consistência do trabalho, Gus (1996) "reforça a necessidade de sistematização do processo de tomada de decisão na busca da eficácia do processo de projetos".

A falta de um planejamento das comunicações pode ocasionar perda de agilidade, extravio ou falta de informações relevantes, desperdício de tempo à procura de informação. Este planejamento deve considerar os canais de comunicação (auditivos e visuais), os protocolos para intercâmbio de informações, a definição do fluxo das informações, a frequência na comunicação, o compartilhamento e o acesso às informações, a delegação das responsabilidades e a estrutura de comunicação, levando em conta o treinamento dos membros das equipes, a localização das empresas e os recursos tecnológicos disponíveis para assegurar que as informações do projeto sejam geradas, coletadas, distribuídas, armazenadas, recuperadas e organizadas de maneira apropriada. (GRILO, 2002; PMI, 2008).

Independente da forma de comunicação empregada ou forma de apresentação da informação adotada, Emmitt (2002) descreve algumas "regras de ouro" que devem estar na mente dos projetistas e ser aplicadas em qualquer circunstância: 
- Clareza e concisão: quanto mais clara e concisa a informação, mais efetiva ela é. Apenas as informações relevantes devem ser transmitidas. Excesso de informações tiram a atenção do receptor para as informações importantes;

- Oportunidade: os projetistas devem observar sua relação em termos de tempo com outros projetistas e a execução da obra. Uma informação de qualidade recebida na hora certa é valiosa. Se for recebida com atraso, perde seu valor;

- Repetição: a repetição de informações em diferentes documentos é desnecessária, desperdiça recursos e se for repetida com pequenas diferenças pode gerar dúvida;

- Checar, checar e checar novamente: com os cronogramas cada vez mais reduzidos, as práticas de checar todos os desenhos e especificações antes da emissão de um projeto foram abandonadas, e muitas vezes o mesmo indivíduo que gerou a informação faz a verificação, o que pode aumentar a probabilidade de erros devido ao excesso de familiaridade com o material.

\subsection{Tecnologia da Informação (TI)}

Segundo Fabricio (2002), a eficiência na colaboração no processo de projeto depende, além dos agentes humanos, da compatibilidade e intercomunicação entre as ferramentas computacionais de apoio à atividade projetual.

A internet vem facilitando o desenvolvimento de projetos de forma colaborativa, integrando todos os envolvidos no processo de projeto da edificação, inclusive o cliente, simultaneamente e não mais sequencialmente (SOUZA FILHO \& CASTRO, 2001 apud ROMANO, 2003).

Para aumento da agilidade na troca de informações em projetos de grandes empreendimentos e aumento de eficiência na comunicação entre os agentes, muitas vezes dispersos geograficamente, empresas oferecem serviços e aplicativos para internet que são utilizados como ferramentas de colaboração de projetos. Estas ferramentas, geralmente provisionadas pelo cliente ou construtora, permitem o armazenamento de arquivos que podem ser visualizados ou postados pelos 
membros da equipe, facilitando a organização e compartilhamento de informações, projetos e documentos. O plano de comunicações deve definir as restrições e permissões de acesso (visualização, postagem), além das responsabilidades dos membros da equipe (gestão do sistema, cópias, registros, etc).

A centralização de banco de dados e informações via internet reduz falhas de comunicação, prazos, custos de impressão e entrega de CDs (compact disks). Estas ferramentas de colaboração possibilitam a rastreabilidade através do registro das operações dos usuários, gestão e controle de cópias dos projetos, gestão de atividades através da distribuição e controle de tarefas atribuidas aos usuários, visão compartilhada dos planos de ação e atividades do cronograma, emissão de relatórios gerenciais de andamento das atividades.

A utilização de banco de dados e programas de gestão de Projetos vem crescendo. Algumas empresas disponibilizam a seus clientes o acesso à páginas de sua intranet com informações sobre o empreeendimento, orçamentos, acompanhamento de cronograma de obra, etc.

Em complementação aos programas que viabilizam a elaboração de projetos bidimensionais e tridimensionais por meios computacionais, foram desenvolvidos diversos aplicativos para cálculo de iluminação, análise de sistemas de ar condicionado, ventilação. A utilização de algoritmos de renderização permitiu inserir imagens estáticas ou tomadas de vídeo no modelo eletrônico, permitindo realizar animações em que uma câmera virtual realiza uma visualização do interior e entorno do edifício projetado (ROMANO, 2003).

Impulsionados pelo conceito de edifícios sustentáveis que buscam melhor eficiência energética e desempenho do edifício foram introduzidos programas, baseados em elementos finitos que realizam simulações em modelos virtuais que permitem verificar o desempenho acústico, luminotécnico e térmico do edifício.

Um conceito mais recente, conhecido como BIM (Building Information Modeling), que envolve a utilização de uma nova geração de programas para a modelagem de informações do edifício baseado na modelagem 3D paramétrica e a interoperabilidade, deve promover uma mudança no processo de produção da construção civil. Um único modelo digital integra todos os desenhos de documentação (plantas, cortes e detalhes) de todas as disciplinas a um banco de 
dados da obra. Com todos os projetos reunidos em um único arquivo eletrônico é possível verificar as interferências antes da execução da obra e qualquer alteração realizada no modelo tridimensional é automaticamente atualizada em todos os arquivos que o compõem, assim como o banco de dados (CICHINELLI, 2011).

Como a documentação dos projetos de uma edificação é a etapa que atualmente consome mais tempo e atenção dos projetistas, ao reduzir o tempo dispendido com a representação do projeto será possível otimizar o tempo para o trabalho intelectual do projetista.

A integração 4D ou 5D de tempo e custo a um modelo geométrico 3D, faz com que as mudanças possam ser controladas não apenas nas etapas de projeto e construção, mas em todo ciclo de vida do edifício (SHEN et al., 2010).

Do modelo produzido podem ser extraídos quantitativos de materiais automaticamente, como ilustrado na Figura 32, o que garante uma quantificação mais precisa, reduz a variabilidade na orçamentação e, ao aumentar a sua velocidade, permite a exploração de mais alternativas de projeto. Segundo Santos, isto permite que a análise de custos se estenda por todas as fases do ciclo de vida do empreendimento, apoiando o processo de decisão (FARIA, 2011).

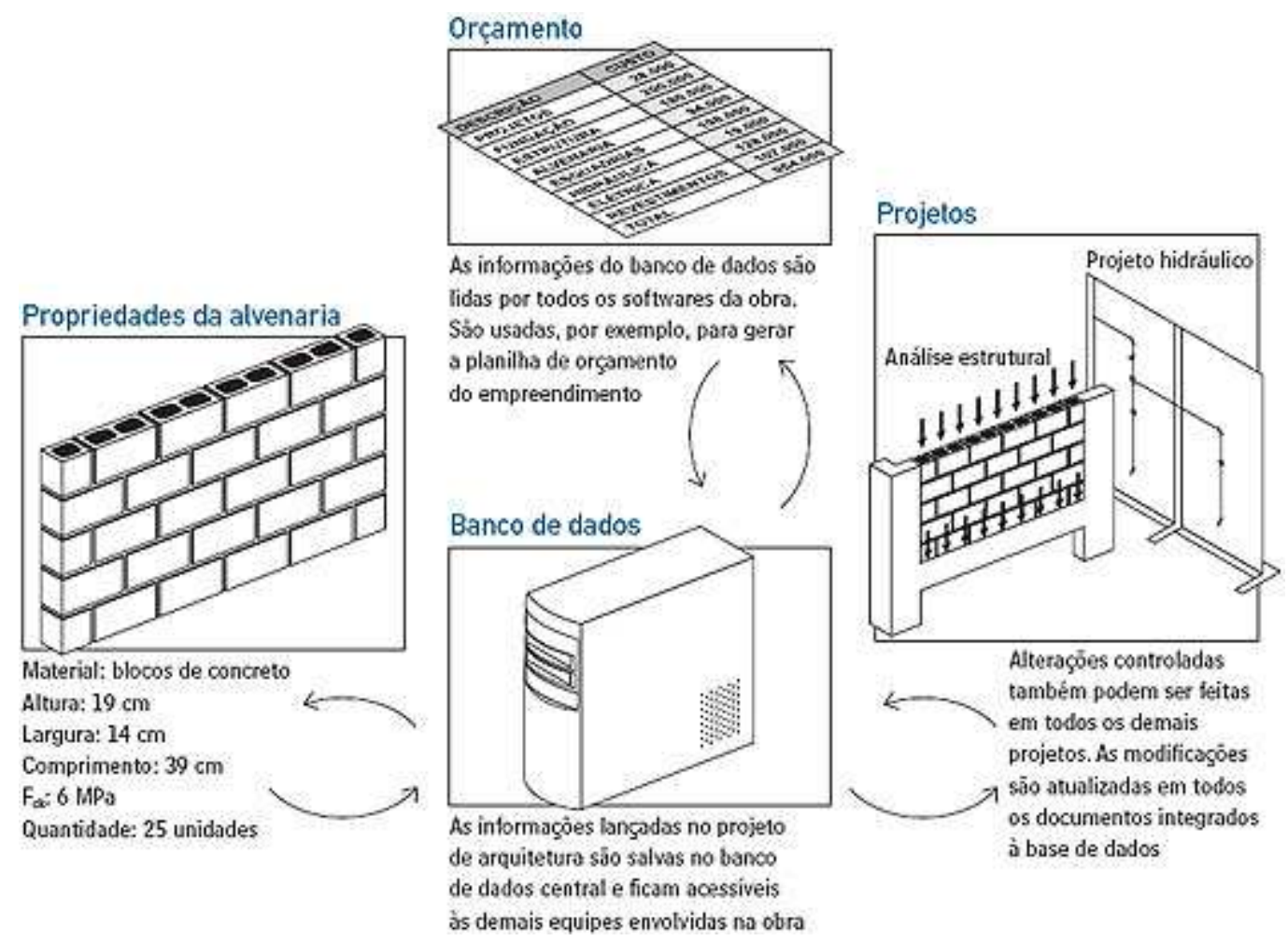

Figura 32 - Construção integrada (FARIA, 2011) 
Existem iniciativas individuais de escritórios de projeto, principalmente de arquitetura, grandes incorporadoras e construtoras no sentido de experimentar a tecnologia em projetos-piloto. No entanto, segundo Santos, a penetração do BIM no setor da construção brasileira será lenta devido ao alto custo de licenças de uso dos programas, demanda por computadores com capacidade de processamento muito maior do que as plataformas de modelos em 2D, além do tempo de capacitação técnica dos projetistas. As principais barreiras destacadas são: a falta de padrões de classificação brasileiros para componentes e materiais; a falta de processo e padrões que estabeleçam o nível de detalhe para modelagem que deve ser adotado em cada fase do projeto (o que envolve obter um consenso entre diferentes escritórios, empresas e profissionais) e a imaturidade dos padrões de troca de informações que dificulta o intercâmbio de dados entre os aplicativos de projeto BIM e programa de orçamentação de forma confiável e completa. Um profissional cada vez mais demandado no exterior é o Gerente BIM (BIM Manager), responsável pela coordenação deste novo ambiente (FARIA, 2011).

Em 2011, foi realizado pelo Sinduscon-SP (Sindicato da Indústria da Construção São Paulo) seminário sobre o BIM, onde profissionais de projeto, consultores e construtoras discutiram os desafios para disseminar o BIM no país. No contexto da construção, onde a disponibilidade de recursos para financiamento estimula 0 aumento das vendas das empreendimentos há uma exigência para redução do ciclo de produção de empreendimentos a partir da compra do terreno. Segundo Maria Angélica Covelo Silva, diretora da NGI Consultoria e Desenvolvimento, esta condição impõe a necessidade de substituição dos sistemas construtivos tradicionais, redução de retrabalho, correção de erros e incompatibilidades de forma que a obra seja contínua e com alta produtividade. A introdução do BIM, onde um modelo digital tridimensional integrando informações de todas as disciplinas (estrutura, hidráulica, elétrica, etc), contribuiria para atingir este novo patamar, além da possibilidade de utilizá-lo na gestão da operação e manutenção futura do edifício. De acordo com Jan Reinhardt, diretor da Adept Project Delivery, EUA, o BIM é uma ferramenta de gestão que pode ser utilizada para coordenar as equipes, negociar espaços entre todas disciplinas, orçar os custos ou simplesmente para fazer perspectivas, ficando a cargo do usuário definir as suas necessidades, visto que 
modelos mais detalhados exigem máquinas com maior capacidade de processamento (BARBOZA, 2011).

Foram levantados pelos participantes como obstáculos para seu desenvolvimento no Brasil são: interoperabilidade entre diferentes soluções e sistemas, falta de qualificação de equipes e desenvolvimento das bibliotecas de componentes.

Segundo Lúcio Soilbehman, da Universidade Carnegie Mellon, as empresas brasileiras devem avaliar o custo-benefício do investimento no BIM e sua real necessidade. Nos EUA a ferramenta BIM é utilizado pelos general contractors, donos do empreendimento, para coordenar o trabalho dos subempreiteiros, além de evitar mudanças que parem a produção da obra. No caso do Brasil, os ganhos da utilização seriam maiores para os construtores com a redução de retrabalho e para o cliente que economizaria os recursos destes retrabalhos, e não para os projetistas que teria que utilizar o sistema BIM adequado ao sistema de cada construtora.

Com o objetivo de conhecer melhor cada ferramenta e explorar o potencial dos projetistas, algumas incorporadora-construtoras de São Paulo, iniciaram um teste com os principais programas BIM disponíveis no mercado ${ }^{8}$.

A implantação do BIM, segundo Eduardo Sampaio Nardelli, professor da Faculdade de Arquitetura e Urbanismo da Universidade Presbiteriana Mackenzie, afeta a composição da equipe de projetos, pois decisões, que normalmente se concentram no projeto executivo, serão antecipadas para as etapas de estudo preliminar. Desta forma, o operador do sistema terá que ser mais experiente, pois terá a responsabilidade de especificador e não apenas de desenhar. A ferramenta já é utilizada por vários escritórios de arquitetura e estrutura e, segundo Fabio Pimenta, diretor da Projetar Projetos e Sistemas, poucas adequações dos sistemas são necessárias para os sistemas de combate a incêndio e de climatização, no entanto, a ferramenta não está adequada para a área de instalações prediais onde faltam adaptações de funcionalidade, bibliotecas e recursos de cálculo para hidráulica e elétrica. Construtoras defendem que os fabricantes de materiais deveriam desenvolver e disponibilizar as bibliotecas de seus produtos.

\footnotetext{
8 Programas que suportam a tecnologia BIM: Active3D (Archimen); Revit (Autodesk); Allplan (Nemetschek); Archicad (Graphisoft); DDS-CAD (Data Design System); MicroStation (Bentley); Solibri; Tekla Structures; VectorWorks.
} 


\subsection{Aspectos Tecnológicos}

Além da importância da integração entre todos os agentes do processo, Gus (1996) reforça a necessidade sistematização do processo de tomada de decisão para garantir a eficácia do processo de projeto. As restrições dos processos e tecnologias construtivas a ser adotados, em função do estágio tecnológico da construtora, devem ser transmitidas à equipe responsável pelos projetos do produto (FONTENELLE, 2002). Para auxiliar as definições dos aspectos tecnológicos, Melhado (1994) propõe uma estrutura como forma de ligação entre as etapas de projeto e execução através de um Banco de Tecnologia Construtiva - BTC da empresa, com informações técnicas e detalhes construtivos atualizados continuamente de acordo com as inovações tecnológicas introduzidas em seu sistema de produção, assim como soluções para problemas surgidos nas etapas do processo de produção dos empreendimentos.

A estruturação do BTC deve compreender os processos de: captação do conhecimento; sistematização da informação e disponibilização da informação. Como diretriz inicial para estruturação de um BTC pode-se adotar: "cada processo ou sistema construtivo deverá possuir um BTC próprio, em função das especialidades de cada um e do grau de inter-relacionamento existente entre os métodos construtivos empregados." (FONTENELLE, 2002).

Fontenelle (2002) sugere que o BTC, como mostra a Figura 33, seja inserido no sistema de qualidade da empresa e a estrutura física estaria localizada na área técnica da empresa que utilizaria as informações como dados de entrada no processo de projeto de novos empreendimento e como fonte de consulta para as outras fases do processo de produção. A retroalimentação do sistema de informação se daria a partir do envio de informações pelos setores ou pessoas responsáveis ao longo das várias fases do processo de produção de cada empreendimento, desde a fase de projeto até a fase de assistência técnica. Um Comitê de Tecnologia, de caráter multidisciplinar, se reuniria periodicamente para avaliar as inclusões do BTC e decidir sobre sua exclusão ou complementação de conteúdos ultrapassados. 


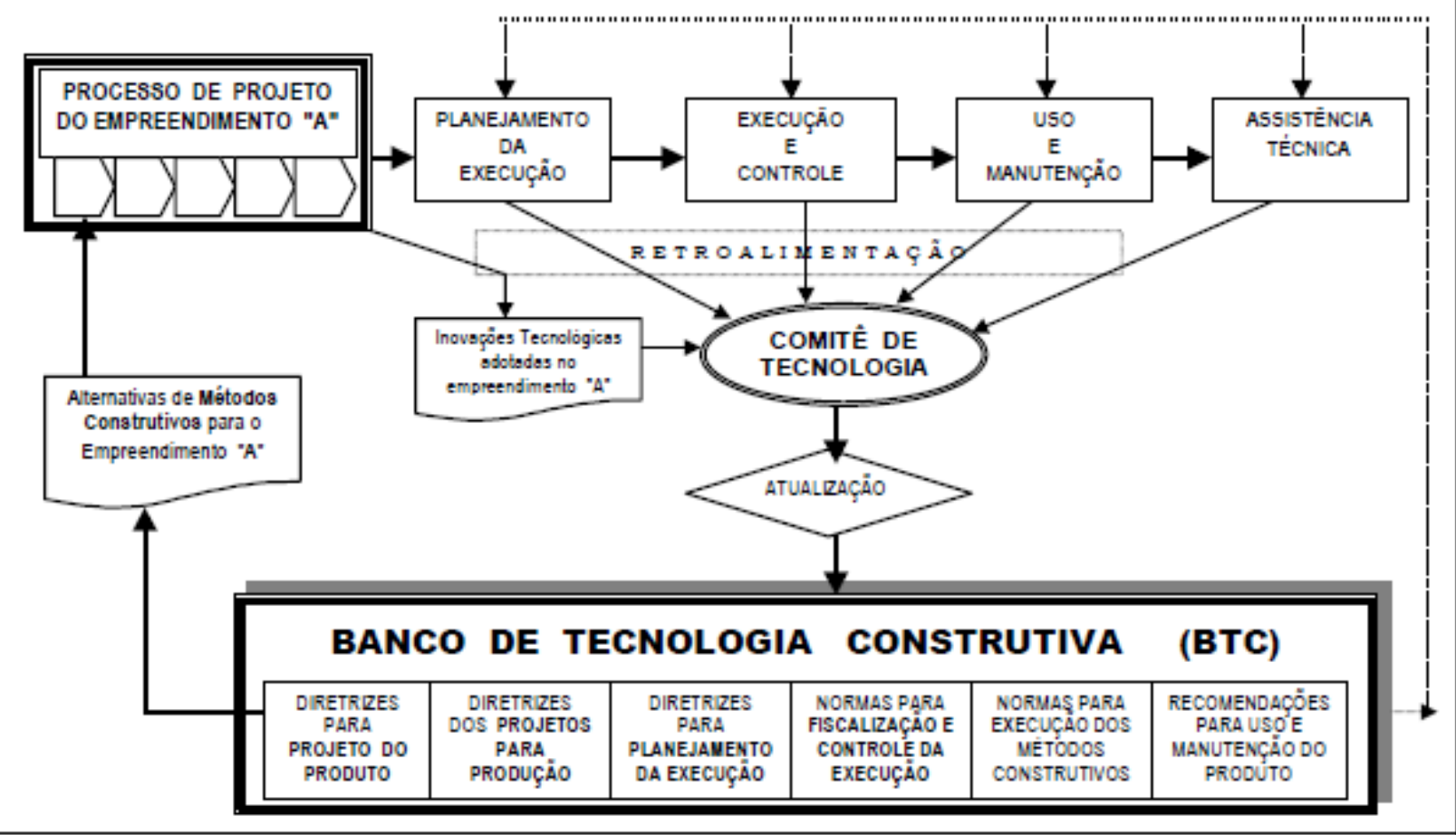

Figura 33 - O BTC inserido no Sistema de Qualidade de uma empresa incorporadora e construtora (FONTENELLE, 2002)

Neste processo, falhas encontradas no projeto de produto pela assistência técnica seriam inseridos nas diretrizes de projeto evitando que não-conformidades (causando problemas patológicos) se repitam em novos empreendimentos. Este conceito está alinhado à proposta de projeto de Melhado (1994) que indica que as informações de uso, operação e manutenção de produtos já entregues devem provocar a retroalimentação e auxiliar na sistematização dos procedimentos de decisão de projeto.

Fontenelle (2002) cita o trabalho de diversos autores que propõe, como complementação ao BTC, um manual do processo de projeto para sistematização de diretrizes, parâmetros e/ ou padrões construtivos e de produtos (tipologia de edifícios) (GUS, 1996; TZORTZOULOS e CTE, 1999; NGI, 1999) .

No caso de obras de natureza semelhante (edifícios residenciais ou comerciais), em que diversos elementos da edificação tem pequenas variantes, é possível padronizar alguns detalhes ou partes do projetos que podem fazer parte do acervo de soluções para obra da empresa, tais como: detalhes de impermeabilização de box de banheiro, soleiras, guarda-corpos, esquadrias, partes da estrutura e de instalações; 
assim como podem ser padronizados componentes (pré-moldado de concreto lajes, vergas, tampas de caixa, etc; kits de instalações hidráulicas) e materiais (tijolos, blocos cerâmicos, acabamentos em geral). A utilização destes padrões não compromete a originalidade do projeto e traz benefícios permitindo: "maior facilidade de comunicação e entendimento entre os intervenientes; diminuição da retrabalho em função da correta execução do projeto, que muitas vezes só insinua suas especificações e de forma incompleta; o aprimoramento dos processos, facilitando a execução e evitando os problemas de pós-construção como infiltrações, trincas, etc; o aprimoramento dos serviços pelo efeito aprendizagem, resultado da definição e repetição dos processos, dos componentes e materiais utilizados; facilidade para 0 treinamento de pessoal de obra em padrões estabelecidos; facilidade no estabelecimento de parceria com fornecedores; possibilidade de projetar transporte e armazenagem de material" (SCARDOELLI et al., 1994 apud ROMANO 2003).

\subsection{Problemas/ Deficiências no processo de projeto}

A maioria das falhas e defeitos das edificações são decorrentes do projeto e/ou de erros de execução, e em menor porcentagem a materiais com defeito ou erros de procedimento, e em menor escala por falta de manutenção (CROCKER, 1990 apud EMMITT, 2002). Muitos defeitos só se manifestam após alguns anos depois da ocupação do edifício, principalmente defeitos ocultos na estrutura. Especial atenção deve ser dada aos casos onde o projeto é detalhado por outro escritório diferente do projetista, como é o caso dos projetos para produção, que deve ter a habilidade de compreender a filosofia atrás do conceito do projeto, os princípios de um bom detalhamento e seleção de mateirias. Os principais defeitos encontrados na construção são conhecidos e ocorrem com frequência: infiltração de água, rachaduras na alvenaria, etc, e algumas causas levantadas por Emmitt (2002) são:

- Falta de habilidade para aplicar conhecimento técnico;

- Detalhamento e especificações inadequados;

- Não conformidade com as normas;

- Informações incompletas; 
- Trabalho pobre;

- Supervisão inadequada;

- Alterações inadequadas que tornam bons detalhes ineficazes;

- Manutenção insuficiente.

Defeitos podem ocorrer mesmo com bons projetos executados por construtoras capacitadas. A pressão para redução de prazos e custo pode acarretar em simpilficações e erros. Ao detectar-se um defeito, apesar da tendência de buscar-se um culpado, é necessário uma cuidadosa identificação das causas e extensão do problema, diagnóstico e recomendação de ação, antes de iniciar qualquer serviço de remediação. Este procedimento encontra-se no campo da patologia das edificações. A deterioração não pode ser previnida, mas através da combinação de um bom detalhamento, boa execução da obra e manutenção regular, pode ser retardada (EMMITT, 2002).

Grilo (2002) identificou no estudos de caso de sua pesquisa diversas deficiências na gestão do processo de projeto: informações incompatíveis, insuficientes para contratação dos fornecedores, incorretas ou omissas; excesso de revisões; falhas na representação dos projetos: ausência de cotas, desenhos sem escala.

Diversas causas são apontadas como origem das deficiências encontradas nos projetos e no processo de gestão, e segundo Grilo (2002) a etapa de projeto constitui um dos principais obstáculos para o desenvolvimento da indústria da construção:

- A terceirização dos projetos em geral não é acompanhada de um processo gerencial que garanta a integração entre as várias tomadas de decisões tomadas em cada um dos projetos (SILVA, 1996)

- Aumento da complexidade dos empreendimentos e número de intervenientes; crescente fluxo de informações e número de documentos gerados; a inexistência de um ciclo de vida padrão para o processo de projeto, que prejudica o entendimento comum a respeito do mesmo (ROMANO, 2003)

- Em projetos complexos, decisões impostas por clientes e legislação, muitas vezes, tomadas com limitações de tempo (KOSKELA et al., 1997 apud FABRICIO, 2002); 
- Deficiências do programa de necessidades;

- Inadequação e desatualização do conhecimento técnico dos projetistas ;

- Falta de planejamento do processo de projeto;

- Requisitos do cliente são perdidos durante o projeto (ANDREY et al., 2000 apud FABRICIO, 2002);

- Improvisações na obra por falta de informações de projeto;

- Falta de clareza dos projetos, prejudicam andamento da obra e qualidade do produto;

- Incompatibilidade entre os projetos;

- Carência de retroalimentação, prejudicada pela natureza temporária das relações;

- Falta de treinamento dos operadores de CAD, muitas vezes sem familiaridade com o processo construtivo;

- Aumento da demanda de desenhos e informações a ser produzida para novos sistemas e equipamentos incorporados ao edifício, cujos processos de execução e montagem requerem conjuntos específicos de subprocessos e atividades, que muitas vezes exigem técnicas de representação diferente da tradicional;

- Procedimentos de qualidade são aplicados de forma restrita e não sistemática nos escritórios de projeto que, dentro das pressões de entrega e orçamentos, tendem a ignorar os procedimentos (BIRNBERG, 1998 apud GRILO, 2002; BAÍA, 1998);

- Apesar da motivação decorrente da expectativa de ganho de eficiência produtiva, organização interna, diferenciação no mercado dos escritórios de projeto, a implantação de sistema de gestão da qualidade enfrenta dificuldades, tais como: carência de recursos físicos e humanos, subcontratação acentuada, resistência do pessoal e convergência de funções sobre os titulares (GRILO, 2002).

Romano (2003) constata que a grande maioria das empresas construtorasincorporadoras conduzem as atividades do processo de projeto sem uma estrutura 
organizacional adequada, conservando práticas que ocasionam muitos problemas no processo construtivo como um todo:

- Não utilizam metodologia adequada para a gestão da qualidade aplicada especificamente ao processo de projeto;

- O projeto é considerado como um custo e não investimento;

- O projeto é desenvolvido de forma insuficiente e/ou inadequada pois não se destina tempo e esforços para o planejamento do projeto;

- Não são envolvidos todos os especialistas necessários no momento da caracterização do produto (JACQUES, 2000 apud ROMANO, 2003);

- São fixados prazos extremamente curtos para as fases iniciais do processo de projeto, forçando o desenvolvimento do projeto na fase de execução da construção, o que gera inúmeros problemas: a divergência entre projetos só é detectada no momento da execução do serviço, centralizando as decisões no engenheiro da obra (SCHMITT, 1998 apud ROMANO, 2003);

- Não é utilizada nenhuma metodologia adequada ao levantamento das necessidades dos cliente, tanto investidor como usuário final;

- O projeto é elaborado de forma fragmentada e sequencial: arquitetura, estruturas, instalações prediais o que implica em retrabalho ou até abandono de projetos inteiros (FABRICIO, 1999);

- Fluxo de informações caótico e desestruturado entre os diversos intervenientes retarda decisões críticas, gera improvisações e aumenta o tempo de desenvolvimento de projeto;

- Não existe definição clara ao longo do desenvolvimento do projeto de quais são as informações de entrada necessárias por cada interveniente (necessidades do cliente, regulamentações públicas, informações de outros projetistas, etc) para execução das tarefas do projeto (TZORTZOPOULOS, 1999);

- Não são desenvolvidos projetos para produção gerando problemas de construtibilidade e improvisações no canteiro de obras (KEHL, 1997 apud ROMANO, 2003): 
- O projeto mostra o que se pretende construir, mas não como construir.

- Os projetistas não especificam tolerâncias dimensionais o que impossibilita fixar dimensões precisas em cada etapa, o que gera desperdício de material e mão de obra (rasgos em alvenaria pronta para passagem de instalações elétricas e hidrúlicas; enchimentos nas folgas deixadas para os vãos de portas, etc).

- Os projetos não são estruturados conforme o sistema de lógica da obra, e não apresenta lista de materiais para compor cada subsistema o que dificulta ajustes de prazo de compra com cronologia da obra, principalmente quando são efetuadas modificações de um projeto durante a obra;

- Os projetos chegam à equipe de obra como "peças de um quebra cabeça" que não se encaixam ou são insuficientes (SCHMITT, 1998 apud ROMANO, 2003);

- Não são utilizados mecanismos para retroalimentação do projeto a partir da avaliação pós-ocupacional e a partir da obra executada: projetos como construído não são documentados; os projetistas não são informados com relação a eventuais problemas ou alternativas levantadas nos canteiros de obras; não são criados bancos de dados que contenham critérios para melhora da construtibilidade;

- Ao término da obra, por falta de uma política da empresa, não é feito o adequado arquivamento das informações, prejudicando as atividades de operação e manutenção (SCHMITT, 1998 apud ROMANO, 2003);

- Impacto muito lento da TI na construção, por deficiências na gestão de processos (ANTAC, 2002 apud ROMANO, 2003).

Para controlar os riscos técnicos da construção e assegurar o cumprimento do contrato com o cliente muitas construtoras assumiram a coordenação dos projetos. Grilo (2002) levantou alguns impactos na gestão da obra decorrentes das deficiências no processo de projeto, conforme Quadro 10. 


\begin{tabular}{|c|c|}
\hline Deficiências no projeto & Impacto na obra \\
\hline $\begin{array}{l}\text { Falta de padronização ou } \\
\text { excesso de personalização }\end{array}$ & $\begin{array}{l}\text { Dificuldade na aquisição, orçamentaçâo, gestâo dos contratos, } \\
\text { controle de alteraçōes, controle dos documentos em obra. }\end{array}$ \\
\hline $\begin{array}{l}\text { Informaçóes conflitantes em } \\
\text { diferentes documentos }\end{array}$ & $\begin{array}{l}\text { Sobrecarga de trabalho para a equipe de obra, dificuldades para a } \\
\text { aquisição, orçamentaçăo, execuçāo, erros de execuçăo, } \\
\text { retrabalhos e perda de materiais. }\end{array}$ \\
\hline Informaçōes indisponiveis & $\begin{array}{l}\text { Sobrecarga para o pessoal de obra, postergação na contrataçāo } \\
\text { dos fornecedores, gestão dos contratos complexa, atrasos no } \\
\text { cronograma, informaçāo insuficiente para contratação. }\end{array}$ \\
\hline $\begin{array}{l}\text { Informaçóes dificeis de } \\
\text { encontrar }\end{array}$ & $\begin{array}{l}\text { Perda de tempo da equipe de obra; dificuldade no levantamento } \\
\text { dos quantitativos. }\end{array}$ \\
\hline $\begin{array}{l}\text { Problemas no fluxo de } \\
\text { informaçōes e na estrutura } \\
\text { de comunicaçāo }\end{array}$ & $\begin{array}{l}\text { Diferentes niveis de informação entre os membros da equipe, } \\
\text { alteraçōes nāo incorporadas no projeto, incompatibilidade entre } \\
\text { informaçōes recebidas dos membros da equipe, informaçōes } \\
\text { confusas. }\end{array}$ \\
\hline $\begin{array}{l}\text { Atraso na incorporação das } \\
\text { alteraçōes nos documentos } \\
\text { de projeto }\end{array}$ & $\begin{array}{l}\text { Documentos obsoletos em obra, risco de erros na execução, } \\
\text { dificuldade no controle dos documentos em obra, documentos } \\
\text { revisados nem sempre incorporam a informação atualizada, } \\
\text { diversos niveis de informaçăo no escritório e na obra, improvisos } \\
\text { na solicitação de propostas (bilhetes anexados com consideraçōes } \\
\text { sobre o projeto), risco de conflitos entre projetistas, construtora e } \\
\text { fornecedores, execução antecede a incorporaçăo da informação } \\
\text { no projeto. }\end{array}$ \\
\hline $\begin{array}{l}\text { Excesso de pendências nos } \\
\text { documentos de projeto }\end{array}$ & $\begin{array}{l}\text { Dificuldade para a gestāo dos documentos em obra, risco de erros } \\
\text { na execução, exigência de soluçăo das pendências em reuniōes } \\
\text { diárias e semanais (task-force meetings) }\end{array}$ \\
\hline $\begin{array}{l}\text { Excesso de revisōes no } \\
\text { projeto }\end{array}$ & $\begin{array}{l}\text { Aumento dos custos, atrasos, equívocos na execução, sobrecarga } \\
\text { de trabalho para o pessoal de obra e para a coordenação, } \\
\text { desgaste da equipe, aumento do custo com cópias e impressōes, } \\
\text { atraso na emissăo dos documentos para a obra. }\end{array}$ \\
\hline $\begin{array}{l}\text { Múltiplos interlocutores na } \\
\text { organizaçāo do cliente }\end{array}$ & $\begin{array}{l}\text { Tomada de decisăo complexa, excesso de alteraçōes, diferentes } \\
\text { niveis de informação entre os interlocutores. }\end{array}$ \\
\hline $\begin{array}{l}\text { Excesso de alteraçōes de } \\
\text { projeto em fases adiantadas } \\
\text { da obra }\end{array}$ & $\begin{array}{l}\text { Gestáo dos contratos com fornecedores complexa, } \\
\text { fornecedores, revisâo dos documentos de projeto, } \\
\text { aumentos dos custos, atrasos, sobrecarga para equipe de obra e } \\
\text { coordenaçăo, projetos com diferentes etapas de desenvolvimento, } \\
\text { tratativas com o cliente, reprogramaçōes, novos orçamentos. }\end{array}$ \\
\hline
\end{tabular}

Quadro 10 - Deficiências no processo de projeto e impacto na gestão da obra (GRILO, 2002)

\subsection{Gestão de mudanças}

A atividade de construção envolve processos complexos e várias incertezas. $O$ sucesso de um Projeto pode ser determinado pela habilidade da equipe de Projeto em gerenciar as inevitáveis mudanças que ocorrem ao longo do Projeto. Para uma 
gestão de mudanças eficaz é essencial compreender as causas e efeitos das mudanças (SUN; MENG, 2009).

A gestão de mudanças busca prever possíveis mudanças, identificar mudanças que já ocorreram, planejar medidas de prevenção e coordenar mudanças ao longo do Projeto (VOROPAJEV, 1998).

Um controle integrado de mudanças deve ser conduzido do início ao término do Projeto, assegurando que apenas as mudanças aprovadas serão realizadas, após a avaliação de seu impacto no tempo e custo (PMI, 2008).

Segundo o manual de boas práticas de gestão de mudanças do Construction Industry Institute - CII (1994) e CIRIA (2001) apud Senaratne; Sexton (2009), para mitigar os efeitos negativos das mudanças devem ser adotados cinco princípios: antecipar a mudança; reconhecer a mudança; avaliar a mudança; resolver a mudança e aprender com a mudança.

Um modelo genérico de gestão de mudanças consiste em cinco estágios: identificação, avaliação, proposta, aprovação, implementação e finalização (SHEN et al., 2010).

Mudanças em projetos de construção são comuns e ocorrem por diversas razões, em qualquer estágio do projeto e pode representar impactos negativos consideráveis. A maior parte das pesquisas classifica as mudanças em: retrabalho e solicitação de mudança. Retrabalho refere-se a refazer um processo ou atividade que estava implementada incorretamente e geralmente é causado por defeitos de qualidade, variância, negligência, desenho pobre, gestão da obra. Retrabalho geralmente está associado a desperdício e pode ser melhorado através da gestão de mudanças. Solicitações de mudança referem-se a mudanças geradas por fontes que não foram antecipadas, como por exemplo: mudança de escopo pelo cliente, mudança de projeto ou tecnologia pelo arquiteto-autor do projeto, custo ou prazo por problemas de fornecimento ou condições climáticas. Como estas mudanças não podem ser evitadas, os requisitos para a gestão de mudanças são a disciplina e coordenação de todos aspectos relacionados à solicitações de mudança, por exemplo: documentos, desenhos, processos, fluxos, cronogramas, custo (SHEN et al., 2010). 
Os impactos e consequências das mudanças de projeto, principalmente definidas às pressas, devem ser avaliados com o cliente de forma integrada verificando o que pode afetar a execução em curso, implicações legais, etc (EMMITT, 2002).

Emmitt (2002) afirma que mudanças de projeto ocorrem por duas razões: para correção de erros nos projetos já emitidos ou porque algum agente envolvido no processo mudou de idéia. A segunda categoria pode afetar a durabilidade, qualidade e desempenho da edificação caso não haja uma avaliação da mudança considerando todos os aspectos do edifício de forma integrada.

Grilo (2002) afirma que mudanças podem ocorrer em decorrência de escopos mal definidos com o cliente ou falta de informações iniciais que acarretam em alterações de projetos. Como em casos onde o cliente inexperiente é pressionado a se comprometer com um programa para evitar atrasos na construção ou tem dificuldade de comunicar suas necessidades estratégicas e operacionais de forma compreensível (BROWN, 2001).

Conforme o empreendimento evolui, a entrada de novos intervenientes no processo pode interferir nos requisitos e propósitos iniciais do cliente, como ilustrado na Figura 34 (BROWN, 2001). Como estes requisitos não costumam ser registrados, comumente são esquecidos, dificultando sua gestão e rastreabilidade (HUOVILA; SÉRN, 1998 apud GRILO, 2002).

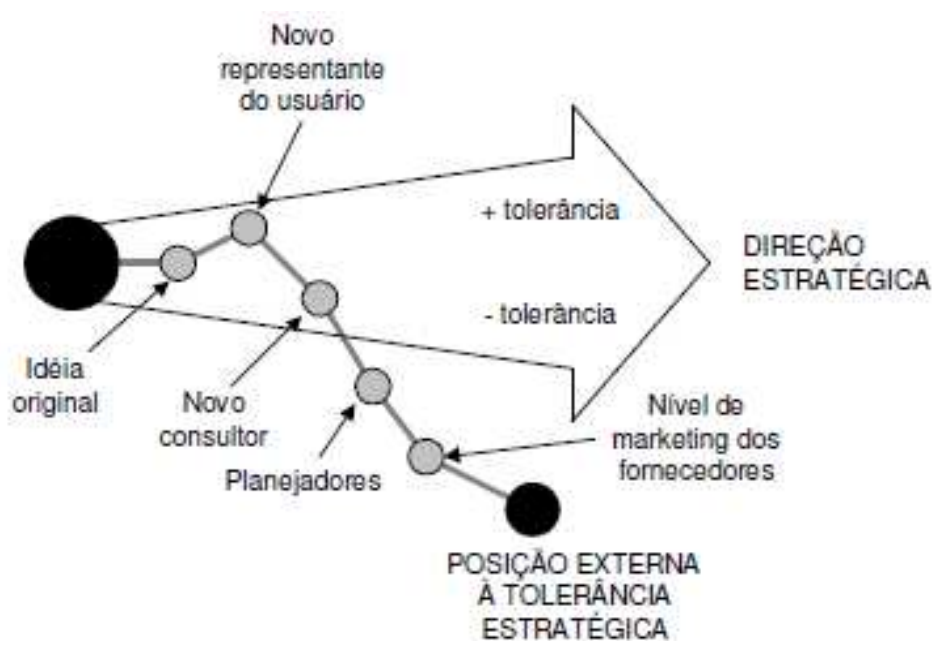

Figura 34 - Perda da estratégia genérica em função da carência de programação estratégica. (BROWN, 2001)

Para assegurar que todos os requisitos do cliente sejam atendidos ao final do projeto recomenda-se que seja realizada uma gestão do escopo para definição e controle 
do que está ou não incluso no projeto, incluindo um plano de gestão de mudanças (PMI, 2008). Deve ser acordado com o cliente um procedimento documentado para gestão das alterações, descrevendo o tipo de modificação, a referência para custos adicionais, a forma de aprovação e formulário para solicitação de modificações (STASIOWSKI, 1994 apud GRILO, 2002). A comunicação constitui um requisito essencial para a gestão do escopo (BIRNBERG, 1998 apud GRILO, 2002).

Mudanças de projeto na fase de execução da obra, segundo Emmitt (2002), são mais impactantes e inevitáveis, principalmente em reformas, e podem ocorrer por:

- Solicitação do cliente. Para minimizar esta possibilidade, o projetista deve explorar e expor todas as possibilidades ao cliente na fase de viabilidade, alertando-o sobre as consequências de mudanças após a aprovação do projeto;

- Solicitação do projetista que mudou de idéia em relação a algum item concebido (atitude anti-profissional que deve ser impedida pelo cliente);

- Problemas imprevistos detectados durante a obra, tais como dificuldades de aquisição de algum material ou problema detectado que exija algum detalhe específico;

- Omissões, erros e incompatibilidade entre projetos/ detalhes, que podem resultar em custos adicionais;

- Solicitação da construtora ou subcontratado para alteração de especificação de algum produto / sistema específico para adequação a produtos/ sistemas que tenha maior familiaridade. Neste caso, a responsabilidade sobre a especificação deve ser transferida para a construtora;

- Solicitação da construtora ou subcontratado para alteração de detalhes por dificuldades de execução detectadas na obra;

- Os 'As builts', em que foram baseados os projetos, não estavam atualizados (muitos clientes não aceitam pagar investigações, laudos).

A resposta dos projetistas à solicitação de mudanças de detalhes depende da personalidade do projetista e da política de sua organização. Alguns projetistas se recusam a mudar o projeto a menos que não haja outra opção, enquanto outros 
aceitam e encorajam a retroalimentação das construtoras para facilitar a execução dos detalhes e, possivelmente, reduzir o custo da execução.

No processo de gestão de mudanças, os membros da equipe de projeto utilizam mais o conhecimento tácito que o explícito em situações coletivas para solucionar problemas, interagindo em reuniões presenciais, onde são gerados e internalizados novos conhecimentos (SENARATNE; SEXTON, 2009). 


\section{Gestão do conhecimento}

A gestão do conhecimento sempre existiu, na troca de experiência entre trabalhadores, na passagem de conhecimento do artesão para o aprendiz, mas o conceito começou a ser difundido entre o meio dos negócios a partir do anos 90 . Como a base da economia industrial passou da utilização de recursos naturais para recursos intelectuais, os executivos foram impulsionados a examinar como 0 conhecimento fundamentava seus negócios e como este conhecimento poderia ser utilizado como fonte de vantagem competitiva.

No campo da administração, Peter Drucker utilizou em 1959 o termo "trabalhador do conhecimento" pela primeira vez em seu livro "Fronteiras do Amanhã". Em 1981, Tom Davenport e Larry Prusak publicam "Conhecimento Empresarial", onde compartilham lições de prática de gestão do conhecimento em 50 empresas e fornecem aplicações práticas de gestão do conhecimento nas organizações. Em 1995, Ikujiro Nonaka e Hirotaka Takeuchi propuseram a teoria da criação do conhecimento organizacional em seu livro "Criação de conhecimento na empresa: Como as empresas japonesas geram a dinâmica da inovação". Ao mesmo tempo, o crescimento de redes de computador facilitou a codificação, armazenagem e compartilhamento de certos conhecimentos a um custo muito mais baixo do que antes (HANSEN; NOHRIA; TIERNEY; 1999).

Nesta época, segundo Maqsood; Walke; Finegan (2004), os sistemas de informação e a tecnologia estavam crescendo continuamente e a tecnologia vinha para solucionar todos os problemas complexos. Ao presumir que o conhecimento obtido de especialistas poderia ser facilmente codificado e replicado a outros indivíduos, surgiram diversas iniciativas, tais como inteligência artificial, para desenvolver diferentes sistemas computacionais especializados para tentar replicar 0 conhecimento humano. Na prática estas iniciativas se mostraram ineficientes, principalmente, devido à complexidade e dificuldade de utilização.

Posteriormente, com o avanço da TI (tecnologia da informação), a internet e a intranet supriram os especialistas de tecnologia com novas ferramentas que tornaram possível a captura, codificação, transferência e compartilhamento de 
conhecimento, mas também sem atingir os benefícios esperados. Estudos realizados sobre os fracassos da gestão do conhecimento neste período apontam que a gestão do conhecimento resulta $90 \%$ da atividade humana e $10 \%$ da tecnologia (EGBU, 2000 apud MASQSOOD; WALKE; FINEGAN, 2004).

Os esforços foram focados em codificar o conhecimento em documentos e aumentar o compartilhamento de conhecimento através da tecnologia sem a preocupação de direcionar ou definir qual conhecimento seria mais importante para a organização, qual conhecimento deveria ser codificado e compartilhado e quem deveria compartilhar com quem. As empresas preocupavam-se apenas com a quantidade acumulada de documentos em seu sistema e pouca atenção foi dada ao contexto em que estes documentos poderiam ter valor, de que forma poderiam ser encontrados e a relação entre os documentos. Os incentivos eram orientados para os indivíduos em uma situação específica. Não se reconhecia que o conhecimento poderia ser compartilhado e criado nas discussões de grupo para resolução de problemas e brainstorming de equipe (reflexão em grupo), e que seria importante encontrar formas de armazenar e compartilhar o conhecimento do grupo (PRUSAK; WEISS, 2007).

A gestão do conhecimento foi caracterizada pela abordagem de "one fits to all", onde as empresas buscavam experiência de outras empresas para implantar iniciativas de gestão do conhecimento, ignorando o contexto e a conexão entre a gestão do conhecimento e a estratégia e cultura organizacional (PRUSAK; WEISS, 2007).

A tendência atual de globalização e aumento da prestação de serviços baseados no conhecimento que permeia o mundo corporativo evidencia a importância da gestão do conhecimento nas empresas em todos os setores da economia. O sucesso de uma empresa do século XXI pode ser determinado pela eficiência com que seus líderes desenvolvem o capital intelectual por meio da criação contínua e compartilhamento do conhecimento, necessário para sustentar sua vantagem competitiva (ICHIJO; NONAKA; 2007).

\subsection{O conhecimento nas organizações}

O conhecimento é a capacidade de aplicar a informação a um trabalho específico que depende da capacidade intelectual e habilidade de um ser humano (DUCKER, 
1998 apud SANTIAGO, 2002). Santiago (2002) esclarece a distinção entre dados (sequência de números, palavras sob nenhum contexto específico); informação (dados organizados e situados em um contexto) e conhecimento (a informação organizada; está relacionado à ação).

Para Davenport; Prusak (1998) apud Santiago (2002), a vantagem competitiva de uma empresa está no que ela sabe coletivamente, na eficiência com que ela usa o que sabe e a prontidão com que ela adquire e usa novos conhecimentos. A experiência e o conhecimento adquirido pelas pessoas integram a memória da organização e são a base para a melhoria contínua.

O conhecimento pode ser interno à organização ou externo; mantido por um indivíduo ou compartilhado por um grupo de pessoas. Em 1995, Ikujiro Nonaka e Hirotaka Takeuchi apresentam um modelo de conversão do conhecimento baseado na distinção entre conhecimento tácito (saber subjetivo, baseado nas experiências pessoais e específicos ao contexto, guardado na cabeça das pessoas) e explícito (objetivo, personificado em documentos, relatórios, etc, transmissível em linguagem formal e sistemática).

O conceito da espiral do conhecimento, exemplificado na Figura 35, mostra que o conhecimento tácito deve ser articulado e então internalizado para tornar-se base de conhecimento de cada indivíduo da organização, começando novamente a espiral, ampliando a aplicação do conhecimento em outras áreas da organização (NONAKA; TAKEUCHI, 1997).

Os quatro processos para criação de conhecimento organizacional definidos por Nonaka, Takeuchi (1997) são: socialização (converter conhecimento tácito em tácito ${ }^{9}$, através de compartilhamento de experiências), externalização (converter conhecimento tácito em explícito, por meio de modelos, analogias), combinação

\footnotetext{
${ }^{9}$ Sabbag (2009) cita como exemplos de processos de conversão de conhecimento tácito em tácito e tácito em explícito: reuniões ao final da cada fase de projeto visando levantar, documentar e compartilhar as lições aprendidas; criação de comunidades de prática e desenvolvimento de redes sociais. Conversão de conhecimento explícito em explícito: as tarefas técnicas e gerenciais, documentos de projeto utilizados e desenvolvidos, tais como: elaboração de proposta, escopo de Projeto. Conversão de conhecimento explícito em tácito: consulta à base de dados de conhecimento para reutilizar as lições aprendidas nas tarefas técnicas e gerenciais.
} 
(converter conhecimento explícito em explícito, através de reuniões, memorandos, banco de dados, conversas telefônicas) e internalização (converter conhecimento explícito em tácito, através da incorporação das experiências adquiridas).

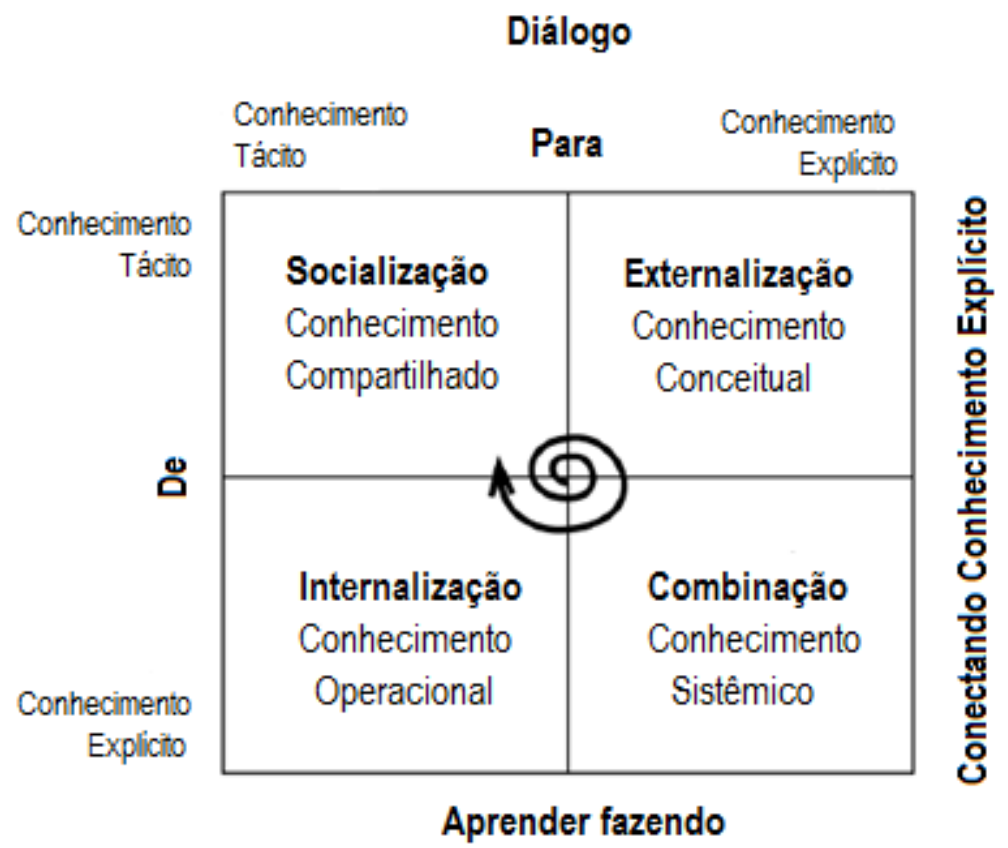

(Adaptado de Nonaka; Takeuchi, 1997)

Figura 35 - Espiral do conhecimento (NAKAMORI, 2003 apud LÊ, BRØNN, 2007)

Segundo Nonaka, Takeuchi (1997), a criação do conhecimento organizacional envolve cinco fases: o compartilhamento do conhecimento tácito (indivíduos compartilham conhecimento interno por toda a empresa); a criação de conceitos (conhecimento tácito compartilhado é convertido em explícito, na forma de um novo conceito, processo); a justificação dos conceitos (a empresa define se deve prosseguir em um novo conceito); a construção de um arquétipo (um novo conceito pode ser convertido um novo serviço, produto) e a difusão interativa do conhecimento compartilhado entre os membros da empresa e com componentes externos, como clientes, parceiros, universidades). Para propiciar a formação da espiral do conhecimento são necessárias cinco condições em nível organizacional: intenção; autonomia; flutuação e caos criativo; redundância e variedade de requisitos.

A gestão do conhecimento nas empresas caracteriza-se pela capacidade de uma empresa criar conhecimento como um ativo corporativo e entender a necessidade 
de administrá-lo e cercá-lo do mesmo cuidado dedicado à obtenção de outros ativos tangíveis (NONAKA; TAKEUCHI, 1997).

Para Malerba; Orsenigo (2000) apenas a distinção entre tácito e explícito não é suficiente do ponto de vista econômico. Nos processos de difusão e uso do conhecimento para gerar novo conhecimento, novos produtos, processos e serviços é importante ressaltar a interação entre o conhecimento tácito e explícito.

Entre as várias definições para gestão do conhecimento na literatura, Kamara et al. (2002) destacam a definição de Webb (1998) como a identificação, otimização e gestão de ativos intelectuais para criação de valor, aumento de produtividade e sustentação de vantagem competitiva. Envolve a captura, consolidação, disseminação e reuso do conhecimento na organização (KAZl et al. 1999 apud KAMARA et al., 2000).

A partir de dados da APQC - American Productivity \& Quality Center (Centro de Qualidade e Produtividade Norte-Americano), organização empenhada em identificar melhores práticas globais de empresas de todo porte e setores, O’Deal; Grayson (2000) compilaram as melhores práticas gerenciais e definiram a gestão do conhecimento como "uma estratégia consciente de obter o conhecimento certo das pessoas certas no momento certo e de ajudar as pessoas a compartilhar e colocar a informação em ação de um modo em que elas se empenhem em melhorar 0 desempenho da empresa.....eé uma estrutura, uma mentalidade gerencial que inclui usar as experiências passadas (bibliotecas, bancos de dados, as pessoas inteligentes) como base e criar veículos novos para a troca de conhecimentos (sites de intranets que viabilizem o conhecimento, comunidades de prática, redes)". Quando explicitamente administrado, o conhecimento organizacional é usado para realizar a missão da empresa.

Como o conhecimento tácito é altamente individualizado e é moldado dependendo do contexto do ambiente, os esforços concentrados em criar, identificar, coletar e organizar as melhores práticas ou o conhecimento não bastam para assegurar sua transmissão e uso. O processo de gestão do conhecimento deve concentrar-se em compartilhar e motivar os receptores para adaptar e aplicar essas práticas a situações novas, criando um novo conhecimento (O'DEAL; GRAYSON, 2000; CHAKRAVARTHY; MCEVILE, 2007). 
A transferência de conhecimento de Projeto para Projeto pode seguir duas rotas: direta (funcionários que detêm o conhecimento adquirido em um Projeto são alocados em outro Projeto) ou desviada (ocorre através de outros meios, tais como: repositórios de conhecimento, manuais da empresa, programas de treinamento, processos de trabalho e "cabeça dos funcionários"), conforme Figura 36. Dependendo da eficiência dos esforços de gestão do conhecimento, os meios adotados nas rotas desviadas podem funcionar como "buracos" onde há perda de conhecimento ou como mecanismos de criação de valor (JEON, 2009).

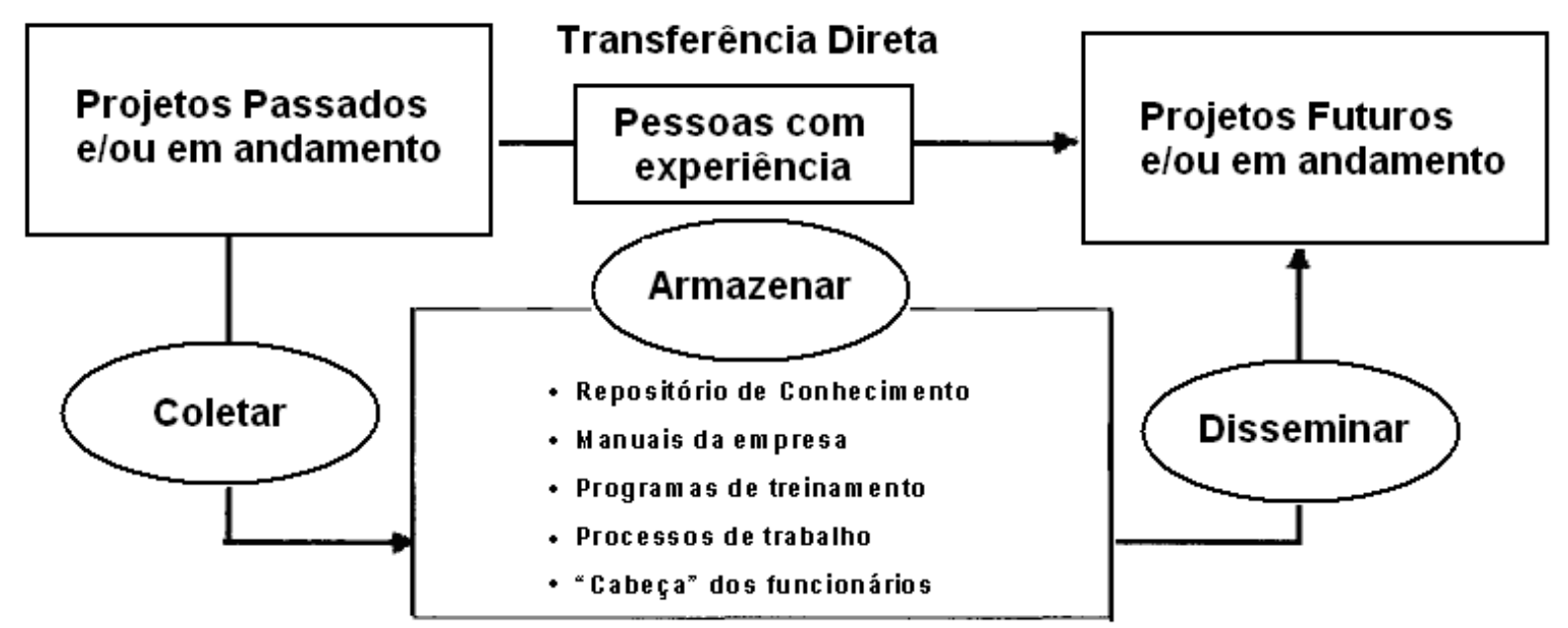

Transferência Desviada

Figura 36 - Duas rotas de transferência de conhecimento entre Projetos (adaptado de JEON, 2009)

A gestão do conhecimento deve prever mecanismos que possibilitem a transferência e compartilhamento de conhecimento tácito, como por exemplo, a criação de comunidades de prática e desenvolvimento de redes sociais. Estas comunidades de prática podem existir de maneira informal, através de fóruns ou discussões da internet onde especialistas podem trocar idéias e deixar seu conhecimento para ser utilizado e compartilhado por outras pessoas, ou formal por meio de conferências, seminários e workshops (LIEBOWITZ; MELGBOLUGBE, 2003 apud MASQSOOD; WALKE; FINEGAN, 2004; CHAKRAVARTHY; MCEVILE, 2007).

Quanto à natureza do conhecimento organizacional, Nakano; Fleury (2005) descrevem duas perspectivas: cognitiva e construtivista. 
Na perspectiva cognitiva, como mostra Figura 37, organizações são sistemas cuja finalidade é o processamento de informações e manipulação de símbolos, e a aprendizagem se dá pela obtenção de representações cada vez mais precisas da realidade, principalmente através de informações originadas de novas experiências (learning by doing = aprender fazendo) (LEVITT; MARCH, 1998). O conhecimento é visto como um insumo que depende do contexto e embora intangível e complexo, é passível de ser armazenado, combinado e reutilizado.
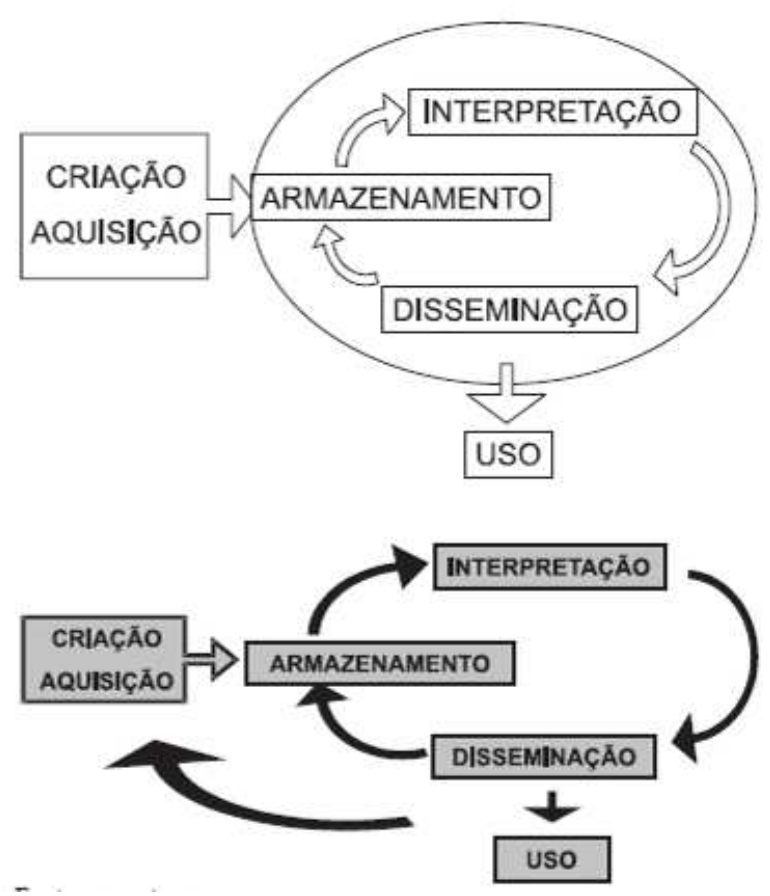

Figura 37 - Processos de aprendizagem e gestão do conhecimento das proposições de perspectiva cognitiva (NAKANO; FLEURY, 2005)

Os principais processos analisados por essas proposições são: criação (geração de novo conhecimento interno à organização) e aquisição (importar novo conhecimento de fontes externas); interpretação (processo de compreensão e atribuição de significado às informações adquiridas); armazenamento (estocagem e alimentação de novas informações, também chamado de memória organizacional) e disseminação (distribuição à toda organização). A disseminação tem papel fundamental na aprendizagem organizacional, pois as organizações não sabem o que sabem (HUBER, 1991), muitas vezes por falta de comunicação adequada ou "compartimentalização" decorrente de estrutura burocrática, onde são propostas formas alternativas de organização, tais como a Engenharia Simultânea, para solucionar o problema (KRUGLIANKAS, 1993 apud NAKANO; FLEURY, 2005). 
Nakano; Fleury (2005) apresentam outras formas de disseminação do conhecimento segundo diversos autores: processos de socialização de novos membros (LEVIT; MARCH, 1988), uso de procedimentos padronizados (MARCH; SIMON, 1958), práticas de $\mathrm{RH}$, treinamentos, rotações de funções (GARVIN, 1994; NONAKA; KONNO, 1998), grupos de discussão (O'DEAL; GRAYSON, 1998), força-tarefa para resolução de problemas específicos (NONAKA; KONNO, 1998), grupos de especialistas que oferecem suporte aos membros da organização (MOORE; BIRKINSHAW, 2000), listas de discussões eletrônicas (O'DEAL; GRAYSON, 1998; OLIVEIRA, 2000), e o uso de intranets e programas de comunicação (CHAIT, 1999; NONAKA; KONNO, 1998; OLIVEIRA, 2000).

Para facilitar a identificação do conhecimento existente e a organização das informações para posterior recuperação, Walsh; Ungson (1991) propuseram um modelo de memória organizacional como uma estrutra de repositórios onde diferentes formas de conhecimento são armazenadas e o conhecimento pode ser recuperado. O modelo é composto de cinco componentes intra-organizacionais: indivíduos (sua memória e habilidades); cultura (crenças, valores, símbolos, estórias); transformações (procedimentos e sistemas); ecologia (instalações e ergonomia) e uma fonte externa à organização: arquivos externos (clientes, concorrentes, grupos de indústrias, governo).

Conner; Prahalad (1996) entendem o conhecimento como uma possessão dos indivíduos, onde o estoque de conhecimento é composto de experiências, insights e habilidades adquiridos através da interpretação dos resultados das ações tomadas pela organização. Cohen; Levinthal (1990) definem o conhecimento como as habilidades, linguagem e informações que a organização adquire ao interagir com o ambiente (NAKANO; FLEURY, 2005).

Grant (1996) identifica a capacidade organizacional da empresa como resultado da integração do conhecimento especializado residente nos indivíduos para a produção de bens e serviços. Pesquisas anteriores sobre aprendizagem organizacional (LEVITT; MARCH, 1988) e visão da empresa baseadas no conhecimento (NONAKA, 1994), centralizavam-se na aquisição, onde a empresa tem papel de armazenar conhecimento do aprendizado de seus membros em seus procedimentos, normas, regras (MARCH, 1991) e criação do conhecimento. 
Na perspectiva construtivista (VON KROGH, 1998 apud NAKANO; FLEURY, 2005), conforme Quadro 11, o conhecimento é um processo de construção, resultado de interações entre o indivíduo e o meio que o circunda e entre indivíduos e o grupo. Depende das capacidades e características pessoais, do contexto e das formas de expressão escolhidas. As organizações são locais físicos onde acontecem as interações (NONAKA; KONNO, 1998 apud NAKANO; FLEURY, 2005). Ganha destaque a administração das pessoas, as interações e a comunicação interpessoal. Os principais processos abordados são a tradução do conhecimento tácito individual para explícito organizacional de forma a poder administrá-lo e a conversão do conhecimento organizacional em tácito individual, através de processos sociais.

\begin{tabular}{|c|c|c|c|}
\hline Processo & Crossan et al. (1999) & Hedlund (1994) & Nonaka e Takeuchi (1995) \\
\hline Aquisição de conhecimento & $\begin{array}{c}\text { Intuição (especificamente } \\
\text { conhecimento tácito individual) }\end{array}$ & Assimilação & Não discutido \\
\hline $\begin{array}{l}\text { Transferência de conhecimento } \\
\text { tácito entre individuos }\end{array}$ & Não discutido & Não discutido & Socialização \\
\hline $\begin{array}{l}\text { Tradução do conhecimento } \\
\text { tácito individual para explícito }\end{array}$ & Interpretação e Integração & Articulação & Externalização \\
\hline $\begin{array}{l}\text { Elaboração e construção de } \\
\text { novo conhecimento explícito }\end{array}$ & Integração & Não discutido & Combinação \\
\hline $\begin{array}{l}\text { Formalização do conhecimento } \\
\text { em procedimentos e rotinas }\end{array}$ & Institucionalização & Extensão & Combinação \\
\hline $\begin{array}{l}\text { Aquisição de novo } \\
\text { conhecimento tácito individual } \\
\text { a partir do explicito organizacional }\end{array}$ & Intuição & Internalização & Internalização \\
\hline Distribuição do conhecimento & $\begin{array}{l}\text { Implicitamente assumido no } \\
\text { processo de Institucionalização }\end{array}$ & Disseminação & $\begin{array}{l}\text { Implicitamente assumido no } \\
\text { processo de socialização }\end{array}$ \\
\hline
\end{tabular}

Quadro 11 - Proposições de perspectiva construtivista (NAKANO; FLEURY, 2005)

"Pouco importa qual a definição de gestão do conhecimento se não for posta em prática. $O$ conhecimento não significa nada se não for transformado em valor para 0 cliente." (BARTH, 2000 apud LÊ, BRØNN, 2007).

\subsection{Estratégias para implementação de gestão do conhecimento}

A formulação de uma estratégia de gestão do conhecimento envolve a verificação de diversos conceitos e fatores inter-relacionados (KAMARA et al., 2002). 
A estratégia adotada na gestão do conhecimento depende da análise dos conceitos de conteúdo (o que deve ser gerenciado; o que significa conhecimento para a organização) e do contexto, onde a prática da gestão do conhecimento deve refletir a experiência e intenções específicas de cada organização. Carrilo et al. (2004) alertam que antes de definir a estratégia de gestão do conhecimento, a empresa precisa entender porque a gestão do conhecimento é importante e quais são os benefícios percebidos de tal iniciativa. Com base nestas informações é possível definir uma estratégia e planejar iniciativas que resultem em benefícios para a empresa. Por exemplo, em uma organização que considera conhecimento como um sinônimo de informação, a estratégia da gestão do conhecimento terá como foco a gestão das informações. Nas organizações onde o conhecimento é o produto de um aprendizado, que é pessoal, o conhecimento está relacionado a dados processados e informação (KAMARA; ANUNBA; CARRILLO, 2004).

O fato da estratégia depender tanto do conteúdo quanto do contexto sugere que a tentativa de desenvolver uma única solução de gestão do conhecimento que se adapte a todas empresas provavelmente não terá sucesso (DIXON, 2000 apud KAMARA, 2002).

Para O'Deal; Grayson (2000), o conhecimento cria valor quando é posto em ação, mas para convertê-lo em valor as empresas precisam de enfoque: identificar qual é o problema ou processo estratégico que poderia ser sanado ou melhorado se o conhecimento sobre as melhores práticas fosse compartilhado e transmitido em sua organização. $O$ enfoque assegura que valiosos recursos sejam aplicados em áreas de alto retorno; ajuda a transmissão do conhecimento "certo" e atrai a atenção por parte da administração ao demonstrar resultados. As empresas deveriam alinhar a atividade de transmissão de conhecimento com a estratégia de vantagem competitiva, onde o enfoque deve ser flexível e mudar de acordo com os acontecimentos.

Compartilhar boas práticas entre diferentes regiões, funções e negócios da empresa pode contribuir para aumentar a rentabilidade ao reduzir ineficiência de retrabalhos e aumentando eficiência e eficácia. O'Deal; Grayson (2000) citam exemplos como a Toyota que articula seu programa de conhecimento entre suas subsidiárias ao redor do mundo promovendo a prática do kaizen (melhoria contínua) de forma que todas unidades produzam o produto com a mesma qualidade, e a GE, onde as melhores 
práticas são compartilhadas em seus mecanismos operacionais (reunião global de lideranças, reuniões gerenciais e executivas) incentivando os profissionais a contribuir com idéias para melhoria das operações.

As diferentes estratégias podem ser atribuídas à distinção entre conhecimento tácito e explícito de Nonaka e Takeuchi (1995) e as diversas classificações são baseadas no foco em $\mathrm{TI}$ ou nas pessoas. O conhecimento explícito é aquele que pode ser documentado e fisicamente guardado em formato eletrônico ou papel que conduz a uma estratégia mais focada em TI. Para a indústria da construção inclui: procedimentos operacionais padrão, guia de melhores práticas, etc. O conhecimento tácito é muito mais difícil de documentar, pois é aquele guardado na cabeça das pessoas e adquirido com a experiência. Portanto, é melhor compartilhado utilizando canais de comunicação tais como: contato face a face, comunidades de prática, lições aprendidas, etc, e tende a uma estratégia de gestão com foco nas pessoas. $\mathrm{Na}$ construção seria a experiência dos membros da equipe do projeto. A transferência de experiências, visto como um processo de externalização, é uma fonte única de conhecimento tácito para os envolvidos em cada obra, tanto da equipe de gestão, projetos quanto a equipe de obra (TIWANA, 2000 apud CARRILLO; CHINOWSKY, 2006; CHAKRAVARTHY; MCEVILE, 2007).

Hansen; Nohria; Tierney (1999) pesquisaram empresas de consultoria, que foram as primeiras a investir em gestão do conhecimento e explorar a utilização de TI para capturar e disseminar conhecimento, e constataram que eram empregadas duas estratégias de gestão do conhecimento:

- Estratégia da codificação: estratégia focada na informática, onde o conhecimento é cuidadosamente codificado e armazenado em banco de dados como repositórios do conhecimento organizacional, podendo ser acessado e utilizado facilmente por qualquer pessoa da empresa.

- Estratégia da personalização: o conhecimento organizacional está intimamente associado à pessoa que o desenvolveu e é compartilhado através de contatos pessoais. A informática é utilizada como meio de comunicação do conhecimento, não de armazenamento. A transferência de experiência é um tipo de aprendizado organizacional que é influenciado por 
fatores técnicos e sociais, mas é sensível a condições informais da organização.

Stahle (1999) apud Kamara et al. (2002) sugere que toda organização é um sistema tridimensional com uma natureza mecânica, orgânica e dinâmica, cada qual apresentando diferentes desafios para a gestão do conhecimento. A natureza mecânica lida mais com o conhecimento explícito, o que envolve sistemas de qualidade, manuais e ferramentas de TI. A natureza orgânica é centrada nas pessoas e envolve mais a gestão de conhecimento tácito o que permite à empresa a trabalhar com flexibilidade adaptando-se às mudanças do ambiente que inclui estratégias, tais como narrativa e comunidades de prática. A natureza dinâmica foca mais na capacidade de relacionamento para facilitar 0 trabalho das equipes interdepartamentais o que facilita a melhoria contínua e inovação.

Scarbrought et al. (1999) apud Kamara et al. (2002) identificam duas abordagens básicas para gestão do conhecimento que classificam como:

- Iniciativas dirigidas pelo fornecimento: onde o problema fundamental da gestão do conhecimento concentra-se no fluxo da informação e conhecimento na organização.

- Iniciativas dirigidas pela demanda: onde a abordagem é focada na perspectiva do usuário e sua motivação e atitude. Esta categoria geralmente inclui sistemas de remuneração e formas de incentivo para compartilhamento de conhecimento.

Segundo Carrillo; Chinowsky (2006), as organizações têm adotado duas estratégias diferentes para implementação da gestão do conhecimento:

- Estratégia voltada ao uso de ferramentas de TI para facilitar a captura, acesso e reuso da informação e do conhecimento (EARL, 2001; O'LEARY, 2001 apud CARRILLO; CHINOWSKY, 2006). Utilizam banco de dados eletrônicos tais como projetos extranet e ferramentas colaborativas para facilitar 0 compartilhamento do conhecimento.

- Estratégia de gestão de recursos humanos focada no estabelecimento de meios para motivar e facilitar os trabalhadores do conhecimento a desenvolver, acrescentar e utilizar seu conhecimento para atingir as metas da 
organização (BEIJERSE, 1999; HAMAN; BRELADE, 2000 apud CARRILLO; CHINOWSKY, 2006). Ela fomenta uma organização de aprendizado, criação de redes de relacionamento, identificação e disseminação lições aprendidas de Projetos anteriores, etc.

A escolha da estratégia para gestão do conhecimento impacta na habilidade de aprendizagem da organização. (LÊ, BRøNN, 2007).

O resultado de pesquisa realizada por Mertins, Heisig, Vorbeck (2003) em 2000, com 148 empresas na Alemanha e dez estudos de caso, quando foram identificadas as atividades mais importantes dos processos essenciais da gestão do conhecimento, descritas no Quadro 12, provou que para o sucesso das iniciativas de gestão do conhecimento deve existir uma combinação e equilíbrio entre métodos e ferramentas baseados nas pessoas e em TI. Foram identificadas quatro atividades essenciais (aplicar, distribuir, gerar, armazenar) e a pesquisa questionou aos entrevistados como era seu grau de domínio (de $5=$ excelente a 1 =muito pobre) dos quarenta métodos de gestão do conhecimento levantados pelos pesquisadores. $O$ resultado destacou as atividades: distribuição do conhecimento através da intranet $(61,8 \%)$, compartilhamento interno através de equipes multidisciplinares $(60,8 \%)$, publicações e jornais internos $(54,3 \%)$ e treinamento e orientação por especialistas sêniores $(51,2 \%)$.

\begin{tabular}{|c|c|}
\hline Processo principal da gestão & o conhecimento \\
\hline $\begin{array}{l}\text { Familiaridade com métodos } \\
\text { para identificação de } \\
\text { conhecimento relevante }\end{array}$ & $\begin{array}{l}\text { 1. Produção de manuais }(56,0 \%) \\
\text { 2. Benchmarking interno e externo }(55,6 \%) \\
\text { 3. Agenciamento do conhecimento, especialistas sêniores } \\
(47,1 \%)\end{array}$ \\
\hline $\begin{array}{l}\text { Categoria de objetivos típicos } \\
\text { de conhecimento }(n=61)\end{array}$ & $\begin{array}{l}\text { 1. Melhoria de processo }(18,5 \%) \\
\text { 2. Transparência de áreas em potencial }(15,1 \%) \\
\text { 3. Transparência de condições }(12,3 \%)\end{array}$ \\
\hline $\begin{array}{l}\text { Familiaridade com métodos } \\
\text { para geração de } \\
\text { conhecimento }\end{array}$ & $\begin{array}{l}\text { 1. Equipe de projetos interdisciplinar com especialistas internos } \\
(66,9 \%) \\
\text { 2. Equipes de projeto com especialistas externos }(53,6 \%) \\
\text { 3. Acesso sistemático para edição de conhecimento e } \\
\text { experiências, por exemplo, acesso à “lições aprendidas" }(51,6 \%) \\
\text { 4. Aquisição de (novo) conhecimento externo }(50,0 \%)\end{array}$ \\
\hline $\begin{array}{l}\text { Familiaridade com métodos } \\
\text { para armazenamento de }\end{array}$ & $\begin{array}{l}\text { 1. Base de dados com informações sobre objetos do } \\
\text { conhecimento }(62,3 \%)\end{array}$ \\
\hline
\end{tabular}




\begin{tabular}{|l|l|}
\hline conhecimento & $\begin{array}{l}\text { 2. Manuais de padrões e métodos já aplicados (59,1\%) } \\
\text { 3. Estudos de caso, relatórios, estórias de sucesso (47,2\%) }\end{array}$ \\
\hline $\begin{array}{l}\text { Familiaridade com métodos } \\
\text { para distribuição de } \\
\text { conhecimento }\end{array}$ & $\begin{array}{l}\text { 1. Intranet (acesso à base de dados, novos grupos) (61,8\%) } \\
\text { 2. Equipes de projeto interdisciplinar para compartilhamento } \\
\text { interno }(60,8 \%) \\
\text { 3. Publicações internas, jornais internos (54,3\%) } \\
\text { 4. Treinamento e orientação por especialistas senior (51,2\%) }\end{array}$ \\
\hline $\begin{array}{l}\text { Familiaridade com métodos } \\
\text { para promover a aplicação do do } \\
\text { conhecimento }\end{array}$ & $\begin{array}{l}\text { 1. Equipes interdisciplinares autônomas (56,6\%) } \\
\text { 2. Treinamento de equipes por especialistas sênior (48,0\%) } \\
\text { Obtenção de opinião de especialistas internos sobre } \\
\text { resultados (30,9\%) }\end{array}$ \\
\hline
\end{tabular}

Quadro 12 - Resultados da pesquisa sobre principais atividades da gestão do conhecimento (adaptado de MERTINS; HEISIG; VORBECK, 2003)

Como o conhecimento é criado através a interação dinâmica entre os envolvidos, uma empresa que cria conhecimento requer um forte comprometimento de todos membros da organização, não apenas da alta direção. O planejamento e implementação da gestão do conhecimento devem estar integrados, e não separados em diversos planos estratégicos específicos de cada departamento. A liderança assume vários papéis, tais como: desenvolver e promover as habilidades para troca de conhecimento; possibilitar e promover a contínua criação da espiral do conhecimento (CHAKRAVARTHY; MCEVILE, 2007).

Para Prusak; Weiss (2007) a ligação entre decisões estratégicas e atividades de gestão do conhecimento está cada vez mais reforçada. Algumas empresas estão focadas em como as atividades de gestão do conhecimento podem auxiliar sua estratégia, procurando aprender com o sucesso e fracasso de outras empresas, e não apenas copiando soluções sem a adaptação necessária à sua realidade, como ocorreu nas primeiras iniciativas frustadas de gestão do conhecimento. Paralelamente, cresce a consciência da necessidade da empresa compartilhar o conhecimento, não apenas internamente, mas com parceiros.

\subsubsection{Fatores interdisciplinares que impactam a gestão do conhecimento} Independente da estratégia selecionada pela empresa, existem vários fatores interdisciplinares que impactam a gestão do conhecimento, tais como cultura 
organizacional (que pode ser definida em termos de processos de trabalho, como cultura colaborativa $\mathrm{x}$ competitiva, informal $\mathrm{x}$ formal, individual $\mathrm{x}$ grupo), $\mathrm{O}$ aprendizado organizacional, e os sistemas e tecnologias disponíveis, conforme indicado na Figura 38 (JASHAPARA, 2004 apud CARRILO; CHINOWSKY, 2006), além do tipo de cliente, aspectos econômicos do negócio, a estrutura organizacional da empresa, as pessoas envolvidas (HANSEN; NOHRIA; TIERNEY, 1999).

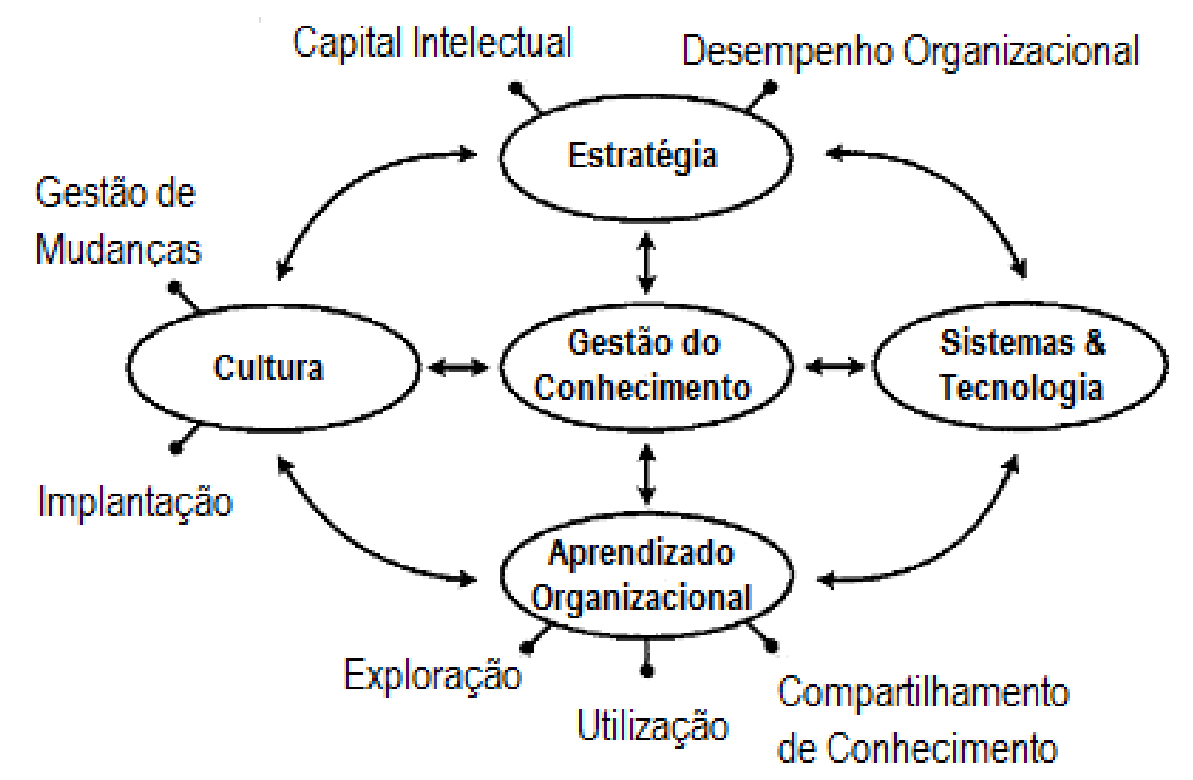

Figura 38 - Dimensões da gestão do conhecimento (adaptado de JASHAPARA, 2004 apud CARRILO; CHINOWSKY, 2006)

\section{Cultura organizacional}

A cultura organizacional influencia o comportamento dos indivíduos e dos grupos presentes na organização, assim como todos outros aspectos: estrutura, infraestrutura, estratégia, processos, programas de desenvolvimento, de melhoria contínua, sistemas de controle e de comunicação (SANTOS, 2004).

Robins (2007) refere-se à cultura organizacional como um sistema de valores compartilhado pelos membros que diferencia uma organização das demais, ou seja, à maneira pela qual os funcionários percebem as características da cultura da empresa. Quanto mais membros aceitarem os valores essenciais da organização e quanto maior seu comprometimento com eles, mais forte será a cultura, criando-se um clima de alto controle comportamental dos funcionários, assegurando que todos 
caminhem na mesma direção. Os funcionários formam uma percepção geral subjetiva da organização com base em fatores como o grau de tolerância a riscos, a ênfase nas equipes e o apoio às pessoas, na qual as percepções favoráveis ou desfavoráveis podem afetar o desempenho e a satisfação dos funcionários.

A gestão da informação foca nos processos e na tecnologia, enquanto os pilares da gestão do conhecimento são as pessoas e sua habilidade em colaborar coletivamente de forma rápida e eficaz. A ponte de ligação entre os dois está baseada em uma cultura comprometida com o compartilhamento de conhecimento (AMIN et al., 2001 apud LÊ, BRøNN, 2007), como mostra a Figura 39.

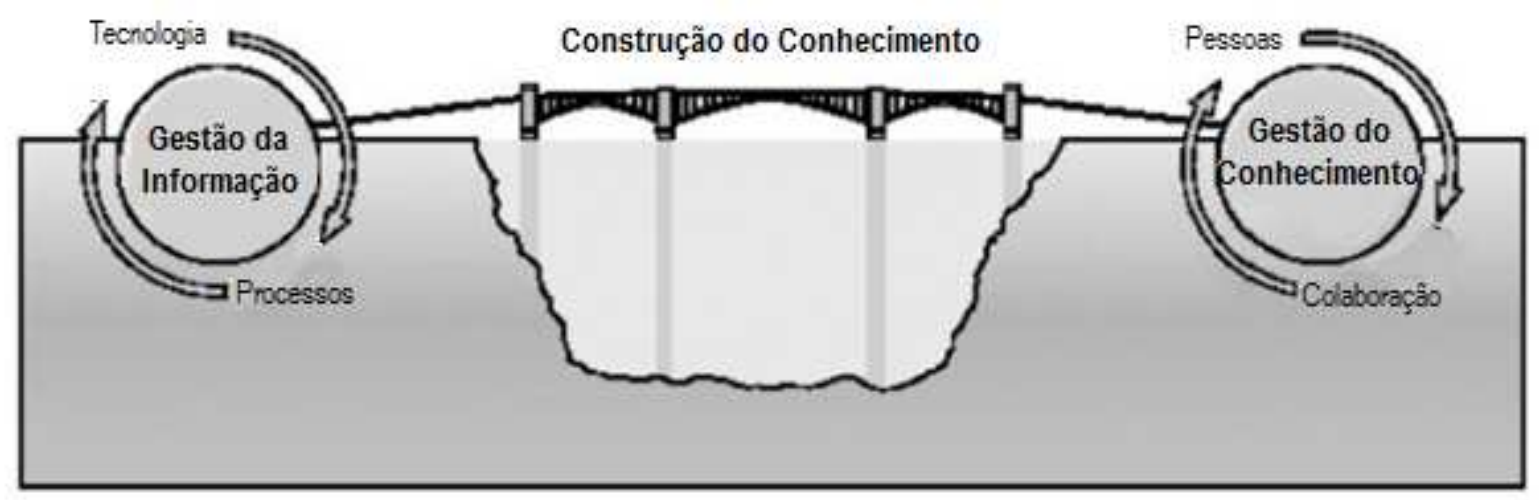

Figura 39 - Ponte da gestão do conhecimento (adaptado de AMIN et al., 2001 apud LÊ, BRØNN, 2007)

O resultado da pesquisa de Mertins, Heisig, Vorbeck (2003) indicou, além da cultura organizacional, a liderança como principal fator para o sucesso da implementação de soluções de gestão do conhecimento, seguidos de uma definição clara de metas da gestão, existência de estruturas e processos e a TI. Quando a gestão do conhecimento é aplicada às condições existentes na organização (instrumentos e métodos existentes), há uma melhor aceitação por parte dos funcionários, e para o sucesso na implementação "quanto mais simples melhor". 


\section{Estrutura organizacional}

O funcionamento das estruturas definidas para cada organização tem relação direta com a cultura organizacional, além de outros fatores condicionantes: objetivos e estratégias; ambiente; tamanho da organização; tecnologia (meios pelos quais a empresa transforma seus recursos financeiros, humanos e físicos em produtos e serviços); recursos humanos (OLIVEIRA, 1994; VIVANCOS; CARDOSO, 2001; CHIAVENATO 2004; ROBBINS, 2007).

A estrutura organizacional define como as tarefas são formalmente distribuídas, agrupadas e coordenadas. Robbins (2007) identifica seis elementos base para seu adequado planejamento: a especialização (descreve o grau em que as tarefas dentro da organização são subdivididas em funções isoladas); a cadeia de comando (equivalente à hierarquia e distribuição da autoridade e da responsabilidade); a amplitude de controle (relacionada à determinação do tamanho apropriado do grupo que um superior pode dirigir sem perder a eficiência); a centralização ou descentralização; a departamentalização e a formalização.

Os principais tipos de departamentalização são: funcional (consiste no agrupamento das atividades e tarefas de acordo com as funções principais desenvolvidas dentro da empresa), geográfica ou territorial, por produtos ou serviços, por fases do processo de produção, por clientes, por Projetos (cada Projeto é um "departamento temporário" cujo lider é o gerente de Projeto), matricial (utilização simultânea de dois ou mais tipos de departamentalização sobre o mesmo grupo de pessoas, com a existência de dupla ou múltipla subordinação). Podem ser classificadas como: fraca (onde o poder é do gerente funcional e o gerente de Projetos atua como facilitador ou coordenador); balanceada ou equilibrada (onde o poder é compartilhado entre 0 gerente funcional e de Projetos); forte (onde o poder é do gerente de Projetos); por centros de custo; celular (forma organizacional que tem como características a quase total ausência de estrutura e alta flexibilidade, em que a informalidade é muito elevada); mista (onde cada parte da empresa tem a estrutura que mais se adapta à sua realidade organizacional) (OLIVEIRA, 1994; VIVANCOS; CARDOSO, 2001; CHIAVENATO 2004; ROBBINS, 2007).

O termo centralização refere-se ao grau em que o processo decisório está concentrado em um único ponto da organização (alta administração). Uma estrutura 
na qual o poder fica disperso entre muitas pessoas pode ser tratada como descentralizada (ROBBINS, 2007).

A formalização se refere ao grau em que as tarefas dentro da organização são padronizadas. Em organizações altamente formalizadas existem definições explicitas de cada tarefa, procedimentos claramente definidos sobre os processos de trabalho. Ao passo que em organizações com baixa formalização, os comportamentos são não-programados e os funcionários tem uma boa dose de liberdade para decidir sobre o trabalho. O grau de formalização também pode variar dentro da própria empresa, em empresas de construção a área comercial tem um baixo grau de formalidade enquanto o departamento de contabilidade deve seguir os procedimentos ditados pela administração (ROBBINS, 2007).

\section{Aprendizagem Organizacional}

Com base na literatura das três correntes de pesquisa relacionadas ao conhecimento organizacional: Aprendizagem Organizacional (Organizational Learning), Visão da Empresa Baseada no Conhecimento e Gestão do Conhecimento, Nakano; Fleury (2005) destacam que na Aprendizagem Organizacional o conhecimento é identificado como um estado ou propriedade de uma organização e o resultado de um processo de aprendizagem, com maior ênfase no processo do que no conhecimento. Na década de 90, com a emergência da Visão da Empresa Baseada no Conhecimento e Gestão do Conhecimento esta posição foi criticada, com a visão de que as organizações "sabem" e não apenas aprendem.

Huber (1991) considera os processos de: aquisição; distribuição; interpretação e memória organizacional integralmente ligados à Aprendizagem Organizacional. Para Weis (1991) apud Malhotra (1996), o aprendizado individual ocorre quando as pessoas dão diferentes respostas ao mesmo estímulo, mas a Aprendizagem Organizacional ocorre quando um grupo de pessoas dá a mesma resposta a estímulos diferentes.

Senge (1991) apud Malhotra (1996), define as Organizações que Aprendem (Learning Organization) como um grupo de pessoas que aumenta continuamente 
sua habilidade de criar o que elas querem criar; o aprendizado deve ser organizado e contínuo, envolvendo todos os membros da organização e não apenas alguns deles. Em um ambiente de grandes mudanças, complexidade e incertezas, a velocidade com que a organização aprende pode ser seu recurso sustentável de vantagem competitiva.

A capacidade de absorção refere-se à habilidade da organização em reconhecer novos valores, informações externas, assimilá-los e e aplicá-los para garantir sua vantagem competitiva. Esta capacidade está relacionada à capacidade do ser humano absorver conhecimento em função de experiência e aprendizado passados, que devido à familiaridade com o assunto propicia maior agilidade nas mudanças (COHEN; LEVINTHAL, 1990).

No caso dos Projetos temporários da construção, a alta capacidade de absorção do cliente/ proprietário do projeto pode ser um facilitador da transferência de conhecimento de um Projeto para outro. Ao identificar o valor de um novo conhecimento criado no Projeto, este pode ser difundido entre as organizações participantes e para outros Projetos. Aliado à capacidade de absorção do cliente/ proprietário, a comunicação tem um papel fundamental para o sucesso da transferência do conhecimento do Projeto (BAKKER et al., 2011).

Devido à complexidade dos Projetos e participação de diversas equipes multidisciplinares, o efeito de uma intervenção em qualquer elemento dos processos do ciclo de vida do empreendimento, não pode ser gerenciada de forma isolada, pois poderá ter consequências em outros elementos do processo, impactando no sucesso da transferência e gestão do conhecimento (BAKKER et al., 2011).

\subsubsection{Atividades dos processos de gestão do conhecimento}

Segundo Mertins, Heisig, Vorbeck (2003), as diversas abordagens sobre gestão do conhecimento enfatizam diferentes atividades, onde o número de atividades varia basicamente de três a oito: identificação, aquisição, desenvolvimento, compartilhamento/ disseminação, utilização, retenção e avaliação, metas do conhecimento, conforme Figura 40 (PROBST et al., 1998). 


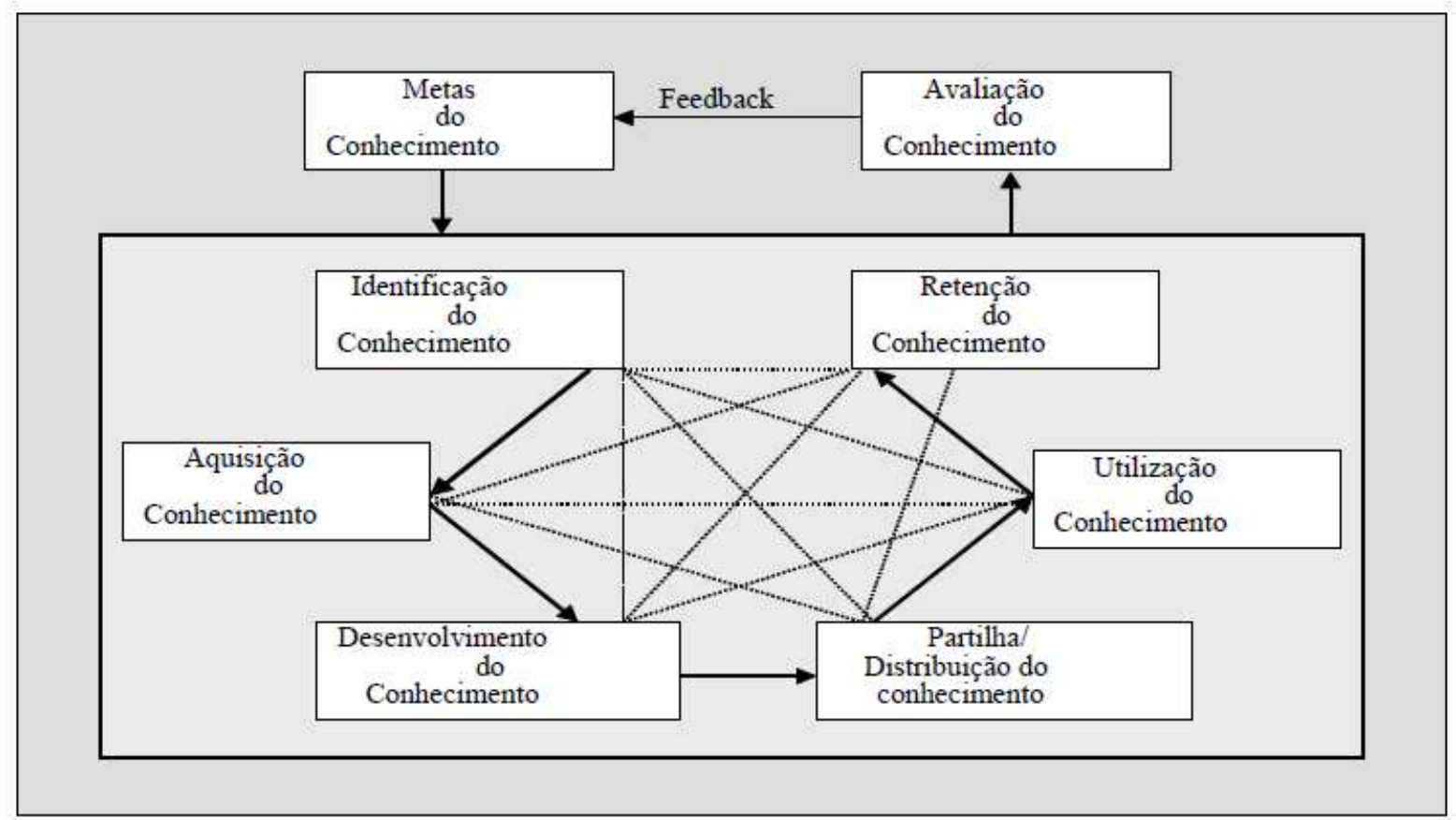

Figura 40 - Processos essenciais da gestão do conhecimento (PROBST; RAUB; ROMHARDT, 2002 apud MATOS et al., 2008)

Mertins, Heisig, Vorbeck (2003) apud Santos; Neto (2008), desenvolveram um modelo de gestão do conhecimento estabelecendo três níveis propostos de ação, conforme Figura 41:

1. A gestão do conhecimento deve ser focada permanentemente em valor adicionado aos processo de negócio (estes definem o campo ou domínios do conhecimento).

2. Os processos essenciais de gestão do conhecimento, divididos em quatro grupos de atividades: criação de novos conhecimentos, armazenamento dos conhecimentos, distribuição (transferência) e aplicação do conhecimento.

3. Áreas ou campos definidos para a gestão do conhecimento, derivados dos fatores críticos de sucesso identificados em sua pesquisa: cultura organizacional, lideranças, recursos humanos, TI, organização e normas, e sistemas de controle (pré-requisto para mensurar os resultados obtidos com as atividades de gestão do conhecimento) . 


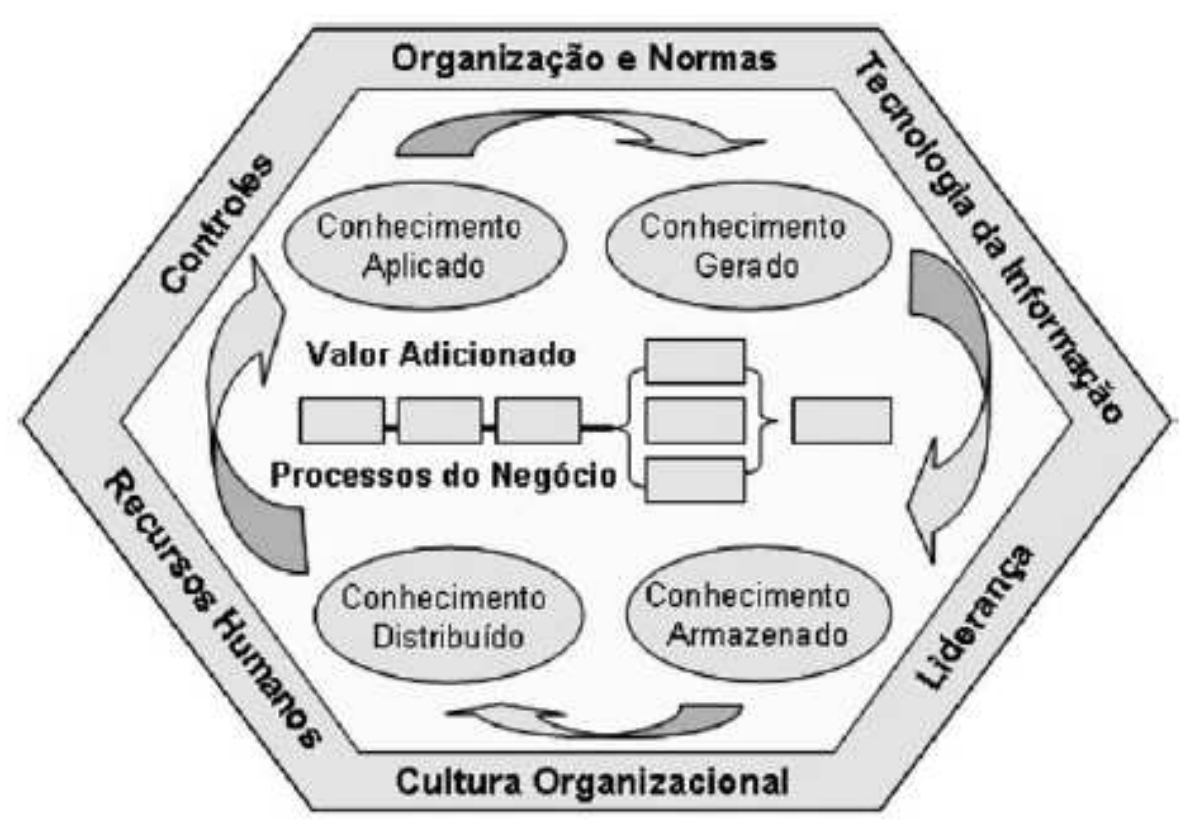

Figura 41 - Áreas definidas para a gestão do conhecimento (MERTINS; HEISIG; VORBECK, 2003 apud SANTOS; NETO, 2008)

Para Prusak (2008) trabalhar com conhecimento envolve quatro atividades distintas: busca pelo conhecimento, negociar com os recursos que detém o conhecimento, adaptar e adotar novo conhecimento e distribuir o conhecimento. Todas estas atividades humanas tomam tempo e atenção. A busca pelo conhecimento pode utilizar recursos de $\mathrm{TI}$, tais como sites de busca, para localizar quem sabe o que se busca e como contatá-lo. Adquirir o conhecimento requer o consentimento e envolvimento de quem detem o conhecimento, pois depende de uma explicação, esclarecimento, questionamento e, muitas vezes, efetivamente trabalhar junto. Adaptar e adotar o novo conhecimento pode exigir tempo para registrar ou adaptar uma experiência à uma necessidade diferente, o que envolve desenvolver novas idéias. Transferir o conhecimento não é uma proposta simples com a enorme quantidade de informação que circula no mundo atual, pois o conhecimento é local, contextual e "stick" (pegajoso), o que requer esforço para ser transferido de um local para outro.

Graças às novas tecnologias, tais como e-learning (aprendizado por meio eletrônico), inúmeras informações são instantaneamente acessadas, no entanto o tempo e trabalho para assimilar o conhecimento continua o mesmo (como aprender francês ou graduar-se em filosofia). Nenhuma técnica ou tecnologia pode reduzir o tempo de aprendizagem sem reduzir a qualidade do aprendizado (PRUSAK, 2009). 


\subsubsection{Ferramentas e aplicações de gestão do conhecimento}

Diversas empresas reconhecem que para implementação da gestão do conhecimento são necessárias ferramentas para sua utilização. Carrilo et al. (2004) argumentam que nem toda ferramenta precisa ser uma ferramenta de TI (que utilize o computador). As empresas deveriam inicialmente identificar os problemas específicos de gestão do conhecimento e então determinar as ferramentas mais apropriadas (ferramentas baseadas na utilização de computador ou não).

Egbu (2004) utiliza o termo "técnicas de gestão do conhecimento" para ferramentas de gestão do conhecimento não baseadas em TI, implantadas nas organizações com diferentes abordagens, e "tecnologias de gestão do conhecimento" para ferramentas baseadas em $\mathrm{Tl}$, que consiste na combinação de tecnologia de equipamento e programa. $O$ processo de seleção da ferramenta de gestão de conhecimento mais adequado é influenciado por diversos fatores. Al-Ghassani apud Egbu (2004) identifica três dimensões críticas para seleção da ferramenta de gestão de conhecimento no setor da construção: o tipo de conhecimento para conversão (entre tácito e explicito), as formas de propriedade do conhecimento (pessoal e compartilhada) e domínio de transferência de conhecimento (entre interna e externa).

O'Dell; Grayson (2000) alertam que deve haver uma combinação dos tipos e necessidades de conhecimento com as aplicações de $\mathrm{TI}$, pois as tecnologias de $\mathrm{TI}$ são facilitadoras (Extranet, Intranet), mas não são uma solução em si mesmas. O conhecimento explícito pode ser compartilhado por meio de máquinas, mas o tácito, mais valioso, que é mais difundido por pessoas, requer uma tecnologia menos sofisticada para sustentá-lo.

A empresa precisa de uma arquitetura padronizada de âmbito empresarial para assegurar a sustentabilidade e a evolução dos esforços da gestão do conhecimento, evitando a proliferação de sistemas separados, específicos por departamento que ocasionarão problemas futuros de integração.

As características ideais de um sistema de gestão do conhecimento listadas pelo Laboratório Internacional Buckman baseados em sua experiência de dez anos são: reduza para um o número de passos na transmissão entre funcionários para reduzir possíveis distorções de conhecimento; permita que todos os funcionários tenham acesso ao sistema e façam suas contribuições em seus idiomas nativos; deixe o 
sistema disponível o tempo todo; utilize um sistema fácil de operar e que possa realizar buscas por qualquer palavra; providencie um sistema que execute atualizações automáticas à medida que a informação é inserida (O'DELL; GRAYSON, 2000).

O'Dell; Grayson (2000) dividem as aplicações de TI usadas para favorecer a transmissão de conhecimento em duas classes, com ferramentas específicas para a aplicação, sendo que o primeiro grupo reflete o enfoque e prática do mercado:

1. Transmissão e troca de conhecimento

- Repositórios estruturados de documentos (ex: bancos de dados de melhores práticas, de informações sobre clientes; bibliotecas eletrônicas que retêm e organizam as mensagens trocadas no correio eletrônico através de encadeamentos ou por assunto de maneira que possam ser pesquisados/ encontrados no futuro);

- Bancos de dados de discussão (o banco de dados é organizado de acordo com grupos de discussão das equipes de projeto ou de trabalho ou redes de conhecimento, definidas como comunidades de prática);

- Indicadores para especialistas (contem uma lista do tipo páginas amarelas de especialistas internos, gerentes de projeto ou outras partes interessadas. A enfase é na comunicação humana);

- Infra-estrutura de vídeo e intercâmbio de documentos (correio eletrônico, vídeo conferências).

2. Análise de dados e suporte ao desempenho

- Sistemas de suporte ao desempenho (usado em tempo real para apoiar o desempenho profissional e a aprendizagem do funcionário. Ex: centrais de atendimento telefônico);

- Sistemas de solução de problemas (usa o conhecimento estruturado em casos e cenários prováveis. Ex: suporte ao cliente);

- Sistemas de conversão de dados em conhecimento (têm como base redes neurais ou outros algoritmos inteligentes estatisticamente 
orientados. Ex. grupos de marketing): exploração de dados; suporte à decisão; análise de dados inteligentes em tempo real.

Hoje a maioria das empresas já dispõe de intranets corporativas e tecnologias baseadas em rede. O'Dell; Grayson (2000) apontam como desafio a decisão de como as aplicações de gestão do conhecimento baseadas em intranet serão usadas e mantidas. São apresentadas como diretrizes para ajudar que as soluções de gestão do conhecimento baseadas na intranet alcancem seu propósito: definir os objetivos; determinar se a tecnologia atual pode ser adaptada ou comprada pronta; avaliar se a capacidade da infra-estrutura física atual para lidar com o tipo e volume do tráfego na intranet; identificar os requisitos de suporte interno para manutenção do sistema; escolher uma localização central para o site da internet, a partir do qual pode-se navegar para outra área; buscar facilidade no uso praticamente dispensando treinamento em termos de tecnologia; facilitar o acesso e uso universais; considerar os custos iniciais, incluindo redes e programas, bem como custos secundários (treinamentos, banda larga aumentada, perda de produtividade por excesso de ferramentas para criação de conteúdo).

Muitas empresas combinam a intranet com ferramentas colaborativas, como o groupware (programa colaborativo), voltadas para a comunicação entre indivíduos, grupos, projetos ou de âmbito empresarial (ex. Lotus Notes, ferramenta de correio eletrônico e troca de conhecimento); páginas amarelas, com dados on-line com lista de pessoas e respectivo conhecimento de seu domínio; repositório de conhecimento, coletânea de conhecimento explícito da organização em formato de documentos, relatórios técnicos, etc (SANTIAGO, 2002).

Pesquisa realizada com empresas de engenharia e construtoras de médio e grande porte no Reino Unido (Carrilo et al., 2004) mostrou que 38\% das empresas utilizavam seminários e conferências como primeiro meio de compartilhar conhecimento. 1/3 das empresas utilizavam comunidades de prática ou rede de relacionamentos técnicos e 1/4 utilizavam brainstorming (reflexão em grupo). 21\% utilizavam pesquisa colaborativa e o restante utilizava sistemas de job rotation e job observation (rotação e observação do trabalho).

73,6\% identificaram a intranet como sua principal ferramenta de suporte à gestão do conhecimento. Extranets foram identificadas apenas em alguns casos limitados. Outras ferramentas de TI identificadas: 
- Sistemas de banco de dados $(62,3 \%)$

- Sistemas de gestão de documentos $(37,7 \%)$

- Fóruns eletrônicos de discussão (15,1\%)

Carrilo et al. (2004) levantam as possíveis razões para a alta utilização da intranet: 1‥ As grandes empresas têm uma quantidade considerável de conhecimento para gerenciar e a intranet é uma ferramenta útil para gerenciar conhecimento explícito; 2 . Alguns tipos de conhecimento requerem um alto grau de segurança e a intranet dispõe de sistemas de proteção para evitar acessos não autorizados; 3‥ A intranet facilita a comunicação à medida que a organização aumenta de tamanho e dispersão geográfica; $4^{\circ}$. As empresas grandes tem recursos para implementar e manter a intranet. No entanto, alertam que estas ferramentas gerenciam 0 conhecimento explícito, mas não são preparadas para solucionar as dificuldades associadas à gestão do conhecimento tácito.

Segundo Prusak; Weiss (2007) apesar da maioria das empresas ainda armazenar documentos de forma isolada, sem agregar maior significado a eles, uma forma simplificada do que está sendo empregado pelas empresas para superar algumas imperfeições dos esforços atuais para gestão do conhecimento é a utilização de videos, audios e textos adicionais nas apresentações de Power Point. Para facilitar a aplicação do conhecimento tem aumentado o foco das empresas nos grupos e comunidades de práticas. Por exemplo, no programa SharePoint, os grupos que trabalham juntos desenvolvem documentos que podem ser compartilhados facilitando aos envolvidos a aplicar o que aprenderam e a compartilhar novas experiências com o grupo, o que pode trazer maior produtividade ao grupo.

Os portais corporativos disponibilizam informações estruturadas em dois espaços de acesso: público, disponível a todos usuários da internet com informações sobre a organização, links externos, etc e restrito (intranet), permitido aos funcionários e a alguns fornecedores, onde são disponibilizadas páginas pessoais; grupos de trabalho ou projetos específicos; ferramentas para colaboração, tais como email e fóruns, documentos, catálogos, manuais e demais documentos da organização. Estes portais constituem um poderoso espaço interativo e favorável para a troca dos ativos intangíveis, fomentando o diálogo e desenvolvimento e novas idéias (COSTA; SCHONS, 2008). 
Em 2003, algumas empresas lançaram versões gratuitas dos sistemas colaborativos, o que impulsionou o número de licenças. Apesar da utilização de um único repositório seja o ideal para proporcionar o rápido e fácil acesso às informações, pesquisas indicam que $50 \%$ das organizações utilizam mais de um repositório e $15 \%$ utilizam mais de cinco repositórios, devido a utilização de diferentes plataformas operacionais, desafios em manter uma única linha de negócios, custos e crescimento contínuo das organizações através de fusões e aquisições. As formas mais utilizadas dos sistemas são como portal de informações da intranet ou extranet da organização ou como biblioteca, tendo a função de repositório e gerenciador colaborativo de documentos (RODRIGUEZ, 2010).

Para Musico (2010), as principais partes interessadas na implementação de um sistema colaborativo devem ter um bom entendimento da arquitetura de armazenamento do programa para que possam tirar vantagem da capacidade de gestão de informações gerenciais e colaboração, desenvolvendo uma plataforma única para apresentação, gestão e facilidade de localização de seus recursos digitais e processos de trabalho.

\subsubsection{Retroalimentação}

No processo de projeto, Grilo (2002) aponta a retroalimentação como importante mecanismo de aprendizagem organizacional, cujo objetivo consiste em identificar, documentar e comunicar os erros cometidos, proporcionando oportunidades para melhoria contínua dos Projetos. As informações podem ser coletadas junto a clientes, construtoras, usuários e gerentes prediais após a ocupação do edifício.

Estudos mostram que em ambientes de multi-Projetos, $70 \%$ das informações podem ser transferidas de um Projeto ao outro, o que representa um potencial para melhoria do desempenho dos Projetos através de uma transferência de aprendizado eficiente e eficaz. A transferência de conhecimento pode ocorrer dentro de cada fase do Projeto, entre as fases de um Projeto ou entre diferentes Projetos, como mostra a Figura 42 (LÊ, BRØNN, 2007). 


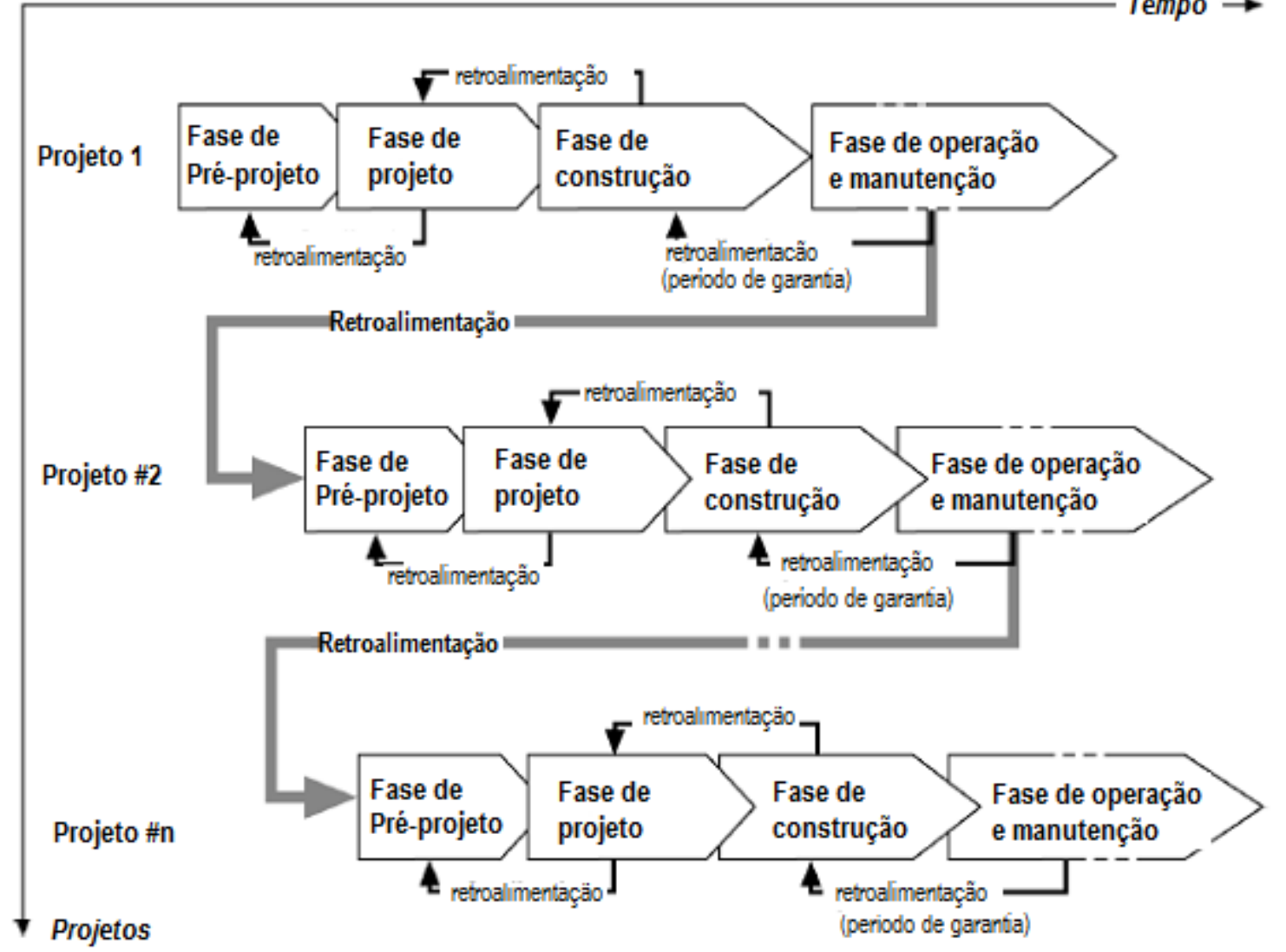

Figura 42 - Principais processos de retroalimentação (adaptado de LÊ, BRØNN, 2007)

Apesar de cada Projeto ser único na indústria da construção, existem processos que são repetíveis e, portanto, podem ser transferidos para outros Projetos através de lições aprendidas que podem ser consideradas como elementos de aprendizado organizacional e gestão do conhecimento da organização. As lições aprendidas fazem parte do aprendizado organizacional ao captar os aspectos positivos e negativos de um Projeto de forma a aprender com a experiência, evitando a repetição de erros que podem repercutir em gastos e danos à reputação da empresa. As lições aprendidas encorajam a captura e disseminação do conhecimento adquirido em Projetos passados, e intensificam o aprendizado e desempenho futuro (CARRILLO, 2005).

Love et al. (2000) apud Carrillo (2005) apontam que para que o aprendizado seja estabelecido a nível organizacional, devem existir processos e estruturas definidas e, para que uma empresa de construção se tranforme em uma organização de aprendizado ela deve estar capacitada em:

- Solucionar problemas sistematicamente; 
- Experimentar novos conhecimentos;

- Aprender com sua própria experiência;

- Aprender com a experiência e melhores práticas dos outros; e

- Transferir conhecimento rápida e eficientemente através da organização.

Algumas empresas de engenharia no Canadá tem usado as lições aprendidas como forma de diferenciação dos concorrentes, devido à sua habilidade em demonstrar que tem um procedimento para conduzir e armazenar as lições aprendidas como forma de prevenir a repetição de problemas similares (CARRILLO, 2005).

No entanto, diversas organizações têm implementado iniciativas de lições aprendidas, mas continuam repetindo os mesmos erros, pois confundem informações e dicas de procedimentos organizacionais com lições aprendidas. Após coletar toda documentação de lições aprendidas de Projetos passados, nota-se que estas lições são muito semelhantes entre um Projeto e outro e as dicas de ferramentas e modelos não agregam valor a novos Projetos, pois já estão incorporadas aos procedimentos de rotina. Segundo Duggal (2011), esta constatação desmotiva a equipe a consultar as lições aprendidas e demonstram que não houve uma preocupação com a contextualização, transmitindo apenas o knowwhat (saber o que). Para que as lições aprendidas cumpram seu papel de fonte de experiência e conhecimento mais profundo, devem conter informações de know-how (saber como) e know-why (saber porque) do tipo:

- O que deu certo ou não e porque;

- Quem já tentou esta abordagem antes;

- Quem são os especialistas indicados para este tipo de Projeto;

- Como os principais desafios foram superados;

- O que levou à satisfação do cliente final;

- Baseado na experiência, o que seria feito de forma diferente;

- Quais são as armadilhas esperadas.

Estas informações devem ser formatadas em estilo de narrativa para transmitir o contexto e experiência de forma eficiente. Duggal (2011) cita a NASA e o Banco Mundial como exemplos de organizações que utilizam a narrativa para compartilhar conhecimento e lições aprendidas. Valioso conhecimento tácito de experiências 
pessoais, que não pode ser capturado em um relatório formal, pode ser aproveitado e transmitido em forma de estória, de forma simples e objetiva.

A NASA promove através do Academy of Program/Project and Engineering Leadership - APPEL (Academia de Programas/ Projetos e Liderança em Engenharia) o compartilhamento de conhecimento, disponibilizando no site Academy Sharing Knowledge - ask (Academia de Compartilhamento de Conhecimento) estudos de caso, multimedia de lições aprendidas, artigos, relatos de conferências e fóruns, além de orientações sobre cursos de capacitação profissional que devem promover a contínua transferência de conhecimento e habilidades no ambiente de trabalho (NASA, 2011).

O aprendizado organizacional ocorre através do aprendizado individual de seus membros, que ao transformarem seus mapas mentais em modelos explícitos contribuem para o modelo mental compartilhado da organização. No entanto, em Projetos multidisciplinares e complexos na construção, a existência de um modelo integrado de aprendizado organizacional, como o modelo da Figura 43, desenvolvido por Kim (1993) apud Lê; Brown (2007), não garante que alguns fatores, muitas vezes relacionados à cultura organizacional ou aspectos sociais, atuem como barreiras na transferência de experiências rompendo o ciclo de aprendizado (LÊ, BRøNN, 2007). 


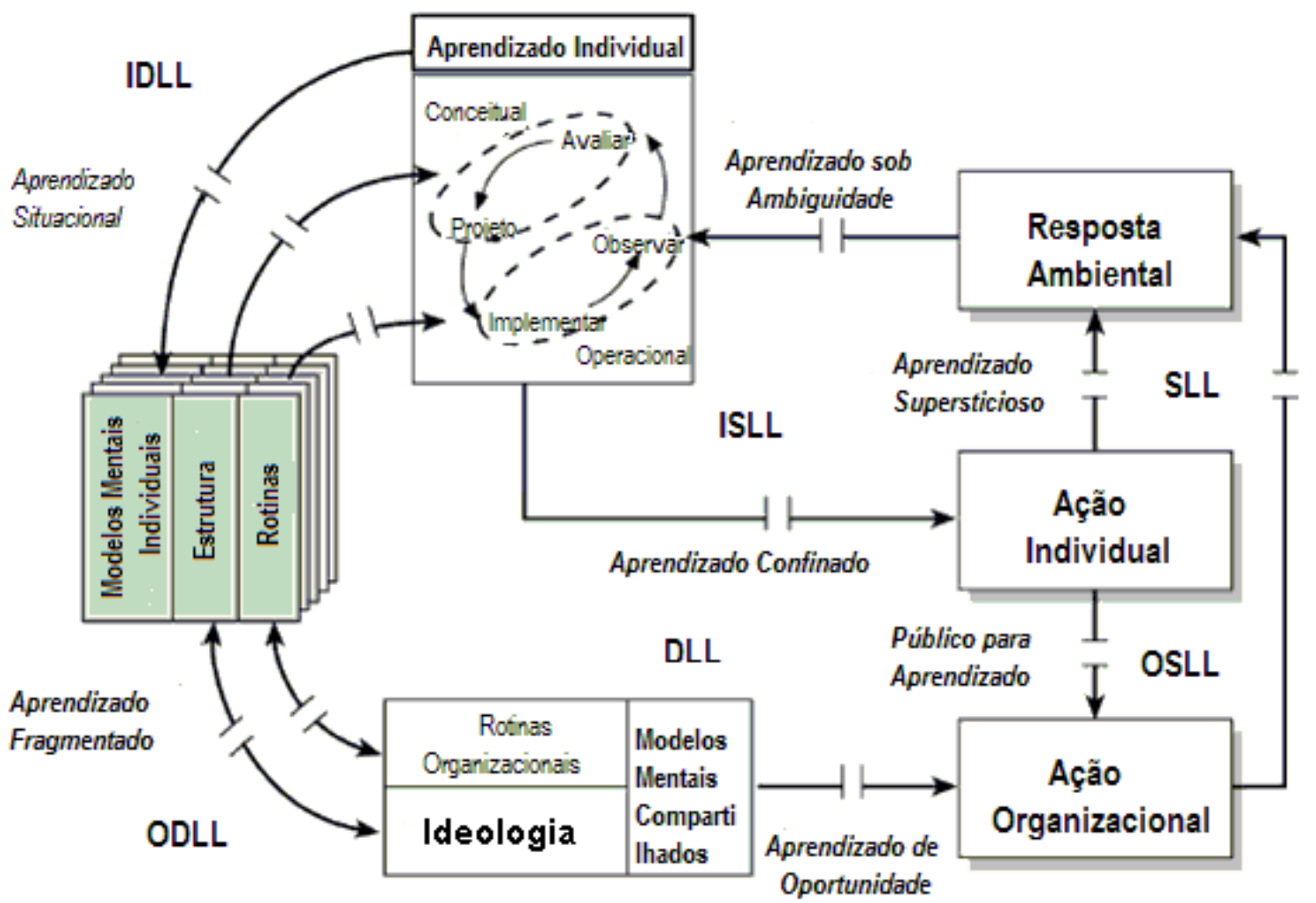

Figura 43 - Um modelo integrado de aprendizado organizacional (adaptado de KIM, 1993 apud LÊ, BRØNN, 2007)

Lê; BrØnn (2007) identificaram algumas barreiras que podem romper o ciclo de aprendizado, no caso da indústria da construção, descrito no Quadro 13, que podem ser influenciadas pelo tipo de orientação de aprendizado definido de acordo com a estratégia de gestão do conhecimento adotada pela organização.

\begin{tabular}{l|l}
\hline \multicolumn{1}{c|}{$\begin{array}{c}\text { Ciclo de aprendizado } \\
\text { incompleto }\end{array}$} & \multicolumn{1}{c}{ Aplicações à indústria da construção } \\
\hline $\begin{array}{l}\text { Aprendizado confinado } \\
\text { (Role-constrained learning) }\end{array}$ & $\begin{array}{l}\text { Poucas demandas, aliado ao fato do cliente ou usuário comprar } \\
\text { "pedaços" do processo, e não um produto final. } \\
\text { Muitos participantes do processo tem conhecimento limitado em } \\
\text { relação ao trabalho dos outros participantes, e os membros da } \\
\text { equipe do projeto e seu papel varia de Projeto a Projeto. }\end{array}$ \\
\hline $\begin{array}{l}\text { Público para o aprendizado } \\
\text { (Audience learning) }\end{array}$ & $\begin{array}{l}\text { O aprendizado dos participantes do Projeto não tem efeito sobre a } \\
\text { organização, suas ações ou sobre a indústria da construção. }\end{array}$ \\
\hline $\begin{array}{l}\text { Aprendizado supersticioso } \\
\text { (Supersticious learning) }\end{array}$ & $\begin{array}{l}\text { Características da produção cujas solicitações passam por processos } \\
\text { de "montagem complicados". }\end{array}$ \\
\hline $\begin{array}{l}\text { Aprendizado sob } \\
\text { ambiguidade } \\
\text { (Learning under ambiguity) }\end{array}$ & $\begin{array}{l}\text { Poucos participantes detêm ou tem interesse financeiro sobre toda a } \\
\text { cadeia produtiva. }\end{array}$ \\
\hline
\end{tabular}




\begin{tabular}{l|l}
\hline Aprendizado situacional & $\begin{array}{l}\text { As pessoas iniciam novos Projetos sem submeter os relatórios dos } \\
\text { Projetos anteriores, devido à falta de tempo. Neste caso nas } \\
\text { organizações com alta rotatividade, com constantes participantes } \\
\text { novos nos Projetos, resulta na transferência de conhecimento } \\
\text { individual e não organizacional. }\end{array}$ \\
\hline $\begin{array}{l}\text { Aprendizado fragmentado } \\
\text { (Fragmented learning) }\end{array}$ & $\begin{array}{l}\text { A indústria é fragmentada, com um grande número de paticipantes } \\
\text { em cada edificação. } \\
\text { É difícil fazer uma distinção entre as atividades de trabalho } \\
\text { operacionais e de Projeto. Em geral, a colaboração é limitada devido } \\
\text { à grande quantidade de participantes, limites geográficos, etc. }\end{array}$ \\
\hline $\begin{array}{l}\text { Aprendizado de } \\
\text { oportunidade } \\
\text { (Opportunistic learning) }\end{array}$ & $\begin{array}{l}\text { Não há um processo de aprendizado contínuo e sistematizado de } \\
\text { tranferência de conhecimento de Projeto para Projeto. A experiência } \\
\text { é acidental e individual. }\end{array}$ \\
\hline
\end{tabular}

Quadro 13 - Rompimento de aprendizado da OADI (observe-assess-design-implement) - SMM (shared mental model) relacionada à indústria da construção (adaptado de LÊ; BRØNN, 2007)

"Ao invés de lições perdidas, com Projetos caindo sempre nos mesmos buracos, você pode utilizar estórias para contar as lições aprendidas e transformá-las em lições aplicadas" (DUGGAL, 2011).

\section{Modelos para transmissão de melhores práticas}

A partir da decisão da empresa de que o conhecimento deve ser compartilhado é necessário uma abordagem metódica para a gestão e a transmissão do conhecimento, e para que o processo transcorra de maneira adequada é preciso: uma necessidade convincente de mudar (definir uma proposição de valor com clareza); uma avaliação perceptiva da situação atual do conhecimento e da transmissão em relação a esse problema ou oportunidade; um planejamento adequado e um envolvimento gerencial em andamento; um bom plano de implementação para proporcionar e alinhar recursos e estruturas organizacionais que estimule a transmissão de conhecimento (O’DELL; GRAYSON, 2000).

O’Dell; Grayson (2000) estabeleceram um modelo para a transmissão de melhores práticas com três componentes principais:

1. As três proposições de valor, que oferecem uma justificativa única para a empresa aderir à mudança viabilizada pelo conhecimento, e enquadram-se em três categorias básicas: 
a. Intimidade com o cliente: aumentar receita, reduzir o custo de venda e aumentar a satisfação e a retenção de clientes;

b. Excelência no lançamento do produto no mercado: reduz tempo do processo de comercialização; incorpora conhecimento e funcionalidade corretos no produto ou serviço; corta custos associados a produtos mal sucedidos.

c. Excelência operacional: melhorias de processos organizacionais por meio da transmissão de melhores práticas (por exemplo: quando uma organização possui operações semelhantes; durante as fusões, quando duas empresas criam uma síntese das melhores práticas; durante alianças estratégicas e parcerias tercerizadas, quando as empresas precisam compartilhar as melhores práticas para alcançarem, coletivamente, um resultado desejado.

2. Os quatro viabilizadores, para assegurar que o conhecimento seja criado, angariado, alavancado e compartilhado são:

a. Tecnologia de informação (TI);

b. Cultura: o maior desafio em instituir mudanças culturais é abandonar a noção de que acumular e reter conhecimento seja fonte de poder. Os executivos devem orientar e inspirar as pessoas a compartilhar 0 conhecimento. Segundo o especialista em gestão do conhecimento, Karl-Erik Sveiby, como a TI pode ser facilmente copiada pela concorrência, a longo prazo apenas uma abordagem de gestão do conhecimento voltada para as pessoas será competitva (baseada no conhecimento tácito e não explícito). O uso do sistema de gestão do conhecimento deve ser gratificante, e deve prever formas de reconhecimento de quem utiliza ou cria conhecimento e quem transmite boas práticas. Estudos com grandes empresas bem sucedidas mostraram que uma estratégia de responsabilidade pessoal que incorpora o desenvolvimento e transmissão de conhecimento nos sistemas de desenvolvimento de carreira de seus funcionários é mais efetivo do que recompensas e incentivos formais. Se a prática ajudar 
as pessoas a realizar o seu trabalho e atingir as suas metas, elas compartilharão o conhecimento;

c. Sistemas de medição;

d. Infra-estrutura organizacional.

É importante medir os Projetos e processos empresariais que estão sendo aperfeiçoados pelas ferramentas de gestão do conhecimento e certificar que os quatro viabilizadores sejam administrados com harmonia.

3. O processo de mudança deve ocorrer em quatro etapas:

a. Planejar: envolve uma auto-avaliação e uma lista de proposições de valor claramente definidas

b. Projetar: envolve esboçar os papéis e as funções de pessoas, tecnologias, bem como ajustes na estrutura organizacional e nas medidas de desempenho

c. Implementar: um programa piloto que testará as novas idéias e reconhecerá as lições do que funciona ou não.

d. Expandir: o programa piloto tornando-o um processo de âmbito empresarial capaz de atrair todos os benefícios da transmissão eficaz.

Baseado em pesquisa realizada com empresas de construção do Canadá, Carrillo (2005) propõe melhorias nos procedimentos de lições aprendidas, de forma que estes façam parte dos processos de negócio da empresa tornando-se sistemáticos:

- Conduzir lições aprendidas para todos os Projetos a partir de determinado valor, complexidade e aspectos de inovação;

- Conduzir lições aprendidas periodicamente, de acordo com as fases do Projeto;

- Conduzir lições aprendidas com todos líderes da equipe e fornecedores para obter diferentes perspectivas dos problemas e para que a causa raiz do problema seja discutida aberta e honestamente. É recomendado um facilitador para evitar confrontos; 
- Utilizar um template padrão para as lições aprendidas para assegurar consistência entre os Projetos. Armazenar e indexar eletronicamente para facilitar acesso;

- Prever avisos sobre a disponibilidade das lições aprendidas pela intranet;

- Estimular gerentes e líderes de Projeto a buscar lições aprendidas de Projetos relevantes anteriores antes de iniciar novos Projetos.

Jeon (2009) desenvolveu um modelo conceitual para sistema de lições aprendidas para empresas de construção, baseado em estudos de caso na Coréia, composto dos seguintes módulos: aquisição (captura lições aprendidas online, que utilizam ferramentas de $\mathrm{Tl}$ e internet, e offline), armazenamento (importante definir previamente como serão organizadas as lições aprendidas no módulo), avaliação (do conteúdo por uma equipe pré-definida; para recompensar quem contribuiu de acordo com o valor de sua contribuição; para atualizar ou eliminar informações desatualizadas); disseminação (das lições pré-avaliadas no módulo anterior garantindo a qualidade do material). Foram identificados como fatores de sucesso do sistema de lições aprendidas:

- Fatores tecnológicos: 1) desenvolver uma arquitetura do sistema alinhada com o ciclo de vida dos Projetos, possibilitando operação no Projeto e entre Projetos; 2) possibilitar o acesso de todos participantes do Projeto, incluindo clientes e fornecedores, e da organização como um todo; 3) manter a integridade do conteúdo para evitar tempo e custo para verificações posteriores; 4) facilitar a interface dos usuários para encorajar a contribuição dos funcionários; 5) o sistema deve ser flexível para absorver todo tipo de contribuição dos diversos participantes e possibilitar futura expansão ou remodelagem, caso necessário.

- Fatores gerenciais: 1) definir uma equipe específica para a gestão e operação do sistema de lições aprendidas para monitorar, facilitar e resolver problemas; 2) promover a participação do usuário final; 3) integrar os esforços online e offline; 4) investimento contínuo em treinamento (como converter lições individuais para lições organizacionais) e estímulo à contribuição.

- Fatores estratégicos: comprometimento da alta direção, mesmo que o retorno dos investimentos não seja facilmente justificado de forma quantitativa a curto 
prazo; alinhar o sistema com outras iniciativas de gestão do conhecimento da organização.

\subsubsection{Exemplos de aplicação da gestão do conhecimento}

Em meados dos anos 70, lições aprendidas foram introduzidas pelo exército americano com as After Action Review - AAR (Revisão após Ação) (GARVIN, 2003 apud CARRILLO, 2005), que tinha quatro questões principais:

- O que estavamos propostos a fazer?

- O que realmente ocorreu?

- Porque isto aconteceu?

- O que pretendemos fazer da próxima vez?

As AARs não focavam no sucesso ou fracasso, mas eram um mecanismo para encorajar as pessoas a aprender com as experiências passadas.

Em 1988, a NASA fundou o PPMI - Program and Project Management Initiative (Iniciativa de Gestão de Programas e Projetos), em resposta ao desastre da nave espacial Challenger, para promover a competência e excelência em gestão de Projetos através de treinamentos para ensinar os fundamentos do conhecimento em gestão de Projetos (NASA, 2011).

Em 1992, foi criada uma equipe para racionalizar e promover a melhoria da gestão de Projetos, pois nesta época o ciclo de vida de um Projeto (da autorização de início ao lançamento) girava em torno de oito anos e o custo e cronograma apresentavam um desvio de $60 \%$ em relação às estimativas planejadas. Foram levantados sete principais fatores relacionados a riscos de custo e técnicos:

- Inadequada formulação de requisitos;

- Dependência não realista em tecnologias não comprovadas;

- Instabilidade anual de financiamento;

- Estrutura organizacional complexa, incluindo interfaces múltiplas e obscuras;

- Estimativas de custo frequentemente ultrapassadas; 
- Adições de escopo por mudanças de requisitos;

- Não cumprimento de cronogramas;

- Estratégias de aquisições que não fomentavam contenção de custos.

O trabalho levou a criação do Conselho de Gestão de Programas e do Conselho de Grupo de Trabalho de Gestão de Programas que estipularam uma política de gestão de Projetos e documentos para orientar e promover Projetos "Faster, Better and Cheaper (Mais rápido, melhor e mais barato)".

Em meados de 1990, ficou claro que os programas de treinamento enfatizavam os currículos, mas não estavam vinculados aos requisitos e sucesso da missão. A partir daí foram identificadas as competências essenciais necessárias nos diferentes estágios da carreira, buscando vincular o sucesso da missão com recursos humanos através do aprendizado.

Em 1998, a quantidade de Projetos aumentou mas, devido a re-estruturação organizacional, houve uma redução do quadro de funcionários. A PPMl evolui para APPEL - Academy of Program/Project and Engineering Leadership (Academia de Programa/ Projeto e Liderança em Engenharia), cuja missão foi capacitar seus profissionais em gestão de Projetos/ programa e liderança em engenharia através da aplicação de estratégias de aprendizado, métodos, modelos e ferramentas, focando o aprendizado individual através de treinamentos orientados, aprendizado em equipe e aprendizado organizacional.

A estrutura de gestão de Projetos e competências do sistema de engenharia da NASA consiste em cinco áreas de competência em Gestão de Projetos, três em áreas de competência Sistemas de Engenharia e cinco em áreas de competência comuns às comunidades de Gestão de Projetos e Sistemas de Engenharia, entre elas Gestão de conhecimento, conforme Figura 44. 
Gestão de Projeto

1.0 Conceituação do Projeto

2.0 Gestão de Recursos

3.0 Implantação do Projeto

4.0 Fechamento do Projeto

5.0 Controle e Avaliação do

Programa
Comum

10 Ambiente interno e externo da NASA

2.0 Gestão de Recursos Humanos

3.0 Garantia de Segurança \& Missão

4.0 Desenvolvimento Profissional \&

de Liderança

5.0 Gestão de Conhecimento
Engenharia de Sistemas

1.0 Sistema de projetos

2.0 Realização do produto

3.0 Gestão Técnica

Figura 44 - Estrutura de Gestão de Projetos e Competências do Sistema de Engenharia da NASA (adaptado de NASA, 2011)

O site ask - Academia de Compartilhamento de Conhecimento disponibiliza estudos de caso, multimedia de lições aprendidas, artigos, relatos de conferências e fóruns, além de orientações sobre cursos que devem promover a contínua transferência de conhecimento e habilidades no ambiente de trabalho (NASA, 2011).

\subsection{Gestão do conhecimento nas empresas de construção}

A indústria da construção é uma indústria baseada em Projetos, que utilizam uma grande variedade de empresas formando uma organização virtual, temporária e multidisciplinar para a entrega do produto (edificação) a um cliente com especificações únicas. Devido à natureza fragmentada em que a indústria é organizada, a eficiência na entrega dos Projetos é inferior às expectativas, o que resulta na insatisfação do cliente e na baixa rentabilidade para as empresas deste setor (CARRILLO et al., 2004).

As equipes virtuais formadas para cada Projeto frequentemente se dispersam ao seu término, sem conduzir uma revisão final do Projeto e disseminar suas lições aprendidas. Desta forma, as experiências, tanto boas quanto más, individuais e da equipe como um todo, não são disseminadas, apesar da importância da troca de experiência entre Projetos e entre organizações para evitar repetição de erros e disseminação de boas práticas (KAMARA et al. 2002). 
Algumas empresas participam de todo o ciclo de vida do empreendimento, da fase de concepção do projeto, planejamento, construção e depois da operação, manutenção e descarte. Estas empresas possuem um conhecimento e experiência com enorme potencial para contribuir para a melhoria da eficiência e qualidade de novas construções, evitando repetição de erros que implicam em custos adicionais. Uma questão central para estas empresas é como transferir as informações históricas da operação e manutenção de forma simples e integrada para a equipe de projetos nos estágios iniciais de novos Projetos, pois não existe uma tradição de envolver representantes destas áreas nas fases de projeto. No entanto, existem poucos estudos sobre o aprendizado entre as fases do Projeto (LÊ, BRØNN, 2007).

Bakker et al. (2011) ressaltam que o cliente/ proprietário do Projeto tem um papel fundamental e pode ser um facilitador da transferência de conhecimento de um Projeto para outro.

O foco atual das pesquisas em gestão do conhecimento nos EUA está se estendendo além das fronteiras da construção para incluir todas as fases do ciclo de vida da construção. Este foco reflete a noção de que o conhecimento na construção está relacionado à construtibilidade, gestão de suprimentos e fornecedores, gestão do processo de projeto, cada um intimamente relacionado às decisões tomadas nas etapas de projeto (CARRILLO; CHINOWSKY, 2006).

A efetiva gestão do conhecimento tem sido evidenciada como vital para intensificar a melhoria contínua e desempenho das empresas envolvidas e, consequentemente, o desempenho do Projeto.

Os requisitos para gestão do conhecimento na construção podem ser discutidos em duas categorias inter-relacionadas: a gestão do conhecimento entre Projetos e a gestão do conhecimento entre as empresas envolvidas (KAMARA et al., 2002; KAMARA; ANUMBA; CARRILLO, 2009).

A gestão do conhecimento do Projeto envolve a gestão do conhecimento na organização virtual temporária do Projeto. Uma característica de uma organização de um Projeto de construção é que o conteúdo e contexto para gestão do conhecimento mudam de acordo com a fase do ciclo de vida do Projeto. Por exemplo, na etapa de projeto, que envolve a definição de soluções de design às necessidades do cliente, há maior necessidade de desenvolvimento de idéias 
inovadoras. É nesta etapa que são tomadas a maior parte das decisões que poderão afetar o ciclo de vida do empreendimento até a fase de operação/ manutenção. Já na fase de construção, a natureza do Projeto é mais mecânica, pois envolve um planejamento programado da construção que deverá ser seguido pelos contratados. Nesta etapa, onde a obra começa a ser erguida, devem ser consideradas as seguintes necessidades:

- Direcionar as necessidades relativas ao Projeto de acordo com os diferentes estágios da obra;

- Transferir o conhecimento entre os diferentes estágios;

- Apoiar e gerenciar o conhecimento dos membros da equipe multidisciplinar que fazem parte da cadeia de suprimentos do Projeto;

- Prover mecanismos de captura do conhecimento no decorrer do Projeto.

A adoção de uma estratégia apropriada de suprimentos e contratos que facilite o contínuo envolvimento das pessoas chave ao longo da duração do Projeto, tais como extranets e reuniões para reflexão contínua sobre o Projeto são meios indicados de gerenciar o conhecimento do Projeto.

Outro desafio da gestão do conhecimento na construção é a transferência do conhecimento entre as diferentes fases de um Projeto, por exemplo, transferir conhecimento das necessidades dos clientes em especificações técnicas e a transferência da intenção e lógica do projeto para a equipe de construção. 0 envolvimento de múltiplas empresas em um Projeto significa que a transferência de conhecimento de um estágio para o próximo depende muito do tipo de estratégia de contratações ou tipo de contrato adotado para o Projeto (McCARTHY et al., 2000 apud KAMARA et al., 2002).

Membros da equipe de projetos constantemente geram novo conhecimento ao coletar, compartilhar e transformar a informação (OTTER; EMMITT, 2008).

Da perspectiva dos projetistas, a solução de problemas de projeto é encontrada de forma tácita e depois codificada em detalhes, especificações e desenhos, utilizando uma linguagem específica de projeto que pode não ser facilmente interpretada de imediato pelo cliente (EMMITT, 2002). 
A gestão do conhecimento nas empresas, segundo Kamara; Anumba; Carrillo (2009) envolve a habilidade de transferir o conhecimento/ aprendizado para os diferentes Projetos com o qual a empresa está envolvida. Envolve também transformar o conhecimento individual em base de conhecimento corporativo. desafio da gestão do conhecimento neste contexto pode ser semelhante a empresas de outros ramos de negócio. No entanto, como o negócio para empresas de construção só se efetiva em resposta a uma necessidade do cliente, a estratégia da gestão do conhecimento deve focar no aumento da habilidade da empresa para oferecer o melhor preço, ganhar contratos assim como obter lucro ao término do Projeto. Foram identificadas como cruciais para a gestão das empresas: conhecimento dos clientes/ mercado, liderança, estratégia, gestão de pessoas, gestão de tecnologia, inovação, gestão de Projetos e medição de desempenho.

Várias estratégias podem ser utilizadas para atingir estes objetivos na prática: utilização de ferramentas de TI para a gestão de conhecimento explícito (por exemplo: sistemas do tipo groupware (programa colaborativo), sistemas baseados no conhecimento (para compartilhar procedimentos operacionais padrão, guia de melhores práticas, lista de especialistas, desenhos, padrões, especificacões, etc) ou a utilização de canais de comunicação tais como: contato face a face, comunidades de prática, lições aprendidas, narrativa, fórum de discussão para a gestão de conhecimento tácito e transferência de experiências da equipe de um Projeto para outro.

Com o rápido avanço das tecnologias de rede, as empresas do setor da construção tem utilizado repositórios interativos acessados via internet como ferramenta para gestão do conhecimento, mas para o retorno do investimento não ficar abaixo das expectativas, também devem ser incorporados os esforços de gestão do conhecimento realizados offline (sem o uso do computador), tais como comunicação e colaboração face-a-face (JEON, 2009).

A falta de referências em relação à gestão do conhecimento na indústria da construção não significa que o conhecimento não seja gerenciado. Segundo Kamara; Anumba; Carrillo (2009), o termo é novo na indústria, mas várias práticas em vigor na indústria da construção contribuem para o gestão do conhecimento, tais como: 
- O envolvimento de pessoas em diferentes atividades é o primeiro meio pelo qual o conhecimento é adquirido e transferido;

- A captura, transferência e reutilização do conhecimento é reforçada pelos acordos contratuais (por exemplo: projeto, iniciativas de financiamento, acordos entre fornecedores e cliente) que possibilitam a continuidade do envolvimento de certos agentes em um ou mais Projetos do mesmo cliente;

- Lições aprendidas são capturadas em procedimentos operacionais, diretrizes de projeto e guia de melhores práticas através de revisões de projeto;

- Redes de contato informais e lista de especialistas são fontes de repositório de conhecimento;

- Diversas ferramentas de TI são utilizadas para apoio das atividades de gestão do conhecimento.

Entretanto, se estas atividades não forem implementadas com uma estratégia de coordenação, os benefícios da gestão do conhecimento não serão percebidos. Estratégias informais baseadas nos indivíduos tem grande risco e tornam a organização vulnerável a fatores externos não previstos e à grandes mudanças estruturais, como por exemplo: mudança da alta direção, expansão, redução do quadro de funcionários, etc.

Brown (2001) sugere seis passos para a gestão do conhecimento no ambiente de um empreendimento:

- Iniciar um website para armazenar dados adminstrativos e do Projeto;

- Promover um servidor para todos os usuários, para minimizar custo e conflitos de programas individuais;

- Implementar e integrar uma única linguagem para os sistemas de TI;

- Introduzir servidores de informação administrada, com sistemas capazes de maximizar o dinamismo, a integração e o desenvolvimento;

- Desenhar os componentes de arquitetura e engenharia em modelos tridimensionais; 
- Promover integração ao longo do ciclo de vida, permitindo a difusão de informações para os usuários, clientes e projetistas, com propósitos operacionais e de aprendizagem.

Brown (2001) ressalta o potencial de aprendizagem contínua ao longo do desenvolvimento de vários empreendimentos através de bancos de dados de desempenho da edificação, avaliações de pós-ocupação (APO) realizadas por clientes, projetistas e fornecedores, e análises de projetos, conforme mostra Figura 45, mas que devido à falta de acessibilidade a estas informações reduz sua aplicação na prática.

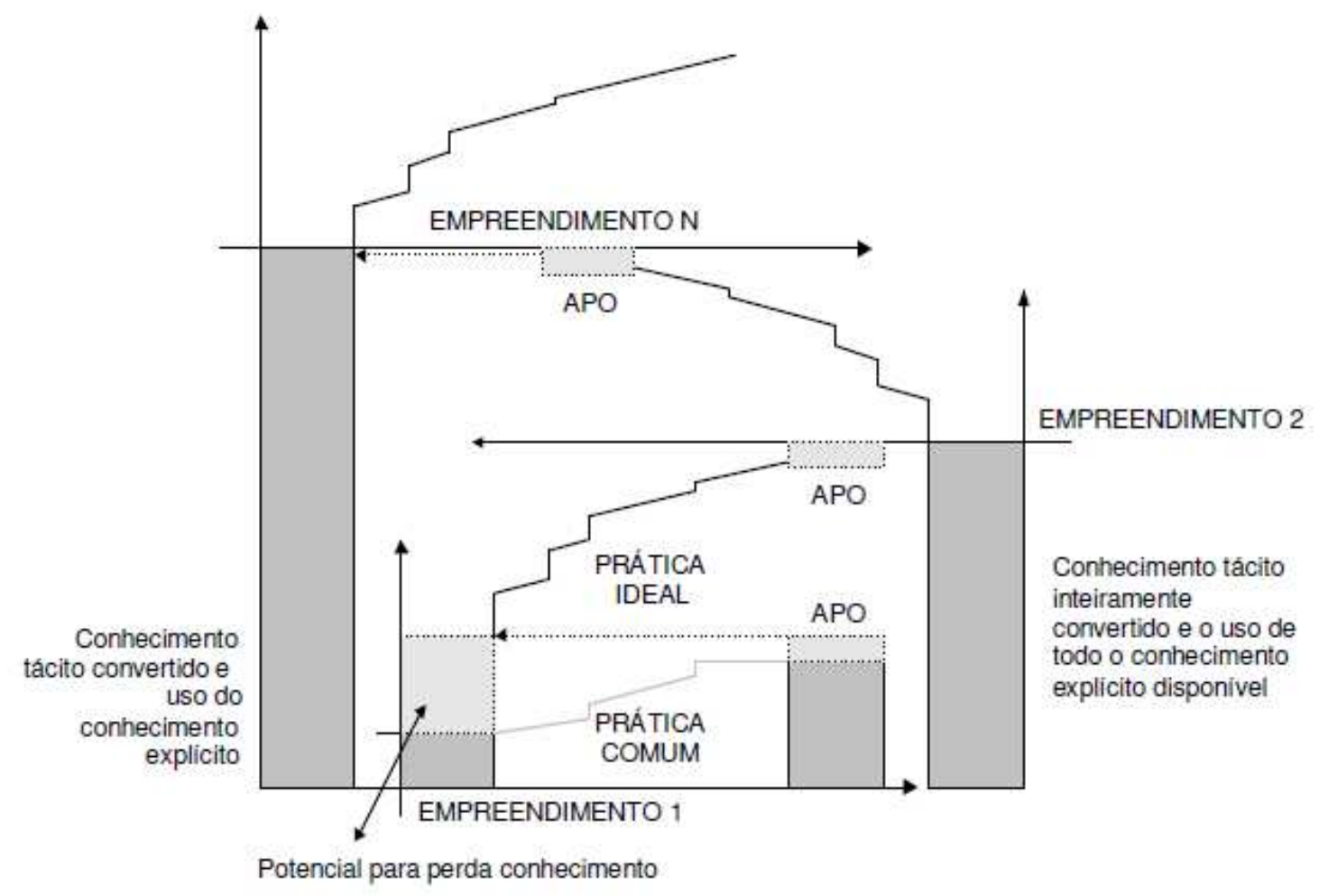

Figura 45 - Aprendizagem ao longo dos empreendimentos (adaptado de BROWN, 2001)

Para Kamara; Anumba; Carrillo (2009), o processo de adotar uma estratégia de gestão do conhecimento em uma empresa de construção deveria incluir:

1. Identificar em que estágio a empresa se encontra para implantação da gestão do conhecimento: identificar sua estrutura, políticas, resistência e capacitação que podem influenciar no sucesso da implantação da gestão do conhecimento. Se for identificada uma necessidade de utilização de grupos de discussão via internet, seria imprescindivel checar se a estrutura de TI é adequada e suporta esse tipo de fórum. 
2. Alinhar a estratégia de gestão do conhecimento com os negócios da empresa, identificando a dimensão do conhecimento para a natureza dos problemas de acordo com o contexto da organização.

3. Integrar a tecnologia com os processos da empresa através de organização corporativa e dos Projetos. As soluções de gestão do conhecimento devem incorporar uma combinação de questões organizacionais e de pessoas com sistemas tecnológicos.

\subsubsection{Razões para implementar uma estratégia de gestão do conhecimento}

As organizações são motivadas a gerenciar o conhecimento por várias razões. Em uma pesquisa realizada sobre gestão do conhecimento com 35 grandes empresas da construção no Reino Unido (que representavam 20\% da amostra de 170 empresas de diversos setores), Robinson et al. (2001) identificaram os principais itens motivadores para gestão do conhecimento na construção como:

- Necessidade de encorajar melhoria contínua (92,5\%)

- Compartilhar valioso conhecimento tácito $(88,7 \%)$

- Disseminar melhores práticas $(86,8 \%)$

- Dar respostas rápidas ao cliente $(84,9 \%)$

- Reduzir retrabalho $(77,4 \%)$

- Desenvolver novos produtos e serviços $(58,5 \%)$.

A principal razão apontada em pesquisa realizada com três empresas de engenharia e três construtoras de grande e médio porte no Reino Unido (CARRILLO et al., 2004) foi a necessidade de compartilhar conhecimento e disseminar melhores práticas. Foi verificada a necessidade de alavancar o conhecimento obtido por funcionários chave da organização para transformá-lo em ativo organizacional, evitando o risco do conhecimento ficar indisponível no caso de perda de funcionários.

Segundo Kamara et al. (2002), a necessidade de gestão do conhecimento nas empresas de engenharia é complementada pela necessidade de inovação, melhoria 
de desempenho do negócio e satisfação do cliente. A indústria da construção opera em um ambiente de mudanças e dinâmico. Os produtos demandados estão tornando-se mais complexos com ênfase em facilidades alinhadas aos conceitos de 'ambientalmente correto'. Os clientes estão mais sofisticados, insistindo em valorizar o seu capital aplicado e exigindo mais unidades de construção com menor unidade de investimento (EGAN, 1998 apud KAMARA et al., 2002).

Em uma pesquisa realizada com 32 entrevistados em 15 empresas de arquitetura e engenharia no Reino Unido sobre o contexto da organização para a gestão do conhecimento do Projeto, transferência de conhecimento entre Projetos e desafios e oportunidades para gestão do conhecimento entre Projetos (KAMARA et al., 2002), foram identificados os itens:

- A necessidade de competir com as mudanças organizacionais decorrentes da alta rotatividade da gerência e mudanças de práticas de negócio (por exemplo: mudança de uma estrutura hierárquica para equipes virtuais);

- A necessidade de reduzir desperdício, evitar duplicação de esforços e repetição de erros similares de Projetos passados e para melhorar eficiência;

- A necessidade de competir com o crescimento e diversificação de atividades de negócio da empresa (por exemplo: de tradicional contratante principal para gerenciador de Projetos, construção e facilidades);

- A gestão efetiva da cadeia de suprimentos na entrega do Projeto (por exemplo: a necessidade do conhecimento dos fornecedores e suas competências).

Em pesquisa realizada com empresas de engenharia, suprimentos e construção do Canadá foi identificado que a utilização de lições aprendidas de Projetos anteriores contribuiu para a melhoria do desempenho de Projetos futuros, pois além de evitar a repetição de erros do passado, possibilita rapidamente resgatar o que deu certo em um Projeto e tentar recriar este sucesso (CARRILLO, 2005). 


\subsubsection{Esforços e barreiras para implementação}

Szulanski (1996) conduziu um estudo em 1994 sobre as etapas e barreiras à efetiva transmissão de conhecimento nas empresas e chegou à conclusão de que a principal e maior barreira para a transmissão, principalmente nas grandes empresas, era a ignorância nas duas extremidades do processo: nem a fonte nem o receptor sabiam que alguém poderia deter o conhecimento de que precisavam ou se interessar pelo conhecimento de que eles possuíam. Outros pontos concluídos foram:

- A capacidade de absorção do receptor: mesmo que um gerente soubesse da melhor prática, talvez não dispusesse dos recursos ou detalhes práticos para implementá-la;

- A falta de um relacionamento pré-existente entre a fonte e o receptor do conhecimento: as pessoas absorvem conhecimento e prática de outras pessoas que elas conhece, respeitam e admiram;

- A falta de motivação: falta uma razão empresarial clara para buscar a transmissão de conhecimento e melhores práticas.

A descoberta mais surpreendente foi que as melhores práticas internas levavam uma média de 27 meses para chegar à empresa inteira (O'DELL; GRAYSON, 2000).

O conhecimento é pegajoso, de difícil transferência. Apesar da existência de boas práticas na empresas, estas não são utilizadas, pois as organizações "não sabem o que elas sabem". Cria-se uma lacuna entre o que a empresa sabe e o que ela realmente aplica (SZULANSKI, 1996).

A capacidade do ser humano absorver o conhecimento é função do que ele já sabe (experiência e aprendizado passado) e está relacionada ao nível de conhecimento do assunto existente (COHEN; LEVINTHAL, 1990).

Ao conciliar e subordinar os diferentes objetivos dos membros da organização surgem os problemas de cooperação. A transferência do conhecimento não é uma abordagem eficiente da integração do conhecimento. Se a produção exige a integração de diversos especialistas em determinados conhecimentos, a eficiência é conseguir uma integração efetiva através da aprendizagem cruzada entre os membros da organização, minimizando a transferência do conhecimento. A 
eficiência não é maximizada quando um indivíduo tem que aprender tudo o que o outro já sabe, mas sim quando há a criação de um modo de interação em que os conhecimentos de um são integrados aos conhecimentos do outro (GRANT, 1996).

Robinson et al. (2001) detectaram em pesquisa com grandes empresas da construção no Reino Unido que, apesar da maioria das empresas ter consciência dos benefícios de uma estratégia para a gestão do conhecimento foram identificadas várias barreiras tais como:

- Cultura organizacional: pode ser um fator de incentivo ou inibição da estratégia de gestão do conhecimento;

- Falta de padronização de processos de trabalho: muitas empresas têm diferentes processos para execução da mesma atividade, principalmente em empresas que passaram por processos de fusão e aquisição, que implica na herança de novos processos. A pesquisa revelou que as empresas reconhecem a necessidade de racionalizar ou sincronizar alguns processos para possibilitar a re-utilização de conhecimento das melhores práticas e trocar experiências;

- Restrições de tempo: como os projetos são caracterizados pelo atendimento às necessidades do cliente que são associados a um prazo fixo, a restrição de tempo é uma barreira às empresas de construção. Muitas empresas consideram sua estrutura organizacional muito enxuta para explorar a gestão do conhecimento a fundo. As pessoas tem a pré-disposição para compartilhar o conhecimento, mas a pressão para entrega dos projetos com cronograma comprimido não permite o registro de experiências para posterior compartilhamento. A falta de organização dos processo internos da empresa faz com que as organizações baseadas em Projetos tenham que lutar para aprender de um Projeto para outro. As constantes reduções de prazo dos Projetos, consequentemente, limitam o tempo para documentar as lições aprendidas;

- Resistência dos funcionários: este fator, que está fortemente relacionada a fatores culturais, pode ser positivo quando os indivíduos tem uma atitude positiva na criação e compartilhamento de conhecimento, ou negativo quando os funcionários estão inseguros quanto a sua situação no emprego, ou não 
confiam em seus empregadores, ficando menos propensos a compartilhar seu conhecimento;

- Comprometimento organizacional a longo prazo;

- A falta de compreensão da gestão do conhecimento;

- Conflito de prioridades na demanda por recursos.

Carrilo et al. (2004) classificaram, conforme ilustrado a Figura 46, os principais desafios encontrados na implementação da gestão do conhecimento em empresas de construção, baseado na média da 1.0 a 5.0 de importância de cada item:

- Falta de processos de trabalho padronizados;

- Falta de tempo suficiente: devido a natureza projetizada das empresas de construção o tempo é associado à necessidade de entregar os projetos no prazo. Isto pode ser demonstrado na falta de registro de lições aprendidas detalhadas envolvendo toda a cadeia de fornecedores e sua subsequente disseminação. A menos que isto seja feito de maneira sistemática, erros serão repetidos com custo e sem resultado de aprendizado. Além disso, as empresas têm a expectativa de que 0 funcionário arque com responsabilidades adicionais para gestão do conhecimento em acréscimo às suas responsabilidades do dia a dia. Neste cenário o compartilhamento de conhecimento não desponta como prioridade, a menos que haja alguma métrica de desempenho incorporada a ele;

- Cultura organizacional: existência de silos verticais na organização que levam à falta de consciência do que os outros já fizeram, uma cultura de competição interna que enfraquece os esforços de compartilhar conhecimento, etc. Carrillo et al. (2004 apud Dermott e O'Dell, 2001) recomendam que as empresas adaptem suas iniciativa de gestão do conhecimento à cultura da empresa, ou seja complementar a forma de trabalho dos funcionários e não forçá-los a mudar;

- Recursos financeiros insuficientes: A baixa margem de lucro das empresas de construção e sua natureza conservativa também levam a uma relutância a investir em iniciativas de gestão do conhecimento e na infraestrutura de suporte necessária. 


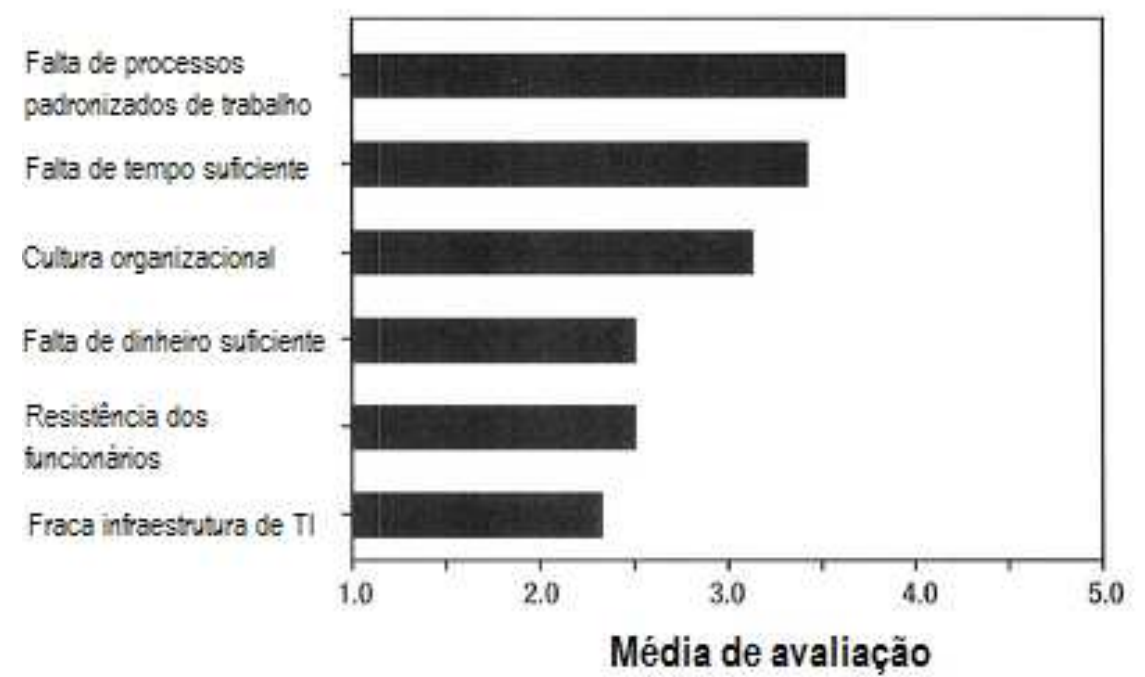

Figura 46 - Barreiras para implantação da gestão do conhecimento por nível de importância (adaptado de CARRILLO, 2004)

Carrillo; Chinowsky (2006) identificaram como barreiras à gestão do conhecimento, com base na pesquisa realizada nos EUA, a falta de tempo disponível para atividades de gestão do conhecimento. Há particularmente um problema quando os benefícios individuais aos funcionários não são propriamente comunicados ou compreendidos. Se o funcionário entende como as iniciativas de gestão do conhecimento impactam diretamente sobre suas atividades diárias de trabalho, eles podem ficar mais incentivados a tomar parte nas atividades.

Ichijo; Nonaka (2007) levantam duas principais razões para a dificuldade das empresas em desenvolver programas efetivos de criação e gestão do conhecimento:

1- As tradicionais disciplinas de gestão que lidam com as noções de estratégia, gestão de $\mathrm{RH}$, finanças e marketing deveriam ser revisadas para que o conhecimento fosse gerenciado de forma criativa, efetiva e eficaz para vantagem competitiva. O conhecimento tácito envolve processos humanos na gestão do conhecimento - criatividade, conversação, julgamento, ensino, aprendizado - difíceis de quantificar e gerenciar de acordo com as disciplinas tradicionais, que envolvem mais meios quantitativos do que qualitativos;

2- O impacto nos negócios das práticas de gestão do conhecimento permanecem vagos.

Prusak; Weiss (2007) apontam como estrátegia corrente em algumas empresas, a busca da redução do custo de transação associado a criação, compartilhamento e 
aplicação do conhecimento que podem incluir busca por especialistas ou conhecimento codificado, qualificar e sistematizar o conhecimento e adaptá-lo ao trabalho. Reduzir os obstáculos ao conhecimento pode ajudar a empresa a aumentar a produtividade dos trabalhadores do conhecimento (o usuário não encontra o conhecimento que precisa, perde tempo procurando conhecimento que não existe, e re-cria conhecimento que está disponível mas não pode ser localizado). As fontes destes obstáculos ou custo de transação incluem:

- Restrições físicas: falta de proximidade, tornando difícil encontrar ou falar com a pessoa certa;

- Restrições técnicas: falta de ferramentas efetivas para busca ou colaboração, desta forma deixando a transação lenta;

- Restrições sociais/ políticas: hierarquia rígida ou incentivos ineficazes dificultam acessar a pessoa ou documento certo ou a pessoa que poderia ajudar;

- Restrições psicológicas/ situacionais: dificuldade em traduzir o conhecimento de um contexto para outro ou absorver o conhecimento;

- Restrições baseadas na confiança: falta de uma cultura baseada na confiança deixando a transação lenta.

As empresas estão adotando medidas para mitigar estas restrições da forma mais eficiente possivel.

\subsubsection{Evolução da gestão do conhecimento na construção}

A revisão da literatura referente às características do setor da construção civil e o processo de projeto identificou que diversos problemas recorrentes do setor persistem por décadas e não foram extinguidos com a implantação dos sistemas de qualidade e gestão de processos e projetos. As pesquisas apontam para uma visão mais holística, envolvendo aspectos inter-pessoais, sociais e intra-organizacionais. 
Da mesma forma, a adoção de uma estratégia para gestão do conhecimento alinhada à estratégia organizacional não garante que o conhecimento gerado seja compartilhado entre todos os envolvidos durante o ciclo de vida do empreeendimento. Algumas barreiras encontradas na implementação de sistemas de gestão de conhecimento, podem ser identificadas nos processos de gestão de Projetos e do projeto, e interferem diretamente em todas as organizações que compõe o setor da construção: falta de tempo, falta de motivação dos envolvidos, falhas de comunicação, falta de integração, cultura organizacional, entre outros.

Os trabalhos colaborativos levantados no capítulo 2 desenvolvidos pela FIATECH, ECPT, CIB priorizam como itens estratégicos: o compartilhamento de conhecimento, a colaboração, a interoperabilidade e a integração entre pessoas, processos e TI.

Alavi; Leidner (2001) identificaram cinco diferentes perspectivas da gestão do conhecimento: 1) Perspectiva do objeto (define conhecimento como algo que pode ser armazenado e manipulado); 2) Perspectiva da condição (enfatiza o acesso ao conhecimento); 3) Perspectiva do estado de espírito (enfatiza o conhecimento e aprendizado através da experiência e estudo); 4) Perspectiva de processo (focando no conhecimento e ação); 5) Perspectiva de competência (vê o conhecimento como uma competência com potencial para influenciar ações futuras). Baseado nesta visão, Rezgui; Hopfe; Vorakulpipat (2010) definiram uma perspectiva evolutiva da gestão do conhecimento no setor da engenharia e construção, como mostrado na Figura 47, e propondo três gerações:

1‥ Geração: Compartilhar o conhecimento (perspectivas 1 e 2): focada na automação dos processos através da TI. Baseada em documentos onde 0 conhecimento requer uma interpretação humana. Objetivo de desenvolver competências intra-organizacionais.

2ª . Geração: Conceber e estimular o conhecimento (perspectivas 3 e 4): através de iniciativas de modelagem até chegar à modelagem de informações do edifício (BIM). Objetivo de desenvolver competências entre organizacões com o foco em Projetos.

3a. Geração: Criar valor a partir do conhecimento existente para benefício dos indivíduos, organização e sociedade (perspectiva 5): edifícios com iniciativas de sustentabilidade com foco no meio ambiente e responsabilidade social. 


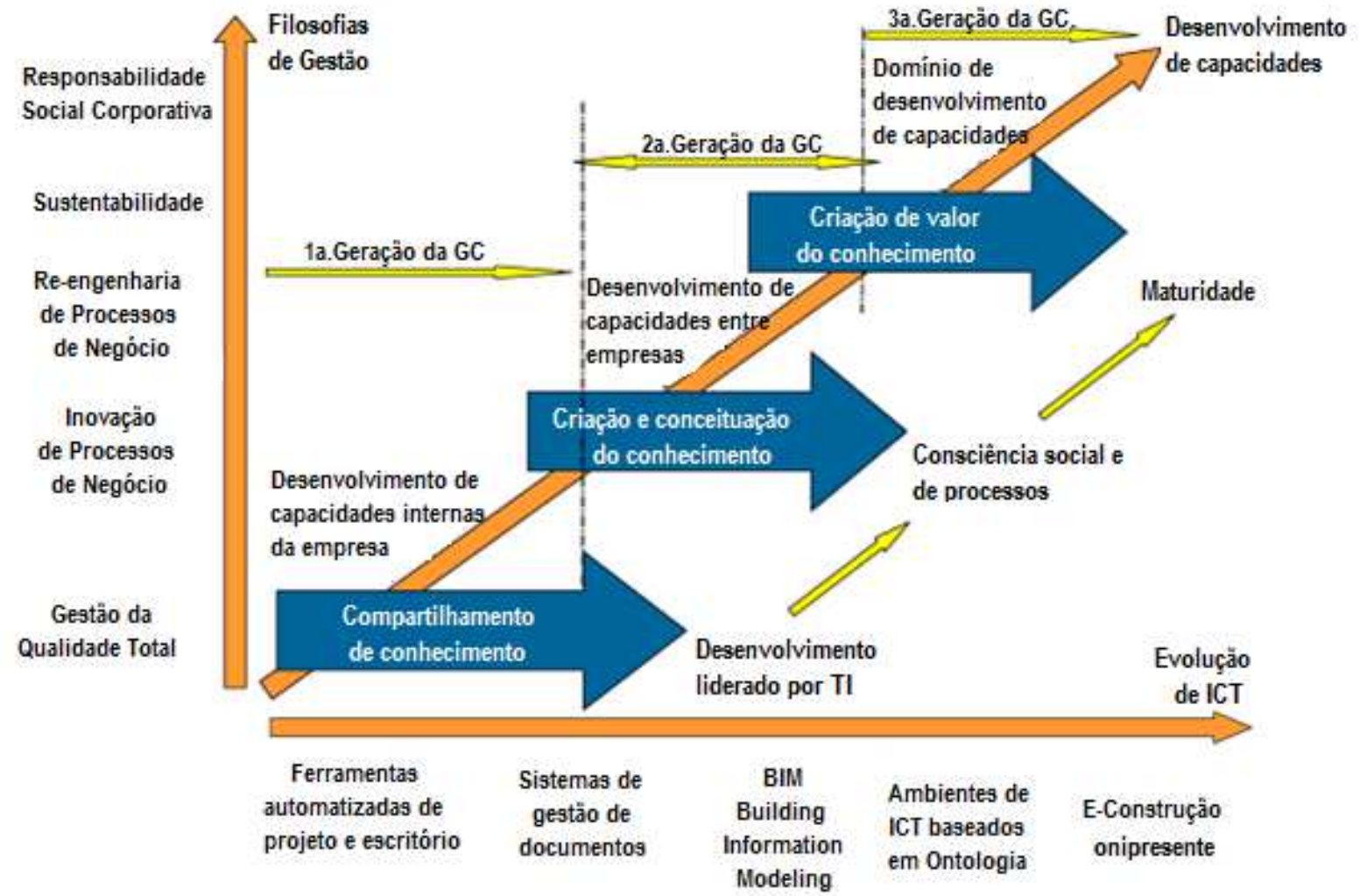

Figura 47 - Propostas de gerações da gestão do conhecimento no setor da engenharia e construção (adaptado de REZGUI; HOFPE; VORAKULPIPAT, 2010)

Conforme esta perspectiva evolutiva da gestão do conhecimento na engenharia e construção, após o desenvolvimento de competências internas às organizações e entre organizações, na próxima geração o foco será a criação de valor para a sociedade. 


\section{Estudos de caso}

Neste capítulo serão apresentados três estudos de caso com dados coletados em construtoras de São Paulo através de entrevistas semi-estruturadas, baseadas no roteiro do Anexo $\mathrm{A}$, realizadas com funcionários envolvidos no processo de projeto, ou que tenham influência sobre este processo, e outros agentes identificados no decorrer dos estudos de caso com potencial para desenvolver iniciativas relacionadas à gestão do conhecimento corporativo.

Além da análise de documentação, foi empregada como fonte de evidência a observação direta, realizando visita às obras em andamento no período da pesquisa para verificar: a aplicação dos procedimentos padrão do processo de projeto da empresa, a comunicação entre equipes de produção e de projeto, além da interação entre os agentes envolvidos no empreendimento (projetistas, equipe de obra, escritório, gerenciadora e cliente).

Ao final do capítulo será apresentada uma análise comparativa dos estudos de caso destacando os aspectos mais relevantes identificados.

\subsection{Estudo de caso: Empresa A}

\subsubsection{Caracterização da Empresa A}

\subsubsection{Informações gerais}

A empresa foi fundada por dois sócios engenheiros de produção em 1973, e tem mais de 5 milhões de metros quadrados de obras construídos e $R \$ 5$ bilhões em contratos nos últimos 10 anos. Atua em diversos segmentos do setor privado, tais como cultura, lazer, edifícios comerciais, residenciais, hotéis, shopping centers, indústrias e varejo.

O foco da empresa é a construção com maior volume de contratos de obras sob encomenda no setor privado, onde o arranjo e atuação das equipes de projetos e 
construção depende do tipo de contrato. Em geral, as licenças e aprovações dos projetos em órgãos públicos ficam sob responsabilidade do cliente.

Além da gestão de Projetos, outro diferencial apresentado pela empresa é o modelo de gestão de obras, baseado no conceito de gestão da Cadeia de Valor e todas as fases da edificação: Concepção; Projetos; Contratação e integração dos fornecedores; Construção; Início de operação (start up); Utilização, mobilizando todos os envolvidos na direção das expectativas do cliente. São apontados como principais diferenciais e benefícios para o cliente:

- Integração das competências e especialidades (o modelo convencional fragmenta as especialidades);

- Participação de fornecedores, trazendo idéias e soluções, desde o início da fase de projetos (pela prática convencional, projetistas e fornecedores não se falam);

- Construtibilidade: a edificação é projetada levando-se em conta como será construída, reduzindo custos;

- Responsabilidade: a empresa assume toda a responsabilidade pela obra (na gestão convencional, as responsabilidades são difusas).

Existe uma unidade dedicada exclusivamente a clientes do setor do varejo onde a empresa atua como gerenciadora em todo o ciclo dos empreendimentos (estudo de viabilidade, projeto, legalização e obra), que não será abordada no estudo de caso.

\subsubsection{Evolução da empresa}

Nos primeiros anos de existência, de 1973 a 1982, as características principais da administração eram: a centralização das decisões, em estilo paternalista, ênfase nos resultados e disposição de aceitar riscos.

Com a crise do início dos anos 80 , a empresa foi obrigada em seis meses a realizar um corte de $80 \%$ do quadro de 3.500 funcionários, reduzindo à metade de seu patrimônio líquido construído durante dez anos. Nesta fase, de 1983/1986, a estratégia de recuperação foi capitalizar rapidamente a empresa através do lucro reduzindo riscos pela seleção de clientes e diversificação (atuação nas áreas de 
telefonia, mercado imobiliário e obras públicas). A empresa busca introduzir princípios de engenharia de produção e de industrialização de processos construtivos.

Em 1986, começa a entrar no ranking das maiores empresas do setor, mas como forma de diferenciação em relação aos concorrentes na fase de 1987 a 1990, os sócios voltam à operação da empresa com a definição de novos objetivos: produtividade (maior competitividade), qualidade (diferenciação), agilidade e flexibilidade (para adaptar-se às mudanças do setor econômico, social ou político). A estratégia para atingir estes objetivos era mudar a cultura do setor da construção civil caracterizado por ser um segmento protegido por lei de defesa da engenharia nacional, cultura autoritária (mestre-feitor) e a cultura de que a execução da obra é de responsabilidade do mestre.

A partir de 1991, a empresa utiliza como diferencial a aplicação sistemática e estruturada da metodologia conhecida como "Engenharia e Análise do Valor" - EAV, baseada na identificação das funções presentes em cada componente do edifício e a verificação se seus custos se justificam face ao valor que agregam, sob o ponto de vista técnico, de uso e mercadológico.

Em 1993, a empresa introduz no mercado brasileiro novas tecnologias de dry construction (construção seca), tais como o drywall (paredes de gesso acartonado), estruturas de concreto, escoras metálicas e fachadas pré-moldadas, trazidas do Canadá, Alemanha e Estados Unidos com o objetivo de racionalização da construção. No entanto, a unidade de negócio foi extinta quando as siderúrgicas começaram a entregar o aço cortado e dobrado e a empresa teve que terceirizar o serviço. A empresa de pré-moldados, criada também na década de 1990, existe até hoje, mas sua participação foi vendida para o sócio canadense.

Em 1998, foi criada a unidade FAST para atender com exclusividade à implantação de postos de combustíveis de uma rede multinacional. A unidade especializou-se em atender empresas que necessitam da execução rápida dos serviços, com a realização simultânea de várias ações com abrangência em todo o território nacional. Com esta especialização a empresa começou a atender à redes bancárias e cadeias do setor de varejo, cuja cadeia de valor compreende: o estudo de viabilidade (técnica e legal), projetos, licenciamento das obras e imóveis, elaboração 
de orçamentos, contratação de fornecedores, logística dos equipamentos e materiais, gestão da obra e manutenção das instalações.

Em 2000, foi a primeira empresa brasileira a fazer parte do USGBC - United States Green Building Council e foi empresa membro-fundador do Green Building Council Brasil.

Em 2006, no planejamento estratégico da empresa, foi adotada como forma de medir o desempenho organizacional a metodologia do BSC - Balanced Scored Card $^{10}$, e criado o Plano de Metas 2010 - estabelecendo planos de investimentos para atingir estes objetivos, levando em conta a rentabilidade, a satisfação dos clientes, a reciprocidade com os fornecedores e a valorização do seu capital humano. Estabeleceu-se como objetivo estratégico atingir uma meta de EBITIDA Earnings Before Interest Taxes Depreciation Amortization (lucro antes dos juros, impostos, depreciação e amortização) de 50 milhões até 2010.

Para oferecer um serviço mais especializado para seus clientes foram criadas unidades de negócio direcionadas para atender às demandas de setores específicos: Hotelaria \& Hospitais, Indústria \& Comércio (envolve Varejo, Cultura, Supermercados e outros), Edificações Imobiliárias (Residenciais e Comerciais), Propriedades (desenvolvimento de negócios imobiliários) e a divisão FAST, categorizada por obras rápidas e em série. $O$ desenho organizacional foi alterado para espelhar a nova estratégia da empresa onde cada unidade de negócio teria suas metas e resultados acordados com a alta administração.

Diversos serviços que não faziam parte da atividade principal da empresa foram terceirizados, tais como: limpeza, processos jurídicos de maior complexidade, contabilidade.

Para sustentar seu crescimento, sem perda das competências técnicas ou da qualidade dos serviços prestados, foi retomado o Programa de Formação de Novos Executivos, que visava identificar novos talentos e capacitar seu corpo técnico e profissional. A base para entrar num ciclo acentuado de crescimento seria: visão no Projeto, processo eficiente e resultado entregue.

10 O BSC - Balanced Scorecard é uma metodologia de medição e gestão de desempenho desenvolvida pelos professores da Harvard Business School, Robert Kaplan e David Norton, em 1992. Esse modelo traduz a missão e a estratégia de uma empresa em objetivos e medidas tangíveis. 
O PMO (Project Management Office) ou Escritório de Projetos foi implantado como unidade independente, diretamente ligada à presidência, para prestar suporte aos gerentes de Projeto e sua equipe, com o objetivo de conduzir e organizar as atividades dos Projetos (obras) da empresa.

Os conceitos e ferramentas da metodologia de gestão de Projetos do PMI (Project Management Institute) foi adotada como base para redesenhar o sistema de gestão próprio, o SMGP - Sistema Método de Gestão de Projetos, a fim de assegurar confiabilidade no atendimento de prazos, nos orçamentos, na qualidade e nos demais requisitos esperados pelos investidores, clientes e usuários da edificação. $O$ ciclo de vida dos negócios foi definido de acordo com as fases de: Proposta e Negociação; Estruturação; Execução e controle; Aceitação; Pós Entrega (Assistência Técnica).

Em 2007, a empresa iniciou a implementação do sistema de gestão empresarial $E$ Business Suíte da Oracle (módulos de gestão de Projetos, administrativo-financeiro e suprimentos), investindo $\mathrm{R} \$ 4$ milhões com retorno do investimento estimado em três anos. O sistema permitiria maior controle das obras, desde a coleta de informações para o orçamento até o faturamento e uma integração maior entre os departamentos do escritório central e as obras e entre todos os departamentos da empresa (MÉTODO, 2008). O PMO conduziu treinamentos para diretores e gerentes sobre os novos sistemas e processos para que replicassem a suas equipes.

Neste ano, a empresa registrou um lucro líquido de $R \$ 14,3$ milhões, o maior de sua história, representando crescimento de $113 \%$ e um aumento de $60 \%$ do quadro de funcionários comparado a 2006, quando contava com 350 funcionários.

Em 2008, com o impacto da crise econômica mundial, o prejuízo líquido da empresa foi de $R \$ 3,8$ milhões. Sem ter como crescer entre as empresas de construção que não fazem obras públicas, chegando ao seu limite de crescimento no segmento de edificação, em 2009, a empresa ampliou sua atuação para infra-estrutura, através da aquisição de uma empresa de engenharia que atua no segmento de óleo e gás.

Com o objetivo de adequar os processos da empresa garantindo a excelência operacional, melhoria da imagem e aumento da competitividade perante o mercado e a sociedade, em 2010 a empresa criou o SIG - Sistema Integrado de Gestão de Qualidade e Meio Ambiente conforme as normas ISO9001, ISO14001 e OHSAS 
18001, com procedimentos para gestão da qualidade, voltado para processos e gestão de meio ambiente, abrangendo procedimentos de obra e processos operacionais/ administrativos do escritório central.

Em 2010, foi criada uma Unidade de Estruturas, cujo foco é a produção de estruturas de concreto para atender a todas as construções da empresa (em São Paulo e no futuro abertura de uma filial no Rio de Janeiro e Salvador) e iniciar parcerias com terceiros. Por ser um braço estratégico da construtora, a nova companhia apresenta vantagens competitivas frente aos concorrentes, pois conta com os mesmos acordos de preço e de prazo da empresa, no que se refere a aço e cimento (a construção da estrutura custa cerca de $25 \%$ do valor total do empreendimento). O novo negócio também compartilha a área de logística, engenharia, projeto, planejamento, orçamento, tecnologia da informação, recursos humanos, jurídico e administrativo. O diferencial apresentado pela empresa é a entrega da obra dentro do prazo, podendo participar do projeto desde a sua concepção e assim reduzir perdas de material e de tempo.

O investimento inicial foi baixo, pois a empresa aluga as máquinas e equipamentos, mas teve que adquirir itens que não costumava comprar, como pregos e parafusos, além de vestuário e refeições para os funcionários que irão integrar o novo quadro da empresa.

A empresa tem expectativa de um crescimento de $30 \%$ e $35 \%$ ao ano e entrada na bolsa em 2014.

\subsubsection{Missão, valor e visão}

A missão da empresa engloba, não apenas a gestão da produção (construção), mas a gestão do empreendimento como um todo: "Prestar serviços de gestão e construção de obras de edificação e infra-estrutura, atuando em todo o ciclo de vida do empreendimento".

Os valores em que a empresa acredita são descritos como: "Agir de forma ética e sustentável; Cumprir o prometido; Progredir sempre; Respeitar o ser humano; Ser uma única Método; Ter compromisso com alto desempenho". 
$\mathrm{Na}$ descrição detalhada destes valores podem ser destacados alguns itens que demonstram que a cultura da empresa pode propiciar iniciativas de gestão do conhecimento:

- Inovar, revolucionar, antecipar-se e criar novos padrões de atuação na busca de melhores resultados;

- Potencializar a sinergia entre funcionários internos e externos;

- Desenvolver e disseminar conhecimento.

- Compromisso com o desenvolvimento contínuo com foco no alto desempenho sejam em processos, soluções tecnológicas e no desenvolvimento de nossos profissionais;

- Identificar, atrair, desenvolver e reter profissionais de alto desempenho;

- Buscar com as melhores práticas a solução para nossos clientes;

Em sua declaração de visão é claramente expressa a estratégia de diferenciação adotada pela empresa e a relevância do conhecimento: "Ser reconhecida como a melhor empresa de engenharia do Brasil nos setores em que atuamos, pela qualidade e desenvolvimento constante de nossos profissionais e pelo alto valor agregado aos clientes através de: Especialização (conhecimento dos negócios do cliente); Domínio do conhecimento técnico em Engenharia; Excelência em gestão de Projetos e Logística e Suprimentos”.

A empresa apresenta ao mercado como seu diferencial:

- Oferecer a melhor solução ao cliente através da especialização (conhecimento do negócio do cliente) e do conhecimento técnico em Engenharia.

- Oferecer excelência no atendimento

- Entregar o prometido através da utilização das melhores práticas em: Coordenação de projeto; Gestão de Projeto; Gestão da cadeia de valor; Construção sustentável. 


\subsubsection{Estrutura organizacional}

A criação de Unidades de Negócio independentes e específicas por setor para atender às demandas de seus clientes, indicou uma tendência da empresa para a descentralização. No entanto, o poder decisório continuou centralizado na alta administração. Com uma demanda inconstante por setor devido às oscilações do mercado, em 2010 houve uma nova alteração na estrutura organizacional da empresa, eliminando as equipes dedicadas exclusivamente às unidades de negócio.

O modelo de estrutura organizacional adotado pela empresa, conforme Figura 48, pode ser classificado como uma estrutura matricial balanceada, que é uma combinação de duas formas de departamentalização: funcional e por Projetos.

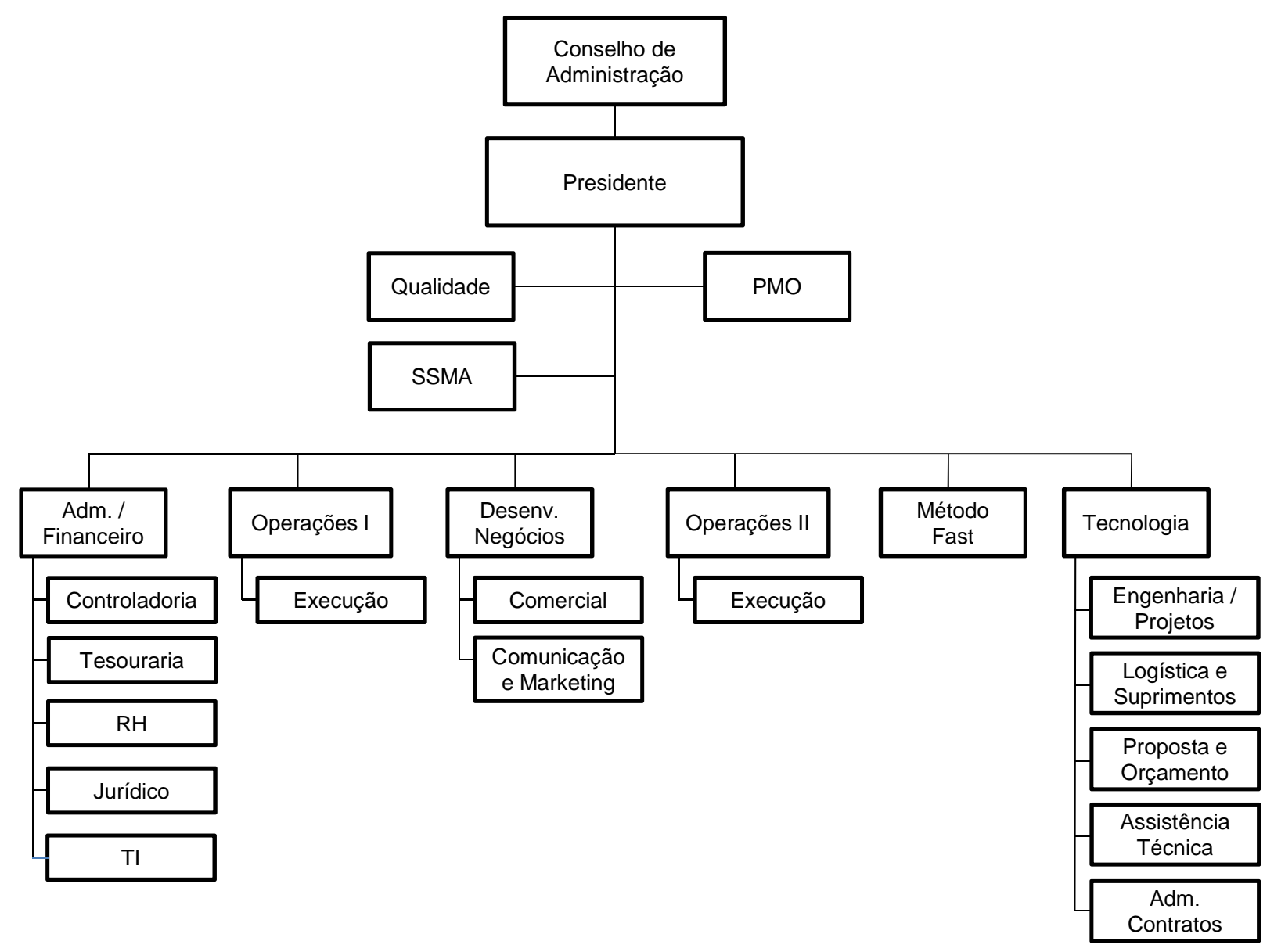

Figura 48 - Estrutura organizacional da Empresa A

Conforme definição do Guia PMBoK (PMI, 2008), um Projeto é "um esforço temporário empreendido para criar um produto, serviço ou resultado exclusivo". Assim cada nova obra é definida como um Projeto: um Gerente de Projetos do 
departamento de Engenharia é designado para cada Projeto assumindo a responsabilidade por ele sem, no entanto, ter autoridade total sobre o mesmo. Alguns membros da equipe são destacados de seus departamentos para trabalharem reportando-se ao gerente de Projeto e outros desenvolvem o Projeto em acréscimo ao seu trabalho normal, devendo reportar-se ao Gerente de Projetos e ao gerente funcional. Desta forma, os membros dos departamentos têm papéis de clientes e fornecedores internos, de acordo com a função que exercem. Existem funcionários que têm dedicação parcial a várias obras, como é o caso do gerente de instalações do estudo de caso.

As unidades de Operação I e II são as unidades que abrigam as equipes formadas para gerenciar os Projetos (obras) que, em conjunto com as áreas de Planejamento, Comercial e Assistência técnica, compõem as áreas funcionais que operam o negócio.

Os departamentos das chamadas unidades de apoio ao negócio, estão organizados conforme a estrutura classificada como funcional: uma hierarquia em que cada funcionário possui um superior bem definido (gerente funcional): $\mathrm{RH}$, Jurídico, Financeiro, TI, Comunicação e Marketing, Engenharia e Projetos, Administração de contratos, Qualidade, PMO, SSMA. Alguns destes departamentos, tais como Jurídico, Engenharia, dão suporte às outras unidades da empresa de acordo com as demandas de serviço destacando um membro específico para acompanhar todo o Projeto.

As unidades de Qualidade, SSMA (Saúde, Segurança e Meio ambiente) e PMO reportam-se diretamente à alta direção da empresa.

A unidade de Tecnologia é composta pelos departamentos de: Engenharia e projetos, Logística e suprimentos, Proposta e orçamento, Assistência técnica e Adminstração de contratos.

A equipe de projetos, subordinada à uma gerente de projetos, é composta por 43 arquitetos da unidade de Tecnologia, incluindo os arquitetos dedicados exclusivamente aos projetos da unidade FAST. Em geral, as obras têm um ou mais arquitetos dedicados dependendo do contrato com cliente, tamanho e complexidade da obra. A equipe de projetos dá suporte à equipe de propostas e orçamentos, quando necessário. 
O processo de compra de materiais, que antes era descentralizado, feito nas obras, passou a ser centralizado no departamento de Suprimentos a fim de otimizar os custos, que implica em boa logística e planejamento. Todos os fornecedores de material, mão de obra e serviços passam por um processo de seleção antes de ser cadastrados como forma de garantir a qualidade do serviço contratado.

A unidade FAST que atende a clientes com necessidades específicas (grande volume de ações simultâneas com ampla abrangência geográfica), dispõe de uma estrutura organizacional independente com arquitetos e engenheiros especializados nos padrões e tipo de demanda destes clientes. Apenas o departamento de Permits (Aprovações legais) desta unidade, que coordena as licenças e aprovações em órgãos públicos, dá suporte às unidades de Operações I e II, quando necessário.

\subsubsection{Ciclo de vida dos empreendimentos}

O ciclo de vida dos negócios da empresa, como mostra a Figura 49, foi estruturado segundo a metodologia do PMI onde foram definidas as fases de:

- Qualificação (etapa de tomada de decisão que define a passagem para a fase de proposta)

- Proposta e Negociação (apoio na concepção: estimativa de custo; construtibilidade; engenharia e análise de valor)

- Estruturação (etapa de pré-execução: Planejamento e Logística; Estrutura de contratações; Qualificações de fornecedores; Contratações; Orçamento executivo)

- Execução e controle (Integração de Fornecedores; Fiscalização em campo; Gestão de contratos; Avaliação de desvios e proposta de soluções; Entregas parciais e finais de cada pacote da obra; Obtenção da certificação ambiental)

- Aceitação

- Pós Entrega (Assistência técnica) 


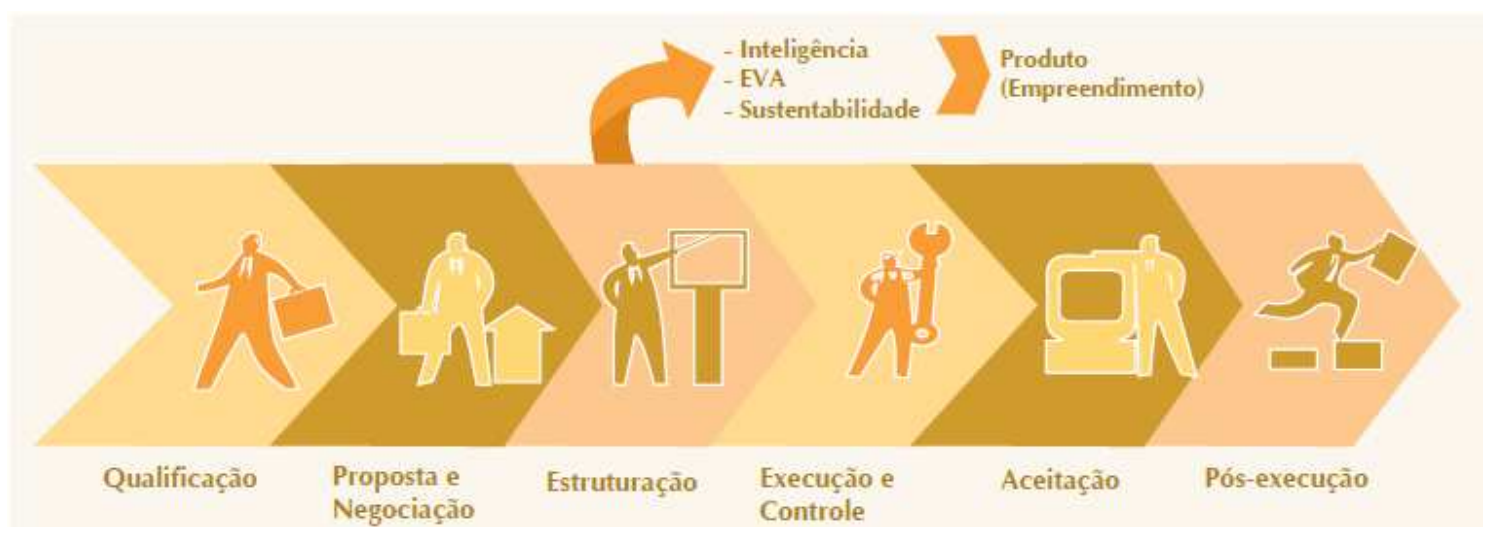

Figura 49 - Ciclo de vida do produto (PARDINI, 2010)

O envolvimento da equipe de engenharia e projetos em todas as etapas do projeto desde sua concepção, passando pela coordenação dos projetos executivos, engenharia e análise de valor, acompanhamento e obtenção de licenças e autorizações, análise de atendimento dos conceitos de sustentabilidade e gestão da construção, depende do tipo de contrato estabelecido com o cliente.

\subsubsection{Sistemas de gestão}

\section{- SMGP (Sistema Método de Gestão de Projetos)}

A fim de assegurar confiabilidade no atendimento de prazos, nos orçamentos, na qualidade e nos demais requisitos esperados pelos investidores, clientes e usuários da edificação, a empresa desenvolveu um sistema de gestão próprio o SMGP (Sistema Método de Gestão de Projetos) que foi redesenhado em 2006 adotando os conceitos e ferramentas da metodologia de gestão de Projetos do PMI (Project Management Institute). Para prestar suporte aos gerentes de Projeto e sua equipe, com o objetivo de conduzir e organizar as atividades dos projetos, foi implantado, como unidade independente, o PMO (Project Management Office) ou Escritório de Projetos que, em 2010, era composto por uma gerente e dois engenheiros recém formados para acompanhar nove obras. As atribuições do PMO são a manutenção do SharePoint implementado em 2009, desenvolvimento e melhoria da ferramentas de gestão, reunião mensal de desempenho, acompanhamento do Plano de Projeto das obras. 
Após a estruturação do site do SMGP em 2007, foram realizados treinamentos sobre sua utilização para todos os diretores, gerentes, engenheiros de planejamento, com o objetivo que estes replicassem para suas equipes de obra. Como não foram todas as obras que conseguiram replicar o treinamento, nas visitas mensais do PMO à obra as dúvidas da equipe são esclarecidas no dia a dia da obra, e novos treinamentos foram estruturados para o pessoal administrativo e de produção. $\mathrm{Na}$ visita é realizada uma reunião de desempenho para acompanhamento da obra: verificar se os processos e o Plano do Projeto estão sendo seguidos, verificar o andamento do cronograma, etc.

Em 2009, o PMO verificou, por meio de uma auditoria nas obras, que apesar da empresa ter estruturado os três pilares da metodologia de gestão de Projetos (processos, treinamento e ferramentas), os funcionários não conheciam direito os processos e estes não eram fáceis de executar. Como forma de integrar as atividades e padronizar as informações e documentos entre todas as obras e departamentos funcionais, o PMO desenvolveu uma ferramenta de colaboração adotada por todos os departamentos da empresa estruturada no SharePoint (programa da Microsoft).

Devido ao grande investimento realizado com a implementação do sistema de gestão empresarial ERP, o PMO não dispunha de verba para aquisição de um novo programa para o sistema colaborativo. Apesar da área de TI não apoiar a utilização, por desconhecimento do programa, o PMO utilizou uma versão gratuita do SharePoint pela internet, que, por ser um sistema de fácil utilização e muito flexível, possibilitando a adaptação de acordo com as necessidades dos usuários, aos poucos começou a ser utilizado por outras áreas da empresa (jurídico, assistência técnica) até que foi tomada a decisão de formalizar sua utilização para toda a organização adquirindo a versão completa do programa.

Para integrar a teoria com a prática foram criados os sites de todas as obras no SharePoint e desenvolvidos: o Guia prático do SMGP, um botão "Saiba Mais" com um texto explicativo sobre o procedimento, além de um link para acessar o procedimento detalhado.

Os procedimentos, registro dos processos foram arquivados e dispostos de acordo com as nove áreas de conhecimento do PMl: Escopo, Tempos, Custos, Riscos e oportunidades, Integração, Qualidade, Recursos Humanos, Aquisições e 
Comunicação. Cada obra tem seu próprio portal, mas os documentos estão no formato de formulário para preenchimento, onde o usuário não tem como alterar sua estrutura. O PMO identifica o melhor material que é produzido pelas obras e atualiza o site modelo onde são divulgadas as melhores práticas (plano de ataque da obra, análise de stakeholders, etc) de uma forma estruturada.

Foram desenvolvidos os indicadores de gestão com notas para cada critério. No entanto, quando os Projetos começaram a ser medidos foi verificado que existiam os processos, os funcionários estavam utilizando as ferramentas de controle, mas os números não representavam a realidade. Por exemplo, apesar de o cronograma apontar um índice de desempenho de prazo bom, a obra atrasava. Por determinação da alta direção, para aumentar a confiabilidade, todas as informações só seriam consideradas válidas pela empresa se estivessem armazenadas nos sistemas SharePoint ou Oracle. Com a certificação ISO 9001 a utilização dos sistemas foi incluida nos procedimentos da empresa tornando-se obrigatória.

Segundo a gerente do PMO, apesar da resistência inicial, as obras estão satisfeitas com a ferramenta, $90 \%$ dos usuários alegam que têm mais controle sobre as informações, que fluem melhor dentro da obra e fora dela. A maior reclamação é com problemas de infra-estrutura, falhas de conexão. Devido à flexibilidade do SharePoint foi possível evoluir o site, acrescentando várias melhorias, de acordo com as necessidades dos usuários para facilitar sua utilização.

Os sistemas da Oracle e SharePoint não são integrados, mas podem auxiliar em alguns tipos de análise, pois existem alguns dados que estão armazenados no SharePoint que podem ser visualizados no site da obra e que tem um link para o aplicativo do Oracle. Algumas informações, como por exemplo, a lista de alteração de escopo está no site do SharePoint e indica um número de ASECs (Aprovação de Alteração de Escopo) aprovadas pelo cliente, mas no Oracle o Plano do Projeto deve ser atualizado conforme o que foi aprovado.

O plano para 2010 foi a previsibilidade com foco na confiabilidade, criando ferramentas para verificar se as informações geradas são confiáveis para tomada de decisões. 
- SIG (Sistema Integrado de Gestão de Qualidade e Meio Ambiente)

Enquanto o PMO tem o foco no Projeto, a área de Qualidade está fazendo a integração entre as áreas funcionais da empresa, para que possam dar suporte para o processo de Operações - as obras. Além da certificação da ISO 9001 com o escopo de engenharia, gestão de obra para construção civil, abrangendo todo ciclo de vida em que a empresa atua, foi desenvolvido o SIG (Sistema Integrado de Gestão de Qualidade e Meio Ambiente), conforme as normas NBR ISO 9001:2000 e ISO 14001:2004, com procedimentos para gestão da qualidade, voltado para processos e gestão de meio ambiente, abrangendo procedimentos de obra e processos operacionais/ administrativos do escritório central.

Alinhado com a estratégia de incentivar a excelência, a empresa mantém um plano de atração, desenvolvimento e retenção de seus talentos, através do Programa de Remuneração Variável, com metas estabelecidas para todos os profissionais e o incentivo de crescimento profissional através do Programa de Desenvolvimento contínuo com treinamentos específicos.

\section{- Gestão da Informação}

A empresa utiliza o sistema ERP, sistema integrado de gestão empresarial EBusiness Suíte da Oracle (módulos de gestão de Projetos, administrativo-financeiro e suprimentos), que unifica as atividades operacionais de diferentes departamentos da empresa.

\subsubsection{Assistência Técnica}

A área de Assistência Técnica, vista como área que dava muito prejuízo para a empresa, iniciou em 2005 um trabalho investigativo que detectou que muitos serviços realizados pela área não eram de manutenção corretiva, e sim ocasionados pela falta de manutenção periódica do proprietário, o que gerava gastos que não eram repassados ao cliente por falta de uma padronização de controle dos serviços.

Após três anos coletando dados foi possível fazer um mapeamento dos problemas da empresa onde foi verificado que muitos eram recorrentes. A partir deste 
mapeamento foi possível identificar quais eram as deficiências da empresa que poderiam ser melhoradas. Esta primeira etapa de análise foi sobre problemas construtivos onde se destacavam como principais problemas: impermeabilização, revestimento e instalações em geral, dentre os dez grupos de sistemas construtivos definidos.

$\mathrm{Na}$ segunda etapa, ao invés de utilizar diversas planilhas de Excel que eram constantemente modificadas, foi também modificada a estrutura da área através da padronização de controle quando foi desenvolvido um sistema de controle de ocorrências e patologias das obras.

Como não era possível padronizar através da aquisição de programa específico, a área fez uma pesquisa no mercado e elegeu o SharePoint para esta estruturação, por ser um programa livre e de fácil utilização. O SharePoint foi utilizado para que a Assistência Técnica tivesse um canal no qual fossem registradas todas as solicitações do cliente (quando entrou a solicitação, quem fez a solicitação, o histórico do cliente gerado através dos dados da pesquisa de satisfação dos atendimentos). Esta iniciativa gerou um banco de dados que possibilitou disponibilizar dados estatísticos para a empresa sobre as ocorrências das obras, para evitar repetição dos problemas. Pôde ser verificado que, dos problemas recorrentes, alguns estavam associados ao gerente. Quando determinado gerente finalizava duas obras foi detectado que as duas obras tinham o mesmo tipo de problema. Não eram problemas isolados, mas problemas de sistema construtivo de um modo geral que se transformavam em uma patologia. Os problemas são decorrentes da forma de execução, pois como a empresa recebe na maioria das vezes o projeto do cliente, os projetos são muito falhos ou incompletos. Com projeto sem detalhamento construtivo, muitas soluções são definidas na obra baseada em experiências anteriores do mestre ou engenheiro de produção que podem não atender às normas técnicas e não há uma avaliação do impacto desta decisão no sistema como um todo.

Os problemas identificados foram separados em: Patologia congênita (falhas de projeto, vêm desde quando o projeto é concebido), Patologias Executivas e Patologias decorrentes de Uso e materiais (lote de fabricação).

Depois de organizar a área, criar um banco de dados eficiente disponibilizando dados estatísticos para toda empresa possibilitando alertar o gerente sobre os 
problemas de suas obra passadas e disponibilizar no site do SharePoint dados a outros gerentes sobre os problemas das outra obras, a área procurou sensibilizar a alta direção de que a empresa deveria dar mais importância a este assunto para a empresa como um todo. Além do prejuízo financeiro, os problemas de patologia poderiam afetar a imagem da empresa, que não é fácil de recuperar.

Em 2009, surgiu a idéia de criar um curso de patologia na construção civil para a equipe de arquitetos e engenheiros para que verificassem, em suas atividades diárias, problemas em potencial.

O curso de patologia foi desenvolvido em dez módulos baseado no mapeamento, cada módulo abordando um sistema construtivo. O material continha informações práticas de problemas encontrados nas obras da empresa e orientações teóricas baseadas em normas técnicas, para que os funcionários tivessem condições de analisar um projeto e identificar se estava atendendo aos requisitos mínimos da norma NBR. O curso foi alinhado ao programa de trainees que criaram os check lists.

No curso de dez meses (uma aula por mês) os 103 participantes foram separados em grupos e incentivados a aplicar os conhecimentos adquiridos em cada módulo em seu dia a dia para, ao final do curso, compartilhar com o grupo através de uma apresentação os conceito aplicado na prática. O objetivo do trabalho final foi identificar se o que estava sendo executado nas obras estava de acordo com as normas e boas práticas apresentadas no curso, se havia experiências anteriores que não foram bem sucedidas, etc. Apesar da empresa não ter um departamento de qualidade na época todos os participantes do curso tornaram-se, de certa forma, agentes da qualidade. $O$ critério para definição dos participantes do primeiro grupo foi o tempo de empresa, priorizando os engenheiros, arquitetos, técnicos e tecnólogos juniores ou novos ingressantes na empresa para que não tivessem os mesmos vícios construtivos dos mais antigos.

Cada módulo (Impermeabilização, Revestimentos de Fachada, Paredes e piso) foi estruturado da seguinte forma:

- Dados estatísticos, mostrando quanto aquele item (por exemplo, o revestimento) corresponde nos problemas da empresa de um modo geral;

- Projeto/ detalhes; 
- Tabelas de causas e efeitos das patologias, onde são divididos em todos os tópicos que podem causar aquela patologia (a causa normalmente é decorrente de diversos fatores que são classificados em: projeto, estrutura de concreto, alvenaria, camada de regularização, argamassa colante, placa cerâmica, execução, diversos, fatores externos que afetam diretamente no item);

- Casos práticos (fotos), porque ocorreram;

- Recomendações para execução (o objetivo é mostrar o que foi feito errado e porque, recomendando melhor forma de execução, mas sem detalhar todo o processo construtivo). A partir daí foi verificada a necessidade da criação do NSC - Núcleo de Sistemas Construtivos para orientar o processo construtivo como um todo;

- Relação de normas técnicas para consulta (Assistência Técnica solicitou que fosse disponibilizado maior número de normas para acesso).

A divulgação dos casos levantados nas obras da empresa foi autorizada pela presidência como forma de conscientização e para evitar a repetição dos erros, com o objetivo que estes se tornem exemplos do passado e que nos próximos cursos sejam apresentados apenas exemplos do mercado.

Ao término do curso foi feito um levantamento onde foram identificados 87 problemas patológicos que foram evitados. Isto mostra que as pessoas treinadas, e que efetivamente assimilaram os conhecimentos, tem grande potencial de contribuição com a melhoria dos resultados das obras. A partir do curso de patologia a área de Assistência Técnica se transformou uma área de consultoria, à qual as pessoas pedem orientação sobre execução dos serviços ou tiram dúvidas sobre problemas, solicitam visitas às obras, e a área de projetos pede orientações para novos Projetos em desenvolvimento a fim de evitar patologias que foram apresentadas no curso (por exemplo: assentamento de piso cerâmico em laje nível zero). Conscientizadas dessa necessidade, as pessoas começaram a desenvolver soluções desta a parte técnica.

O curso foi ministrado pela Assistência Técnica, mas no próximo ano será feita uma parceria com a área de projetos, para unir a experiência de retroalimentação da Assistência Técnica com as dificuldades encontradas na área de projetos nas etapas 
de compatibilização e com o objetivo de desenvolver projetos mais racionalizados, alinhado às necessidades do cliente na fase de manutenção periódica. Melhores soluções de projeto podem minimizar o tempo e os gastos com manutenção, tornando a empresa mais competitiva.

Serão incorporados aos próximos cursos exemplos de patologias do mercado, pois os problemas da empresa não diferem do que acontece no mercado. Temas sobre os quais a empresa já está conscientizada serão menos detalhados. A impermeabilização, que foi apontada como o maior problema da Assistência Técnica, está chamando a atenção da equipe da obra, de forma que nenhum serviço é executado sem projeto, o que reduziu os problemas. O serviço de impermeabilização em si não representa um custo elevado para a Assistência Técnica, principalmente por estar na garantia do fornecedor. Mas os custos associados a ele, tais como os revestimentos de piso, são muito elevados e são arcados pela empresa. Além do transtorno causado ao cliente que já está ocupando o edifício, prejudica a imagem da empresa.

Foi verificado que mesmo seguindo as recomendações da norma nem todos os problemas são evitados. Existem muitos problemas que surgem depois da obra executada, que são decorrentes de uma falha na concepção de projeto ou forma de execução. $\mathrm{Na}$ época de chuvas, principalmente as chuvas que superam o índice pluviométrico normal, as calhas não suportam o volume de água, pois não foi previsto em projeto. A Assistência Técnica alertou a área de projetos para analisar se os novos projetos estão dimensionados de acordo com os índices pluviométricos reais e não conforme a norma que está defasada. Nos check lists foram indicadas as recomendações da norma incluindo as recomendações de boas práticas baseada na experiência da empresa. Estas recomendações foram enviadas ao SindusCon para incorporar à NBR, pois a gerente da Assistência Técnica faz parte do grupo que está avaliando duas normas e da revisão do Manual do proprietário e Manual de manutenção de condomínio.

Não houve uma situação que determinado projetista apresentasse problemas recorrentes, pois todos ficam numa mesma média, mas foi possível mapear quais fornecedores davam mais trabalho. Por exemplo, determinada empresa de instalações dava muito prejuízo, pois gerava muitos chamados da Assistência 
Técnica e não atendia adequadamente o pós-obra mesmo estando em período de garantia.

Um problema que ocorria com frequência anteriormente por falta de retroalimentação era a contratação, pela área de suprimentos, de fornecedores que não estava prestando um bom serviço no período de garantia. Para resolver esta situação, a Assistência Técnica começou a entregar mensalmente a Suprimentos uma avaliação dos fornecedores, que foi posteriormente aprimorado por Suprimentos evoluindo para um sistema de avaliação de fornecedores.

O curso de patologia é interno, mas algumas áreas já pensaram em envolver os fornecedores: suprimentos já pensou em cada obra dar treinamento aos fornecedores, projetos já pensou em compartilhar sua experiência com os projetistas, mas como a Assistência Técnica tem uma equipe muito reduzida não viabilizaria este trabalho. A equipe é composta por cinco pessoas: uma gestora, três técnicas e um auxiliar administrativo para atuar em trinta obras com perspectiva de mais três até o final do ano.

O material do curso está disponibilizado no SharePoint no site de treinamento da Assistência Técnica, mas para facilitar a busca a pessoa pode digitar uma palavra chave em qualquer tela do site, sem entrar na pasta da Assistência Técnica, e o programa lista todos assuntos relacionados àquela palavra.

Foi feito um link com o Método Wiki que tem uma página com as informações da Assistência Técnica. Se a pessoa digitar revestimento será listado tudo que existe no NSC sobre os sistemas construtivos (como executar) e tudo relacionado ao curso de patologia.

Para que o NSC começasse a desenvolver os seus trabalhos (era uma equipe muito jovem e nova na empresa) foram realizadas várias reuniões onde a Assistência Técnica disponibilizou material desenvolvido até aquele momento, assim como o grupo do PET - Projeto de Especialidades Técnicas, que também já havia desenvolvido um bom material (esta iniciativa foi descontinuada com a mudança de gerencia de projetos). Se o NSC estiver bem estruturado e tudo for efetivamente seguido, haverá uma redução das ocorrências de patologia. Diminuindo o volume de trabalho da Assistência Técnica a equipe poderá ser mais enxuta, possibilitando aumentar a atuação na Qualidade na obra. 
Como muitas decisões são tomadas na obra a empresa percebeu a importância do As Built para a Assistência Técnica detectar eventuais problemas após a entrega da obra, que não estão demonstrados no projeto executivo, evitando intervenções desnecessárias que acarretam em custos.

Quando um Projeto se encerra ele só é repassado à Assistência Técnica após seguir uma série de procedimentos: existe um check list de documentos que a equipe de obra deve providenciar contendo: todas as ASECs (Alterações de Projeto autorizadas pelo cliente); o projeto executivo; o As Built não é obrigatório, pois muitas vezes o cliente não quer contratá-lo; Termos de entrega definitivos e provisórios; Manuais de garantia de equipamento; Manual do Proprietário; rastreabilidade dos principais assuntos técnicos que ocorreram durante a obra (histórico de problemas encontrados com algum sistema na obra).

Quando a Assistência Técnica é acionada pelo cliente, deve analisar qual é o problema, a solução, se está dentro do prazo de garantia, pois apesar de prestar serviço apenas de manutenção corretiva, muitas vezes a solicitação refere-se a uma manutenção preventiva. No caso de uma orientação sobre determinado serviço, não há um custo para o cliente a menos que seja necessário algum reparo. Quando o dano foi causado por mau uso, a Assistência Técnica pode fazer o reparo em parceria com o cliente, mas o custo não é arcado pela empresa.

Se for detectado que um erro é congênito (proveniente do projeto) o projetista é acionado pela Assistência Técnica; por exemplo, se não for especificado em um projeto de fachada que é necessário prever juntas a cada 3-6 $\mathrm{m}$, conforme estabelecido na NBR. Como o projetista tem o perfil de não assumir a responsabilidade, segundo a gerente da Assistência Técnica, nunca foi possível imputar-Ihe a responsabilidade para que assumisse o custo decorrente do erro de projeto. Para serviços mais caros, do tipo pavimentação asfáltica, é sempre feito um seguro de projeto, mas as obras mais antigas não têm este seguro. Foi citado como exemplo o caso de um projeto de estrutura metálica que especificava um material inadequado que foi aplicado e deverá ser substituído pela empresa, mesmo a obra não estando mais no período de garantia. 


\subsubsection{Funcionários entrevistados (unidades de análise)}

Foram coletados dados através de entrevistas semi-estruturadas realizadas com funcionários das áreas de Projetos do escritório central e da obra que participaram do processo de projeto, conforme Quadro 14. O engenheiro de instalações da área de Orçamentos participou da fase de proposta onde foram estudadas alternativas de projetos com o projetista de instalações, indicado pelo cliente, com o objetivo de redução de custo da obra para viabilizar contratação da empresa e o gerente de instalações da obra.

As áreas identificadas com potencial para desenvolver iniciativas relacionadas à gestão do conhecimento foram o PMO (Escritório de Projetos) que re-estruturou o sistema de gestão da empresa, o NSC (Núcleo de Sistemas Construtivos) e a Assistência Técnica. A gerente da área de projetos faz parte do Núcleo de Sustentabilidade e coordenou a implantação do sistema de qualidade como gerente da área de Processos e Desenvolvimento, pois foi responsável pela implantação da ISO 9001 na unidade Fast. Devido à obtenção de certificação LEED Gold, a obra tem uma engenheira de Qualidade e sustentabilidade responsável pelo Plano de Execução para certificação e acompanhamento do processo junto à consultoria de sustentabilidade externa. A engenharia de Planejamento e controle é também responsável pelo registro das Lições Aprendidas da obra.

\begin{tabular}{|c|c|c|c|}
\hline Departamento & Cargo & $\begin{array}{l}\text { Tempo de } \\
\text { formado }\end{array}$ & $\begin{array}{l}\text { Tempo de } \\
\text { empresa }\end{array}$ \\
\hline $\begin{array}{l}\text { Escritório de Projetos PMO } \\
\text { (Escritório central) }\end{array}$ & Gerente & 3,5 anos & 4 anos \\
\hline $\begin{array}{l}\text { Núcleo de Sistemas Construtivos } \\
\text { NSC (Escritório central) }\end{array}$ & Coordenador & 3,5 anos & 6 meses \\
\hline $\begin{array}{l}\text { Projetos, Processos e } \\
\text { Desenvolvimento (Escritório central) }\end{array}$ & Gerente & 14 anos & 15 anos \\
\hline Orçamentos (Escritório central) & Engenheiro de Instalações & 21 anos & 2,5 anos \\
\hline Instalações (Obra) & Gerente de Instalações & 22 anos & 10 anos \\
\hline Projetos (Obra) & Coordenadora de projetos & 15 anos & 4 anos \\
\hline Projetos (Obra) & Estagiária de projetos & $\begin{array}{l}\text { Ultimo ano } \\
\text { faculdade }\end{array}$ & 5 meses \\
\hline Qualidade e Sustentabilidade (Obra) & Engenheira & 9 anos & 2 anos \\
\hline
\end{tabular}




\begin{tabular}{llcc}
\hline Planejamento e controle (Obra) & $\begin{array}{l}\text { Engenheira Coordenadora de } \\
\text { Planejamento e Controle }\end{array}$ & 5 anos & 3 anos \\
& Gerente Assistência Técnica & 5 anos & 9 anos \\
\hline Escritório central &
\end{tabular}

Quadro 14 - Funcionários entrevistados da Empresa A

\subsubsection{Caracterização do empreendimento analisado}

O Quadro 15 resume algumas características do empreendimento do estudo de caso da Empresa A, ilustrado pelas figuras: Figura 50: foto da obra em andamento, Figura 51: modelo 3D do edifício, Figura 52: projeto de implantação e Figura 53: planta do pavimento tipo.

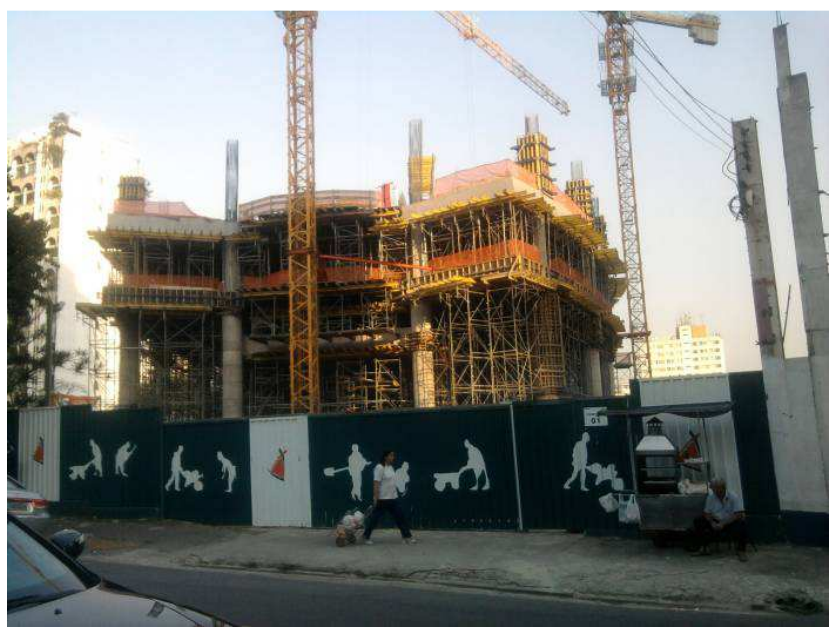

Figura 50 - Foto da obra no dia da visita

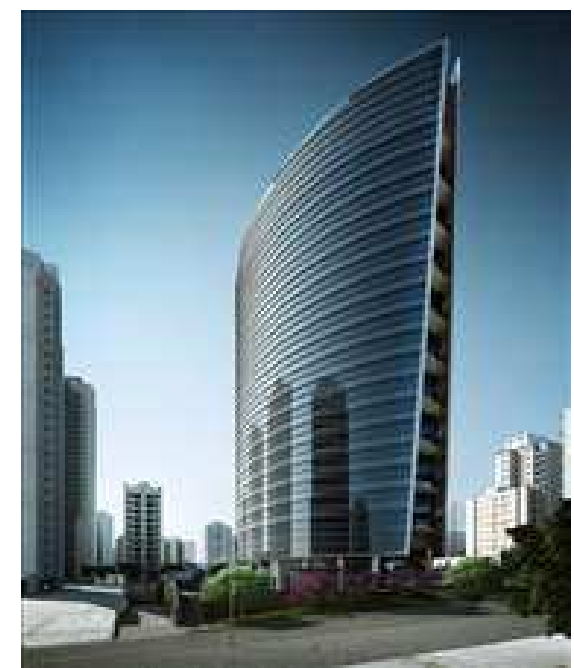

Figura 51 - Perspectiva do edifício

\section{Características do empreendimento}

\begin{tabular}{l}
\hline Localização \\
\hline Área Construída \\
\hline Prazo da Obra \\
\hline Tipo de Cliente \\
\hline Método de seleção
\end{tabular}

Obra sob encomenda de um edifício comercial de escritórios triplo A que visa a certificação LEED Gold com: 5 subsolos, térreo, mezaninos, torre com 18 pavimentos tipo (1.814 a $\left.2.018 \mathrm{~m}^{2}\right)$ e ático para áreas técnicas São Paulo - SP $70.402 \mathrm{~m}^{2}$ $2^{\mathrm{a}}$ fase: 20 meses $(2010-2011)$

Promotor imobiliário privado: Investidor americano em parceria com incorporadora brasileira

Projetistas: a construtora não era responsável pela contratação dos projetistas. Auxiliou a incorporadora na equalização de proposta de alguns projetistas de produção.

Construtora: Negociação, após concorrência para atingir preço alvo Sistema contratual da construtora Sequencial tradicional (obra teve início após o término dos projetos executivos) com as fases de projeto, concorrência e construção 


\begin{tabular}{ll}
\hline $\begin{array}{l}\text { Arranjo funcional das } \\
\text { equipes de projeto e } \\
\text { construção }\end{array}$ & Equipe de projeto separada da equipe de construção \\
\hline $\begin{array}{l}\text { Modalidade de pagamento } \\
\text { da construtora }\end{array}$ & Preço fixo: Contrato por administração com preço alvo \\
\hline Gerenciadora & Fiscalização por equipe da própria incorporadora (cliente) \\
\hline Coordenador dos projetos & $\begin{array}{l}\text { Coordenação do escritório de arquitetura brasileiro contratado pelo } \\
\text { cliente para "tropicalização" do projeto de arquitetura americano, } \\
\text { compatibilização e coordenação de projetos }\end{array}$ \\
\hline Entrevistas realizadas & Em 2010 - Em obra \\
\hline
\end{tabular}

Quadro 15 - Descrição do empreendimento estudo de caso Empresa A

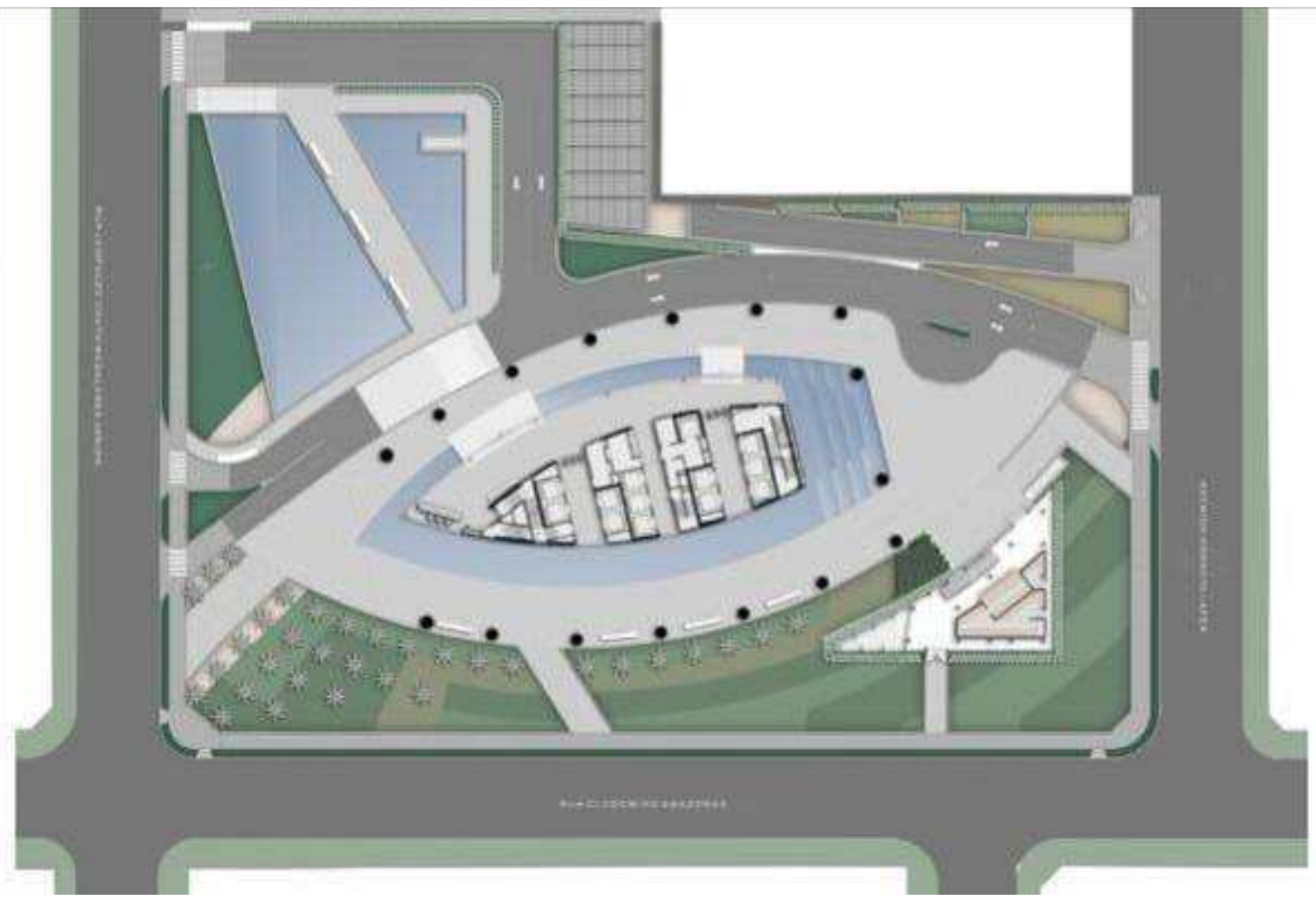

Figura 52 - Implantação

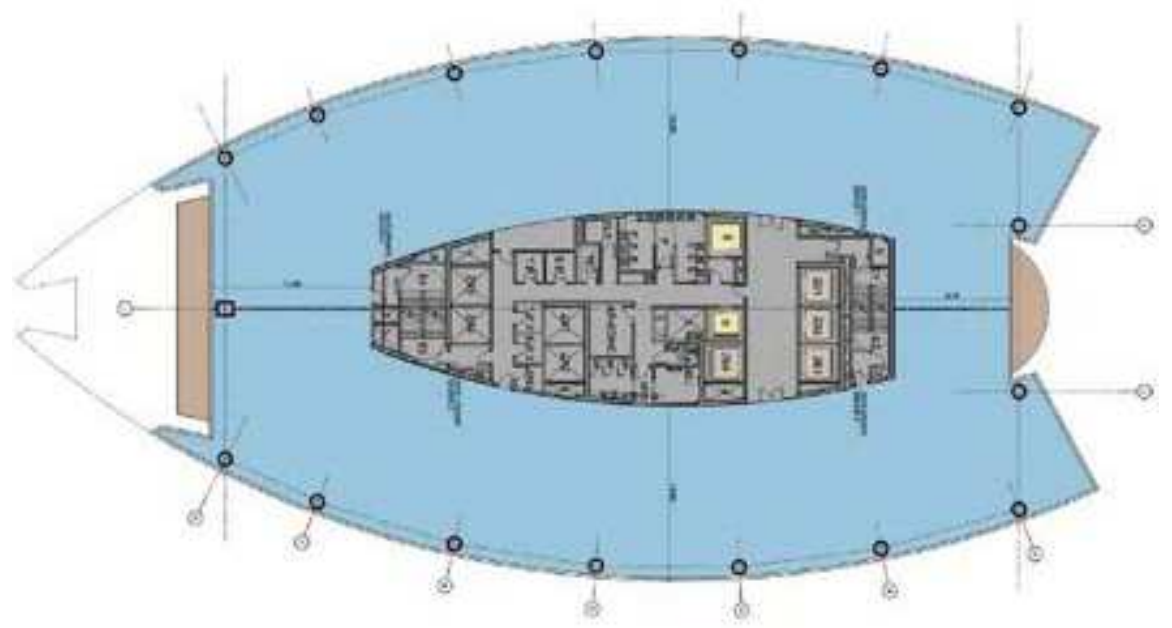

Figura 53 - Planta do pavimento tipo 
A construtora foi inicialmente contratada pelo cliente para execução da $1^{\text {a }}$ fase da obra com escopo de relocação de uma escola que encontrava-se no terreno, para possibilitar o início da obra de um empreendimento comercial (uma torre de edifício triplo A). O terreno da escola vizinha foi incorporado ao terreno final para aumento do potencial construtivo, o que representou um mês de atraso para o início da obra em relação ao previsto.

Apesar do projeto legal e básico da escola e edifício comercial ter sido desenvolvido por um arquiteto brasileiro, o cliente decidiu contratar um escritório de arquitetura americano para desenvolver um novo projeto para o empreendimento comercial e outro escritório de arquitetura brasileiro para "tropicalização" (tradução do projeto, adequação das especificações e detalhamento do projeto) do estudo preliminar, compatibilização e coordenação dos projetos executivos.

Paralelamente à obra de relocação da escola, a construtora participou das reuniões, realizadas com a presença dos projetistas, incorporadora e investidor, na fase de pré-construção para dar auxílio em relação a custo e prazo, no desenvolvimento do projeto do edifício comercial. $O$ estudo de engenharia e análise de valor tinha como objetivo a redução de custo da obra, pois se chegasse ao preço alvo não haveria concorrência.

Como o resultado da primeira estimativa de custo da obra foi muito superior à verba disponível para o empreendimento, foi necessária a concorrência para execução da $2^{\mathrm{a}}$ fase da obra. $\mathrm{Na}$ fase de Proposta, a Empresa A desenvolveu alternativas com $\mathrm{O}$ projetista de instalações indicado pelo cliente, que também assumiu no risco o estudo do projeto, para redução de custo.

Após a elaboração do pré-executivo no qual o valor estimado atingiu a expectativa do cliente, no final de 2009, como resultado do trabalho integrado entre as equipes de Planejamento, Projetos e Obra da 1 1 . fase, a empresa fechou o contrato para a execução da $2^{\mathrm{a}}$. fase do edifício comercial.

O escopo do contrato inicial, em um terreno de aproximadamente $7.970 \mathrm{~m}^{2}$, contava com fundação, estrutura, acabamentos civis e instalações elétricas, hidráulicas e de ar condicionado, alguns itens de automação de sete pavimentos que faziam parte da permuta com os proprietários do terreno, e parte dos acabamentos do $6^{\circ}$. ao $12^{\circ}$. 
pavimento, pois o restante dos pavimentos seriam entregues "na casca" para os futuros locatários.

\subsubsection{Os agentes do empreendimento}

Foram identificados como principais agentes do empreendimento:

Cliente: composto por um investidor (fundo norte-americano) em parceria com uma incorporadora brasileira que é responsável pela incorporação, vendas e gestão do empreendimento (inclui coordenação dos projetos), onde os representantes do cliente perante a construtora são o investidor americano, o gerente de Projetos da incorporadora que participou da fase de pré-construção e o arquiteto coordenador da incorporadora brasileira que iniciou a participação desde o início da obra (visita três vezes por semana a obra). A incorporadora brasileira tem uma porcentagem de participação do empreendimento para atuar como gerenciadora. Os clientes são responsáveis pela contratação dos projetistas e da construtora, participam das reuniões de projeto e gerenciais para definição do produto e aprovação de verbas, trazem interessados na locação e investidores para conhecer a obra, acompanham o arquiteto-autor do projeto americano na aprovação dos protótipos, detalhes, acabamentos e materiais.

Construtora: Contratada pelo cliente para execução da obra. A obra faz parte da Unidade de Operações da Empresa A e, de acordo com o organograma da obra, a equipe é composta por: um gerente de Projetos, uma engenheira e um estagiário de Qualidade e Sustentabilidade, um encarregado administrativo com três auxiliares administrativos, uma arquiteta coordenadora e uma estagiária de projetos, uma engenheira de Aquisições e uma assistente de Suprimentos, um coordenador de obras que é responsável pela equipe composta por: uma coordenadora de planejamento e controle com dois engenheiros de planejamento e custo, um gerente de instalações com dedicação parcial e um engenheiro de instalações, um engenheiro de produção de fachada e dois engenheiros de produção que coordenam duas equipes compostas por um técnico de produção, um mestre de obras e um estagiário. A equipe de SSMA é coordenada pelo gerente de segurança, que fica no escritório central, e por uma equipe de dois técnicos de segurança e um 
enfermeiro. $\mathrm{O}$ médico do trabalho atua parcialmente de acordo com demandas específicas.

A equipe de projetos interna da construtora é responsável por coordenar os projetos para equipe de produção e fornecedores e sinalizar necessidades, prazos, que possam influenciar no andamento da obra, além da elaboração do manual do proprietário e As Built dos projetos de arquitetura (as demais disciplinas são de responsabilidade dos instaladores e fornecedores).

A engenheira responsável pela coordenação de custos e planejamento físico da obra coordena três pessoas: engenheiro de Planejamento físico, engenheiro de controle de custos e engenheiro de Planejamento e aquisições. As atribuições da equipe são: supervisionar controle de custos; acompanhar contratações; verificar quais são as verbas disponíveis para disponibilizar recursos para contratação; montagem de editais (definição de quantidades e escopo); após a contratação, lançar contratação no controle de custo; controle do dia a dia da obra através das medições; controle entre o que foi previsto no contrato, o que foi medido e o saldo disponível através do sistema e planilha em Excel e registro das Lições aprendidas no SharePoint.

A engenheira de Qualidade e Sustentabilidade conta com um estagiário e é responsável pelo Plano de Execução para a certificação LEED.

A Figura 54 mostra o organograma da obra. 


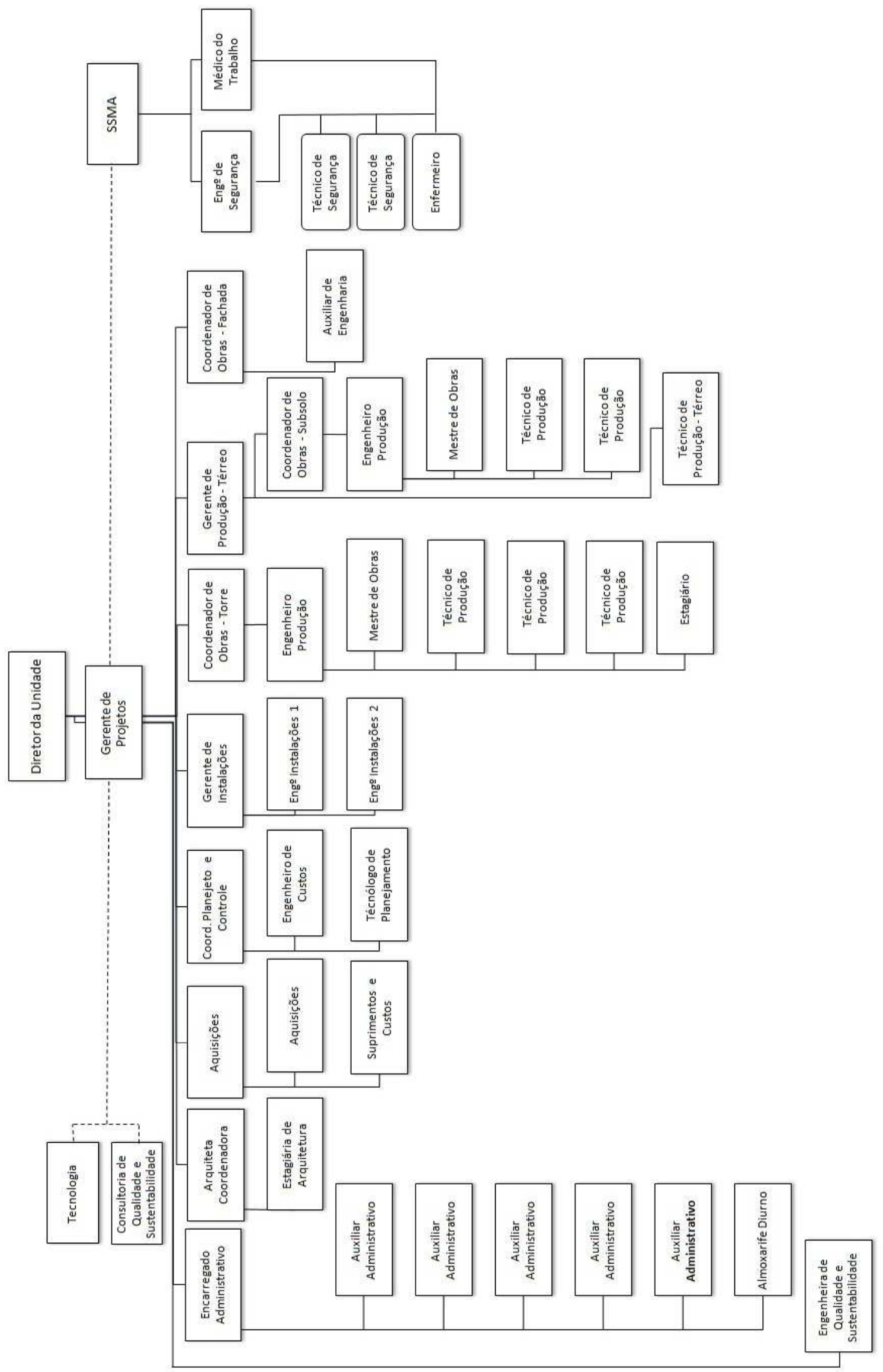

Figura 54 - Organograma da obra 
Projetistas: Todos os projetos foram contratados pelo cliente, sem a participação da construtora, com exceção dos projetos para produção. O projeto legal e básico da escola e edifício comercial foi desenvolvido por um arquiteto brasileiro, que foi substituído pelo cliente. Um escritório de arquitetura americano foi contratado para desenvolver um novo projeto para o empreendimento comercial e outro escritório de arquitetura brasileiro para "tropicalização" (tradução do projeto, adequação das especificações e detalhamento do projeto) do estudo preliminar, compatibilização e coordenação dos projetos executivos de todas as disciplinas, além do projeto executivo da escola que inclui uma revisão da concepção da fachada. O escritório de arquitetura americano elaborou um estudo preliminar, que equivale a um projeto básico brasileiro, com mais detalhes e especificações e participa de reuniões de projeto por telefone e visita a obra uma vez por mês para aprovação de protótipos e esclarecimento de dúvidas de projeto.

Além da Arquitetura (escritório americano e brasileiro), as disciplinas contratadas pelo cliente foram: Fundações; Estrutura de concreto; Estrutura metálica; Projeto de fôrmas; Hidráulica; Elétrica; SPDA (sistema de proteção e detecção de incêndio); Telefonia; Luminotécnica; Automação e controle; Ar condicionado; Impermeabilização; Acústica; Paisagismo.

Compatibilização dos projetos: $O$ arquiteto brasileiro fez a compatibilização dos projetos, mas como a construtora também foi responsabilizada pelo cliente pela compatibilização dos projetos, após identificar vários problemas de compatibilidade, que poderiam impactar em prazo e custo da obra, contratou uma empresa terceirizada para este serviço.

Projetos para produção: Apesar da resistência do cliente, os projetos para produção, tais como escoramento, esquadrias, fachadas, fôrmas, foram contratados de acordo com a necessidade identificada pelo gerente de Projetos da obra em conjunto com a equipe de construção, pois não havia nenhum membro da equipe da construtora com as competências necessárias para esse desenvolvimento.

Consultores: Para obtenção de certificação LEED Gold o cliente contratou uma consultoria de Sustentabilidade. Foram também contratadas consultores de esquadrias e fachada, elevadores e pedras. 
Fornecedores: Diversos fornecedores de materiais e de serviços participam da obra, assim como das fases de pré-construção. As contratações são feitas pela equipe de Suprimentos baseada no planejamento da obra.

\subsubsection{Processo de projeto}

\subsubsection{Formação da equipe de projeto}

A seleção da equipe de projeto pode ser realizada pelo cliente ou pela construtora, dependendo do tipo de contratação. Quando a Empresa A é responsável pela coordenação dos projetos, em geral o cliente contrata um arquiteto para desenvolver o estudo de viabilidade inicial e a construtora, além da execução da obra, para seleção, contratação e coordenação dos projetistas das demais disciplinas, consultores e projetistas para produção. Neste caso, a relação com os projetistas é direta, sendo de responsabilidade da equipe de projetos: elaborar os escopos de projeto para a negociação e contratação (de responsabilidade da área de Suprimentos); definir diretrizes de projeto de acordo com as necessidades do cliente; elaborar e monitorar o cronograma de entrega de Projetos com a equipe de Produção e projetistas; definir o gerenciador de documentos (ferramenta de colaboração); verificar e analisar criticamente os projetos. Quando o cliente fornece todos os projetos e é responsável pela coordenação dos projetos, a equipe de projetos da obra é responsável pela interface com a coordenação do cliente. De acordo com a complexidade da obra, ficando a cargo do gerente de Projetos da obra a definição da necessidade de contratação de consultores e projetos para a produção.

Os critérios de seleção dos projetistas são baseados nas características do empreendimento, indicação do cliente ou arquiteto-autor do projeto, parceria, custo e avaliação de fornecedor. A área de projetos está criando um cadastro de preços históricos de projeto por tipo de edifício (por exemplo: shopping center) e por m2.

A empresa desenvolveu um modelo padronizado de contrato e escopo de serviço de projeto, que foi baseado nos Manuais de Escopo desenvolvidos por entidades e 
associações setoriais de projeto com apoio do SECOVI-SP (Sindicato da Habitação do Estado de São Paulo), no qual há uma descrição do conteúdo do projeto a ser desenvolvido por cada especialidade, nível de detalhamento desejado em cada fase do projeto.

Todos os projetistas que já prestaram serviço à empresa são cadastrados no SharePoint da área de projetos. O procedimento de Suprimentos, que atende aos requistos da ISO 9001, determina que todos os fornecedores da empresa devem ser homologados e avaliados. Pelo sistema da qualidade não seria necessário fazer uma avaliação para fornecedores contratados pelo cliente, mas como este fato ocorre com frequência, a empresa decidiu incluir a avaliação de todos os projetistas e consultores de projeto com quem a empresa tenha influência direta com a realização do produto. A avaliação é do ponto de vista de relacionamento, atendimento, retorno de revisões, retorno de dúvidas e esclarecimentos, prazo de retorno, disponibilidade, etc. Os fornecedores são avaliados por cada uma das obras e são compilados por Suprimentos. Quando um fornecedor é bem avaliado por uma obra e mal avaliado por outra obra, ou recebe notas muito baixas de avaliação, este é separado e é feita uma avaliação do gráfico de tendência para identificar qual é a causa raiz do problema. Se a causa não for identificada é formado um comitê de avaliação formado não apenas dos profissionais que lidam diretamente com o fornecedor, como por exemplo, o arquiteto coordenador, mas o engenheiro de produção que utiliza o projeto em campo (as informações de projeto não são claras, faltam informações), suprimentos (o projeto tem muitas dúvidas quando enviado para cotação), etc.

A avaliação do fornecedor é feita pela equipe da obra e sua frequência ou forma de avaliação é definida no Plano de Projeto no início da Obra (o Plano de Projeto padrão pode ser flexibilizado nestes itens). Por exemplo: cada um faz a avaliação individualmente e o responsável de Suprimentos encaminha ao escritório central ou todos se reunem para fazer uma avaliação em conjunto.

Os papéis e responsabilidades de cada agente (internos e externos) estão definidos claramente no Logigrama de coordenação de projetos que estabelece as responsabilidades de todos agentes do processo em todas as fases do processo de projeto, e após a contratação o Plano de Coordenação que é enviado ao projetista onde são definidas as regras da coordenação. 
Na obra analisada, a construtora não participou da seleção dos projetistas, com exceção dos projetos para produção.

\subsubsection{Gestão do processo de projeto}

A atuação da área de projetos (coordenação de projetos interna ou externa) depende da característica do empreendimento e do tipo de contrato com o cliente. A empresa pode ser contratada para coordenar o projeto desde o início de seu desenvolvimento, na fase de concepção do empreendimento, acompanhando e dando suporte à elaboração dos projetos e estimativas de custo da obra, ou receber todos os projetos prontos para execução. A coordenação dos projetos legais, em geral, fica sob responsabilidade do cliente ou da gerenciadora.

O ciclo de vida do processo de projeto acompanha o ciclo de vida dos negócios da empresa. A gerente da área de projetos, como área funcional, define a matriz de responsabilidade na qual ficam muito claras quais serão as atividades que serão desenvolvidas pelo coordenador de projetos na obra.

Nas fases de Proposta e Negociação a equipe de coordenação de projetos está centralizada no escritório central, subordinada à gerente do departamento de projetos. Nesta fase podem ser desenvolvidas atividades de: suporte à equipe de propostas; engenharia e análise de valor onde a participação de fornecedores, traz idéias e soluções, desde o início da fase de projetos; avaliação quanto à construtibilidade buscando redução de custos; análise de atendimento dos conceitos de sustentabilidade; elaboração de proposta de coordenação de projetos.

Após a aprovação da proposta, nos casos em que a empresa é contratada para contratar e coordenar os projetos, na fase de Estruturação o coordenador de projetos seleciona projetistas para participar da licitação de projetos, elabora os escopos de contratação, solicita e equaliza as propostas de projeto.

A utilização de um gerenciador de documentos de projeto (ferramenta de colaboração) fica a critério do cliente. Quando este não tem um sistema pré-definido a empresa sugere um gerenciador que tenha maior familiaridade e atenda às características específicas da obra. 
Quando contratada, a equipe de projetos desenvolve a coordenação, engenharia e análise de valor no desenvolvimento do projeto. Como exemplo, a empresa foi contratada para desenvolver o projeto básico de um edifício comercial recebido do cliente, contratar os projetos complementares, fazer a compatibilização entre os projetos e adaptar o projeto para obter a certificação LEED. A equipe de projeto é composta pelo arquiteto-autor do projeto contratado pelo cliente e da construtora: um arquiteto pleno para coordenação, um arquiteto pleno para auxiliar na parte operacional (SharePoint, planejamento) e um engenheiro de instalações, ambos com dedicação parcial.

$\mathrm{Na}$ fase de Execução e controle, quando tem início a obra, o arquiteto passa a fazer parte da equipe da obra subordinada ao gerente de Projetos da obra até a fase de Aceitação onde a equipe volta ao escritório central.

Como a área de projetos revisou os processos e procedimentos relativos à coordenação de projetos para alocar no site corporativo baseado na plataforma do SharePoint, como parte do projeto de uma trainee, em 2009, com a implantação da ISO 9001 não houve uma mudança drástica do que já estava em prática pelos coordenadores, sendo necessárias apenas algumas revisões para atender às exigências da norma.

Existe uma área no site de coordenação de projetos do SharePoint onde estão arquivados os modelos, ferramentas e procedimentos para utilização e consulta:

- Ficha de análise crítica de projetos;

- Relatório de análise crítica de projetos (avalia o nível de informação, atendimento aos padrões, compatibilidade, qualidade gráfica e de soluções e indica ações necessárias, riscos e oportunidades identificados);

- Ficha de solicitação de esclarecimentos (solicita esclarecimento aos projetistas);

- Relatório de esclarecimentos de projeto (informa os esclarecimentos para equipe de produção);

- Relatório de alterações de projeto (indica se as alterações terão impacto em prazo, custo);

- Mapa de equalização de propostas de projeto; 
- Logigrama de coordenação de projetos (estabelece as responsabilidades de todos agentes do processo em todas as fases do processo de projeto: diretores e gerentes de Tecnologia, Operações, Engenharia e projetos, coordenação da obra e de projetos, produção, suprimentos, projetistas, consultores, fornecedores, cliente e gerenciadora);

- Modelo de proposta de coordenação de projetos;

- Modelo de proposta de custos de coordenação de projetos;

- Matriz de controle de projetos;

- Manual de coordenação de projetos;

- Tutorial para nomenclatura padrão de projetos.

Estes padrões são os mesmos utilizados em todas as obras e são organizados e atualizados por uma arquiteta responsável do departamento de projetos.

Os arquitetos dedicados a cada obra são responsáveis pela definição das diretrizes e o cronograma de projetos; recebimento e controle das revisões de projeto; análise crítica dos projetos; coordenação de esclarecimentos de projeto; atualização e liberação dos documentos para a equipe de produção e fornecedores para execução; monitorar e entregar os As Builts e manual do proprietário.

A obra analisada tem uma coordenadora e uma estagiária de projetos, que controlam os itens e documentos relacionados à coordenação de projetos que constam no Share point:

1) Lista Mestra: Lista contendo nome do desenho e com arquivo anexado, possibilitando download. Atualizada semanalmente no cabide de projetos e entregue ao engenheiro de produção e mestre. Contém as seguintes informações: Nome da disciplina; Título; Nome da revisão; Data da revisão; Cabide em que está pendurado; Se está analisado ou não; Se está liberado para obra; Se já foi executado/ provisório; Para quem foi entregue (conforme Lista de Controle e Distribuição de Arquivos e Plotagem); Número de cópias enviadas aos fornecedores ou projetistas

2) Relatório de Análise Crítica de Projetos. Contém as seguintes informações: Disciplina; Fase de projeto (Executivo); Data; Título; Nome do arquivo; Quantidade de folhas; Nível de Informação: muito Bom/ Bom/ Regular/ Ruim; 
Compatibilidade; Qualidade gráfica; Atendimento aos padrões; Qualidade das soluções; Comentários; Riscos e oportunidades identificados; Ação: Revisar projeto/ Esclarecer projeto/ Liberar para execução; Status das ações: Realizada/ Pendente/ Cancelada; Observações.

3) Relatório de Esclarecimento/ Alterações de Projeto. Contém as seguintes informações: Disciplina: Estrutura de Concreto; Setor: Fundação; Área: Torre ou Periferia; Caráter: Alteração de Projeto; No. da alteração; Nome do arquivo; Data do questionamento; Questionamento; Prioridade: Alta/ Média/ Baixa; Causa do esclarecimento; Responsável; Histórico; Data resposta/ alteração; Resposta/ alteração; Causa da alteração; Fonte; Linha de base; Impacto: Custo/ Prazo/ Qualidade...; Riscos identificados; Status: ok.

4) Documentos Enviados e Recebidos: Controle de projetos que foram enviados para a produção. Contém as seguintes informações: Classificação: Enviado; Título; Nome do documento; Data de envio; Enviado por; Empresa que enviou; Recebido por; Data recebimento; Empresa que recebeu; Documentos de Coordenação.

5) Cronograma de Projeto

6) Linha Base de Projeto: refere-se ao projeto utilizado como base para o orçamento.

A equipe de projeto da obra do estudo de caso desenvolveu os seguintes controles que não existiam no SharePoint:

1) Lista de Controle e Distribuição de Arquivos e Plotagem: indica a quantidade de cópias a ser entregue para cada membro da equipe da obra: engenheiro de produção/ mestre/ cabide/ empreiteira/ fornecedores que estão na obra naquela etapa (topografia/ protenção).

2) Mapa de Cabides: indica como os projetos estão organizados no cabide da obra. Cada cabide tem um código (E: 1a..Fase/ T: Torre/ LM: Lista Mestra) e sequência numérica (01a: Arquitetura - folhas 000 a 414, 02b: Arquitetura folhas 450 a 800/ 02: Estrutura: Formas e Fundações, etc). Ex: Cabide E02 (1 . Fase - Fundações)

Através do SharePoint, no qual a gerente da área de projetos tem acesso a todos os controles de cada obra, são realizadas as auditorias do sistema de gestão da 
qualidade onde é possível verificar se os procedimentos estabelecidos estão sendo seguidos, se as análises críticas do projeto, listas de verificação estão sendo feitas, etc. Não pode haver um desvio de procedimento, como por exemplo, o arquiteto ajudar a equipe de obra na produção, deixando de realizar as atividades sob sua responsabilidade. Os processos podem ser rastreados pelo SharePoint, indicando quando foi realizada a última atualização do documento, quantas vezes ele foi acessado, possibilitando um controle quantitativo, mas não qualitativo.

Como cada novo empreendimento tem suas características específicas, em geral definidas pelo arquiteto-autor do projeto em comum acordo com o cliente (não são projetos que serão reproduzidos em série), não existem diretrizes, tais como parâmetros e padrões de processos construtivos ou estratégia de produção, para o desenvolvimento dos projetos que sejam impostas pela empresa. Nos casos em que a empresa tem possibilidade de realizar análises de valor, podem ser feitas sugestões ou alterações no projeto para redução de prazo ou custo da obra.

Não há uma padronização de projeto da empresa a ser seguida pelos projetistas. Existe um tutorial para nomenclatura padrão dos projetos que é utilizado no caso onde os projetos são contratados pela empresa.

Baseado no Manual de procedimentos de coordenação de projeto é feito um Plano de Coordenação, específico para cada obra, que é enviado ao projetista onde são definidas as regras da coordenação: quem fala com quem, qual ferramenta de colaboração será utilizada, quem faz as atas de reunião, o cronograma de entrega dos projetos.

O cronograma de projetos na fase pré-construção foi elaborado pelo coordenador de projetos, mas os prazos não foram atendidos pelos projetistas. A coordenadora de projetos da obra identifica como uma causa o momento econômico, pois os projetistas estão muito sobrecarregados e a mão de obra está escassa. Após o início da obra, os prazos de projeto (revisões ou novas necessidades identificadas) são definidos com a equipe de produção de acordo com o cronograma estabelecido pelo engenheiro de planejamento e validado pelo gerente de Projetos da obra.

Verificou-se que a equipe de projetos da obra aplica o padrão de controle e gestão do processo de projeto, além de criar novas ferramentas para melhoria do processo. 


\subsubsection{Atuação da construtora no processo de projeto}

A construtora havia realizado uma estimativa de custo da obra da $2^{2}$ fase, mas como o resultado foi muito superior à verba disponível para o empreendimento foi feita uma parceria com o projetista para estudar alternativas para viabilizar a obra.

Foi desenvolvido um ante-projeto com projetista de instalações indicado pelo cliente para realizar as consultas prévias às concessionárias e quantificação de material (em um edifício de 18 andares qualquer economia em metragem de fiação seria replicada por 18 vezes).

O projetista não ofereceu resistência aos estudos realizados pela construtora, pois entendeu que o objetivo era agregar valor ao projeto e os parceiros da construtora tinham conhecimento e experiência em relação ao assunto.

Como o projetista não era de São Paulo, a construtora pôde agregar valor ao projeto contratado pelo cliente trabalhando junto às concessionárias, buscando adequar o projeto às normas regionais, além de alternativas com foco na redução de custo (por exemplo: sugerir alternativas de tipo de cabos utilizados). Foi realizado um estudo de viabilidade comparando os aspectos positivos e negativos da compra de três geradores versus a compra de energia (concessionária subsidia gerador se for firmado contrato de fornecimento de combustível com ela).

O projetista estava acostumado a projetar esgoto a vácuo que é uma boa solução, mas de custo mais elevado, por exemplo: o vaso sanitário deste sistema tem custo dez vezes superior ao convencional, pois apesar da tubulação ter diâmetro menor, o ferro fundido é mais caro que o PVC. Como o cliente era americano não aceitava uso do PVC por questões de normas de incêndio internacionais (PVC emana fumaça ao queimar), apesar deste material ser aceito pelo LEED (busca da certificação LEED Gold). Como alternativa à tubulação de PVC e ferro fundido foi desenvolvido um produto novo de mercado junto aos fornecedores (uma tubulação de PPR - poliestileno), um pouco mais caro que PVC, mas mais barato que o ferro fundido, que viabilizou o sistema e foi utilizado na tubulação de esgoto, água potável, dreno de ar condicionado.

O projetista de luminárias desenvolveu, junto ao fabricante de lâmpada e luminárias, uma luminária que possibilitasse atender às premissas do LEED que exige menos que $11 \mathrm{~W} / \mathrm{m} 2$. No entanto, como o resultado foi uma luminária com um custo muito 
elevado, a construtora contatou outros fabricantes de luminárias para desenvolver uma luminária que tivesse o mesmo rendimento e curva de resolução, obtendo uma redução de custo significativa ( $\mathrm{R} \$ 150 /$ luminária).

Devido à demanda de mercado, os produtos que atendem às especificações necessárias para certificação LEED estão com valores reduzidos em relação a alguns anos atrás e a tendência é que em cinco anos já não haja tanta diferença de preço igualando o preço com os outros produtos.

A engenheira de Qualidade e sustentabilidade informou que são exigidos muitos documentos jurídicos e é necessário organização dos itens que tem relação com o controle da obra. Dos 73 pontos necessários para atingir a certificação LEED Gold dez estão relacionados à obra e 63 são relacionados a itens de projeto. Para atingir a certificação Gold a pontuação mínima é de 60 pontos (senão só será possível obter certificação Silver).

A consultoria externa de sustentabilidade faz um acompanhamento semanal na obra, onde emite relatórios para acompanhamento da pontuação. Em meados de 2010, a obra encontrava-se em fase de implantação e estruturação (treinamentos, gestão de resíduos, organização da obra).

A participação na elaboração de escopo de contratação dos fornecedores é muito importante devido às exigências do LEED de diversos documentos (declarações ambientais dos materiais: tintas, colas, adesivos para estrutura, impermeabilizantes). Como o mercado ainda não está muito preparado existem muitas dúvidas que devem ser sanadas antes da contratação para não trazer risco de não obter a pontuação mínima necessária. A consultoria faz uma pré-aprovação dos produtos e se a declaração não atender aos limites pré-estabelecidos, o produto deve ser substituído.

A meta do Plano de execução inclui itens tais como:

- Gestão de resíduos: Meta 20\% de redução;

- Regionalidade dos materiais: mede a quantidade de carbono emitido decorrente de transporte de materiais para obra. Como a obra está na cidade de São Paulo deve atingir a pontuação necessária; 
- Utilização de madeira certificada: como as madeireiras já têm material desenvolvido, a dificuldade encontrada poderá ser em relação ao preço;

- Qualidade do ar interno da obra (exemplo: técnicas de varrição, lixamento, etc);

- Reciclagem;

- VOC (composto volátil dos produtos incorporados ao edifico devem atender a norma americana, exemplo: colas);

- Educação ambiental;

- Comissionamento básico e avançado (treinamentos para operação do edifício).

Os itens relativos ao projeto foram desenvolvidos com os projetistas, a consultoria e acompanhados pela equipe de projeto da obra.

Alguns itens de projeto podem impactar a obra como, por exemplo: para atender a meta de $10 \%$ de aumento de eficiência energética a consultoria fez quinze simulações virtuais de desempenho. A última simulação indicou que a solução de projeto não atenderia a meta desejada. Por dificuldade de negociação com o fabricante foi necessário alterar a especificação do vidro que já estava previsto na contratação.

Outro item verificado na simulação foi a disposição da dimerização: se fossem implantadas duas linhas de dimerização junto a fachada melhoraria a pontuação da eficiência energética.

Como as alternativas têm um impacto em custo e eventualmente prazo, fica a cargo do cliente a decisão de alterar o projeto ou especificações para atender aos requisitos do LEED. A equipe de Planejamento levanta todos os custos de material que fazem parte da curva $A$ e qual a porcentagem do contrato que ele representa do montante do projeto para verificar o impacto do LEED no planejado.

A engenheira de Planejamento e controle que está na obra desde o início da $2^{\mathrm{a}}$. fase indicou como soluções tecnológicas diferenciadas aplicadas:

- Proteção com fibra de coco na parede diafragma; 
- Concretagem de $1.600 \mathrm{~m} 3$ de sapata realizados em quatro finais de semana, sendo $400 \mathrm{~m} 3$ de concretagem por final de semana, viabilizadas com utilização de concreto especial com gelo;

- Como as plantas dos pavimentos com lajes de $2.000 \mathrm{~m} 2$ é variável, para atender à concepção de arquitetura da forma de um barco, foi contratado um consultor para garantir a geometria das fôrmas em função da geometria do prédio: as colunas excêntricas nos dois eixos tem $15 \mathrm{~m}$ de altura no térreo.

Segundo a coordenadora de projetos, como o sistema construtivo já estava muito bem pré-definido pelos projetistas de arquitetura não foram feitas muitas alterações (estrutura de concreto com sistema de fachada unitizado, em que o caixilho é integralmente produzido na fábrica, o que garante maior velocidade na obra). Como a meta era redução de custo, a estrutura metálica da cobertura, que estava muito pesada, foi substituída por concreto, sem alterar o partido da arquitetura.

Foi utilizado um sistema para coletar água da cobertura, reduzindo o número de descidas de águas pluviais e, consequentemente, o espaço de entre forro.

Para redução de prazo de obra foram utilizadas tubos de papelão para fôrmas das colunas de concreto.

O contrato do arquiteto-autor do projeto americano previa visitas mensais à obra para aprovação de protótipos, acabamentos, especificações e detalhes e esclarecimento de dúvidas de projeto. Como o padrão de qualidade americano é muito alto, muitas vezes o arquiteto-autor do projeto não ficava satisfeito com os protótipos devido à qualidade dos materiais especificados que não têm similaridade no Brasil, o que interfere diretamente no resultado da cor, brilho, etc.

Do ponto de vista de manutenção foram previstas gôndola para limpeza das fachada que tem brises. O gerente de instalações, que faz parte da equipe de duas obras, promoveu a transferência de uma soluções de uma obra para outra, não se limitando à sua área. Para evitar reforço de piso no térreo, o gerente de instalações sugeriu ao gerente de Projetos da obra a solução dada à instalação das cremalheiras dentro do prédio, para não interferir na fachada, aplicada em outra obra, que foi aceita pelo projetista de estrutura. 
A elaboração do Manual do Proprietário faz parte das atribuições da equipe de projetos da obra, e o escopo inclui todos os equipamentos elétricos, mecânicos, hidráulicos e de incêndio que são produzidos pelas instaladoras e equipe de instalações da obra. O gerente de instalações utiliza um manual padrão de comissionamento para as obras em que ele participa (relatórios, ensaios e testes de todos os equipamentos ocorridos na fábrica, em campo (obra) e depois de instalados que indicam que todo o sistema está de acordo com o projetado). Este manual, que não faz parte do padrão da empresa, foi desenvolvido aproveitando sua experiência em outras obras e por exigência do último cliente (incorporadora norteamericana) que incluiu diversos itens.

\subsubsection{Comunicação no processo de projeto e obra}

Os meios de comunicação entre os membros da equipe de projeto são: telefone, email (comunicação escrita), ferramenta de colaboração de projetos e gerenciador de arquivos (depende do cliente) e reuniões, onde os assuntos e decisões são registrados em atas, elaboradas pelo arquiteto da obra ou gerenciadora $e$ disponibilizados a todos envolvidos através do SharePoint. A frequência das reuniões de projeto varia de acordo com a fase do projeto e demanda, assim como os profissionais participantes.

A passagem do material desenvolvido pela equipe de orçamentos (pastas e CDs com todas as propostas e mapas de equalização) para a equipe da obra foi feita em uma reunião onde foram apresentados em Power Point todos os itens que foram considerados no orçamento, custo de venda e o valor de cada pacote de trabalho.

$\mathrm{Na}$ obra analisada, já estava definida a utilização do gerenciador de arquivos SADP (Sistema de Armazenamento de Dados de Projetos) onde os projetistas postam os novos projetos ou revisões, a equipe de projetos da obra recebe os projetos, cadastra no SharePoint, plota e encaminha à equipe de obra, de acordo com a Lista de Controle e Distribuição de Arquivos e Plotagem. Há um protocolo de entrega que é arquivado em pasta indicando quem enviou, quem recebeu e quantas cópias foram enviadas. 
Os projetos são plotados e analisados com base no documento Análise Crítica de Projetos pela área de projetos e produção. Dependendo do resultado, esta análise pode gerar a necessidade de um esclarecimento do projetista que pode resultar em uma revisão de projeto.

Quando a obra recebe uma revisão nova, os projetos da revisão anterior devem ser entregues à equipe de projeto para evitar que existam revisões obsoletas na obra. Este procedimento foi estabelecido após alguns meses do início da obra, pois devido à grande quantidade de folhas de projeto (atualmente aproximadamente 300 folhas) a equipe da obra ficava com várias revisões em mão, o que poderia causar confusão no momento da execução.

As reuniões realizadas na obra são:

- Reuniões semanais de Controle Integrado de Mudanças para verificar se as mudanças identificadas pela equipe da obra em relação a novos projetos recebidos podem gerar mudança de escopo e quais ações devem ser tomadas;

- Reunião gerencial semanal com cliente tem uma ata contínua na qual os assuntos resolvidos são ocultados e itens pendentes continuam visíveis até sua resolução. São pontuados todos os problemas da obra: mudança de escopo, prazos, mudança de acabamentos, andamento da obra;

- Reunião mensal de Lições Aprendidas: são levantadas no SharePoint e apresentadas para a equipe todas as Lições Aprendidas desde o início do projeto que são vinte até o momento. Existe uma lista de Lições Aprendidas de cada área da obra: Projetos/ Produção/ Planejamento Físico/ Qualidade/ Aquisições/ Administrativo que deve ser identificada por cada área. Após a reunião a engenheira de Planejamento faz o registro no SharePoint para disponibilizar a informação à equipe e às áreas do escritório que tem permissão de acesso (PMO/ Alta direção/ gerencia - as outras obras não tem acesso). As Lições Aprendidas existentes são: cinco de Aquisições, quatro de Custo, sete de Escopo, duas de Integração, duas de projeto, sendo: Monitorar projetos de terceiros (projetistas contratados pelo cliente) e Monitorar projetos para produção (ex. fôrmas, escoramento, fachada). Verificar se os projetos 
para produção estão adequados aos projetos básicos dos projetistas e se foram validados;

- Reunião mensal de Análise de Risco e Monitoramento: lista de riscos de: cliente, contrato, administrativo-gerencial, econômico-financeiro, meio ambiente, engenharia e projeto produção, segurança do trabalho e qualidade.

- Reunião de Análise de Stakeholders (partes interessadas), que faz parte do Plano de Projetos, após a reunião de Controle Integrado de Mudanças na qual são revisitados todos os itens. Mas se for identificado algum risco iminente ou lição aprendida no decorrer da semana, eles podem ser registrados ou tratados e na reunião semanal específica quando são consolidados. O PMO faz visita mensal à obra quando é apresentado o relatório gerencial: planejamento físico, custos, cada área de conhecimento, etc;

- Reunião quinzenal (ou mensal) de equipe;

- Reunião de programação semanal das atividades detalhada de trabalho da produção, empreiteiros de campo com o engenheiro responsável pelo planejamento físico da obra para fechar o cronograma contratual e de produção.

A troca de informações entre projetos, obra e os projetistas pode ser realizadas por telefone (para esclarecimento de dúvidas mais urgentes), e-mail ou via SADP (para troca de arquivos). O SharePoint apenas é utilizado pela equipe interna da empresa.

Segunda a coordenadora de projetos da obra, a comunicação com os projetistas foi muito boa. Nunca se negaram a esclarecer dúvidas por telefone. Às vezes a demora em esclarecer alguma dúvida de projeto da obra era maior, em decorrência do tempo necessário para o projetista relembrar o projeto, que havia sido finalizado e entregue a mais de um ano.

A construtora tinha livre acesso aos projetistas. A função da coordenação na obra era estipular prazos para entrega das revisões dos projetos e alertar a incorporadora, que tinha o papel de gerenciadora, caso não fossem atendidos os prazos. 


\subsubsection{Tecnologia da Informação (TI)}

O Oracle e SharePoint foram implantados para organizar o banco de dados da empresa e fluxo de informações entre os agentes do processo internos e externos (cliente, construtora, projetistas, fornecedores, etc).

As informações do SharePoint foram estruturadas por departamentos e por obra. A permissão de acesso aos sites do SharePoint é definida pela área que o controla (jurídico, $\mathrm{RH}$, assistência técnica, etc) e o acesso ao site das obras é definido pelo PMO. Uma obra não pode visualizar dados de outra obra para evitar comparações ou comentários negativos. Todos os sites só podem ser visualizados pela alta direção. As melhores práticas são identificadas pelo PMO e disponibilizadas a toda empresa no site modelo (Plano de ataque da obra, análise de stakeholders, etc). Os sites de algumas obras são acessados pelos clientes, caso seja solicitado.

Todas as informações contábeis e financeiras referentes a custo, aprovações de ordens de compras de suprimentos, notas fiscais estão registradas no Oracle.

Informações referentes às áreas funcionais $(\mathrm{RH}$, planejamento, suprimentos, jurídico, assistência técnica) e obras, intranet e noticias estão no SharePoint.

Todos os registros da etapa de proposta estão armazenados no SharePoint (mapa de cotação e equalização, e-mails trocados com fornecedor sobre as propostas) e depois da contratação são colocados em uma pasta de documentos de início que vão para a obra quando ela iniciar. Desta forma as informações não ficam com as algum pessoas, evitando perda de informações do processo no caso de desligamento de algum funcionário da empresa.

Não há um procedimento para utilização e armazenamento de e-mails, mas o PMO incentiva que todos armazenem os documentos (atas de reunião, diário de obra, projetos) no SharePoint e apenas o link, evitando enviar arquivos por e-mail.

\section{- BIM (Building Information Modeling)}

O Núcleo de Modelagem é responsável pela implementação e aplicação da tecnologia BIM (Building Information Modeling) dentro da empresa e em projetos que possuam esta demanda. O BIM é baseado na construção de modelos virtuais que possibilitam a troca de informação entre toda a cadeia da construção civil, desde 
fornecedores até o cliente final. Atualmente, o Núcleo conta com cinco profissionais que atendem aproximadamente dez projetos. A coordenadora do Núcleo, que havia desenvolvido competências para utilização do programa, participou do Programa de Trainees da empresa apresentando como tema de trabalho a implantação do BIM. A empresa entendeu a amplitude e importância da tecnologia para agregar valor aos serviços de engenharia prestados aos clientes.

Esta iniciativa demonstra que a empresa está investindo em construir competências essenciais para entrar em um mercado emergente e construir as habilidades pessoais necessárias para sustentar a liderança do produto.

Como todas empresas baseadas em Projetos, há uma dificuldade maior em acumular conhecimento e desenvolver rotinas. As competências da empresa, resultado do processo de aprendizado, poderão ser armazenadas em objetos (modelos) que incorporam representações do conhecimento (desenhos, modelos virtuais, guias de procedimento, etc) e poderão ser re-utilizados em outros Projetos semelhantes.

Ao longo dos últimos dois anos, a empresa vem implantando os conceitos da ferramenta e investiu cerca de $\mathrm{R} \$ 350 \mathrm{mil}$ em programas e treinamento dos funcionários. Segundo a coordenadora do Núcleo, o instrumento foi importante para evitar o que já ocorreu antes com um empreendimento da própria empresa no qual tiveram de ser gastos $R \$ 700$ mil com retrabalho em forros e vigas por falta de compatibilização.

O BIM tem apoiado internamente a área de Propostas e Orçamentos, como uma ferramenta de gestão do processo. A partir do modelo virtual é possível avaliar várias opções de custos dependendo do tipo de revestimento escolhido, do tamanho do pé direito e da quantidade de cimento, etc (MÉTODO, 2010).

Segundo a gerente da Assistência Técnica, a empresa é pioneira na utilização do BIM nos projetos. Com todas as disciplinas compatibilizadas em 3D, facilitando a visualização das interferências serão prevenidos alguns problemas na obra, auxiliando a Assistência Técnica na identificação de causas de problemas após a entrega da obra sem precisar quebrar o que já foi construído. O BIM está em aplicação em um projeto comercial em Salvador, no qual o cliente comprou o serviço como piloto, pois irá operar o empreendimento. 


\subsubsection{Aspectos Tecnológicos}

A empresa sempre foi conhecida no mercado pelo domínio do conhecimento técnico em Engenharia e pelas iniciativas de inovação, mas com a terceirização dos serviços, o controle dos processos e o conhecimento ficaram dispersos e poderiam acarretar em dificuldade na garantia de desempenho dos produtos (empreendimento), na garantia de qualidade e no controle da produção e dos fornecedores. No final de 2009 foi criado o departamento de Tecnologia o NSC Núcleo de Sistemas Construtivos com o objetivo de implantar a gestão de tecnologias construtivas:

- Consolidar conhecimento técnico através de procedimentos (ferramentas + processos);

- Disseminar este conhecimento na empresa para valorização da Engenharia;

- Controlar tecnologias e analisar oportunidades de melhoria contínua;

- Executar ações de desenvolvimento tecnológico.

O Sistema de Gestão da Qualidade servirá de apoio para o estabelecimento dos processos de gestão da produção - padronização e gestão das tecnologias construtivas.

O NSC passou por uma fase de estruturação para definir os sistemas construtivos, ferramentas, estruturação no Share Point. Nesta fase foram identificadas 180 tecnologias e destas foram selecionadas 120 mais usuais para elaboração de procedimentos técnicos. A meta para 2010 foi realizar 100 procedimentos. No entanto, este número é flexível, pois caso alguma obra solicite um novo procedimento este terá prioridade sobre os procedimentos que ainda não serão utilizados.

Os Processos Técnicos foram divididos em grupos de sistemas construtivos:

- Infraestrutura;

- Superestrutura;

- Vedações;

- Revestimentos;

- Impermeabilizações;

- Materiais; 
- Planilhas e formulários de apoio.

$\mathrm{Na}$ fase de produção, o NSC visita as obras para colher informações para elaboração dos procedimentos. A sequência para elaboração dos procedimentos técnicos foi priorizada de acordo com a necessidade das obras. Por exemplo, como a maior parte das obras encontra-se no início foram desenvolvidos inicialmente procedimentos de fundação, movimentação de terra, estrutura. Para elaboração dos procedimentos muito específicos podem ser envolvidos os fornecedores (por exemplo, laje sky deck que permite retirar a forma sem tirar o escoramento). A equipe de projetos é envolvida quando algum procedimento menciona algum detalhe que deve ser especificado em projeto.

Cada Procedimento Técnico tem os seguintes tópicos:

- Objetivos;

- Documentos relacionados: Projetos, Documentos da Qualidade (Formulário de Controle e Aceitação de Processos Construtivos/ Tutorial/ Controle de qualidade de materiais), Segurança, Meio Ambiente;

- Método Executivo (indica o fluxo das atividades, descreve a atividade, o que deve ser verificado, quais são as interferências);

- Glossário de termos técnicos relacionados;

- Referência (normas técnicas).

Além do procedimento técnico, o NSC elabora o Formulário de Controle e Aceitação de Processos Construtivos que tem como função identificar não conformidades. $\mathrm{O}$ acompanhamento do serviço segue os seguintes critérios:

- O que verificar

- Como verificar

- Onde verificar

- Tolerância

- Itens que devem ser verificados (seguindo a legenda: Aprovado/ Reprovado/ Aprovado após re-inspeção/ NA). Se algum item for reprovado, mas o problema for simples e puder ser sanado com um retrabalho, fica registrado no campo de observações da Ficha de controle qual foi a solução adotada. 
No caso de problemas repetitivos ou mais graves é aberta uma ação corretiva e deve ser feita uma observação sobre os itens reprovados com a indicação de qual será a solução para acompanhamento.

Quando for identificada uma não conformidade com a necessidade de abertura de uma ação corretiva, esta fica registrada no SharePoint no site da obra em questão.

Faz parte da gestão tecnológica a coleta, compilação e análise de indicadores de desempenho para elaboração de ações de melhoria que podem estar relacionados a ações corretivas para atender ao padrão estabelecido ou revisão de critérios para adequação aos padrões tecnológicos específicos da empresa. Desta forma, consolidando o padrão de tecnologia da empresa.

Ainda não foi definido como estas informações serão compiladas, pois neste processo inicial de certificação os Formulários são preenchidos no formato em papel, mas a empresa tem estudado formas para que os registros sejam armazenados diretamente no banco de dados, como por exemplo, utilizando palm tops.

$\mathrm{Na}$ fase de implantação, após a publicação de um novo Procedimento Técnico e Formulário de Controle no SharePoint, o NSC envia um Formulário de Aprovação para a obra que deve ser preenchido após a primeira utilização do procedimento. A validação é feita pela equipe de produção e a aprovação ou comentários para alteração, no caso de não aprovado, são feitos pelo gerente responsável pela obra. Caso seja necessária alguma alteração do procedimento a equipe do NSC faz uma reunião com a equipe da obra para avaliar se o procedimento deve ser alterado ou não.

Para divulgação o NSC realizou nas obras treinamento sobre os processos técnicos e o uso das respectivas ferramentas utilizando um Tutorial em Power Point onde são apresentados pontos importantes de atenção, fotos de problemas patológicos. $O$ engenheiro de produção recebe o treinamento e replica ao restante da equipe utilizando o Tutorial como base. Os informes sobre o NSC hoje são enviados por email, mas encontra-se em elaboração um Boletim informativo que será incorporado ao site das obras. 
A base tecnológica consolidada facilita o desenvolvimento de inovações que podem ser identificadas internamente, pela equipe NSC ou de acordo com a utilização nas obras ou externamente, através de fornecedores.

A equipe de Suprimentos não interage com o NSC. O NSC tem interface na fase de planejamento na definição dos procedimentos e da tecnologia construtiva a ser utilizada nas obras. As informações da Assistência Técnica são utilizadas para melhoria dos processos. O NSC ainda não tem recursos para dar suporte a todas estas áreas.

\subsubsection{Problemas/ Deficiências no processo de projeto}

O PMO é responsável pelo acompanhamento da evolução das obras e segundo a gerente do PMO, o maior problema que pode resultar em falha no processo de projeto é a comunicação e envolvimento entre planejamento e produção, principalmente quando a obra é muito grande e segmentada. Por exemplo, a obra está adiantada, mas o projeto da próxima atividade a ser executada não está pronto, pois a área de projeto não foi informada desta necessidade.

Não foi estabelecido pela Qualidade um procedimento para passagem de informações da área de Proposta e orçamento para a obra. Antes do início da obra existe uma reunião em que todos os documentos utilizados na elaboração da proposta ao cliente são entregues à equipe de obra.

Segundo a gerente da Assistência Técnica, o projeto é uma parte muito importante, pois invariavelmente tudo passa pelo projeto, até um problema executivo da obra parte de uma concepção de projeto. Por exemplo, ao executar uma impermeabilização em uma parede que está muito próxima a um pilar o operário não consegue dar um bom acabamento que poderá ocasionar um problema de vazamento posteriormente. O projeto está correto, o cálculo do pilar, etc, mas não foi pensado na dificuldade de execução do serviço.

As deficiências de projetos mais encontradas pela Assistência Técnica são: a falta de compatibilização, informações erradas (que vem de outros projetos) e a falta de informações. 
Segundo a coordenadora de projetos, na obra sempre acorrem problemas com projeto. Apesar de haver duas empresas compatibilizando os projetos, nos pavimentos intermediários do lobby que tinha pé direito triplo, no momento da montagem das fôrmas foi detectado que o projeto de estruturas tinha problemas. $O$ serviço foi interrompido até que os projetos fossem revisados $e$ as fôrmas reformadas. O problema passou pela coordenação, pela equipe de projetos da obra e só foi detectado no momento da execução.

Após identificar vários problemas de compatibilidade, que poderiam impactar em prazo e custo da obra, a construtora contratou outra empresa terceirizada para compatibilização dos projetos, apesar da resistência do cliente e projetistas. Como os projetos haviam sido entregues ao cliente em abril/2010, o retorno dos projetistas para revisão dos projetos foi muito difícil. Para eles o projeto já havia sido compatibilizado e teriam que fazer o trabalho de novo. Quando a revisão era decorrente de falha de compatibilização ou não atendimento à norma técnica era bem aceita, mas quando tratava-se de uma revisão para melhoria da construtibilidade, eles não aceitavam. Por não visitar a obra, muitos detalhes de projeto eram muito velhos e ultrapassados e deveriam ser atualizados. No entanto, a maioria dos projetistas não tinha interesse nos comentários da construtora, para detalhes que poderiam ser executados de maneira diferente. Principalmente, os projetistas que têm vários detalhes padrão prontos, pois teriam que alterá-los. Nestes casos, muitas vezes a construtora atualiza o As Built sem informar ao projetista.

Apesar do gerente de Projetos da obra e a própria Empresa A ter um perfil de buscar envolver os projetistas para chegar a uma solução em conjunto, muitas vezes, a coordenadora de projetos entrava em contato com o projetista: "Seu detalhe não vai dar certo. Você poderia enviar outro?' e nunca mais recebia um retorno. Quando a equipe de produção e qualidade, que costuma acompanhar a obra de perto, detectava esses pontos, a solução da obra para evitar riscos foi elaborar croquis para aprovação do projetista antes da execução.

$\mathrm{O}$ arquiteto era o projetista que tinha maior interesse nas diferentes soluções encontradas pela obra, mas só visitava a obra depois de muita insistência da coordenadora. 


\subsubsection{Gestão de mudanças}

Do ponto de vista de fase de projeto, segundo a gerente da área de projetos, o ideal é que as alterações sejam realizadas antes da contratação da construtora para que a obra inicie com os projetos definidos.

No entanto, grande parte das mudanças que ocorrem na obra é decorrente de mudanças de projeto, por falta de detalhes, falta/ falha de compatibilização (cerca de 80\%). Quando o PMO detectou que muitas alterações de escopo vinham em decorrência dos projetos houve o interesse em vincular as ASECs (Aprovação de Alteração de Escopo) com as informações que vinham da coordenação de projetos. A Lista de Alterações de projeto do site foi estruturada de forma que pudesse ser agrupada de acordo com vínculos pré-estabelecidos de forma a compor uma ASEC (por exemplo: alteração de pacote das esquadrias - possibilita PMO ter uma rastreabilidade com a área de projetos).

Segundo a gerente do PMO, quando a mudança não é por causa de uma alteração de escopo pode ser por falta de produtividade do fornecedor. Muitas vezes 0 fornecedor não tem estrutura, e não consegue atender o prazo acordado, causando um impacto de mudança no cronograma.

No caso das alterações de escopo é realizado o Controle Integrado de Mudança. Todas ASECs que são enviadas ao cliente tem um quadro que mostra qual será o impacto de uma mudança (alteração do prometido para o cliente, SSMA, risco, fornecedores, etc). O PMO sempre faz um acompanhamento dos indicadores para verificar se todos os impactos foram registrados. Muitas obras conseguiram implantar o Comitê de Controle Integrado de Mudança com reuniões periódicas (semanais) com participação do gerente, coordenador de projetos, planejamento, produção e administrativo. Com isso, quando ocorre uma mudança todos podem verificar quais os impactos em suas atividades. O PMO estimula a criação do comitê e reuniões, pois após realizar uma reunião muitas obras começaram a se mobilizar ao perceber que há um ganho com a antecipação de problemas.

Uma alteração de projeto é uma entrada para o Controle Integrado de Mudanças que tem um formulário que indica o que originou a mudança: revisão de projeto, lista de dúvidas de projetos, análise crítica de projetos. Quando a alteração de escopo é gerada por motivos de projeto são avaliadas as nove áreas de conhecimento do $\mathrm{PMI}$, se gera acréscimo de custo, de prazo, etc. Se alterar algum item de contrato, 
automaticamente passa para aprovação do gerente de planejamento e controle, é gerada uma ASE (Alteração dos Serviços Extra Contratuais) para aprovação do gerente de Projeto e do cliente.

Para que o conhecimento gerado e compartilhado entre a equipe, decorrente das mudanças, seja armazenado, compartilhado e retransmitido para Projetos futuros da empresa, o PMO criou no SharePoint um campo para registro de Lições Aprendidas, que está com listas enormes. Mês a mês, o PMO cobra que sejam registradas ao longo da obra as Lições Aprendidas. O PMO está estudando uma forma estruturada para a divulgação das Lições Aprendidas de uma obra para o restante da empresa de forma que não seja uma "caça às bruxas" para achar os culpados ao término de uma obra que não tenha atingido o resultado esperado. "Aprendemos que não deve ser contratado desta forma" - não agregaria nada atribuir a culpa à área de Suprimentos.

$\mathrm{Na}$ reunião de resultados, todo mês os gerentes apresentavam as obras, mas os participantes não mostravam interesse ou os resultados eram maquiados para melhorar a margem da obra. O PMO está formatando o SharePoint para que os dados registrados não possam ser alterados e com isto sejam mais confiáveis.

Na obra analisada, quando ocorre uma mudança de escopo é feito um pleito de solicitação de mudança de escopo para validação do cliente.

Em casos de emergência é feita uma formalização da mudança por e-mail, informando ao cliente que haverá um impacto de custo que será apresentado em um pleito no prazo máximo de três dias.

Foram feitos pela Empresa A nove pleitos de mudança de escopo até 2010, tais como: aumento de prazo por atraso de projeto; por causa de chuva; mudança de solução de projeto (concreto com gelo nas vigas de transição).

Até meados de 2010, a pedido do cliente foram realizadas mudanças de projeto, tais como: localização de rampas do subsolo; número de subsolos sob a escola; acabamentos. Os prazos de contrato eram negociados com cliente em função das mudanças, pois muitas delas interferiam nas frentes de trabalho da obra que já estavam em andamento.

Em entrevista realizada em 2011, o gerente de instalações da obra informou que a única alteração na concepção do projeto de elétrica, onde estava previsto uma 
central de gerador a diesel, foi a instalação de uma usina de geração de energia para garantir que o edifício tivesse $100 \%$ de capacidade de geração de energia, por opção do cliente. Uma empresa realizará os projetos, fornecerá e instalará os equipamentos, sem custo inicial para o cliente. $O$ valor será pago em contrato de 15 anos de manutenção e fornecimento de energia no horário de ponta (das 17hs às $20 \mathrm{~h} 30 \mathrm{mi}$ ), onde a tarifa da concessionária é mais cara. Após o período de exploração o equipamento é repassado ao proprietário.

Quando a construtora ganhou a concorrência o edifício deveria atender às exigências para certificação LEED Silver, mas como mudou para LEED Gold foi pleiteado aumento de custo, pois como no caso do ar condicionado, alguns sistemas são mais caros que os convencionais.

Para atender ao LEED Gold foi necessário alterar alguns equipamentos de ar condicionado que já estavam comprados, para adotar um sistema de roda entálpica e aproveitar a exaustão do ar frio dos banheiros que seria jogada fora, no sistema de ar condicionado.

Com os contratos de locação, o cliente autorizou algumas alterações de projeto, prevendo três recepções no lobby por solicitação dos futuros locatários.

A construtora havia sido contratada para executar apenas sete pavimentos sendo o restante realizado após a locação, mas como para obtenção do Habite-se é obrigatório que sejam executados pelo menos os sanitários de todos os pavimentos, foi feito um aditivo do contrato. Como os sanitários não haviam sido realizados, foi possível atender às necessidades específicas dos locatários que surgiram antes do término da obra.

Antes do início da obra, para aumentar o potencial construtivo do terreno, o cliente comprou um terreno de uma escola vizinha, mas para a liberação deste trecho do terreno para demolição e escavação, o contrato previa que seria necessário obter o Habite-se da nova escola. Como os processos legais atrasaram, a obra teve início com um mês de atraso em relação ao previsto.

Segundo coordenadora de Planejamento e controle, a obra está conforme o planejado. Era previsto que em algumas fases de execução tais como estrutura e fachada, houvesse alguma diferença entre o previsto e realizado, para isso a produção foi puxada o que resultou em um pulmão de 45 dias entre o executado e 0 
prazo contratual na 1a. data marco do cronograma. Ao final de 2010, o pulmão era de 20-25 dias em função da estrutura.

Quando a estrutura atingir a laje do 11․ Pavimento será iniciada a fachada em pele de vidro dos andares já realizados garantindo o fechamento para início dos acabamentos internos.

\subsubsection{Gestão de riscos}

Existe um processo estruturado de monitoramento de riscos em que, no início do Projeto, é feita uma identificação de riscos. Cada um deles é analisado de acordo com o grau e a probabilidade de impacto para definir quais riscos terão um plano de resposta (qual é a ação, quem será o responsável) e se serão quantificados ou não. Todas as obras têm um Plano do Projeto onde é definido o mapa de riscos e a avaliação de riscos é feita na validação do Plano. O gerente do Projeto determina a periodicidade da análise, e o PMO faz um monitoramento deste mapa de riscos, e na reunião mensal com a equipe os riscos são reavaliados para verificar se foi identificado algum risco novo não previsto. No processo de ação preventiva da ISO este documento foi definido como ponto de monitoramento de risco para não criar dois controles paralelos.

A Assistência Técnica não participa da elaboração da análise de risco no início do Projeto, mas forneceu uma relação de itens que foram incluídos na análise de risco pelos gerentes de Projetos.

A coordenadora de planejamento informou que a obra tem uma reunião mensal de Análise de Risco e Monitoramento. Até 2010, foram identificados doze riscos em Projetos, tais como:

- Atraso na liberação de projeto;

- Coordenação de projetos sob responsabilidade da incorporadora. O papel da construtora é apenas sinalizar necessidades, prazos, que possam influenciar no andamento da obra;

- Compatibilização dos projetos que podem impactar em prazo e custo (a construtora contratou uma empresa terceirizada que identificou vários 
problemas de compatibilidade, onde foram tomadas ações para mitigar os problemas antes da execução) - o orçamento tem uma contingência para cobrir este custo;

- Mudança de escopo de projetos;

- Utilização de revisões obsoletas de projetos na obra pelos empreiteiros;

- Agilidade na distribuição de informações não eficiente;

- Não atendimento do prazo;

- Atraso no recebimento de projetos e erros de projeto gerando retrabalho (ex: projeto de fôrmas chegou após a execução da fôrma), cliente aprovou ASEC que estendeu o atraso do projeto;

- Risco de responsabilidade de soluções não detalhadas em projeto sugeridas pela obra que recaem sobre a construtora. Para minimizar o risco, a obra tem passado um croqui da solução ao projetista para validação antes da execução. O coordenador do cliente é responsável por passar ao projetista para aprovação;

- Folga de elevadores: o projetista não previu uma folga adequada entre a estrutura de concreto e a caixa de elevadores. Foi necessário estudar junto ao fornecedor algumas ações para tentar aumentar a folga;

- Execução da fachada do pavimento 16ㅇ. ao 18‥ pavimento: o cliente solicitou que fosse verificada a possibilidade de executar as fachadas dos andares da cobertura (16ํ. ao 18․) que são mais procurados e valorizados, antes da execução dos andares $8^{\circ}$. ao 15\%. A obra explicou ao cliente que esta execução poderia impactar no caminho crítico da obra visto que a execução da fachada dos andares $6^{\circ}$. ao $12^{\circ}$., que são os andares sob responsabilidade de execução de acabamento da construtora, encontram-se no caminho crítico da obra (já foi abortado).

As análises de projeto eram realizadas com a equipe de produção e qualidade quando era identificada a construtibilidade do projetado além de condições de fornecimento de materiais especificados.

Para evitar o risco de prazo de importação, a construtora sugeriu ao arquiteto-autor do projeto algumas alternativas de materiais nacionais com a mesma qualidade, por exemplo, o piso do lobby, onde a aprovação era feita através de amostras. 


\subsubsection{Gestão do conhecimento}

\subsubsection{Iniciativas de gestão do conhecimento}

A gerente da área de projetos, que também atua na área de Processos e Desenvolvimento, aponta como iniciativas de gestão do conhecimento no campo da tecnologia os três núcleos implantados com o objetivo de oferecer a melhor solução para o cliente, os quais estão direcionados:

- à busca e desenvolvimento das melhores práticas para os principais sistemas construtivos empregados (NSC - Núcleo de Sistemas Construtivos);

- à evolução no processo de desenvolvimento de projetos, reduzindo retrabalho, gerando maior precisão nas estimativas e maior eficiência no emprego de recursos (BIM - Núcleo de Modelagem)

- à identificação de oportunidades de melhoria de desempenho e redução de impacto ambiental e social nos projetos (Núcleo de Sustentabilidade).

Além destas iniciativas foram identificadas: o site colaborativo - SharePoint, 0 registro de Lições aprendidas, a Engenharia e Análise de Valor (EAV), a Método WIKI, o Curso de Patologia e sistema com dados de ocorrências da Assistência técnica, os Projetos Aplicativos de Trainees, e as demais descritas a seguir.

\section{BIM - Núcleo de Modelagem}

A aplicação da tecnologia BIM (Building Information Modeling) possibilitará a troca de informação entre toda a cadeia da construção civil, desde fornecedores até o cliente final.

O BIM tem apoiado internamente a área de Propostas e orçamentos, como uma ferramenta de gestão do processo. Do modelo produzido podem ser extraídos quantitativos de materiais automaticamente o que garante uma quantificação mais precisa, reduz a variabilidade na orçamentação e ao aumentar a sua velocidade permite a exploração de mais alternativas de projeto. A partir do modelo virtual é possível avaliar várias opções de custos dependendo do tipo de revestimento escolhido, do tamanho do pé direito e da quantidade de cimento, etc. 
Segundo a Assistência Técnica, com todas as disciplinas compatibilizadas em 3D, facilitará a visualização das interferências sendo prevenidos alguns problemas na obra, auxiliando a Assistência Técnica na identificação de causas de problemas após a entrega da obra sem necessidade de quebra.

O modelo poderá auxiliar a equipe de operação e manutenção do empreendimento, ao representar um As Built em 4D. Além da representação tridimensional dos projetos, o modelo terá registradas informações sobre as características de cada componente, tais como material, acabamentos, etc.

\section{NSC - Núcleo de Sistemas Construtivos}

NSC - Núcleo de Sistemas Construtivos com o objetivo de implantar a gestão de tecnologias construtivas:

- Consolidar conhecimento técnico através de procedimentos (ferramentas + processos);

- Disseminar este conhecimento na empresa para valorização da Engenharia;

- Controlar tecnologias e analisar oportunidades de melhoria contínua;

- Executar ações de desenvolvimento tecnológico.

\section{Núcleo de Sustentabilidade}

O Núcleo de Sustentabilidade, criado em 2008, realiza pesquisas e dá suporte ao cliente, projetistas e equipe de produção, não apenas nos empreendimentos que buscam certificação de sustentabilidade (LEED, AQUA), mas em todos os empreendimentos, a fim de buscar uma redução do investimento e dos custos de operação e manutenção garantindo a sustentabilidade ambiental competitiva aos seus empreendimentos.

São realizadas reuniões para troca de informações entre os arquitetos e engenheiros da empresa, centralizadas apenas nos profissionais que estão desenvolvendo alguma atividade que envolva a certificação. 


\section{SIG - Sistema Integrado de Gestão}

O SIG foi um sistema imposto pela alta direção para integrar o sistema de Qualidade e gestão do Meio Ambiente e centralizar o conhecimento.

O SIG foi baseado nas normas ISO 9001, ISO 14001 e OHSAS $18001 \mathrm{com}$ procedimentos para gestão da qualidade, voltado para processos e gestão de meio ambiente, abrangendo procedimentos de obra e processos operacionais/ administrativos do escritório central, com o objetivo de adequar os processos da empresa de forma a garantir a excelência operacional, melhoria da imagem e aumento da competitividade perante o mercado.

\section{Site colaborativo - SharePoint}

O site disponibiliza os melhores modelos de ferramentas de gestão de Projetos identificados pelo $\mathrm{PMO}$ e de coordenação de projetos estruturados pela área de projetos (conhecimento explícito). As lições aprendidas e boas práticas (conhecimento tácito) poderiam ser compartilhadas entre todas as obras.

\section{Lições aprendidas}

Segundo a gerente do PMO, o preenchimento das Lições aprendidas ainda não faz parte da cultura da empresa, apesar do modelo existir no SharePoint. O PMO tem estimulado seu uso, em suas visitas periódicas à obra, mas apenas algumas obras tiveram iniciativa e produziram um material consistente, como a obra analisada no estudo de caso. Para isso foi dedicado um dia específico para que cada membro da equipe escrevesse pelo menos cinco Lições aprendidas. $O$ registro de Lições aprendidas ainda precisa ser estimulado e talvez informando melhor sobre qual conteúdo esperado, pois muitas pessoas acham que pequenas iniciativas não devem fazer parte das Lições aprendidas ou que apenas casos de problema encontrados e solucionados devem ser registrados. Será criado um evento para divulgação das Lições aprendidas.

Já faz parte do procedimento da obra analisada a reunião mensal de Lições Aprendidas para obter material para a lista de Lições Aprendidas, para o qual foi 
designado um responsável, a gerente de planejamento, para o registro no SharePoint.

O foco das Lições Aprendidas de projetos refere-se ao controle dos projetos e prazos, que podem influenciar no andamento da obra ou causar retrabalho, caso não sejam validados pelos projetistas: 1 - Monitorar projetos de terceiros (projetistas contratados pelo cliente) e 2 - Monitorar se os projetos para produção (ex. fôrmas, escoramento, fachada) foram validados pelos projetistas.

Segundo o gerente de instalações, que participa de duas obras, as Lições Aprendidas deveriam ser divulgadas entre todas as obras e não ficar restrito a cada obra, através de uma apresentação para divulgação à toda empresa. Desta forma, poderia melhorar a interação entre o escritório central e as obras.

Cita, como exemplo, uma experiência da obra que foi registrada nas Lições Aprendidas: antes da escavação na rua deve ser checada a existência e interferência com rede de esgoto existente para execução de tirantes.

\section{Engenharia e Análise de Valor (EAV)}

Segundo a gerente de projetos, a fase mais propícia para a construtora realizar Engenharia e Análise de Valor e interferir nos projetos apresentando uma nova solução tecnológica é a fase de "Proposta e negociação", antes da contratação, quando a proposta ainda está sendo elaborada. Isto é possível desde que o cliente esteja disposto a aceitar novas sugestões para redução de custo ou prazo, sem perda da qualidade. Quando a empresa participa de uma concorrência com planilha fechada não é possível propor novas soluções de engenharia e a concorrência geralmente é baseada no menor preço.

Depois da contratação existe a possibilidade de interferência nas soluções de projetos quando a empresa for contratada por administração e existir um custo alvo e bônus por atingí-lo, ou contratação por PMG - Preço Máximo Garantido, onde a construtora recebe um bônus sobre o que conseguir reduzir em termos de custo.

Conforme obra analisada, as mudanças não previstas são propícias para a troca de experiência entre os envolvidos para solucionar os problemas, fonte de conhecimento tácito para equipe de obra e projetos. Algumas soluções também são 
necessárias para reduzir prazos de execução (proteção com fibra de coco na parede diafragma, concretagem com gelo, fôrmas de colunas de papelão), redução de custo (substituição da estrutura metálica da cobertura por concreto) ou atendimento a exigências externas (desenvolvimento de sistemas de ar condicioando para atender a certificação LEED).

\section{Método WIKI}

O PMO havia desenvolvido em seu portal o Método Wiki para que fosse um canal de troca de conhecimento entre os profissionais da empresa, mas a maior dificuldade era fazer as pessoas utilizarem o portal de forma espontânea, dependendo sempre de incentivos e estímulos para divulgação. Para tornar o Wiki uma ferramenta de fato, foram criadas várias funções para aumento de seu conteúdo e utilização. Todo o Guia Prático do SMGP foi instalado em páginas da Wiki, assim como alguns dos procedimentos da qualidade que viraram botões Saiba Mais, facilitando a auditoria. O PMO coletou material sobre gestão de Projetos e criou páginas da Wiki comentando o conteúdo deste material. Se algum diretor participar de alguma palestra o material é divulgado no Wiki.

Foram enviados e-mail para as obras indicando o caminho para acessá-los, mas a equipe da obra não utiliza a ferramenta por falta de conhecimento, tempo ou interesse.

\section{Assistência Técnica: Curso de Patologia, Sistema com dados de ocorrências, Manual do Proprietário}

Além do enfoque de ações nas atividades de gestão na qual foi formatado o SIG, foram criadas iniciativas para valorização do conhecimento técnico, tais como o Curso de Patologias liderado pela Assistência Técnica.

O curso foi desenvolvido em dez módulos baseado em um mapeamento inicial, cada módulo abordando um sistema construtivo. O material continha informações práticas de problemas encontrados nas obras da empresa e orientações teóricas baseadas em normas técnicas, para que os funcionários tivessem condições de analisar um projeto e identificar se estava atendendo os requisitos mínimos da norma NBR. O 
curso foi alinhado ao programa de trainees que participaram da elaboração dos check lists.

Com o curso e conscientização sobre os problemas patológicos nas obras, foi percebida uma redução nos principais problemas, tais como revestimentos de fachada ( $90 \%$ da obras tinham problemas relacionados à fachada).

Foi planejada uma semana do conhecimento para divulgação dos trabalhos com palestras, mas não foi possível realizá-la, pois mobilizaria toda a empresa. Assim, as apresentações foram feitas para um grupo composto por alguns diretores e gerentes e os melhores trabalhos foram selecionados para uma apresentação na reunião de resultados da empresa com a presença de todos os gerentes, diretores e presidência.

Além do curso, a área de Assistência Técnica disponibiliza à toda empresa um banco de dados com o mapeamento das ocorrências e problemas patológicos das obras a fim de evitar repetição de erros do passado.

No SharePoint da área existe um modelo de Manual do Proprietário padrão em Word que será adaptado pelo arquiteto da obra e só será entregue ao cliente após a avaliação técnica da Assistência Técnica e do jurídico. Este procedimento visa evitar que $o$ arquiteto preencha algum item de forma equivocada, por exemplo a garantia de uma obra é de cinco anos e se for preenchido de forma errônea a responsabilidade será da empresa. A Assistência Técnica sugeriu que o Manual seja preenchido ao longo da obra e não ao final da obra, assim a Assistência Técnica tem condições de analisá-lo com mais calma. Foi verificado que o Manual da Assistência Técnica não tem incorporado o manual de comissionamento desenvolvido pelo gerente de instalações da obra.

A gerente da Assistência Técnica fazia encontros com membros de Assistência Técnica de outras empresas (construtoras, incorporadoras) para debater assuntos de modo genérico, sem evidenciar a empresa em si. Incorporadores que fazem o serviço de manutenção condominial fazem bons planos de manutenção preventiva, embutindo este custo no custo do imóvel; construtoras focam na parte financeira (como é distribuída a manutenção); a Empresa $A$ focou mais no problema construtivo, pois se minimizar a quantidade de patologias, aumenta a margem da empresa, agregando valor ao Projeto. 


\section{Projetos Aplicativos de Trainees}

Com a visão de que a equipe é o patrimônio mais importante da empresa, em 2006 foi retomado o Programa de Formação de Novos Executivos, que visa identificar novos talentos e capacitar seu corpo técnico e profissional.

Os trainees, selecionados após período de estágio, no qual passam por todos departamentos da empresa, devem desenvolver um Projeto Aplicativo a partir de oportunidades identificadas para melhoria dentro da empresa. Vários Projetos tiveram como resultado melhoria de processos ou serviram de base para novas atividades, como o caso do Núcleo de Modelagem BIM.

\section{Gestão do processo de projeto}

O processo de projeto, ao permear todo o ciclo de vida do empreendimento, tem um importante papel na gestão do conhecimento entre Projetos, entre as empresas envolvidas e entre o projeto e a obra. A gestão eficiente e eficaz do processo utilizando as ferramentas de gestão (análise crítica dos projetos, registro de alterações de projeto, etc) e meios de comunicação (sistemas colaborativos, reuniões com registro em atas) adequados, reduz a possibilidade de falhas de compatibilização, conflito de informações, atrasos, retrabalho e garante a transferência do conhecimento entre as diferentes fases.

Conforme relatado pela gerente do PMO, a empresa passou por um processo de amadurecimento progressivo na gestão dos Projetos, acompanhada pela gestão dos processos de projeto.

A evolução do PMO pode ser descrita como: em 2006 foram redefinidos os processos da empresa. Em 2007, o foco foi o treinamento das pessoas. Em 2008, foi focado em ferramentas - Oracle. Como a empresa já tinha os três pilares da metodologia, mas não estava funcionando direito, em 2009, foi um ano de compliance, para avaliação da conformidade. Em 2010, o foco foi confiabilidade, criando ferramentas para verificar a confiabilidade das informações para tomada de decisões. Em 2011, o plano foi a previsibilidade. 


\section{Sugestões para melhoria da construtibilidade}

O membros da equipe de projetos e produção da obra constantemente geram novo conhecimento ao transformar a informação recebida dos projetistas, para otimizar uma solução ou garantir a construtibilidade de um detalhe, compartilhando experiências. A solução de problemas de projeto é encontrada de forma tácita e depois codificada em detalhes, especificações e desenhos que podem ser compartilhados em outros Projetos (revisão de detalhes padrão obsoletos).

\section{Gestão de suprimentos/ fornecedores}

Com o envolvimento de múltiplas empresas em um Projeto, a transferência de conhecimento de um estágio para o próximo depende muito do tipo de estratégia de suprimentos ou tipo de contrato adotado para o Projeto. O livre acesso da equipe de obra aos projetistas permitiu agilidade nas tomadas de decisão e a socialização permite que novo conhecimento seja gerado.

A interação entre os fornecedores, projetista e construtora é importante para análise da construtibilidade, racionalização e solução de problemas (como relato de folga elevador insuficiente, alternativas para "tropicalizar" as especificações).

\subsubsection{Esforços e barreiras para implementação}

Diversos fatores podem impactar a implementação de ferramentas ou atividades de gestão do conhecimento.

As dificuldades encontradas para implantação do SIG e SharePoint, identificadas pela gerente de projetos, Processos e Desenvolvimento, que coordenou a implantação da ISO 9001 e SIG foram:

- A resistência das pessoas para aprender e utilizar novas ferramentas;

- Resistência à mudança de procedimentos que fazem parte de sua rotina;

- Pouco tempo disponível para a pessoa se dedicar a aprender coisas e procedimentos novos;

- Grande rotatividade de funcionários; 
- Integração do sistema existente com o novo sistema.

Segundo a gerente do PMO: "implantar é fácil, o difícil é manter e dar continuidade." Foi verificado que as obras começaram a utilizar o SharePoint por insistência do PMO nas visitas mensais e a partir do momento que foi imposto como obrigatório pela alta direção. O PMO pôde constatar que, mesmo disponibilizando todas ferramentas e procedimentos, o treinamento de cada indivíduo foi crucial para o sucesso da utilização e disseminação do sistema de gestão da empresa.

Como estímulo à utilização do SharePoint e ferramentas de gestão, o presidente fez uma convocação a diversas áreas da empresa para participar da apresentação do Plano de Projeto de uma obra que estava iniciando onde compareceram quarenta pessoas do escritório central, entre elas gerentes das áreas funcionais (comercial, $\mathrm{RH}$, acionista, etc). Com esta iniciativa as pessoas têm sido motivadas a elaborar Planos de Projeto cada vez melhores. Como a apresentação foi feita ao presidente da empresa, cada área que apresentou a sua parte do Plano, firma um compromisso para sua realização. A gerente do PMO verificou que "este contato é importante, pois cada funcionário passa a se sentir parte da empresa."

No início, a implantação de um registro de Lições Aprendidas foi associado pelas equipes de obra como "caça às bruxas", no qual o objetivo seria encontrar os motivos e culpados pelo resultado negativo das obras. Após treinamento e reuniões com o PMO foi assimilado o conceito e real objetivo da iniciativa.

A utilização do BIM, segundo o gerente de instalações da obra, dependerá mais da iniciativa dos clientes/ incorporadores, pois como a construtora, em geral, recebe 0 projeto pronto para execução não tem como interferir sem que haja um custo.

O NSC desenvolveu vários procedimentos, mas, segundo a gerente de Planejamento da obra, se foram validados por outra obra podem não se adequar a todas as obras. "A iniciativa é boa, mas não tem dado muito tempo para a obra analisar os processos, pois o prazo estipulado pelo núcleo é de apenas dois dias. Além disso, os custos relativos a atividades do NSC e ISO 9001 têm que ser absorvidos pela obra."

Para mensurar os resultados das iniciativas de gestão do conhecimento, a gerente de projetos informou que todo sistema da ISO 9001 tem medição mensal dos 
indicadores, que alimentam as reuniões gerenciais de análise crítica. O núcleo do BIM implantou um índice de satisfação e uma ficha de pesquisa de satisfação do serviço prestado (clientes externos e internos - área de orçamento).

Algumas iniciativas da equipe de obra para disseminar o conhecimento adquirido com a experiência encontraram resistência por parte dos projetistas, que podem ser avaliadas como insegurança ou restrições de tempo para analisar o benefício para sua empresa. A pressão com prazos de entrega dos projetos, principalmente em empresas de pequeno porte que participam de equipes em diversos Projetos, representa uma barreira ao estabelecer um conflito de prioridades: prazo $x$ qualidade.

Ao identificar que algumas patologias das obras estavam associadas às pessoas e não aos processos construtivos, a Assistência Técnica teve que conscientizar a alta direção que o Curso de Patologia e treinamento das equipes traria resultados sobre o desempenho da empresa ao reduzir a grande incidência de ocorrências de assistência técnica.

\subsubsection{Síntese do Estudo de Caso Empresa A}

Nas fases de Pré-construção, a interação entre equipes de projeto e obra da construtora e os projetistas tem grande potencial para transmissão e geração de novo conhecimento, como foi verificado na fase de Proposta no estudo de caso da Empresa $A$, quando a construtora em parceria com projetistas desenvolveram alternativas para redução de custo da obra, agregando valor ao Projeto.

A engenharia e análise de valor utilizada na fase de Proposta propicia a criação de novo conhecimento interno à organização e aquisição ao importar novo conhecimento de fontes externas (fornecedores e consultores especializados).

Ao participar das reuniões de projeto na etapa de concepção, com o objetivo de evitar uma concorrência da obra, e depois na etapa de Proposta para encontrar alternativas para redução de custo, a Empresa A contribuiu nos estudos para viabilização do empreendimento com itens relativos a custo, prazo e construtibilidade. 
Como grande parte das decisões tomadas na fase de concepção do projeto poderá afetar o ciclo de vida do empreendimento até a fase de operação/ manutenção, o projeto tem um papel importante como síntese do conhecimento gerado pela equipe, e meio de transmissão de conhecimento para as etapas subsequentes, no qual ficam armazenadas as novas soluções ou revisões decorrentes da melhoria dos processos ou mudanças de escopo do cliente.

Foram necessárias novas alternativas de projeto ao buscar atender aos requisitos da certificação LEED Gold, tais como soluções de fachada a partir do resultado de simulações computacionais para checar eficiência energética da edificação.

Da perspectiva dos projetistas, as soluções de problemas de projeto são encontradas de forma tácita, em um processo de socialização quando ocorre a transferência de conhecimento entre os agentes envolvidos, e que depois são codificados em detalhes, especificações e desenhos.

Foi constatado que a adoção de uma estratégia apropriada de suprimentos e contratos que facilite o contínuo envolvimento das pessoas chave ao longo da duração do projeto, aliado a meios de socialização, tais como extranets e reuniões para reflexão contínua sobre o projeto são propícios para o compartilhamento de experiências e, a partir daí, criação de conhecimento tácito. De acordo com a coordenadora de projetos, o contrato da construtora (Empresa A) previa livre acesso para consultar os projetistas contratados pelo cliente, o que facilitou a comunicação entre projeto e produção. O que demonstra o importante papel do cliente ao estabelecer por meio das estruturas contratuais, relações de responsabilidade, confiança entre os agentes, propiciando a troca de conhecimento.

Ao deparar com alguns problemas, a equipe de obra buscava encontrar soluções e apresentá-las aos projetistas, para garantir a construtibilidade de detalhes obsoletos utilizados como padrão nos projetos. No entanto, ao invés de potencializar seu conhecimento, o que poderia melhorar o desempenho da empresa, muitos projetistas não aproveitaram a iniciativa da construtora para aquisição de novo conhecimento, por falta de tempo e interesse. Em virtude do bom momento econômico do país, todos os projetistas estavam muito sobrecarregados, conduzindo vários projetos simultaneamente, o que comprova que os fatores ambientais externos interferem na gestão do conhecimento. 
A transferência de conhecimento depende do consentimento e envolvimento de quem detém o conhecimento e pode ocorrer de forma informal. No caso dos Projetos temporários da construção, a alta capacidade de absorção do cliente/ proprietário do projeto pode ser um facilitador da transferência de conhecimento de um Projeto para outro. Ao identificar o valor de um novo conhecimento criado no Projeto, este pode ser difundido entre as organizações participantes e para outros Projetos. Aliado à capacidade de absorção do cliente/ proprietário, a comunicação tem um papel fundamental para o sucesso da transferência do conhecimento do Projeto. Além do cliente, outros agentes que participam do processo podem atuar como facilitadores, como o exemplo citado pelo gerente de instalações, que informou sobre uma solução de estrutura adotada em outra obra e, após o contato entre os gerentes de Projetos de cada obra, a solução foi adotada com sucesso no novo contexto.

Deve haver uma combinação dos tipos e necessidades de conhecimento com as aplicações de TI, pois as tecnologias são facilitadoras (extranet, intranet), mas não são uma solução em si mesmas.

A escolha do SharePoint como sistema colaborativo na Empresa A foi baseada na expectativa de produtividade mais alta do trabalho em equipe, propiciada por ambiente de trabalho colaborativo; implementação rápida pela facilidade de utilização do programa; custos de equipamentos e programa relativamente baixos. A ferramenta mostrou-se útil para gerenciar o conhecimento explícito, mas ao acompanhar a utilização do SharePoint e procedimentos de gestão nas obras, o PMO identificou que seria necessário mais treinamento, divulgação e incentivo para que todos os funcionários responsáveis pela atividade principal da empresa o utilizassem. Apenas armazenar o conhecimento do aprendizado de seus funcionários em seus procedimentos, normas, regras, não garante que este conhecimento esteja sendo utilizado.

A disseminação tem papel fundamental na aprendizagem organizacional, pois as organizações não sabem o que sabem, muitas vezes por falta de comunicação adequada ou "compartimentalização", como exemplificado no caso do manual de comissionamento desenvolvido pelo gerente de instalações da obra com as instaladoras que não foi assimilado ainda pela Assistência Técnica, ou o 
desconhecimento da equipe da obra de alguns aplicativos desenvolvidos no escritório central, tais como Método Wiki.

A divulgação de melhores práticas de gestão pelo PMO (conhecimento explícito) propicia a melhoria contínua dos procedimentos operacionais, criando uma memória organizacional. No entanto, a equipe residente na obra sente que há uma distância muito grande entre o que é desenvolvido no escritório central da realidade das obras.

O alto grau de centralização da empresa, concentrando o processo decisório em um único ponto da organização (alta administração e escritório central), influencia a forma de divulgação das informações e conhecimento na empresa.

As restrições de acesso aos sites do SharePoint das obras, para evitar comparações entre as obras ou comentários negativos, limita o compartilhamento de conhecimento em toda empresa. O fluxo livre de informações entre todos os envolvidos poderia criar um ambiente que motiva a transferência de informação e conhecimento.

Detectou-se que a iniciativa da criação do NSC nasceu desvinculada da obra e, ao ser desenvolvido por profissionais do escritório central, sem uma vivência de campo, envolvendo as equipes de obra apenas para a validação dos procedimentos já elaborados, pode não ter uma aplicabilidade condizente com o objetivo que gerou a iniciativa.

A aquisição de novo conhecimento relativo a sistemas construtivos ou questões tecnológicas ocorre mais entre a obra e os fornecedores, que trazem experiência de outros Projetos que foram bem sucedidos, do que do conhecimento organizacional disponibilizado na forma de conhecimento explícito.

Quanto aos projetos, verificou-se que a empresa disponibiliza ferramentas de controle e gestão do processo de projeto, que são aplicadas na obra, para garantir a efetiva gestão da qualidade buscando eliminar as causas dos problemas antes da execução dos projetos, reduzindo falhas e retrabalho. Todas decisões tomadas nas etapas de projeto são registradas nas ferramentas de controle do SharePoint. No entanto, não foram identificadas estratégias para transferir o conhecimento/ aprendizado para os diferentes Projetos e aos projetista e fornecedores com o qual a empresa está envolvida. 
A equipe da obra analisada já assimilou a rotina de participação das reuniões de Lições Aprendidas quando são registradas as experiências passadas pela equipe (externalização).

O estabelecimento de quantidade mínima mensal de registro de Lições Aprendidas e a obrigatoriedade no preenchimento pode desmotivar a equipe, pois para "cumprimento de metas" o objetivo das Lições Aprendidas pode ser alterado, passando de registro de experiências para dicas de procedimentos organizacionais, que não agregarão valor a novos Projetos. Principalmente, se a dica já estiver incorporada aos procedimentos de rotina, como é o caso das Lições Aprendidas da área de Projetos registradas na obra que se referem: ao controle dos projetos $e$ prazos, que podem influenciar no andamento da obra ou causar retrabalho, caso não sejam validados pelos projetistas.

Apesar de estimular o registro de Lições Aprendidas, a Empresa A não dispõe de um processo estruturado de retroalimentação, baseado em informações coletadas junto a equipes de obra, para as equipes internas e externas à empresa (projetistas e consultores). Esta interação só ocorre no caso de problemas detectados após o término da obra, quando a área de Assistência Técnica aciona os projetistas ou fornecedores após identificar que eles são os responsáveis pela origem do problema.

A restrição de acesso para consulta da base de dados de conhecimento de outras obras, inviabiliza a reutilização das Lições Aprendidas, tanto nas tarefas técnicas quanto gerenciais. Ao invés de restringir, a empresa deveria divulgar interna e externamente, inclusive aos clientes, que tem um procedimento para conduzir e armazenar as Lições Aprendidas para prevenir a repetição de problemas similares, como forma de diferenciação dos concorrentes. O conhecimento pode criar valor quando é posto em ação, mas para convertê-lo em valor as empresas precisam de enfoque.

O trabalho de mapeamento desenvolvido pela Assistência Técnica possibilitou identificar problemas que poderiam ser sanados ou melhorados (por exemplo, algumas patologias estavam associadas às pessoas e não aos processos da empresa), aumentando o desempenho dos negócios da empresa. 
Como oportunidade para divulgar o conhecimento adquirido, foi criado um mecanismo de aprendizagem organizacional, através do Curso de Patologias, cujo objetivo consiste em identificar, documentar e comunicar erros cometidos para evitálos nas novas obras.

Em relação aos sistemas de gestão de Projetos e coordenação de projetos, o PMO pode ser destacado como essencial para garantir a eficiência com que a organização usa o que sabe e a prontidão com que ela adquire e usa novos conhecimentos, para sustentar sua vantagem competitiva, que está baseada no que ela sabe coletivamente. Quanto aos aspectos tecnológicos, a gestão do conhecimento está mais focada no registro de conhecimento explícito do que no desenvolvimento de inovações. Não há um processo de aprendizado contínuo e sistematizado de tranferência de conhecimento de Projeto para Projeto.

Apesar de não ser detectado um processo estruturado de planejamento para implantação de um sistema de gestão de conhecimento, foram identificadas várias iniciativas corporativas e individuais, que muitas vezes surgiram de necessidades identificadas nas atividades específicas de cada departamento.

\subsection{Estudo de caso: Empresa B}

\subsubsection{Caracterização da Empresa B}

\subsubsection{Informações gerais}

A empresa iniciou suas atividades no segmento industrial em 1971, e participou de mais de 550 obras, com mais de sete milhões de metros quadrados construídos no Brasil. Atua em quatro segmentos, com foco no mercado corporativo: Industrial, Logística, Comercial (shopping centers, varejo, corporativo, hospitais, hotéis, educação e cultura) e Edificações de missão crítica (callcenters, data centers, semicondutores, pesquisa \& desenvolvimento), destacando-se na construção de diversos shopping centers e projetos de varejo que representam $39 \%$ de suas vendas. 
A empresa busca nichos mais especializados, como é o caso da construção de data centers, que já representavam em $2011,21 \%$ do faturamento da empresa.

Em 2003, criou uma unidade de incorporação, que inaugurou um parque logístico, centro empresarial e torres corporativas, que em 2011 representaram 36\% dos lucros da empresa.

A cultura da empresa está focada no forte relacionamento com seus diversos públicos, entre eles, clientes, fornecedores e funcionários, ancorado na confiabilidade, transparência e sustentabilidade.

Além das práticas de gestão ambiental adotadas pela empresa desde 1998, em 2004 foi a primeira empresa de engenharia e construção a criar um Sistema de Gestão Integrado - SGI, baseado nas certificações ISO 9000, OSHAS 1400 e ISO 18000. Desde 2008, desenvolveu um sistema próprio de qualidade, PRqd Programa Racional de qualidade e desempenho, com base na experiência adquirida ao longo de anos de atuação, que estabelece padrões para a gestão dos contratos, visando o pleno monitoramento dos riscos desde os tecnológicos, jurídicos, da marca e da gestão de pessoas e à maximização do desempenho do empreendimento nos quesitos de qualidade construtiva e de operação.

A empresa atua em todo território nacional oferecendo serviços de pré-construção, com o objetivo de agregar valor ao negócio do cliente e construção.

\subsubsection{Evolução da empresa}

A empresa foi fundada em 1971, por um engenheiro civil, na cidade de São Paulo, atuando na primeira fase dedicada à atividade de construção. O país passava naquele período por um forte ciclo de crescimento decorrente de uma agressiva política de investimentos em infraestrutura e instalações industriais. Como diferencial competitivo, a empresa deu foco na implementação de diversas tecnologias construtivas inovadoras. Com a proposta de racionalização de processos construtivos introduziu o modelo de pré-fabricação de estruturas em canteiro.

Em sua $2^{\mathrm{a}}$ fase, a partir dos anos 80 , após sucessivos choques econômicos decorrentes de crises no mercado petrolífero, surgiram novos negócios no segmento 
comercial, em particular shopping centers, além de hotéis e hospitais. A empresa passa também a oferecer os serviços de engenharia, com destaque para a gestão e coordenação de projetos.

Acompanhando a tendência do mercado nos anos 90 , em sua $3^{a}$ fase, são introduzidos novos conceitos tais como: Engenharia e Análise de Valor, gestão integrada de custo e a modalidade Preço Máximo Garantido, aumentando o foco no cliente.

Em 1999, a empresa adquire o primeiro módulo do sistema de gestão integrada (ERP) para integrar as áreas Contábil e Financeira, que na época possuíam um sistema próprio para cada departamento e com fluxo de informações feito em papel, o que obrigava as áreas a redigitarem e processarem novamente as informações ao final dos processos.

A empresa adiciona ao seu portfólio os serviços de pré-construção e design\&build (projeto e construção) como grande diferencial competitivo de mercado, e assume contratações na modalidade turn-key (chave na mão). A empresa passa a uma fase de maior terceirização de mão-de-obra. Novos segmentos são incorporados, em particular o de edificações de missão crítica.

Em 2004, tem início a 4ª fase, quando a gestão estratégica de negócios agrega ao foco no cliente, o foco do cliente buscando respeitar $e$ atender às suas necessidades. Para tanto, quanto mais clara, rigorosa e desafiante for a exigência demandada pelo cliente, melhor o desempenho.

Para atender as demandas de competitividade do setor, que exige maior qualidade, não apenas nos serviços técnicos prestados, mas em segurança e meio ambiente, a alta direção ressalta a importância de aprimorar as competências da empresa. Em 2004, foi a primeira empresa de engenharia e construção a ser certificada no Sistema de Gestão Integrado - SGI, obtendo as certificações ISO 9001 (desenvolvimento e gerenciamento de projetos), ISO 14001 (meio ambiente) e OHSAS 18001 (segurança e saúde ocupacional).

Após um ano de pesquisa, foi implantado em 2004, um novo sistema para atender à rotina de uma empresa construtora, com foco nas áreas de Suprimentos, Gestão de Contratos, Controladoria, Financeira e Folha de Pagamento. O objetivo foi interligar, 
através de um único sistema, os vários pontos da rede, iniciado com a requisição de compras até o pagamento.

Além da reformulação do sistema de gestão, em 2006, foi implantada uma nova estrutura organizacional com uma estrutura nuclear tendo o cliente no seu centro. $A$ mudança para uma estrutura nuclear foi realizada para estimular a interdependência entre os profissionais a partir de uma organização mais horizontal, que alinhasse a atuação da empresa a uma estratégia comum a todos, para reduzir as dificuldades de crescimento eliminando alguns "gargalos".

No planejamento estratégico foram definidas quatro dimensões, relacionadas à missão e visão da empresa, a partir das quais são traçadas metas e indicadores anuais de desempenho: Governança Corporativa, Marca, Conhecimento e Sustentabilidade.

Para a empresa a essência do conhecimento está na sua efetiva aplicação. Seus principais compromissos estão na dinâmica de inovação, na excelência de desempenho e na devida gestão de riscos e oportunidades. A gestão do conhecimento deve ser um processo sistemático, articulado e intencional, apoiado na produção, na organização e na acessibilidade de conteúdo.

A empresa busca intensificar o processo de valorização da Marca entre os funcionários através de ciclos de treinamento para orientá-los sobre a utilização da Marca e a importância do site como instrumento de venda, além de resgate da memória da empresa, alinhando essas diretrizes com a conscientização de reafirmar a essência da marca no mercado.

Para atingir seus objetivos estratégicos a empresa focou na construção de competências, capacitação e parcerias estratégicas. Por exigência das condições de mercado, o empenho foi voltado inicialmente para as competências técnicas, tais como conhecimento, tecnologia de ponta, saber fazer, etc. No entanto, para o desenvolvimento das competências comportamentais, foi contratada uma consultoria e foram definidas as competências necessárias para que o funcionário tivesse um alto desempenho possibilitando, desta forma, colaborar para um melhor resultado da empresa, tanto do ponto de vista qualitativo (nas relações humanas e qualidade), como quantitativo (o ganho real econômico). O processo iniciou com a definição de nove competências fundamentais para a organização: 
1. Visão Estratégica / Negócios

2. Inovação e Gestão de Mudanças

3. Orientação para o Cliente

4. Orientação para Resultados/ Qualidade

5. Compartilhamento de Informações e Teamwork (trabalho em equipe)

6. Influência e Negociação

7. Liderança e Gestão de Pessoas

8. Auto-desenvolvimento

9. Expertise Técnica

Cada competência recebeu uma graduação, sendo que cada funcionário estabeleceu as metas para o seu crescimento e os itens em que deveria focar o desenvolvimento de suas competências. Inicialmente foram avaliados o Núcleo Integrador (formado pelo presidente, vice-presidente e quatro diretores executivos), outros executivos e depois os coordenadores.

Com o aquecimento da economia brasileira, aumento da demanda no setor, uma equipe alinhada, um modelo de gestão bem estruturados e consistência dos sistemas em 2007, a empresa viu condições para adotar uma estratégia de crescimento. A estratégia baseada na experiência da empresa e portifólio de clientes buscava a integração da empresa como um todo: do escritório às obras. A alta direção busca divulgar a estratégia com clareza, através do Núcleo Integrador, a todos os níveis da empresa, utilizando a mesma terminologia, reconhecendo os mesmos valores entre todos.

No período da crise de 2008, a empresa ampliou sua atuação nos segmentos de shopping centers, varejo e saúde, que continuaram aquecidos.

A partir de 2008, a empresa decide investir em um portifólio estratégico com o objetivo de criar um lastro patrimonial que permita a redução parcial do risco de volatilidade do mercado de construção civil, por meio de um fluxo de caixa estável e de longo prazo. Foi criado um Núcleo de Gestão de Portifólio classificado em Corporativo (centro empresarial e torres corporativas no Rio de Janeiro) e Centros 
Logísticos (centro logísitico em São Paulo e Campinas) que, em 2011, representaram $36 \%$ dos lucros da empresa.

Para buscar maior eficiência, transferência de conhecimento de forma organizada e estruturada, monitoramento de riscos e maximização das oportunidades foi criado em 2008, o PRqd - Programa Racional de qualidade e desempenho, que nasceu da decisão de abdicar das certificações ISO que não estavam adequadas às especificidades da empresa.

Além do desenvolvimento dos programas de gestão, em 2009, para consolidar os fundamentos da estrutura reformulada, destacaram-se a avaliação de desempenho, desenvolvimento de lideranças e definição do mapa estratégico. As dimensões estratégicas, conforme Figura 55, foram reformuladas unificando Marca e Sustentabilidade (um compromisso inseparável da Marca) e transformando o Potencial Humano em uma nova dimensão, visto que as organizações são formadas essencialmente pela articulação entre pessoas.

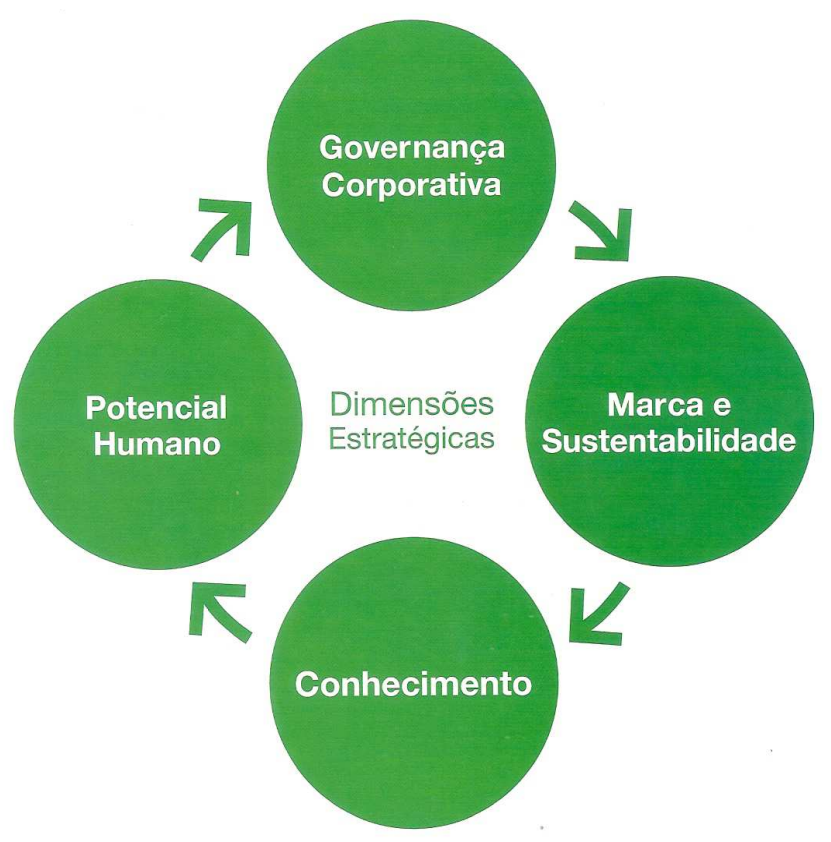

Figura 55 - Dimensões estratégicas da Empresa B

Com a paralisação de projetos de novas fábricas devido à crise de 2009, assim como outras empresas de engenharia, a Empresa $B$ desenvolve mercados ligados a consumo e serviços, onde a tomada de decisões de novos investimentos é mais veloz, tais como shopping centers, hospitais e data centers (D'AMBROSIO, 2011). 
A fase atual (2011) está focada na consolidação da missão da empresa de construir edificações e gerenciar empreendimentos com alto desempenho, atuando na originação de negócios estruturados e constituição de um portfólio estratégico focado no segmento de logística.

Em 2011, a empresa venceu o $7^{\circ}$ Ranking ITCnet 2010 - "As 100 maiores da Construção", como a maior construtora e a mais sustentável, no segmento comercial.

\subsubsection{Missão, valor e visão}

A missão da empresa é apresentada como: "Construir edificações e gerenciar empreendimentos com alto desempenho".

São adotados como valores e princípios:

- $\quad$ Orientação para o cliente;

- Sustentabilidade: compromisso inseparável da Marca, percebida como garantia de confiabilidade, desempenho e valor;

- Interdependência: perceber as partes no todo e o todo nas partes e estimular sua interação;

- Melhoria contínua: incrementar o desempenho através do conhecimento, inovação e aprendizado contínuo.

Além da resolução de conflitos, a fim de reconhecer as contradições e atuar de forma pró-ativa, orientando-se pela confiabilidade e transparência. A Visão da empresa é: "ser a marca de maior confiabilidade em seu mercado". Aliado a critérios de qualidade e desempenho, a empresa destaca como diferencial e fator marcante de sua gestão o fato da não-repetitividade, onde cada contrato é encarado como único, e o perfil e necessidades dos clientes são atendidos com exclusividade. 


\subsubsection{Estrutura organizacional}

Em 2004, a empresa rompe com a estrutura organizacional clássica piramidal, vertical e hierárquica e introduz um conceito figurado da organização, segundo o modelo de "Estrutura Nuclear", ilustrado na Figura 56.

Os diversos núcleos de decisão são organizados baseado nos princípios do Sistema Solar, onde o cliente é a figura central e a razão de todas as ações. Os núcleos que gravitam em torno do cliente são denominados: Desenvolvimento de Negócios, Gestão de Contratos, Engenharia, e Administração e Finanças. Os quatro núcleos atuam no chamado "campo integrador", onde todas as ações se complementam, no sentido de atender a todas as necessidades do cliente. O presidente, vice-presidente e diretores executivos atuam como um Núcleo Integrador. A criação desta estrutura mais solta teve como objetivo facilitar e intensificar a comunicação entre os diversos setores da empresa, ganhando em velocidade na informação, na decisão, na identificação e resolução de problemas, no atendimento.

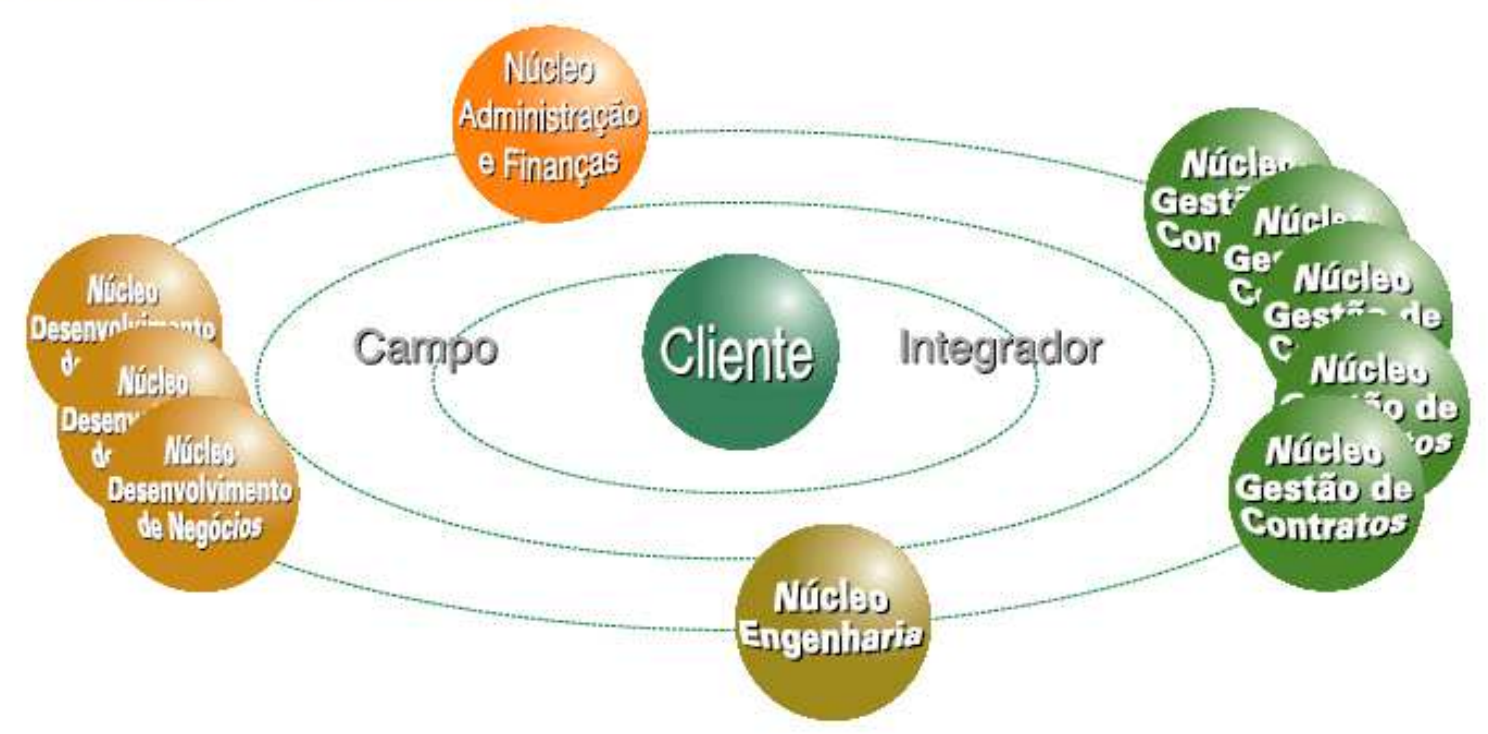

Figura 56 - Estrutura organizacional da Empresa B: Estrutura Nuclear

Esta nova forma de organização, baseada na horizontalidade, teve como objetivo estimular a interação entre os profissionais, valorizando a interdepêndencia entre os seguintes núcleos que compõem a estrutura:

- AFI - Núcleo de Administração e Finanças

- GDO - Núcleo de Desenvolvimento Organizacional 
- GPO - Núcleo de Gestão de Portfólio: responsável pela gestão do Portifólio Estratégico da empresa, composto por empreendimentos Corporativos e Centros Logísticos

- DDN - Núcleo de Desenvolvimento de Negócios: responsável pelo desenvolvimento de negócio na etapa de pré-construção.

- GET - Núcleo de Gestão Técnica: responsável pelo orçamento, planejamento e acompanhamento dos contratos

- ENG - Núcleo de Engenharia: responsável pela gestão dos projetos e apoio de engenharia na fase de pré-construção.

- GCO - Núcleo de Gestão de Contratos: responsável pela gestão dos contratos (gerente responsável pela obra)

No Núcleo Integrador encontra-se a área de Desenvolvimento Sustentável, responsável pela Sustentabilidade, que deve reger todas as relações da empresa contribuindo para o reconhecimento da Marca como expressão de confiabilidade, desempenho e valor. Atua sob a perspectiva da longevidade, a fim de assegurar o sucesso dos negócios da empresa no longo prazo e, ao mesmo tempo, contribuindo para o desenvolvimento da sociedade e a preservação do planeta.

A equipe responsável pela gestão de projetos da empresa, liderada pelo gestor do Núcleo de Engenharia, é composta por dois GP - Gerentes de Projeto e treze coordenadores de projetos, sendo que, em 2011, dois coordenadores estavam participando de Projetos em fase de concorrência e onze encontravam-se locados em obras.

Após recente re-estruturação da área, em função da complexidade de cada obra, será definido se o GP deverá atuar em conjunto com o coordenador de projetos. $\mathrm{O}$ GP entrevistado estava participando de dois projetos em desenvolvimento na empresa, sendo um deles objeto do presente estudo de caso (Data Center).

A estrutura de distribuição da empresa pode ser caracterizada como uma estrutura matricial balanceada, que é uma combinação de duas formas de departamentalização: funcional e por Projetos, na mesma estrutura organizacional. Nesta estrutura, o Gestor do Contrato tem uma influência semelhante aos gestores dos Núcleos (áreas funcionais). Na fase de pré-construção, onde o projeto começa a ser desenvolvido, os coordenadores de projetos permanecem no EC - Escritório 
Central orientados pelo Núcleo de Engenharia e quando a obra inicia, ficam alocados na obra, respondendo diretamente ao Gestor do Contrato.

Apesar de ser uma empresa de construção, a Empresa B especializou-se na área de coordenação de projetos, por uma demanda do mercado. Antigamente, as construtoras orçavam com base em projetos mais definido e detalhado, pois 0 empreendedor só iniciava a concorrência depois que o projeto estivesse finalizado. Hoje, o cliente contrata a construtora para iniciar a obra enquanto os projetos estão em fase de desenvolvimento. Neste caso, a coordenação de projetos precisa focar nas prioridades de entrega para atender ao cronograma da obra.

\subsubsection{Ciclo de vida dos empreendimentos}

O ciclo de vida dos negócios da empresa pode ser estruturado em quatro fases, que serão realizadas de acordo com a contratação:

\section{- Originação}

Estruturação de negócios, que podem envolver desde a prospecção de terrenos até alternativas financeiras que viabilizam contratos do tipo built to suit (construção sob medida).

\section{- Pré-Construção}

Fase de concepção preliminar do empreendimento, provendo informações técnicas e de custos que norteiam as tomadas de decisão e a melhor estimativa do valor do investimento. Tais serviços se caracterizam por:

- Estudo de Sustentabilidade;

- Projetos Preliminares;

- Engenharia e Análise de Valor (EAV);

- Licenciamentos;

- Planejamento e Custos.

O Núcleo de Engenharia atua na Pré-Construção de $100 \%$ das obras contratadas, o que muda é o seu grau de participação. A Tabela 2 mostra o grau de participação do Núcleo de Engenharia na 1를 quinzena de abril/2011. 


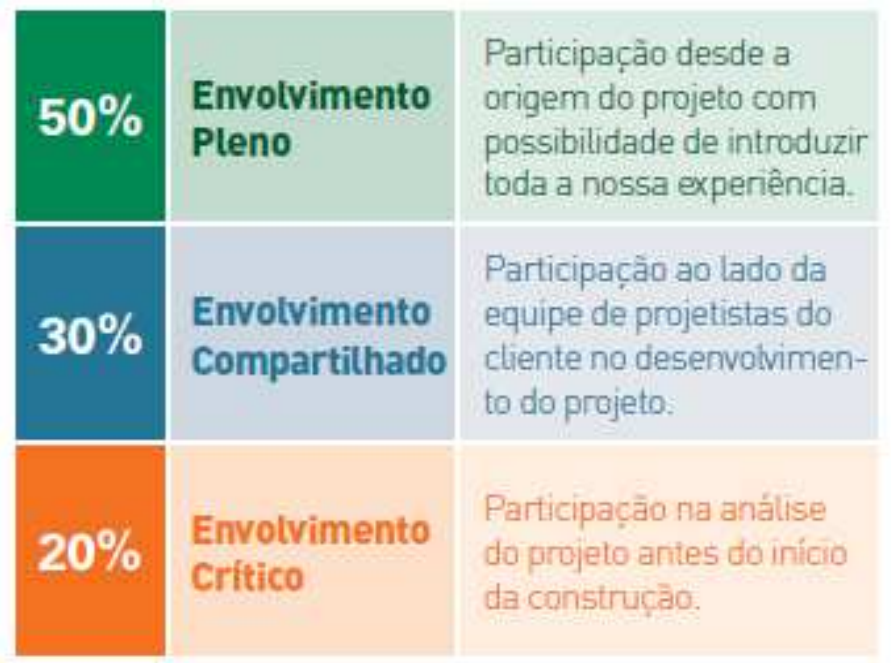

Tabela 2 - Grau de envolvimento da empresa nas obras em andamento (1ª quinzena de abril/2011) (Pessotto; Simões; Villa, 2011)

\section{- Engenharia e Construção}

Quando os projetos executivos são disponibilizados pelo cliente, a atuação da empresa inclui a validação dos projetos do cliente, estudos de Engenharia e Análise de Valor, desembaraço junto aos órgãos públicos / concessionárias e toda a assistência pós-obra e start-up das instalações.

\section{- Projeto e Construção}

Inclui o desenvolvimento dos projetos, além da modalidade de Engenharia e Construção. A delimitação das responsabilidades varia com a complexidade de cada contrato, sendo configurada junto ao cliente.

\subsubsection{Sistemas de gestão}

- Sistema de Gestão Integrado - PRqd (Programa Racional de qualidade e desempenho)

A empresa criou o Sistema de Gestão Integrado - SGI que foi aplicado quando a empresa buscava a certificação ISO 9000, OSHAS 1400 e ISO 18000 em 20032005, mas, posteriormente, foi adaptado para o PRqd - Programa Racional de qualidade e desempenho. 
De acordo com a gerente de Planejamento, responsável pelo desenvolvimento e implantação do PRqd, foi verificado que a certificação era muito rígida e obrigava um trabalho dos funcionários para atender o momento da auditoria, que fazia com que os profissionais ficassem ansiosos, além de interromper suas atividades de rotina. Frente às não conformidades, e devido à quantidade de papéis para preencher e a preocupação em atender à certificadora, não havia aderência, pois os profissionais ficavam cansados e estressados. Os executivos entenderam que isto não era um benefício a favor da empresa e que os clientes não reconheciam isso como um diferencial. Foi observado que o sistema era mais importante para a empresa do que se preocupar apenas com uma certificação. Diante desta situação, e após a aceitação da alta direção (presidente e vice presidente), a empresa optou por desenvolver um programa próprio de qualidade e desempenho, estabelecendo padrões para a gestão dos contratos, e visando ao pleno monitoramento dos riscos desde os tecnológicos, jurídicos, da marca e da gestão de pessoas e à maximização do desempenho do empreendimento nos quesitos de qualidade construtiva e de operação.

Foram definidas quatro Células de Processos: Conformidade, Comunicação e Relacionamento, Tecnológico e Operacional, compostas por um conjunto de processos relacionados a um campo de conhecimento e conectados a uma das Dimensões Estratégicas, conforme Figura 57.

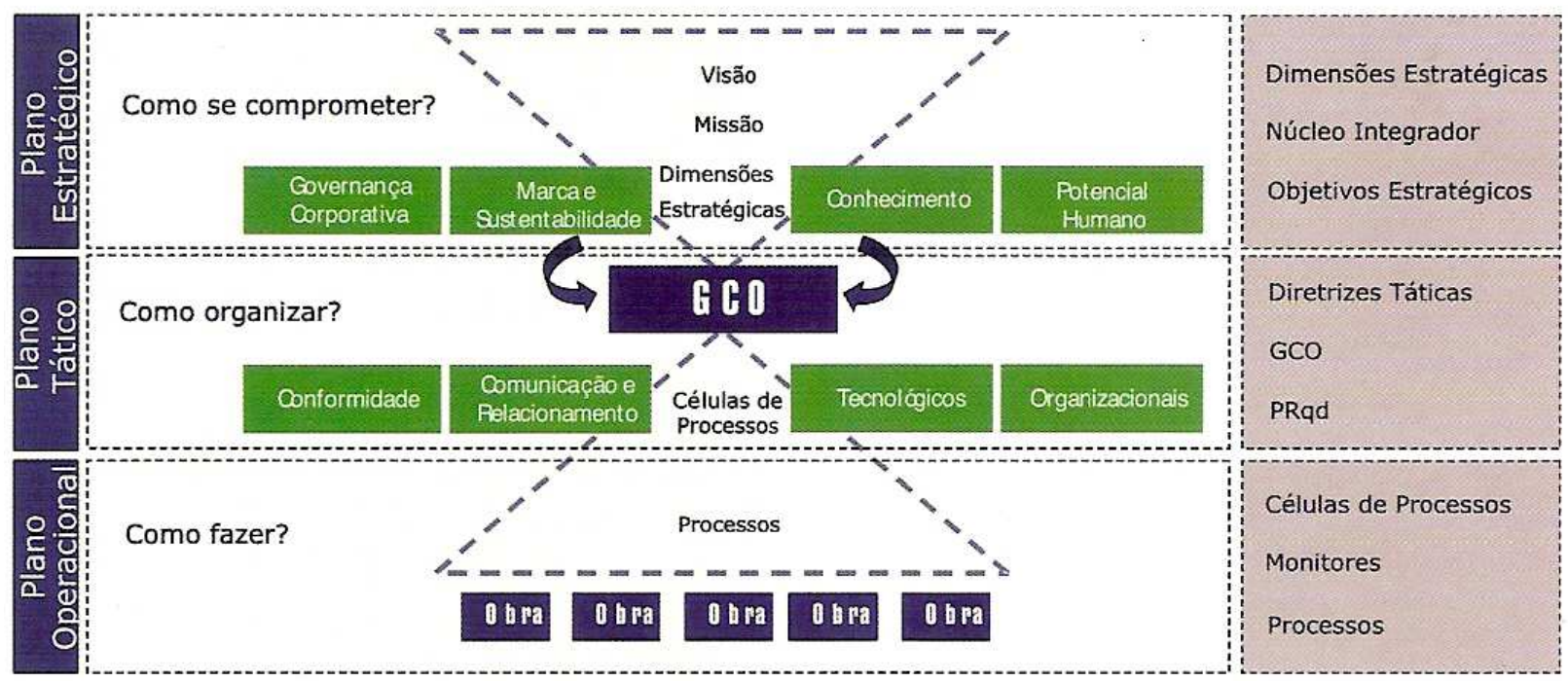

Figura 57 - Dimensões Estratégicas x Células de Processos (VILLA; SARTORELLI, 2009) 
Em 2008, foram formados grupos de trabalho para organizar as práticas baseadas na experiência e conhecimento acumulados pela empresa e estruturá-las na forma de processos. Foram listados 56 processos críticos para a gestão eficiente dos contratos (obras) e identificadas as melhores práticas em cada processo. Cada líder de célula definiu como monitores os profissionais que detinham profundo conhecimento dessas práticas para desenhar o fluxo dos processos e organizar o conhecimento envolvido, de forma matricial, conforme Figura 58.

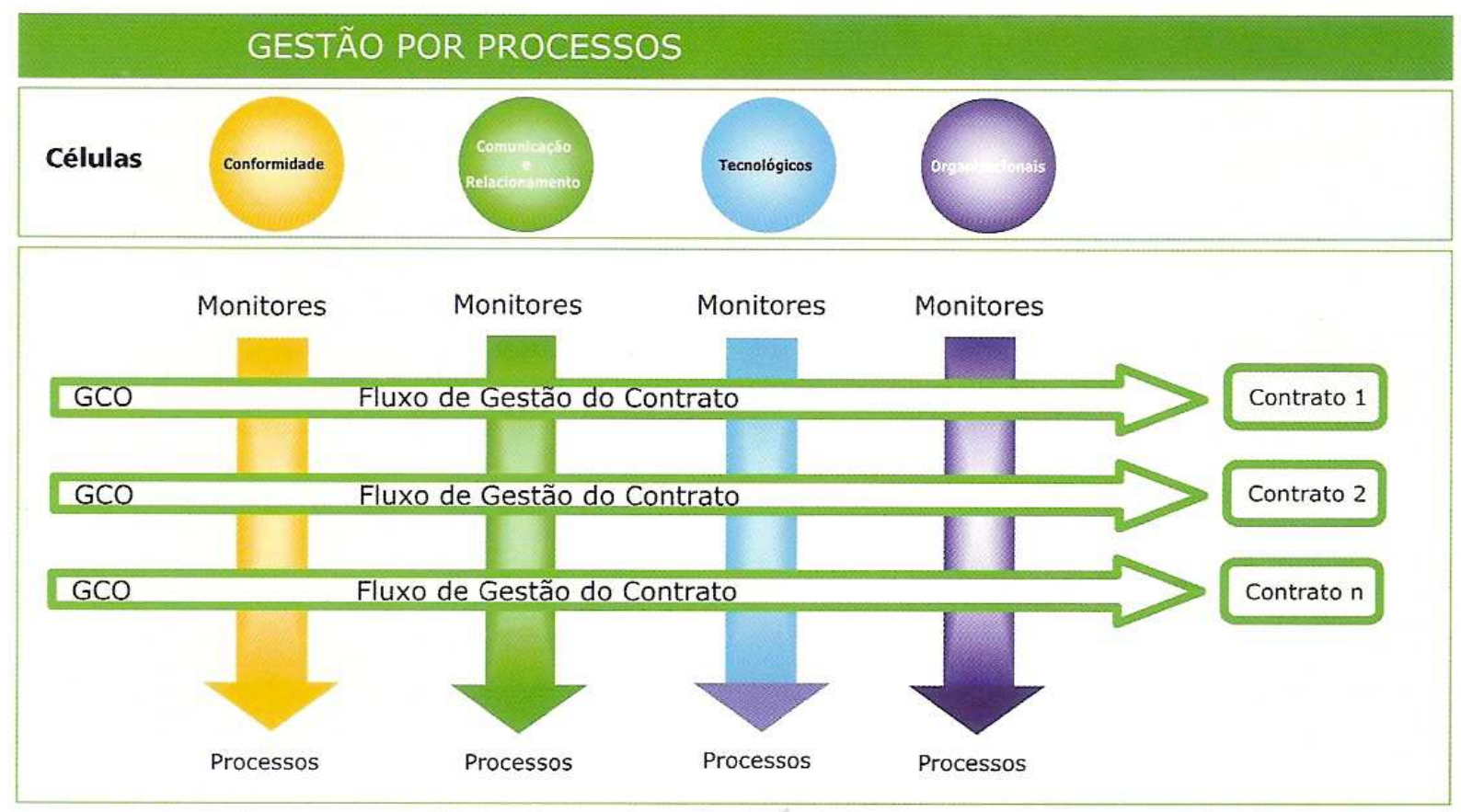

Figura 58 - Organização matricial do PRqd (VILLA; SARTORELLI, 2009)

Em novembro de 2009, foi feito o lançamento do PRqd durante o Seminário anual de Integração, disponibilizando um banco de conhecimento a todos profissionais da empresa.

Todos os processos são aplicados 100\% na obra; ainda não há um PRqd para as áreas de orçamento, administração e finanças.

Foi utilizado um programa da IBM que funciona como uma biblioteca: tem um espaço para pesquisar e outro espaço livre para depositar o material produzido pelos funcionários. 
Com a implantação do PRqd, todos funcionários trabalham com as metas que são propostas em cada um dos processos que estão incorporados à sua rotina de trabalho, sabendo que os processos estão sendo monitorados.

\section{Implantação do PRqd}

A implantação foi feita de cima para baixo, por determinação da alta direção. Cada uma das quatro Células de Processos está associada a um diretor executivo (patrocinador) que é o líder de todos os processos de sua Célula, contando com a ajuda dos monitores, que são os próprios funcionários da empresa. Não houve grande resistência dos funcionários, segundo a gerente de Planejamento, pois para a implantação dos processos foram escolhidos os profissionais que tinham maior domínio sobre os processos naquele momento para atuar como monitores. Os monitores redigiram todos os processos, que de certa forma já faziam parte da rotina da obra, numa estrutura padrão, não tão rígida como na certificação, criaram o fluxo, a missão dos processos e o PD - Processo Detalhado.

No final do período de um mês os monitores verificaram como foi o desempenho dos processos sob sua responsabilidade para que fosse feito um mapeamento de cada processo nas obras e verificada a adesão dos usuários. O retorno das obras é importante para identificar onde os processos podem ser melhorados, para verificar se o que está sendo solicitado está muito específico ou de difícil compreensão. Além de suas atividades diárias, o monitor também dá apoio ao usuário quando ele não entende como fazer os processos ou orienta o profissional que está começando na empresa.

Segundo a gerente de Planejamento, a adesão dos funcionários foi muito grande, pois $100 \%$ da empresa têm acesso ao PRqd e todos sabem que cada célula está associada a uma dimensão estratégica da empresa e todos são responsáveis pelos processos, seja um auxiliar administrativo ou gerente de obra.

De início, o sistema foi implantado baseado em uma avaliação quantitativa, na qual o monitor verifica apenas se os processos foram realizados e postados no sistema na data pré-estabelecida. Ainda não há uma avaliação qualitativa do que foi produzido, pois como o sistema foi implantado em 2009, a empresa passou por um período de aprendizado e encontrava-se em um processo de adaptação. 
Em meados de 2010, foi feito um lançamento para apresentar aos usuários a melhoria dos processos implantada e os critérios de avaliação, para definir a qualidade desejada. Será avaliada a qualidade da informação que o usuário está postando e, no caso de uma informação ruim, verificado se o usuário está com alguma dificuldade de utilização ou se tem alguma deficiência. O monitor deverá avaliar a informação postada do mês anterior (previsão) e confrontar com o resultado obtido.

\section{Estrutura do sistema PRqd}

O PRqd é um dos aplicativos corporativos do sistema integrado ERP acessado virtualmente pelo usuário, através de uma identificação para acesso e uma senha, de qualquer localização geográfica.

As permissões de acesso aos processos estão definidas de acordo com o perfil do usuário. Todos os profissionais da empresa têm acesso livre aos: Processos, Anexos dos Processos e ao Banco de Conhecimento. Para o usuário novo existe o E-Book que informa o que é o PRqd, o que se espera do usuário, o que são as células.

A estruturação, orientada por uma empresa de consultoria, foi baseada em uma metodologia de gestão por processos, onde os processos foram agrupados em quatro Células de Processos: Conformidade (processos chave para mitigar riscos), Comunicação e Relacionamento (como a empresa é vista do ponto de vista das partes interessadas), Tecnológicos (processos essenciais da operação da empresa) e Organizacionais (processos vitais para garantir a performance da operação). Cada célula é composta por um conjunto de processos relacionados a um campo de conhecimento que está conectado a uma das Dimensões Estratégicas, conforme Figura 59. 

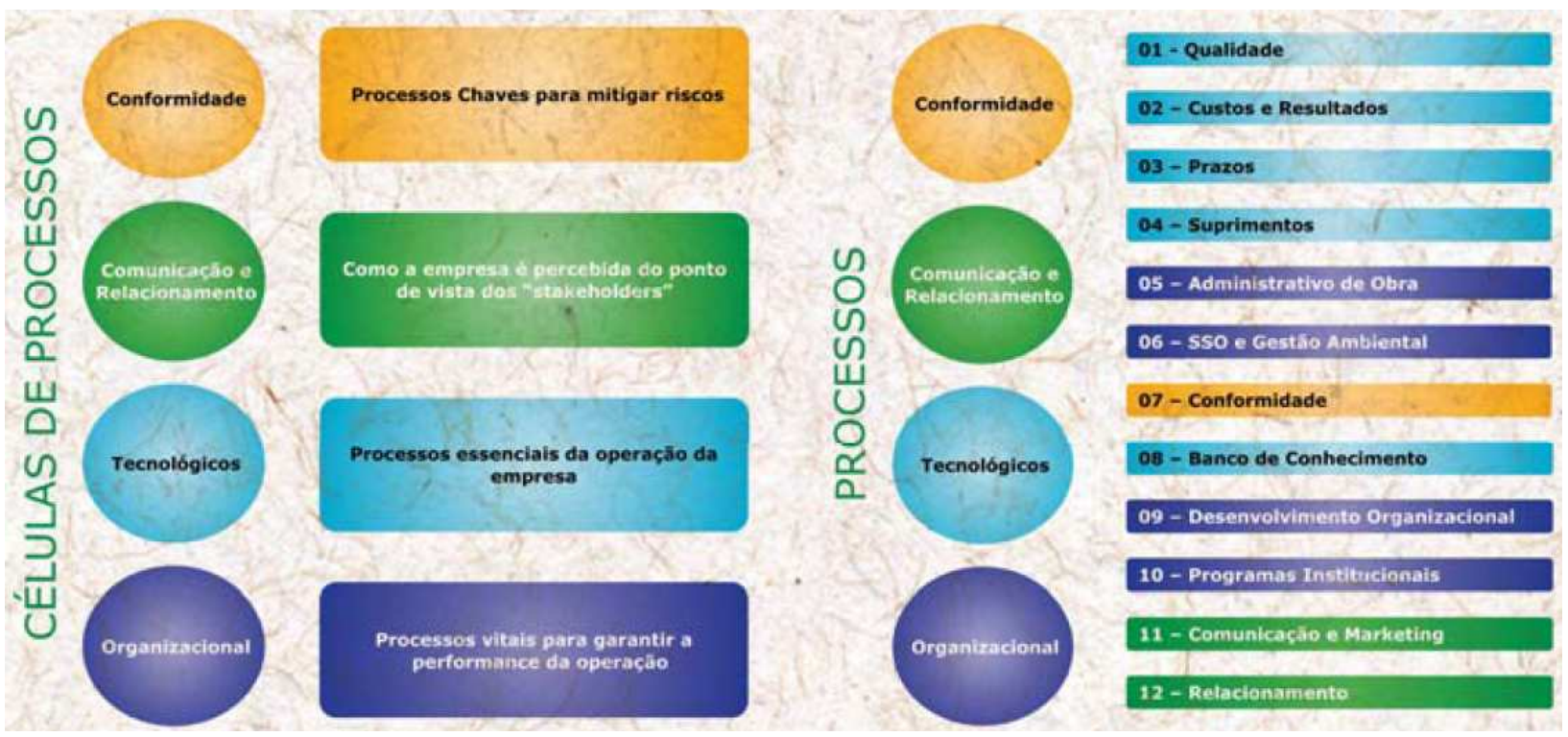

Figura 59 - Células de Processos (VILLA; SARTORELLI, 2009)

A importância da metodologia foi identificar o inter-relacionamento das áreas, por exemplo, o departamento de Gestão de Contratos, responsável pela construção, não trabalha sem a informação da GET - Gestão Técnica, responsável pelos orçamentos, para fazer o produto Planejamento Executivo (processo destinado à elaboração do planejamento executivo das principais atividades identificadas no início do empreendimento atendendo a grade básica pré-estabelecida pela GET).

Todos os 56 processos têm um Fluxo de Processos indicando as áreas relacionadas a ele e um PD - Processo Detalhado com a seguinte grade básica:

- Objetivo, que está associado à missão;

- Documentos que o usuário deve pesquisar antes da elaboração do processo (semelhante às IT - Instruções Técnicas da ISO 9001);

- Responsabilidades;

- Procedimentos de como fazer o produto.

Os Anexos são localizados em outro tópico do sistema: Banco de Conhecimento>Planejamento Executivo>Anexos. Estes Anexos são o modelo institucional em Word (editor de texto) que pode ser editado como base para produção do novo produto.

O usuário alocado na obra tem acesso à sua obra que é identificada por um número. Para elaborar o produto de um processo ele acessa a pasta onde está armazenado 
o processo, identifica o fluxo do processo, de quem ele depende para obter as informações, lê como é o PD - Processo Detalhado, baixa o Anexo Modelo e após preenchê-lo, publica o documento no mesmo local do site. O documento é publicado em Word para que o departamento de Planejamento do escritório central faça a conversão com senha e limite de acesso. Os usuários não podem imprimir ou divulgar o material produzido para pessoas externas à empresa, pois são assuntos confidenciais.

Quando é postado um processo novo, uma mensagem é enviada para $100 \%$ dos usuários: Visite o PRqd. Foi orientado aos usuários para não notificar os outros a cada nova publicação de rotina, devido ao volume de informações e publicações que são geradas constantemente.

No Banco de Conhecimento encontra-se o: Planejamento Executivo (Ex: Alvenaria estrutural), Indicador de Produtividade (estratégico, focado para gestores e área de orçamentos com informações relevantes para novos orçamentos), Acervo Técnico e Lições Aprendidas. No Planejamento Executivo encontram-se: Fluxo de Processos, Missão do processo.

Outros produtos disponíveis:

- Avaliação de fornecedor - conteúdo proveniente das obras e compilado pela área de Planejamento e divulgado para as áreas técnicas

- Lições Aprendidas - divididas por tema: técnico, projeto ou administração (com informações mais relevantes - diferentes soluções para problemas encontrados, etc)

- Manuais de Operação e Manutenção de todas as obras (não é permitida visualização de todas as obras)

- Relatório de atividades - relatório mensal aos clientes (não tem um processo estruturado, já é uma rotina da empresa e a frequência varia de acordo com o contrato: mensal, quinzenal) 


\section{- Gestão da Informação}

Para otimizar as atividades operacionais a empresa implantou em 1999, após um ano de pesquisa, o primeiro módulo (Contabilidade e Financeiro) do Sistema de ERP (Enterprise Resourse Planning) como ferramenta de integração de informações entre os diversos núcleos e processos, através de um único sistema, possibilitando eficiência na compilação dos dados. Em 2004, o sistema foi ampliado para Suprimentos, Gestão de Contratos, Controladoria, Folha de Pagamento. Otimizar e integrar atividades operacionais possibilita a todos maior foco na gestão de negócio e menor perda no processamento de informações.

\subsubsection{Assistência Técnica}

O departamento de Assistência técnica, que faz o acompanhamento pós-obra, interage com a engenharia sob consulta. Quando há algum problema a Assistência Técnica consulta a engenharia para buscar informações sobre a obra, projetos e dar sugestões de solução.

\subsubsection{Funcionários entrevistados (unidades de análise)}

Através do site da Empresa $B$ foi identificada como iniciativa relacionada à gestão do conhecimento um sistema de gestão integrada conduzido pela área de Planejamento. Além da gerente de Planejamento responsável pelo desenvolvimento, implantação e monitoria do PRqd da área de Planejamento, foram realizadas entrevistas semi-estruturadas para coleta de dados com o gerente de projetos, que coordena os arquitetos do escritório central e da obra, e é responsável pela monitoria do PRqd da área de projetos; o arquiteto coordenador de projetos e o engenheiro de produção da obra do estudo de caso, conforme Quadro 16.

\begin{tabular}{l|l|l|l}
\hline \multicolumn{1}{c|}{ Departamento } & \multicolumn{1}{c|}{ Cargo } & $\begin{array}{c}\text { Tempo de } \\
\text { formado }\end{array}$ & $\begin{array}{l}\text { Tempo de } \\
\text { empresa }\end{array}$ \\
\hline $\begin{array}{l}\text { Núcleo de Gestão Técnica } \\
\text { (Escritório central) }\end{array}$ & Gerente de Planejamento & 18 anos & 21 anos \\
\hline Núcleo de Engenharia (Escritório & Gerente de projetos & 24 anos & 17 anos \\
\hline
\end{tabular}


central)

\begin{tabular}{llll}
\hline Projetos (Obra) & Coordenador de projetos & 9 anos & 6 anos \\
& & & \\
\hline Produção (Obra) & Engenheiro de Produção & 8 anos & 2 anos \\
\hline
\end{tabular}

Quadro 16 - Funcionários entrevistados da Empresa B (unidade de coleta de dados)

\subsubsection{Caracterização do empreendimento analisado}

O Quadro 17 resume algumas características do empreendimento do estudo de caso da Empresa B.

\begin{tabular}{|c|c|}
\hline $\begin{array}{l}\text { Características do } \\
\text { empreendimento }\end{array}$ & $\begin{array}{l}\text { Obra sob encomenda de um data center para empresa multinacional } \\
\text { de telecomunicações que visa a certificação LEED Silver com: } 2 \\
\text { pavimentos e áreas técnicas. }\end{array}$ \\
\hline Localização & Alphavile - SP \\
\hline Área Construída & Em alteração na data da visita. \\
\hline Prazo da Obra & $\begin{array}{l}9 \text { meses (agosto/2010 a abril/2011) + } 2 \text { meses de lista de pendências } \\
\text { (maio e junho/2011) }+4 \text { meses de operação assistida (julho a } \\
\text { outubro/2011) }\end{array}$ \\
\hline Tipo de Cliente & Usuário final \\
\hline \multirow[t]{2}{*}{ Método de seleção } & $\begin{array}{l}\text { Projetistas: o cliente contratou o arquiteto-autor do projeto e a } \\
\text { construtora foi responsável pela contratação dos demais projetistas e } \\
\text { consultores. }\end{array}$ \\
\hline & Construtora: Contrato por preço fechado \\
\hline \multirow{2}{*}{$\begin{array}{l}\text { Sistema contratual da } \\
\text { construtora }\end{array}$} & Acelerado (obra teve início antes do término dos projetos executivos). \\
\hline & Previsão de término dos projetos: $4^{\circ}$. mês após o início da obra. \\
\hline $\begin{array}{l}\text { Arranjo funcional das } \\
\text { equipes de projeto e } \\
\text { construção }\end{array}$ & $\begin{array}{l}\text { Equipe de projeto separada da equipe de construção, mas com } \\
\text { participação da construtora no desenvolvimento dos projetos. }\end{array}$ \\
\hline $\begin{array}{l}\text { Modalidade de pagamento } \\
\text { da construtora }\end{array}$ & Preço fixo \\
\hline Gerenciadora & $\begin{array}{l}\text { Uma gerenciadoras para civil e uma gerenciadora especializada em } \\
\text { data center }\end{array}$ \\
\hline Coordenador dos projetos & Arquiteto autor do projeto \\
\hline Entrevistas realizadas & Em 2010 - Em obra \\
\hline
\end{tabular}

Quadro 17 - Descrição do empreendimento do estudo de caso Empresa B

Diversos fatores contribuíram para a escolha da Empresa B para este projeto: ela já havia desenvolvido outros projetos semelhantes para data center e a gerenciadora do cliente especializada em data centers já havia trabalhado com a Empresa $B$ na obra de um data center para empresa do setor bancário.

O projeto, que busca a certificação LEED Silver, prevê um edifício de dois pavimentos para abrigar o data center de uma empresa multinacional de 
telecomunicações, com laje de piso, pilares pré-moldados de concreto e cobertura metálica, além de edifícios anexos (refeitório, auditório, administração, portaria) e áreas técnicas (gerador, chillers).

Segundo o coordenador de projetos da obra, o cliente é muito importante, pois tem uma operação mundial que pode reverter em outros negócios para a empresa.

Devido ao zoneamento, não será permitido acesso pela zona residencial lindeira ao terreno, e por exigência da prefeitura será construído um viaduto, que faz parte do escopo de serviço da construtora, para acesso ao platô onde estará instalado o data center.

Além da execução da obra, a empresa B foi contratada pelo cliente para contratação dos projetos complementares baseado em estudo preliminar de arquitetura. De acordo com o gerente de projetos, o objetivo de desenvolver o projeto junto com a construção, foi buscar soluções técnicas e mais econômicas com um foco diferente do projetista que muitas vezes foca a solução estética e técnica, e não econômica.

A área de propostas desenvolveu um orçamento baseado em um estudo preliminar e premissas de custo, definindo que os projetos deveriam ser desenvolvido dentro de uma verba fechada. Depois de firmado o contrato de pré-construção, teve início o desenvolvimento dos projetos com a participação do arquiteto-autor do projeto.

O programa, referente aos equipamentos, já veio bem definido pelo cliente, pois é a parte que tem um custo maior no projeto; a construção representa $10 \%$ do valor da implantação de um data center deste porte.

O cronograma previa nove meses de obra (de agosto/2010 até abril/2011) com dois meses de check-list (verificação de pendências) (maio e junho/2011) e quatro meses de operação assistida (haverá uma equipe da construtora de apoio na fase de instalação dos equipamentos de ar condicionado, gerador, etc).

A visita e entrevistas com equipe de obra foram realizadas no segundo mês da obra, onde estavam em andamento os serviços de fundação.

Como os projetos ainda não estavam totalmente finalizados, a obra foi dividida em seis etapas e foram liberados para produção parte dos projetos de fundação até a etapa 3. O término dos projetos tinha previsão de término quatro meses após o início das obras. 


\subsubsection{Os agentes do empreendimento}

Foram identificados como principais agentes do empreendimento:

Cliente: empresa multinacional de telecomunicações (usuário final) que tem como representante um gerente da área de tecnologia TI que faz um acompanhamento diário da obra, apesar de não ter vivência de obra.

Construtora: Contratada pelo cliente para execução da obra, contratação e desenvolvimento dos projetos complementares e para produção. A obra faz parte do Núcleo de Gestão de Contratos da Empresa B e, de acordo com o organograma da obra, a equipe é composta por: um Gestor do Contrato, um engenheiro de produção, um arquiteto coordenador (com previsão de incorporar mais um arquiteto), dois mestres de obras (Área externa/ Data center e viaduto) e um encarregado administrativo. O Gerente de Projetos do Núcleo de Engenharia acompanha a obra dando suporte ao coordenador de projetos, conforme Figura 60.

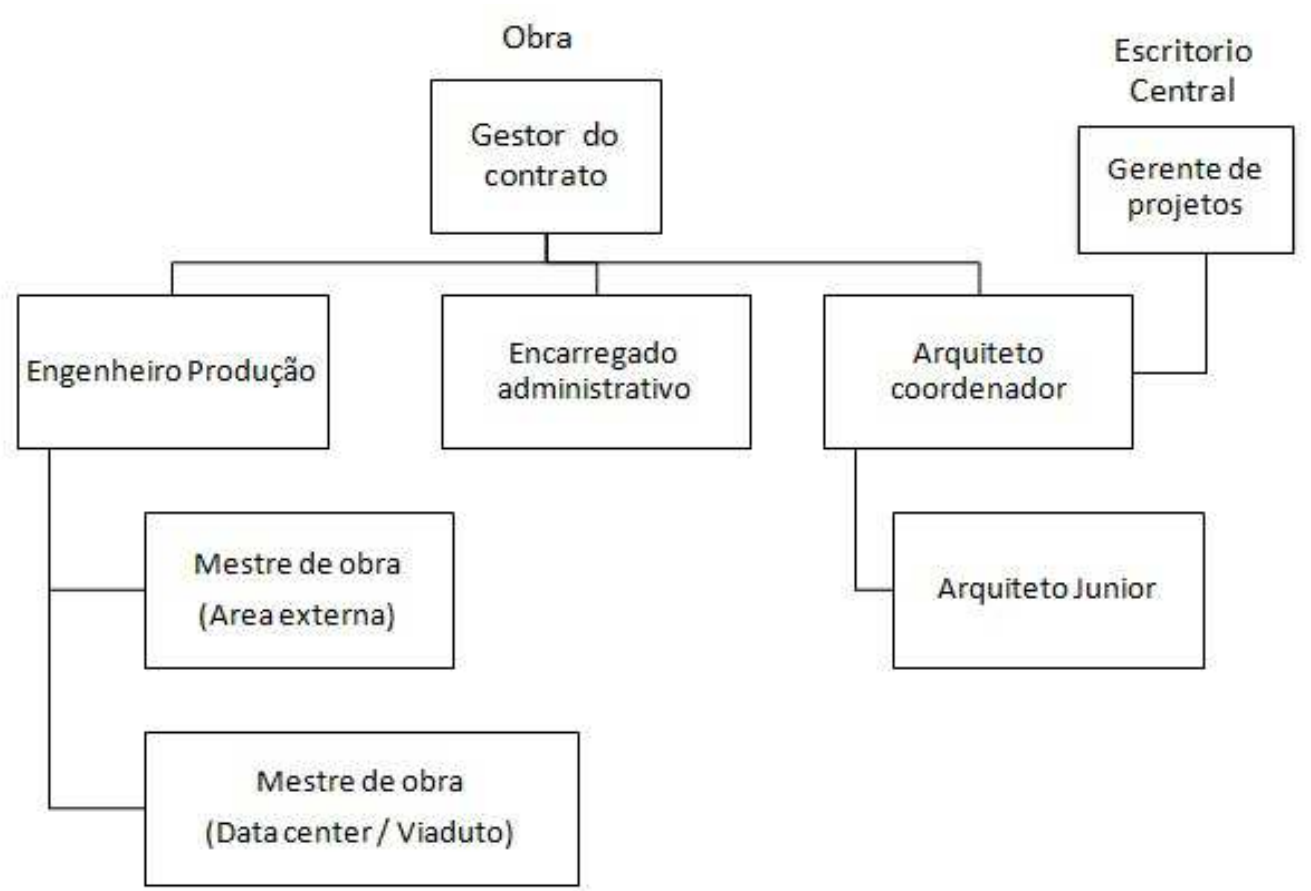

Figura 60 - Organograma da obra

A equipe de projetos interna da construtora é responsável por coordenar os projetos, liberar os projetos para equipe de produção, fornecedores e sinalizar necessidades, prazos, que possam influenciar no andamento da obra, além da elaboração dos As 
Built dos projetos de arquitetura (as demais disciplinas são de responsabilidade dos instaladores e fornecedores).

Gerenciadora: Foram contratadas pelo cliente duas gerenciadoras: uma para fiscalização da obra civil e aprovação dos projetos e uma gerenciadora especializada em data centers, para verificação da instalação dos equipamentos e $\mathrm{TI}$, que já havia participado de outra obra de data center com a Empresa B.

Projetistas: O projetista de arquitetura - autor do projeto foi contratado pelo cliente, sem a participação da construtora. A construtora foi responsável pela indicação e contratação dos projetistas complementares e dos projetos para produção.

Além da Arquitetura, as disciplinas contratadas foram: Fundações; Estrutura de concreto; Estrutura metálica; Piso de alto desempenho; Projeto de formas; Instalações prediais; Instalações de sistemas; Ar condicionado; Impermeabilização; Acústica; Paisagismo.

Compatibilização dos projetos: $\mathrm{O}$ arquiteto-autor do projeto era responsável pela compatibilização dos projetos.

Projetos para produção: A necessidade de projetos para produção, tais como escoramento, caixilho, fôrmas, foram identificadas pelo gerente de projetos em conjunto com o Gestor de Contratos da obra.

Consultores: Para obtenção de certificação LEED Silver o cliente contratou uma consultoria de Sustentabilidade.

Fornecedores: Diversos fornecedores de materiais e de serviços participaram da obra, assim como das fases de pré-construção. As contratações são feitas pela equipe de Suprimentos baseadas no planejamento da obra.

\subsubsection{Processo de projeto}

\subsubsection{Formação da equipe de projeto}

Os projetos que são desenvolvidos pela empresa no Núcleo de Gestão de Portfólio (por exemplo: centro de distribuição em São Paulo) ou cuja contratação é de sua 
reponsabilidade, como no estudo de caso, são feitos por projetistas terceirizados que são selecionados entre os fornecedores que já estão cadastrados na empresa. No PRqd existe um critério de cadastramento, onde o fornecedor é pré-qualificado e posteriormente qualificado no período de obra onde é monitorado e depois avaliado. Existe um processo de suprimentos que é a Avaliação de desempenho do fornecedor, projetista e consultor, no qual estes são avaliados nos aspecto de administração, execução, suprimentos e segurança do trabalho, onde cada item tem uma ponderação diferenciada já pré-estabelecida pelos executivos da empresa (cada item tem um peso). Os fornecedores são avaliados por cada uma das 4 áreas da obra a partir destas ponderações e uma escala de notas. Caso o fornecedor não atenda às expectativas da empresa será convidado a retirar-se da obra e é eliminado do cadastro.

O critério de seleção para cadastramento dos projetistas é baseado em serviços já prestados para a empresa. Segundo o gerente de projetos, a empresa é um pouco fechada para novos projetistas.

Para definição de qual empresa participará da seleção para composição da equipe de projetos é formado um comitê composto pelo gestor dos projetos, gestor técnico e arquiteto da obra, onde são avaliados os projetistas de acordo com: o perfil; a quantidade de projetos que estão envolvidos no momento para verificar se ele terá condição de atender a esta nova demanda; o desempenho e atendimento no momento (se o projetista estiver desenvolvendo muitos projetos simultaneamente pode não atender prontamente a todos). Em geral é feito um rodízio com os projetistas que estão cadastrados. Em todo processo de seleção, a não ser que a diretoria ou cliente determine um único fornecedor, deve ser feito um mapa de cotação com três empresas. O custo é levado em consideração, principalmente em contratos com verba restrita, como o caso do data center.

Na solicitação de proposta é enviado um Anexo de cotação, que é uma cópia do contrato padrão, alterado com adequação das premissas específicas para cada projeto. Se a proposta do projetista estiver neste formato fica mais simples a contratação.

Os projetistas de fundação, em geral, são contratados com acompanhamento de obra. As outras disciplinas, instalações, estrutura, etc, são contratadas com visitas 
quando o projeto requer mais a presença do projetista, como no caso de uma reforma para detectar interferências no local.

No estudo de caso, a Empresa B não participou da fase de definição de programa junto ao cliente. Após elaboração de um estudo preliminar do escritório de arquitetura-autor do projeto, o cliente contratou a construtora, para indicar e contratar os projetos complementares.

A avaliação dos fornecedores, na qual cada quesito tem um peso, é feita no final da obra: se atendeu ao prazo, trouxe inovações tecnológicas, forma de atendimento, prazo de entrega dos projetos. Segundo a gerente de Planejamento, pode ocorrer de um projetista ser bem avaliado por uma obra e mal avaliado por outra, devido à circunstâncias e especificidades de cada obra. O resultado da avaliação fica disponível no banco de conhecimento da empresa PRqd.

A equipe de produção da obra faz uma avaliação do subempreiteiro e fornecedores, não dos projetos.

\subsubsection{Gestão do processo de projeto}

$\mathrm{Na}$ fase de Pré-Construção, a equipe de projetos interage com os diversos núcleos da empresa.

Com o Núcleo de Gestão Técnica na elaboração de proposta ao realizar:

- Análise crítica dos projetos para verificar se há informações suficientes para execução do serviço.

- Engenharia e Análise de Valor, propondo soluções, alteração de especificações que otimizem o tempo de execução, buscando melhoria de prazo e de preço, proporcionando retorno mais rápido ao cliente.

Com o Núcleo Desenvolvimento de Negócios participando da concepção de projeto preliminar dos empreendimentos.

$\mathrm{Na}$ fase de Construção, a composição da equipe envolvida em cada empreeendimento, a atuação do coordenador de projeto e a interferência da construtora no processo de projeto depende do tipo de contratação:

- Quando o cliente contrata a construtora para participar desde o início do processo de projeto, aumenta a capacidade de agregar valor ao projeto com 
sugestões baseadas na experiência da empresa. O foco da análise é diferente do projetista, que muitas vezes busca uma solução estética e técnica, mas não econômica;

- Quando a construtora é contratada para a execução da obra e compatibilização dos projetos é possível fazer uma análise crítica e rever alguma solução de projeto que deve ser avaliada de acordo com seu impacto em custo e prazo;

- Quando a construtora ganha uma concorrência e a obra começa imediatamente, o coordenador de projetos já vai para a obra, não havendo um período de estudo preliminar. Muitas vezes, mesmo que sejam identificadas opções de melhoria do projeto, não há mais tempo para a construtora atuar, pois a aplicação da alteração de projeto pode implicar em retrabalho, e aumento de prazo;

- Quando o cliente contrata uma coordenação dos projetos externa, a atuação do coordenador de projetos da construtora fica limitada a cobrar os projetos dos projetistas para atender ao cronograma da obra.

Em função da complexidade da obra é definido se o gerente de projetos do Núcleo de Engenharia deve atuar em conjunto com o coordenador de projetos da obra.

O gerente de projetos exerce também o papel de monitor do PRqd orientando novos coordenadores de projeto sobre os processos padrão da empresa, além da atualização e estabelecimento destes padrões.

A área de projetos tem no PRqd um processo para desenvolvimento e realização de projetos que:

- Indica os procedimentos para desenvolvimento de projeto;

- Documentos para validação do projeto pelo cliente;

- Codificação de desenhos, carimbo (que pode ser alterado conforme solicitação do cliente).

O sistema de gerenciamento utilizado pela Empresa B é o SADP (Sistema de Armazenamento de Dados de Projeto), mas pode ser adotado outro sistema de acordo com as exigências do cliente. O coordenador de projeto define quem pode acessar o sistema e em que condições. O cliente pode ser cadastrado no sistema, onde ficam registradas as aprovações com controle de data e hora. 
As ferramentas de controle utilizadas pelo cordenador de projetos são:

- Ata de reunião;

- Lista de projetos;

- Lista de pendências;

- Remessa de documentos para obra ou validação cliente;

- Controle de desenhos aprovados pelo cliente;

- Ordem de modificação (quando o cliente quer fazer alguma modificação em relação ao que foi contratado é apresentada para aprovação do cliente).

A validação do projeto é feita na passagem de uma etapa para a outra (por exemplo, de projeto básico para projeto executivo). Pode ser feita por ata de reunião, através do SADP ou por cópia impressa dos projetos com remessa de documentos para validação do cliente ou a quem é delegado o poder de validação, como por exemplo, a gerenciadora como no estudo de caso.

Além disso, existe a validação da construtora sobre o que será executado, que é função do coordenador de projetos, pois a validação do projeto pelo cliente não exime a responsabilidade da construtora de checar o projeto antes de liberar para a equipe de produção.

Quando a instaladora, por exemplo de ar condicionado, sugere a alteração de algum equipamento especificado pelo projetista, é feito um data sheet (planilha de dados técnicos) para aprovação do projetista.

Os projetos para equipe de produção são recebidos do coordenador de projetos da obra com carimbo de "Liberado para execução/ Com comentários/ Para conhecimento". Uma via fica com engenheiro de produção e uma fica com o mestre. O destino da via obsoleta fica a critério do engenheiro de produção (arquiva ou joga fora).

O As Built é de responsabilidade da coordenação de projetos. A coleta e armazenamento das informações de alteração da obra é uma atribuição do engenheiro de campo para depois passar para coordenação gerar os As Builts ou enviar o material para que os projetistas façam os ajustes necessários nos projetos.

A contratação dos As Builts depende da disciplina: 
- Fundações e Estrutura de concreto são contratados com As Built, pois envolve maior responsabilidade técnica do projetista;

- Arquitetura pode ser realizado com empresa terceirizada ou na própria obra;

- Ar condicionado e instalações são de responsabilidade da instaladora, além de data book para ser incorporado ao Manual do proprietário;

- Estrutura metálica envolve o projeto de fabricação do fornecedor.

A equipe de Planejamento é responsável pelo manual do proprietário.

$\mathrm{Na}$ fase de Construção, o coordenador de projetos da obra deve postar no PRqd o seguinte material:

- Indicadores de prazo para indicar desvios e orientar o Gestor do Contrato se os prazos de projeto estão atendendo a obra (estes indicadores passaram para a responsabilidade do Gestor do Contrato (Obra), pois antes este material era avaliado pelo monitor do PRqd que não conhecia a obra, então não tinha como avaliar qualitativamente);

- Atendimento a premissas contratuais estabelecidas no início do projeto.

O cronograma de projetos é estabelecido em conjunto com o cronograma da obra sob supervisão do Gestor do Contrato.

\subsubsection{Atuação da construtora no processo de projeto}

A empresa não participa da fase de definição de programa junto ao cliente. Em geral, o cliente contrata um escritório de arquitetura e contrata a construtora com um projeto básico para que ela contrate os projetos complementares: fundação, estrutura de concreto e metálica, instalações, impermeabilização, acústica, ar condicionado.

Quando a equipe de projetistas está montada a equipe de engenharia da construtora começa a discutir soluções técnicas para atender às necessidades do cliente.

A coordenação de projetos da construtora tem um foco diferente do arquiteto-autor do projeto que está mais preocupado com a qualidade do produto: o projeto. A construtora também foca na qualidade do projeto, mas procura dar soluções mais 
práticas para quem vai executar, pois a equipe tem a vivência de obra. A interferência da engenharia da construtora, dando sugestões técnicas, refere-se mais a itens que possam dar problema de execução.

De posse da sondagem do terreno, de acordo com as características do solo, são definidas com o projetista de fundação duas ou três soluções técnicas para elaboração de um comparativo de custo de cada solução. A escolha da solução não depende apenas do menor preço, mas da disponibilidade de equipamentos no mercado ou do prazo para execução. Esta análise é feita com a colaboração da obra, envolvendo além da engenharia, o Gestor do Contrato, que será responsável pela execução.

São apresentadas sugestões baseadas na sequência construtiva, prazos da obra, como por exemplo, no caso de estrutura de concreto: pré-moldado ou moldado in $10 \mathrm{co}$.

A coordenação de projetos sempre tem uma forte atuação no projeto para economizar e potencializar o contrato sem perder a qualidade e sem alterar sua concepção. O foco é entender a operação do cliente, para sugerir alterações e melhorias de projeto não apenas quanto a durabilidade, mas funcionalidade, pois muitas vezes o representante do cliente é um gerente que não tem a percepção do operador. Como exemplo, o coordenador de projetos da obra participou de um projeto para centro de distribuição no qual o arquiteto-autor do projeto havia previsto diversas escadas entre docas que poderiam causar colisão e dificultar a manobra dos caminhões.

Segundo o coordenador de projetos, há dois ou três anos, a Empresa B entendeu que o projeto poderia ser um diferencial em relação ao mercado, e passou a vender o pacote de pré-construção, antecipando através de contatos comerciais junto a clientes que ela já tinha. A área de projetos foi fortalecida e em vários casos acabou dispensando a concorrência ao entrar na fase de desenvolvimento de projetos (préconstrução) e viabilizando o contrato. Na empresa e na construção civil em geral, o arquiteto era apenas um facilitador, responsável pela distribuição do projeto e interface entre as disciplinas com foco na execução. Mas quando existe um interesse comercial, o papel do projeto fica mais forte: "o projeto se transforma em um produto que a empresa pode vender". O arquiteto tem uma visão mais ampla dos interesses do cliente, diferente do engenheiro que tem uma formação voltada à 
execução da obra e resultados. No estudo de caso, a equipe de orçamentos havia previsto pintura da laje de concreto, que não seria necessário na visão do coordenador de projeto, e especificou louças sanitárias de linha popular para o maior data center da América Latina que terá tecnologia de ponta no país e deve ser visitado por autoridades nacionais e internacionais. Ao propor a alteração de itens que haviam sido acordados em contrato para melhoria do projeto, o cliente sente mais segurança na empresa, pois verifica que a empresa quer o melhor para ele, não apenas vislumbrando o lucro.

A obra foi dividida em 6 etapas e foram liberados inicialmente para a equipe de produção parte dos projetos de fundação até a etapa 3, pois os projetos ainda não estavam totalmente finalizados. Como a obra encontrou muitas interferências de rochas devido às características do solo, o consultor de fundações contratado acompanhava diariamente as escavações fornecendo soluções para execução em forma de croqui. Cada vez que era encontrada uma rocha na perfuração da estaca era necessário alterar os projetos do bloco, da armação, pois além de deslocar a posição prevista para o bloco muitas vezes foi necessário criar mais estacas por bloco. Os croquis do consultor de fundação eram enviados por e-mail para o projetista de estrutura para alteração dos projetos dos blocos. Todas alterações de projetos tem que passar pela análise da gerenciadora civil para aprovação, mesmo o projeto e consultor sendo contratados pela construtora.

Os 32 pontos de sondagem realizados antes do início dos projetos não haviam identificado nenhuma rocha até 30 metros de profundidade. Como o projeto previa estacas de 16 a 25 metros, a equipe de campo tem tentado diversas soluções para retirar ou romper as rochas (quebrar com martelete hidráulico, martelete elétrico, retro-escavadeira com rompedor na ponta), mas muitas vezes as rochas aparecem em várias profundidades: $3,5 \mathrm{~m}$ (retirado com retro-escavadeira), $7 \mathrm{~m}$ ou $10 \mathrm{~m}$.

Devido às interferências, as 3 etapas iniciais ainda estavam em andamento e a obra previa finalizar o trecho referente à etapa 1 em 15 dias, quando estava previsto o início da locação dos pré-moldados (pilar/ viga/ laje). A previsão de finalização da etapa 4 estava prevista para cinco dias após o término da etapa 1.

O projeto de fundação das áreas externas ainda não havia sido finalizado, pois houve interferência com tubulação de água pluvial, que não estava prevista, e com o 
muro do vizinho (estaca pegou a base do muro), sendo necessário novo levantamento da área.

Segundo o coordenador de projetos a retro-alimentação da construtora aos projetistas ocorre mais com os projetos que foram mais detalhados, onde houve a preocupação do projetista. Para os projetistas que fizeram um projeto muito simples, com poucas informações não há porque fazer uma retro-alimentação.

\subsubsection{Comunicação no processo de projeto e obra}

O cliente definiu o programa e a construtora ficou responsável de desenvolver os projetos executivos complementares.

Como o projeto de arquitetura precisa de um retorno de todas as disciplinas para definição do projeto foram estabelecidas rotinas de reuniões técnicas de desenvolvimento de projeto e reuniões com o cliente para discutir o andamento dos projetos. Eram realizadas reuniões de projetos semanais com a presença dos projetistas e consultores, mas outras reuniões poderiam ser agendadas de acordo com a necessidade da obra.

Segundo o engenheiro de produção, o responsável do cliente visita diariamente a obra, mas como ele é um gerente da área de tecnologia e não tem vivência de obra passava sua ansiedade para a equipe de produção.

Não houve uma reunião de passagem dos projetos ou eventuais problemas identificados pela equipe de orçamento para equipe de produção, os projetos foram apenas entregues ao engenheiro responsável pela produção.

Como a obra teve início antes do término dos projetos, a equipe de produção não teve tempo de analisar os projetos antes da execução, por isso é possível haver problemas que só serão detectados na execução.

A estrutura da Empresa $B$ é feita de forma que toda equipe da obra é responsável pela verificação dos projetos. A equipe de produção pode acessar diretamente os projetistas, independente do coordenador de projeto. 
$\mathrm{Na}$ obra analisada, o cliente definiu a utilização do gerenciador de arquivos SADP (Sistema de Armazenamento de Dados de Projetos) onde os projetistas fazem a postagem dos novos projetos ou revisões, para a equipe da obra.

São utilizados como meio de comunicação entre os membros da equipe de projeto, além do SAPD e reuniões, o telefone e e-mail (comunicação escrita e transmissão de croquis de soluções definidas na obra).

Reuniões trimestrais são realizadas entre todos os coordenadores de projetos da empresa. Esta frequência foi definida devido à dificuldade de reunir toda a equipe que encontra-se em vários estados do país (Paraná, Goiás). Nesta reunião os coordenadores apresentam suas experiências na obra, trocando idéias entre si. É feita uma avaliação dos fornecedores, projetistas, assim como são levantadas dificuldades encontradas com cliente, documentação.

A empresa promove diversos Fóruns de Alinhamento que foram criados para discussão e disseminação de conteúdo estratégico entre as lideranças e suas equipes.

A RECON - Reunião de Configuração de Negócio tem como objetivo informar o Gestor de Contrato (GCO) sobre os principais fatores críticos do novo negócio. O gestor de desenvolvimento de negócios (DDN) apresenta o cliente e seu foco ao GCO e compartilha as principais características do contrato, os risco e oportunidades (passagem do contrato para obra).

Anualmente, a empresa se reune em um Seminário de Integração, para repassar e comunicar mudanças de estratégia ou do modelo de gestão. Este evento é uma oportunidade de troca de informações e de maior aproximação entre a diretoria e todos os funcionários.

\subsubsection{Tecnologia da Informação (TI)}

Como a TI é uma área muito dinâmica e não havia no mercado soluções prontas para a realidade específica da empresa, foram desenvolvidas algumas soluções tecnológicas próprias.

Para atender todas as demandas da empresa foi firmada uma parceria, de 2010 a 2013, com empresa do mesmo ramo de atividade, para desenvolvimento de um 
Plano Diretor de Tecnologia da Informação e Comunicação. Entre as ações de TI, com o objetivo de agilizar a comunicação, estão: a substituição do Lotus Notes pelo Outlook; a implantação de ferramenta de conferência via internet utilizada inicialmente pela área de projetos; a reestruturação do back up para se tornar único em toda a empresa; a aquisição da ferramenta que dará suporte ao Portal da empresa e ao PRqd (SIMODO; FERRIGNO, 2010).

Alinhada às dimensões estratégicas traçadas pela empresa, com o foco na integração de informações entre os diversos núcleos e processos foi definida como ferramenta um sistema de ERP (Sistemas Integrados de Gestão Empresarial), inicialmente, implantando os módulos Contábil e Financeiro e em seguida nas áreas de Suprimentos (Mapas, Pedidos, Contratos), Gestão de Contratos (Requisições, Autorizações para Pagamentos, medições, etc), Controladoria, Financeira, Folha de Pagamento, além dos módulos de Orçamento/ Planejamento de Obras e Business Intelligence serão importantes ferramentas de Governança Corporativa.

O desempenho do sistema está vinculado a várias ações de gestão integrada, onde atividades operacionais otimizadas possibilitam a todos maior foco na gestão de negócios e menor perda no processamento de informações.

Segundo a gerente de Planejamento, a implantação do novo sistema integrado ERP, no qual o PRqd é um dos aplicativos corporativos, contou com um processo de aderência, que consistiu em entrevistas com os usuários para que todas as fases do fluxo de informação fossem atendidas. O processo de implantação estendeu-se às obras para garantir a confiabilidade das informações, centralizadas em um único banco de dados, e tornar a empresa mais competitiva e ágil, buscando eliminar o retrabalho.

\subsubsection{Aspectos Tecnológicos}

No processo de orçamento, que ainda não foi estruturado no PRqd, em geral não há participação da equipe de obra. Após o fechamento de um contrato é realizada uma reunião onde são expostos para a equipe da obra quais os problemas detectados na fase de orçamento e os principais cuidados que a obra tem que ter no momento da execução do empreendimento. Elegem-se dos 56 processos separados por células, 
os 20 processos mais críticos para aquele contrato e o departamento de orçamento sugere 4 ou 5 itens importantes que deverão ser planejados e registrados no documento chamado Planejamento Executivo. O Gestor do Contrato tem um período de 30 dias depois desta reunião para estudar os projetos, entender o cliente, validar as informações e confirmar se poderá cumprir ou não o que foi sugerido pela equipe de orçamento.

Existe um processo para auxiliar o Gestor do Contrato a produzir o Planejamento Executivo, onde está definido o que deve ser abordado: qual é a sequência executiva, como será feito o controle de qualidade, como será garantido o custo estimado para cada serviço, etc.

Periodicamente, o Gestor do Contrato vai controlar a obra de acordo com o que ele redigiu no Planejamento Executivo, complementando com as informações de controle no campo. Segundo a gerente de Planejamento, uma obra não tem acesso ao material de outra obra por questões de sigilo e para evitar competição ou exposição dos colegas. Este material produzido pelas diversas obras é selecionado, depositado e disponibilizado pelo Núcleo de Gestão Técnica no PRqd onde todos têm acesso e podem utilizá-lo como um banco de pesquisa possibilitando produzir um planejamento sempre melhor. Por exemplo, se alguma obra já fez uma estrutura de pré-moldado, os outros profissionais têm acesso às dificuldades encontradas ou previstas na época e têm a oportunidade de fazer um estudo de valor em busca de uma solução técnica melhor que a anterior e assim sucessivamente, sempre trazendo melhorias para a empresa.

$\mathrm{Na}$ obra analisada no estudo de caso, para elaboração do Planejamento Executivo, o Gestor do Contrato e o engenheiro de produção utilizaram a base do PRqd. Foi elaborado um Planejamento Executivo para cada etapa da obra onde foi detalhado cada serviço: bloco, estaca, tubulão, pré-moldado. Segundo o engenheiro de produção, o Planejamento Executivo deve ser atualizado diariamente para verificar o andamento da obra em relação ao planejado. Por exemplo, estava previsto executar 10 estacas por dia, mas a obra está executando três estacas devido às interferências.

De acordo com o engenheiro de produção, os procedimentos e planilhas padrão do PRqd auxiliam muito no planejamento e controle da obra. Por exemplo: é realizada uma Ficha de Liberação de cada bloco onde constam todos envolvidos no serviço: 
empreiteiro, mestre, topógrafo, responsáveis pela conferência de locação, as fôrmas, o concreto.

\subsubsection{Problemas/ Deficiências no processo de projeto}

De acordo com o gerente de projetos, nos últimos anos os projetos estão muito simplificados, principalmente o de arquitetura que costumava ser mais detalhado. Com a utilização do AutoCAD, imaginava-se que o tempo para realização dos projetos diminuiria, mas o que houve foi um aumento do número de projetos desenvolvidos simultaneamente.

Antigamente, o projeto era desenvolvido com mais antecedência, havia mais tempo para realizar a compatibilização, e os projetos chegavam mais completos para a obra. Um engenheiro conseguia tocar uma obra sozinho sem a figura do coordenador de projetos da construtora.

Os maiores problemas detectados nos projetos são relacionados à falta de informações ou informações erradas. Muitos projetos são realizados com base em outros projetos desenvolvidos pelo projetista e as informações não são atualizadas, principalmente no campo de notas de projeto. Como o volume e velocidade impostos pelo mercado para realização dos projetos têm aumentado, os projetistas muitas vezes não revisam os projetos antes de liberá-los para a construtora.

Outro problema enfrentado em relação aos projetos é a falta de compatibilização entre as disciplinas. Como nem sempre está no escopo do arquiteto-autor do projeto a compatibilização entre as disciplinas, a construtora procura conscientizar o cliente da importância de sua contratação para realização deste serviço para evitar problemas na fase de execução da obra.

\subsubsection{Gestão de mudanças}

Segundo o coordenador de projetos, a origem das mudanças de projeto podem ser decorrentes de: 
- Falhas de projeto, como por exemplo, o projeto não atende à uma norma do Corpo de Bombeiros: faltam escadas ou saídas de emergência, a largura dos corredores não está dimensionada corretamente para rota de fuga, etc;

- Modificações para redução de prazo de execução;

- Solicitações do cliente.

É muito rara uma interferência da construtora no projeto de arquitetura, do ponto de vista estético ou de acabamentos. Na obra podem ser realizadas algumas alterações nos procedimentos executivos que não refletem em uma alteração de projeto.

Caso seja detectada a necessidade de alteração de projeto, a nova sugestão é sempre encaminhada aos projetistas para aprovação.

No estudo de caso, as soluções de projeto têm que ser muito rápidas e dinâmicas, devido ao prazo reduzido da obra. Além da concepção de toda periferia ainda estar pouco desenvolvida, no segundo mês após o início da obra, o programa previsto para atender 100 pessoas foi alterado para 270 pessoas, pois foi incorporado ao data center uma área administrativa. Em decorrência do aumento do número de funcionários foi necessário instalar um refeitório para atender à legislação, além de outros detalhes de implantação que tiveram que ser alterados: número de vagas, bicicletário, capacidade da portaria, aumento da capacidade do ambulatório. Todas as adequações necessárias por causa da mudança de programa tiveram que ser realizadas em um mês, e acabaram refletindo na entrega de outros projetos (como por exemplo, fôrmas), mas ainda sem impacto no cronograma da obra, que é atualizado semanalmente. Com isso as atividades de projeto estão sendo realizadas simultâneas à execução da obra exigindo participação maior do coordenador de projeto na obra que passará a dedicar-se em tempo integral ao projeto e será contratada uma assistente para auxiliá-lo.

\subsubsection{Gestão de riscos}

O desenvolvimento de um programa próprio de qualidade e desempenho - PRqd, estabelecendo padrões para a gestão dos contratos, visa o pleno monitoramento dos riscos desde os tecnológicos, jurídicos, da marca e da gestão de pessoas, além 
da maximização do desempenho do empreendimento nos quesitos de qualidade construtiva e de operação.

A análise de risco é feita desde a fase de orçamento para chamar atenção da equipe da obra, que é composta por membros das áreas de Suprimentos, Planejamento, Administração, Segurança do Trabalho e Meio Ambiente, Coordenação de projetos, sobre alguns aspectos que podem estar envolvidos com custo, relação com vizinhança, cliente, etc.

Após o fechamento de um contrato é realizada uma Reunião de Configuração de Negócio (RECON) onde são expostos para o futuro Gestor do Contrato (obra) os principais fatores críticos do negócio: quais problemas foram detectados na fase de orçamento e os principais cuidados que a obra tem que ter no momento da execução do empreendimento. Nessa reunião, o gestor de Desenvolvimento de Negócio apresenta o cliente e seu foco, além de compartilhar as principais características do contrato e os riscos/ oportunidades decorrentes. Neste momento elegem-se dos 56 processos do PRqd separados por células, os 20 processos mais críticos para aquele contrato. Se a obra tem problemas com prazo, será feito um acompanhamento criterioso do processo prazo, se a obra tem um problema com o meio ambiente, estará descrito que cuidados devem ser tomados em relação ao meio ambiente. O departamento de orçamento (Núcleo de Gestão Técnica - GET) sugere 4 ou 5 itens importantes que deverão ser planejados e redigidos pelo Gestor do Contrato e sua equipe, com muito critério, no documento chamado Planejamento Executivo, que deverá ser apresentado no prazo de 30 dias para nova RECON, quando é definindo em caráter definitivo, como serão desenvolvidas as atividades durante a obra. A Figura 61 ilustra este modelo de trabalho. 


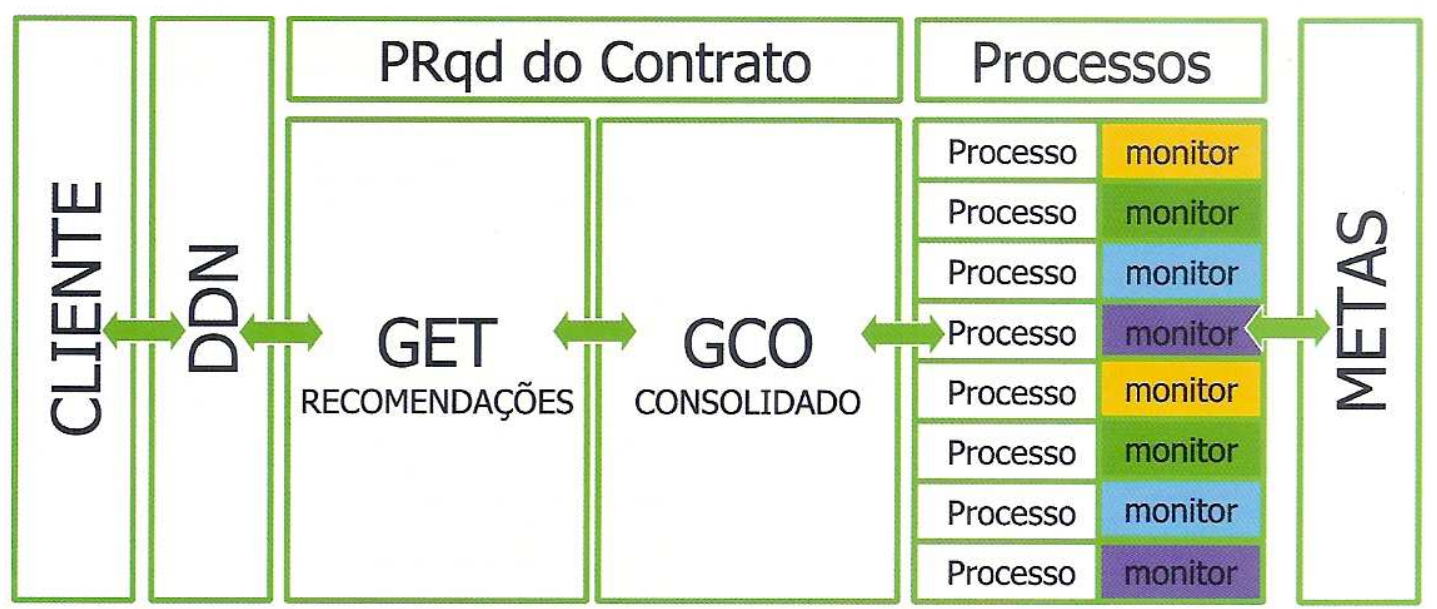

Figura 61 - Modelo de trabalho do PRqd (VILLA; SARTORELLI, 2009)

Como a falta de compatibilização entre os projetos é muito frequente, a construtora busca contratos que incluam no escopo a coordenação de projetos para reduzir o risco de retrabalho devido a projetos errados ou a falta de informações suficientes para execução correta da obra.

No estudo de caso, as reuniões realizadas com o cliente no desenvolvimento dos projetos foram importantes para minimizar problemas e conduzir o processo de forma condizente com suas necessidades.

\subsubsection{Gestão do conhecimento}

\subsubsection{Iniciativas de gestão do conhecimento}

\section{PRqd - Programa Racional de qualidade e desempenho}

Banco de conhecimento organizacional estruturado que estabelece padrões da empresa, disponibilizado a todos os funcionários e utilizado para orientar novos funcionários.

A área de projetos tem no PRqd um processo para desenvolvimento e coordenação de projetos. As obras tem compartilhado as boas práticas no Planejamento 
Executivo, que pode ser utilizado como base em uma nova obra com as mesmas características.

\section{Programa Trainee}

O Programa de Trainee tem o objetivo de identificar, atrair e desenvolver jovens profissionais para atuar na operação da empresa. É um dos principais veículos para a eficiência do modelo de gestão adotado e para perpetuação da empresa. $O$ Programa de um ano possibilita uma visão de toda operação, sua complexidade e interdependência.

\section{Lições aprendidas}

Ao término da obra, no processo de Lições Aprendidas, a equipe da obra descreve algumas dificuldades encontradas e soluções adotadas, compila e relata seu aprendizado às demais equipes da empresa através de uma apresentação em Power Point.

De acordo com o gerente de projetos, é realizado um seminário de Lições Aprendidas no escritório central, que reúne todos os profissionais da empresa, quando quatro obras, que encerraram quase simultaneamente, fazem sua apresentação sobre suas diferentes experiências, que deve durar 20-30 minutos no máximo, para não se tornar cansativa, e ao final da apresentação há um espaço para perguntas e respostas.

O engenheiro de produção entrevistado participou da obra de um shopping center no qual foram apresentadas as Lições Aprendidas sobre a instalação de uma grande clarabóia, que não tinha projeto, e foi definida na obra em reuniões com o fornecedor.

No PRqd, as Lições Aprendidas são divididas por tema: técnico, projeto ou administração (com informações mais relevantes da obra, diferentes soluções para problemas encontrados, etc)

O desempenho da obra não é divulgado, segundo a gerente de Planejamento, pois o objetivo das Lições Aprendidas é disseminar o conhecimento aos demais funcionários para utilização em novas obras, "não é uma competição". 
Na ocorrência de eventuais problemas decorrentes dos projetos, segundo a gerente de Planejamento, não há um procedimento formalizado para retroalimentação dos projetistas ou fornecedores. É feita uma divulgação ao público técnico interno da empresa: arquitetos, engenheiros, técnicos, administrativos, compradores e cada profissional que se relaciona com os projetistas vai recomendar outra solução quando ocorrer um projeto similar.

Houve um workshop de Lições Aprendidas de manutenção no qual foram apresentados os problemas que ocorreram em algumas obras para evitar que se repetissem.

\section{Engenharia e Análise de Valor}

A Empresa B foi contratada pelo cliente por ter experiência na execução de obras de data centers. Ao ser contratada para participar do desenvolvimento dos projetos pôde agregar valor ao projeto com sugestões para redução de custo e prazo, sem perda da qualidade e com base nas premissas estabelecidas com o cliente, que será o usuário final da edificação.

\section{Programas de capacitação}

Ao identificar uma deficiência recorrente na produção de cronogramas básicos utilizando o MSProject, tanto por parte dos engenheiros, arquitetos, quanto auxiliares técnicos, foi realizada uma campanha de capacitação geral para este público da empresa, da qual $50 \%$ do público aderiu espontaneamente ao programa de capacitação.

\section{Gerenciamento de suprimentos/ fornecedores}

O tipo de contrato adotado para o projeto permitiu a transferência de conhecimento entre os projetistas e a construtora e entre as fases do ciclo de vida do empreendimento. O livre acesso da equipe de produção aos projetistas permitiu agilidade nas tomadas de decisão e resolução de problemas. A participação da construtora no desenvolvimento dos projetos permitiu a socialização e geração de novo conhecimento. 


\subsubsection{Esforços e barreiras para implementação}

De acordo com a gerente de Planejamento, na implantação de um novo processo é necessário disponibilizar uma ferramenta que facilite a comunicação, pois problemas de infra-estrutura (equipamentos) podem impactar negativamente, causando dificuldade ao usuário e, consequentemente, desmotivá-lo. Por exemplo, se o usuário tem o processo, sabe fazer a leitura do processo, tem o apoio do monitor, tem o repositório onde ele retira a informação que precisa, elabora o documento, mas no momento de depositar o que foi produzido a ferramenta não está funcionando, o sistema pode cair em descrédito (por exemplo, a obra não consegue se conectar ao servidor do escritório central).

A implantação do PRqd, segundo a gerente de Planejamento, teve pouca resistência dos funcionários, pois a montagem do material que o compõe foi resultado de várias reuniões da equipe de coordenação para colocar no papel os procedimentos que a maioria das pessoas já costumava praticar. Alguma resistência foi observada em funcionários novos que, às vezes, trazem vícios de outra empresa ou pessoas que não utilizavam os procedimentos como a maioria.

Como a diretoria estimula a melhoria continuada, se for identificada alguma oportunidade de melhoria ou falha no material publicado, este será ajustado.

$\mathrm{Na}$ ocasião da entrevista com a gerente de Planejamento, estava prevista uma reunião final com a equipe da $1^{\text {a }}$ obra onde o Prqd foi aplicado como programa, que teve início em março/2009 e estava em processo de conclusão (jun/2010), para verificar quais foram as dificuldades encontradas. Será verificado se a equipe não conseguiu cumprir um processo integralmente por causa do prazo, por modificações que ocorreram no decorrer da obra ou por causa de alguma característica cultural da empresa do cliente. São dados importantes para conhecer o cliente e saber onde estarão as dificuldades na próxima obra deste cliente.

Apesar do usuário ter todas as ferramentas da metodologia disponíveis, a dificuldade identificada foi de tempo para produção dos processos, que poderia ser uma questão de necessidade de melhoria do processo ou da transmissão da informação.

A metodologia encontra-se bem aderida pelos funcionários, o problema atual é de infra-estrutura. A ferramenta tem atendido bem às necessidades, com exceção das 
datas de postagem, que são obrigatórias. Existem alguns processos com datas estabelecidas para postagem, e os outros processos que não tiverem uma data específica têm como data limite de postagens o dia 5 de cada mês, para no dia 80 monitor colher as informações para análise. "Como a maioria dos usuários deixa para postar os processos no último dia, o sistema não dá conta, fica lento o que causa reclamação dos usuários." Já se tentou definir datas diferentes para cada usuário, o que dificultou a administração do monitor. Como a empresa verificou que não está capacitada para definir sobre ferramentas está pesquisando, com o apoio de uma consultoria externa, a melhor forma de contornar este problema.

O programa utilizado de base para o PRqd foi um sistema da IBM, que é um programa que não faz modelagem por processos, mas possibilita compartilhar facilmente informações. Segundo a gerente de Planejamento, não há como avaliar se esta é a melhor ferramenta de mercado, mas foi a melhor ferramenta identificada no momento de implantação, pois o foco do desenvolvimento do PRqd foi a metodologia e não estudar a fundo as ferramenta de TI: "Talvez existam outras ferramentas que sejam mais adequadas, mas teria que ser avaliado se estas ferramentas se aplicariam bem à empresa".

Este não é o melhor programa, pois o usuário tem que sair do Fluxo de Processo para acessar outro arquivo de referência. Para acessar o Processo Detalhado (PD), o usuário deve voltar à tela inicial do site (Banco de Conhecimento) e no mesmo lugar onde estava armazenado o processo acessar o PD. Este aspecto também está sendo avaliado pela empresa de consultoria para não correr o risco de comprar um programa inadequado.

Apesar de todos os processos dp PRdq estarem descritos passo a passo, às vezes o usuário não conseguia realizá-lo de forma adequada. Conversando com os usuários foi detectado que haviam muitos detalhes e muitas informações desnecessárias que nunca seriam utilizadas. Os monitores reconheceram que alguns processos estavam errados e foram "enxugados", corrigidos ou totalmente reescritos. No conceito de melhoria, $100 \%$ dos processos foram revistos e o objetivo é reduzir de 56 para 40 processos.

Com a melhoria foi inserido o item de Indicadores, estabelecendo quais são os critérios de monitoramento dos processos, que na metodologia inicial não estavam previstos. Estes indicadores existiam, mas estavam redigidos em outra matriz e 
ficava difícil para o usuário pesquisar, gerando muitas dúvidas sobre qual o objetivo de tudo isso.

Outro ponto identificado foi que os usuários estavam publicando o Planejamento Executivo depois de iniciar a execução da atividade na obra, publicando fotos do serviço já executado. O departamento de Planejamento e o líder da célula identificaram que este procedimento estava errado, pois como se tratava de uma atividade de planejamento deveria ser elaborada antes da execução. Como parte do plano de melhorias foram convocados os cinco principais gerentes operacionais de obra e foi feito um brainstorming (reflexão em grupo), quando a equipe de Planejamento pediu orientações dos usuários sobre o que poderia ser melhorado no processo e quais as dificuldades encontradas para rever os processos. Estrategicamente, foram chamados os gestores informando que as obras não estavam conseguindo executar os processos ("estavam todos vermelhos no status") por conta das dificuldades levantadas no brainstorming. O processo foi melhorado e teve uma boa aderência, pois não foi um processo unilateral, contando com a participação do usuário na melhoria do processo.

Como exemplos de melhoria decorrente da utilização dos processos foram destacadas pela gerente de Planejamento:

- Existia um padrão de fluxo de caixa da empresa, porém a qualidade das informações estava comprometida, pois havia erros recorrentes de $10 \%$ de desvio. A partir de processos e formulários padronizados e da definição de um desvio padrão, em conjunto com o líder da célula de Conformidades, que é reponsável pela administração e finanças, foi possível identificar quais obras e quais usuários tinham mais dificuldade na produção do fluxo de caixa e orientá-los.

- Foi verificado com os usuários das obras que havia uma deficiência na produção de cronogramas básicos utilizando o MSProject, tanto por parte dos engenheiros, arquitetos, quanto auxiliares técnicos que utilizavam esta ferramenta. Mediante a recorrência deste problema foi realizada uma campanha de capacitação geral para este público da empresa, na qual 50\% do público aderiu espontaneamente ao programa de capacitação. 


\subsubsection{Síntese do Estudo de Caso B}

Verificou-se um forte empenho da empresa na valorização da Marca como importante instrumento de venda no mercado, assim como o conhecimento, que faz parte das quatro dimensões definidas no planejamento estratégico da empresa desde 2006, a partir das quais são traçadas as metas e indicadores anuais de desempenho. É enfatizada a importância da organização e acessibilidade do conhecimento para que este seja aplicado na inovação, desempenho, aprendizado contínuo e gestão de riscos e oportunidades. A empresa reconhece que para atingir os objetivos estratégicos é necessário desenvolver as competências técnicas e comportamentais de seus funcionários, promover a articulação eficiente entre as pessoas, além de estabelecer parcerias estratégicas.

Para estruturação do PRqd foram designados monitores responsáveis por cada área da empresa e contratada uma consultoria externa, em busca de maior eficiência e transferência de conhecimento de forma organizada, possibilitando monitorar riscos e maximizar as oportunidades.

A preocupação inicial foi com o conteúdo, implantação e resultados esperados do PRqd, e não com a ferramenta de TI a ser empregada, que ficou em segundo plano contando com o apoio de uma consultoria externa. No entanto, na implantação do sistema foram detectados problemas de infra-estrutura (equipamentos) que causaram um impacto negativo aos usuários.

O PRqd tem um papel importante na aprendizagem organizacional ao estruturar o conhecimento da empresa, relacionado à sua atividade principal (engenharia e construção), e como forma de disseminação do conhecimento a todos os funcionários e novos ingressantes na empresa. Para garantir sua utilização foi importante definir os monitores como responsáveis pela atualização e disseminação do PRqd em suas respectivas áreas.

Como a empresa contrata diversos parceiros externos, a avaliação de desempenho de fornecedores, que inclui projetistas, é importante para selecionar aqueles que atendem às expectativas da empresa e têm foco no compartilhamento de conhecimento. 
O processo de projeto da empresa está estruturado no PRqd e foi verificado que é utilizado pela equipe de obra. A forma de atuação da equipe de projetos depende do tipo de contratação; no estudo de caso foi possível agregar valor ao projeto do cliente com sugestões baseadas na experiência da empresa, com o foco da análise diferente dos projetistas, que buscam soluções estéticas e técnicas, mas nem sempre mais econômicas.

Apesar de cada projeto ser encarado como único para atendimento das necessidades com exclusividade do cliente (centro da estrutura nuclear da empresa), a experiência da empresa em segmentos específicos, como por exemplo: data center, é um fator que pode contribuir como diferencial na tomada de decisão de contratação, como no estudo de caso.

A empresa busca participar da fase de desenvolvimento dos projetos (préconstrução) para compartilhar sua experiência com os projetistas e cliente, como no estudo de caso, propiciando a criação de novo conhecimento e minimizando eventuais problemas de execução.

A coordenação de projetos é um diferencial de mercado, e a empresa passou a vendê-la junto com o pacote de pré-construção a seus antigos clientes, já fidelizados. Ao viabilizar novos contratos, o papel da área de projetos ficou fortalecido na empresa.

Além da experiência da empresa, a participação de consultores externos e fornecedores possibilita a criação de novo conhecimento contribuindo para a valorização do projeto. $O$ objetivo de desenvolver os projetos simultaneamente à execução da obra foi buscar soluções técnicas com foco na redução de prazo e custo da obra. No entanto, a contratação de projetos complementares concomitante ao início da obra prejudicou a equipe de produção que não teve tempo para analisar os projetos e, eventualmente contribuir com sua experiência, antes de colocá-los em execução.

Como o orçamento da obra foi baseado em um estudo preliminar e premissas de custos, não houve uma passagem de conhecimento da equipe de proposta para execução.

Para minimizar os riscos, o cliente contratou, além de uma gerenciadora para fiscalização da obra civil, uma gerenciadora com conhecimento específico para 
verificação da instalação dos equipamentos, que representam $90 \%$ do valor investido no empreendimento. O tipo de contratação não estabeleceu limites de comunicação entre os membros da equipe. $O$ fluxo livre de informações entre a equipe de produção da construtora e os projetistas propiciou maior agilidade nas soluções de problemas da obra, como no caso das fundações que foram acompanhadas pelo consultor que definia com o engenheiro de produção a solução no local e repassava aos projetistas para atualização dos projetos.

A participação da construtora nas definições do projeto, vislumbrando não apenas o lucro da empresa, aumentaram a confiabilidade da empresa perante o cliente.

Além da coordenação dos projetos e sugestão de melhorias, o arquiteto da construtora tem o papel de detectar e minimizar as deficiências dos projetos para reduzir o risco de retrabalho. Entre os maiores problemas detectados nos projetos da Empresa B estão: falta de informação, informações erradas ou desatualizadas, falta de revisão, falta de compatibilização entre disciplinas. Muitos problemas são decorrentes do grande número de mudanças ao longo da obra, por solicitação do cliente ou interferências imprevistas, além do tempo escasso para elaboração e adequações dos projetos.

A retroalimentação da construtora aos projetistas ocorreu mais nos projetos onde havia mais detalhamento e interesse do projetista.

Os coordenadores de projeto internos têm a oportunidade de compartilhar experiências nas reuniões trimestrais do departamento. A frequência destas reuniões foi definida devido a dificuldade de reunir toda a equipe de projeto que encontra-se dispersa nas obras em diversos estados do país. Não foi identificado um processo específico para retroalimentação entre projetistas e novos projetos.

No caso da produção, são compartilhadas as boas práticas no Planejamento Executivo que é continuamente melhorado baseado na experiência vivenciada em cada obra e atualizado pela área de Planejamento no PRqd.

As Lições Aprendidas são relatadas ao final de cada obra, com informações sobre soluções adotadas para problemas encontrados e armazenadas no PRqd de acordo com o tema: técnico, projeto ou administração, com livre acesso para consulta de todos os funcionários. São promovidos alguns seminários específicos para divulgação das Lições Aprendidas, como o exemplo da área de manutenção. 
Verificou-se que parte do sucesso da implantação do PRqd deve-se ao fato de envolver as equipes, através dos monitores de cada área, desde o início da estruturação do sistema e no processo de revisão para melhoria das ferramentas. Ao basear-se na adaptação e melhoria dos processos já existentes e incorporados ao dia a dia dos funcionários, facilitou sua utilização propiciando menor resistência. Ao relacionar os processos do PRqd a campos de conhecimento que estão conectados a uma das dimensões estratégicas da empresa e às metas dos funcionários, deixa clara a importância de sua utilização.

Os maiores problemas enfrentados foram de infra-estrutura de $\mathrm{Tl}$, ocasionados pela falta de planejamento inicial sobre o programa e equipamentos necessários para suportar o sistema a ser adotado, devido à falta de parâmetros e capacidade de julgamento da equipe envolvida cujo enfoque foi, prioritariamente, no conteúdo.

\subsection{Estudo de caso: Empresa C}

\subsubsection{Caracterização da Empresa}

\subsubsection{Informações gerais}

A Empresa C, com sede na Alemanha, presta serviços de engenharia e construção oferecendo, nos principais mercados do mundo, um portifólio de opções que envolve serviços de engenharia e construção desde o desenvolvimento do estudo de viabilidade para contratos built-to-suit, pré-construção, desenvolvimento de projetos, construção e assistência técnica pós-obra, até concessões e serviços de operação para Projetos complexos de todos os tipos.

A partir de 1966, inicia suas atividades no Brasil, com sede em São Paulo, atuando no mercado de Edificações (nos segmentos: edifícios de escritórios, shopping centers, hipermercados e megastores, escolas, hotéis edifícios residenciais, centros de distribuição, data centers e call centers, centros culturais, lazer e exposições, hospitais e laboratórios), Industrial (indústria de processos contínuos, bem como na indústria de manufatura) e no mercado de Infra-estrutura (nos segmentos de 
energia, túneis, pontes, barragens, saneamento, obras de vias públicas, metrôs e vias férreas de alta velocidade, aeroportos, portos e estádios).

Executou mais de 400 obras e em 2010, contava com aproximadamente 500 profissionais, sendo 200 engenheiros.

\subsubsection{Evolução da empresa}

A empresa fundada na Alemanha em 1875, pelos irmãos Helfmann, passa a sociedade anônima em 1896. Em 1924, estabelece seu nome definitivo.

Em 1966, tem início as atividades no Brasil com o contrato para estudo de viabilidade técnica e projetos para a construção da Linha 1 do Metrô São Paulo e Usina Angra dos Reis.

O primeiro contrato de construção ocorre em 1969 para uma montadora de automóveis. A partir de 1970, realiza vários serviços de construção, prédios de escritórios, shopping centers, hotéis, bancos, hipermercados, residências, data centers e principalmente no setor industrial, que consolidam sua posição no mercado.

Em 1980, parte do capital da empresa é nacionalizado a partir da compra de um grupo brasileiro, mas em 1997 a matriz re-adquire a participação do grupo.

No anos 80, expande para o mercado de edificações e, na década de 90, ocupa a posição de uma das maiores construtoras do Brasil neste segmento recebendo em 2000 o prêmio "A construtora do ano" da revista O Empreiteiro.

A partir de 1999, a matriz constatou que, para se tornar uma empresa global, precisava sair da Alemanha, onde se concentrou até a década de oitenta, passando a adotar uma estratégia de crescimento que consistia em adquirir, se associar, comprar e promover parcerias com diversas empresas ao redor do mundo (sulafricana, australiana, holandesa, americana).

A filial do Brasil obtém em 2000, a certificação ISO 9001 (Qualidade). Em 2001, há uma intensificada atuação no segmento de indústrias pesadas e infra-estrutura. 
Com a internacionalização do portifólio e a pulverização das ações, em 2004, a empresa tem maior exposição à comunidade financeira, figurando como segundo maior grupo de engenharia e construção do mundo em faturamento.

A partir de 2006, tem início no Brasil as operações de Facilitiy Management (Gestão de Facilidades) no qual a empresa oferece a seus clientes a gestão de infraestrutura, de serviços técnicos e de condomínios comerciais - desde manutenção, reparos, fornecimento de energia, gestão de espaços vazios, até a conservação de equipamentos de produção.

Em 2007, obtém as certificações OHSAS 1801 (Saúde e Segurança do Trabalho) e ISO 14001 (Meio Ambiente).

No final de 2009, $80 \%$ das ações da empresa no Brasil são vendidas para um grupo de origem alemã, que atua no mercado de construção, desenvolvimento imobiliário, hoteleiro e meio ambiente, entre outros. O grupo, que completou 100 anos de história em 2009, já estava presente no mercado de meio ambiente no Brasil por meio de várias empresas e na construção civil.

\subsubsection{Missão, valor e visão}

A Empresa C apresenta como sua missão: "Oferecer aos Clientes soluções de engenharia e construção para todo ciclo de vida de empreendimentos, atuando como um prestador de serviços de excelência na América do Sul".

Em sua visão, a empresa afirma que está construindo o futuro, juntamente com seus parceiros, incrementando de forma sustentável seus valores: Transformando visão em valor.

De sua visão são derivados os princípios, que compõem o código corporativo de conduta, e orientam o relacionamento com os parceiros, clientes e acionistas:

- Serviços orientados ao cliente;

- Funcionários como fator de sucesso;

- Sustentabilidade;

- Estratégia para geração de valores. 


\subsubsection{Estrutura organizacional}

Para atender às particularidades de seus clientes, a estrutura organizacional da Empresa $\mathrm{C}$ é organizada por Projetos, atuando com Áreas de Negócios focadas nas demandas de cada mercado e segmento: Edificações, Industrial, Infra-estrutura e Facilitiy Management (Gestão de Facilidades). Sua estrutura flexível favorece a mobilização de recursos e especialistas adequados para cada tipo de Projeto.

Para a execução de cada empreendimento contratado é utilizado um mapa de processos formado por atividades de gestão corporativa e operacional relacionadas ao ciclo de vida do empreendimento, visando assegurar a satisfação de seus clientes e integração entre todos os níveis organizacionais.

A estrutura organizacional foi concebida para uma organização descentralizada, flexível e com controle coordenado. Possui poucos níveis hierárquicos com responsabilidade e níveis de autonomia bem definidos. O relacionamento entre as unidades, que envolvem a negociação entre seus responsáveis, pode ser caracterizado como matricial no qual as operações são descentralizadas sendo executadas em cada empreendimento (Unidades de Negócio), com controle coordenado pelas áreas de suporte (Unidades de Serviço) e respectivas diretorias.

Para atender ao processo do negócio, foram definidos três níveis hierárquicos: Diretoria Executiva, Diretorias de Negócios, Nível de Serviço/ Operativo (Unidades de Serviço/ Negócio), conforme Figura 62.

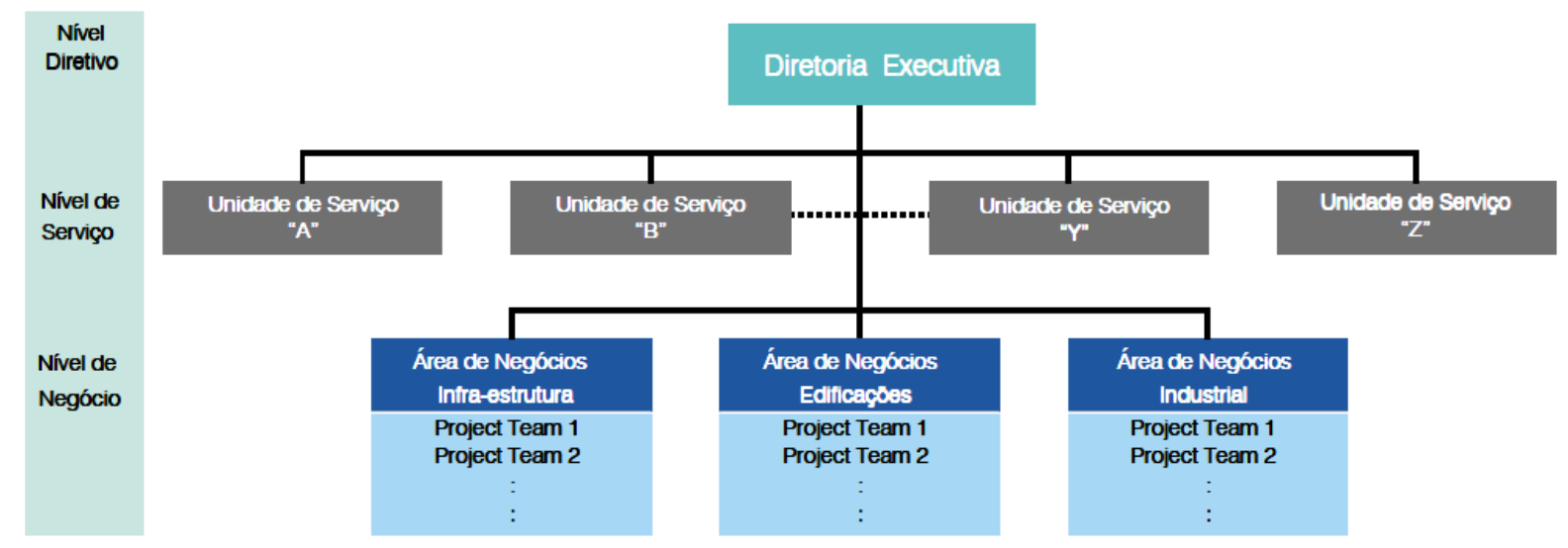

Figura 62 - Estrutura organizada por Projetos (KOWALEWSKI, 2008) 
As Unidades de Serviço, localizadas no escritório central, colocam à disposição dos Project Teams (equipes de Projeto) e das Unidades de Negócio (obras) seu conhecimento, experiência e o apoio necessário.

Ao Project Team (equipe de Projeto) cabe obter o contrato, constituir a Unidade de Negócio para a execução do contrato e executar a obra conforme os requisitos definidos entre a empresa e o cliente.

Cada área de negócio da empresa tem uma pessoa da área de Controle que responde ao diretor da área de negócio e ao gerente de Controlling (Controle). Esta área é responsável pela previsão e acompanhamento dos negócios para avaliação de eventuais desvios baseado em relatórios de custos detalhados. Dependendo do volume da obra pode haver uma pessoa específica na obra com esta responsabilidade ou, no caso de obras menores, este acompanhamento é feito pelo responsável de planejamento.

\subsubsection{Ciclo de vida dos empreendimentos}

O ciclo de vida dos negócios da empresa, conforme Figura 63, contempla os serviços completos de engenharia e construção oferecidos pela empresa, apoiada na rede global de um dos maiores grupos de engenharia e construção do mundo, desde estudo de viabilidade para contratos built-to-suit, pré-construção, desenvolvimento de projetos, construção até assistência técnica pós-obra, atendendo a todas as necessidades dos seus clientes.

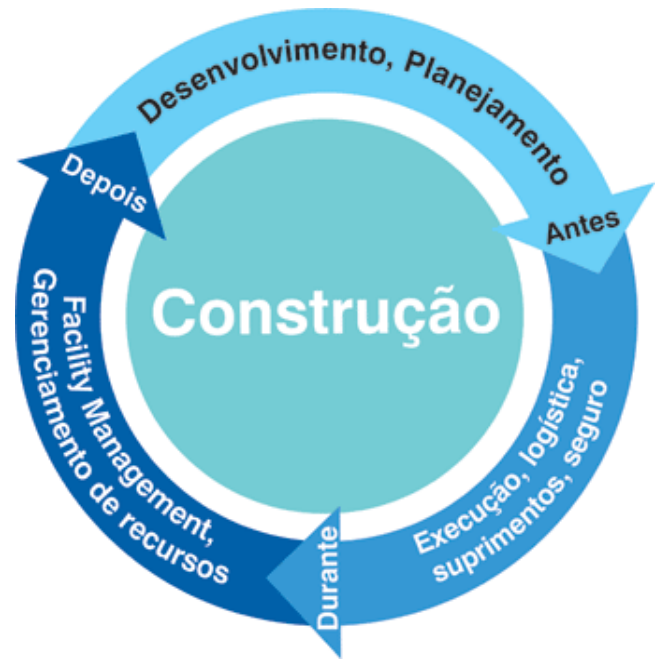

Figura 63 - Ciclo de vida do empreendimento (KOWALEWSKI, 2008) 
Para entrega do empreendimento contratado pelo cliente, todas as atividades da empresa são direcionadas ao Processo Principal do Negócio, conforme Figura 64.

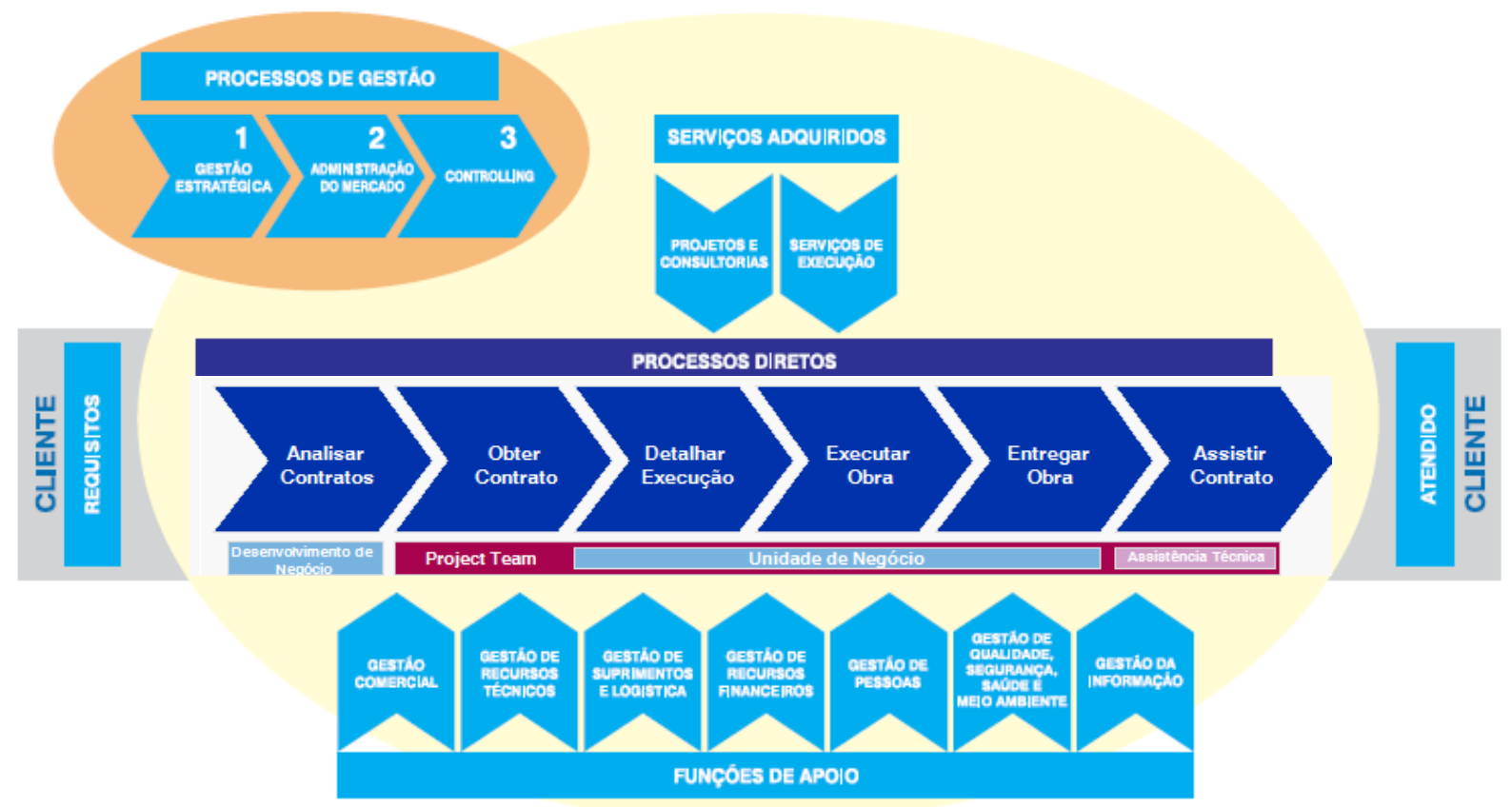

Figura 64 - Processo principal do negócio ao longo do ciclo de vida do empreendimento (adaptado de KOWALEWSKI, 2004)

Além da execução da obra, o cliente pode optar pela contratação da Pré-construção, que é uma etapa que antecede a fase de construção quando a empresa tem a oportunidade de transmitir seu conhecimento e experiência, colaborando no desenvolvimento dos projetos com soluções de melhor custo/ benefício, inovações e metodologias construtivas buscando aumentar a eficiência na realização do empreendimento (RAMPASSO; SOUZA, 2010). As principais atividades da préconstrução são:

- Coordenação e integração dos projetos;

- Obtenção de licenças;

- Definição das soluções técnicas para os sistemas de utilidades;

- Engenharia e Análise de valor (recomendação de soluções alternativas visando adequação ao custo e prazo pretendidos pelo cliente);

- Indicação e negociação com fornecedores;

- Planejamento (métodos construtivos, plano de ataque e cronograma); 
- Orçamento da obra.

A fase de Gerenciamento e Construção envolve as atividades de:

- Engenharia: o Gerente do Contrato, responsável pela elaboração da proposta ao cliente lidera uma equipe multidisciplinar para 0 atendimento ao planejamento e orçamento da obra;

- Suprimentos e Logística: tomada de preços, equalização das propostas dos fornecedores, negociações, contratações, controle do fornecimento, recebimento e estocagem;

- Controle da qualidade: implementação do plano da qualidade com inspeções, testes, calibragem de equipamentos, comissionamento ou partida, de modo a garantir a qualidade do produto contratado;

- Programas de saúde, segurança e meio ambiente: implementação dos programas com atendimento das normas, legislação vigente, requisitos do cliente;

- Controle da implantação (Controlling): uma equipe autônoma verifica sistematicamente o andamento da implantação, faz a checagem do planejado versus realizado e propõe medidas corretivas quando necessárias.

\subsubsection{Sistemas de gestão}

\section{- Sistema integrado de gestão (Management System)}

A empresa possui um sistema integrado de gestão, o Management System, o qual assegura que tanto os requisitos contratuais do cliente quanto os objetivos da organização sejam atingidos. Este contém todas as orientações necessárias para as operações da empresa como, a filosofia empresarial, o modelo de organização e os processos das atividades requeridas pelo modelo de negócio, em consonância com os requisitos das normas internacionais de qualidade, saúde, segurança e meio ambiente. 
Em 2004, o Management System foi revisado, conforme Figura 65, após reestruturação da empresa, desvinculando a filial brasileira do sistema formal da matriz alemã e tornando o sistema mais enxuto, simplificando a estrutura de documentação, adotando arquivos eletrônicos em substituição ao papel, mas mantendo as políticas e diretrizes corporativas.

Management Book (MB):

Manual de Organizaçăo e Gestāo, contém a Filosofia, as Diretrizes e descreve toda a organizaçāo e sisternas de gestão da nossa Empresa.

Plano de Gestāo da UN (PG-UN):

Documento que descreve como os requisitos das Normas ISO 9001 , ISO 14000 e OHSAS18000, sāo atendidas na Unidade de Negócio.

Procedimento Operacional (PO):

Documento que descreve e contém as orientaçðes do como fazer.

Ficha de Execução e Controle (FEC): Contém a orientaçáo de execuçấo básica dos serviços e evidência as verificaçöes feitas.

Registro do Sistema (RG):

Formulários preenchidos e evidências do sistema (ex.: cronograma)

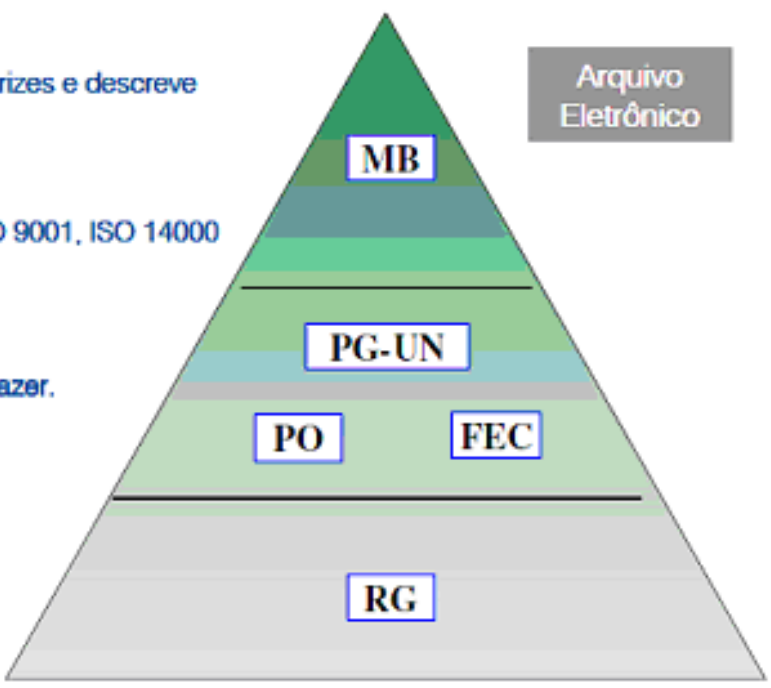

Figura 65 - Estrutura de documentação do Management System (KOWALEWSKI, 2008)

As orientações para atendimento do sistema integrado de gestão são apresentadas no Management Book que atende aos requisitos da norma NBR ISO 9001.0 Management Book contém toda a estratégia, as diretrizes, a estrutura, os processos e procedimentos da empresa e demonstra como as áreas da empresa se interrelacionam durante a execução desses processos. É um manual de uso diário das lideranças, um instrumento de trabalho dos diretores, gerentes e coordenadores, além de instrumento de integração para o colaborador que acaba de ingressar na empresa ou para aquele que foi promovido.

\section{- Sistema de gestão da qualidade}

De acordo com o diretor da Empresa C no Brasil, para obter sucesso, uma construtora precisa investir em um sistema de gestão como um todo. A qualidade é um dos componentes desse sistema de gestão, ao lado das políticas estratégicas, do treinamento e, em especial, da tecnologia da informação. A matriz mundial 
obteve o certificado ISO 9001 há muitos anos com um manual. A empresa aprendeu, depois de algum tempo, que isso não era suficiente para proporcionar aos clientes um serviço de qualidade. A qualidade é um dos pontos. Na filial do Brasil foi certificado o sistema de gestão - Management System, a forma de trabalhar e não apenas um manual da qualidade (COZZA, 1999).

\section{- Gestão de saúde e segurança}

Desde o final de 2006, a gestão de saúde e segurança segue as diretrizes da OHSAS 18001, assegurando que todas as atividades da empresa são desenvolvidas visando fundamentalmente a proteção do ser humano, a preservação de seus ativos, a continuidade dos serviços, a execução das tarefas por pessoas especializadas e habilitadas e para tanto atua com eficácia na prevenção de acidentes do trabalho e de doenças ocupacionais, eliminando ou minimizando os níveis de exposição aos riscos e diminuindo assim, a freqüência de ocorrência e a gravidade das lesões oriundas de acidentes de trabalho.

\section{- Gestão do meio ambiente}

Certificada em dezembro de 2006, de acordo com norma NBR ISO 14001, a gestão ambiental da empresa tem como foco principal o levantamento, em cada empreendimento, de todos os aspectos ambientais envolvidos e respectivos impactos além de toda a legislação em função da natureza das atividades que serão desenvolvidas e da sua localização geográfica.

Com base nessas informações, medidas de controle são definidas e implementadas para garantir que tanto a política ambiental da empresa quanto seus objetivos e indicadores sejam atingidos plenamente.

Se mesmo assim, algum impacto indesejado vier a ocorrer, o Management System possui rotinas para implementação de ações corretivas abrangentes capazes de eliminá-los e, mais do que isso, prevenir sua reincidência. 


\section{- Gestão da Informação}

A filial do Brasil está alinhada com o mesmo modelo utilizado pelo grupo, com um sistema corporativo integrado de informação e de gestão do negócio - padrão SAP, assegurando de forma transparente, a integração entre os sistemas operacionais e de controle de custos, o que facilita e agiliza a tomada de decisões dos executivos da empresa.

\subsubsection{Assistência Técnica}

A partir de 2009, a Unidade de Serviço Assistência Técnica - US ATC, anteriormente subordinada à Área de Negócio de Engenharia e Construção, passa a integrar a Unidade de Serviços Técnicos da Área de Facility Management (Gestão de Facilidades).

É de responsabilidade da Assistência Técnica, ao receber uma reclamação do cliente verificar se a patologia foi ocasionada por terceiros, se a manutenção periódica ocorreu conforme Manual do Proprietário ou se o problema é estrutural.

O objetivo da integração visou combinar a experiência dos profissionais das duas unidades para responder às oportunidades de novos Negócios em Manutenção Volante no mercado de facilities; fortalecer parcerias com clientes oferecendo serviços após o término do período de garantia; desenvolver processos e relatórios periódicos e criar históricos para consulta das áreas de engenharia, suprimentos (avaliação de fornecedores) e orçamentos (verbas de garantia) (VENTURA et al.; KAWAMOTO; MASCHIO; RODRIGUES, 2009).

\subsubsection{Memória Técnica - MT}

A Memória Técnica - MT surgiu pela iniciativa de um gerente da área de Engenharia para armazenar as informações das obras da empresa. O objetivo era criar um ambiente onde todos pudessem buscar informações relativas às obras já realizadas, sem a necessidade de procurar alguém da equipe de Engenharia.

O processo existe há vários anos e teve vários picos diferentes. Como os profissionais do escritório não tinham muita oportunidade para visitar as obras, foi 
criado inicialmente com muitas informações e material interno e de obra com o objetivo de criar uma ferramenta para melhorar o processo de orçamento (ex.: composições de preço unitário, cálculo de despesas indiretas, etc) e planejamento na etapa de elaboração de propostas técnicas.

Há dois anos (desde 2009), o Gerente de Controlling assumiu a MT, atuando um pouco como tutor, sempre buscando a contribuição das outras áreas. $\mathrm{Na}$ visita mensal a cada obra é solicitada uma retroalimentação de itens interessantes detectados pela equipe de obra no período, o que aumentou o conteúdo armazenado na MT.

Segundo a gerente de projetos, ficou acordado entre as Unidades de Serviço que a cada seis meses será alimentada a MT, quando cada área envia o material para a área de Controlling que sintetiza o material, transforma em PDF, arquiva e divulga na MT. É feita uma reunião de divulgação semestral para aproximadamente 20-30 pessoas.

A MT tem sido revisada ao longo do tempo, retirando informações desnecessárias e agregando outras importantes. Segundo o gerente de Controlling, para a última revisão realizada foi formado um grupo de trabalho composto pela área de Engenharia, projetos, Suprimentos e Administração para definir quais informações seriam importantes como lições aprendidas para melhoria dos processos. Foi definido que seriam incluídas, sem depender de empresa tercerizadas de arquivamento, informações que pudessem agregar valor ao conhecimento corporativo, como por exemplo, atualização de informações sobre dados técnicos de equipamentos; dicionário técnico com termos em inglês da área de projetos; soluções diferenciadas adotadas nas obras; garantias; como operar o que foi instalado; retroalimentação de execução das obras. Não seriam incluídas informações que podem variar ao longo do tempo por motivos alheios à empresa, como por exemplo, legislação.

Da área de projetos estão armazenados o Manual do Proprietário (garantias), ARTS, dicionários técnicos, mas como os arquivos estão em PDF, caso seja necessário o arquivo que possa ser editado existe uma cópia controlada em pastas especiais sob guarda da gerente de projetos. Os desenhos não são armazenados na intranet para não sobrecarregar o sistema. 
Não foi identificada a necessidade de um contador de acessos à MT. O gerente de Controlling faz uma visita mensal em cada obra quando é feito o acompanhamento econômico-financeiro e técnico da obra, baseado em um relatório gerencial mensal com informes sobre o andamento dos projetos, licenças, resultado econômico. Neste momento, é verificado se a obra teria alguma contribuição interessante para registro na MT.

A área de Controlling enfatiza a importância da MT e procura estimular a participação solicitando que a cada visita mensal seja feita alguma contribuição da obra. Não há resistência à utilização, mas a contribuição e grau de interesse dependem muito de cada indivíduo. O que pode ser alegado é o aspecto de agregar mais uma tarefa à rotina. Não foi pensado em como estimular a motivação para contribuição, como por exemplo, premiação.

Como forma de retorno para quem escreveu algo que foi publicado na MT existe um campo para comentários. Várias pessoas participam concordando ou não, ou comentando sobre o tema. Há um registro indicando para quem foi enviado e quem leu.

Todo profissional que ingressa na empresa passa por um processo de integração das áreas onde cada unidade explica como ela trabalha. A MT é apresentada, principalmente para a área de orçamentos, que tem demonstrado interesse em utilizá-la pelo seu conteúdo. Os dados também são importantes para o planejamento de novas obras. O gerente de Controlling cita como exemplo, quando tornou-se obrigatório o uso de protetor solar em obra, sendo que este item não havia sido contemplado no orçamento. A área de Controlling solicitou um levantamento de quantas bisnagas foram gastas nos últimos 3 meses na obra para checar quanto foi o gasto não previsto: Se se gasta 1 bisnaga/ pessoa a cada 20 dias; gasta-se 2 bisnagas/ mês/ pessoa; cada bisnaga custa $R \$ 9,00$ e se o efetivo deste período foi de 100 pessoas, gastou-se $R \$ 1.800 /$ mês $\times 12$ meses de obra. Em outra obra foi orçado vale transporte local, mas a maior parte da mão-de-obra vem de outra cidade e utiliza transporte inter-municipal. A mesma avaliação pode ser feita para uniformes, capacetes, etc. Nos próximos orçamentos estes dados podem servir de negociação da proposta comercial com o cliente.

Ainda existe muito pouco material para consulta mais técnica, como por exemplo, para estudo de uma solução tecnológica diferenciada, pois o foco principal é o custo: 
como reduzir custos e divulgar para todas as obras. Existe um material chamado Lições Aprendidas que é desenvolvido pela equipe da obra no final do empreendimento onde são apresentadas as soluções técnicas utilizadas diferente do planejado.

Como o foco ainda é a obra e a área de Facility Management está mais focada em shopping centers e áreas comerciais, não existe uma avaliação pós-ocupação dos empreendimentos para trazer informações para melhoria dos projetos ou soluções de engenharia visando menor custo de manutenção.

\section{Estrutura da Memória Técnica}

O sistema da MT foi desenvolvido em Microsoft Acess e está disponível na rede corporativa com acesso via intranet com autorização de acesso para todos profissionais do escritório e obra. Não foi desenvolvido nenhum programa específico ou ferramenta de gerenciamento de documentos, pois chegou-se à conclusão de que não era o momento adequado para investir neste ponto. A preocupação maior tem sido a geração do conteúdo do que a ferramenta de armazenamento. Quando houver uma necessidade maior de busca de informação, talvez seja avaliada outra ferramenta de TI mais específica. Ainda não há um índice, um banco de dados para busca por tema; a busca é por palavra-chave.

A MT contém dados e informações organizados através de menus. Os menus foram estruturados de acordo com a dinâmica organizacional da empresa que apresenta as relações entre a organização e os processos diretos do negócio ao longo do ciclo de vida do empreendimento, definidos no Management Book, conforme Figura 66. Para cada uma destas etapas serão disponibilizadas informações na MT que foram coletadas ao longo deste ciclo de vida.

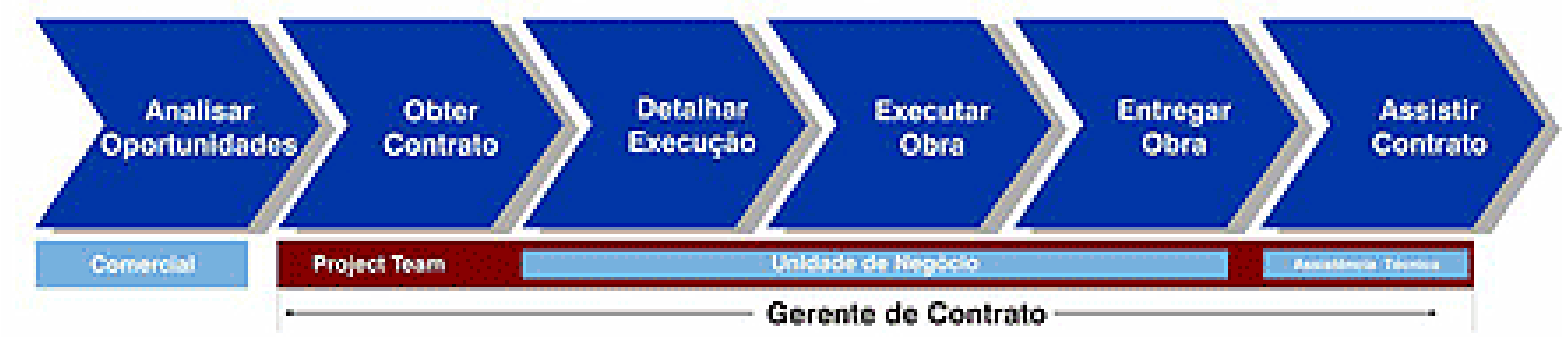

Figura 66 - Processo principal do negócio ao longo do ciclo de vida do empreendimento (tela Memória Técnica) 
Após a obtenção do contrato, ocorrem diversas interações ao mesmo tempo em que o Project Team vai sendo formado até a sua consolidação em Unidade de Negócio. O menu de busca da MT foi concebido respeitando o sequenciamento de processos, de modo a facilitar a identificação das informações:

1. Detalhar Execução:

- Biblioteca Técnica: contém dicionário técnico inglês-português (com mais de dez mil expressões abrangendo termos técnicos, comerciais, contratuais, financeiros e contábeis), lista de normas técnicas, metodologia executiva mais utilizadas (utilizado por planejamento da área de negócios para plano de ataque da obra, logística, etc), tabelas, manuais técnicos, planejamento de custo, passo a passo de MSProject;

- Sustentabilidade: Conceitos básicos de sustentabilidade, principais certificações (LEED, AQUA) e consultorias existentes.

\section{Executar Obra}

- Lista de Equipamentos: que existem do canteiro central da empresa com foto (por exemplo: tipo de grua, especificações técnicas, tabelas de alcance e capacidade de carga, etc);

- $\quad$ Sistemas de Controle: controle de material de terceiros (cimbramento);

- $\quad$ Feedback (o que deu certo ou errado nas obras);

- $\quad$ Fichas Técnicas: informações que vem da obra.

\section{Entregar Obra}

- Manual do Proprietário: de todas as obras, com possibilidade de busca por: código da UN, Unidade de Negócio, estado, mercado ou segmento;

- Fotos e Vídeos de obras concluídas separado por segmentos;

- Lições Aprendidas.

4. Assistir Contrato

- Reparos efetuados em período de garantia. Apresenta:

- Os custos de reparos em \% agrupados por tipo de obra; 
- Fotos das principais patologias agrupadas por tipo de serviço e comentários das possíveis causas de patologias (OBRA BRUTA: Contenções, Superestrutura, Cobertura, Alvenarias, Impermeabilizações, Pisos de Concreto, Drenagem e ACABAMENTOS: Esquadrias, Revestimento Cerâmico, Forro de Gesso, Pinturas, Fachadas, Instalações, Áreas Externas, Diversos).

Estes dados podem auxiliar a equipe de orçamento a prever uma verba a mais de fiscalização dos itens que apresentam maior incidência de problemas patológicos. Possibilita agir sobre pontos que a empresa teve problemas no passado para que sejam previstas ações para minimizar os problemas no futuro e fazer orçamentos prevendo estes itens. Ações que podem ser tomadas: verificar o projeto, aumentar fiscalização, orientar as pessoas da área de produção para tomar cuidado com certos itens.

É possível identificar quais são as principais patologias que ocorrem em cada segmento. Conforme relatado pelo gerente de Controlling, a maior parte dos problemas de obras industriais é o piso de concreto, shopping center é alvenaria e residencial é muito mais de acabamentos.

Por falta de recursos, não é feita uma avaliação minuciosa de cada obra para detectar se a causa foi relacionada a projeto, fornecedor, falta de controle, etc. A área de Controlling faz uma consulta à área de garantia sobre as principais patologias para verificar algumas das possíveis causas detectadas (ex: encontro de pilar e alvenaria, junta de piso de concreto, encunhamento mal feito, etc). Não há muitos casos de falhas ou problemas detectados por causa de projetos, geralmente são problemas relacionados à execução. Um problema de projeto em algum item que seja comum a todas as unidades em uma obra residencial, como por exemplo, uma porta, representa um custo grande de reparo devido à repetitividade, ao passo que apenas um problema de uma obra industrial pode ter um custo muito maior.

Como as obras da empresa não têm características que possibilitem uma repetitividade de soluções, a maior dificuldade é prever se haverá uma próxima obra onde poderá ser utilizada determinada informação. 


\subsubsection{Funcionários entrevistados (unidades de análise)}

A iniciativa de gestão do conhecimento foi identificada na revista periódica Tapume de 2009, disponível no site da empresa, conduzida pelo gerente de Planejamento e Controlling (controle) do Núcleo de Gestão Técnica. A Memória Técnica - MT, disponível na rede corporativa da empresa, é uma ferramenta criada visando contribuir no processo de melhoria da empresa coletando e compartilhando experiências e informações relevantes obtidas ao longo dos processos diretos do Negócio (COLOMERA; SOUZA, 2009).

As entrevistas semi-estruturadas para coleta de dados foram realizadas com o gerente de Planejamento e Controlling (controle), responsável pela MT; a gerente de projetos do escritório central, responsável pelos arquitetos coordenadores de projeto da empresa, que indicou a obra do estudo de caso. Na obra foram entrevistados a coordenadora de projetos e o engenheiro de produção, conforme Quadro 18.

\begin{tabular}{l|llc}
\multicolumn{1}{c|}{ Departamento } & \multicolumn{1}{c|}{ Cargo } & $\begin{array}{c}\text { Tempo de } \\
\text { formado }\end{array}$ & $\begin{array}{c}\text { Tempo de } \\
\text { empresa }\end{array}$ \\
\hline $\begin{array}{l}\text { Núcleo de Gestão Técnica } \\
\text { (Escritório central) }\end{array}$ & $\begin{array}{l}\text { Gerente de Planejamento e } \\
\text { Controlling }\end{array}$ & 18 anos & 21 anos \\
\hline $\begin{array}{l}\text { Núcleo de Engenharia (Escritório } \\
\text { central) }\end{array}$ & Gerente de Projetos & 24 anos & 17 anos \\
\hline Projetos (Obra) & Coordenadora de Projetos & 9 anos & 6 anos \\
\hline Produção (Obra) & Engenheiro de Produção & 8 anos & 2 anos \\
\hline
\end{tabular}

Quadro 18 - Funcionários entrevistados da Empresa C

\subsubsection{Caracterização do empreendimento analisado}

O Quadro 19 resume algumas características do empreendimento do estudo de caso da Empresa C, ilustrado pelas figuras: Figura 67: fotomontagem do empreendimento e Figura 68: planta do pavimento tipo. 


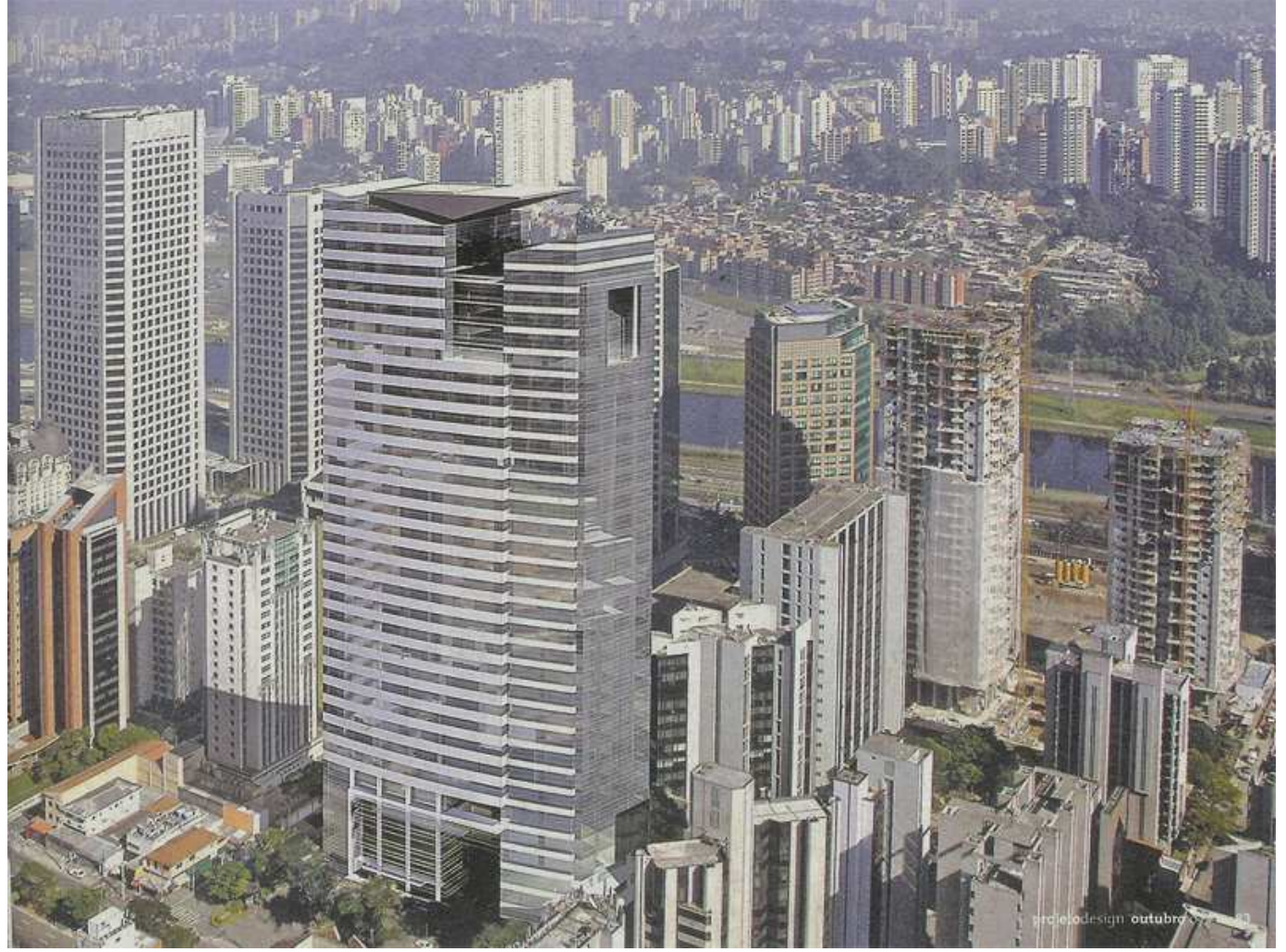

Figura 67 - Fotomontagem do empreendimento (MAGALHÃES, 2008)

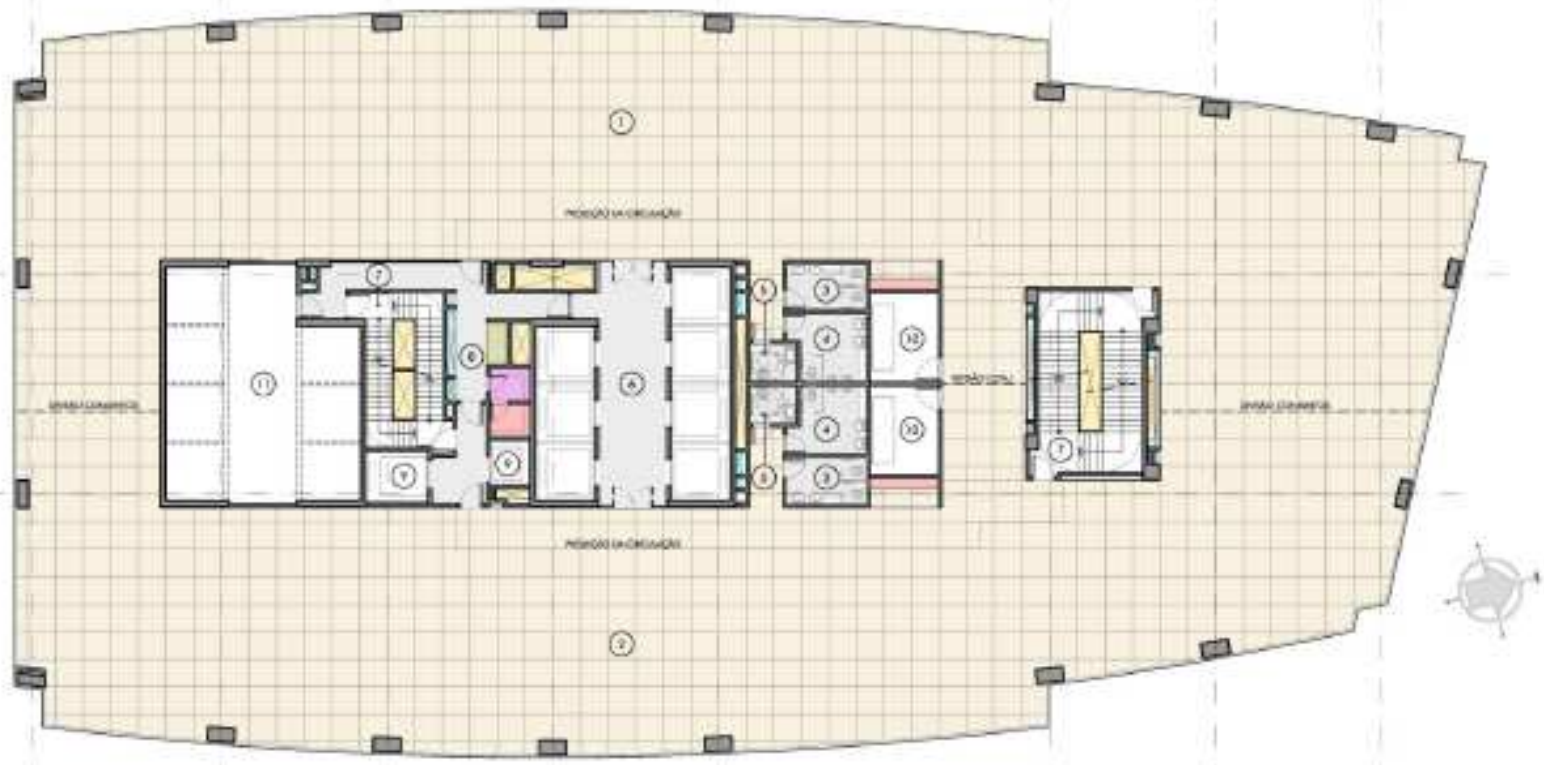

Figura 68 - Planta pavimento tipo com área de 1.600 m2 (MAGALHÃES, 2008)

\section{Características do empreendimento}

Obra sob encomenda de um edifício comercial que visa a certificação LEED Gold, compreendendo 35 andares, cinco subsolos, um edifíciogaragem adicional, térreo e cobertura preparada para heliporto (ao final da obra foi obtida a certificação LEED Platina). 


\begin{tabular}{ll}
\hline Área Construída & $101.200 \mathrm{~m}^{2}$ \\
\hline Prazo da Obra & 34 meses (Jun 2008 - Abr 2011) \\
\hline Tipo de Cliente & $\begin{array}{l}\text { Gestor de fundos imobiliário brasileiro com investidores estrangeiros } \\
\text { (seguradoras, fundos de pensão entre outros). }\end{array}$ \\
\hline Método de seleção & $\begin{array}{l}\text { Projetistas: a construtora não era responsável pela contratação dos } \\
\text { projetistas. Os projetistas foram contratados pelo cliente através da } \\
\text { gerenciadora, sem a participação da construtora, com exceção dos } \\
\text { projetos para produção. }\end{array}$
\end{tabular}

Construtora: Negociação, após concorrência para atingir preço alvo.

\begin{tabular}{ll}
\hline $\begin{array}{l}\text { Sistema contratual da } \\
\text { construtora }\end{array}$ & $\begin{array}{l}\text { Sequencial tradicional (obra teve início após o término dos projetos } \\
\text { executivos) com as fases de projeto, concorrência e construção. }\end{array}$ \\
\hline $\begin{array}{l}\text { Arranjo funcional das } \\
\text { equipes de projeto e }\end{array}$ & $\begin{array}{l}\text { Equipe de projeto separada da equipe de construção com } \\
\text { construção }\end{array}$ \\
gerenciador como mediador.
\end{tabular}

\begin{tabular}{lll}
\hline $\begin{array}{l}\text { Modalidade de pagamento } \\
\text { da construtora }\end{array}$ & $\begin{array}{l}\text { PMG (Preço Máximo Garantido): Contrato no qual a construtora é } \\
\text { remunerada por uma taxa de administração. Há um preço máximo } \\
\text { fechado entre as partes. Se os gastos forem menores, a construtora } \\
\text { participa dos ganhos com a contratante. }\end{array}$ \\
\hline Gerenciadora & $\begin{array}{l}\text { Contratada pelo cliente desde o projeto básico para o o } \\
\text { acompanhamento de projetos, financeiro e produção. }\end{array}$ \\
\hline Coordenador dos projetos & $\begin{array}{l}\text { Escritório de arquitetura (autor do projeto) contratado pelo cliente, } \\
\text { para compatibilização e coordenação de projetos. }\end{array}$ \\
\hline Entrevistas realizadas & Em 2010 - Em obra
\end{tabular}

Quadro 19 - Descrição do empreendimento do estudo de caso da Empresa C

Com base em dados de pesquisa de mercado, o gestor imobiliário definiu demolir um edifício comercial de 16 andares, construído em 1980, para implantação de um novo edifício, no mesmo local, que representasse um destaque na paisagem urbana, a fim de potencializar o terreno.

Em 2008, a Empresa C foi contratada para implosão do edifício localizado em movimentada área comercial da cidade de São Paulo, sendo que o prédio mais próximo estava localizado a menos de seis metros. Foi adotada técnica de implosão em área confinada, modalidade que exige grande perícia. Foi desenvolvido um cronograma e elaborado um plano de gerenciamento de crise com auxílio da Subprefeitura, Defesa Civil, Polícia Militar, Guarda Civil Metropolitana e Corpo de Bombeiros. Para reduzir os impactos ambientais foram posicionadas 20 piscinas de 1.000 litros dentro do prédio em andares distintos e cobertura, sismógrafos para monitorar vibrações e para evitar estilhaços o edifício foi envolvido até o 6‥ andar por cinco camadas de telas protetoras (KELETI, 2008; SILVA, 2008).

Após a implosão, ilustrada na Figura 69, foram gerados $8.500 \mathrm{~m}^{3}$ de entulho, sendo $6.500 \mathrm{~m}^{3}(76 \%)$ destinados à reciclagem e $2.000 \mathrm{~m}^{3}$ (24\%) a aterro inerte licenciado (MAGALHÃES, 2010). 


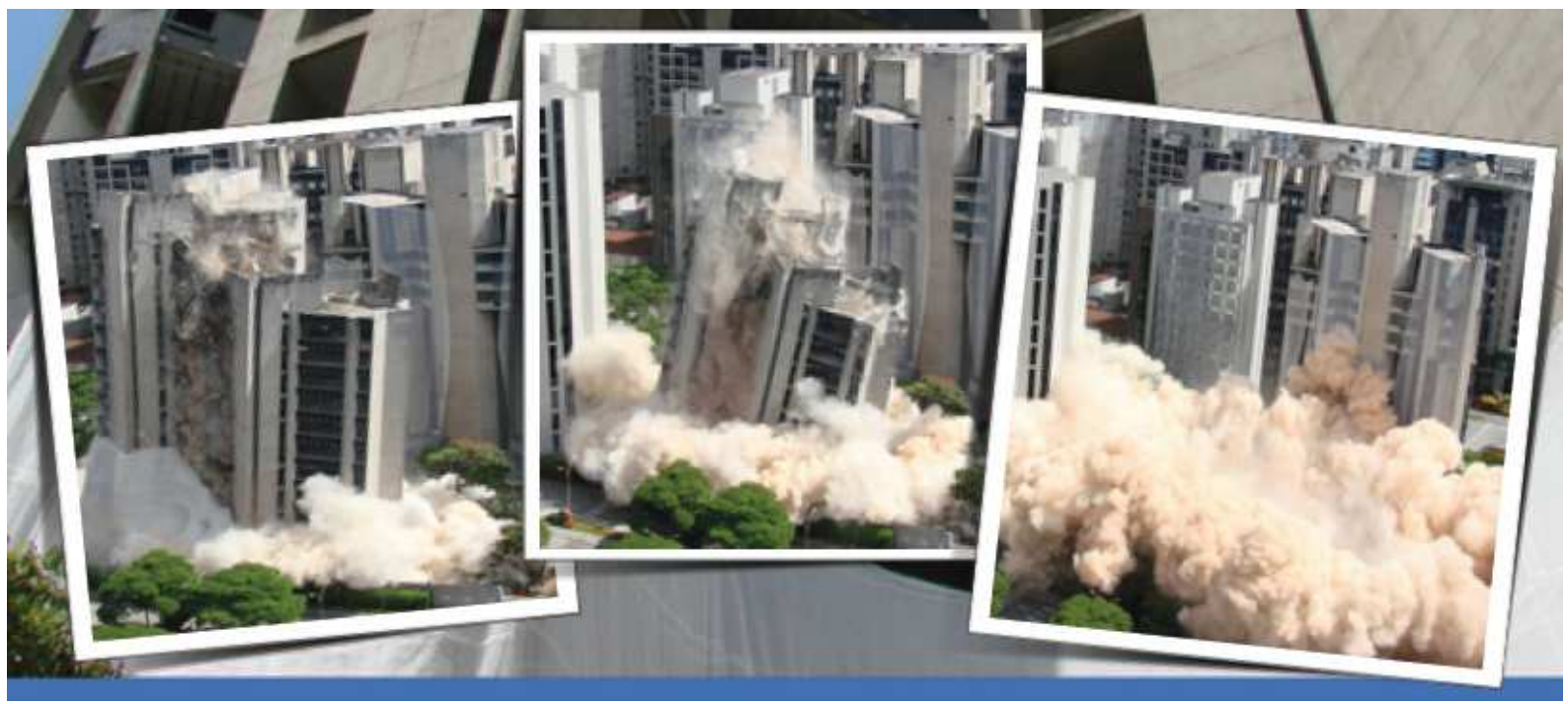

Figura 69 - Foto da implosão do edifício existente no terreno (SILVA, 2008)

Em 2009, a empresa foi contratada para a construção do novo edifício comercial, com orçamento baseado em um projeto básico, sem detalhamento. Na fase de proposta foi feita uma análise de valor, principalmente nas instalações. O caixilho foi concebido pelo arquiteto-autor do projeto e consultor de esquadrias, com o envolvimento de fornecedor alemão, o que facilitou sua posterior contratação. $\mathrm{Na}$ civil foi adotado o banheiro pronto que não estava previsto no projeto.

Os conceitos de sustentabilidade foram incorporados ao novo edifício desde a concepção do projeto até sua construção, com o objetivo de atender ao propósito comercial e conforto do usuário buscando aumento da eficiência dos sistemas, melhoria dos custos operacionais e facilidade de manutenção. Foi estabelecida a meta de certificação LEED (Leadership in Energy and Environmental Design) categoria Gold, dos quais alguns dos requisitos são: as reduções de consumos de água (40\%), energia (30\%) e do custo do condomínio.

Como indicado na Figura 70, o novo edifício terá 35 andares, sendo 32 lajes corporativas de $1.600 \mathrm{~m}^{2}$, cinco subsolos e um edifício-garagem anexo, com área total de $101 \mathrm{mil} \mathrm{m}^{2}$. A partir do $27^{\circ}$ ao $35^{\circ}$ pavimento, devido à complexidade dos recuos das varandas, sky light e um heliponto em balanço em estrutura metálica, constituiu-se praticamente numa outra obra. 


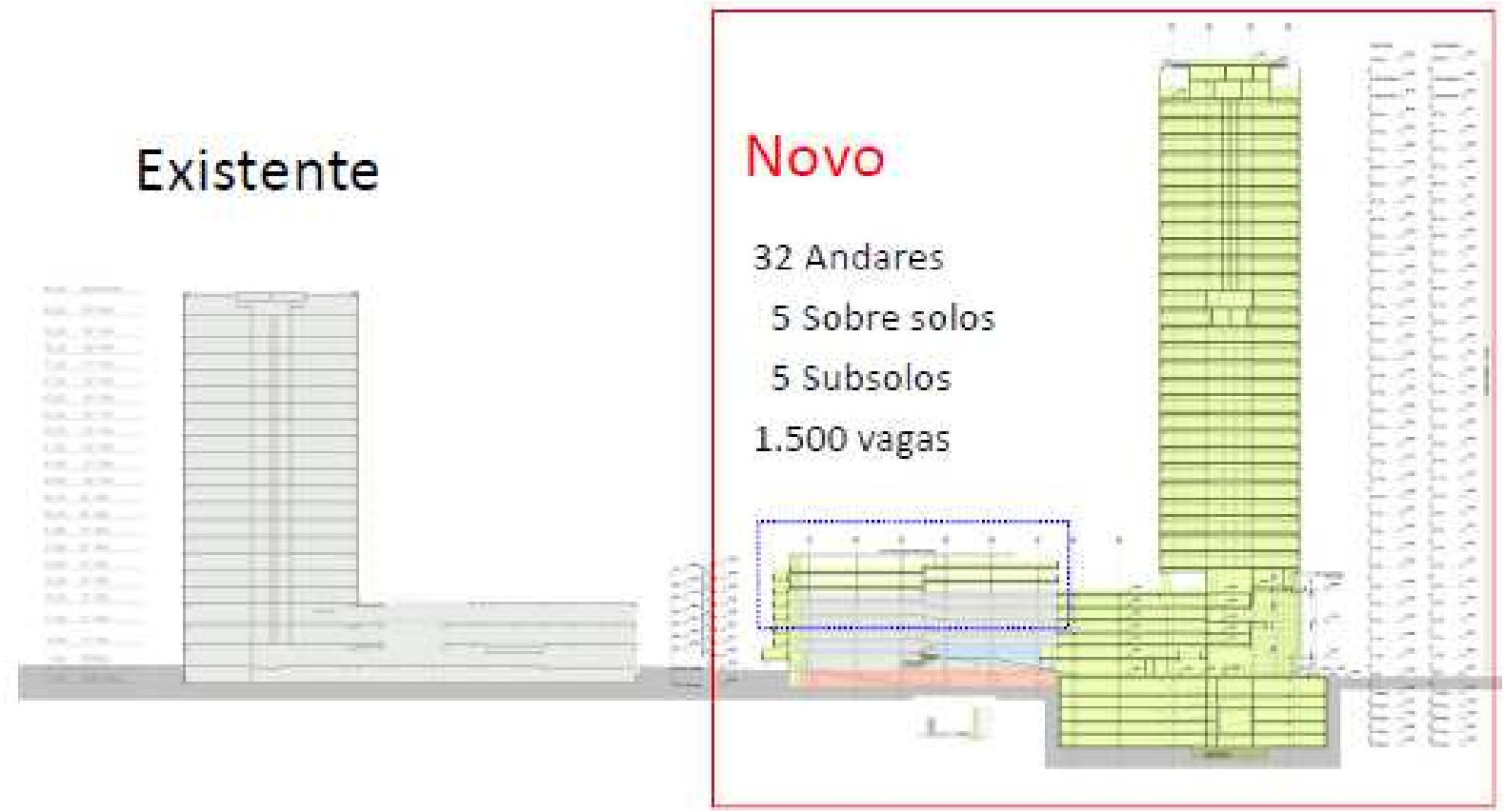

Figura 70 - Corte longitudinal ao terreno (MAGALHÃES, 2008)

Como o projeto já foi concebido com o objetivo de obter a certificação LEED, as adequações necessárias para atender às exigências foram feitas na fase de projeto básico, com a consultoria de Sustentabilidade, sem o envolvimento da construtora. No entanto, várias premissas relativas à fase de construção tiveram que ser atendidas pela Empresa $\mathrm{C}$ no decorrer da obra.

Dentre as concepções de sustentabilidade e tecnologias desenvolvidas e incorporadas no projeto e construção, destacam-se:

- Espaço sustentável: boa localização do empreendimento na cidade; excelente matriz de transportes; grande capacidade de estacionamento;

- Eficiência no uso racional de água: uso de águas cinzas para mictórios, bacias e irrigação; dispositivos sanitários eficientes;

- Eficiência energética: aproveitamento de luz natural; vidros de alto desempenho; iluminação eficiente; geração de energia fotovoltáica na cobertura; sistema de condicionamento com água gelada e variador de frequência; supervisão predial e medição individualizada;

- Emissões atmosféricas: gases refrigerantes com baixo potencial de agressão à camada de ozônio; neutralização de gases efeito estufa emitidos na fase de construção; 
- Gestão de resíduos: plano de gestão de resíduos e central de coleta de lixo seletivo; desvio de $75 \%$ dos resíduos gerados de aterros; reutilização de água dos chuveiros dos vestiários em lava-rodas; controle de saída de sedimentos para as ruas do entorno;

- Consumo de materiais: uso de material com alto conteúdo reciclado; demolição certificada; priorização de materiais extraídos e fabricados em um raio de 800 quilômetros da obra;

- Qualidade do ambiente construído: renovação de ar $27 \mathrm{~m}^{3} / \mathrm{h}$; proibição do fumo (desde a obra); controle de colas e materiais sintéticos; iluminação natural e visão plena para o exterior;

- Programa de educação ambiental: para desenvolver a consciência ambiental crítica dos funcionários da obra e usuários (BUILDINGS, 2010).

Como a fase de projeto se estendeu muito (segundo a coordenadora de projetos da obra, os projetos já estavam em desenvolvimento há mais de um ano antes da contratação da construtora), houve um certo desgaste por parte dos projetistas. Em função disso, a maior dificuldade que a obra enfrentou com os projetistas foi a demora na entrega dos projetos liberados para a obra que eram recebidos "muito em cima da hora".

A obra teve início com os serviços de montagem de canteiro, terraplanagem, mas teve que ser interrompida pelo prazo de um mês, já previsto no cronograma, aguardando a aprovação de processo de autorização de corte e transplante de árvores, quando foi retomanda a fase de fundação em julho/2009. Segundo o coordenador de produção, o planejamento da obra não seguiu um padrão convencional, prevendo executar várias frentes de serviço simultaneamente para viabilizar o curto prazo de obra acordado com o cliente.

Foi contratada pelo cliente uma consultoria para obtenção da certificação LEED Gold, fazendo parte do seu escopo acompanhamento da produção para verificar se todos os requisitos estavam sendo atendidos em relação às exigências do LEED. A obra precisou disponibilizar uma equipe enorme para atender adequadamente às exigências, principalmente quanto à limpeza da obra, controle de poeira, etc, que varia dependendo do tipo de serviço que está sendo executado, pois há fases da obra em que ela não fica completamente limpa. De acordo com o coordenador de 
produção, isto exige mais esforços da produção, mas traz um benefício em relação à organização. Como os fornecedores contratados já tinham conhecimento dos procedimentos corretos para descarte de resíduos, não sobrecarregou a equipe da obra.

\subsubsection{Os agentes do empreendimento}

Foram identificados como principais agentes do empreendimento:

Cliente: gestor de fundos imobiliário brasileiro, fundado em 2006, com investidores da Europa, da Ásia e dos Estados Unidos (fundos de pensão, seguradoras entre outros) responsável pela incorporação, vendas e contratação dos projetos, gerenciadora e construtora.

Foram seus sócios que decidiram construir um prédio de escritórios apto a receber certificações ambientais - o que encarece a obra em até $6 \%$, mas a valoriza na venda. A estratégia da empresa prevê, no futuro, administrar algumas obras próprias, contratando diretamente até mesmo fornecedores de equipamentos elétricos e hidráulicos, para reduzir até $20 \%$ do valor pago a uma construtora (AMORIM, 2010).

Construtora: Contratada pelo cliente para execução da obra. A obra faz parte da Área de Negócios Edificações da Empresa C e, de acordo com o organograma da obra, a equipe de produção é composta por 11 pessoas: 4 mestres (2 de estruturas e 2 de acabamentos), 2 coordenadores de produção, 1 engenheiro de produção, 1 estagiário, 1 engenheiro de planejamento e 2 engenheiros de instalação. Como apoio técnico, a área de projetos tem 2 arquitetos (a arquiteta entrevistada está desde o início da obra, mas não participou da fase de pré-obra). A equipe de suprimentos tem 3 compradores. A equipe de qualidade, meio ambiente e segurança do trabalho tem 14 pessoas: 1 engenheira coordenadora, 5 técnicos e 1 auxiliar de segurança do trabalho, 2 técnicos de qualidade e 1 auxiliar, 1 engenheiro e 1 técnico de meio ambiente, 2 auxiliares de enfermagem que atuam no escritório e em campo, além de serventes, carpinteiros envolvidos. Conforme organograma da obra, na Figura 71, foi observado que a equipe de gestão da qualidade é maior que a de gestão da produção. 
O líder do Project Team que participou do projeto desde a fase de concorrência é o Gerente de Contrato que é o líder da obra responsável pela formação da equipe.

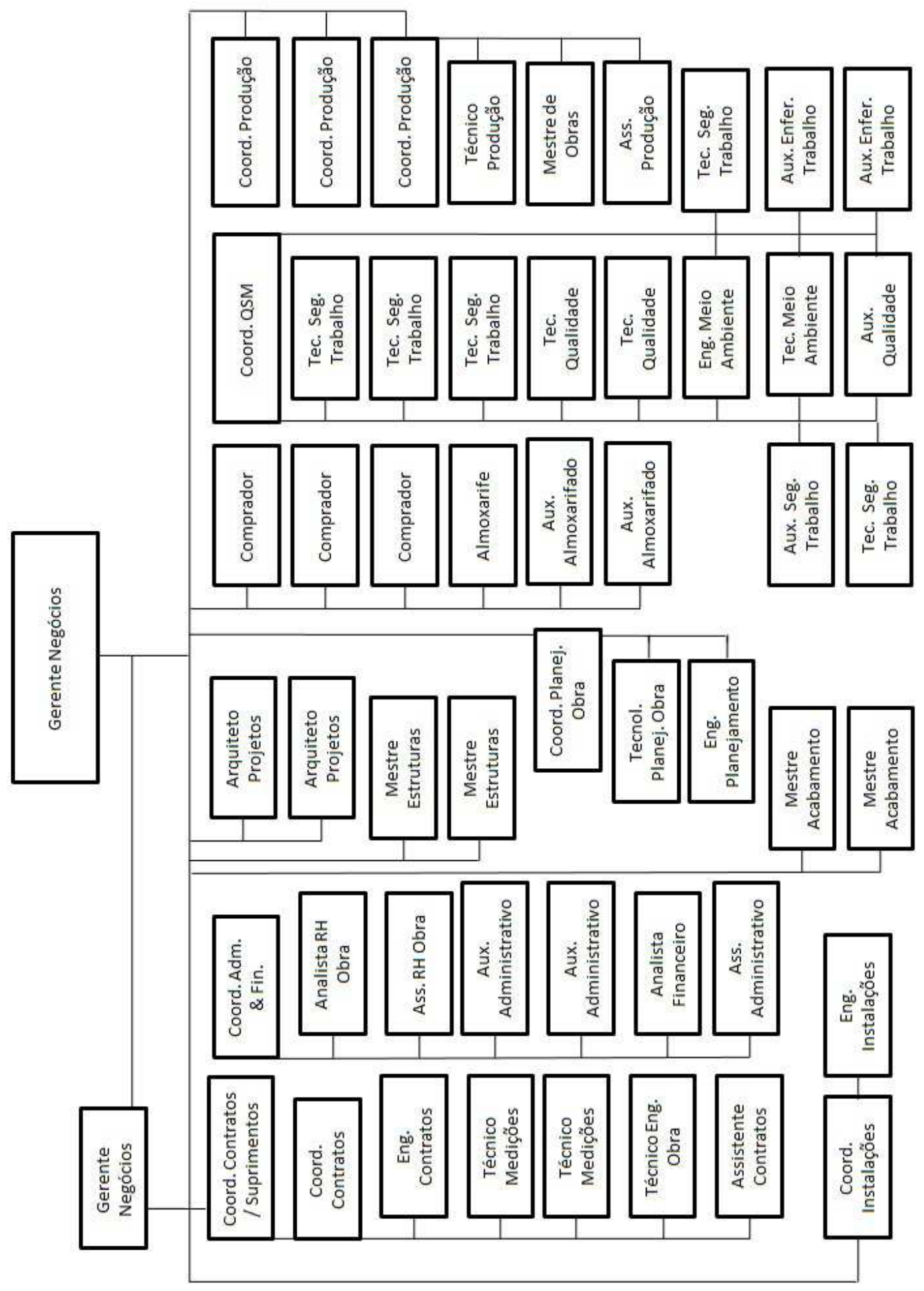

Figura 71 - Organograma da obra 
Gerenciadora: contratada pelo cliente desde 0 projeto básico para 0 acompanhamento de projetos, cronograma, produção, meio ambiente e organização da obra como um todo. A gerenciadora tem 6 7 pessoas na obra, que envolve responsáveis por projetos, financeiro e produção. Faz a mediação entre a obra, os projetistas e o cliente. Caso haja alguma alteração de custo ou prazo, a construtora documenta e passa para a gerenciadora para verificação e aprovação junto ao cliente.

Projetistas: Todos os projetos foram contratados pelo cliente, através da gerenciadora, sem a participação da construtora, com exceção dos projetos para produção.

Além da Arquitetura, as disciplinas contratadas foram: Fundações; Estrutura de concreto; Estrutura metálica; projeto de formas; Hidráulica; Elétrica; SPDA (sistema de proteção e detecção de incêndio); Telefonia; Luminotécnica; Automação e controle; Ar condicionado e ventilação; Impermeabilização; Acústica; Elevadores; Sistema viário; Paisagismo.

Compatibilização dos projetos: $O$ arquiteto-autor do projeto foi contratado pelo cliente, para compatibilização e coordenação de projetos.

Projetos para produção: a necessidade dos projetos de fabricação é informada pela equipe de produção e a equipe de projetos da obra ratifica a necessidade para contratação via gerenciadora.

Consultores: Para obtenção de certificação LEED Gold o cliente contratou uma consultoria de Sustentabilidade, fazendo parte do seu escopo o acompanhamento da produção para verificar se todos os requisitos estão sendo atendidos em relação às exigências do LEED. Foram também contratados consultores de fachadas $e$ caixilhos, concreto, elevadores e estudo de vento.

Fornecedores: Diversos fornecedores de materiais e de serviços participam da obra, assim como das fases de pré-construção, como por exemplo o fornecedor de caixilho. As contratações são feitas pela equipe de Suprimentos, baseadas no planejamento da obra. 


\subsubsection{Processo de projeto}

\subsubsection{Formação da equipe de projeto}

De acordo com a gerente de projetos, no caso de estudo de viabilidade a equipe de projetos é composta por projetistas terceirizados e o tipo de contratação muitas vezes depende da solicitação do cliente. Apesar de haver projetistas que atendam melhor às necessidades da empresa (dão respostas mais rápidas, etc), não há projetistas parceiros, a Empresa $\mathrm{C}$ está sempre aberta a contratar novos projetistas.

Como as obras estão localizadas em várias regiões do Brasil, os projetos legais geralmente são conduzidos pelo cliente, por consultores terceirizados.

Para contratação dos projetistas é montado um escopo padrão que inclui o número de visitas à obra, cuja quantidade depende do tamanho e complexidade da obra. Para algumas disciplinas, tais como: fundações, estrutura, a visita é essencial.

Existe um critério de avaliação de projetistas por disciplina que está disponível no sistema SADP para toda a empresa. Se o projetista não atender aos requisitos será retirado do cadastro da empresa e terá um tempo de espera de aproximadamente cinco anos para uma nova oportunidade. Há casos em que o projetista já vem contratado pelo cliente, mas a Gerente de projetos relata que já houve casos da empresa conseguir rescindir o contrato com o projetista baseado nos critérios de avaliação.

Existe uma periodicidade de avaliação e uma nota mínima para continuar trabalhando para a empresa. A nota varia de 0 a 10 e existem dez critérios de avaliação para todas as disciplinas, entre eles: Qualidade do projeto; Detalhamento; Especificação; Solução de engenharia; Assertividade; Cumprimento de prazo; Facilidade de localização; Qualificação; Resolução de problemas; Pré-disposição para negociação.

Após a contratação a avaliação do projetista é registrada no sistema da empresa. Mesmo se não for contratado, a avaliação fica arquivada para consulta.

$\mathrm{Na}$ obra do estudo de caso, todos projetistas foram contratados pelo cliente e a Empresa $\mathrm{C}$ não foi contratada para coordená-los. 


\subsubsection{Gestão do processo de projeto}

$\mathrm{Na}$ área de projetos, na ocasião da entrevista, existiam onze arquitetos alocados nas obras e dois no escritório central em treinamento, à espera de uma nova obra. Ao término da obra, caso não haja uma obra iniciando o arquiteto retorna ao escritório central. Caso todos os arquitetos estiverem escalados para alguma obra, a gerente de projetos seleciona um novo profissional do mercado para treinamento. Como a estrutura da empresa é descentralizada, os arquitetos das obras têm autonomia, e não precisam se reportar sempre ao escritório central. Dentre as atribuições do arquiteto coordenador durante a obra estão: analisar alterações de projeto, negociar e aprovar serviços adicionais, coordenar complementação de projeto, disponibilizar projetos liberados para obra, etc.

$\mathrm{Na}$ fase de pré-construção, que tem como objetivo formar o orçamento real para o cliente, são envolvidas as áreas de engenharia, projetos, orçamentos e o Gerente do Contrato (gestor da obra). O projeto é desenvolvido em paralelo ao desenvolvimento do orçamento para seleção tecnológica e de sistemas construtivos. Depois que todos estiverem de acordo com a solução adotada, a decisão é comunicada ao cliente.

$\mathrm{Na}$ fase de estudo é feita uma avaliação (engenharia de valor) levando em conta a vida útil do empreendimento, pois, segundo a gerente de projetos, há interesse da empresa em atuar com a área de Facility Management dos empreendimentos.

Diferente de uma empresa incorporadora-construtora, que executa obras próprias, a Empresa $C$ não trabalha com padronização de sistemas construtivos, pois faz obras variadas para clientes variados, de grupos completamente diferentes: edificações, infra-estrutura, industrial.

O planejamento das atividades de projeto é feito desde o início do processo pela gerente de projetos utilizando o MSProject e depois é conduzido pelo arquiteto coordenador da obra. O cronograma de projetos faz parte do cronograma geral da obra que é feito pelo responsável de planejamento. Como foi detectada uma deficiência na utilização do MSProject, toda a equipe de projetos está em fase de treinamento.

Como a empresa não tem o domínio sobre todos os projetos, como no caso em que o projeto já vem pronto por parte do cliente e não há como interferir, existe um 
procedimento de coordenação com um modelo desejável, mas que não é obrigatório. Assim, o modelo para orientação e padronização dos projetistas terceirizados, que inclui muitos itens baseados no modelo da AsBEA (Associação Brasileira de Escritórios de Arquitetura), contendo: como é o formato de apresentação, como é o arquivo eletrônico, como o arquivo deve ser enviado, padrão de legenda, é implantado quando possível. Como o sistema de gerenciamento de arquivos geralmente é definido pelo cliente, não há um padrão imposto pela empresa.

Existe um padrão corporativo de ferramentas acessado pela intranet que é aplicado às atividades de coordenação de projetos e contém arquivos editáveis de:

- Procedimentos de coordenação de projetos;

- Ata de reunião (que funciona como controle de pendências);

- Controle de atas de reunião (pode ser encontrada por uma busca do tema da ata);

- Lista de presença;

- Modelo de carta;

- Follow up (planilha de acompanhamento);

- Controle de documentos/ projetos (indicado número da revisão, não o conteúdo da revisão);

- DRT - Distribuição de Projetos: Guia de remessa de projeto (cada nova revisão de projeto que é entregue para produção deve ser assinada, e deve ser devolvida a revisão anterior), GRC - Guia de Remessa de Documentos/ Cópias;

- Lista de pendências (planilha em Excel), que não é obrigatória (não precisa passar pela auditoria da qualidade) e está sendo utilizada há uns dois anos e contém os itens: qual é a pendência, solicitação, onde está o registro, data, status de quando foi solucionada, indicação em vermelho para atividades em andamento;

- Avaliação de fornecedores/ projetistas (quando contratados pela empresa). 
Como no estudo de caso a construtora não faz a coordenação dos projetos, as ferramentas mais utilizadas são a ata de reunião, o controle de projetos, a DRT e GRC.

Não há um padrão de controle e arquivamento de e-mail, pois geralmente não é necessário. Em geral, só são arquivados os "E-mails importantes", que podem servir como um documento, dentro da pasta das disciplinas. A gerente de projetos cita a obra de um shopping que era muito grande na qual foi necessário criar um controle específico dos e-mails (numeração, tema, lista).

Existe um fluxo básico do processo de projeto no procedimento atual, que encontrava-se em fase de desenvolvimento na ocasião da entrevista.

$\mathrm{Na}$ área de Engenharia estão disponíveis:

- Dados recebidos do cliente: edital, ata de reunião, carta, correspondência, projeto;

- Descrição dos cargos;

- Plano de gestão;

- Homologação de projetistas: aparece o status do projetista, se existe algum problema relacionado com o projetista, ele aparece bloqueado (pagamento fica bloqueado e pode ser barrada uma nova contratação);

- Consulta técnica: para quem será enviado, de que se trata, para que é, quem recebeu, quem assinou, detalhamento;

- Padrões de Manual do Proprietário como base para preenchimento dos responsáveis da obra pela: Qualidade, Segurança e Meio Ambiente, Engenharia e Apoio técnico.

No estudo de caso, o As Built é de responsabilidade da equipe de projetos da construtora e deve ser feito internamente. $O$ projeto de instalações será realizado pela instaladora. O Manual do Proprietário do cliente final, que seria do empreendimento para o locatório, será entregue pela gerenciadora e o Manual de Proprietário da obra para o cliente está sendo preparado pela equipe de qualidade da construtora. 


\subsubsection{Atuação da construtora no processo de projeto}

De acordo com a gerente de projetos, há um grande incentivo da diretoria da empresa para que os funcionários participem de seminários e feiras na Alemanha para atualização em relação à novas tecnologias, e além disso, a área de Suprimentos está sempre se atualizando com as novidades de mercado através dos fornecedores. Por isso, raramente uma solução que venha do projetista não é de conhecimento da empresa.

$\mathrm{Na}$ obra do estudo de caso, a Empresa $\mathrm{C}$ desenvolveu em parceria com consultor de caixilhos brasileiro e empresa fornecedora de caixilhos, o projeto e o planejamento da fachada unitizada. Devido às elevadas exigências de qualidade e de desempenho estrutural, os painéis de grandes dimensões (2,50 $\times 4$ metros), os prazos curtos e as garantias contratuais exigidas, foi selecionado um fornecedor da Alemanha, pois os empreendedores exigiram uma empresa internacional, com experiência mundial em edifícios de porte semelhante.

Este sistema industrializado de fachada unitizada, criado nos Estados Unidos, consiste na produção de painéis pré-moldados de concreto prontos levados diretamente para o local de instalação, permitindo uma melhora na produtividade, sem a ação de mau tempo ou variação climática e evitando desperdícios, pois as soluções são definidas desde o início do projeto.

A tipologia adota na fachada, o caixilho projetante paralelo, foi inovadora. O caixilho de abertura é conectado ao sistema de detecção de fumaça de incêndio para captação de ar, e o sistema de eliminação suga a fumaça. Para a movimentação, o caixilho possui dois motores e outro para travamento, que é acionado para fechar todo o perímetro e suportar as condições de vento nas condições mais extremas.

Para testar o sistema da fachada, segundo a NBR 10.821 (norma para Caixilhos para Edificação - Janela), foi realizado ensaio de desempenho, para verificação de estanqueidade e deformação sob cargas de vento, com protótipo em escala real.

Como a fachada não tinha nenhum canto com $90^{\circ}$, exigiu que a execução atendesse perfeitamente ao projeto, pois a tolerância da estrutura para que a fachada se fechasse era de $40 \mathrm{~mm}$ no prédio inteiro.

Para atender ao cronograma reduzido e evitar desperdício de material foi sugerido pela empresa utilização de um sistema pré-fabricado de banheiro pronto. 
Alguns projetos complementares foram definidos junto com a equipe de produção, de acordo com as necessidades da obra, como por exemplo os projetos de vigas complementares para elevadores.

O heliponto havia sido projetado com estrutura de concreto, mas teve que ser alterado para estrutura metálica devido ao grande balanço. Como estava muito acima da última laje, a solução em concreto demandaria grande quantidade de cimbramento e um tempo maior de execução, causando problema com o prazo da obra.

Como foi abandonado o projeto de um clube na cobertura, a sobrecarga na fundação foi reduzida permitindo a construção de mais dois andares em estrutura metálica no edifício garagem.

Após o ensaio no túnel de vento, foi necessário enrijecer a estrutura aumentando os pilares do térreo para evitar torção na empena lateral direita.

\subsubsection{Comunicação no processo de projeto e obra}

A passagem das informações do escritório central para a obra segue um padrão, no qual a pasta de documentos que foi utilizada por orçamentos é encaminhada para arquivo da obra, e às vezes até o profissional que participou do orçamento poderá compor a equipe de obra. Como o Gestor do Contrato participa desde o início do processo, assim como o arquiteto coordenador e o engenheiro de instalações, muitas vezes, não existe a necessidade de passar as informações. Na obra do estudo de caso houve uma reunião de início de obra (kick off) onde as informações da fase de orçamento foram passadas para os principais envolvidos da equipe da obra (coordenadores de apoio técnico, coordenador de produção e administrativo).

A equipe de projetos da obra tem um contato limitado com o escritório central, pois a obra é uma Unidade de Negócio independente. A interação do escritório central com a obra ocorre nas visitas da gerente de projetos à obra para avaliação de desempenho anual e revisão de metas dos arquitetos. Uma vez por mês, há uma reunião com diretores e o Gerente de Controle do escritório central para checar o andamento da obra, mas a equipe de projetos não participa. 
No início do projeto foram realizadas reuniões semanais com a construtora no escritório do projetista de arquitetura, que depois passaram a ser quinzenais até o ponto em que o projeto foi entregue como "Liberado para obra".

Os projetos novos são cadastrados pelos projetistas no gerenciador de arquivos SADP, definido pelo cliente, em que todos envolvidos recebem uma mensagem informando sobre a postagem. A equipe de projetos da obra recebe os projetos, plota as vias para produção com carimbo "Liberado para a obra", substituindo a cópia antiga pela nova revisão. O controle é feito através de documento Guia de Remessa de Documentos/ Cópias - GRC.

Segundo a gerente de projetos, no caso de falta de informações de projeto deve ser feita uma consulta técnica ao projetista. Esta consulta pode ser feita pelo engenheiro de produção ou instalações desde que depois passe pelo conhecimento do arquiteto coordenador. Projetos não é soberano à produção, ele é o centralizador das informações de projeto. No entanto, na obra do estudo de caso toda mediação entre a Empresa $\mathrm{C}$ e o cliente ou projetistas era feita através da gerenciadora. Segundo a coordenadora de projetos, como a Empresa $C$ não tem o contato direto com os projetistas muitas vezes as respostas às solicitações não atendiam à obra da melhor forma.

A interação entre a equipe de projetos e produção é diária, onde ocorrem reuniões conforme necessidade da obra, com a presença do consultor ou projetista, quando necessário.

Para cada contratação de serviço a equipe de produção faz uma "Requisição para contratação de serviço ou compra de material", informando suas necessidades. Desde o início do processo todas as áreas são envolvidas, complementando informações ou no caso de alguma divergência, entram em contato com a equipe de produção para esclarecimento ou ajuste, para não contratar "coisas a mais ou a menos". A necessidade dos projetos de fabricação é informada pela produção e a equipe de projetos ratifica a necessidade.

A obra tem uma interação com o escritório central, na utilização das FEC - Fichas de Execução e Controle, que determinam as fases executivas e controle que são adaptadas para cada obra. Todos fornecedores, tais como: parede diafragma, mureta guia, parede de dry wall, etc, antes do início do serviço, estabelecem com a 
equipe de qualidade da obra os principais passos da sequência executiva baseado na FEC.

\subsubsection{Tecnologia da Informação (TI)}

Todos os processos de Orçamento e Proposta são informatizados. A empresa utiliza um sistema de gestão integrado, o SAP (System Auswendetes Program), que foi customizado para suas necessidades, tornando-se o Aristóteles. O módulo Kubos gerencia um banco de dados constituído ao longo de 15 anos, com informações referentes aos subempreiteiros, incluindo cotações de materiais. Há ainda o módulo Renus, que gerencia a parte de custos e de administração financeira, e o Business Inteligent, que permite a análise de todas as informações, inclusive as relativas às obras (RODRIGUES, 2009).

A empresa iniciou, em 2010, um projeto piloto em planejamento com programa Synchro, uma ferramenta de gerenciamento de projetos que permite a visualização de projetos de engenharia em CAD 3D por meio de interação com o planejamento físico em MS Project, com o objetivo de analisar com maior assertividade as etapas de planejamento e visualizar a execução de cada atividade ao longo do tempo. Além de agregar valor às propostas técnicas e facilitar o entendimento do planejamento de acessos, canteiros, entre outros, no projeto piloto foi possível verificar incompatibilidades de projeto. Depois de testado, o conhecimento poderá ser replicado para outras obras (DIEPENBRUCK; SARAIVA, 2010).

\subsubsection{Aspectos Tecnológicos}

A empresa sempre foi conhecida no mercado da construção civil pelo domínio do conhecimento técnico. Pela exigência de prazos cada vez menores, as construtoras têm que aperfeiçoar constantemente o processo produtivo buscando alternativas e novas tecnologias principalmente para as atividades que necessitam de grande demanda de mão-de-obra. 
$\mathrm{Na}$ obra do estudo de caso, o cronograma reduzido da obra, com datas limites contratuais intermediárias, exigiu soluções diferenciadas de engenharia e de planejamento: mastro de lançamento de concreto para grandes volumes, banheiros prontos, fachada unitizada e utilização de três gruas. Conforme Figura 72, os prazos foram atendidos e muitas vezes antecipados.

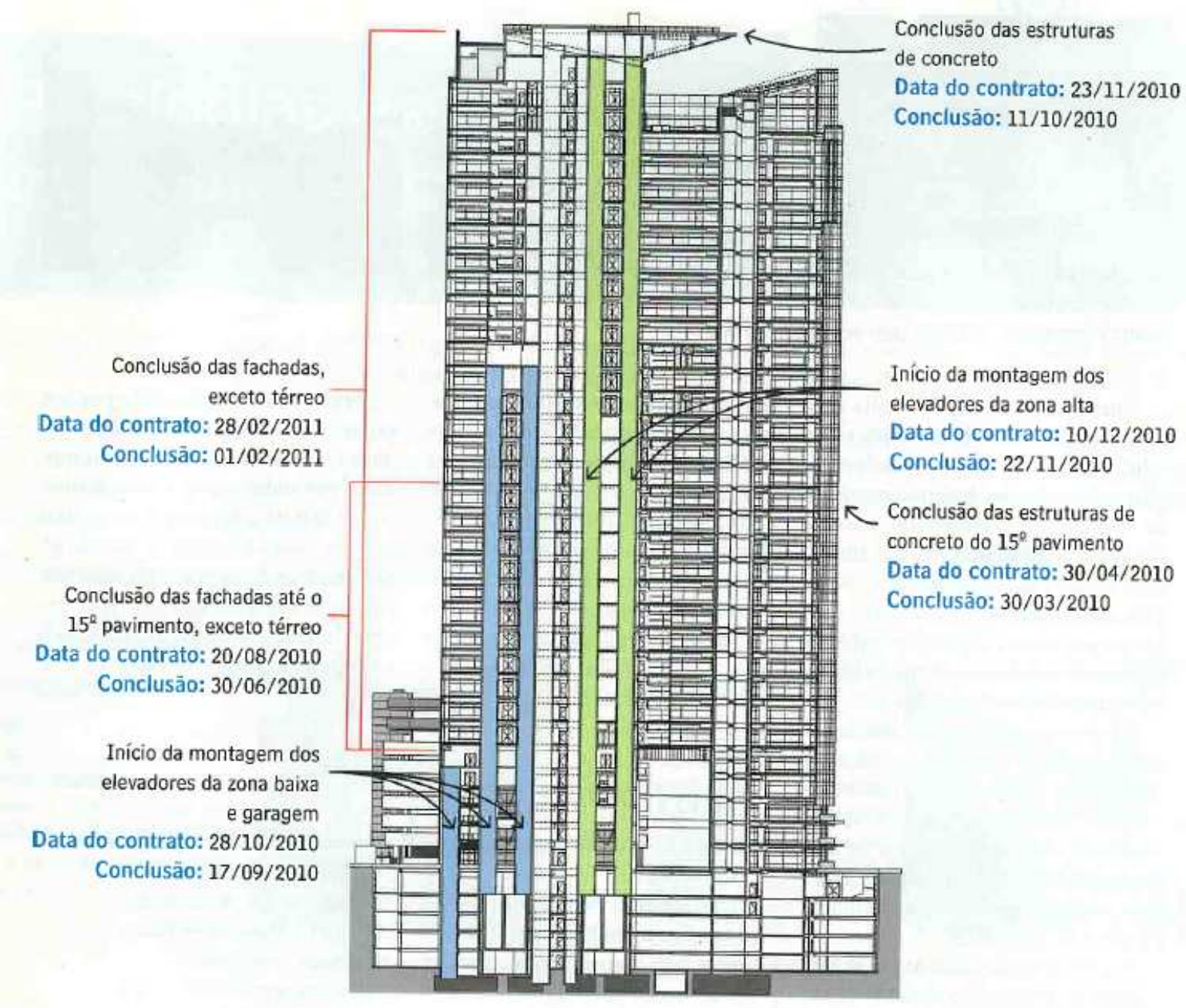

Figura 72 - Datas de contrato das entregas parciais da obra e datas de conclusão (TAMAKI, 2011)

A necessidade de implantar uma tecnologia diferenciada surgiu pela grande quantidade de concreto aplicado nas lajes do pavimento tipo, sendo que cada laje possui uma área de aproximadamente $1.850 \mathrm{~m}^{2}$ e volume de $620 \mathrm{~m}^{3}$.

Em janeiro de 2010, a obra implantou um novo equipamento, uma lança para distribuição do concreto na etapa de execução das lajes, para diminuir a necessidade da mão-de-obra na execução das concretagens. Esta lança, é 
conectada sobre uma torre que, por sua vez é fixada à superestrutura e deve ser movimentada de acordo com a evolução da obra, a cada dois andares. O concreto é bombeado e recebido na lança através de uma tubulação convencional e o controle e direcionamento da lança são feitos por meio de um controle remoto. Com este equipamento, a distribuição do concreto é realizada quase que totalmente pela lança, que alcança 30 metros de raio, o que permite atingir toda a laje de $1.850 \mathrm{~m}^{2}$ concretada em duas fases, e consequentemente, são reduzidos os esforços físicos dos operários para o deslocamento manual do mangote, tarefa que exigia 0 emprego de muita força física, em função do seu peso. A utilização do distribuidor de concreto também possibilitou maior velocidade na aplicação do concreto e disponibilizar demais equipamentos da obra, como a grua ou o elevador cremalheira para execução de outras tarefas durante as concretagens (ARAÚJO; ROLIM, 2010). Como resultado, a conclusão da concretagem ocorreu com dois meses de antecedência em relação ao prazo contratual.

Para executar o bloco principal de fundação, devido ao grande volume de concreto, para evitar a retração muito rápida e fissuração, foi necessário uso de gelo adicionado na betoneira para controle da temperatura.

Para atender ao cronograma reduzido e evitar desperdício de material foi utilizado um sistema de módulos pré-fabricado, banheiro pronto, em que os banheiros são fabricados em uma linha de produção industrial e chegam prontos à obra, como ilustrado na Figura 73, bastando posicioná-los na área planejada e conectá-los às redes de água, esgoto e energia. Desta forma, todas as etapas de controle de materiais, acabamentos, execução de instalações e controle de qualidade são realizadas na fábrica (controle de qualidade nas várias etapas: estanqueidade, vazão, caimento, pressão e circuitos elétricos).

Outras vantagens na utilização do sistema são: redução de custos; diminuição de infra-estrutura para abrigar menor número de funcionários; gestão de compras e almoxarifado (reduzindo 230 itens a um único fornecedor); índice zero de quebra e desperdício de materiais; sistemático controle do processo; instalação fácil e rápida; permite acabamento personalizado sob medida para cada projeto (GARCIA, 2010). 


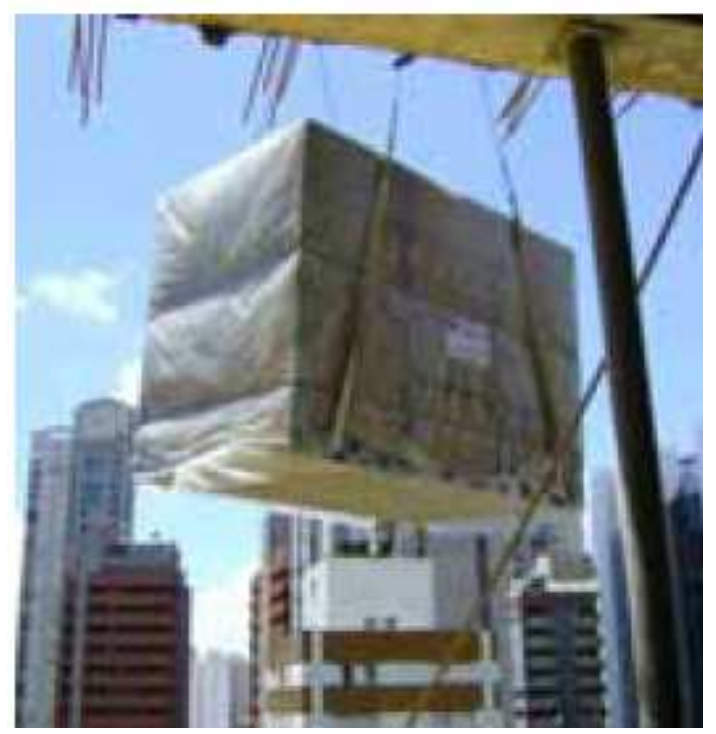

Figura 73 - Banheiro pronto chegando à obra (GARCIA, 2010)

O sistema de fachada unitizada permitiu execução contínua da fachada ao mesmo tempo em que se executava a estrutura, sendo finalizadas simultaneamente. Os caixilhos foram produzidos no primeiro subsolo da obra e instalados sempre a partir de um andar acima de onde seriam montados. A operação de montagem não levava mais que 15 minutos. Enquanto os caixilhos do primeiro ao $26^{\circ}$ andar foram realizados em cinco meses, do $27^{\circ}$ ao $35^{\circ}$ andar foram realizados em oito meses devido aos inúmeros recortes, varandas, reentrâncias e inclinações, que exigiram mais tempo para o perfeito encaixe e garantia da continuidade.

Para atender aos prazos de contrato, além de soluções tecnológicas foi amplamente empregada a experiência da empresa para superar os desafios impostos pela localização do terreno em área comercial densamente povoada com tráfego intenso e falta de espaço de canteiro.

A empresa tem uma unidade de Logística para obras com logística diferenciada e que envolvem movimentações complexas dos subcontratados, como no estudo de caso, em que foram utilizadas três gruas de tamanhos diferentes (uma grua é capaz de suportar até 4 toneladas na ponta de uma lança de $45 \mathrm{~m}$ atingindo a altura de $167 \mathrm{~m}), 2$ elevadores cremalheiras com cabines duplas adaptadas para as necessidades do empreendimento, além do apoio com caminhões guindauto ("Muncks") e carretas nas diversas movimentações de materiais e mudanças internas (NUNES; SOUZA, 2010). 


\subsubsection{Problemas/ Deficiências no processo de projeto}

O cliente contratou os projetistas, a coordenação dos projetos e uma gerenciadora, desde a fase de projeto básico. Apesar da coordenação de projetos ser de responsabilidade do arquiteto-autor do projeto e a gerenciadora ter estabelecido um cronograma de projetos no início da obra, devido às diversas revisões, o cronograma não era cumprido e foi abandonado.

A obra iniciou apenas com o projeto de fundação e o projeto básico de arquitetura. $\mathrm{O}$ atraso do cliente na entrega dos projetos, que eram de sua responsabilidade, prejudicou a produção, principalmente em relação à fase de estrutura. Nesta época o mercado estava muito aquecido e havia dificuldade de aquisição de material e mão de obra, como exemplo, o prazo de entrega do aço passou de 60 para 90 dias. Como o projeto de estrutura não estava desenvolvido o necessário para fazer um pedido de aço cortado e dobrado, para minimizar o risco de falta de materiais e não impactar o cronograma da obra foi definida a aquisição de barras retas e montagem de canteiro de corte e dobra. Para solucionar o problema de falta de espaço para estoque na obra foi alugado um canteiro externo.

A construtora teve alguns prejuízos financeiros e em relação ao prazo devido ao atraso na entrega dos projetos e falhas de compatibilização. De acordo com a coordenadora de projetos, o projeto de arquitetura foi finalizado em 2009, e o projeto de estrutura foi entregue para a obra em final de 2010: "Como é possível uma compatibilização?".

Como a fase de projeto se estendeu muito (os projetos já estavam em desenvolvimento há mais de um ano antes da contratação da construtora), houve um certo desgaste por parte dos projetistas. Em função disso, a maior dificuldade que a obra enfrentou com os projetistas foi a entrega dos projetos "Liberados para a obra" muito em cima da hora, como por exemplo, os projetos de estrutura. Por causa destas defasagens de entrega houve vários problemas de compatibilização entre as disciplinas. Segundo a coordenadora de projetos, os projetos executivos foram bem executados, mas na passagem para o "Projeto Liberado para a obra" houve um atropelo, que prejudicou a construtora. Na falta de detalhes, como os projetistas não foram contratados para acompanhamento de obra, a construtora teve que dar soluções na obra. 
Como os projetistas não foram contratados pela construtora, e principalmente devido às características da obra, onde tudo acontece ao mesmo tempo, a produção sentiu a falta de agilidade na comunicação com projetistas. Quando a obra precisava de alguma informação ou tinha algum questionamento aos projetistas era necessário passar pela gerenciadora, o que demorava de 3 a 4 dias para recebimento da resposta. "Quando a construtora contrata os projetos, ela tem uma ferramenta que é o pagamento".

Para a produção, os principais problemas encontrados na obra em relação aos projetos foram, segundo o coordenador de produção, a falta de detalhes e compatibilidade entre projetos. "Faz tempo que os projetos pecam pela falta de detalhes para a obra, em todas as disciplinas, principalmente em detalhes construtivos que acabam sendo resolvidos pela equipe de obra baseado em experiências anteriores". O envolvimento dos projetistas com a obra depende do tipo de contratação. Se o projetista foi contratado para um acompanhamento da obra, estes detalhes são desenvolvidos, caso contrário fica a cargo da equipe de projetos da obra.

Segundo a coordenadora de projetos da obra, os projetos estão com problemas de compatibilização, pois a maior parte dos projetos é entregue para a obra pouco tempo antes da execução, o que não permite uma análise mais detalhada para detectar eventuais problemas, além da equipe de projetos não ter recursos suficientes para isto, pois a Empresa $C$ não foi contratada para compatibilização $e$ coordenação dos projetos.

De acordo com o coordenador de produção, claramente o responsável de uma disciplina não conversou com o outro, como exemplo citado da "casa de máquinas com dutos batendo em tubos de hidráulica, furação de viga não prevista, alturas de ramais de sprinkler indevidas". Muitas vezes a obra é obrigada a realizar protótipos para contornar estes problemas. Nesta obra, por exemplo, a casa de fancoil (equipamento de ar condicionado) no pavimento tipo previa muitas instalações e não foi previsto espaço suficiente para passagem de todos os sistemas, sendo necessário rever todos os projetos. Para agilizar o processo, a equipe de obra deu a solução e passou aos projetistas para validação.

Para minimizar estes problemas, toda obra da Empresa $C$ tem uma equipe de projeto, pois muitos projetos tem falta de informação, falta de definição de 
acabamentos, etc. A equipe de projeto precisa definir com agilidade para que as informações estejam disponíveis na fase de contratação e para não impactar na execução: "ficar fornecedor parado à espera de uma definição de projeto".

Outra dificuldade foi em relação às exigências do LEED. Os projetos tinham materiais especificados que não puderam ser utilizados, como por exemplo, tintas. $O$ consultor de sustentabilidade analisava a ficha técnica de todos os materiais empregados na obra e se não atendesse às exigências deveriam ser substituído para nova avaliação. Como o assunto ainda é novo, não foi totalmente assimilado por todos fornecedores de materiais.

\subsubsection{Gestão de mudanças}

De acordo com a gerente de projetos, as alterações de projeto geralmente partem do cliente e, de dois a três anos, estão muito relacionadas ao custo da obra. $\mathrm{O}$ cliente, que muitas vezes não é da área da construção civil, já traz uma estimativa de custo pré-definida e depois verifica que não é possível realizar o empreendimento dentro do custo previsto. Aí entra a engenharia de valor da empresa propondo as alterações necessárias para adequação ao custo. Outras vezes, o cliente simplesmente muda de idéia por causa do mercado, etc.

Com exceção da diretoria, nenhuma área da Empresa $\mathrm{C}$ pode interferir em mudanças de projeto ou alteração de especificação por causa de orçamento. Desde o início do projeto, são realizadas reuniões para conhecimento do cliente.

Existem várias formas de registrar as modificações de projeto. A prioritária, principalmente quando a solicitação de alteração vem do cliente, é a ata de reunião, na qual fica registrado e assinado por ele. Outra forma é o próprio projeto emitido que tem que passar por uma revisão e deixar claro o que foi alterado. Dependendo do cliente é preciso fazer algo mais formal, por exemplo, a Petrobrás, que tem um documento chamado NAB - Nota de As Built ou consulta técnica. Se a empresa ou a Petrobrás solicitar uma mudança todos têm que assinar o documento concordando e este é encaminhado ao projetista para revisão ou é guardado para revisão total na fase do As Built final. 
O arquiteto coordenador da obra é responsável pelo registro das mudanças de projeto de arquitetura que ocorrerem ao longo da obra para base do As Built final. O As Built de arquitetura pode ser feito pelo projetista, quando consta do escopo de contratação, mas quando o projeto vem contratado do cliente, muitas vezes o projeto já foi entregue e pago há mais de três anos, então com a autorização do cliente, a Empresa $\mathrm{C}$ contrata outro projetista para o As Built. Na obra do estudo de caso, o As Built é de responsabilidade da equipe de projetos da construtora e deve ser feito internamente. $O$ projeto de instalações será realizado pela instaladora.

De acordo com o coordenador de produção, as grandes mudanças de projeto (arquitetura) ocorreram na fase de orçamento, antes do início da execução, o que não gerou um impacto na produção. As maiores mudanças de projeto na fase de orçamento para a fase de execução, foram relacionadas a alguns pontos que não estavam definidos, como por exemplo, acabamentos do lobby e sanitários.

A equipe de planejamento e controle da obra faz uma verificação do que foi alterado em relação ao orçado para checar se haverá além do impacto de custo um impacto no prazo. O custo é negociável com o cliente, mas muitas vezes um impacto de prazo pode não ser identificado desde o início. Caso haja alguma alteração de custo ou prazo, a obra faz um documento que é passado para a gerenciadora para verificação e aprovação junto ao cliente.

Quando a obra se depara com algum problema que inviabilize a execução do projeto, o projetista é convocado para solucioná-lo com a equipe de obra. A obra não pode mudar deliberadamente um projeto sem autorização do cliente ou projetista, principalmente por questões de direitos autorais. No caso de não ser possível executar o projeto conforme especificado o projetista revê o projeto ou autoriza a mudança sugerida pela obra.

As informações ficam registradas em ata de reunião e no cronograma impactado (cronograma que mostra os eventos que foram atrasados e o motivo do atraso). Por exemplo, no caso de uma disciplina de projeto não ser finalizada por causa de alguma atividade predecessora.

Durante a obra foram necessárias algumas adaptações devido a imprevistos:

- Como o terreno é uma alteração de rocha, as escavadeiras normais não conseguiam escavá-lo para as sapatas da fundação direta executadas de 20 
a 21 metros abaixo do nível da rua, sendo necessário utilização de martelo pneumático e o picão para desmonte.

- Estavam previstos 17 metros de escavação para a contenção dos cinco subsolos, que, ao atingirem material de altíssima capacidade, não atingiram sua cota, e tiveram que ser suplementados na execução da obra.

- Por restrição da prefeitura à altura do prédio, que obrigaria a eliminação de um andar, a solução de laje adotada no projeto inicialmente (lajes e vigas engastadas nos pilares da fachada) foram alteradas para lajes e vigas protendidas para redução da altura piso a piso e acomodação das instalações.

\subsubsection{Gestão de riscos}

Um bom desempenho, no passado, não representa qualquer garantia de sucesso no futuro, segundo o Diretor da Empresa C no Brasil. "Basta uma grande obra com um grande erro para a empresa perder o lucro acumulado de muitos e muitos anos. $O$ risco tem de ser medido caso a caso. Um dos grandes fatores de sucesso de uma empresa é saber medir os riscos. Se você tem medo de tudo e acha tudo arriscado, não ganha obra nenhuma. Se você é aventureiro demais, não vai ter uma vida muito longa. Quem sabe avaliar riscos tem sucesso" (COZZA, 1999).

A empresa dispõe de uma área responsável pelo Controlling Empresarial, que abrange toda parte do planejamento e acompanhamento dos indicadores econômico-financeiros da empresa (controle de custo, reuniões mensais nas obras), tais como o resultado, o volume de novos contratos, o valor de serviços executados, etc, e Controlling Técnico com ênfase na parte operacional e técnica da obra, como por exemplo o controle de mão-de-obra, produtividade, cronograma, etc.

A partir da implementação de uma ferramenta, desenvolvida pela matriz, para a sistematização da análise crítica de contratos, em 2004, a Unidade de Controlling não faz o simples controle, mas se apóia na consolidação, no acompanhamento e na medição do desempenho do Management System. 
Além do lucro estabelecido para cada négocio, uma das missões da empresa é remunerar o capital investido pelos acionistas. Com a negociação das ações da empresa na bolsa internacional de valor, a Gestão de Risco é uma ferramenta fundamental para indicar aos acionistas por onde caminha a empresa, baseado no aprofundamento da análise mensal de chances e riscos de cada obra e da empresa em comparação ao resultado orçado; definição e o acompanhamento de planos de ação, de acordo com o sistema global de gestão de riscos do grupo.

Em todos os Projetos o Gerente do Contrato faz uma matriz de risco, onde são avaliados aproximadamente 150 itens que podem representar um risco (cliente, financiamento, licença ambiental, executivo trabalhista, solo contaminado, etc), probabilidade de acontecer e ação para eliminar ou mitigar o risco. A área de Controlling fornece um padrão de matriz, orienta o Gerente, alertando sobre o que tem acontecido em outras obras, e depois faz uma análise para checar a consistência e questionar eventuais dúvidas, mas a responsabilidade sobre a matriz é do Gerente do Contrato.

$\mathrm{Na}$ área de projetos existem duas situações de análise de risco de projeto: uma análise prévia informal do material que é recebido para orçamento e uma análise formal, onde a área de Controling faz uma análise de riscos que avalia 0 empreendimento como um todo. Esta análise pode acontecer em paralelo ao processo de orçamento, para não prejudicar o prazo de entrega da proposta, mas dependendo do resultado pode ser definido que a empresa não irá participar da concorrência. Um exemplo de risco na área de projetos, por exemplo, pode ser algum item fora de norma.

Após a fase de Pré-construção, onde é realizada a contratação de projetistas e viabilização do negócio (estudo de alternativas de construção, métodos construtivos, materiais para viabilizar custo), começa a etapa de construção e gerenciamento. $O$ departamento de Controlling Técnico é responsável pelo acompanhamento e controle físico-financeiro de todas as obras, com o foco específico em custo.

De acordo com o Gerente de Controlling, o acompanhamento é realizado a fim de verificar o que está sendo executado, o que está sendo gasto e o que foi feito certo ou errado. Estas informações são importantes para servir de base para a equipe de planejamento e orçamento evitar repetição de soluções que não foram bem sucedidas e identificar custos não previstos na fase de orçamento. 
A Memória Técnica - MT é o resumo do aprendizado do que deu certo ou errado. O objetivo da MT é divulgar para todas as áreas da empresa o que foi detectado na fase de acompanhamento e controle.

O maior desafio da obra do estudo de caso foi o prazo de contrato que levou a empresa a tomar algumas decisões para minimizar os riscos.

Durante a obra, a compra de aço precisou ser revista, pois verificou-se que o fornecedor não atenderia na velocidade e quantidade demandada pela obra, sendo necessário dobrar o aço na obra, onde a perda é maior.

Devido à falta de espaço para canteiro e para reduzir o risco de falta de abastecimento do fornecedor, a empresa precisou de dois espaços externos para acomodar os materiais, e depois transportá-los para a obra (uma área de estoque a $4 \mathrm{~km}$ do local e o depósito da construtora a mais de $60 \mathrm{~km}$ do canteiro). Como o terreno encontrava-se em área de grande circulação de veículos durante o dia, foi necessário cuidadoso planejamento das chegadas e saídas de caminhões.

Quando à obra atingiu o $5^{\text {a }}$ andar, foi verificado pelo Gerente do Contrato que o cronograma não seria atendido. Para liberar a grua para serviços paralelos, tais como cimbramento, fôrmas e instalação de banheiros prontos, foi definida a utilização de uma bomba lançadora de concreto, equipamento hidráulico para distribuição de concretagem das lajes e pilares que também aumentou a produtividade da concretagem.

A limitação de espaço físico levou a empresa a utilizar diversos equipamentos especiais para a movimentação interna de materiais, como guindautos e minicarregadeiras, miniescavadeiras, mobilizando aproximadamente 50 equipamentos (M\&T, 2010). 


\subsubsection{Gestão do conhecimento}

\subsubsection{Iniciativas de gestão do conhecimento}

\section{Jornal interno}

Publicado desde 1994, o jornal interno é um importante veículo de comunicação entre o escritório central e as obras e demais departamentos da empresa. Inicialmente era destinado exclusivamente ao público interno, mas passou a ser distribuído aos funcionários da empresa, clientes e fornecedores, e para apresentações institucionais pela área de Desenvolvimento de Negócios. O jornal conta com a publicação de reportagens sobre as Unidades de Negócio, curiosidades sobre os funcionários, novas tecnologias, obras da empresa, além de divulgar os workshops, lições aprendidas e agenda de eventos técnicos externos. Toda publicação conta com um artigo que faz referência a uma técnica construtiva ou nova solução de engenharia adotada nas obras.

\section{Project Team (Equipe de Projeto)}

$\mathrm{Na}$ fase de proposta é composto um Project Team (Equipe de Projeto), que é uma célula de trabalho em que participam profissionais de diversas áreas (comercial, engenharia, suprimentos, financeira, administrativa) e consultores externos, caso necessário, para a elaboração da proposta de negócio que contemple tanto os aspectos financeiros como de tecnologia. A proposta não é somente orçada mas avaliada seguindo critérios objetivos sobre viabilidade. $O$ grupo estuda as soluções adotadas e executa um planejamento. No caso da proposta ganha, a célula de trabalho se transforma em uma Unidade de Negócio, conforme esquematizado na Figura 74, e o líder designado para o Project Team será o gestor do empreendimento durante sua execução até a pós-entrega, aplicando o que foi planejado. De acordo com a diretora comercial da empresa, as informações são repassadas aos próximos Project Teams pelo líder (Gerente do Contrato), que é um veiculador das informações (RODRIGUES, 2009). 


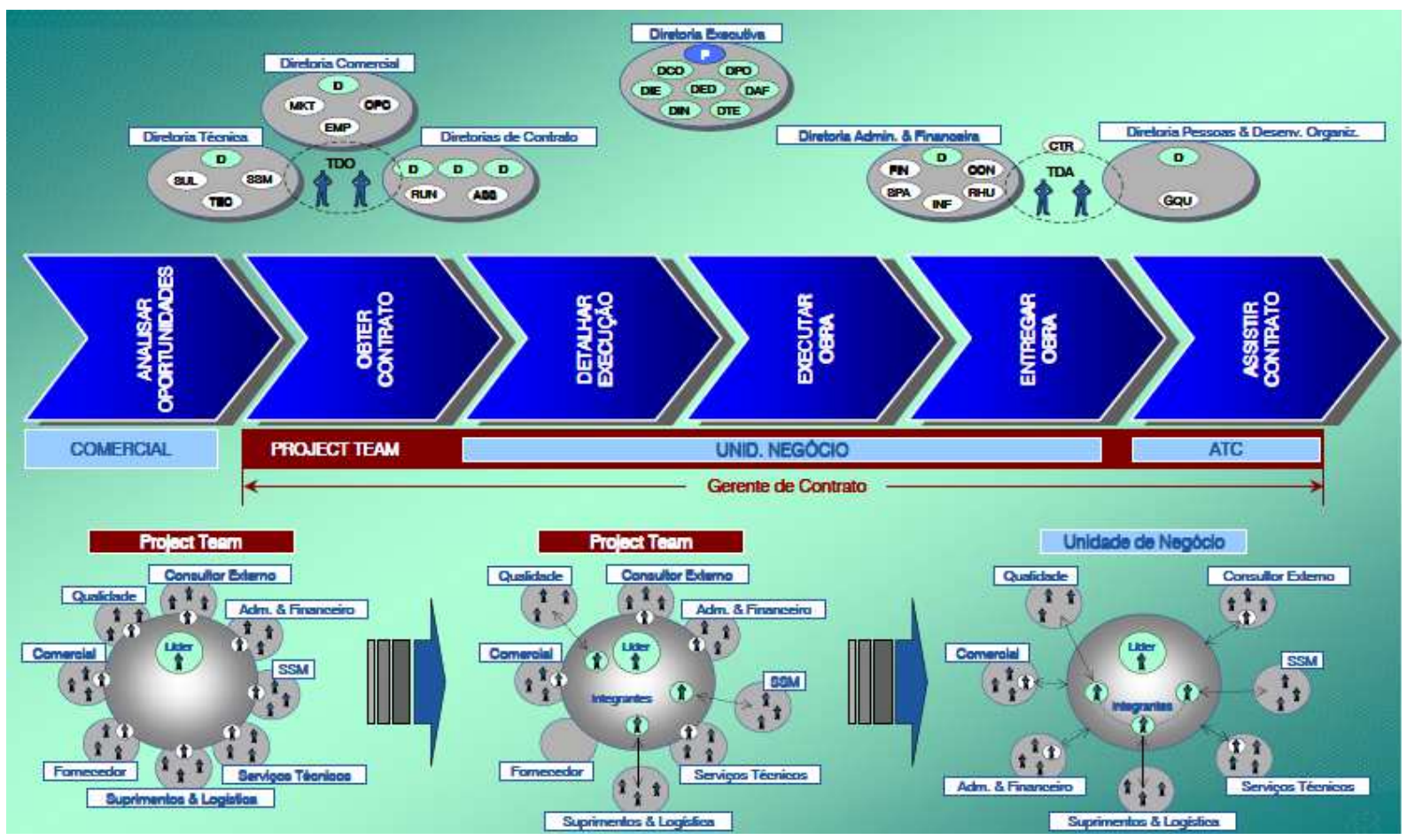

Figura 74 - Dinâmica Operacional (KOWALEWSKI, 2008)

\section{Banco de dados do departamento de Orçamento e Proposta}

O sistema de gestão integrado, SAP tem um módulo Kubos que gerencia um banco de dados constituído ao longo de 15 anos, com informações referentes aos subempreiteiros, programações e listagens de orçamentos, incluindo cotações de materiais, utilizado pelo departamento de Orçamento e Proposta, unidade que se reporta diretamente à Diretoria Comercial.

O Kubos é uma ferramenta essencial para se preparar uma boa proposta, pois além das informações, permite uma visão geral da atividade e das experiências ou resultado das obras. Além de um banco de dados com os preços de materiais e serviços, os índices, ou seja, composições de custos, são parâmetro retirados das próprias obras da empresa. Dessa forma, é possível avaliar quanto tempo a empresa leva para executar determinadas tarefas e quais os sistemas adequados ou possíveis de ser empregados. As novas soluções técnicas melhoram a qualidade do orçamento porque essa experiência positiva é transmitida para outros Projetos permitindo otimizar prazos e custos. 


\section{Programa Lições Aprendidas}

Ao término de cada contrato, são realizados workshops (seminários) com a equipe interna da empresa (não envolvem terceiros) para troca de experiências e aprendizados adquiridos durante a execução do empreendimento, visando aperfeiçoar técnicas e serviços. O material apresentado, chamado Lições Aprendidas, é desenvolvido pela equipe da obra ao final do empreendimento e faz parte das tarefas do check list de entrega final (Fechamento dos contratos, Manual do Proprietário, CND, documentos, etc). A obra reporta se foi utilizada alguma solução técnica diferente do planejado, por quais motivos, quais dificuldades encontradas. Existe uma apresentação modelo que pode ser aperfeiçoada a cada obra.

O Lições Aprendidas permite que soluções e alternativas aplicadas em uma obra possam ser implementadas também em outros Projetos da empresa. Os funcionários podem acessar o material da palestra e de outros eventos no Memória Técnica, disponível no diretório corporativo.

De acordo com a gerente de projetos, as Lições Aprendidas (retroalimentação) referentes aos projetos são transmitidas aos projetistas no dia a dia, nas próprias reuniões para soluções de projeto. Quando a construtora é contratada apenas para execução da obra baseada em projetos contratados pelo cliente, a retroalimantação fica prejudicada .

\section{Projeto Feedback}

Para promover a melhoria contínua da empresa, a Unidade de Serviço Controlling implantou, em 2009, o Projeto Feedback, buscando fechar o ciclo PDCA ${ }^{11}$ através da retroalimentação do processo, para garantir que as informações obtidas nas Unidades de Negócios (obra) retornem à empresa, especialmente às áreas de orçamentos e planejamento, que continuamente buscam viabilizar novos negócios. A Unidade de Negócio envia mensalmente suas contribuições à Unidade de Serviço

\footnotetext{
${ }^{11}$ O ciclo PDCA, também conhecido como ciclo de Deming, tem por princípio tornar mais claros e ágeis os processos na gestão de uma empresa. PDCA são as iniciais das palavras em inglês que resumem as suas quatro etapas: Plan (planejar), Do (executar), Check (verificar) e Act (agir).
} 
Controlling, que é responsável por formatar as informações e encaminhá-las aos interessados, para que sejam feitas análises e comentários. Estas análises e comentários são enviados de volta à Unidade de Negócio, para esclarecimentos adicionais ou apenas como retorno.

As informações são armazenadas em um banco de dados pela Unidade de Serviço RIS (Gestão de Riscos) e disponibilizadas às Unidades de Serviço e Diretoria, por meio da intranet, conhecida como MIS - Management Information System (Sistema de Informações Gerenciais).

Diversas contribuições já foram disponibilizadas, tais como as soluções construtivas adotadas; controles específicos desenvolvidos para monitorar o consumo de materiais, mão de obra e equipamentos; composições abertas com custos reais de diversas etapas construtivas, que servirão para balizar futuras estimativas; descrição de situações divergentes em relação aos itens considerados no contrato ou na proposta, entre outros.

A gerente de projetos informou que ainda não existe um feedback de pós-ocupação da área de Facilities Management, pois esta área faz parte de outra empresa do grupo que existe há apenas três anos. Nos treinamentos onde os gerentes e coordenadores das duas empresas (Facilities Management e construtora) participam, são trocadas algumas informações. Existe um desejo de estruturação desde 2009, mas ainda não foi nada implantado. Por exemplo, Facilities Management poderia retroalimentar a área de projetos no caso de especificação de algum material que está dando problema de manutenção em todas as obras. Talvez a área de Controlling, que permeia por todas as áreas, fará este tipo de análise.

\section{Memória Técnica - MT}

Conforme definição do gerente de Controlling, responsável pela Memória Técnica, a MT é o resumo do aprendizado organizacional do que deu certo ou errado. O objetivo da MT é divulgar para todas as áreas da empresa o que foi detectado na fase de acompanhamento e controle, para evitar repetição de erros e propiciar a melhoria contínua.

Desta forma, a área de Controlling atua como um integrador de todas as áreas da empresa, além de estimular o registro do conhecimento tácito das equipes de obra. 


\section{Capacitação de Jovens Profissionais}

Em maio de 2010, a Empresa C iniciou um novo programa de desenvolvimento chamado Capacitação de Jovens Profissionais, que tem como objetivo preparar engenheiros e arquitetos recém formados com conhecimento e qualificações técnicas, bem como da filosofia empresarial e aspectos comportamentais.

O programa prevê a elaboração e aplicação de um projeto de melhoria para a área da escolha do engenheiro ou arquiteto e o desenvolvimento específico de determinadas qualificações comportamentais ou técnicas, com o apoio de mentores, profissionais voluntários da empresa (PINHEIRO; DOMINGOS, 2010).

Outra ação realizada pelo programa é a apresentação do Trabalho de Conclusão de Estágio que tem sido nos últimos dois anos, um ponto de destaque. Os Estagiários que finalizam seu período de estágio na empresa elaboram e apresentam um trabalho relatando quais foram as unidades onde atuaram, atividades desempenhadas e conhecimentos adquiridos. Nesta apresentação, o Estagiário também propõe um Projeto de Melhoria, em que sugere ações de melhoria para diferentes áreas da empresa.

\section{Workshops (seminários)}

Os workshops têm sido uma importante ferramenta de desenvolvimento técnico e comportamental, que visam alinhar as práticas e procedimentos entre Unidades de Serviço e de Negócio. Nesses eventos, os funcionários têm a oportunidade de debater assuntos do dia-a-dia com o objetivo de melhoria contínua dos processos.

De acordo com a gerente de projetos, até 2009, não havia nada estruturado para transmissão de informações entre os membros da equipe de projetos, mas hoje cada área promove workshops específicos. Projetos têm um workshop anual (não obrigatório), onde cada obra é estimulada a mostrar como está o status, o que aconteceu de novo. Quem fez algum curso específico faz uma palestra para divulgar o conhecimento adquirido aos outros membros da equipe. O tema do $2^{\circ}$. workshop de projetos foi o programa Revit e em 2010 o tema foi a certificação LEED.

Foi estabelecido um evento por ano, pois não é possível reunir todos os arquitetos da área em um curto espaço de tempo, devido a dispersão geográfica das obras. 
Uma frequência maior poderia gerar reclamações das pessoas que não pudessem participar.

Para o levantamento de temas de maior interesse ou necessidade, as equipes de Recursos Humanos, Financeira e de Coordenadores Administrativos \& Financeiros e Coordenadores de Contratos são consultadas.

São os próprios funcionários que fazem os workshops acontecerem, e além de apresentações, outras atividades, como estudos de casos e discussões em grupo, são aplicadas como forma de potencializar o aprendizado.

\section{Escola Técnica}

Além dos workshops, existem muitos treinamentos internos desenvolvidos pelos próprios funcionários da empresa de acordo com sua especialidade, como por exemplo: impermeabilização, programa MS Project, sistema de gestão integrado, gestão de projetos, sustentabilidade.

Com aplicabilidade direta nas atividades do dia-a-dia, o principal objetivo da Escola Técnica é buscar, por meio de troca de conhecimento, a melhoria contínua e a qualidade dos trabalhos executados.

Como as inscrições são voluntárias, cada colaborador investe em seu próprio desenvolvimento, especializando-se em assuntos de seu interesse e de acordo com suas necessidades.

\subsubsection{Esforços e barreiras para implementação}

A utilização do Management System já se encontra incorporada pelos funcionários da empresa, pois já faz parte da cultura organizacional contendo a filosofia empresarial, o modelo de organização e os processos das atividades requeridas pelo modelo de negócio.

A ferramenta de gestão do conhecimento conduzida pela área de Controlling Memória Técnica - MT é um canal para divulgação de informações, mas, segundo a Gerente de projetos, como as pessoas não são obrigadas a utilizar é preciso criar 
um hábito nos funcionários. $\mathrm{O}$ foco ainda está restrito a assuntos mais relacionados a custo, que são utilizados prioritariamente pela equipe de orçamentos do escritório central.

Como o esforço de envolver e obter a contribuição de outras áreas (engenharia, projetos, suprimentos e administração) ainda é recente, aproximadamente dois anos, não foi desenvolvido muito material para utilização das equipes de obra. De acordo com a coordenadora de projetos do estudo de caso, a obra não fez utilização do MT. Segundo o coordenador de produção, a MT ainda é pouco utilizada, apenas consulta quando há um serviço que nunca realizou antes. Em geral, a equipe de produção baseia-se na experiência de obras anteriores.

Este fato reforça a importância das apresentações de Lições Aprendidas como forma de disseminação do conhecimento adquirido pela equipe de cada obra.

Ao tratar de temas de interesse dos funcionários, os workshops tornam-se mais atrativos à participação e contribuem para a padronização dos processos e aprimorar o conhecimento dos funcionários através da troca de experiências. Para a área de projetos é um momento de integração da equipe que encontra-se dispersa em diversas localidades, para troca de experiências vividas (conhecimento tácito) nas Unidades de Negócio (obras).

A Escola Técnica é uma forma de incentivar os indivíduos a divulgar para a empresa seu conhecimento, atuando como instrutores, e recebendo como recompensa 0 reconhecimento de seus colegas. Como a inscrição nos treinamentos é voluntária, a participação ocorre devido ao interesse do funcionário em promover seu desenvolvimento, sem que haja uma imposição da empresa.

O Jornal Interno dos funcionários traz informações sobre atividades desenvolvidas na empresa, além de novos contratos firmados e divulgação de novas soluções tecnológicas empregadas nas obras. Ao ser divulgado aos clientes e fornecedores, torna-se uma meio de divulgação das competências internas da empresa. 


\subsubsection{Síntese do Estudo de Caso C}

Para atingir a excelência na prestação de serviços, conforme missão da Empresa $C$ e de acordo com diretor da empresa, uma construtora precisa investir em um sistema de gestão como um todo para obter sucesso. A qualidade é um dos componentes desse sistema de gestão, ao lado das políticas estratégicas, do treinamento e, em especial, da tecnologia da informação. Apesar da Empresa $C$ ser uma filial de um grande grupo com sede na Alemanha, foi possível adaptar o sistema de gestão para a realidade brasileira.

Além das ferramentas de gestão corporativa bem estruturadas, foram identificadas várias iniciativas de gestão do conhecimento, envolvendo a participação dos funcionários, muitas vezes de forma colaborativa e voluntária, tais como o Jornal Interno e a Escola Técnica.

Dos diversos fatores que podem impactar a implementação de ferramentas ou atividades de gestão do conhecimento, verificou-se que a cultura organizacional influi de forma positiva quando estimula a troca de conhecimento entre seus funcionários (workshops, Memória Técnica, treinamentos), mesmo sem uma remuneração específica.

Ao detectar uma deficiência na utilização do MSProject, ferramenta necessária para a coordenação de projetos, toda equipe de projetos foi direcionada a um treinamento interno específico.

A área de Controlling é responsável pelo acompanhamento dos negócios da empresa para detectar e avaliar eventuais desvios. No entanto, ao conduzir a Memória Técnica tem como objetivo estimular o aprendizado organizacional divulgando à todas as áreas da empresa o que foi detectado na fase de acompanhamento e controle, baseado na retroalimentação das obras, para evitar repetição de erros e propiciar a melhoria contínua.

Não há resistência à utilização, mas a contribuição e grau de interesse dependem muito de cada indivíduo e do estímulo da área de Controlling. O que foi alegado por alguns funcionários é o aspecto de agregar mais uma tarefa à sua rotina.

Por falta de recursos, não é feita uma avaliação minuciosa de cada obra para detectar se a causa das falhas é relacionada ao projeto, fornecedor, execução ou 
falta de controle, mas é possível identificar quais são as principais patologias de acordo com cada segmento.

Como as obras da empresa não têm características que possibilitem uma repetitividade de soluções, a maior dificuldade é prever se haverá uma próxima obra onde poderá ser utilizada determinada informação da Memória Técnica. Os dados já armazenados ainda são focados no custo, por isso são mais utilizados pela equipe de orçamento na elaboração de novas propostas, assim como o Projeto Feedback. Fica clara a preocupação de transferência de conhecimento de um Projeto para outro para melhor controle dos custos envolvidos.

Do ponto de vista técnico, a divulgação de melhores práticas é feita em encontros para apresentação de material desenvolvido pela equipe de obra para disseminação de Lições Aprendidas, que fica disponível no diretório corporativo da empresa para utilização em novos Projetos.

O conceito de Project Team (Equipe de Projeto), que estabelece uma célula de trabalho composta por profissionais de diversas áreas da empresa com um objetivo de elaborar uma proposta, tem grande potencial de transmissão e geração de novo conhecimento a partir da troca de experiência entre profissionais de áreas distintas e profissionais que participaram de diferentes Projetos.

Apesar da Unidade de Serviço Assistência Técnica estar subordinada à Unidade de Serviço da área de Facility Management (Gestão de Facilidades) desde 2009, ainda não há um processo de retroalimentação entre esta divisão da empresa e a de construção. A integração entre as áreas tem potencial para alimentar as fases de concepção de projeto e especificações técnicas, além de agregar valor às soluções dadas em obra, baseadas na experiência de operação e manutenção.

Assim como nas Empresas A e B, a ênfase das iniciativas de gestão do conhecimento na Empresa C é sobre o conteúdo, e não ferramentas de TI. O maior enfoque da $\mathrm{TI}$ é sobre os ambientes de trabalho colaborativos a fim de facilitar o compartilhamento de informações.

O estudo de caso indicou que os processos e ferramentas de gestão do processo de projeto são utilizadas pela equipe de obra. No entanto, como a construtora não foi contratada para a coordenação dos projetos, não foi possível utilizar algumas ferramentas de gestão, como por exemplo, análise crítica dos projetos, que 
pudessem agregar mais valor aos projetos ou aplicar algumas das ferramentas para evitar atrasos no cronograma de entrega de projetos.

A integração entre projetos-produção também foi prejudicada, pois a construtora não teve acesso direto aos projetistas devido ao tipo de contrato, que previa a gerenciadora como mediadora entre a construtora e os projetistas e cliente.

O desafio de prazo reduzido da obra estimulou o compartilhamento de conhecimento entre a construtora e fornecedores para desenvolver soluções diferenciadas de engenharia, planejamento e logística para aumento de produtividade, além da redução de desperdício. O conhecimento em ação cria valor ao Projeto e a todos os envolvidos.

Como a construtora foi contratada apenas para execução da obra e não participou da fase de concepção dos projetos, as mudanças de projeto que ocorreram principalmente na fase de orçamento, não tiveram tanto impacto na produção.

Os atrasos na entrega de projetos e falhas de compatibilização foram os principais problemas que acarretaram prejuízos financeiros à empresa. Com a falta de detalhes, principalmente detalhes construtivos, e a incompatibilidade entre projetos, em todas as disciplinas, a construtora precisou contar com o conhecimento e a experiência dos membros da equipe de obra, baseado em experiências anteriores, para solução dos problemas detectados ao longo da execução.

Assim como as obras das empresas A e B, foi necessário substituição de materiais especificados para atender às exigências do LEED e muitos fornecedores ainda não haviam assimilado todas as condições necessárias para fornecimento.

Para cumprir o prazo de obra acordado em contrato e devido à limitação de espaço físico de canteiro, várias decisões foram tomadas para minimizar os riscos. A integração entre os agentes e transferência de conhecimento entre as empresas envolvidas no desenvolvimento do empreendimento garantiu o bom desempenho e antecipação do cronograma em diversas fases da obra. 


\subsection{Análise comparativa dos estudos de caso}

Ao analisar a trajetória das empresas, nota-se a evolução da estratégia, inicialmente com foco na implementação de novas tecnologias construtivas para racionalização dos processos construtivos, passando por uma fase com foco na gestão da qualidade e gestão de projetos para, posteriormente, investir nos sistemas de gestão integrada e incremento de desempenho por meio do conhecimento e aprendizado contínuo.

Com aproximadamente 40 anos de atuação no mercado da construção, as três empresas analisadas conseguiram consolidar sua marca no subsetor de empreendimentos imobiliários para o setor privado. No entanto, para manter sua posição no mercado e destacar-se em relação às empresas que oferecem serviços limitados à execução da obra, as Empresas $\mathrm{A}, \mathrm{B}$ e $\mathrm{C}$ têm como missão oferecer ao cliente serviços de engenharia e construção para todo o ciclo de vida do empreendimento, enfatizando a importância da gestão integrada para atingir o alto desempenho dos Projetos. A marca, que pode inspirar confiabilidade, foi estabelecida, na Empresa B, como um dos quatro pilares do planejamento estratégico para intensificar sua valorização entre os funcionários e reafirmar a essência de sua marca no mercado. Além do atendimento ao cliente, o desenvolvimento de competências internas passa a fazer parte da estratégia organizacional. A base de valores das três empresas pode ser resumida em: cumprir o prometido de forma ética e sustentável buscando a melhoria contínua.

Para que os objetivos da organização sejam atingidos e o atendimento ao cliente esteja de acordo com os valores apresentados pelas empresas, além das certificações de Qualidade (ISO 9001), Meio Ambiente (ISO 14001), Saúde e Segurança (OHSAS 18001), todas empresas dispõem, ou estão em fase de melhoria, de sistemas de gestão integrados: SIG na Empresa A; PRqd na Empresa B e Management System na Empresa C.

O SIG da Empresa A é um sistema de gestão da qualidade, voltado para processos e gestão do meio ambiente, abrangendo procedimentos de obra e operacionais do escritório central.

O PRqd da Empresa B foi definido como um sistema de gestão por processos em que cada célula é composta por um conjunto de processos relacionados a um 
campo de conhecimento que está conectado a uma das dimensões estratégicas da empresa e às metas dos funcionários.

De acordo com o diretor da Empresa C, para obter sucesso, uma construtora precisa investir em um sistema de gestão como um todo, ao lado das políticas estratégicas, do treinamento e, em especial, da tecnologia da informação.

Nas três empresas notou-se que a gestão da informação tem como foco otimizar as atividades operacionais integrando diversos departamentos através de sistemas de ERP (Enterprise Resource Planning) ou Sistemas Integrados de Gestão Empresarial para melhoria do controle de custos.

Nas iniciativas de gestão do conhecimento foi verificado que não faz parte da estratégia das empresas envolver recursos da área de TI, pois a preocupação inicial das empresas tem sido a geração do conteúdo, e não a ferramenta de armazenamento e suporte. Na Empresa A, alguns departamentos tiveram a iniciativa de utilizar um programa livre de forma experimental, sem a participação da área de TI, antes da implantação definitiva do mesmo. Na Empresa B, foi contratada uma consultoria externa para estruturação do sistema de gestão, desenvolvimento de fluxo de processos, mas a definição do programa foi provisória, pois não foi uma das prioridades estabelecidas. Ao identificar que o programa utilizado não atendia adequadamente ao sistema, foi contratada uma consultoria para auxílio na definição de novo programa. No caso da Empresa C, existia um padrão de sistema corporativo integrado de informação e de gestão do negócio da matriz alemã que foi seguido pela filial brasileira.

As ferramentas de colaboração de projetos, gerenciador de arquivos e a intranet são utilizados nas três obras analisadas e já foram incorporados aos procedimentos de gestão das empresas, facilitando o compartilhamento de informações e conhecimento. Em relação à $\mathrm{TI}$ na área de projetos, além do suporte aos procedimentos operacionais, organização de dados e fluxo de informações, foi identificada, na Empresa $A$, uma iniciativa de inovação para implementação e aplicação da tecnologia BIM com a criação do Núcleo de Modelagem, ampliando as opções de serviços oferecidos ao cliente. A Empresa $\mathrm{C}$ deu início a um projeto piloto com uma ferramenta de gerenciamento de projetos que permite a visualização de projetos de engenharia em CAD 3D por meio de interação com o planejamento físico em MS Project, em caráter experimental. 
Para agregar valor ao cliente, por meio de um atendimento com exclusividade, confiabilidade e qualidade, faz parte da visão das empresas a importância de manter e treinar profissionais com especialização e domínio do conhecimento técnico em engenharia e gestão de projetos.

Quanto à execução e coordenação de projetos, as três empresas têm especialização em obras por encomenda, com projetos exclusivos, desenvolvidos por empresas de projeto terceirizadas (contratadas pelo cliente ou pela própria construtora). Todas as empresas têm em seu quadro de funcionários arquitetos sob a responsabilidade de um gerente da área de projetos para atuar, quando contratadas, na gestão do processo de projeto, tanto na fase de execução da obra quanto de desenvolvimento dos projetos. Após receber um treinamento sobre os procedimentos organizacionais de gestão de projetos, estes arquitetos estão aptos a atuar como gestores do processo de projeto dedicados a uma obra específica (Unidade de Negócio).

A estrutura organizacional das três empresas pode ser classificada como matricial balanceada, que combina a departamentalização funcional das Unidades de Serviços (responsáveis por atividades relacionadas à Qualidade, Administração e Finanças, Recursos Humanos, Desenvolvimento de Negócios, Tecnologia, entre outras) e por Projetos das Unidades de Negócios (obras), que são constituídas por uma equipe específica liderada por um gerente responsável por cada contrato. Neste tipo de estrutura, os coordenadores de projeto, que fazem parte da Unidade de Serviço de projetos, ao integrar a equipe locada na obra (Unidade de Negócio) passam a responder ao Gerente do contrato, mantendo pouco contato com a gerencia da área de projetos, que fica alocada no escritório central. Como os processos e ferramentas de gestão de projetos estão bem estruturados, disseminados e consolidados, não foi apresentada nenhuma deficiência ou desconhecimento dos processos por parte dos coordenadores de obra nas empresas pesquisadas. 


\section{Gestão do conhecimento}

As lideranças à frente das iniciativas de gestão do conhecimento das Empresas $\mathrm{A}, \mathrm{B}$ e C, responsáveis pela implantação, monitoramento, controle e validação do conteúdo (plano tático), são áreas das Unidades de Serviços, diretamente subordinadas à alta direção da empresa (plano estratégico), conforme Quadro 20, com atividades relacionadas a planejamento, gestão e controle de custo.

\begin{tabular}{c|l}
\hline Empresa & Unidade de Serviço \\
\hline A & PMO; Qualidade (Projetos, Processos e Desenvolvimento); Assistência Técnica \\
\hline B & Núcleo de Gestão Técnica (Planejamento) \\
\hline C & Controlling (Controle) \\
\hline
\end{tabular}

Quadro 20 - Lideranças à frente das iniciativas de gestão do conhecimento das Empresas A, B e C

Além do apoio da alta direção da empresa, diversos pontos identificados nos estudos de caso, alinhados aos itens que constam da missão, visão das Empresas A, B e C, descrito no Quadro 21, demonstram que os valores e a cultura podem influenciar e propiciar iniciativas espontâneas de gestão do conhecimento.

\begin{tabular}{|c|c|c|c|}
\hline & Empresa A & Empresa $\mathrm{B}$ & Empresa C \\
\hline Missão & $\begin{array}{l}\text { Prestar serviços de gestão } \\
\text { e construção de obras de } \\
\text { edificação e infra-estrutura, } \\
\text { atuando em todo o ciclo } \\
\text { de vida do } \\
\text { empreendimento. }\end{array}$ & $\begin{array}{l}\text { Construir edificações e } \\
\text { gerenciar } \\
\text { empreendimentos com alto } \\
\text { desempenho. } \\
\text { Adotando como princípio a } \\
\text { "Melhoria continuada: } \\
\text { incrementar o } \\
\text { desempenho através do } \\
\text { conhecimento, inovação } \\
\text { e aprendizado contínuo". }\end{array}$ & $\begin{array}{l}\text { Oferecer aos Clientes } \\
\text { soluções de engenharia e } \\
\text { construção para todo ciclo } \\
\text { de vida de } \\
\text { empreendimentos, atuando } \\
\text { como um prestador de } \\
\text { serviços de excelência na } \\
\text { América do Sul. }\end{array}$ \\
\hline Visão & $\begin{array}{l}\text { Ser reconhecida como a } \\
\text { melhor empresa de } \\
\text { engenharia do Brasil nos } \\
\text { setores em que atuamos, } \\
\text { pela qualidade e } \\
\text { desenvolvimento constante } \\
\text { de nossos profissionais e } \\
\text { pelo alto valor agregado } \\
\text { aos clientes através de: } \\
\text { Especialização } \\
\text { (conhecimento dos } \\
\text { negócios do cliente); } \\
\text { Domínio do conhecimento } \\
\text { técnico em Engenharia; } \\
\text { Excelência em gestão de } \\
\text { projetos e Logística e } \\
\text { Suprimentos. }\end{array}$ & $\begin{array}{l}\text { Ser a marca de maior } \\
\text { confiabilidade em seu } \\
\text { mercado. }\end{array}$ & $\begin{array}{l}\text { A Empresa C está } \\
\text { construindo o futuro. } \\
\text { Juntamente com nossos } \\
\text { Parceiros expandimos } \\
\text { horizontes, aproximamos } \\
\text { pessoas e organizações, } \\
\text { criamos novas maneiras de } \\
\text { pensar e agir, e } \\
\text { incrementamos de forma } \\
\text { sustentável os valores } \\
\text { que nos foram confiados. }\end{array}$ \\
\hline
\end{tabular}

Quadro 21 - Missão e visão das Empresas A, B e C 
O foco da gestão do conhecimento é direcionado dependendo do conteúdo (content) e contexto (context), que refere-se ao cenário da organização para a aplicação do conhecimento.

Mesmo sem uma estratégia explícita estruturada para gestão do conhecimento, foi verificado a partir das iniciativas, individuais ou corporativas, das empresas analisadas, que há uma semelhança no tipo de conhecimento que é importante ser gerenciado em empresas de engenharia e construção, que estão relacionados aos serviços prestados pela empresa: elaboração de propostas técnicas, coordenação de projetos, orçamento, planejamento, controle e execução da obra.

Parte do conhecimento, considerado um sinônimo de informação, será direcionado para a gestão da informação (conhecimento explícito):

- Procedimentos operacionais;

- Resultados operacionais;

- Informações sobre clientes;

- Dados dos Projetos (obras);

- Banco de dados para orçamento;

- Dados técnicos de equipamentos e termos técnicos;

- Processos, procedimentos e ferramentas de coordenação de projeto;

- Procedimentos e tecnologias construtivas;

- Procedimentos de execução da obra;

- Manuais de qualidade;

- Procedimentos Segurança, Saúde e Meio Ambiente;

- Banco de dados de suprimentos e fornecedores;

- Modelagem de informações do edifício baseado na modelagem 3D paramétrica (BIM);

- Dados de ocorrências da Assistência Técnica.

O conhecimento tácito, que envolve o conhecimento gerado a partir da interação entre as pessoas, pode ser moldado dependendo do contexto do ambiente. Para se transformar em valor para o cliente o conhecimento deve ser posto em ação. A gestão do conhecimento tácito tem como desafio direcionar a aplicação do conhecimento individual otimizando a capacidade de trabalho entre equipes 
(internas e externas) para compartilhamento, criação e, posterior, retenção do conhecimento gerado, levando em conta as fases do ciclo de vida da construção. Envolve o conhecimento gerado nas atividades relacionadas a:

- $\quad$ Engenharia de valor;

- Pesquisa de aplicação de inovações tecnológicas;

- Parcerias estratégicas com fontes externas (consultores, fornecedores, projetistas);

- Soluções para melhoria da construtibilidade obtidas na fase de execução da obra;

- Melhores Práticas (soluções diferenciadas adotadas nas obras para melhoria dos procedimentos existentes);

- Lições Aprendidas;

- Retroalimentação da Assistência Técnica;

- Seminários e treinamentos baseado na vivência dos funcionários.

Além dos sistemas integrados de gestão e colaboração, a maior parte das iniciativas de gestão do conhecimento é focada nas pessoas, onde a TI atua, basicamente, como suporte para sua operacionalização, conforme Quadro 22.

\begin{tabular}{|c|c|}
\hline Empresa & Iniciativas focadas em TI \\
\hline $\begin{array}{l}\text { A (Share Point) } \\
\text { B (PRqd) }\end{array}$ & $\begin{array}{l}\text { - Ferramentas colaborativas para facilitar o compartilhamento do conhecimento, } \\
\text { onde estão disponibilizados: }\end{array}$ \\
\hline $\begin{array}{l}\text { C (Management } \\
\text { System/ } \\
\text { Memória } \\
\text { Técnica) }\end{array}$ & $\begin{array}{l}\text { Procedimentos operacionais padrão; Melhores práticas de gestão de Projeto } \\
\text { (modelos); Sistema de qualidade; BIM; Manual de coordenação de projetos; } \\
\text { Procedimentos construtivos desenvolvidos; Banco de dados da Assistência } \\
\text { Técnica; Management book; Banco de dados de orçamento. }\end{array}$ \\
\hline Empresa & Iniciativas focadas nas pessoas \\
\hline \multirow[t]{4}{*}{ A, B, C } & $\begin{array}{l}\text { - Reuniões entre vários profissionais da empresa e fornecedores para engenharia } \\
\text { de valor na fase de proposta; }\end{array}$ \\
\hline & $\begin{array}{l}\text { - Reuniões e redes sociais com fornecedores e consultores externos na fase de } \\
\text { planejamento e execução da obra para desenvolvimento de novas soluções de } \\
\text { engenharia; }\end{array}$ \\
\hline & - Registro de Lições aprendidas (ao término e ao longo das fases do projeto); \\
\hline & •Workshops; \\
\hline
\end{tabular}


- Treinamentos;

\begin{tabular}{ll}
\hline A & $\cdot$ Projetos Aplicativos de Trainees; \\
& $\cdot$ Wiki; \\
& $\cdot$ Curso de Patologia; \\
\hline B & $\cdot$ Programa de Trainees; \\
& $\cdot$ Programas de Capacitação; \\
\hline C & $\cdot$ Jornal Interno; \\
& $\cdot$ Projetos Feedback; \\
& $\cdot$ Capacitação de Jovens Profissionais; \\
& $\cdot$ Escola Técnica.
\end{tabular}

Quadro 22 - Ferramentas e práticas associadas à gestão do conhecimento identificadas nas Empresas A, B e C

A definição de lideranças à frente das iniciativas de gestão do conhecimento e sistemas bem estruturados não garantem seu sucesso, pois vários fatores interdisciplinares podem impactar a gestão do conhecimento. Baseado na literatura, foram avaliados nas três empresas, os principais fatores de impacto, conforme descritos no Quadro 23.

\section{Estrutura Organizacional}

- Estrutura matricial: combina uma estrutura funcional (Unidades de Serviço - Escritório central) com outra por Projetos (Unidade de Negócio - Obras). Propicia disseminar o conhecimento organizacional ao deslocar um arquiteto da Unidade de Serviço para diversas obras;

- Centralizada: processo decisório está concentrado na alta administração da empresa que define quem tem acesso a conhecimentos, quem participa de reuniões, seminários e cursos;

- As Unidades de Negócios (obra) tem autonomia para execução de cada Projeto, mas o controle financeiro é centralizado e controlado pelo escritório central;

- Alto grau de formalização, com procedimentos claramente definidos sobre os processos de trabalho;

- A estrutura visa facilitar a comunicação entre os diversos setores da empresa, ganhando em velocidade na informação, na decisão, na identificação e resolução de problemas, no atendimento ao cliente. No entanto, com a estrutura por Projetos, as equipes de obra ficam focadas em sua Unidade de Negócio, e o conhecimento fica mais retido nos indivíduos;

- A estrutura funcional pode levar a compartimentação de conhecimento. Ao integrar as Unidades de Negócio (obra), membros das Unidades de Serviço (escritório central) promovem a transferência de conhecimento;

- O cliente é a figura central e a razão de todas as ações que devem ser direcionadas ao atendimento de suas necessidades;

- Determina se o conhecimento é criado internamente ou depende de consultores especializados externos;

- O mapeamento de competências internas fica a cargo do gerente de cada Unidade de Serviço. Não existe um mapeamento unificado de todos funcionários da empresa. 
Cultura e Aprendizagem Organizacional

- As empresas deixam claro em sua visão e valores a importância do domínio do conhecimento em engenharia e gestão de Projetos para atingir o alto desempenho. O conhecimento faz parte dos objetivos estratégicos;

- Grande enfoque dado à marca já consolidada no mercado;

- As equipes das Unidades de Negócio (obra) são focadas no desempenho de sua obra;

- Colaborativa: os indivíduos têm que unir esforços para atingir um objetivo comum = bom desempenho do Projeto (Obra);

- Manter na fase de obra as Equipes de Projeto (Project Team) formadas desde o início do Projeto (fase de proposta) estimula a colaboração;

- Focada no grupo, e não no indivíduo;

- Restringe a troca de conhecimentos relacionados à desempenho (uma obra não acessa os dados de outra obra);

- O conhecimento compartilhado através dos sistemas integrados é selecionado (as lideranças filtram as melhores práticas antes de publicá-las);

- Não há sistemas de reconhecimento de talentos ou de recompensa para compartilhamento ou registro de conhecimento;

- Para estimular a colaboração, o Memória Técnica permite postar comentários do que foi registrado e acompanhar o número de acessos ao registro;

- Há dependência de consultores externos em relação aos projetos para produção e fornecedores para materiais ou sistemas construtitvos específicos;

- Alta direção busca a integração da empresa como um todo: do escritório às obras. Foco no desenvolvimento de um sistema próprio de gestão integrada;

- Incentivado o compartilhamento de lições aprendidas entre as equipes de diferentes obras apenas ao término da obra (workshop). Não há incentivo para transferência de conhecimento entre as obras no período de execução;

- Falta de tempo e recursos para compartilhar experiências entre as equipes de diferentes obras, ao longo da execução da obra;

- Incentivado o compartilhamento de conhecimento com fornecedores e consultores, mas depende do tipo de contrato;

- Desenvolvimento de competências individuais para potencializar desempenho (treinamentos);

- As empresas buscam ampliar sua atuação (competências) em novos segmentos para ampliar serviços oferecidos ao mercado;

- As mudanças de cada obra são gerenciadas, mas não há uma transferência de conhecimento para outras obras;

- Não há sistemas de compartilhamento de conhecimento estruturado entre a empresa e os parceiros. O compartilhamento ocorre de acordo com a necessidade de cada Projeto;

- O cliente e os fornecedores têm o importante papel de facilitadores na transferência de conhecimento entre Projetos. Ao identificar valor de um novo conhecimento criado no Projeto podem difundí-lo entre as empresas participantes do empreendimento. 
Sistemas e tecnologias de informação (TI)

- Utilizam sistema integrado e centralizado de gestão, acessado pelo escritório e pelas obras, para controle e armazenamento de informações dos Projetos da empresa e informações contábeis/ financeiras referentes a custo;

- TI com maior enfoque nos ambiente de trabalho colaborativo (facilitar compartilhamento de informações) do que sistemas de gestão do conhecimento;

- Todos os projetos, o que inclui desenhos, especificações, correspondências, etc, são armazenados em servidor eletronicamente;

- Os documentos de projeto são compartilhados externamente com clientes, projetistas e alguns fornecedores, através de sistemas colaborativos;

- As áreas de TI tem função de suporte e não estratégica. O envolvimento com as iniciativas de gestão do conhecimento identificadas são mais relacionadas à infra-estrutura;

- A maior preocupação das empresas tem sido mais em relação a geração do conteúdo do que a ferramentas ou programas de armazenamento. A avaliação de uma ferramenta de TI mais específica só ocorre quando há uma necessidade maior de busca de informação.

\section{Meios de comunicação entre os agentes}

- Os principais meios de comunicação entre os membros da equipe de projeto são: telefone, email (comunicação escrita), ferramenta de colaboração de projetos e gerenciador de arquivos (depende do cliente) e reuniões, onde os assuntos e decisões são registrados em atas, elaboradas pelo arquiteto da obra ou gerenciadora e disponibilizados a todos envolvidos através do sistema centralizado;

- As reuniões propiciam compartilhamento de conhecimento tácito e criação de novo conhecimento;

- A frequência das reuniões de projeto varia de acordo com a fase do projeto e demanda, assim como os profissionais participantes;

- A visita de projetista à obra propicia transferência e geração de novo conhecimento a partir da interação com a equipe da obra, mas depende do escopo de contratação;

- A troca de informações entre projetos, obra e os projetistas pode ser realizadas por telefone (para esclarecimento de dúvidas mais urgentes), e-mail ou via dos sistemas colaborativos (para troca de arquivos), em geral definidos pelo cliente.

Quadro 23 - Fatores que impactam a gestão do conhecimento, levantados nas Empresas A, B e C

O conhecimento nas fases do ciclo de vida do empreendimento e negócios das Empresas

Apesar das diferentes denominações de cada fase, o ciclo de vida dos negócios das

Empresas A, B e C, seguem as mesmas etapas do ciclo de vida característico de um 
empreendimento do setor imobiliário, conforme Quadro 24. A fase de Obsolescência e Reciclagem não se encontra incluída no ciclo de vida de negócio das empresas.

FASES DO CICLO DE VIDA DO EMPREENDIMENTO

\begin{tabular}{|c|c|c|c|c|c|c|c|}
\hline \multirow[b]{2}{*}{$\stackrel{0}{\longrightarrow}$} & \multirow{4}{*}{ 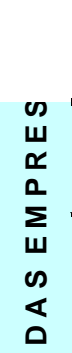 } & \multirow[b]{2}{*}{ A } & \multirow{2}{*}{$\begin{array}{c}\text { Planejamento do } \\
\text { empreendimento }\end{array}$} & \multirow{2}{*}{\begin{tabular}{|c|}
$\begin{array}{c}\text { Desenvolvimento } \\
\text { do projeto }\end{array}$ \\
Estruturação \\
\end{tabular}} & \multirow{2}{*}{$\begin{array}{c}\text { Execução da Obra } \\
\text { Execução e Controle/ } \\
\text { Aceitação }\end{array}$} & \multirow{2}{*}{$\begin{array}{c}\text { Operação e } \\
\text { Manutenção } \\
\text { Pós Entrega } \\
\text { (Assistência } \\
\text { Técnica) }\end{array}$} & \multirow[t]{2}{*}{$\begin{array}{l}\text { Obsolescência e } \\
\text { Reciclagem }\end{array}$} \\
\hline & & & & & & & \\
\hline 0 & & \multirow{2}{*}{ B } & \multirow{2}{*}{ Originação } & Pré-Construção & $\begin{array}{l}\text { Engenharia e } \\
\text { Construção }\end{array}$ & \multirow{2}{*}{ Assistência Técnica } & \\
\hline$\frac{0}{0}$ & & & & \multicolumn{2}{|c|}{ (Projeto e Construção) } & & \\
\hline $\begin{array}{l}0 \\
0 \\
0 \\
w\end{array}$ & $\begin{array}{l}0 \\
0 \\
0 \\
0\end{array}$ & C & Analisar Contrato & Obter Contrato & $\begin{array}{l}\text { Detalhar Execução/ } \\
\text { Executar a obra/ } \\
\text { Entregar a obra }\end{array}$ & Assistir contrato & \\
\hline$\sum_{4}^{\infty}$ & $\begin{array}{l}\sigma \\
w \\
z\end{array}$ & & $\begin{array}{l}\text { Desenvolvimento } \\
\text { de Negócios }\end{array}$ & \multicolumn{2}{|c|}{ Project Team (Unidade de Negócios) } & Assistência Técnica & \\
\hline
\end{tabular}

Quadro 24 - Ciclo de vida dos negócios das Empresas A, B e C comparado ao ciclo de vida do empreendimento

Na fase de Planejamento do empreendimento, o cliente faz a contratação do arquiteto-autor do projeto para desenvolvimento do estudo de viabilidade. Dependendo da complexidade do empreendimento podem ser contratados projetos de outras disciplinas para maior acuracidade das estimativas de custo. Com base nestes estudos, o cliente contrata uma construtora para elaboração de estimativa de custo da obra e participação do processo de desenvolvimento dos projetos, contribuindo com sua experiência, ou apenas para a execução da obra. $O$ conhecimento da construtora pode ser um diferencial nesta etapa, mas nem sempre garante sua contratação, pois o custo da obra, em geral, é o principal item levado em consideração na concorrência. Por parte da construtora, nesta fase todas empresas realizam uma análise de riscos com a participação de profissionais das áreas de engenharia, projetos, orçamentos e controle para elaboração da proposta comercial com base na avaliação do negócio, cliente e eventuais riscos do contrato. Nesta fase podem ser firmadas parcerias com fornecedores de materiais e serviço visando a troca de conhecimento para definição de soluções de engenharia que atendam ao prazo e custo da obra que será apresentado na proposta comercial. A gerenciadora pode ser contratada desde o início desta etapa ou apenas a partir da contratação da construtora. O escopo de gerenciamento e tipo de relação entre agentes varia de acordo com a contratação. 
A Empresa A participou das reuniões de projeto com projetistas e cliente nesta fase para, através da engenharia de valor, buscar uma redução do custo da obra. Como não foi possível atingir o preço alvo estabelecido pelo cliente, apesar da ativa participação da construtora, compartilhando seu conhecimento com todos envolvidos, foi necessária uma concorrência para sua contratação. No estudo de caso da Empresa B, por tratar-se de um data center que exige um conhecimento específico, a experiência da Empresa $B$ foi percebida como diferencial por parte do cliente que contratou-a para participar no desenvolvimento dos projetos. Para viabilizar sua contratação, a Empresa $\mathrm{C}$ adotou diversas soluções alternativas, como por exemplo o banheiro pronto, como forma de redução de prazo e custo da obra.

As práticas de gestão do conhecimento identificadas nesta fase foram compiladas de acordo com os principais processos de aprendizagem e gestão do conhecimento no Quadro 25.

\section{Fase de Planejamento do Empreendimento}

\section{Recuperação e Uso do conhecimento}

- Recuperação de registro de projetos anteriores similares, dados do cliente, lições aprendidas para análise de riscos e tomada de decisão ("Go - No go": dar andamento ao processo ou abortar) e elaboração de proposta de serviço para o cliente (Empresa A, B, C);

- Recuperação de conhecimento adquirido atráves de pesquisa/ treinamento - Núcleo de Sustentabilidade (Empresa A);

- Utilização de Banco de dados de Orçamentos para novas propostas (Empresa C);

- Aplicação de competências internas para desenvolvimento de novos serviços - Núcleo de Modelagem - BIM (Empresa A);

- Utilização de dados da Memória Técnica nos orçamentos sobre as principais patologias por segmento (Empresa C);

- Utilização de Lições Aprendidas para novas propostas (Empresa A, B, C);

- Aplicação de conhecimento adquirido em seminários e treinamentos na elaboração de novas propostas (Empresa A, B, C).

\section{Criação de novo conhecimento}

- Engenharia de valor: a equipe da construtora desenvolve, em parceria com projetistas, alternativas para redução de custo, prazo e melhoria da construtibilidade da obra, agregando valor ao projeto do cliente (Empresa A, B, C);

- Project Team (Equipe de Projeto): célula de trabalho composta por profissionais de diversas áreas da empresa para elaboração de nova proposta (Empresa C).

\section{Aquisição de conhecimento}

- Importação de novo conhecimento de fontes externas através da interação com fornecedores e consultores especializados para verificar soluções disponíveis no mercado que possam ser aplicadas ao projeto e à produção: racionalização, utilização de equipamentos para aumentar produtividade, etc (Empresa A, B, C); 
Retenção do conhecimento

- Registro de análises de valor, alterações de projeto, sugestões de métodos construtivos, estimativas de custo, etc realizadas na fase de proposta para passar à equipe de produção, após contratação ou para base de novas propostas, no caso da empresa não ganhar a concorrência (Empresa A, B, C);

\section{Compartilhamento de conhecimento \\ - Parceria com fornecedores e consultores externos para novas soluções de engenharia (Empresa A, B, C); \\ - Interação com projetistas para adaptações do projeto para otimização de custo e prazo da obra (Empresa A, B, C); \\ - Contribuição de vários departamentos da empresa com seu conhecimento para a elaboração de nova proposta (Empresa A, B, C).}

\section{Quadro 25 - Práticas associadas à gestão do conhecimento identificadas na fase de} Planejamento do Empreendimento nas Empresas A, B e C

A fase de Planejamento do Empreendimento pode ter influência no processo de projeto a partir da necessidade de revisão dos projetos e/ou especificações técnicas para: adequação do produto ao mercado; alterações solicitadas pelo cliente (usuário) para adequação à suas necessidades; exigências legais ou adaptação às soluções desenvolvidas com fornecedores/ fornecedores. Em geral, a construtora desenvolve novas soluções para elaboração de proposta comercial ao cliente, mas só interfere no processo de projeto a partir de sua contratação.

A partir da aprovação da viabilidade, tem início a etapa de Desenvolvimento do projeto, na qual os projetistas desenvolvem os projetos executivos. No caso da construtora, esta fase é dedicada à estruturação da equipe de obra/ projeto, planejamento da obra, contratação de fornecedores, entre outros. Quando a construtora participa dos projetos, tem a possibilidade de agregar seu conhecimento aos projetistas na definição de aspectos tecnológicos (sistemas e detalhes construtivos, etc) que interferem diretamente na produção.

Para as Empresas A e C, esta etapa foi dedicada à estruturação da equipe e planejamento da obra, contratação de fornecedores, enquanto na Empresa $B$, o arquiteto coordenador da obra e o Gerente de projetos participaram das reuniões com projetistas, gerenciadora e cliente (usuário final), contribuindo com sugestões técnicas e mais econômicas para incorporar aos projetos. Na Empresa C, como a empresa não foi contratada para a gestão dos projetos, a atuação da coordenadora de projetos da obra era mais restrita, além de toda interação com projetistas ser intermediada pela gerenciadora, limitando a comunicação entre as partes. Para dar 
continuidade ao trabalho de engenharia de valor realizado na elaboração da proposta, o Gerente de Contrato que participou da fase de concorrência assumiu o papel de lider da equipe do Projeto (Project Team).

As práticas de gestão do conhecimento identificadas nesta fase foram compiladas de acordo com os principais processos de aprendizagem e gestão do conhecimento no Quadro 26.

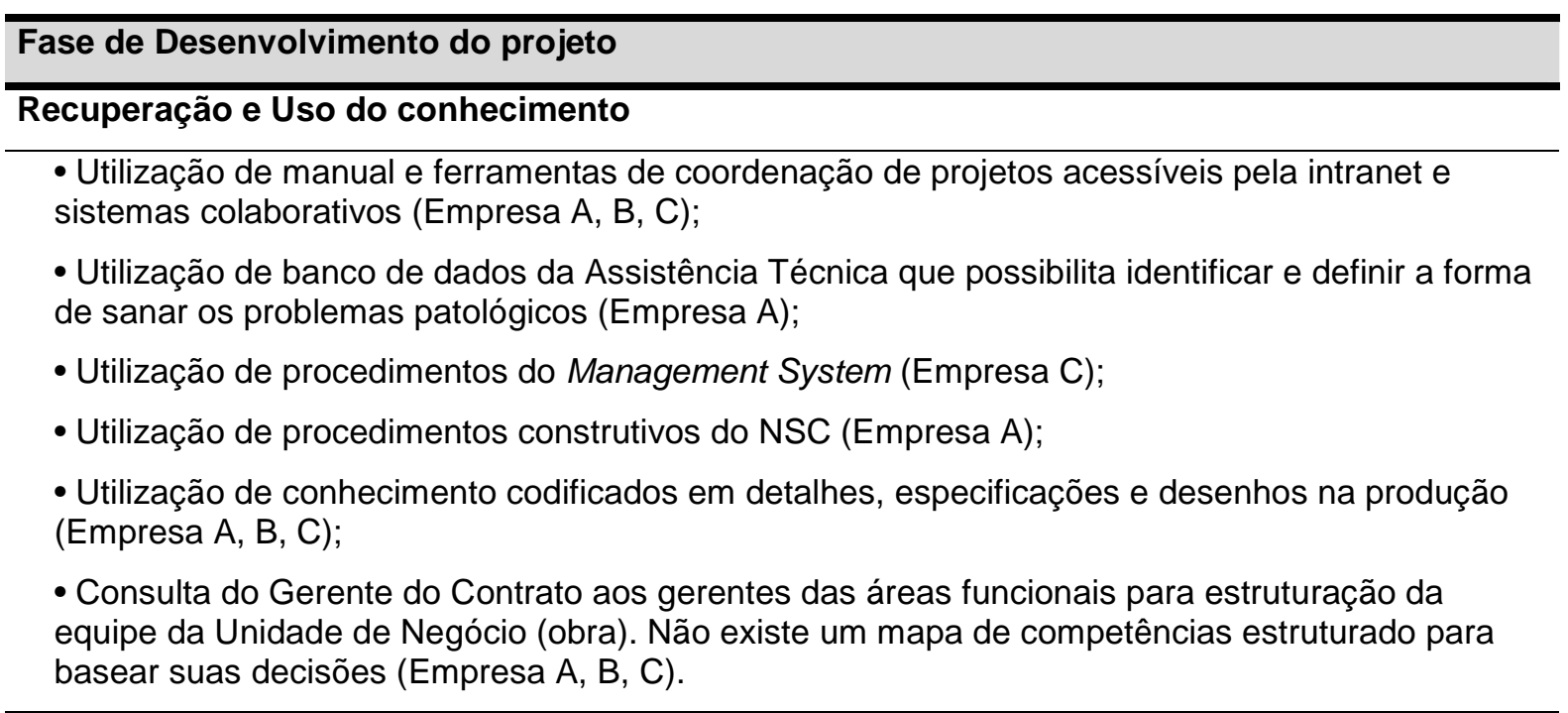

Criação de novo conhecimento

- Elaboração de modelagem (BIM), quando contratado (Empresa A);

- Alteração de soluções de projeto para atender à mudanças de escopo, quando solicitado pelo cliente (Empresa A, B, C);

- Participação da construtora nas reuniões de projeto na etapa de concepção contribuindo nos estudos para viabilização do empreendimento com itens relativos a custo, prazo e construtibilidade (Empresa A, B);

- Desenvolvimento de novas alternativas de projeto para atender aos requisitos da certificação ambiental LEED (Empresa A, B, C);

\section{Aquisição de conhecimento}

- Adquirir conhecimento de fornecedores de serviços e materiais (depende dos sistemas contratuais), que trazem experiência de outros projetos bem sucedidos (Empresa A, B, C);

- Contratação de consultoria externa para estruturação do PRqd, em busca de maior eficiência e transferência de conhecimento de forma organizada, possibilitando monitorar riscos e maximizar as oportunidades (Empresa B);

- Treinamentos regulares para utilização dos sistemas de TI e ferramentas de gestão desenvolvidos pela empresa (Empresa A, B, C);

\section{Retenção do conhecimento}

- Elaboração de Planos de Projeto (Empresa A) e Planejamento Executivo (Empresa B), para compartilhar boas práticas;

- Armazenamento de documentos técnicos do projeto, codificados em detalhes, especificações e desenhos, com novas soluções ou revisões decorrentes da melhoria dos processos ou mudanças de escopo do cliente (Empresa A, B, C); 
- Registro em planilhas de custo (Empresa A, B, C);

- Atualização dos dados armazenados no PRqd pelos monitores em suas respectivas áreas (Empresa B);

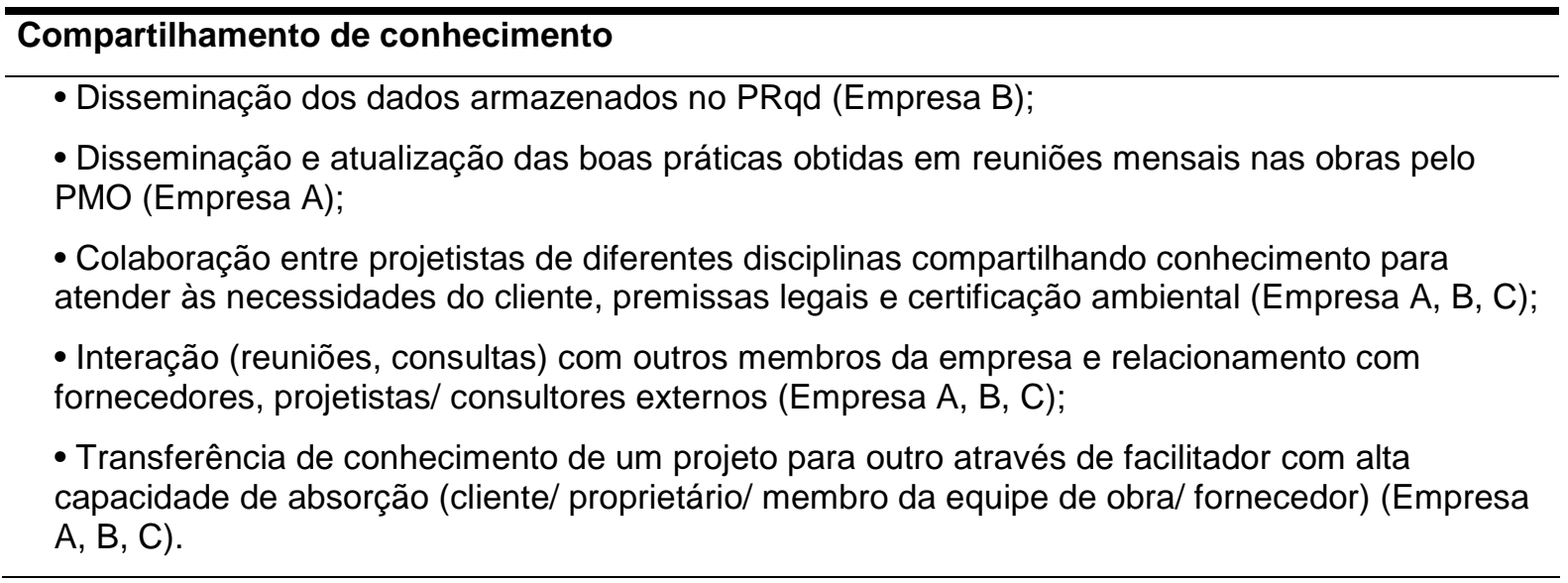

Quadro 26 - Práticas associadas à gestão do conhecimento identificadas na fase de Desenvolvimento do projeto nas Empresas A, B e C

A fase de Desenvolvimento do projeto pode ter influência no processo de projeto a partir da necessidade de revisão dos projetos e/ou especificações técnicas para: adaptação às novas soluções de engenharia; adaptação às soluções desenvolvidas com fornecedores/ fornecedoress; adequação aos requisitos da certificação ambiental; exigências legais (processos em aprovação em órgãos reguladores); alterações solicitadas pelo cliente para adequação do produto ao mercado ou mudanças de projeto sugeridas pela construtora para redução de prazo ou custo da obra, acordadas com o cliente.

A etapa de Execução da Obra, dedicada à execução e controle da obra, gestão de contrato de fornecedores, é muito semelhante nas três empresas com maior participação da equipe de obra. No estudo de caso $B$, a participação do usuário final teve início na fase de desenvolvimento dos projetos e foi intensa na fase de obra, o que não ocorreu nos estudos de caso $\mathrm{A}$ e $\mathrm{C}$, no qual o usuário final será o locatário. A equipe de projetos da construtora desenvolve atividades de compatibilização e coordenação de projetos, quando contratada, ou apoia a equipe de produção, principalmente para suprir as deficiências encontradas nos projetos.

Além do controle de requisitos do cliente, durante a vigência do contrato, a construtora realiza o monitoramento dos riscos, principalmente relacionados às mudanças, sob responsabilidade do Gerente do Contrato (obra) e acompanhado 
pelo escritório central: PMO na Empresa A, Núcleo de Gestão Técnica na Empresa $B$ e Unidade de Controlling na Empresa C.

De acordo com o Gerente de Controlling, o acompanhamento é realizado a fim de verificar o que está sendo executado, o que está sendo gasto e o que foi feito certo ou errado e é importante disseminar estas informações para evitar repetição de soluções que não foram bem sucedidas e identificar custos não previstos na fase de orçamento.

Como a atividade de construção envolve processos complexos com vários intervenientes e diversas incertezas, as mudanças são inevitáveis. Grande parte das mudanças que ocorrem na obra são decorrentes de alterações de projeto e devem ser avaliadas e controladas pela equipe da obra. Todas as mudanças, seja por solicitações do cliente, decorrentes de mudança de escopo, redução de custo ou prazo; restrições legais; correção de erros; requisitos para certificação; imprevistos na obra, tem um impacto, geralmente negativo, pois podem acarretar em retrabalho, aumento de prazo e custo. No entanto, propicia uma maior interação das equipes envolvidas gerando um ambiente propício para geração de novo conhecimento. $\mathrm{O}$ meio mais propício para compartilhamento de experiências são as reuniões, com a presença dos projetistas, construtora e fornecedores, em busca de novas soluções.

Para minimizar a principal deficiência apontada nos três estudos de caso, a falta de compatibilização entre os projetos, as empresas buscam contratos que incluam no escopo a coordenação de projetos, para reduzir o risco de retrabalho devido a projetos errados ou por falta de informações suficientes para execução correta da obra.

Os principais problemas e deficiências no processo de projeto detectados nos estudos de caso, com potencial para gerar impactos na obra, foram:

- Constantes alterações de escopo do cliente com as obras em andamento (causa excesso de revisões de projetos e exige reprogramação de planejamento da obra);

- Diferença de padrão de qualidade dos materiais do país de origem do arquiteto - autor do projeto e do mercado nacional (dificuldade de aprovação de materiais e modelos com os arquitetos americanos); 
- Mudanças de projeto necessárias para atender aos requisitos da certificação LEED, não detectados no início do projeto;

- Modificações de projeto para redução de prazo de execução;

- Início da obra sem que todos projetos estivessem finalizados (atividades de projeto realizadas simultâneas à execução da obra);

- Prazos do cronograma de projetos não cumpridos devido à estimativa de prazos equivocada ou excesso de mudanças;

- Conflito de informações (falta de compatibilização do projeto e entre a demais disciplinas, mesmo que a compatibilização faça parte do escopo do arquitetoautor do projeto);

- Informações incompletas ou erradas (muitos projetos são realizados com base em outros projetos desenvolvidos pelo projetista e as informações não são atualizadas, principalmente no campo de notas de projeto);

- Atraso na entrega de revisões de projeto para obra (projetista tem de revisar um projeto executivo que já havia sido entregue há mais de um ano);

- Conflito de prioridades (projetistas participam de várias equipes de Projetos diferentes com prazos reduzidos);

- Desgaste por parte dos projetistas, que não tinham em seu escopo de contratação reuniões ou visitas à obra, par atender solicitação da construtora;

- Falta de verificação dos projetos, por parte dos projetistas, antes de liberá-los para a construtora (devido ao volume e velocidade impostos pelo mercado para realização dos projetos). Pressão com prazos de entrega dos projetos pode gerar um conflito de prioridades: prazo x qualidade;

- Retrabalho decorrente de mudanças de projeto necessárias devida às interferências encontradas no decorrer da obra;

- Construtibilidade (detalhamento inadequado: detalhes com soluções ultrapassadas; detalhes genéricos ineficazes, sem a devida adaptação; detalhes sem compatibilização com o projeto);

- Não atendimento à normas técnicas; 
- $\quad$ Falta de detalhes construtivos;

- Dificuldade da construtora em conscientizar o cliente da necessidade de contratação de projetos para produção (quando não está no escopo da construtora a contratação destes projetos);

- Fornecedores de materiais não atendem às especificações de projeto (mercado ainda não está preparado para atender à todas exigências da certificação LEED).

As práticas de gestão do conhecimento identificadas nesta fase foram compiladas de acordo com os principais processos de aprendizagem e gestão do conhecimento no Quadro 27.

\section{Fase de Execução da obra}

\section{Recuperação e Uso do conhecimento}

- Utilização de manual e ferramentas de coordenação de projetos acessíveis pelo sistema colaborativo (Empresa A, B, C);

- Divulgação de melhores práticas de gestão (conhecimento explícito) propicia a melhoria contínua dos procedimentos operacionais, criando uma memória organizacional (Empresa A, B, C);

- Utilização de informações do modelo (BIM), quando contratado (Empresa A);

\section{Criação de novo conhecimento}

- Novas soluções definidas a partir da transferência de conhecimento de outro Projeto através de um facilitador (cliente/ proprietário/ fornecedor) difundido entre as organizações participantes e para outros Projetos (Empresa A, B, C);

- Estudo de novas alternativas de projeto e especificações para atender aos requisitos da certificação LEED (Empresa A, B, C);

- Reuniões para reflexão contínua sobre o projeto onde há compatilhamento de experiências e criação de conhecimento tácito (Empresa A, B, C);

- Busca de soluções, pela equipe de obra, para garantir a construtibilidade de detalhes obsoletos utilizados como padrão nos projetos (Empresa $A, B, C$ );

\section{Aquisição de conhecimento}

- Colaboração entre projetistas de diferentes disciplinas compartilhando conhecimento para atender às necessidades do cliente e premissas legais (Empresa $A, B, C$ );

- Interação (reuniões, consultas) com outros membros da empresa e relacionamento com fornecedores, projetistas/ consultores externos (Empresa A, B, C);

\section{Retenção do conhecimento}

- Retenção de conhecimento gerado na busca de soluções de problemas de projeto, encontradas de forma tácita em um processo de socialização entre os agentes envolvidos, que depois são codificados em detalhes, especificações e desenhos (Empresa A, B, C);

- Nível individual: membros da equipe registram lições aprendidas, que podem ser revistas nas reuniões ao final da cada fase de projeto (Empresa A) ou ao término da obra (Empresa B, C);

- Atas de reunião; Planos de Projeto; Documentos técnicos do projeto, codificados em detalhes, 
especificações e desenhos, onde ficam armazenadas as novas soluções ou revisões decorrentes da melhoria dos processos ou mudanças de escopo do cliente (Empresa A, B, C);

- Registro na Memória Técnica de eventual desvio detectado na fase de acompanhamento e controle, baseado no feedback das obras (Empresa C);

- Registro de Lições aprendidas ao longo da execução da obra (Empresa A, B, C).

\section{Compartilhamento de conhecimento}

- Coletivo: reuniões formais face a face; Internet; gerenciador de arquivos de projeto (Empresa A, $\mathrm{B}, \mathrm{C})$;

- Livre acesso da construtora (depende do tipo de contrato) para consulta aos projetistas contratados pelo cliente, facilita a comunicação entre projeto e produção (Empresa A, B);

- Retroalimentação da construtora aos projetistas, depende do interesse do projetista e ocorre mais nos projetos onde houve maior preocupação com o detalhamento (Empresa A, B).

Quadro 27 - Práticas associadas à gestão do conhecimento identificadas na fase de Execução da obra nas Empresas A, B e C

Foi verificado que grande parte da gestão do conhecimento corporativo das construtoras são focadas na gestão, planejamento e execução da obra, como observado nos Procedimentos Técnicos do Núcleo de Sistemas Construtivos da Empresa A, no Planejamento Executivo do PRqd na Empresa B e nos procedimentos do Management Book na Empresa C.

A necessidade de interação entre projeto e obra aumenta à medida que aumenta a quantidade de problemas e mudanças. No entanto, além das atas de reunião, não foi identificado um processo estruturado para registro e disseminação do conhecimento gerado ao solucionar problemas de projeto ou melhoria da construtibilidade no decorrer da obra. Os registros mensal de Lições Aprendidas na Empresa $A$ referem-se mais a questões de gestão do processo de projeto e não soluções de projeto. As apresentações de Lições Aprendidas nas Empresas B são realizadas ao término da obra e as apresentações não devem ser muito longas para não ser cansativas. Na Empresa $\mathrm{C}$, além do workshop ao término de cada obra, foram observados alguns registros de Lições Aprendidas no decorrer da obra no Jornal Interno com foco na execução. Os workshops da área de projetos tratam de temas mais abrangentes: sustentabilidade, BIM, não específicos dos projetos.

A fase de Execução da obra pode ter influência no processo de projeto a partir da necessidade de revisão dos projetos e/ou especificações técnicas para: adequação aos requisitos da certificação ambiental (não detectados na fase de projeto); adequação a problemas imprevistos detectados durante a obra; exigências legais 
(detectadas após vistorias na obra); adaptação às soluções desenvolvidas com fornecedores/fornecedoress; correção de erros ou incompatibilidade entre projetos; alterações de detalhes sugeridas pela construtora para solucionar problemas de construtibilidade; elaboração de novos detalhes omissos; adaptação a produtos disponíveis no mercado; alterações solicitadas pelo cliente para adequação do produto ao mercado ou mudanças de projeto sugeridas pela construtora para redução de prazo ou custo da obra, acordadas com o cliente.

$\mathrm{Na}$ etapa de Operação e Manutenção, quando o usuário final passa a ocupar o edifício, tem início a atuação da equipe de assistência técnica das construtoras para identificar e solucionar as patologias que podem ser separadas por: congênitas (falhas decorrentes de projeto mau concebido), patologias executivas e patologias decorrentes de uso. O Curso de Patologia, estruturado pela área de Assistência Técnica da Empresa A, foi identificado como importante ferramenta de retenção do conhecimento tácito (experiência das pessoas) que ao ser compartilhada através dos treinamentos e aplicada nas obras, é transformada em conhecimento organizacional. Ao identificar patologias congênitas decorrentes de falhas de projeto antes de sua execução, é possível evitar aumento de custos e prazo desnecessários.

Nas Empresas B e C, não foi identificada interação entre as áreas de projeto e assistência técnica. Em geral, a assitência ténica consulta a área de projetos apenas no caso de dúvidas relativas a projetos já executados. Na Empresa C, a Unidade de Serviço Assistência Técnica, anteriormente subordinada à Área de Negócio de Engenharia e Construção, passou à integrar a Unidade de Serviços Técnicos da Área de Facility Management (Gestão de Facilidades), com foco nos novos Negócios em Manutenção Volante no mercado de facilidades, mas sem interação para retroalimentação da área de projetos.

As práticas de gestão do conhecimento identificadas nesta fase foram compiladas de acordo com os principais processos de aprendizagem e gestão do conhecimento no Quadro 28. 


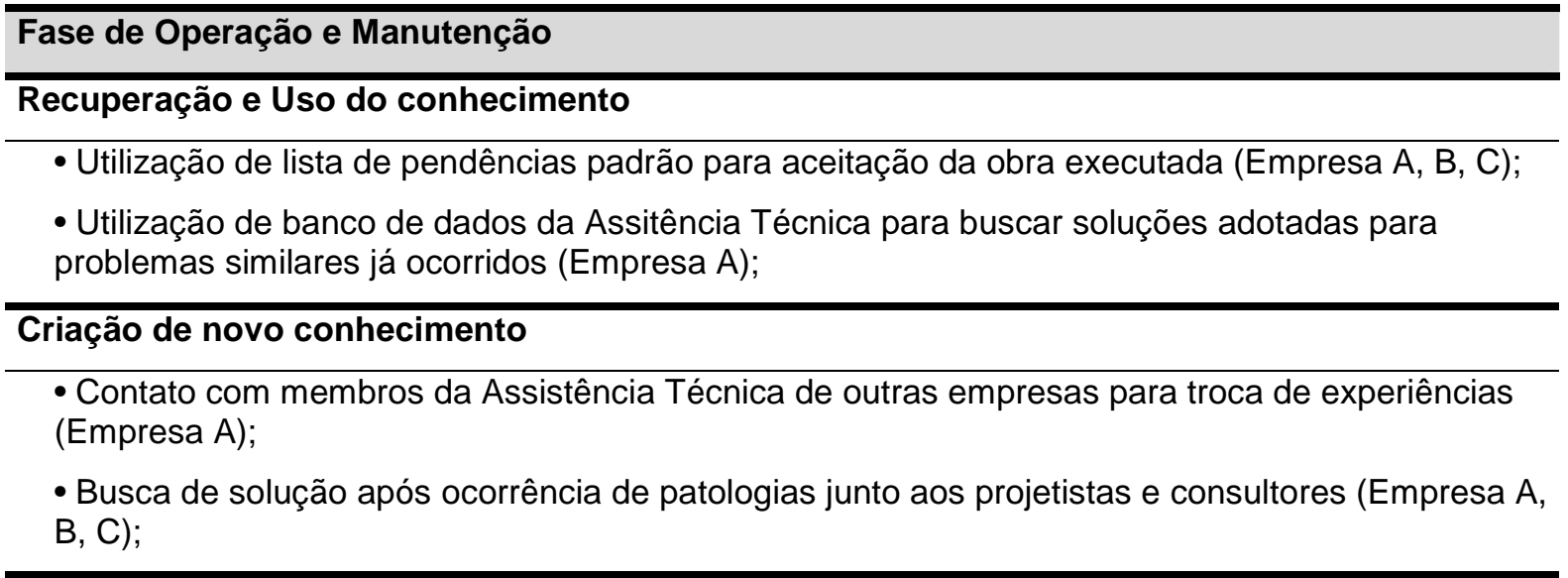
Aquisição de conhecimento

- Interação com equipe de operação e manutenção (Empresa B);

\footnotetext{
Retenção do conhecimento

- Registro de lista de pendências da obra (Empresa A, B, C);

- Atualização do modelo de Manual do proprietário (Empresa A, B, C);

- Registro de ocorrências e patologias no banco de dados da Assitência Técnica (Empresa A);

- Atualização de material do Curso de Patologias (Empresa A);

- Registro de Lições Aprendidas (Empresa A, B, C);
}

\section{Compartilhamento de conhecimento \\ - Disponibilização do banco de dados da Assitência Técnica para toda empresa para evitar repetição de erros ou aplicar soluções preventivas (Empresa A); \\ - Seminários específicos para divulgação das Lições Aprendidas (Empresa B, C); \\ - Curso de Patologias (Empresa A). \\ Quadro 28 - Práticas associadas à gestão do conhecimento identificadas na fase de Operação e Manutenção nas Empresas A, B e C}

A fase de Operação e Manutenção pode ter influência no processo de projeto a partir da necessidade de revisão dos projetos e/ou especificações técnicas para: correção de patologias detectadas após a entrega da obra; alterações de detalhes para solucionar problemas de operação e manutenção (não identificados no projeto); alterações de materiais especificados em projeto que não atendem adequadamente à operação; alterações solicitadas pelo usuário para adequação do produto à suas necessidades.

A etapa de Obsolescência e Reciclagem, ocorre quando cessa a criação de valor ao usuário do edifício e há um direcionamento para a renovação e re-uso da edificação onde tem início o processo de desenvolvimento de um novo empreendimento. Apesar de não constar do ciclo de vida de negócios das 
empresas, apenas no estudo de caso $\mathrm{B}$, o empreendimento foi realizado sobre terreno desocupado. Esta etapa deu início ao estudo de caso $A$, na qual foi necessário demolir uma escola existente, para liberação do terreno, e reconstruí-la no terreno vizinho. No estudo de caso $C$ foi demolido parte do empreendimento existente no terreno e o novo edifício foi adequado ao edifício remanescente. $O$ sucesso da implosão do antigo edifício localizado em área comercial densamente ocupada foi decorrente da realização de um minucioso plano de gestão de crise e execução baseado na experiência da construtora.

Além das práticas de gestão do conhecimento, foi identificado em que fase do ciclo de vida do empreendimento são aplicadas estas iniciativas nas empresas analisadas e quais os agentes envolvidos. A atuação da construtora no ciclo de vida do empreendimento depende do tipo de contratação e, em geral, fica mais restrita às fases de planejamento e execução da obra, como apontado no Quadro 29.

O envolvimento de outros agentes, como por exemplo os responsáveis pela manutenção e operação, que poderiam agregar valor ao projeto, mas cuja atuação não foi detectada nos estudos de caso.

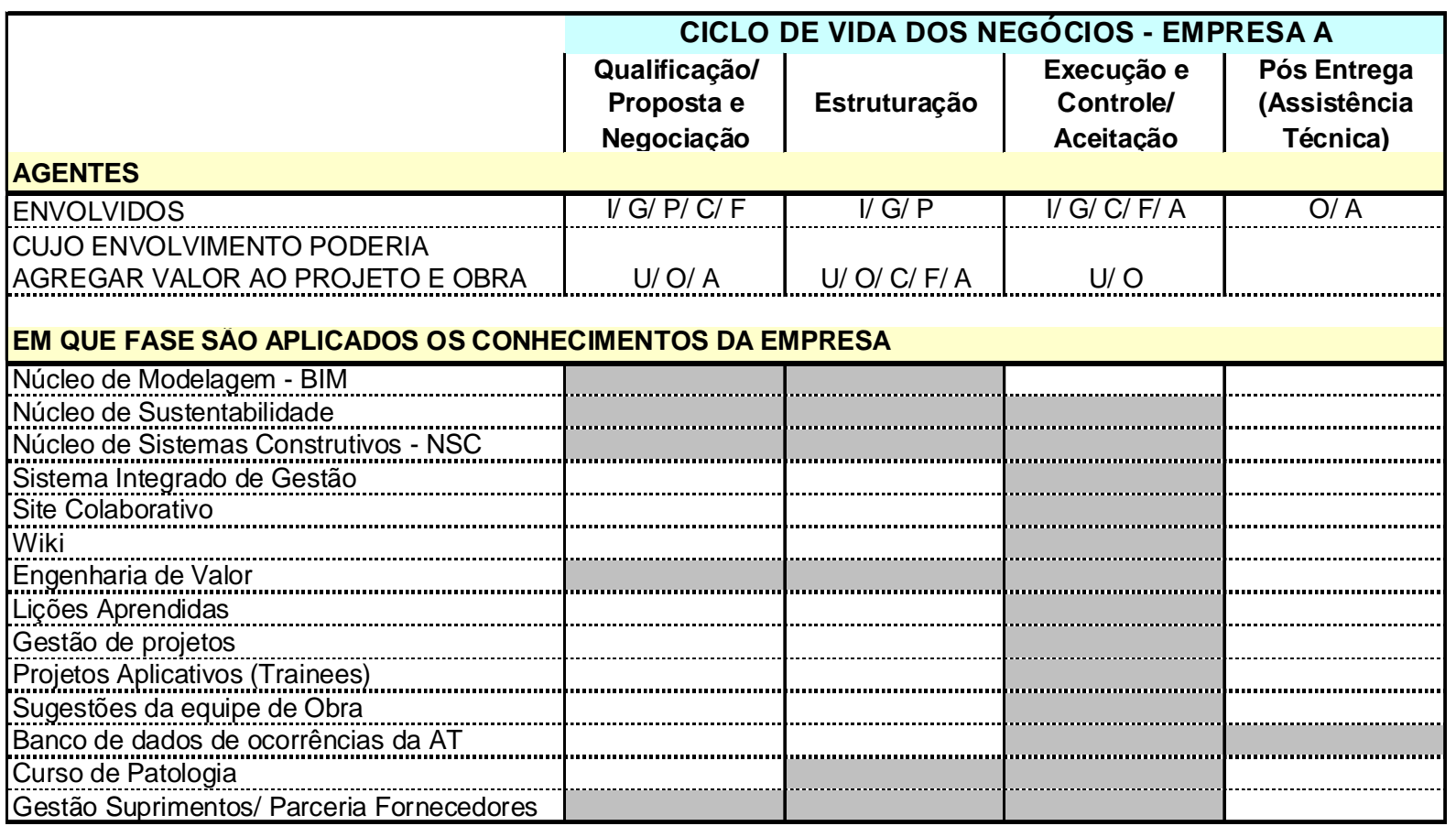




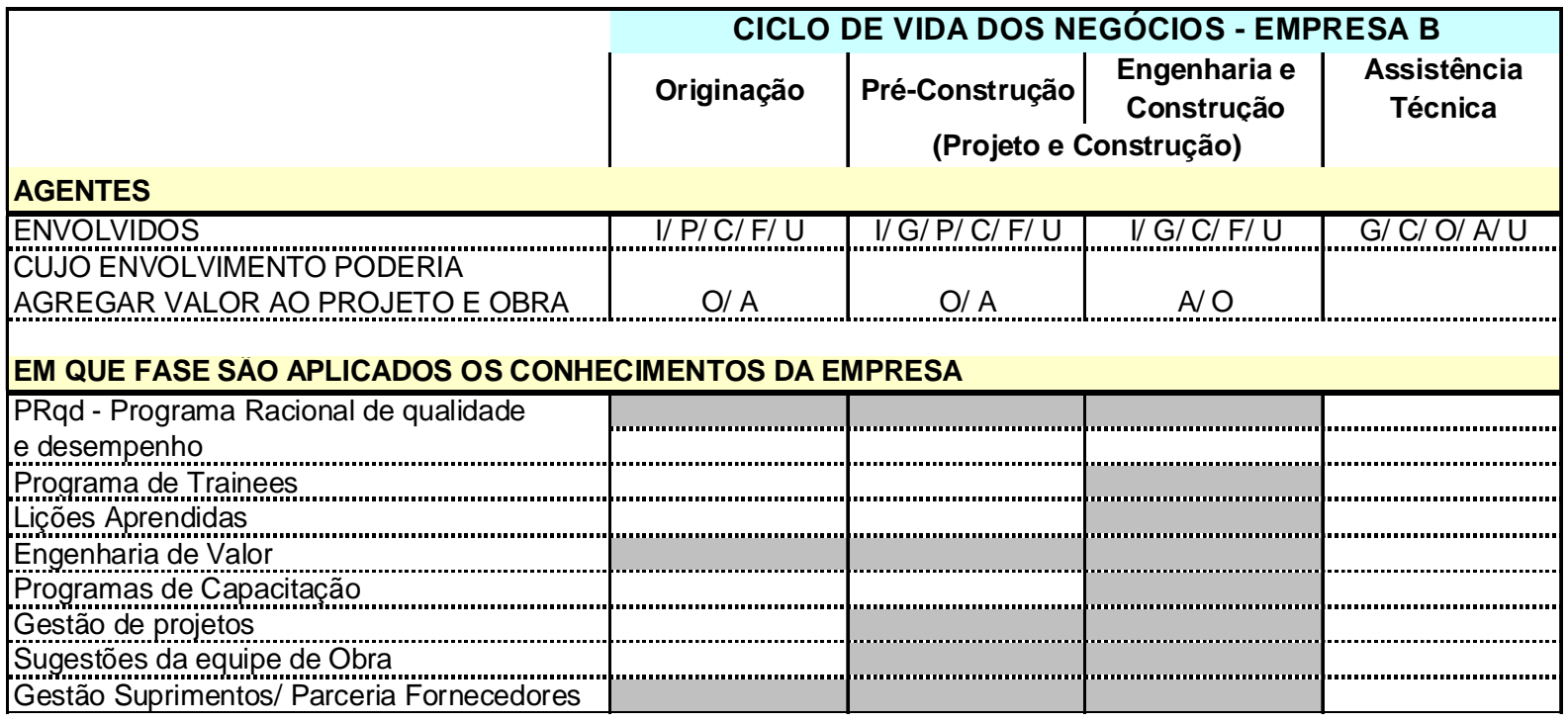

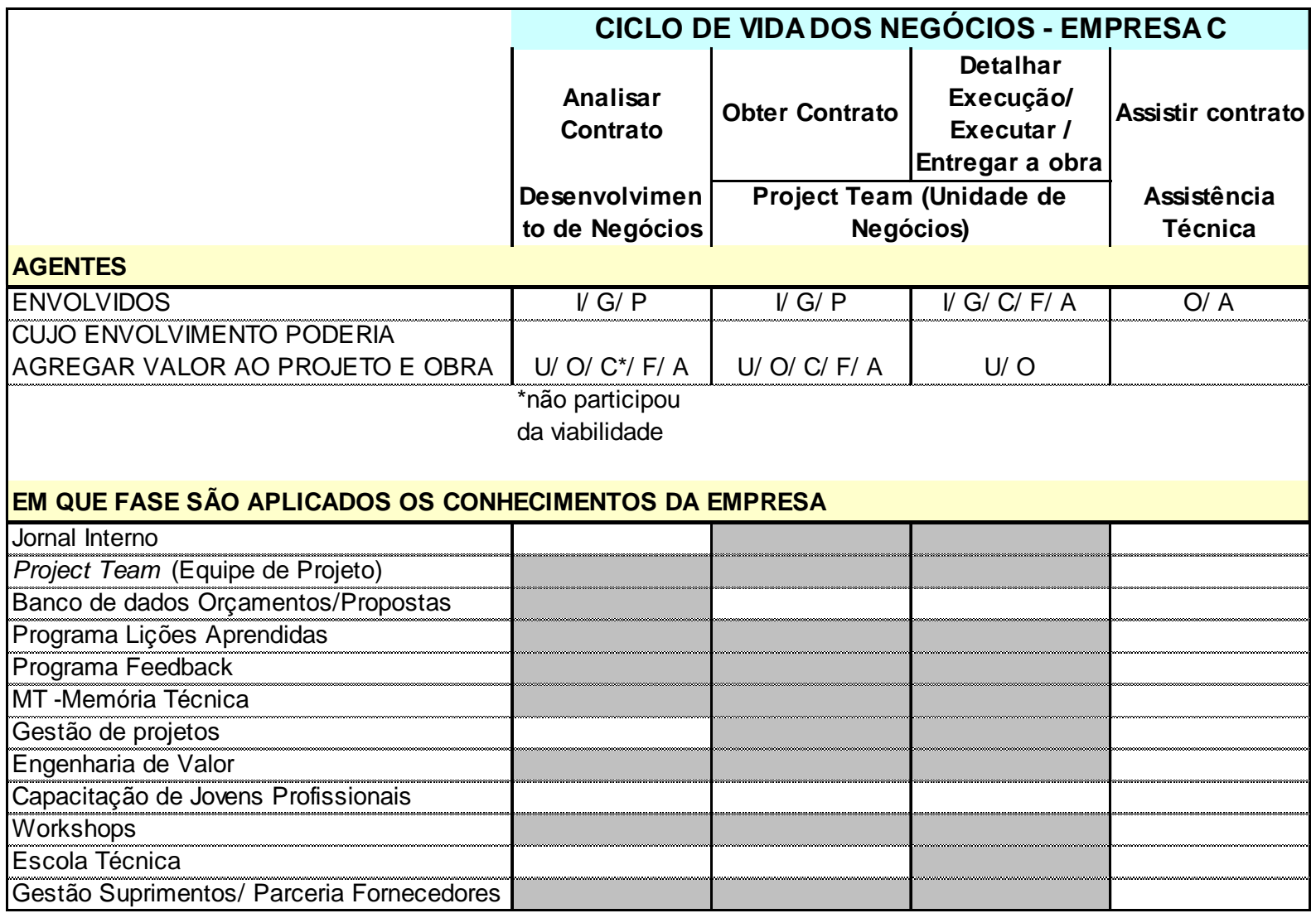

\section{LEGENDA AGENTES}

\begin{tabular}{lll}
\hline I Incorporadora (Cliente) & C Construtora & O Operação e Manutenção \\
G Gerenciadora & F Fornecedores & U Usuário (Cliente) \\
P Projetistas/ Consultores & A Assistência Técnica &
\end{tabular}

Quadro 29 - Agentes envolvidos e iniciativas de gestão do conhecimento aplicadas ao ciclo de vida do empreendimento nas Empresas A, B e C 
Ao analisar os dados coletados, constatou-se que a participação de determinados agentes em outras fases do ciclo de vida poderia agregar valor ao projeto e à obra melhorando o desempenho do empreendimento.

No estudo de caso A, após a retro-alimentação do conhecimento adquirido pela Assistência Técnica (Curso de Patologias) aos coordenadores de projeto, engenheiros e trainees, foi verificado, através de indicadores, que houve uma redução das principais patologias nas novas obras.

No estudo de caso B, o envolvimento do usuário final, gerenciadora e construtora no desenvolvimento do projeto possibilitou a colaboração e compartilhamento de experiência entre equipes de projeto, obra e gestão.

No estudo de caso $C$, o envolvimento do fornecedor de caixilhos na fase de concepção de projetos, antes de sua contratação, evitou retrabalho de revisão de projetos, contribuindo para manter o cronograma estimado para execução da obra.

\section{Interação entre coordenação de projetos e coordenação da execução de obras}

Nos três estudos de caso, a concepção e elaboração dos projetos, contratados pela própria construtora ou pelo cliente, foram desenvolvidos por empresas terceirizadas de projeto de organizações distintas.

Basedo nas três situações identificadas por Melhado et al. (2005) quanto à possibilidade de interação entre coordenação de projetos e coordenação da execução de obras, mencionado na Quadro 6 do capítulo 2, verificou-se que além do escopo de contratação da empresa construtora, o tipo de relação com o cliente, fornecedores e gerenciadora tem grande influência nesta interação.

Apesar de não ter participado do planejamento do empreendimento, além da execução da obra, a construtora do estudo de caso $\mathrm{B}$, foi contratada pelo usuário final para a contratação de todas disciplinas necessárias (com exceção da arquitetura) e acompanhamento do desenvolvimento dos projetos desde sua concepção. Desta forma, a equipe de projetos da construtora pôde agregar ao projeto seu conhecimento na busca de soluções para redução de prazo e custo da obra. Apesar da existência de duas gerenciadoras, a interação entre coordenação 
de projetos e produção foi grande, pois como a contratação dos projetistas foi conduzida pela construtora, o contrato de algumas especialidades já previa visitas à obra e contato direto com os projetistas e consultores, o que agilizou a solução de problemas da obra.

No estudo de caso A, a empresa foi contratada após definido o produto, mas como havia participado do estudo de viabilidade econômico-financeiro na fase de pré-obra para auxiliar o cliente no pré-orçamento do empreendimento, teve uma interação maior com os projetistas. Desta forma, ao desenvolver, sem contrato assinado, alternativas em parceria com o projetista de instalações na fase de concorrência, atingiu o valor alvo necessário para sua contratação para execução da obra. No decorrer da obra, a gerenciadora participava das reuniões para definições de projeto em conjunto com a construtora, permitindo que esta fizesse consultas diretas aos projetistas.

No estudo de caso $C$, a empresa foi contratada apenas para execução da obra, sem participação do desenvolvimento e coordenação dos projetos. Devido ao tipo de contrato, todo o contato com o cliente ou projetistas era feito através da gerenciadora, que atuava como mediadora, o que reduziu a interação entre coordenação de projetos e produção. Como o principal desafio da obra era o prazo, o impacto deste procedimento prejudicou a equipe da obra, pois muitas vezes as respostas às solicitações não atendiam à obra da melhor forma (conteúdo ou tempo necessário para resposta). Esta situação foi agravada, pois como a fase de projeto se estendeu muito, quando a obra teve início já havia um desgaste por parte dos projetistas, que não tinham em seu escopo de contratação reuniões ou visitas à obra.

Foi verificado que existe grande interação das construtoras com os fornecedores de sistemas construtivos, materiais, etc, na fase de elaboração de proposta, quando são feitas as análises de engenharia de valor sobre o projeto recebido do cliente com o objetivo de propor novas soluções técnicas para otimização de prazo de execução e redução de custos. O envolvimento dos projetistas, em geral, só ocorre após a contratação da construtora.

No estudo de caso $\mathrm{C}$, houve o envolvimento do fornecedor no desenvolvimento do projeto por intermédio do consultor de caixilhos. Este envolvimento facilitou sua contratação para a fornecimento dos caixilhos, e a interação entre projetista 
(arquiteto - autor do projeto), consultor e fornecedor antes do início da obra, evitando modificações de detalhes de projeto que poderiam ser necessárias no caso da contratação de outro fornecedor.

Foi constatado que a certificação ambiental das edificações é um aspecto que acrescentou novas variáveis tanto ao projeto e especificações, como às premissas de execução da obra e fornecimento de materiais, e teve um impacto direto na obra (suprimentos, produção). No estudo de caso $\mathrm{C}$, ao analisar o organograma da obra, constata-se que a quantidade de recursos da equipe responsável pelo gerenciamento e controle da qualidade, responsável pela gestão do processo de certificação, equipara-se à equipe de produção da construtora. A relação entre os agentes também é alterada, a partir da contratação de um consultor de sustentabilidade que passa a definir requisitos que devem ser atendidos pelos projetistas e construtora para obteção da certificação. No estudo de caso $\mathrm{A}$, itens de projeto já contratados tiveram que ser alterados para atender às exigências da certificação.

\section{Facilitadores e barreiras para gestão do conhecimento}

Foram identificados como facilitadores da gestão do conhecimento nas empresas A, B e C:

- Apoio da alta administração (nível estratégico) para algumas das iniciativas individuais de gestão do conhecimento iniciadas pelos departamentos da empresa (nível tático ou operacional);

- Existência de aplicações de TI (extranet, intranet, programas) que podem facilitar a divulgação das informações e conhecimento na empresa;

- Existência de um departamento (PMO) responsável pelo estímulo à utilização e treinamento do SharePoint e ferramentas de gestão e divulgação de melhores práticas;

- Existência de um sistema colaborativo que disponibiliza os modelos de ferramentas de gestão de Projetos e de coordenação de projetos; 
- Estrutura contratual: o contrato permitia que a construtora tivesse livre acesso aos projetistas e consultores contratados pelo cliente, o que facilitou a comunicação entre projeto e produção;

- Alta capacidade de absorção do cliente, fornecedores e de alguns funcionários facilita a transmissão de conhecimento entre empresas e entre diferentes Projetos;

- Mecanismos de aprendizagem organizacional desenvolvidos por iniciativa de alguns departamentos (exemplo: Curso de Patologias, Memória Técnica, Jornal Interno).

No Quadro 30, foram compiladas as principais barreiras encontradas na implantação das iniciativas de gestão do conhecimento, mencionadas pelos entrevistados na coleta de dados, e outras barreiras detectadas ao analisar os dados dos estudos de caso.

\section{Barreiras mencionadas pela empresa}

- Resistência das pessoas para aprender e utilizar novas ferramentas;

- Resistência à mudança de procedimentos que fazem parte de sua rotina;

- Pouco tempo disponível para a pessoa se dedicar a aprender coisas e procedimentos novos;

- Muitos funcionários novos;

- Grande rotatividade de funcionários;

- Integração do sistema existente com o novo sistema;

- Tempo necessário para produção do material exigido pelo novo processo;

- Tempo para adaptação dos funcionários as mudanças de procedimentos que fazem parte de sua rotina;

- Algumas iniciativas envolvem o esforço e a contribuição de diversas áreas da empresa;

- Memória Técnica é um canal para divulgação de informações, mas como as pessoas não são obrigadas a utilizar é preciso criar um hábito nos funcionários;

- Por falta de orientação, no início o registro de Lições Aprendidas foi associado pelas equipes de obra como "caça as bruxas";

- Retrabalho dos monitores para revisão e correção de processos muitos detalhados e com muitas informações desnecessárias no PRqd;

- No início, não foi esclarecido aos usuários os objetivos do PRqd, o que dificultou sua assimilação. Posteriormente, foi criado o item de Indicadores, estabelecendo quais são os critérios de monitoramento dos processos;

- O monitor também deve disponibilizar tempo para dar apoio ao usuário do PRqd, além de suas atividades diárias;

- No início, os funcionários deixavam para atualizar os dados no PRqd no último dia obrigatório e tinham problemas com acesso ao sistema; 
- Problemas de infra-estrutura podem impactar negativamente, causando dificuldade ao usuário e consequentemente, pouca aderência;

- Como não houve um planejamento de TI, o sistema existente não suportava o acesso de muitos usuários simultaneamente e ficava lento, o que causa reclamação dos usuários;

- O sistema foi implantado baseado em uma avaliação quantitativa, onde o monitor verifica apenas se os processos foram realizados e postados no sistema na data pré-estabelecida. Ainda não há uma avaliação qualitativa do que foi produzido;

- Alguma resistência foi observada em funcionários novos que, às vezes, traz vícios de outra empresa ou pessoas que não utilizavam os procedimentos como a maioria;

- Dificuldade em definir a ferramenta de TI mais adequada para o PRqd;

- Além da implantação é necessário treinamento para garantir utilização adequada: os usuários estavam publicando o Planejamento Executivo depois de iniciar a execução da atividade na obra;

- Algumas iniciativas dependem de contratação do serviço (exemplo BIM).

\section{Barreiras detectadas no estudo de caso}

- Alto grau de centralização da empresa influencia a forma de divulgação das informações e conhecimento na empresa (o sistema não permite o compartilhamento de informações sobre desempenho de uma obra para outra);

- Datas de postagens obrigatórias e necessidade de grande quantidade de registros somados às atividades de rotina pode desmotivar a equipe;

- Não existe um processo estruturado para retroalimentação dos projetistas terceirizados e novos projetos;

- Sem orientação adequada o objetivo das Lições Aprendidas pode não ser assimilado de forma correta pelos funcionários gerando um material sem efeito para a organização;

- Não há um processo de aprendizado contínuo e sistematizado de transferência de conhecimento de um Projeto para outro;

- Falta de motivação das equipes de obra (não foi identificado formas de incentivo);

- Falta de recursos financeiros (apesar do apoio, a alta administração nem sempre disponibiliza recursos suficientes);

- Dificuldade em quantificar os ganhos com as iniciativas de gestão do conhecimento para avaliar os impactos nos negócios da empresa;

- Falta de ferramentas para busca de competências internas (pessoas);

- Como transformar o conhecimento tácito em memória organizacional e transmitir melhores práticas a todos (foi detectado pela Assistência Técnica da Empresa A que alguns problemas patológicos estavam associados a determinados gerentes, independente do tipo de obra).

Quadro 30 - Barreiras encontradas pelas empresas no decorrer da implantação de suas iniciativas de gestão do conhecimento e detectadas no estudo de caso

O portifólio das empresas, composto por diversas obra complexas, comprova que há o domínio do conhecimento técnico. Além dos aspectos tecnológicos focados na execução ou equipamentos, para atender às demandas de prazo do mercado e alto desempenho, as construtoras têm empregado soluções diferenciadas de engenharia que poderiam ser assimiladas pelos projetistas nas fases de concepção do projeto 
evitando a necessidade de adaptações do projeto às novas tecnologias na fase de obra (por exemplo: banheiro pronto, sistemas unitizado de fachada).

A partir dos estudos de caso, verifica-se que os pontos onde houve uma maior integração entre projeto-produção (cliente, projetista, construtor, fornecedor) podem ser benéficos para todos os envolvidos ao antecipar os conflitos, disseminar as informações de projeto aos responsáveis pela obra e vice-versa, favorecendo a retroalimentação dos projetos e ampliando as competências dos projetistas ao compartilhar experiência com equipe de produção.

As três empresas tem consciência da importância da gestão do conhecimento, que não consiste apenas em sistemas colaborativos para agilizar a comunicação, mas faltam indicadores para medir a eficiência das iniciativas em curso e justificar a necessidade de recursos financeiros para a alta direção.

Nas estruturas projetizadas, a experiência das empresas é fundamental para o bom planejamento e execução. Os processos de Lições Aprendidas devem ser sistemáticos, como na Empresa $A$, e não apenas ao término da obra, mas com objetivos claros para evitar o acúmulo de "lições perdidas" e desestimular a contribuição das equipes. É importante definir e divulgar a todos a estrutura do sistema de armazenamento e gestão para facilitar o acesso e busca para novos Projetos (alinhado ao ciclo de vida do projeto, por temas, por disciplina).

Além das atividades de aquisição e retenção do conhecimento, deve ser dado maior ênfase às atividades de recuperação e uso do conhecimento (aplicação das Lições Aprendidas) para evitar utilização indevida, como detectado na Empresa B, no qual o Planejamento estava sendo realizado após a realização dos serviços. 


\section{CONCLUSÕES E PROPOSIÇÕES}

As principais atividades da cadeia de valor da construção de um empreendimento imobiliário envolvem a criação física do produto: aquisição do terreno, projeto, construção, marketing, entrega ao cliente e serviço pós-venda.

O projeto, ao permear todo o ciclo de vida do empreendimento, pode atuar como meio de comunicação entre todos agentes envolvidos e registro dos requisitos do cliente, restrições legais e normativas, com informações técnicas necessárias para a definição do custo global do empreendimento e concretização da obra, além de impactar na qualidade do produto final, produtividade da execução, vida útil do edifício e influenciar nos custos da manutenção e operação. Desta forma, deveria ser entendido, não como um custo, mas como um investimento, cujo retorno será refletido na melhor qualidade do produto gerado e maior eficiência da produção.

No caso de empresas construtoras que trabalham com produtos de vários segmentos, não repetitivos, não é possível sistematizar informações, padronizar processos e componentes que são adotados como premissas nos projetos de novos produtos de determinado segmento de atuação. Por não atuar diretamente na tomada de decisão sobre a definição do produto final do empreendimento, e, em geral, receber os projetos com o produto totalmente definido pelo cliente, o valor agregado pela construtora ao projeto será proveniente da interação entre os agentes.

Com a entrada de novos concorrentes de menor porte no mercado da construção, com custos competitivos, as construtoras de maior porte, como as pesquisadas nos estudos de caso, têm oferecido novos serviços a seus clientes como forma de diferenciação, agregando outras atividades, não restritas apenas à execução da edificação, como é o caso da coordenação de projetos, engenharia de valor e assessoria de sustentabilidade, para justificar seus preços mais elevados. Verificouse a concentração das atividades das empresas dos estudos de caso de acordo com suas competências essenciais (gestão da produção), com algumas atividades paralelas visando desenvolver novas competências para aumento da competitividade, como o Núcleo de Modelagem BIM, estruturado pela Empresa A para oferecer novos serviços aos clientes. 
Com Projetos cada vez mais complexos, equipes multifuncionais de empresas com vários ambientes culturais, organizacionais e diferentes níveis de conhecimento, 0 bom desempenho do empreendimento depende de diversos fatores, entre eles: a gestão eficiente dos processos; a comunicação eficaz entre todos envolvidos; a integração entre os agentes, conciliando seus diversos interesses nos resultados do Projeto e a gestão do conhecimento.

Ao implantar um sistema de gestão do conhecimento focado não apenas na execução da obra, as construtoras poderiam demonstrar ao cliente a possibilidade de ampliar a criação de valor do projeto, como ilustrado na Figura 75 , ao compartilhar seu conhecimento de engenharia com as equipes envolvidas desde a fase de desenvolvimento dos projetos, além de minimizar estruturas e processos ineficientes que têm como consequência o retrabalho, desperdício, repetição de erros, muito frequentes na construção, e o surgimento de patologias. Uma eventual inconsistência de alinhamento entre as necessidades do cliente pode levar à destruição de valor ao adotar-se soluções de projeto acima das expectativas (refletindo em aumento de custo e prazo previstos).

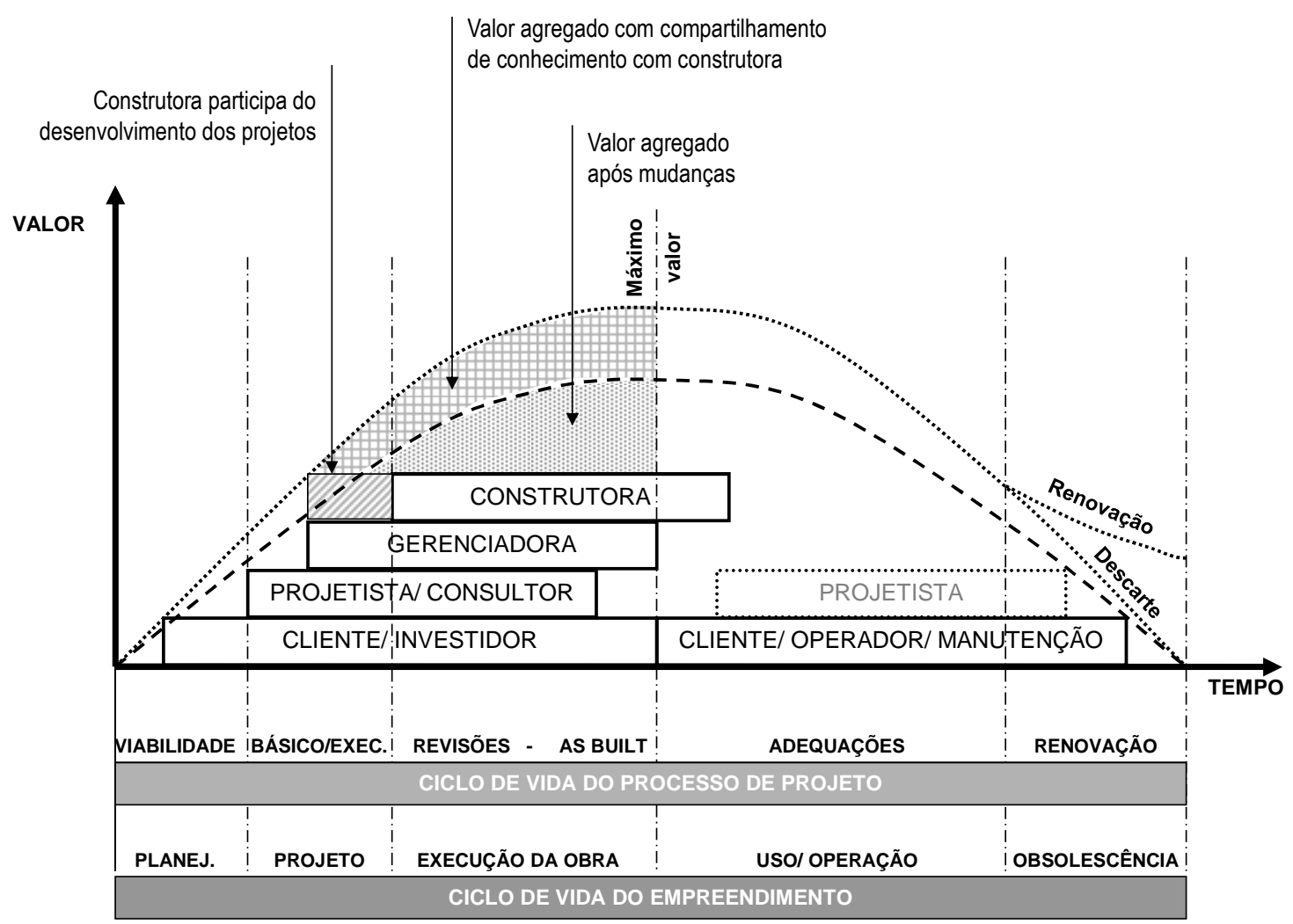

Figura 75 - Comparativo de fluxo de valor do projeto com atuação da construtora a partir da fase de Desenvolvimento dos projetos ou apenas na fase de Execução da Obra 
O conceito de qualidade do projeto evoluiu passando a incorporar questões, não apenas relacionadas ao planejamento e controle eficazes do processo de projeto, mas incorporando a análise dos impactos sobre a vida útil da edificação, construtibilidade, sustentabilidade, entre outros. Neste cenário, a integração e colaboração entre projeto-construção-operação, durante o processo de projeto e entre vários Projetos, aliada à retroalimentação como mecanismo de aprendizagem organizacional, figura como peça fundamental para melhoria contínua dos projetos agregando valor à toda a cadeia do setor.

O projeto deve atender a diversos requisitos, como mostra a Figura 76. Do ponto de vista da sustentabilidade, o processo de interação entre as equipes para desenvolvimento do projeto do produto, ao longo do ciclo de vida do empreendimento, tem o potencial de compartilhar e gerar novos conhecimentos. Com o objetivo de maximizar a eficiência na fase de uso, ao prolongar a vida útil da fase de operação e manutenção, o projeto deve buscar um edifício de maior durabilidade, aliado à flexibilidade, manutenibilidade, adaptabilidade à mudanças sociais, eco-eficiência, desempenho e facilidade de uso pelo usuário. Como constatado nos estudos de caso, para atendimento aos requisitos das certificações ambientais podem ocorrer adequações de projeto e desenvolvimento de materiais por parte dos fornecedores, propiciando geração de novo conhecimento.

\section{- Durabilidade \\ - Flexibilidade \\ - Manutenabilidade \\ - Adaptabilidade à mudanças sociais \\ - Facilidade de uso pelo usuário \\ - Eco-eficiência \\ - Desempenho}

\section{SUSTENTABILIDADE}

\author{
SUENTABILIDADE
}

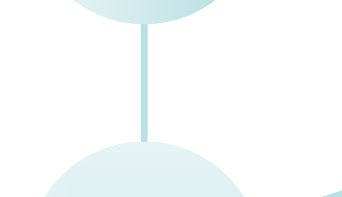

\section{CLIENTE}

\section{PROJETO}

- Atendimento à normas

- Restrições legais

\section{CONSTRUÇÃO}

FORNECEDOR

- Construtibilidade

- Especificações técnicas
- Atendimento à demanda de mercado

- Custo

- Retorno de investimento

- Desempenho financeiro

\section{Figura 76 - Requisitos do projeto}


Para a empresa construtora garantir uma vantagem sustentável, além do posicionamento, é necessário: fazer escolhas; garantir a integração do conjunto de atividades da empresa e rever sistematicamente o conhecimento organizacional para proteger-se de imitações dos concorrentes; promover a colaboração e o compartilhamento de idéias; "esquecer" conhecimentos antigos que se tornaram obsoletos para adaptar-se às mudanças de mercado e potencializar as competências da empresa que podem ser perdidas, caso o foco da empresa seja, por exemplo, apenas o retorno aos acionistas, como ilustrado na Figura 79.

A gestão do conhecimento, se alinhada à estratégia da empresa, pode agregar valor aos negócios atuais e propiciar inovação com novos negócios, com a flexibilidade necessária para acompanhar as mudanças do ambiente (tecnológicas e do mercado).

Partindo do princípio de que o conhecimento é uma competência essencial das empresas de projeto e construtoras, a gestão do conhecimento aplicada ao processo de projeto pode contribuir no atendimento aos requisitos dos investidores, clientes e usuários e na melhoria do desempenho do empreendimento. Melhoria obtida através da criação de valor agregado ao projeto, obra e operação, e entre Projetos; otimização de processos para aumento da eficiência operacional e redução de prazo e custo; compartilhamento eficiente de informações entre Projetos e a cadeia de suprimentos; aumento da base de conhecimento corporativo (memória organizacional); estímulo de competências essenciais e desenvolvimento de novas competências; desenvolvimento de soluções para melhoria da construtibilidade; planejamento da manutenção na fase de projeto para garantia da qualidade de uso e operação do edifício; incorporação de informações sobre durabilidade e manutenibilidade no processo de projeto; retroalimentação para evitar repetição de erros, minimizando problemas que podem influir negativamente no resultado do empreendimento (incompatibilidade entre projetos ou falta de informações; estruturas e processos ineficientes; revisões e modificações de projeto tardias; falhas de projeto que geram retrabalho, desperdício e patologias).

Com base na literatura pesquisada, os requisitos para gestão do conhecimento na construção podem ser discutidos em duas categorias inter-relacionadas: a gestão do conhecimento entre Projetos e a gestão do conhecimento entre as empresas envolvidas. Vale destacar que o conhecimento gerado pela interação entre agentes 
em cada Projeto, de diferentes segmentos, com característica única e com uma organização virtual temporária para seu desenvolvimento, conforme indicado na Figura 77, também requer uma gestão eficiente e eficaz para que seja incorporado à memória organizacional da empresa com a externalização do conhecimento tácito em conhecimento explícito, através de modelos, detalhes, procedimento, lições aprendidas para disseminação e utilização em outros Projetos.

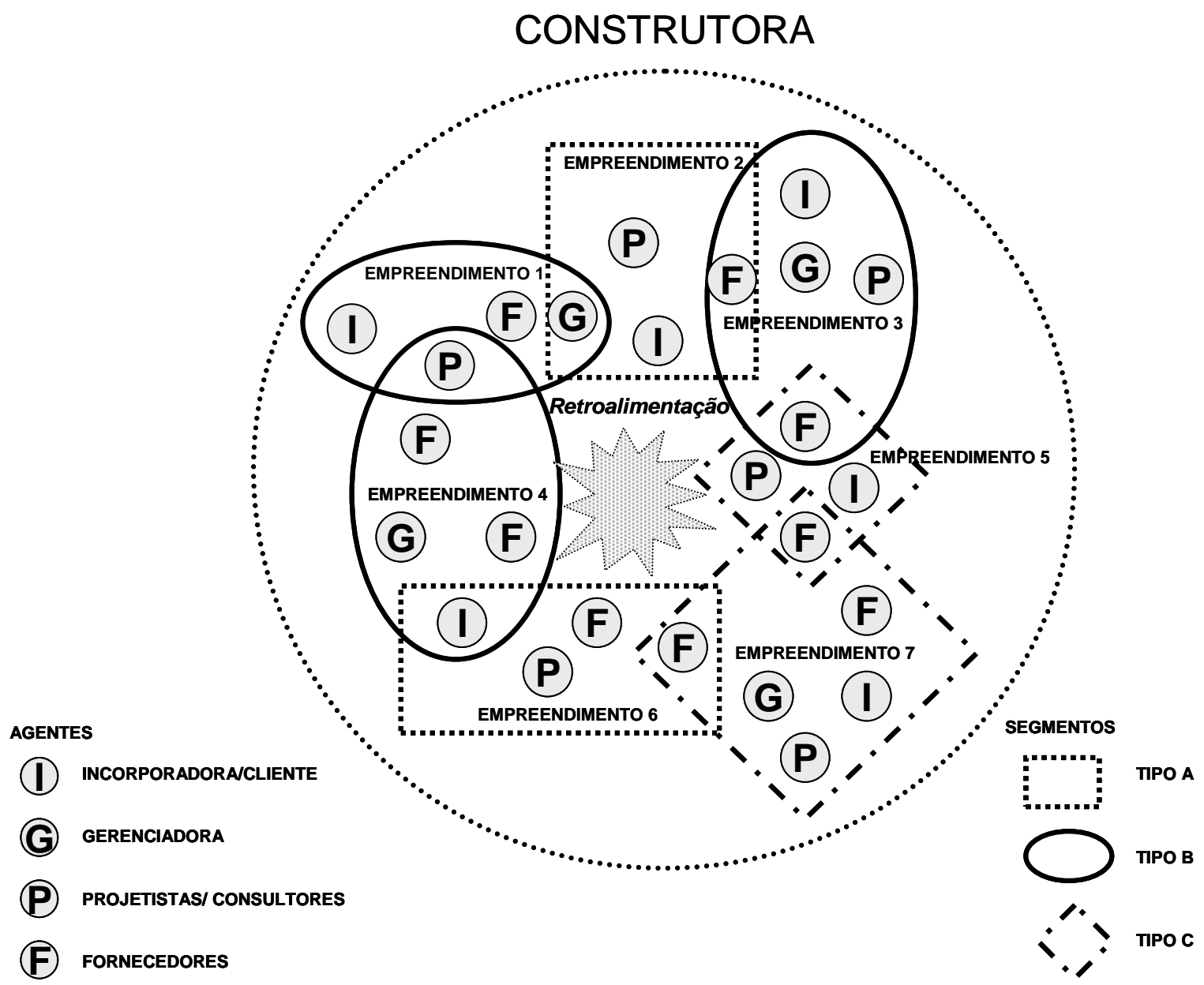

Figura 77 - Projetos (empreendimentos) de segmentos diversos realizados pela construtora e interação entre agentes

Os Projetos cruzam com as Operações ${ }^{12}$ em vários pontos durante o ciclo de vida do produto. Nestes pontos ocorre a transferência de entregas, conhecimentos ou recursos entre o Projeto e as Operações para viabilizar a entrega do trabalho.

\footnotetext{
${ }^{12}$ Projetos: Atividades organizadas para atingir o plano estratégico da empresa. Operações: Esforços permanentes para execução de atividades contínuas que produzem o mesmo produto ou serviços, como por exemplo equipe de manutenção preventiva ou equipe de produção da obra.
} 
Como verificado no estudo de caso da Empresa A, o manual de comissionamento elaborado pela equipe de projeto e instaladora da obra, com informações sobre os sistemas e equipamentos instalados, será utilizado pela equipe de manutenção do edifício na fase de Uso e Operação. A integração da Assistência Técnica com a área de gestão de Facilidades da Empresa C visou combinar a experiência dos profissionais das duas unidades para responder às oportunidades de novos Negócios em Manutenção Volante no mercado de facilities (facilidades); fortalecer parcerias com clientes oferecendo serviços após o término do período de garantia; desenvolver processos e relatórios periódicos e criar históricos para consulta das áreas de engenharia, suprimentos (avaliação de fornecedores) e orçamentos (verbas de garantia). Este ponto poderia ser mais explorado pela empresa, envolvendo equipes de manutenção para transmissão de seu conhecimento às equipes de projetos.

Como o processo de projeto permeia todas as fases do ciclo de vida do empreendimento representa um importante meio de transferência de informação e conhecimento entre as fases do ciclo de vida do Projeto, marcadas pela conclusão de um ou mais resultados principais (um estudo de viabilidade, um desenho ou um protótipo) e entre as fases do ciclo de vida do empreendimento, com a possibilidade de compartilhamento de conhecimento e valor criado através de aspectos técnicos, de gestão e econômicos do Projeto. A Figura 78 mostra os fluxos de transferência do conhecimento na construção: entre Projetos, entre fases do ciclo de vida do Projeto, entre empresas e agentes.

Ao passar para a fase de Obsolescência, quando cessa a criação de valor ao usuário, pode ter início um processo de reciclagem em que será desenvolvido um novo empreendimento através da renovação, re-uso da edificação existente ou demolição para nova construção. Nesta fase o conhecimento e esforços da equipe devem ser direcionados para a redução dos impactos ambientais negativos, tais como uma demolição total, buscando alternativas para a renovação do edifício, como o estudo de caso da Empresa C. 


\section{Agentes e Comunicação/ Integração/ Colaboração}

Como grande parte das decisões tomadas na fase de concepção do projeto poderá afetar o ciclo de vida do empreendimento até a fase de operação/ manutenção, o projeto tem um papel importante como síntese do conhecimento gerado pela equipe, e meio de transmissão de conhecimento entre as etapas subsequentes, onde ficam armazenadas as novas soluções ou revisões decorrentes da melhoria dos processos ou mudanças de escopo do cliente, como mostrado na Figura 78.

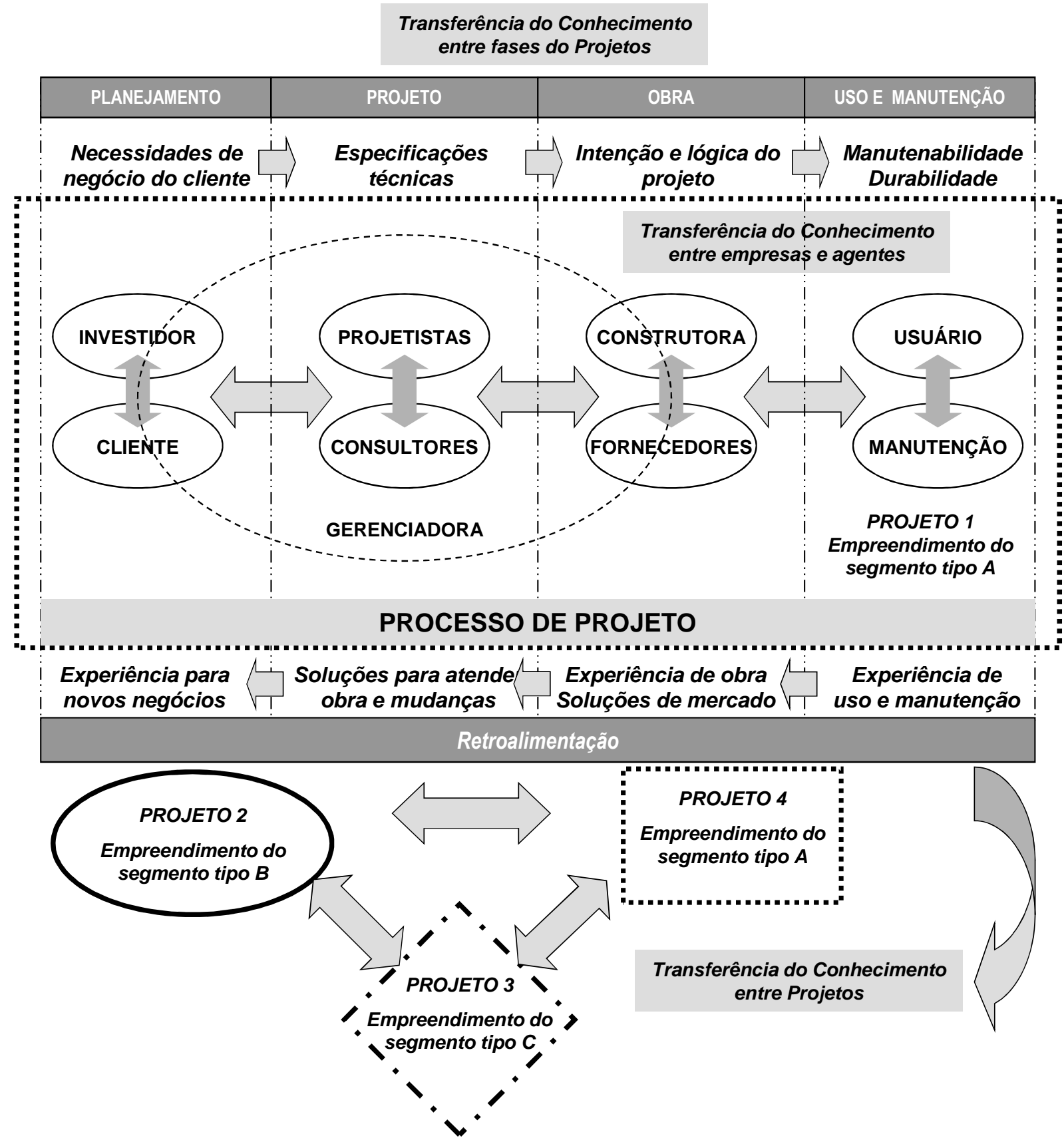

Figura 78 - Fluxos de transferência do conhecimento: entre Projetos 1, 2, 3 e 4 (empreendimentos), entre fases do ciclo de vida do Projeto, entre empresas e agentes 
A contratação de uma gerenciadora para desenvolvimento do empreendimento ou gestão da obra, assim como o arranjo funcional da equipe (gerenciadora como mediadora, como construtor ou único ponto de contato com o cliente), depende, em grande parte, das características do cliente (experiência no ramo, competências internas, complexidade da organização, confiança do empreendedor em relação à construtora). Além de promover uma relação harmoniosa com as equipes gerando um ambiente propício ao crescimento do trabalho em equipe, dependendo de sua forma de atuação, a gerenciadora estará envolvida com a proposição de alternativas técnicas e avaliação do impacto nos custos e prazos.

O estudo de caso apresentou evidências de que a interação entre agentes das diversas organizações envolvidas no processo de projeto (projetistas, construtora, cliente, fornecedores) em todo o ciclo de vida do empreendimento, além de antecipar os conflitos e disseminar as informações de projeto aos responsáveis pela obra, tem um enorme potencial de geração de novo conhecimento tácito. Verificouse que diversos fatores podem impulsionar esta interação, tais como dúvidas no dia a dia de execução da obra, reuniões de acompanhamento de projeto, solução de problemas de construtibilidade, atendimento a exigências de certificação de sustentabilidade, inclusive mudança de escopo do cliente. Nos contratos de preço fixo, no qual o construtor assume a maior parte dos riscos técnicos e pecuniários da construção, é possível propor ao cliente alternativas técnicas e econômicas para redução de prazo ou custo da obra, baseadas em experiência ou negociação com fornecedores. No entanto, a retroalimentação dos projetos, que poderia ser favorecida por esta integração, ampliando as competências dos fornecedores e projetistas, não é um processo estruturado e depende, principalmente, da disposição dos projetistas em assimilar o conhecimento tácito gerado no decorrer da obra.

O contato face-a-face em reuniões para desenvolvimento e resolução de problemas de projeto ou para registro e apresentação de lições aprendidas foram identificados como melhores canais de comunicação para compartilhar conhecimentos relacionados ao processo de projeto, tanto para equipes de gestão, projeto e obra.

Foi constatado que a necessidade de interação entre projeto e obra aumenta à medida que aumenta a quantidade de problemas imprevistos e mudanças. No entanto, além das atas de reunião, não foi identificado um processo estruturado para registro e disseminação do conhecimento gerado ao solucionar problemas de projeto 
ou melhoria da construtibilidade no decorrer da obra. O foco dos registros de mudanças são, basicamente, para controle de custos.

O arranjo funcional da equipe de projeto e construção, assim como a estrutura do contrato firmado com as empresas influi na forma de comunicação, que constitui um item importante para estimular ou dificultar sua interação. O contato direto entre construtora e projetistas propicia uma troca de conhecimento que pode ser reduzida no caso de um gerenciador como mediador. Enquanto situações em que o gerenciador participa de reuniões com a construtora e projetistas, propicia maior possibilidade de transferência de conhecimento tácito que pode gerar novos conhecimentos a partir das experiências individuais dos participantes. Em obras com prazo reduzido, como no estudo de caso da Empresa $\mathrm{C}$, a mediação do gerenciador deve garantir a qualidade e prontidão no retorno das informações do projeto para a equipe de produção a fim de evitar impactos no cronograma de execução da obra.

O sucesso de um contrato depende da escolha de um modelo de comunicação entre os participantes que permita a integração e colaboração necessárias para acrescentar o conhecimento de cada parte às metas e objetivo comuns do Projeto, e não apenas metas individuais.

\section{Sistemas e tecnologias de informação (TI)}

Os sistemas de $\mathrm{TI}$ utilizados pelas empresas analisadas para armazenamento de documentos, informações e padrão de projetos (que inclui desenhos, especificações, correspondências, procedimentos, manuais), e que podem ser compartilhados externamente (via extranet), atendem às necessidades de acessibilidade às informações (armazenamento e transmissão) para aplicação em novos Projetos, e comunicação dos envolvidos (clientes, contratados e fornecedores).

As ferramentas colaborativas, principalmente baseadas na internet, têm contribuído para facilitar a comunicação e estruturar o compartilhamento de informação entre os envolvidos no processo de projeto.

A utilização de programas para a modelagem de informações do edifício baseado na modelagem 3D paramétrica (BIM), contendo toda documentação dos projetos de 
todas as disciplinas integrada em um banco de dados, permitirá explorar alternativas de projeto com dados para análise de custo apoiando o processo decisório tanto na fase de projeto como de uso do edifício. No Brasil, a implantação do BIM ainda encontra-se em caráter incipiente nas construtoras e escritórios de projeto e depende da interoperabilidade entre diferentes soluções e sistemas, qualificação de equipes e desenvolvimento das bibliotecas de componentes para efetiva utilização e disseminação no setor.

Constatou-se que a estratégia focada em TI para desenvolvimento das ferramentas de gestão do conhecimento deve ser equilibrada com atividades com foco nas pessoas e no conhecimento gerado ao longo do processo de projeto, estimulando a troca de experiência entre os membros da equipe do projeto, fornecedores e obra (registro e divulgação de melhores práticas e lições aprendidas).

Nas iniciativas de gestão do conhecimento identificadas, o foco das equipes envolvidas foi prioritariamente com o conteúdo e não ferramentas de TI, principalmente, por falta de recursos e inexperiência.

Além de disponibilizar as ferramentas de gestão do conhecimento (procedimentos operacionais padrão, sistemas de qualidade, ferramentas colaborativas para facilitar o compartilhamento do conhecimento) incorporados à sistemas de gestão integrados, deve ser dado ênfase aos treinamentos para capacitação e estímulo das equipes para garantir sua utilização, além de definir profissionais mais experientes para orientar as pessoas, monitorar os processos, e divulgar as melhores práticas identificadas.

\section{Mudanças e risco}

A maior parte das obras do portifólio das empresas analisadas faz parte do subsetor de obras empreitadas, com projetos diferenciados, onde a harmonização do projeto com as necessidades da produção (obra) figura como ponto importante para atendimento aos prazos e custos planejados.

A gestão do processo de projeto já está incorporada às competências internas das construtoras do porte das empresas analisadas nos estudos de caso, não só como 
estratégia de competitividade, mas para redução dos riscos associados aos projetos. Além do aumento da complexidade tecnológica que exige profissionais tecnicamente capacitados, a complexidade gerencial aumenta a medida que os projetos são modificados diversas vezes, principalmente, após o início da obra. As mudanças de escopo de trabalho no decorrer da obra podem gerar riscos que, caso não sejam identificados prontamente, podem acarretar em dificuldade no cumprimento dos prazos da obra ou aumento de custo, que nos contratos de preço fixo afetam o resultado da obra. Conforme constatado nos estudos de caso, a maior fonte de mudanças está relacionada ao processo decisório do cliente, que oscila para atender a demandas do mercado (aumento de potencial de área construída); necessidades de futuros locatários; exigências de investidores (especificação de materiais mais nobres ou importados para valorar o empreendimento); valorização do negócio (certificação de sustentabilidade); restrições comerciais (alternativas para redução de custo da obra para aumentar retorno aos acionistas); demandas operacionais internas (no caso de cliente-usuário). Desta forma, a gestão dos riscos constitui um aspecto fundamental, que deve ser monitorado pela construtora aliado a um controle de mudanças, principalmente em contratos de preço fixo.

Fatores que influenciam o processo de projeto tais como: o método de seleção das equipes; o sistema contratual adotado que define as relações contratuais e funcionais entre os agentes, cultura, estilo e estrutura organizacional; grau de maturidade da empresa em gestão de Projetos e ativos de processos organizacionais, podem influenciar os processos de gestão do conhecimento, assim como a alocação de riscos de acordo com o sistema contratual adotado. Os ativos de processos organizacionais podem ser agrupados em duas categorias: processos/ procedimentos para a condução do trabalho (normas, diretrizes, políticas, modelos) e a base de conhecimento corporativo para armazenamento e recuperação de informações (banco de dados, arquivos do Projeto, informações históricas e lições aprendidas).

A complexidade dos processos na construção envolve várias incertezas e tomadas de decisão que geram mudanças inevitáveis ao longo do processo de projeto e impactam diretamente na gestão da obra e do empreendimento.

As empresas devem estar preparadas para gerenciar e aprender com as mudanças, que nem sempre tem consequências negativas. Ao deparar com um problema, 
através da interação com a equipe de obra, os membros da equipe de projeto podem encontrar uma nova solução melhor que a original gerando novo conhecimento.

\section{Conhecimento organizacional/ Transmissão de melhores práticas}

Em todas as fases do ciclo de vida do empreendimento foram identificadas práticas de gestão do conhecimento referentes aos principais processos de aprendizagem e gestão do conhecimento analisados: Recuperação e Uso do conhecimento/ Criação de novo conhecimento/ Aquisição de conhecimento/ Retenção do conhecimento/ Compartilhamento de conhecimento, conforme descrito na Análise comparativa dos estudos de caso do capitulo 5. No entanto, a característica fragmentada do setor da indústria da construção, baseada na relação temporária entre os envolvidos, reflete diretamente no aprendizado. Não há uma estrutura planejada para incorporar o conhecimento tácito, muitas vezes gerado de forma incidental, à memória das organizações e tão pouco do setor. A gestão do conhecimento deveria ser aplicada para armazenar, gerenciar, atualizar e, principalmente, disponibilizar e disseminar, formal ou informalmente, o conhecimento (tácito e explícito) a todos os agentes da cadeia da construção, possibilitando um processo de aprendizado sistemático e contínuo.

Como a transferência de conhecimento está muito relacionada à experiência das pessoas e empresas envolvidas em cada Projeto, ressalta-se a importância da transmissão de melhores práticas.

Seminários e fóruns de discussão promovidos por entidades de classe ou organizações que atuam em diferentes áreas do setor são importantes para disseminar boas práticas e compartilhar informações com diversas empresas. Mas, em geral, os representantes das empresas participantes são membros da alta direção ou do escritório central (como por exemplo: suprimentos, sustentabilidade) que podem não estar totalmente familiarizados com a realidade da equipe de produção e todas suas particularidades. É importante que o resultado dos encontros sejam divulgados internamente à toda organização, não limitando-se a um grupo restrito de pessoas para que seja incorporado ao conhecimento organizacional e 
possa ser compartilhado e assimilado por diversas áreas da empresa, evitando "nichos de conhecimento".

Independente da estratégia adotada para gestão do conhecimento é importante manter o conteúdo (conhecimento explícito) armazenado nos sistemas integrados das empresas constantemente atualizado e criar oportunidades para disseminar o conhecimento tácito, principalmente gerado nas obras de cada empreendimento, para que seja posto em ação ao ser aplicado em outros Projetos, resultando em retorno à organização, aumentando sua eficiência e eficácia, conforme esquematizado na Figura 79.

Como verificado nos estudos de caso, a atuação da construtora na fase de desenvolvimento dos projetos, tem grande potencial para fomentar a geração de novo conhecimento ao transmitir e compartilhar sua experiência com os demais agentes do processo através da:

- Engenharia de valor;

- Interação entre equipes de projeto e obra;

- Interação com fornecedores e consultores especializados (fontes externas);

- Disseminação de lições aprendidas;

- Retroalimentação da Assistência Técnica.

O conhecimento acumulado ao longo do processo de projeto deve ser codificado em detalhes, especificações e desenhos para utilização em novos Projetos, assim como as lições aprendidas.

Como a cultura organizacional influencia o comportamento dos indivíduos e dos grupos presentes na organização, a empresa deve verificar se os valores compartilhados pelos membros são condizentes com os objetivos estratégicos da organização. Quanto mais membros aceitarem os valores essenciais da organização, maior será o seu comprometimento com eles e mais forte será a cultura. Em uma cultura comprometida com o compartilhamento de conhecimento, as equipes devem ser incentivadas a divulgar as soluções inovadoras, assim como encorajadas a aprender com as experiências passadas, não focando apenas no sucesso ou fracasso. É importante esclarecer a todos que o aprendizado pode vir de uma experiência direta, com soluções encontradas na obra para superar 


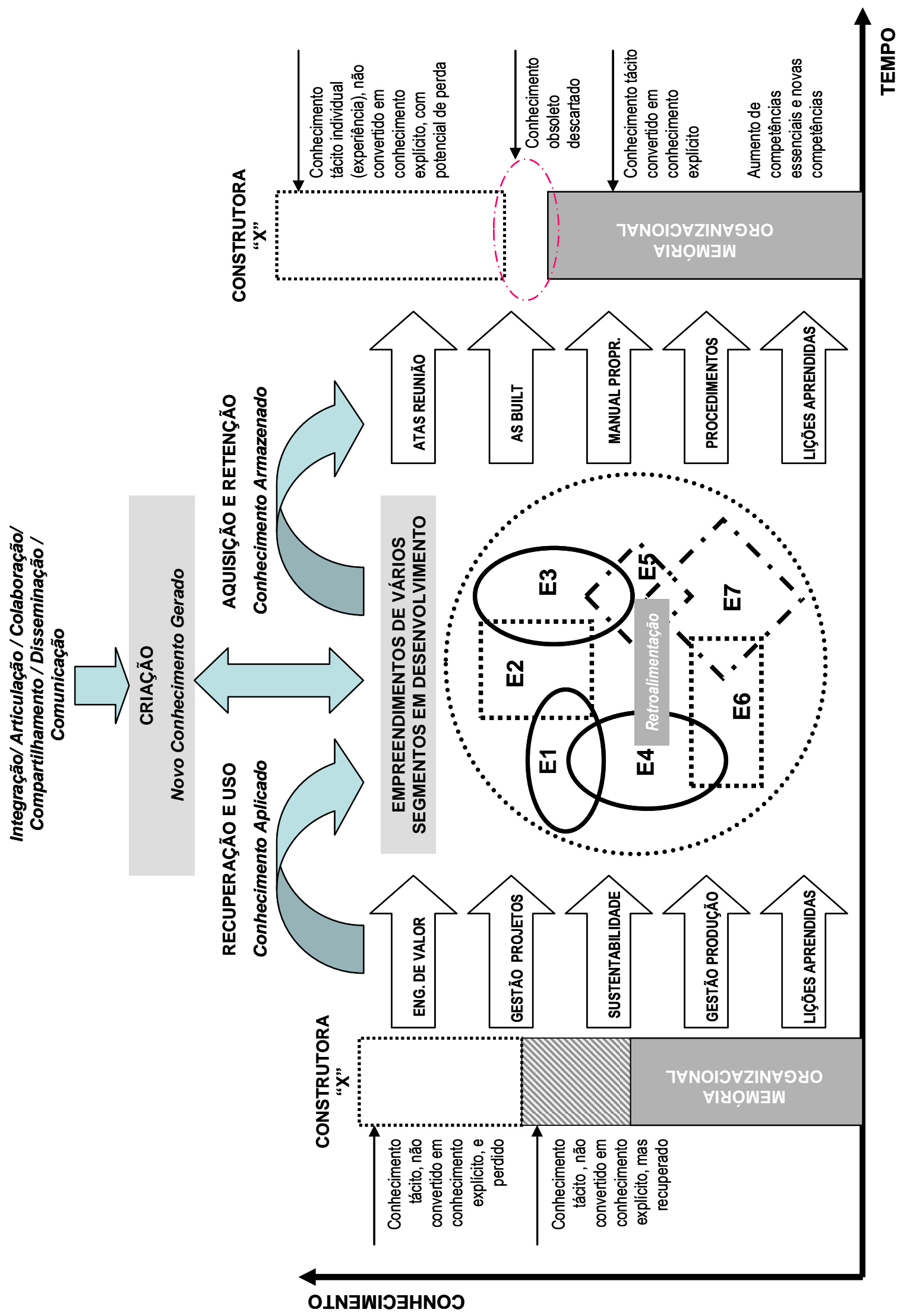

Figura 79 - Processos de aprendizagem e gestão do conhecimento em empresa construtora no desenvolvimento de empreendimentos imobiliários 
dificuldades, assim como da tentativa e erro. As Lições Aprendidas com "insucessos" não têm como objetivo apontar os erros focando no fracasso, mas evitar a repetição destes erros, pois problemas detectados antecipadamente podem ser reparados ao invés de mascarados ou postergados, beneficiando a todos.

As boas práticas devem ser compartilhadas com equipes internas da organização, e com parceiros externos (projetistas, fornecedores, consultores). Com a ausência de um processo estruturado de retroalimentação, o aprendizado dos participantes do processo de projeto pode se perder, não tendo efeito algum sobre as organizações, suas ações ou sobre a indústria da construção.

Para transmitir o contexto e experiência de forma mais eficiente as Lições Aprendidas poderiam ser formatadas em estilo de narrativa, ao invés de registros formais escritos. Os fóruns para apresentação e divulgação das Lições Aprendidas poderiam ter uma frequência maior, sendo abertos a todos os interessados internos e externos à organização, não se limitando à área que produziu seu conteúdo. Além da oportunidade de transmitir sua experiência individual, a geração de novo conhecimento pode ser estimulada através da discussão do tema entre os participantes do fórum.

A iniciativa da Assistência Técnica da Empresa A e Controlling da Empresa C, estimulando a identificação de habilidades, competências e conhecimento existente na organização para compartilhamento e interação com outras áreas e construção de novo conhecimento, deve ser reconhecida como exemplo a ser replicado em outras áreas. O Curso de Patologias e a Memória Técnica poderiam ser difundidos, não apenas internamente, mas aos parceiros - projetistas e fornecedores, proporcionando oportunidade para melhoria contínua dos projetos e produtos.

Foi constatado nos estudos de caso a importância de definir uma liderança, com o apoio da alta direção, como o PRqd na Empresa B, para conduzir, coletar e organizar as melhores práticas e o conhecimento individual, além de criar um ambiente propício para troca de informações entre todas áreas da empresa; facilitando a busca e o contato entre as competências existentes na empresa para consulta e troca de experiência (lista de especialistas - monitores); estabelecendo meios para motivar os profissionais a desenvolver e utilizar o conhecimento para atingir as metas da organização e propiciando a retroalimentação entre Projetos e entre as organizações participantes. 
Como o conhecimento organizacional está intimamente associado à pessoa que o desenvolveu e é compartilhado, principalmente, através de contatos pessoais, para assegurar sua transmissão e uso, evitando a "compartimentação", as empresas deveriam estimular as pessoas a participar de comunidades de prática e redes sociais para compartilhar experiências, além de divulgar os especialistas sêniores da empresa para oferecer suporte e aconselhamento a todos os membros da organização, principalmente no início de novos Projetos.

A experiência relatada pela gerente da Assistência Técnica da Empresa A, na qual profissionais responsáveis pela Assistência Técnica de diferentes empresas reuniam-se informalmente para trocar idéias sobre suas áreas, constitui um exemplo de iniciativa de compartilhamento de conhecimento, além das fronteiras da empresa, que deveria ser estimulado e replicado para outras áreas.

Para a gestão do conhecimento organizacional, além de uma liderança apoiada pela alta direção e sistemas bem estruturados, foram identificados os seguintes aspectos, fundamentais para a eficácia do processo de projeto e sucesso na transferência de conhecimento, descritos na Figura 80.

INTEGRAÇÃO

ARTICULAÇÃO

COLABORAÇÃO

COMPARTILHAMENTO

DISSEMINAÇÃO

COMUNICAÇÃO EFICAZ entre agentes (conciliar interesses)

de sistemas (qualidade, projetos, gestão, TI)

entre processos

entre equipes, Projetos, empresas

de conhecimento (experiência, informação, idéias, planejamento de atividades.....)

de melhores práticas (retroalimentação, treinamentos, seminários)

entre todos agentes envolvidos (ferramentas colaborativas, reuniões, etc)

Figura 80 - Aspectos fundamentais para eficácia do processo de projeto e sucesso na transferência de conhecimento 


\section{CONSIDERAÇÕES FINAIS}

O objetivo de identificar e analisar as práticas associadas à gestão do conhecimento em empresas construtoras e sua influência no processo de projeto, assim como os objetivos específicos propostos para a pesquisa, dentro da área de estudo delimitada, foram atingidos.

As iniciativas e melhores práticas identificadas nas três empresas analisadas podem servir de exemplo para aplicação em outras empresas do setor da construção civil, não restrito a construtoras.

O trabalho desenvolvido identificou diversos problemas e deficiências no processo de projeto, comuns às empresas analisadas, que poderiam ser minimizados com um sistema de gestão do conhecimento eficiente.

Podem ser destacadas como contribuições da pesquisa realizada a constatação de que:

- Existem diversas iniciativas de gestão do conhecimento empregadas com sucesso pelas construtoras analisadas;

- Iniciativas individuais, postas em prática, com resultados positivos, podem ser incorporadas aos procedimentos e processos organizacionais da empresa;

- Muitas iniciativas de gestão do conhecimento não dependem de grandes recursos financeiros;

- O sucesso na implantação e manutenção das iniciativas de gestão do conhecimento depende mais das pessoas do que de uma infra estrutura de TI robusta;

- Quanto mais alinhados aos processos já existentes na empresa, o sistema será assimilado pelas pessoas com maior facilidade e a resistência será menor;

- As iniciativas de gestão do conhecimento devem ser alinhadas com as áreas que utilizarão as ferramentas para que não seja despediçado tempo e recursos na elaboração de ferramentas que não terão utilidade na prática;

- Quanto maior a interação entre todas as áreas da empresa, incluindo o nível estratégico, crescem as chances de sucesso da implantação do sistema; 
- As Unidades de Serviço devem estar constantemente alinhadas às Unidades de Negócios (obras) para atualização do conhecimento gerado continuamente, não apenas ao término da obra;

- As Unidades de Negócios (obras) devem ser estimuladas a registrar e disseminar suas lições aprendidas para que sejam incorporadas à memória organizacional da empresa, e utilizadas em novos Projetos;

- A visão sistêmica do cliente (contratante) influi diretamente na transferência de conhecimento entre as empresas envolvidas no desenvolvimento do empreendimento (estabelece o tipo de relação e comunicação entre os participantes, baseado no escopo de contratação; potencializa ou neutraliza a colaboração e transmissão do conhecimento);

- As construtoras têm desenvolvido competências internas, tais como: compatibilização e coordenação de projetos, elaboração de detalhes construtivos no decorrer da obra, para minimizar os riscos relacionados à baixa qualidade dos projetos;

- A falta de tempo para revisão e compatibilização influi diretamente na qualidade dos projetos;

- O valor do projeto pode aumentar com a participação da construtora nas fases que antecedem a obra (planejamento e desenvolvimento do projeto);

- A fase de desenvolvimento do projeto é uma etapa estratégica do ciclo de vida do empreendimento com relação a agregação de valor ao produto, custo de produção (obra) e manutenção/ operação;

- Lições Aprendidas são importantes para evitar a repetição de erros, mas, principalmente, para possibilitar recriar o sucesso.

No setor da construção, como apontado em diversos grupos de pesquisa, a gestão do conhecimento deve ser estabelecida como prioridade para minimizar estruturas e processos ineficientes e aumentar o valor agregado ao projeto, obra e operação.

A atuação da construtora em novas atividades do ciclo de vida do empreendimento, não restrita às atividades relacionadas à produção do edifício, possibilita agir como integradora, agregando mais valor ao projeto ao compartilhar seu conhecimento com os demais agentes e melhorar o desempenho do Projeto como um todo. 
O principal desafio da gestão do conhecimento na construção, com empreendimentos cada vez mais complexos e com inúmeros agentes envolvidos, é a transferência do conhecimento ao longo do processo de projeto:

- Entre as diferentes fases do ciclo de vida de um projeto;

- Dentro de cada fase;

- Entre projetos;

- Entre as empresas e agentes envolvidos no desenvolvimento do empreendimento.

O foco da gestão do conhecimento deve estar alinhado aos aspectos fundamentais, levantados na pesquisa, para a eficácia do processo de projeto e sucesso na transferência de conhecimento:

- Integração entre agentes e sistemas;

- Articulação entre processos;

- Colaboração entre equipes, Projetos e empresas;

- Compartilhamento de conhecimento;

- Disseminação de melhores práticas;

- Comunicação eficaz entre todos agentes envolvidos.

A partir das barreiras e facilitadores identificados para implantação de iniciativas relacionadas à gestão do conhecimento, são propostas como sugestão para estudos futuros:

- Estabelecer diretrizes para implantação de um sistema de gestão do conhecimento focado no processo de projeto, alinhadas à estratégia da empresa;

- Identificar o perfil de profissional indicado para conduzir este processo de implantação e capacitação necessária;

- Definir mecanismos para motivação da equipe para colaborar e utilizar, de forma adequada, o sistema de gestão do conhecimento; 
- Identificar as ferramentas de tecnologia da informação mais adequadas para gestão do conhecimento em empresas de construção;

- Definir ferramentas mais adequadas para gestão do conhecimento em cada etapa do processo de projeto relacionadas ao ciclo de vida do empreendimento;

- Definir mecanismos de transferência e compartilhamento de conhecimento tácito na empresa e entre empresas;

- Definir mecanismos para transformar o conhecimento tácito em ativos organizacionais (como a experiência das pessoas pode ser transformada em conhecimento organizacional);

- Identificar a relação das práticas de gestão de projetos adotadas com os demais processos da empresa (suprimentos; orçamento; planejamento; obra; assistência técnica) para propiciar a transferência interna de conhecimento;

- Definir modelos de transmissão de melhores práticas para cada tipo de agente envolvido no processo de projeto (fornecedores, clientes, projetistas, consultores, gerenciadora, construtora);

- Estabelecer indicadores e sistemas para medição do impacto da gestão do conhecimento no processo de projeto e nos negócios da empresa;

- Identificar mecanismos para disseminar o conhecimento na cadeia do setor da construção civil. 


\section{REFERÊNCIAS BIBLIOGRÁFICAS}

AGOPYAN, V. Inovação é risco? Notícias da Construção- Sinduscon São Paulo, no 98, ano 7, março 2011.2 Disponível em: http://www.sindusconsp.com.br/downloads/imprensa/noticiasdaconstrucao/2011/e d98.pdf. Acesso em: 02 abr. 2011.

AMORIM, L. Os sócios da Prosperitas criaram a maior gestora de fundos imobiliários do país ao planejar do começo ao fim os empreendimentos em que investem. Revista EXAME, Fev, 2010.

ARAÚJO, L.; ROLIM, R. Distribuidor de concreto na UN REC Berrini. Revista Tapume. No. 96. Mar/ Abr 2010. Disponível em: http://www.hochtief.com.br/tapume/pdf/O_Tapume_096.pdf Acesso em: 25 mar. 2011.

ASSOCIAÇÃO BRASILEIRA DE ESCRITÓRIOS DE ARQUITETURA (ASBEA). Manual de contratação dos serviços de arquitetura e urbanismo. Ed. 2, São Paulo: PINI, 2000.

ASSUMPÇÃO, J.F.P. Gerenciamento de empreendimentos na construção civil: Modelo para planejamento estratégico da produção. Tese (Doutorado) Escola Politécnica, Universidade de São Paulo, São Paulo, 1996.

BAÍA, J. L. Sistemas de gestão da qualidade em empresas de projeto: aplicação ao caso das empresas de arquitetura. 1998. 244 p. Dissertação (Mestrado) - Escola Politécnica, Universidade de São Paulo, 1998.

BAKKER, R.M.; CAMBRÉ, B.; KORLAAR, L,; RAAB, J. Managing the project learning paradox: A set-theoretic approach toward project knowledge transfer. International Journal of Project Management, Volume 29, Issue 5, July, 2011. p. 494-503.

BARBOZA, N. Sinduscon-SP debate desafios para disseminar o BIM no país. Revista Notícias da Construção- Sinduscon São Paulo, no 97, ano 7, janeiro/ fevereiro 2011.

Disponível

em: http://www.sindusconsp.com.br/downloads/imprensa/noticiasdaconstrucao/2011/e d97.pdf Acesso em: 02 abr. 2011.

BARROS, M. M. B. Metodologia para implantação de tecnologias construtivas racionalizadas na produção de edifícios. Tese (Doutorado) - Escola Politécnica, Universidade de São Paulo, 1996. 
BLANCO, M., Por que atender à Norma de Desempenho? Pini Web. Disponível em: http://www.piniweb.com.br/construcao/gestao/por-que-atender-a-norma-dedesempenho-173881-1.asp, 12/05/2010. Acesso em: 25 mar. 2011.

BRASIL, Portal. PAC - Programa de Aceleração do Crescimento. Disponível em: http://www.brasil.gov.br/pac/ Acesso em: 08 abr. 2011.

BROWN, S. A. Communication in the design process. Spon Press, London, 2001.

BUENO, J. C. Melhores práticas em projetos de infra-estrutura: sistemas contratuais complexos e tendências num ambiente de negócios globalizado. 9․ Conferência Internacional da LARES, Real State e os efeitos da crise financeira, 2009.

BUILDINGS. Alto padrão com foco na sustentabilidade. Revista Buildings -

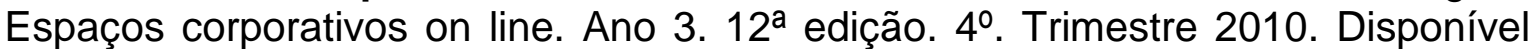
em: http://issuu.com/buildings/docs/revista_12. Acesso em: 02 out. 2011.

CARDOSO, F. F.; SILVA, F. B.; FABRICIO, M. M. Os fornecedores de serviços de engenharia e projetos e a competitividade das empresas de construção de edifícios. In: NUTAU'98. Arquitetura e Urbanismo: tecnologias para o século XXI. São Paulo, 1998. Anais. São Paulo: FAU/USP, 1998 (1 CD-ROM).

CARRILLO, P. Lessons learned practices in the engineering, procurement and construction sector. Engineering, Construction and Architectural Management, 12(3), p. 236-250, 2005.

CARRILLO, P.; CHINOWSKY, P. Exploiting knowledge management: the engineering and construction perspective. Journal of Management in Engineering, ASCE 22, pp. 2-10, 2006.

CARRILLO, P.; ROBINSON, H., AL-GHASSANI, A., ANUMBA, C. Knowledge management in UK construction: strategies, resources and barriers. Project Management Journal, 35(1), p. 46-56, 2004.

CARVALHO, M.M., LAURINDO, F. J. B. Estratégia Competitiva: dos conceitos à implementação. São Paulo: Editora Atlas, v.1, 2007.

CBIC. Construção Civil: Análise e Perspectivas. Banco de dados da CBIC Câmara Brasileira da Indústria da Construção, Brasília, Dezembro, 2010. Disponível em: http://www.cbicdados.com.br/files/textos/063.pdf Acesso em: 08 abr. 2011. 
CEOTTO, L. H. Coordenação de Projetos - um assunto que necessita maior prioridade de desenvolvimento. Revista Téchne Web. Disponível em: http://www.revistatechne.com.br/engenharia-civil/135/imprime93367.asp Acesso em: 26 fev. 2011.

CHAKRAVARTHY, B; MCEVILE, S. Knowledge management and corporate renewal. Artigo integrante do livro: Knowledge Creation and Management: New Challenges for Managers. Oxford University Press, 2007.

CHIAVENATO, I. Introdução à teoria geral da administração: Edição compacta. 3. ㄹ edição revisada e atualizada, São Paulo, Editora Campus, 2004.

CICHINELLI, G. C. Especialista em BIM (Building Information Modeling) explica como o conceito pode revolucionar os processos de orçamentação. Revista Guia da Construção, PINI Web Disponível em: http://revista.construcaomercado.com.br/guia/habitacao-financiamentoimobiliario/94/entrevista-133084-1.asp. Acesso em: 20 mai. 2011.

COHEN, W.M.; LEVINTHAL, D.A. Absorptive-capacity-a new perspective on learning and innovation. Administrative Science Quarterly 35, 128-152, 1990.

COLOMERA, M.; SOUZA, S. Memória Técnica. Revista O Tapume. No. 93. Set/ Out 2009.2 Disponível em: http://www.hochtief.com.br/tapume/pdf/O_Tapume_093.pdf Acesso em: 25 jan. 2010

COSTA, M. D.; SCHONS, C. H. Portais corporativos no apoio à criação de conhecimento organizacional: uma abordagem teórica. Revista de Ciência da Informação - v.9 n.3 junho, 2008.

COZZA, E. Peso pesado. Pini Web. 01 nov. 1999. Disponível em:

http://www.piniweb.com.br/construcao/noticias/peso-pesado-85743-1.asp Acesso em: 25 jan. 2011

D'AMBROSIO, D. Racional cresce com a expansão de data centers. Valor Econômico, 12 jul.2011.

DIEPENBRUCK, T; SARAIVA, W. Modelagem de informação da construção. Revista O Tapume. No. 102. Mar/ Abr 2010. Disponível em: http://www.hochtief.com.br/tapume/pdf/O_Tapume_102.pdf. Acesso em: 15 jul. 2011

DUGGAL, J. S. Avoid Repeated Project Woes: Try A Different Approach to Lessons Learned. Disponível em: http://www.pmi.org/eNews/Post/2011_0610/lu_repeated_project_woes.html. Acesso em: 10 jun; 2011. 
EGBU, C. O. Managing Knowledge and Intellectual Capital for Improved Organisational Innovations in the Construction Industry: An Examination of Critical Success Factors. Engineering, Construction and Architectural Management (ECAM) Journal, Vol. 11 No 5., pp. $301-315,2004$.

EMMITT, S. Architectural Management in Practice. London, Longman, 1999.

EMMITT, S. Architectural Technology. Blackwell Science, Oxford, 2002.

FABRICIO, M. M. Projeto Simultâneo na construção de edifícios. São Paulo, Tese (Doutorado em Engenharia de Construção Civil e Urbana) - Escola Politécnica, Universidade de São Paulo, 2002.

FARIA, R. Construção integrada. Revista Techne, no.168, Março, 2011. Disponível em: http://www.revistatechne.com.br/engenharia-civil/127/artigo64516-1.asp Acesso em: 02 abr. 2011.

FIGUEIREDO, N., Importância da Certificação de Construções Ambientalmente Sustentáveis. I Seminário Internacional: "Promovendo Construções e Reformas Sustentáveis na Cidade de São Paulo", Julho, 2007.

FONTENELLE, E. C. Estudos de caso sobre a gestão do projeto em empresas de incorporação e construção. Dissertação (Mestrado em Engenharia de Construção Civil e Urbana) - Escola Politécnica, Universidade de São Paulo, 2002.

FORMOSO, C.T., TZORTZOPOULOS, P.; LIEDTKE, R. A model for managing the product development process in house building. Engineering Construction and Architectural Management, 9(5-6), 419-432, 2002.

FRANCO, L. S. Aplicação de diretrizes de racionalização construtiva para a evolução tecnológica dos processos construtivos em alvenaria estrutural não armada. Tese (Doutorado). Escola Politécnica, Universidade de São Paulo, 1992.

GARCIA, C. Banheiros prontos. Revista Tapume. No. 98. Jul/ Ago 2010. Disponível em: http://www.hochtief.com.br/tapume/pdf/O_Tapume_098.pdf Acesso em: 25 mar. 2011.

GRANT, R. M. Toward a knowledge-based theory of the firm. Strategic Management Journal, v.17, Winter Special Edition, p. 109 - 22, 1996. 
GRILO, L. M. Gestão do processo de projeto no segmento de construção de edifícios por encomenda. Dissertação (Mestrado). Escola Politécnica, Universidade de São Paulo, 2002.

GRISHAM, T.; SRINIVASAN, P. Designing Communications on International Projects. CIB World Building Congress, Cape Town South Africa, 2007.

GRISHAM, T.; WALKER, D. H. T. Nurturing a Knowledge Environment for International Construction Organizations Through Communities of Practice. Construction Innovation Journal 6(4): 217-231, 2005.

GUS, M. Método para a concepção de sistemas de gerenciamento da etapa de projetos da construção civil: um estudo de caso. Dissertação (Mestrado) Universidade Federal do Rio Grande do Sul, Porto Alegre, 1996.

HAMMARLUND, Y.; JOSEPHOSON, P.E. Qualidade: cada erro tem seu preço.

Tradução de: V.M.C.F. Hachich. Revista Téchne, n.1, p.32-4, Nov./Dec, 1992.

HANSEN, M. T.; NOHRIA, N., TIERNEY, T. What's your strategy for managing knowledge? Harvard Business Review 77.2, March-April, p106, 1999.

HUBER, G. Organizational learning: the contributing processes and the literatures. Organizational Science, v.2, n.1, p. 88-115, Feb. 1991.

ICHIJO, K; NONAKA, I. Knowledge Creation and Management: New Challenges for Managers. Oxford University Press, 2007.

JEON, J. Success factors for a lessons-learned system in a construction organization. Cost Engineering, 51(5), 13-20, 2009.

JOHN, V. M., Desafios da Construção Sustentável. Fórum PINI Empreendimentos Imobiliários Sustentáveis: Viabilidade, Projeto e Execução, São Paulo, Agosto, 2008.

JOHN, V. M., Mudanças radicais. Revista Notícias da Construção- Sinduscon São Paulo, no 62, ano 6, novembro 2007.2 Disponível em: http://www.sindusconsp.com.br/downloads/imprensa/noticiasdaconstrucao/2007/ed6 2.pdf Acesso em: 02 abr. 2011. 
KAMARA, J. M.; AUGENBROE, G.; ANUMBA, C.J.; CARRILLO, P.M. Knowledge management in the architecture, engineering and construction industry, Construction Innovation. pp. 53-67, 2002.

KAMARA, J. M.; ANUMBA, C.J.; CARRILLO, P.M. Knowledge Management. Artigo do Institution of Civil Engineers (ICE), 2004. Disponível em: http://ice.org.uk/rtfpdf/Knowledge\%20Management.pdf. Acesso em: 23 out. 2009.

KELETI, P. Hochtief implode prédio comercial. Revista Tapume. No. 84. Mar/ Abr 2008. Disponível em: http://www.hochtief.com.br/tapume/pdf/O_Tapume_084.pdf Acesso em: 25 mar. 2011.

KOKKALA, M. Conference report on CIB IDS2009 - Improving Construction ans Use through Integrated Design Solutions. CIB News article, CIB Priority Themes Integrated Design Solutions, 2009. Disponível em: http://www.fiatech.org/images/stories/research/ids2009.pdf Acesso em: 25 out. 2010.

KOWALEWSKI, M. Nós estamos construindo o futuro. Trabalho apresentado na disciplina TG-001- - Importância estratégica da tecnologia e da gestão da produção do PECE - Programa de Educação Continuada da Escola Politécnica, PósGraduação Lato Sensu - Tecnologia e Gestão da Produção de Edifícios - MBAUP/TGP, 2008.

KOWALEWSKI, M. Nova versão do Management System. Rumo à certificação. Revista O Tapume. No. 64. Nov/ Dez 2004. Disponível em: http://www.hochtief.com.br/tapume/pdf/O_Tapume_064.pdf Acesso em: 25 mar. 2011

LÊ, M.A.T.; BR ØNN, C. Linking experience and learning: Application to multiproject building environments. Engineering, Construction and Architectural Management, Vol. 14, Iss. 2; p. 150, 2007.

LEVITT, B.; MARCH, J. G. Organizational Learning. Annual Review of Sociology, v.14, p.319-340, 1998.

LOTURCO, B. Projetos coordenados. Matéria extraída da Revista Téchne Web. Disponível em: http://www.revistatechne.com.br/engenhariacivil/135/imprime93333.asp Acesso em: 05 jul. 2008.

MAGALHÃES, O. P. Trajetória de um empreendimento. Encontro Internacional de Sustentabilidade na Construção. São Paulo. 2008. Disponível em: 
http://www.cte.com.br/eventos/eventos2008/sustentabilidade/ Acesso em: 05 set. 2010.

MALERBA F., ORSENIGO L. Knowledge, innovative activities and industry evolution. Industrial and Corporate Change, Vol.9, number 2, 2000.

MALHOTRA, Y. Organizational Learning and Learning Organizations: An Overview., 1996. Disponível em: http://www.brint.com/papers/orglrng.htm. Acesso em: 05 mai. 2010.

MAQSOOD, T.; WALKER, D.H.T.; FINEGAN, A.D. Current State of Knowledge Management, Potential and Trends: Implications for the Construction Industry. CRC Construction Innovation Conference, 2004.

MARKIDES, C. C. A dynamic view of strategy. Sloan Management Review, [S. I.], 1999.

MELHADO, S.B. Qualidade do projeto na construção de edifícios: aplicação ao caso das empresas de incorporação e construção. São Paulo, 294p, Tese (Doutorado) - Escola Politécnica, Universidade de São Paulo, 1994.

MELHADO, S.B. Gestão, cooperação e integração para um novo modelo voltado à qualidade do processo de projeto na construção de edifícios. Tese (Livre-Docência) - Escola Politécnica, Universidade de São Paulo, São Paulo, 235p., 2001.

MELHADO, S. B.; ADESSE, E.; BUNEMEER, R.; LEVY, M. C.; LUONGO, M.; MANSO, M.A. A gestão de projetos de edificações e o escopo de serviços para coordenação de projetos. Revista Téchne Web. Disponível em: http://www.revistatechne.com.br/engenharia-civil/135/imprime93370.asp Acesso em: 05 ago. 2009.

MELHADO, S. B.; BARROS, M. M. S. B.; SOUZA, A. L. R. Metodologia envolvendo os novos procedimentos de projeto. Relatório CPqDCC n.20.088EP/SC-1. São Paulo, EPUSP, 1996.

MELHADO, S. B.; FABRICIO, M. M. Projeto da produção e projeto para produção: discussão e síntese de conceitos. In. ENCONTRO NACIONAL DE TECNOLOGIA DO AMBIENTE CONSTRUÍDO: qualidade no processo construtivo, 7., 1998, v.2, p. 731-37, Florianópolis. Anais... Florianópolis: UFSC/ANTAC, 1998. 
MELHADO, S.B. (Coord.) et al. Coordenação de projetos de edificações. São Paulo: O Nome da Rosa, 2005.

MERTINS, K, HEISIG, P., VORBECK, J. Knowledge Management: concepts and best practices. 2a ed., Berlin. Spring-Verlag, 2003.

MÉTODO Engenharia investe R\$ 4 milhões em novo ERP. TI Inside On line. 29 junho $2008 . \quad$ Disponível em: http://www.tiinside.com.br/News.aspx?ID=91282\&C=262\#ir Acesso em: 29 jul. 2009.

MÉTODO investe em tecnologia BIM. Brasil Econômico. 01/09/2010. Disponível em: http://www.metodo.com.br/imprensa/midias/400/Metodo-investe-em-tecnologiaBIM.aspx Acesso em: 08 nov. 2010.

MIGUEL, P. A. C. Estudo de caso na engenharia de produção: estruturação e recomendações para sua condução. Revista Produção, v. 17, n. 1, p. 216-229, Jan./Abr, 2007.

M\&T. Quando o canteiro não comporta os equipamentos. Revista M\&T Manutenção e Tecnologia. Edição 130. 15 março, 2010.

Disponível

em:

http://www.revistamt.com.br/index.php?option=com_conteudo\&task=printMateria\&id= 48. Acesso em: 9 jul. 2011.

MUSICO, C. Optimize SharePoint: Storage Ensure Governance, Performance and Scalability. Best practice in SharePoint solution. Disponível em: KMWorld.com

http://www.kmworld.com/Readers/Subscriber.aspx?Redirect=http://www.kmworld.co m/PDF/KMWhitePaper.aspx?IssuelD=2294. Acesso em: 19 set. 2010.

NAKANO, D.N.; FLEURY, A.C.C. Conhecimento organizacional: uma revisão conceitual de modelos e Tabelas de referência. Produto \& produção, vol.8, n.2, p.11-23, junho, 2005.

NASA. APPEL - Academy of Program/Project and Engineering Leadership. Disponível em: http://www.nasa.gov/offices/oce/appel/about/about_us.html. Acesso em: 10 jun. 2011.

NONAKA, I.; TAKEUCHI, H. Criação de Conhecimento na Empresa. Rio de Janeiro: Editora Campus, 1997. 
NUNES, L.; SOUZA, S. ECO Berrini Destaque em sustentabilidade para São Paulo. Revista Tapume. No. 103. Mai/ Jun 2011. Disponível em: http://www.hochtief.com.br/tapume/pdf/O_Tapume_103.pdf Acesso em: 02 set. 2011.

O'DELL, C.; GRAYSON Jr. C. J., Ah...Se Soubéssemos Antes o que Sabemos Agora. As melhores práticas gerenciais ao alcance de todos. Editora Futura, São Paulo, 2000.

OLIVEIRA, D. P. R., Sistemas, Organização \& Métodos: Uma abordagem gerencial. 5a .Edição, São Paulo, Editora Atlas, 1994.

OLIVEIRA, T. Desafios gerenciais. Revista Construção e Mercado, no. 83, junho, 2008.

OTTER, A.; EMMITT, S. Design Team Communication and Design Task Complexity: The Preference for Dialogues. Architectural Engineering and Design Management, Volume 4, Number 2, pp. 121-129(9), 2008.

PARDINI, A. F. Foco no ciclo de vida do produto. Método News, no.03, Ano 2, Mar/ Abr/ Mai, 2010.

PESSOTTO, D; SIMÕES, N; VILLA, P. Pré-Construção. Muito prazer! Conexão, Ano 12, no.45, Jan/ Fev/ Mar/ Abr.2011. Disponível em: http://www.racional.com/pdf/jornal_interno/Conexao_45_web.pdf. Acesso em: 02 set. 2011.

PETRELLA, G. Maturidade na Indústria da Construção. Estudo de caso: Hochtief do Brasil. IV Seminário Internacional de Maturidade em Gerenciamento de Proejtos - PMI SP, 2004, Disponível em: http://www.maturityresearch.com/novosite/biblio/Trabalho 1100 GUILHERME\%2 OPETRELLA.pdf Acesso em: 20 mai. 2011.

PICCHI, F. A. Sistemas de qualidade: uso em empresas de construção de edifícios. Tese (Doutorado). Escola Politécnica, Universidade de São Paulo, 1993.

PINHEIRO, A. P. Como anda a Escola Técnica. Revista O Tapume. No. 99. Set/ Out 2010. Disponível em: http://www.hochtief.com.br/tapume/pdf/O_Tapume_099.pdf Acesso em: 25 mar. 2011

PINHEIRO, A. P.; DOMINGOS, C. Capacitação de Jovens Profissionais. Tapume, Ano XVII, no.97, Mai; Jun. 2010. Disponível em: 
http://www.hochtief.com.br/tapume/pdf/O_Tapume_097.pdf Acesso em: 22 ago. 2010.

PINI. Norma de Desempenho é publicada. Pini Web. Disponível em: http://www.piniweb.com.br/construcao/tecnologia-materiais/norma-de-desempenhoe-publicada-88794-1.asp, 14/05/2008. Acesso em: 25 mar. 2011

PMI - Project Management Institute. Conjunto de conhecimentos em gerenciamento de projetos - Guia PMBok. 4ª edição, 2008.

PMI - Project Management Institute. Estudo de Benchmarking em Gerenciamento de Projetos Brasil 2010. Project Management Institute - Chapters Brasileiros, 2010. Disponível em: http://www.pmsurvey.org/ Acesso em: 09 mai. 2011.

PORTER, M.E. What is Strategy? Harvard Business Review, p.61-78, Nov-Dec, 1996.

PORTER, M. E. Vantagem competitiva: criando e sustentando desempenho superior. Rio de Janeiro, Campus, 152p, 1989.

PORTER, M. E. A estratégia e a responsabilidade social. Fórum Mundial de Estratégia - HSM, São Paulo, Agosto, 2008.

PORTER, M.E; MILLAR,V. How information gives you competitive advantage. Harvard Business Review, p.149-160, 1985.

PRADO, D.; ARCHIBALD, R. Pesquisa sobre Maturidade em Gerenciamento de Projetos: Maturidade Brasill 2010. Disponível em: http://www.maturityresearch.com/novosite/2010/downloads/PesquisaMaturidade2010 -Rel.GeralCompleto-V4.pdf Acesso em: 21 mai. 2011.

PRAHALAD, C. K. Reexame de Competências. Revista HSM Management, nov/dez, 1999.

PRUSAK, L.; WEISS, L.; Knowledge in Organizational settings: How organizations generate, disseminate and use knowledge for their competitive advantage. Texto integrante do livro ICHIJO, K; NONAKA, I. Knowledge Creation and Management: New Challenges for Managers. Oxford University Press, 2007.

PRUSAK, L. The Costs of Knowledge. Ask - Academy Sharing Knowledge. The NASA Source for Project Management and Engineering Excellence - APPEL, 
Winter, 2008. Disponível em: http://askmagazine.nasa.gov/issues/36/36d_kn.html Acesso em: 21 mar. 2011.

PRUSAK, L. Slow learning. Ask - Academy Sharing Knowledge. The NASA Source for Project Management and Engineering Excellence - APPEL, Fall, 2009. Disponível em: http://askmagazine.nasa.gov/issues/36/36d_kn.html Acesso em: 21 mar. 2011

RAMPASSO, K; SOUZA, S. O que é Pré-Construção? Tapume, Ano XVII, no.97, Mai; Jun. 2010.2 Disponível em: http://www.hochtief.com.br/tapume/pdf/O_Tapume_097.pdf Acesso em: 22 ago. 2010.

RATH, N. Collaboration Needs Records Management: Without RM, Chit-Chat is Highly Risky. Best practice in SharePoint solution. Disponível em: KMWorld.com http://www.kmworld.com/Readers/Subscriber.aspx?Redirect=http://www.kmworld.co m/PDF/KMWhitePaper.aspx?IssuelD=2294. Acesso em: 19 set. 2010.

REZGUI, Y., HOFPE C. J., VORAKULPIPAT, C. Generations of knowledge management in the architecture, engineering and construction industry: An evolutionary perspective. Advanced Engineering Informatics, 24, 219-228, 2010.

ROBBINS, STEPHEN P., Comportamento Organizacional. 11a. Edição, São Paulo, 2007.

ROBINSON, H. S.; CARRILLO, P. M.; ANUMBA, C. J.; AL-GHASSANI, A. M. Perception and barriers in implementing knowledge management strategies in large construction organizations. RICS COBRA Conference, Glasgow, 3-5 September, pp. 451-160, 2001.

ROBINSON, H. S.; CARRILLO, P. M.; ANUMBA, C. J.; AL-GHASSANI, A. M. Knowledge management practices in large construction organisations. Engineering, Construction and Architectural Management, Vol. 12 Iss: 5, pp.431 445, 2005.

RODRIGUES, M. Orçamento participativo. Revista Construção Mercado. Pini Web. Edição no. 1. Jan. $2009 . \quad$ Disponível em: http://www.piniweb.com.br/construcao/noticias/orcamento-participativo-82618-1.asp Acesso em: 20 jul. 2010.

RODRIGUEZ, M. Microsoft SharePoint and Content Aggregation. Best practice in SharePoint solution. Disponível em: KMWorld.com http://www.kmworld.com/Readers/Subscriber.aspx?Redirect=http://www.kmworld.co m/PDF/KMWhitePaper.aspx?IssuelD=2294. Acesso em: 19 set. 2010. 
ROMANO, F. V. Modelo de Referência para o Gerenciamento do Processo de Projeto Integrado de Edificações. Tese (Doutorado em Engenharia de Produção) - Programa de Pós-Graduação em Engenharia de Produção, Universidade Federal de Santa Catarina, 2003.

SABBAG, P. Y. A gestão do conhecimento e as práticas de gestão de projetos. Palestra SENAC-SP - IPEMAC Melhores Práticas para GP, 2009. Disponível em: http://www.mundopm.com.br/eventos/ipemac/ppt/sabbag08.pdf Acesso em: 19 mar. 2011.

SANTIAGO JUNIOR, J. R. S. O desenvolvimento de uma metodologia para gestão do conhecimento em uma empresa de construção civil. Dissertação (Mestrado). Escola Politécnica, Universidade de São Paulo, 2002.

SANTOS, I. C. Um modelo estruturado de gestão do conhecimento em indústrias de base tecnológica: um estudo de caso de uma empresa do setor aeronáutico. Tese de doutorado. São Paulo: Escola Politécnica da USP, 2004.

SANTOS, I. C.; NETO, J. A. Gestão do conhecimento em indústria de alta tecnologia. Produção, v. 18, n. 3, p. 569-582, 2008.

SENARATNE, S.; SEXTON, M.G. Role of knowledge in managing construction project change. Engineering, Construction and Architectural Management, Vol. 16 Iss: 2, pp.186-200, 2009.

SHEN, W.; HAO, Q.; MAK, H.; NEELAMKAVIL, J.; XIE, H.; DICKINSON, J.; THOMAS, R.; PARDASANI, A.; XUE, H. Systems integration and collaboration in architecture, engineering, construction, and facilities management: A review . Advanced Engineering Informatics, Volume 24, Issue 2, Pages 196-20.7, April, 2010.

SILVA, L. Implosão do Edifício REC Berrini. Revista Tapume. No. 85. Mai/ Jun 2008. Disponível em: http://www.hochtief.com.br/tapume/pdf/O_Tapume_085.pdf Acesso em: 25 mar. 2011.

SILVA, M.A.C. Metodologia de seleção tecnológica na produção de edificações com o emprego do conceito de custos ao longo da vida útil. Tese (doutorado) Escola Politécnica, Universidade de São Paulo, São Paulo, 1996.

SILVA, S.A.R., Qual a diferença de construtora e gerenciadora? Revista Construção Mercado. No. 77 - Dezembro, 2007. 
SIMODO, P.; FERRIGNO, R. A hora e a vez da tecnologia. Conexão, Ano 12, no.43, Jun/ Jul/ Ago/ Set/ Out. 2010. Disponível em: http://www.racional.com/pdf/jornal_interno/Conexao_43.pdf Acesso em: 22 abr. 2011.

SOLANO, R. P. Coordenação dos documentos de projetos de edificações: uma ferramenta auxiliar de melhoria de qualidade proposta pelo projeto arquitetônico. Dissertação (Mestrado em Arquitetura), Universidade Federal do Rio Grande do Sul, Porto Alegre, 2000.

SOUZA, A.L.R. Preparação e coordenação da execução de obras: transposição da experiência francesa para a construção brasileira de edifícios. São Paulo. Tese (Doutorado) - Escola Politécnica, Universidade de São Paulo, 2001.

SUN, M.; MENG, X. Taxonomy for change causes and effects in construction projects. International Journal of Project Management, Volume 27, Issue 6, Pages 560-572, August 2009.

SZULANSKI, G. Exploring internal stickiness: Impediments to the transfer of best practice within the firm. Strategic Management Journal, 17 (Winter Special Issue): 27-43, 1996.

TAMAKI, L. Rápido Berrini. Revista Techne. Editora Pini. Edição no. 171. Ano 19. Jun. 2011.

TERRA, J. C. C. Gestão do Conhecimento: $\quad 0$ grande desafio empresarial (artigo). Disponível em http://www.terraforum.com.br. Acesso em: 06 mar. 2009

TOLEDO, J. C. Gestão da mudança da qualidade de produto. Tese Doutorado) Escola Politécnica, Universidade de São Paulo, São Paulo, 1993.

TZORTZOPOULOS, P. Contribuições para o desenvolvimento de um modelo do processo de projeto de edificações em empresas construtoras incorporadoras de pequeno porte. Dissertação (Mestrado) - Universidade Federal do Rio Grande do Sul. Porto Alegre, 1999.

TZORTZOPOULUS, P.; COOPER, R. Design management from a contractor's perspective: The need for clarity. Architectural Engineering and Design Management, 3(1), 17-28, 2007. 
VAKILI-ARDEBILI, A.; BOUSSABAINE, A.H. Creating value through sustainable building design. in Architectural Engineering and Design Management, 3(2), 83-92, 2007.

VARGAS, N. Prestadora de serviço ou indústria? PINI Web - O Portal da Construção. Disponível em: <http://www.piniweb.com/revistas/construcao/index.asp?MATE6_COD=15568>. Acesso em: 04 mar. 2009.

VENTURA, A; KAWAMOTO, A.; MASCHIO, L.; RODRIGUES, R. Assistência Técnica aos contratos é integrada aos Serviços Técnicos de Facility Management. Revista O Tapume. No. 92. Jul/ Ago 2009. Disponível em: http://www.hochtief.com.br/tapume/pdf/O_Tapume_092.pdf Acesso em: 25 mar. 2011

VILLA, P.; SARTORELLI, G. PRqd - Processos estruturados e à nossa disposição. Conexão, Ano 10, no.40, Jan/ Fev/ Mar/ Abr.2009. Disponível em: http://www.racional.com/pdf/jornal_interno/Conexao40WEB.pdf. Acesso em: 22 abr. 2011.

VIVANCOS, A. G.; CARDOSO, F. F. Estruturas organizacionais de empresas construtoras de edifícios. BT/PCC/306. São Paulo, EPUSP-PCC, 2001. 14 p.

VOROPAJEV, V. Change management - a key integrative function of PM in transition economies. International Journal of Project Management 16 (1), 1998.

WALSH, J. P.; UNGSON, G. R. Organizational memory. The Academy of Management Review, v.16, n.1, p.57-91, 1991.

YIN, R. K. Estudo de Caso - Planejamento e Método. 2. ed. São Paulo: Bookman, 2001. 


\title{
ANEXO A - ROTEIRO DE ENTREVISTA ESTUDO DE CASO
}

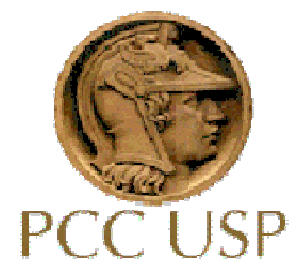

\author{
ESCOLA POLITÉCNICA DA UNIVERSIDADE DE SÃO PAULO \\ Departamento de Engenharia de Construção Civil \\ Área de Concentração: Engenharia de Construção Civil e Urbana
}

\section{GESTÃO DO CONHECIMENTO APLICADA AO PROCESSO DE PROJETO NA CONSTRUÇÃO CIVIL: ESTUDOS DE CASO EM CONSTRUTORAS}

\author{
Mestrando: Arq. Márcia Cristina Ito Medeiros \\ Orientador: Prof. Dr. Silvio Burrattino Melhado
}

\section{Questionário para entrevista}

Objetivo: Coleta de dados e informações para caracterização do processo de projeto praticado pelas empresas (envolvendo o planejamento do projeto, formação da equipe, integração entre os agentes, gestão da documentação técnica), sistemas de gestão e iniciativas de gestão do conhecimento.

\section{Dados entrevistado}

Empresa:

\section{Endereço:}

Entrevistado:

Data:

Cargo/ Departamento:

Dados para contato (Telefone/ E-mail):

Tempo de empresa/ Tempo de formado:

\section{1) CARACTERIZAÇÃO DA EMPRESA}

1.1) Informações gerais

a) Atividade principal: Incorporadora (com Construção contratada a terceiros)/ Construtora de Incorporações próprias/ Construtora de Incorporações de terceiros e de clientes privados/ Gerenciadora/ Outros:

b) Tempo de atuação no mercado: anos

c) Porte da empresa: número de empregados: área construída: , etc.

d) Principais mercados de atuação: Edifícios residenciais/ Edifícios comerciais/ Hotéis/ Hospitais/ Obras industriais/ Outros: 


\section{2) Estrutura organizacional}

a) Qual a estrutura organizacional da empresa?

b) Existe um ciclo de vida comum a todos os empreendimentos? Quais são as fases?

c) Em que etapas do processo de desenvolvimento imobiliário a empresa participa?

Planejamento (definição do produto): concepção, definições, análise e avaliação do conjunto de informações técnicas e econômicas iniciais e estratégias do empreendimento. (Caracterização do empreendimento

Elaboração de projetos: Arquitetura, complementares, para produção.

$\checkmark$ Preparação para execução: fase de transição entre as etapas de elaboração de projetos e execução (Planejamento, Contratação de fornecedores de Mão-de-obra e Material - Suprimentos)

Execução (Obra)

d) A equipe envolvida em cada empreendimento é exclusiva ou compartilhada? A composição da equipe é padrão? Qual é a equipe do empreendimento em questão?

e) A coordenação de projetos é interna ou externa (arquiteto responsável pela concepção do projeto ou terceirizada)?

Quando interna: A quem o coordenador de projetos está subordinado? Quais são as suas atribuições e responsabilidades?

$\square$ Quando externa: Quem é o responsável pela contratação do coordenador? Existe um perfil pré-estabelecido/ escopo de serviço para contratação da coordenação de projetos (prevê acompanhamento da obra, participação de reuniões com o cliente)?

\section{3) Métodos de seleção dos agentes do empreendimento:}

Projetistas: convite direto, seleção restrita, proposta técnica em seleção restrita?

Construtora: Concorrência aberta ou fechada; negociação; qualificação?

$\square$ Gerenciadora?

\section{4) Sistema contratual:}

Integrado/ Separado de projeto e construção/ Gerenciador como mediador, consultor ou com risco?

Contrato permite a comunicação entre construtor e projetista? Cliente e construtor?

\section{2) SISTEMAS DE GESTÃO}

a) A empresa possui algum sistema de gestão que tenha influência direta com o processo de projeto (gestão da qualidade/ de projetos/ do conhecimento)? Em caso de certificação nas normas ISO, qual o tipo e escopo da certificação, quando houver? Quem é o responsável pelos sistemas? 
b) Existe um sistema de informações que integre o fluxo de informações entre os processos de gerenciamento do empreendimento?

c) As obras têm atendido aos requisitos estabelecidos pelo proprietário, projetista e construtor?

\section{1) Gestão do Conhecimento - GC}

a) Que conhecimento precisa ser gerenciado (informação, conhecimento pessoal?) e como (GC para solucionar um problema)? Existe alguma iniciativa de GC entre Projetos e entre as empresas de engenharia, GC suprimentos e fornecedores, GC do processo de projeto?

b) Quais são as razões para adotar uma estratégia de GC?

c) Quais são as dificuldades (barreiras) encontradas na implantação das iniciativas de GC?

d) Quais ferramentas/ instrumentos de GC a empresa utiliza para captura, armazenamento e compartilhamento de $\mathrm{C}$ ? Transferência do $\mathrm{C}$ entre as diferentes fases de um projeto (cliente, projeto, obra):

Focadas em TI: Sistemas de banco de dados, Sistemas de gerenciamento de documentos, Fóruns eletrônicos de discussão.

Focadas nas pessoas/ organização: Seminários; Treinamentos; Narrativas e histórias orais; E-learning; Comunidades de prática/ Networks técnicos; Mapeamento de Competências e Habilidades; Brainstorming; Job rotation/ Job observation; Registro de lições aprendidas; Benchmarking.

e) Existe alguma métrica ou indicador para mensurar a GC? Como por exemplo: Quantidade de Procedimentos, Instruções Operacionais e Documentos/ Quantidade de Treinamentos, Workshops/ Quantidade de Reuniões voltadas a GC/ Registro de Lições Aprendidas.

f) Quais são os benefícios percebidos com a GC?

g) Quais dos aspectos levam as pessoas da sua empresa a compartilhar o $\mathrm{C}$ em seus projetos?

\section{3) PROCESSO DE PROJETO DA EDIFICAÇÃO}

a) Quais são as etapas do processo de projeto da qual a empresa participa: Planejamento e concepção do empreendimento; Estudo preliminar; Projeto Legal; Projeto Executivo?

3.1) Seleção dos projetistas e consultores/ coordenação: Formação da equipe de projeto

a) Como e em que fase de cada empreendimento a equipe de projeto é selecionada (projetistas/ consultores/ projetistas para produção)?

b) Quem é o responsável pela seleção?

c) Quais são os critérios de seleção (contratados conforme as características do empreendimento/ parceria/ custo/ prazo de entrega/ qualidade/ etc)?

d) Existe um modelo padronizado de contrato e escopo de serviço pré-definido (conteúdo do projeto a ser desenvolvido por cada especialidade; nível de detalhamento desejado; indicadores de projeto a serem utilizados, etc)? 


\section{2) Definição do programa:}

a) Quem é o responsável pela elaboração do programa do produto (edifício)?

b) Na definição do produto são levados em consideração aspectos de vida útil (ciclo de vida) do edifício e o custo ao longo da vida útil (na especificação de materiais, definição de sistemas construtivos e instalações)? Como isso é feito?

c) É comum que o programa sofra alterações ao longo do projeto? Quais são as alterações mais freqüentes? Qual é a origem das alterações (cliente, usuário, alteração de solução tecnológica, mudança do mercado, etc) ?

\section{3) Seleção Tecnológica:}

a) Dentro das etapas de desenvolvimento de projeto, quando e como são tomadas as principais decisões acerca da "seleção de tecnológico-construtiva"? Quem participa da definição das soluções (projetistas, fornecedores, construtora, etc) ou a empresa impõe o seu padrão construtivo como diretriz ao desenvolvimento dos projetos? Existe um manual de orientação?

b) Como está documentado/ organizada a experiência construtiva da empresa? Quem é responsável? Existe um setor de pesquisa e desenvolvimento de tecnologia?

c) A equipe de execução da obra contribui com sua "experiência construtiva" durante a elaboração dos projetos?

d) Qual é o critério utilizado para a "seleção de tecnológico-construtiva"? O critério é definido de acordo com o tipo de empreendimento?

\section{Experiências anteriores}

$\square$ Menor custo inicial da solução (É utilizado algum indicador de custo de soluções?)

$\square$ Melhor custo-benefício em relação à vida útil da edificação

$\square$ Racionalização do processo de execução

e) De que forma e em que momento, em geral, são introduzidas novas tecnologias? No processo de projeto ou na produção? Em que fase?

\section{4) Coordenação de projetos}

d) A empresa utiliza um gerenciador de documentos de projeto? Existe um padrão para troca de arquivos eletrônicos entre a equipe de projeto? Quem tem acesso (obra, projetistas, coordenador, cliente)?

e) Há uma padronização de projeto da empresa a ser seguida pelos projetistas? Existe um manual?

f) De que modo essas informações são passadas aos projetistas ao longo do processo de projeto de cada empreendimento? Em que etapas?

g) Existe um fluxo básico de desenvolvimento de projetos? Ele é padronizado ou é desdobrado de acordo com a tipologia de cada empreendimento (hotéis, residencial, etc)? 
h) Como é estabelecido o planejamento das atividades de projetos (definição das atividades, sequenciamento, estimativas de duração)? Quem estabelece os prazos de entrega dos projetos? A equipe de produção é envolvida?

i) A coordenação de projetos inclui os Projetos Legais, Projetos para Produção e "As builts"? Como estes projetos são incluídos no processo de projetos?

j) Existem procedimentos de controle de recebimento, análise crítica e verificação/ validação dos projetos, memoriais e especificações ao final de cada etapa de projeto? Quem é o responsável pela validação/ aceitação dos projetos?

k) Quais ferramentas são aplicadas às atividades de coordenação dos projetos (atas de reunião, planilha de controle de entrega, lista de pendências, etc)? Estas ferramentas são compartilhadas com equipe de produção após o início da obra? Onde são armazenadas?

I) Quais são os meios de comunicação entre os membros da equipe de projeto (e-mail, gerenciador, reuniões)?

m) Qual é a freqüência das reuniões de projeto (são periódicas ou sob demanda)? Quais profissionais participam? São registradas atas de reunião? Como são registrados novos conhecimentos para disseminação?

n) Existe algum "protocolo de passagem de informações" para a equipe de produção?

o) Quais as principais dificuldades encontradas na coordenação de projetos (datas previstas são cumpridas/ integração entre os projetistas etc)?

p) Os projetos têm atendido às expectativas dos agentes do processo de projeto: equipe de produção, cliente, integração entre projetistas, etc? Existe algum sistema para avaliar o desempenho e qualificar os projetistas terceirizados?

q) Existe algum conflito envolvendo as informações de projeto (tomada de decisão, etc)?

\section{5) Projetos para Produção:}

a) Quem decide e quando são definidos quais subsistemas/ serviços serão desenvolvidos em forma de projetos para a produção?

b) Quais projetos para a produção costumam se contratados (execução formas, lajes, alvenaria, revestimentos, esquadrias, estrutura metálica, cobertura, canteiro de obra, etc.)? Quem contrata? Quem elabora estes projetos (construtora, fornecedor, projetista, etc)?

c) Quando são realizados estes projetos (simultâneos aos projetos executivos/ após o início das obras)? Como é estabelecida a seqüência das atividades de projetos?

d) $O$ escopo destes projetos faz parte das reuniões de coordenação? $O$ engenheiro da obra participa?

e) Há troca de informações entre os projetistas de produção e projetistas do edifício durante o desenvolvimento dos projetos? Em que fase?

\section{6) Acompanhamento da Obra/ Interface com a Produção:}

a) Existe um controle de cópias de projeto enviadas à obra?

b) Os projetos foram recebidos antes do início da obra? 
c) Os projetistas fazem um acompanhamento da Obra? Qual o objetivo? Com que freqüência?

d) São realizados registros de modificações dos projetos? Como?

e) Os projetos são apresentados de maneira clara, com detalhes construtivos, especificações suficientes e sem problemas de construtibilidade?

f) Quando a equipe de produção tem algum questionamento em relação aos projetos ou quando existe a necessidade de tomada de decisão (individual ou multidisciplinar) sobre algum item de projeto, o processo decisório é eficiente? O prazo das respostas atende às necessidades da obra?

g) Quais são as deficiências encontradas no processo de projeto?

h) É possível detectar quais os impactos na gestão da obra (retrabalho, atraso, aumento de custo) são decorrentes de não conformidades no projeto (falta de compatibilização, não atendimento às exigências do cliente, falta de informações, etc)?

\section{4) SISTEMA DE INFORMAÇÃO/ COMUNICAÇÃO/ RETROALIMENTAÇÃO}

a) Como é organizado o fluxo de informações entre os agentes do processo (cliente, construtora, projetistas, fornecedores, etc)? Como é a gestão desta interface? Quem é responsável? Como é o controle e troca de informações?

b) Como são registradas as informações formais (documentadas - conhecimento explicito) e informais (não documentadas - conhecimento tácito)?

c) Existe um banco de dados com a base de conhecimento da empresa? Como estão organizadas as informações: por projeto/ obra, por sistema construtivo, por lições aprendidas ou natureza dos problemas ocorridos (estrutura analítica do conhecimento)? Todos os funcionários têm acesso? Como é o processo para alimentação do banco de dados?

d) As lições aprendidas ao longo processo de projeto, e durante a obra, são transmitidas à equipe de projeto e à equipe de produção? Como?

e) As diretrizes de projeto da empresa são atualizadas a partir dos resultados ou dados das fases posteriores do processo de produção (execução, entrega, uso e manutenção)? Quem é responsável?

f) As informações sobre os processos de produção são armazenadas/ documentadas para melhoria da construtibilidade? Quem é responsável? Estas informações são disponibilizadas aos projetistas? De que forma?

g) Como são registradas e transmitidas as melhores práticas na organização (intranet, fórums, seminários, documentos impressos, banco de dados)?

h) São realizadas avaliações pós-ocupação dos empreendimentos? Como os resultados são passados para a equipe de projeto e demais membros da empresa?

i) Quais são as dificuldades encontradas em relação à comunicação no processo de projeto?

j) Existe algum processo de troca do conhecimento e das experiências entre as empresas que participam do desenvolvimento do empreendimento (brainstorming, comunidade de prática)? Em que fase do ciclo de vida do empreendimento? 
k) Na fase de obra, como a equipe de produção procede quando se depara com um problema relacionado ao projeto?

\section{5) PROCESSO DE MUDANÇAS/ GESTÃO DE RISCO}

a) Quais departamentos podem interferir nas decisões tomadas pela equipe de projeto que possam interferir no processo de projeto (suprimentos, orçamento, planejamento, alta direção, etc)?

b) Quais são as principais fontes de mudança dos projetos (clientes, problemas de projeto, não atendem às normas, alteração de premissas, etc)? Em que fase as mudanças ocorrem com maior freqüência? Como são gerenciadas as mudanças na fase de obra? É feita alguma avaliação sobre os impactos da mudança sobre o custo, tempo, desempenho, qualidade? Quais são os profissionais envolvidos nesta avaliação?

c) Como são aprovadas as mudanças e quem é o responsável? Qual é o fluxo de tomada de decisão?

d) As alterações de projetos durante a obra são registradas? Como? Quem é o responsável? Existe um procedimento formal para o registro dessas alterações?

e) Ao compreender o contexto, razões e impacto das mudanças houve alguma situação em que a mudança propiciou a criação de valor para o projeto?

f) Como o conhecimento gerado e compartilhado entre a equipe, decorrente das mudanças é armazenado, compartilhado e retransmitido para projetos futuros da empresa?

g) Existe alguma avaliação de riscos do Projeto? Em que fase? Como são gerenciados os riscos?

h) Como a comunicação e a cultura da organização afetam a tomada de decisão frente aos riscos e sua gestão (como é o processo decisório)?

i) Existe algum tipo de sinal que possa identificar futuros riscos no processo de projeto e minimizar insucessos (técnicas para identificação de risco)?

\section{6) CONDIÇÃO QUANTO À DIVULGAÇÃO DE INFORMAÇÕES E DOCUMENTOS FORNECIDOS PELA EMPRESA ENTREVISTADA}

A empresa pode ser citada diretamente - sem restrições quanto à divulgação.

$\square$ A empresa pode ser citada diretamente - divulgação autorizada das informações fornecidas, mas não da íntegra de documentos.

Informações apenas para análise voltada à Dissertação de Mestrado (não citar a empresa diretamente)

Outra condição 